


\section{Cormell alniversity}

THE GIFT OF

University of Minnerota Libiary

A.297733 


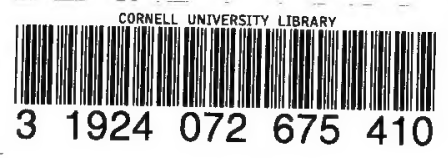




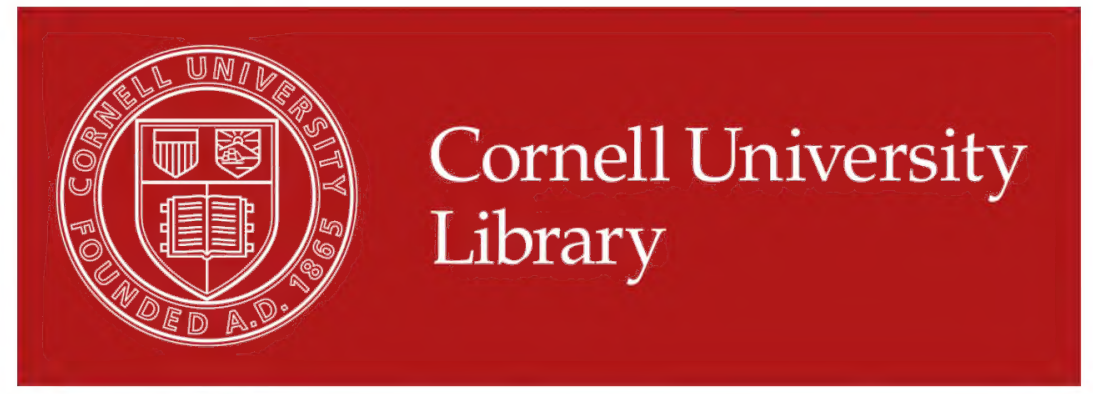

The original of this book is in the Cornell University Library.

There are no known copyright restrictions in the United States on the use of the text.

http://www.archive.org/details/cu31924072675410 


\title{
MINNESOTA ALGAE
}

\section{VOLUME I}

The Myxophyceae of North America and Adjacent Regions Including Central America, Greenland, Bermuda, THE West Indies and HaWaII

\author{
JOSEPHINE TILDEN \\ Assistant Professor of Botany \\ University of Minnesota
}
REPORT OF THE SURVEY
Botanical Series
VIII

MINNEAPOLIS, MINNESOTA

APRIL 1, 1910 
Published by AUthority of the BOARD OF REGENTS OF THE UNIVERSITY FOR

The People of Minnesota

EDition 2,500 Copies 


\section{PREFACE}

Although the recent appearance of the last volume of De Toni's "Sylloge Algarum," the "Myxophyceae," has removed some of the greatest difficulties which confront the student of this branch of Algology, yet, with the general literature concerning the blue-green algae in its present state, he has a vexatious problem before him if he attempt to work to any purpose in this group of plants. The original specific descriptions with their accompanying notes and figures, are scattered far and wide, many of them in foreign periodicals and rare works. In general these cannot be obtained in more than a very few of the largest botanical libra ries. In the United States, at least, there is much need for a work in English, suitable for use as a general hand-book, which shall contain descriptions and illustrations of these plants. On the other hand, such a work ought not to be written until a considerable amount of information has been obtained from all parts of the country. An accurate treatise of this sort should be prepared only as a result of general investigation carried on by a large number of workers over the entire area to be covered, at all seasons of the year. For instance, many species have so far been reported from a single locality, which without doubt are growing in profusion in other parts of the country. Without question numerous new species await discovery when the study of the group has become more general.

It would seem then that two books need to be written, one as a cause and one as a result of such investigation. If the present treatise proves to be of use as a foundation or ground-work for the second volume, and if it shall be the means of assisting those who are disposed to follow this fascinating branch of microscopic study, the hopes of the author will be realized. The work has been prepared with a view to answering the need of such botanists as do not have access to the special libraries and of others who have not unlimited time to devote to the looking up of literature. Special prominence has been given, in the arrangement of the text, to two features. The student has constantly before him practically all that is known relating to the geographical distribution and the recorded history of each plant in American localities. To quote from Mr. G. S. West, "One cannot emphasize too much the importance of a sound knowl-" edge of the geographical distribution of some of the more lowly types of Cryptogams. . . Such a knowledge, which can only be acquired by the patient labors of the systematist, will throw much light on one of the most interesting of all problems concerned with the later phases of the earth's history, namely, the land-connections of previous periods." It is very much hoped that this volume may encourage interest on the part of general botanists, high school teachers, college students, physicians and bacteriologists in these little plants which are of late coming to be considered of importance even outside of botanical circles.

In the present volume the author has brought together the specific descriptions of all the blue-green algae so far known to exist in North America and the adjacent regions (including the Arctic Regions, Alaska, Greenland, Canada, Newfoundland, Labrador, the United States, Lower California, Mexico, Central America, the Bermudas, the Bahamas, the West Indies and the Hawaiian Islands). In addition there are figures illustrating many of the species. The figures have been photographed from the original and redrawn. A number of them are original with the author. An attempt has been made to have the figures all drawn to the same scale which may be an improvement over the ordinary method. Very simple keys are furnished for the families, genera and species. The second paragraph of each specific description contains the names in chronological order of a number of articles and works referring to the species in question. It is 
believed that the plan of writing out in full the author's name and the title of his article will prove a great saving in time for the one who uses the book. In the case of amateurs it will also serve to give in a short time an intimate knowledge of the names of algologists and an idea of the work already done in the group.

The descriptions in general follow those of Gomont, Bornet, Thuret and Flahault. Constant reference has of course been made to Forti's recent volume. Wherever possible the original descriptions have been consulted. Possibly a mistake has been made in not repeating the synonym after each title. Instead each synonym has been inserted but once, following the first article in which it occurs. The principal aim of the book, however, is to encourage original investigation" in the field among the plants themselves. For a full list of synonyms, reference must be made to De Toni's "Myxophyceae."

I wish to tender my best thanks to Dr. Frederic E. Clements for advice and much kind assistance during the preparation and publication of this volume which was undertaken at his request. To Miss Charlotte Waugh I am much indebted for her painstaking work upon the pen and ink drawing of the figures.

The author hopes that several persons in each state or section of the country may decide to undertake a systematic and careful investigation of the blue-green algae in their neighborhoods, and would be very glad to enter into a correspondence with such workers.

JOSEPHINE E. TILDEN.

Kimberly Road, Epsom,

Auckland, New Zealand, December 21, 1909. 


\section{MYXOPHYCEAE}

\section{(Cyanophyceae. Schizophyceae) The Blue-Green Algae}

Algae typically blue-green, the coloring matter being a mixture of two pigments, chlorophyll and phycocyanin; pigments of other colors sometimes present.

Plant body unicellular or multicellular, sometimes endowed with a peculiar motion; plants existing usually in gelatinous masses, sometimes solitary among other algae.

Reproduction always asexual, either by simple cell division in one, two or three directions of space, or by means of hormogones (multicellular fragments of the plant body, at first motile, afterwards coming to rest), or by means of non-motile gonidia formed within gonidangia, or by means of resting gonidia (formed from ordinary cells).

Habitat: Plants found in fresh, brackish or salt water, in hot springs, in mineral springs, in aerial situations, or as endophytes.

Order I. Coccogoneae. Plants unicellular, single or associated in families or colonies which are usually surrounded by a copious gelatinous integument, rarely forming filaments; reproduction occurs commonly by the vegetative division of cells, rarely by the formation of non-motile gonidia from the division of the contents of a gonidangium (mother cell).

Order II. Hormogoneae. Plants multicellular, filamentous, attached to a substratum or free-floating; filaments simple or branched, usually consisting of one or more rows of cells within a sheath; reproduction occurs by means of hormogones or resting gonidia.

\section{Order I. COCCOGONEAE}

Family I. Chroococcaceae. Plants showing no difference between basal and apical regions, solitary or associated in families or colonies; 
reproduction by vegetative division of cells in one, two or three directions of space.

Family II. Chamaesiphonaceae. Plants often showing a difference between basal and apical regions, solitary or associated in families or colonies, usually epiphytic or attached to shells; reproduction by means of non-motile gonidia formed by the division of the contents of a mother cell (gonidangium).

\section{Family I. CHROOCOCCACEAE}

1. Plants solitary or associated in small, indefinite families or colonies, not stirrounded by a common (colonial) gelatinous tegument.

I Cells spherical; reproduction by cell division in three directions

Chroococcus

2 Cells spherical; reproduction by cel! division in one direction only

Synechocystis

3 Cells oblong, ellipsoidal or cylindrical; sheath wanting; reproduction by cell division in one direction only

Synechococcus

4 Cells cylindrical or oblong-conical; sheaths thick, hyaline; reproduction by cell division in one direction only Chroothece

II. Plants associated in families or colonies, surrounded by a common gelatinous tegument.

I Colonies without definite shape

(I) Individual sheaths usually thick, remaining through many divisions, sheath of original mother-cell surrounding entire colony

A Cells spherical

a Cells enclosed in a vesicle-like, thick, colorless or colored sheath, spherical (after division oblong), single or in colonies; cell contents blue-green, or of various colors

\section{Gloeocapsa}

b Cells surrounded by an elliptical membrane, forming colonies, arranged in short filaments

Entophysalis

c Cells surrounded by thick sheath, forming spherical colonial masses; plant mass cushion-like, cartilaginous, incrusted with lime at base, curled at periphery

\section{Chondrocystis}

B Cells elongate

a Cells cylindrical-oblong, surrounded by a thick, mucous sheath, solitary or forming small colonies

\section{Gloeothece}

(2) Individual sheaths not distinct; colony surrounded by common tegument formed of dissolved individual sheaths

A Cells spherical (or angular from mutual pressure); cell division in all directions

B Cells oblong; cell division in one direction

Aphanocapsa

Aphanothece

2 Colonies having a definite characteristic shape

(I) Colonies free-floating 
A Cells having an indefinite arrangement, forming several layers

a Cells spherical or oblong; colony spherical or oblong, solid

\section{Microcystis}

b Cells spherical; colonies of variable shape, at first solid, becoming saccate and clathrate Clathrocystis

c Cells pear-shaped or heart-shaped; colony spherical or ellipsoid, solid

Gomphosphaeria

B Cells having a definite arrangement, forming a single layer os cube

a Colonies spherical, hollow

(a) Cells spherical, lying just within the periphery of the colony

Coelosphaerium

(b) Cells spherical or elongate; individual sheaths distinct

b Colonies fiat

Coelosphaeriopsis

- (a) Cells of some definite or symmetrical shape, quadrangular or triangular, solitary or forming colonies

Tetrapedium

(b) Cells spherical; colonies rectangular Merismopedium

c Colonies cubical, solid; cells spherical or elliptical

(2) Colonies adherent to substratum

Eucapsis

A Cells spherical or elongate, regularly arranged in radial rows; colonies cushion-like, hard, leathery, verrucose

Oncobyrsa

B Cells spherical or oval, irregularly arranged in radial rows; colonies irregularly lobed, epiphytic

Chlorogloea

Genus CHROOCOCCUS Naegeli. Gatt. Einz. Alg. 45. I849.

Plants either free-floating or forming a gelatinous or crust-like plant mass in damp places, in fresh or salt water, or within the tissues of other plants, occurring as spherical or angular cells, each surrounded by a more or less definite sheath, solitary or united in twos, fours, eights, etc., but not held together in definite colonies by a common gelatinous tegument; sheaths thin or wide, homogeneous or lamellose, colorless or colored; cell contents homogeneous or granular, usually of a blue-green color, sometimes violet, olive-green, orange or yellowish; reproduction by successive division of the cells alternately in three directions of space.

I Sheaths hyaline, often lamellose; cell contents orange or yellowish.

1 Cells less than $3 \mathrm{mic}$. in diameter C. rubrapunctus

2 Cells more than 15 mic. in diameter

(I) Plant mass yellowish green; cells $25-50$ mic. in diameter

C. macrococcus

(2) Plant mass orange-colored; cells 19-34 mic. in diameter

C. turicensis 
II Sheaths hyaline, yellowish or brownish, often lamellose; cell contents blue-green, rarely olive-brown, reddish-green, brownish-violet or copper-red.

I Cells not embedded in a gelatinous mass, mostly solitary among other algae

(1) Sheaths thick, distinctly lamellose; cell contents blue-green

A Sheaths colorless; cells I3-25 mic. in diameter

C. turgidus

B Sheaths yellowish or brownish; cells 5.8-I I mic. in diameter

C. schizodermaticus

(2) Sheaths not lamellose
A Cells 5-7 mic. in diameter
C. minutus
B Cells 1.7 mic. in diameter
C. multicoloratus

C Growing in hot water; cells I-I.5 mic. in diameter

C. thermophilus

2 Cells embedded in a gelatinous mass, not free-floating

(I) Sheaths lamellose

A Sheaths slightly lamellose; plants 4-8 mic. in diameter

C. varius

B Sheaths lamellose, finally irregularly peeling off; plants 6-I I mic. in diameter

C. decorticans

(2) Sheaths not lamellose, sometimes scarcely visible

A Plants 5 mic. in diameter, mostly subquadrate, often triangular, rarely multiangular; sheaths scarcely perceptible

\section{C. refractus}

B Plants $4-7.5$, rarely 9 mic., in diameter, spherical

\section{C. helveticus}

C Plant mass pale yellowish; sheaths oblong-elliptical; cells 7.5-13 mic. in diameter; cell contents blue-green, yellowish or orange

C. pallidus

D Plant mass green, later becoming black; sheaths distinct, ellipsoid; cells 2.7-6.6 mic. in diameter; cell contents blue-green

\section{C. cohaerens}

E Plant mass blue-green or olive; sheaths scarcely visible; plants 3-4 mic. in diameter; cell contents blue-green C. minor

F Plant mass lead-colored or green becoming black; sheaths thick, mucous; plants $3-8$ mic. in diameter; cell contents blue-green

C. membraninus

3 Cells embedded in a gelatinous, free-floating mass

(I) Plants 8-I3 mic. in diameter, much crowded; cell contents green
or blue-green
C. limneticus

(2) Plants 13 mic. in diameter, usually in groups of two; groups lying apart from each other; cell contents grayish-purple

\section{C. purpureus}


I. Chroococcus rubrapunctus Wolle. Bull. Torr. Bot. Club. 6: 18I. I877. De Toni. Syll. Algar. 5: 8. 1907.

Plants 2-2.5 mic. in diameter, spherical, single or in masses, aquatic; sheaths thin, gelatinous; cell contents homogeneous, yellowish-orange, surrounding a large orange-red area.

Pennsylvania. Not infrequent on boarded sides of basins and old timbers. (Wolle).

2. Chroococcus macrococcus (Kuetzing) Rabenhorst. Flora Europaea Algarum. 2: 33. I865. De Toni. Syll. Algar. 5: 8. I907.

Nordstedt. De Algis Aquae Dulcis et de Characeis ex Insulis Sandc $\in$ nsibus a Sv. Berggren 1875 reportatis. 3. 1878 . Lemmermann. Algenfl. Sandwich-Inseln. Bot. Jahrb. 34:614. 1905.

\section{Plate I. fig. I.}

Plant mass more or less extensive, mucous, somewhat thick, yellowishgreen; plants $30-80 \mathrm{mic}$. in diameter, spherical, single or in pairs or fours; sheaths thick, lamellose, colorless, later irregularly peeling off; cells 25-50 mic. in diameter; cell contents homogeneous, yellowish, orange or darkcolored.

Greenland. (Boergesen). Hawaii. In stagnant water, Volcano Mauna Kea. Island of Hawaii. (Berggren).

3. Chroococcus turicensis (Naegeli) Hansgirg. Prodr. Algenfl. Böhman. 2: 16o. f. 58b. I892. De Toni. Syll. Algar. 5:9. 1907.

\section{Plate I. fig. 2.}

Plant mass gelatinous, smooth, orange-colored; plants spherical, single or in pairs or. fours; sheaths moderately thick; cells 19-34 mic. in diameter; cell contents finely granular, orange-colored, rarely blue-green.

Greenland. (Boergesen).

4. Chroococcus turgidus (Kuetzing) Naegeli. Gatt. Einz. Alg. 46. I849. De Toni. Syll. Algar. 5: II. 1907.

Nordstedt. De Algis Aquae Dulcis et de Characeis ex Insulis Sandvicensibus. 3. 1878. Dickie. On the Algae found during the Arctic Expedition. Journ. Linn. Soc. Bot. 17: 9. I880. Farlow. Marine Algae New England. 27. I88I. Wolle. Fresh-Water Algae. U. S. 334. pl. 210. f. 40, 4I. I887. Collins. Algae of Middlesex County. J6. I888; Marine Algae of Nantucket. 4. I888. Bennett. Plants of Rhode Island. II6. I888. Wolle and Martindale. Algae. Britton's Catalogue of Plants found in New Jersey. Geol. Surv. N. J. 2:612. 1889. Martindale. Marine Algae of the New Jersey Coast and Adjacent Waters of Staten Island. Mem. Torr. Bot. Club. I: 89. I889. Mackenzie. A Preliminary List of Algae collected in the neighborhood of Toronto. Proceedings of Canadian Institute. III. 7: 270. I890. Anderson. List of California Marine Algae, with notes. Zoe. 2: 217. I891. Collins. Algae. Rand and Redfield's Flora of Mount Desert Island, Maine. 249. 1894. West and West. On some Freshwater Algae from the West Indies. Journ. Linn. Soc. Bot. 30:275. I895. Setchell. Notes on Cyan- 
ophyceae. III. Erythea 7:54. I89g. Collins, Holden and Setchell. Phyc. Bor.-Am. Fasc. I6. no. 751. 1900. Collins. Preliminary Lists of New England Plants.-V. Marine Algae. Rhodora 2: 4I. I900; The Algae of Jamaica. Proc. Am. Acad. Arts Sci. 37: 239. Ig0I. Saunders. The Algae. Harriman Alaska Expedition. Proc. Wash. Acad. Sci. 3:396. I901. Setchell and Gardner. Algae of Northwestern America. Univ. Calif. Pub. Bot. I: I79. I903. Riddle. Brush Lake Algae. Ohio Nat. 5:268. 1905. Lemmermann. A1genf. Sandwich-Inseln. Bot. Jahrb. 34: 6I4. 1905.

\section{Plate I. fig. 3 .}

Plants spherical, oblong-ellipsoid or more or less angular from compression, single or associated in families of two, four, rarely eight; sheaths thick, usually lamellose, hyaline; cells $13-25$, rarely 40 mic. in diameter; ccll wall thin; cell contents homogeneous, pale blue-green, later becoming brownish and granular.

Arctic regions. Among Nostoc. Shores of Discovery Bay. (Dickie). Alaska. Distributed through a mass of $\mathrm{Microcystis}$ marginata which formed a slimy coating on a perpendicular cliff over which water was trickling. Juneau. (Saunders). Among other algae in pools of fresh water cr on dripping rocks. Glacier Valley. Unalaska. (Lawson). Canada. High Park. Toronto, Ontario. (Mackenzie). Maine. Common among various algae in lagoon. Little Cranberry Isle. (Collins). Massachusetts. On slimy rocks and piers. Cape Ann. (Davis). On woodwork near high water mark. Everett. Medford. (Collins). On woodwork. County of Nantucket. (Collins). Connecticut. (Collins). Rhode Island. Common. (Bennett). New York. Pier. Stapleton, Staten Island; on rocks in brook near Silver Lake, spring and summer. (Pike). New Jersey. Terrestrial. On moist rocks. Frequent. (Wolle). Ohio. Brush Lake. Champaign County. Fall of I902. (Riddle). Washington. In brackish water. Whidbey Island. (Gardner). California. On slimy rocks and cliffs at high water. (Anderson). In fresh, brackish and even in somewhat alkaline waters. (Setchel1). West Indies. Among various algae. Jamaica. July igoo. (Pease and Butler). Hawaii. In stagnant water. Mauna Kea. Island of Hawaii. (Berggren).

Var. fuscescens (Kuetz.) De Toni. Richter. Süsswasseralgen aus dem Umanakdistrikt. Bib. Bot. Heft. 42. 3. I897. De Toni. Syll. Algar. 5: I3. I907.

Cell contents becoming dark-colored.

Greenland. Umanak. (Vanhöffen).

5. Chroococcus schizodermaticus West. Algae of English Lake District. Journ. Roy. Mic. Soc. 742. pl. Io. f. 61, 63. I892. De Toni. Syll. Algar. 5: 13. 1907.

West and West. On some Freshwater Algae from the West Indies. Journ. Linn. Soc. Bot. 30: 275. pl. I6. f. I9. I895.

Flate I. fig. 4.

Plants 21-42 mic. in diameter, somewhat globose or triangular, some- 
times kidney-shaped associated in colonies of two, three or four; colonies solitary or in small groups; sheaths very thick, straw-colored or dark-colored, strongly lamellose, (lamellae 5-10), finally irregularly peeling off; cells 5.8-I I mic. in diameter; cell wall somewhat thick; cell contents granular, blue-green. liott).

West Indies. On damp wall of dam. Sharp's River. St. Vincent. (E1-

6. Chroococcus minutus (Kuetzing) Naegeli. Gatt. Einz. Alg. 46. I849. De Toni. Syll. Algar. 5: 14. I907.

Collins, Holden and Setchell. Phyc. Bor.-Am. Fasc. 20. no. 951. 1902.

Plants 6-9 mic. in diameter, ro-13 mic. in length, spherical or oblong, more or less angular, usually united in twos; sheaths somewhat orbicular, hyaline, distinct; cells 5-7 mic. in diameter, 9-1o mic. long; cell contents homogeneous or granular, pale blue-green.

Maine. Growing in high pool. Cape Rosier. July i898. (Collins).

7. Chroococcus multicoloratus Wood. Fresh-Water Algae North America. II. pl. 5. f. 6. 1872. De Toni. Syll. Algar. 5: II. I907.

Plate I. fig. 5 .

In a riucous mass with other algae; plants 3 mic. in diameter, spherical and single, or angular, semi-spherical or irregular and associated in oblong families of from two to four (rarely eight); sheaths thick, hyaline, not lamellose; cells 1.7 mic. in diameter; cell contents mostly homogeneous, sometimes minutely granular, yellowish-green, bluish-green, yellowish, brownish, blackish, sometimes tinged with bright lake.

Pennsylvania. On wet rocks. Near Philadelphia. (Wood).

8. Chroococcus thermophilus Wood. Am. Journ. Sci. Arts. I22. 1869; Contr. Hist. Fresh-Water Algae North America. I2. 1872. De Toni. Syll. Algar. 5: 10. 1907.

Wolle. Fresh-Water Algae U. S. 335. I887.

Plants subglobose or oblong, angular, single or in twos or fours, associated in families; sheaths very thick, transparent, not lamellose, homogeneous; cells I-I.5 mic. in diameter; cell contents sometimes minutely granular, sometimes homogeneous, greenish.

California. In Nostoc colonies. In hot springs (100 $-120^{\circ} \mathrm{F}$.) Benton's Spring. Owen's Valley, sixty miles southwest from the town of Aurora. (Partz).

9. Chroccoccus varius A. Braun in Rabenhorst. Die Algen Europas. no. 246, 248, 2456. I86I-78. De Toni. Syll. Algar. 5: 21. I907.

Tilden. American Algae. Century II. no. I98. I896; Observations on some West American Thermal Algae. Bot. Gaz. 25: 104. pl. 8. f. 21. 1898; Am. Alg. Cent. VI. no. 600. I902. Collins, Holden and Setchell. Phyc. Bor.Am. Fasc. 25. no. I202. I905.

Plant mass gelatinous-mucous, dull brown or olive green; plants 4-8 mic. in diameter, globose, single or in twos or fours, rarely forming larger fam- 
ilies which occur as shapeless bunches; sheaths of medium thickness, hyaline, уегу slightly lamellose, often pale yellow or orange in color, almost opaque; cells 2-4 mic. in diameter; cell contents pale bluish gray or bluish green, sometimes yellowish.

Massachusetts. On walls of greenhouse. Botanic Garden. Cambridge. January I899. (Collins). Montana. In hot springs. Lo Lo Hot Springs. Lo Lo. September I898. (Griffiths). Wyoming. On rocks near vent of geyser. Sometimes heated. Norris Geyser Basin. June I896. In overflow from spring, temperature $4 \mathrm{I}^{\circ} \mathrm{C}$. Frying Pan Basin, July I8g6. Yellowstone National Park. (Tilden). Forming a green coating on floor of overflow channel. Temperature $49^{\circ} \mathrm{C}$. Constant Geyser, Norris Geyser Basin; in acid waters, Green Spring, between Norris Geyser Basin and Beaver Lake. Yellowstone National Park. I897. (Weed).

Dr. Setchell is undoubtedly right in placing the Yellowstone specimens in the genus Pleurocapsa. (See P. c a 1 daria.)

Io. Chroococcus decorticans A. Braun. Betracht. ueber die Erschein. Verjung. in der Natur. 194. I85I. De Toni. Syll. Algar. 5: I8. 1907.

Wolle. Fresh Water Algae. III. Bull. Torr. Bot. Club. 6: 18I. 1877.

Plants 6-I I mic. in diameter, single or associated in families of two or four; sheaths distinct, lamellose, finally irregularly peeling off; cell wall solid, colorless; cell contents blue-green.

Pennsylvania. Submerged timbers. (Wolle).

II. Chroococcus refractus Wood. Contr. Hist. Fresh-Water Algae North America. II. pl. 5. f. 5. 1872. De Toni. Syll. Algar. 5:20. 1907.

Buchanan. Notes on the Algae of Iowa. Proc. Iowa Acad. Sci. I4: ro. T908.

Plants 5 mic. in diameter, mostly subquadrate, very often triangular, rarely multiangular, closely associated in solid families; families often lobed; sheaths thin, scarcely perceptible, transparent; cell contents finely granular, brownish, olive-green, or yellowish, highly refractive.

Pennsylvania. Growing abundantly on wet rocks along the Reading Railroad between Manayunk and the Flat Rock tunnel. (Wood). Iowa. Ames. 1884. (Bessey).

12. Chroococcus helveticus Naegeli. Gatt. Einz. Alg. 46. pl. I. I849. De Toni. Syll. Algar. 5: I7. 1907.

Lagerheim. Ueber einige Algen aus Cuba, Jamaica und Puerto-Rico. Bot. Notiser. I99. 1887.

Plants 4-7.5 mic., rarely 9 mic. in diameter, spherical, associated in families of two, four or eight; sheaths spherical, gelatinous, scarcely visible; cell wall very thin, colorless; cell contents homogeneous or somewhat granular, blue-green or greenish, pale or yellowish in color.

West Indies. On Utricularia in stagnant water. Near Fajardo. Porto Rico. April 1885. (Sintenis). 
13. Chroococcus pallidus Naegeli. Gatt. Einz. Alg. 46. pl. I. f. 2. I849. De Toni. Syll. Algar. 5: 19. I907.

Snow. The Plankton Algae of Lake Erie. U. S. Fish Commission Bull. for I902. 22: 392. I903.

Plant mass mucilaginous, pale yellowish; plants 7.5-13 mic. in diameter, globose, single or in families of two, four or eight; sheaths oblong-elliptical, colorless; cells 6-I I mic. in diameter; cell walls somewhat thick, homogeneous, hyaline; cell contents finely granular, greenish, yellowish or orange, rarely bluish or blue-green.

Ohio. Put-in-Bay. Lake Erie. Summers of 1898 , 1899, 1900. (Snow).

I4. Chroococcus cohaerens (Brébisson) Naegeli. Gatt. Einz. Alg. 46.1849. De Toni. Syll. Algar. 5:21. 1907.

Wolle. Fresh-Water Algae U. S. 335. pl. 210. f. 42. 1887. Webber. The Fresh-Water Algae of the Piains. Am. Nat. 23: Ior I. 1889. Saunders. Protophyta-Phycophyta. Flora of Nebraska. 16. pl. I. f. I. 1894. West and West. On some Freshwater Algae from the West Indies. Journ. Linn. Soc. Bot. 30: 275. 1895. Collins, Holden and Setchell. Phyc. Bor.Am. Fasc. I5. no. 701. 1900. Collins. Phycological Notes of the late Isaac Holden,-II. Rhodora. 7: 235. I905.

Plant mass green, or later becoming greenish black, gelatinous; sheaths distinct, hyaline, ellipsoid; cells 2.7-6.6 mic. in diameter, globose or oblong, in twos or fours forming colonies 7 -I5 mic. in diameter; cell wall thin; cs:ll contents homogeneous or slightly granular, of a turbid, blue-green color.

United States. On damp walls, rocks, etc. (Wolle). Maine. On shaded cliffs. Eagle Island. Penobscot Bay. July 1892. (Collins). Connecticut. Among other algae, on abutment of Factory Pond dam. December. (Holden). Nebraska. Stagnant water. Thedford. (Webber, Saunders). West Indies. Amongst other algae on trees. Summit of Trois Pitons (4500 ft.). Dominica. November and December, I892. (Elliott).

i5. Chroococcus minor (Kuetzing) Naegeli. Gatt. Einz. Alg. 47. pl. I A. f. 4. I849. De Toni. Syll. Algar. 5: 23. I907.

West and West. On some Freshwater Algae from the West Indies. Journ. Linn. Soc. Bot. 30:275. I895. Bessey, Pound and Clements. Additions to the reported Flora of the State. Bot. Surv. Nebraska. 5: r2. I90I.

\section{Plate I. fig. 7 .}

Plant mass mucous-gelatinous, dull blue-green or olive green; 3-4 mic. in diameter, rotund, single or in pairs, angular; sheaths mucous, scarcely visible; cell walls very thin, hyaline; cell contents homogeneous, ustually pale bluish-green.

Nebraska. In aquarium. Lincoln. (Bessey). West Indies.'On damp wall of dam. Sharp's River. St. Vincent; on trees. Summit of Trois Pitons (4500 ft.). Dominica. (Elliott).

Forma minima W. and G. S. West. loc. cit. 275. pl. 16. f. 18. 1895.

Cells I-I.9 mic. in diameter; families Io-23 mic. in diameter. 
West Indies. With the type from the above-named localities. On lime trees. Shanford Estate. Dominica. (Elliott).

16. Chroococcus membraninus (Meneghini) Naegeli. Gatt. Einz. Alg. 46. I849. De Toni. Syll. Algar. 5: 23. 1907.

Collins, Holden and Setchell. Phyc. Bor.-Am. Fasc. 25. no. I20I. I905.

Plant mass somewhat membranaceous, mucous, lead-colored to green, becoming blackish; plants 3-8 mic. in diameter, globose or subglobose, single, or associated in families of twos or fours; families 8-26 mic. in diameter; sheaths thick, mucous, hyaline; cell walls thick, colorless; cell contents minutely granular, blue or blue-green.

California. Forming a zone, yellowish red just above, and blue-green just below, the edge of the water, very low, in "The Lagoon," Niles, Alameda County. November I898. (Setchell).

I7. Chroococcus limneticus Lemmermann. Beiträge zur Kenntniss der Planktonalgen. Bot. Centralb. 76: 153. 1898. De Toni. Syll. Algar. 5: 16. 1907.

Snow. The Plankton Algae of Lake Erie. U. S. Fish Commission Bull. for 1902. 22: 392. 1903.

\section{Plate I. fig. 8.}

Plant mass floating free; tegument wide; plants 8-13 mic. in diameter, much crowded, before division globose, after division hemispherical; sheaths hyaline, distinct, lamellose; cell contents greenish or pale blue-green.

Ohio. Put-in-Bay. Lake Erie. Summers of 1898, I899, I900. (Snow).

I8. Chroococcus purpureus Snow. The Plankton Algae of Lake Erie. U. S. Fish Commission Bull. for 1902. 22: 388. 390. I903.

Plate I. fig. 9.

Plant mass gelatinous, floating free; tegument wide; plants 13 mic. in diameter, spherical, or just before division elongated, usually arranged two by two in colonies of four or eight; sheaths thin; cell contents grayish-purple, changing to brown under unfavorable conditions.

Ohio. Common in the plankton of Lake Erie. Put-in-Bay. (Snow).

Genus SYNECHOCYSTIS Sauvageau.

Bull. Soc. Bot. de France. 39: cxv. I892.

Plants always globose; sheaths none; cell walls thin not diffuent; cell contents blue-green; reproduction by division of the cells in one direction only.

19. Synechocystis aquatilis Sauvageau. Sur les Algues d'eau douce récoltées en Algérie pendant la session de la Société Botanique en I 892. Bull. Soc. Bot. de France. 39: cxvi. pl. 6. f. 2. 1892. De Toni. Syll. Algar. 5:26. 1907.

Collins, Holden and Setchell. Phyc. Bor.-Am. Fasc. 25. no. I206. 1905. 
Plate I. fig. Io.

Submerged; plants 5-6 mic. in diameter, single or in pairs; cell walls hvaline, very thin; cell contents pale blue-green.

California. On the outside of a dripping water tank, Berkeley. April I904. (Gardner).

\section{Genus SYNECHOCOCCUS Naegeli.}

Gatt. Einz. Alg. 56. pl. I. I849.

Plants oblong, cylindrical or ellipsoidal, usually single, occasionally forming families of two or four united in a row or chain; sheaths none; cell walls thin; cell contents blue-green, sometimes yellowish, pinkish or pale orange; reproduction by division of the cells in one direction only.

I Cell contents blue-green.

I Cells 7-15 mic. in diameter, I4-26 mic. in length

S. aeruginosus

2 Cells 2 mic. in diameter, 4-6 mic. in length

S. racemosus

3 Growing in hot salt water; cells 3 mic. in diameter, 6 mic. in length

S. curtus

20. Synechococcus aeruginosus Naegeli. Gatt. Einz. Alg. 56. pl. I E. f. I. I849. De Toni. Syll. Algar. 5:27. 1907.

Farlow. Notes on the Cryptogamic Flora of the. White Mountains. Appalachia. 3: 236. I883. Tilden. Am. Alg. Cent. II. no. I95. I896; On some Algal Stalactites of the Yellowstone National Park. Bot. Gaz. 24: I98. pl. 8. f. 6. I897. Observations on some West American Thermal Algae. Bot. Gaz. 25: 103. I898. Collins. Algae of the Flume. Rhodora. 6: 230. 1904 .

\section{Plate I. fig. II.}

Plants 7-15 mic. in diameter, I4-26 mic. in length, oblong or somewhat cylindrical, obtusely rotund at both ends, single or in pairs; cell contents homogeneous, light or pale blue-green.

Greenland. (Boergesen). New Hampshire. Moist rocks at the Flume. Lake Willoughby. (Farlow). Wyoming. One of the three species of Blue-green algae which formed algal "stalactites." Growing in a small cave made by the cone of a geyser. Valley of the Nez Perces Creek. Lower Geyser Basin. Yellowstone National Park. June 1896. (Tilden).

2I. Synechococcus racemosus Wolle. Fresh-Water Algae. V. Bull. Torr. Bot. Club. 8: 37. I88I. De Toni. Syll. Algar. 5: 28. 190\%.

Plant mass amorphous, blue-green; plants 2 mic. in diameter, two to four times longer than broad, oblong-cylindrical, with rounded ends, often showing a regular vertical arrangement, densely aggregated; cell contents homogeneous, pale blue-green.

Pennsylvania. Glass sides of aquarium. Bethlehem. (Wolle).

22. Synechococcus cürtus Setchell in Collins, Holden and Setchell. Phyc. Bor.-Am. Fasc. 28. no. I35I. I907. 
Plants 3 mic. in diameter, 6 mic. long just before dividing, slightly elongated, single or united by strands of transparent jelly; cell walls very thin, scarcely visible; cell contents pale bluish-green.

California. Floating in myriads in hot salt water, near Key Route power house. Oakland. September 1905. (Gardner).

\section{Genus CHROOTHECE Hansgirg.}

Oesterr. Bot. Zeit. 34: pl. I. I884.

Plant mass somewhat gelatinous, dark-yellowish; plants cylindrical or oblong-conical, with rotund ends, single or in pairs; sheaths wide, lamellose, hyaline, increasing greatly in thickness at one pole; cell contents distinctly granular, bright blue-green or orange-yellow; reproduction by division of the cells in one direction only.

I Plants $18-24$ mic. in diameter

C. richteriana

II Plants 1.5 mic. in diameter

C. cryptarum

III Plants II-I2.5 mic. in diameter

C. monococca

23. Chroothece richteriana Hansgirg. Bot. Notiser. 128. I884; Prodromus der Algenflora von Böhmen. 2; I34. f. 45. I892. De Toni. Syll. Algar. 5:29. 1907.

Collins, Holden and Setchell. Phyc. Bor.-Am. Fasc. I5. no. 702. I900. Collins. The Algae of Jamaica. Proc. Am. Acad. Arts Sci. 37:239. Igor.

\section{Plate I. fig. I2.}

Plant mass somewhat gelatinous, thick, more or less expanded, bluegreen or yellowish, becoming darker; plants I8-24 mic. in diameter, once to twice as long as wide, single or in pairs; sheaths up to $6 \mathrm{mic}$. in diameter, somewhat colorless.

Bermudas. On rocks. The Flats. Bermuda. January Igoo. (Farlow). West Indies. Among other algae, in small quantity. Montego Bay. (Pease and Butler).

24. Chroothece ? cryptarum Farlow in Collins, Holden and Setchell. Phyc. Bor.-Am. Fasc. 16. no. 752. 1900. De Toni. Syll. Algar. 5: 30. I907.

Plant mass irregular, gelatinous, widely expanded, of a pale blue-green or dirty yellow color; plants $\mathbf{1 . 5} \mathrm{mic}$. in diameter, $3 \mathrm{mic}$. in length, oblong or rod-shaped; sheaths gelatinous, colorless, becoming lamellate and develcping below into densely branching Urococcus-like stalks, 7-9 mic. in diameter, 25-50 mic. in length; cell contents blue-green, without definitely shaped chromatophore; cell division usually in one, occasionally in two directions.

Bermudas. On calcareous rocks in caves by the seashore. Bermuda. January Ig0o. (Farlow).

25. Chroothece monococca (Kuetzing) Hansgirg. Prodromus der Algenflora von Böhmen. 2: I34. I892. De Toni. Syll. Algar. 5: 30. 1907.

Plant mass amorphous, gelatinous, blue-green; families $15-20$ mic. in diameter; plants II-I2.5 mic. in diameter, up to twice as long as broad, ellip- 
soid or oblong, obtusely rounded on both ends, single or in pairs; cells 4-6 mic. in diameter; cell contents blue-green.

Var. mellea (Kuetz.) Hansgirg. loc. cit. I35. I892. De Toni. loc. cit. 3 I.

Wolle. Fresh-Water Algae. II. Bull. Torr. Bot. Club. 6: 137. 1877. (Gloe ocapsa mellea Kuetz.).

Cell contents yellowish-red or yellowish-brown.

Colorado. (Wolle).

Genus -GLOEOCAPSA Kuetzing. Phyc. Gen. I74. I843.

Plants spherical (or immediately after division oblong), either single or a number associated in families; each cell enclosed in a vesicle-like. strongly thickened, usually distinctly lamellose sheath; sheaths often very thick, colorless or colored, usually lamellose; lamellae often peeling off; cell contents blue-green, bluish, steel-blue, reddish, yellowish, etc.; reproduction by division of the cells alternately in three directions.

When a cell divides into two daughter-cells, each one secretes a sheath about itself, the two still being enclosed by the sheath of the mother-cell. As division goes on, the sheath of the original cell remains enveloping the entire family, and in fact all the sheaths remain in existence. Therefore, there will always be one less than twice as many sheaths as there are cells in the family (in a family of four cells there will be seven sheaths; in a family of sixteen cells there will be thirty-one sheaths). Later generations of cells are smaller than the first ones.

I Sheaths colorless

I Sheaths lamellose

(I) Sheaths wide

A Plant mass steel blue, green, olive or dull yellow; plants 7-8 mic. in diameter; sheaths very wide, indistinctly lamellose; cells 3-5 mic. in diameter

G. granosa

B Plant mass dull green or olive; plants $3-4.5$ mic. in diameter; sheaths very thick, with numerous concentric lamellae

G. polydermatica

C Plant mass green; plants 7 -I5 mic. in diameter; sheaths very thick, more or less distinctly lamellose; cells 2.2-3.4 mic. in diameter

G. fenestralis

D Plant mass somewhat olivaceous; plants 6-17 mic. in diameter; sheaths thick; cells 3.7-6 mic. in diameter G. arenaria

(2) Sheaths narrow

A Plant mass pale yellow becoming greenish; growing in hot water; plants 19-39 mic. in diameter; cells 3-6 mic. in diameter

G. montana

B Plant mass mucilaginous, dull green or gray becoming blackish, or red becoming brownish; plants 7-II mic. in diameter; cells 3-4.5 mic. in diameter G. quaternata

C Plant mass a calcareous crust, light gray or green; plants 6-9 mic. in diameter

G. calcarea 
D Plant mass gelatinous, brownish, growing on $Z$ os te $r$ a sheaths numerous, distinct; cells 9-I I mic. in diameter, $19-26$ mic. in length

G. zostericola

2 Sheaths sometimes lamellose

(I) Plant mass blue-green or greenish; sheaths not distinctly lamellose
A Free-floating; cells $.75-2.8$ mic. in diameter
G. punctata

B On wet rocks; plants 4-8 mic. in diameter; cells $2-3$ mic. in diameter

G. aeruginosa

(2) Plant mass olive or green; plants 6.2-Io mic. in diameter; sheaths narrow, lamellose when old; cells 2.5 mic. in diameter

G. gelatinosa

(3) Plant mass dull olive; plants 7-I I mic. in diameter; sheaths thick, not at all or scarcely lamellose; cells $3-6$ mic. in diameter

G. conglomerata

3 Sheaths not lamellose

(I) Plant mass flesh-colored to yellowish; plants $2.5-5.5$ mic. in diameter; cell contents flesh-colored to honey-colored

G. mellea

(2) Plant mass black; plants 9-I 4 mic. in diameter; cells 3.5-4.5 mic. in diameter; cell contents pale blue-green G. atrata

II Sheaths yellowish or brownish

I Sheaths lamellose

(I) Plant mass dull olive to brownish-green; sheaths colorless or yellowish

G. muralis

(2) Plant mass grayish-brown to black; sheaths very thick, yellowish or orange, becoming darker

G. rupestris

2 Sheaths sometimes lamellose

(I) Plants 4.5-5.5 mic. in diameter; sheaths usually not lamellose; cells I.5-2 mic. in diameter

G. fusco-lutea

(2) Plants I2 mic. in diameter; sheaths homogeneous or lamellose; cells 3-4.5 mic. in diameter G. sparsa

(3) Colonies subglobose; sheaths somewhat lamellose; cells 9-I5 mic. in diameter

G. gigas

3 Sheaths not lamellose; plant mass olive-green; plants $5-8$ mic. in diameter

c. crepidinum

III Sheaths violet, purple or red.

I Sheaths lamellose

(I) Plant mass purple, sometimes becoming black

A Sheaths deep purple or copper-brown; plants 6-12 mic. in diameter

G. magma

$B$ Sheaths violet or reddish-purple; plants 7.5-I2 mic. in diameter; cells $2-4.5 \mathrm{mic}$. in diameter

G. janthina 
C Sheaths very thick, opaque, intensely lamellose; plants IO-I 7 mic. in diameter; cells 4-7 mic. in diameter G. ralfsiana

2 Sheaths sometimes lamellose; plant mass colorless or dark purple, growing in hot water; plants 6-7.8 mic. in diameter; cells $\mathrm{I}-2.6 \mathrm{mic}$. in diameter

G. thermalis

3 Sheaths not lamellose

(I) Plant mass violet becoming gray or black

A Plants 4-8 mic. in diameter; sheaths violet, thick, often opaque; cells I.8-2.5 mic. in diameter G. ambigua

B Plants IO-I7 mic, in diameter; sheaths violet or rose-colored; cells 3.5 mic. in diameter G. violacea

(2) Plant mass reddish-orange, dark red or black

A Plants II-24 mic. in diameter; sheaths very thick, soon peeling off G. dubia

B Sheaths intensely blood-red, very wide; cells $3.5-9$ mic. in diameter G. sanguinea

26. Gloeocapsa granosa (Berkeley) Kuetzing. Tab. Phyc. I: p1. 36. f. VIII. I845-I849. De Toni. Syll. Algar. 5: 53. 1907.

Wolle. Fresh Water Algae. III. Bull. Torr. Bot. Club. 6: I82. I877. (Gloeothece granosa Rabenh.).

Plate I. fig. I3.

Plant mass compact, gelatinous, somewhat cartilaginous, granular, steel blue, green, olive, or dull yellow, more or less spreading; plants $7-8$ mic. in diameter, globose or oblong, usually two or four in families I8-60 mic. in diameter; sheaths very wide, many times exceeding the lumen of the cell, indistinctly lamellose, colorless or nearly so; cells 3-5 mic. in diameter; cell contents homogeneous or granular, pale blue-green.

Pennsylvania. Wet rocks. (Wolle).

27. Gloeocapsa polydermatica Kuetzing. Tab. Phyc. I: pl. 20. 1845-I849. De Toni. Syll. Algar. 5:5I. I907.

Wolle. Fresh-Water Algae U. S. 331. pl. 210. f. 29-31. 1887. Collins. Algae. Flora of the Blue Hills, Middlesex Fells, Stony Brook and Beaver Brook Reservations of the Metropolitan Park Commission, Massachusetts. I26. I896. Setchell and Gardner. Algae of Northwestern America. Univ. Calif. Pub. Bot. I: I79. I903.

Plate I. fig. I4.

Plant mass gelatinous, more or less compact, dull green or dusky olive; plants 3-4.5 mic. in diameter, spherical; sheaths very thick, hyaline, lamellose, with numerous concentric firm lamellae; cell contents somewhat homogeneous, blue-green or green.

Alaska. On dripping rocks. Near Iliuliuk, Unalaska. (Setchell and Lawson). Massachusetts. On dripping rocks. Cascade, Middlesex Fells. 
(Collins). Pennsylvania. (Wolle). Hawaii. Volcano Mauna Kea, Island of Hawaii. (Berggren).

28. Gloeocapsa fenestralis Kuetzing. Phyc. Gen. 173. I843. De Toni. Syll. Algar. 5: 53. 1907.

Snow. The Plankton Algae of Lake Erie. U. S. Fish Comm. Bull, for I902. 22: 392. 1903 .

\section{Plate I. fig. I5.}

Plant mass thin, mucous, expanded, irregular, green; plants 7-I5 mic. in diameter, spherical or oblong, associated in families $16-48$ mic. in diameter; sheaths very thick, colorless, more or less distinctly lamellose, often quickly peeling off; cells 2.2-3.4 mic. in diameter; cell contents homogeneous or granular, pale blue-green.

Ohio. Put-in-Bay, Lake Erie. (Snow).

29. Gloeocapsa arenaria (Hassall) Rabenhorst. Fl. Eur. Algar. 2: 39. I865. De Toni. Syll. Algar. 5: 54. 1907.

West. The Freshwater Algae of Maine. Journ. of Bot. 27:207. 1889. Bessey. Miscellaneous Additions to the Flora of the State. Bot. Surv. Nebraska. 2: 46. I893. Saunders. Protophyta-Phycophyta. Flora of Nebraska. 16. pl. I. f. 3. I894. Buchanan. Notes on the Algae of Iowa. Proc. Iowa Acad. Sci. 14:9. 1909.

Plate I. fig. I6.

Plant mass mucous, adherent, olivaceous; plants 6-I7 mic. in diameter, spherical, associated in families up to $43 \mathrm{mic}$. in diameter; sheaths oblong or somewhat spherical, thick, colorless, lamellose; soon peeling off; cells 3.7-6 mic. in diameter; cell contents distinctly granular, blue-green or green, becoming darker.

Maine. (West). Minnesota. Near Minneapolis. (Lilley). Iowa. Abundant on flower pots in greenhouse. Ames. 1904. (Buchanan). Forming thin blue-green coating on damp stones. Grinnell. Ig05. (Fink). Nebras-ka. On flower pots in greenhouse. Lincoln. (Saunders).

30. Gloeocapsa montana Kuetzing. Phyc. Gen. I73. no. I. I843. De Toni. Syll. Algar. 5: 51. 1907.

Tilden. American Algae. Cent. II. no. 197. 1896. (G1. m o nta n a ca I(lari i Sur.).

\section{Plate I. fig. I7.}

Plant mass amorphous, somewhat thick, mucous, pale yellow, becoming greenish; plants 19-39 mic. in diameter, spherical or somewhat spherical, usually solitary; sheaths lamellose, colorless, sometimes peeling off; cells 3-6 mic. in diameter; cell contents somewhat opaque, homogeneous, or slightly granular, pale blue-green.

Wyoming. In warm owerflow water. Lower Geyser Basin, Yellowstone National Park. June I8g6. (Tilden). 
3I. Gloeocapsa quarternata (Brébisson) Kuetzing. Tab. Phyc. I: pl. 20. f. I. 1845-1849. De Toni. Syll. Algar. 5: 52. 1907.

Collins. The Algae of Jamaica. Proc. Am. Acad. Arts Sci. 37:239. I90I. Tilden. American Algae. Cent. V. no. 499. I90I; Collection of Algae from the Hawaiian Islands. Haw. Almanac and Anntual for 1902. II3. Igor; Algae Collecting in the Hawaiian Islands. Postelsia: The Year Book of the Minnesota Seaside Station. I: I68. Ig02.

\section{Plate I. fig. I8.}

Plant mass mucous, gelatinous, more or less spread out, dull, green becoming blackish, or red becoming brownish; plants 7-I l mic. in diameter, usually spherical, solitary or in twos or fours; sheaths narrow, lamellose, colorless, rotund or oblong; cells $3-4.5$ mic. in diameter; cell contents homogeneous or slightly granular, blue-green or greenish.

West Indies. Roadside. Bath. Jamaica. July Igoo. (Pease and Butler). Hawaii. Forming a gray-green, mucilaginous coating, on wet cliffs, South of Laupahoehoe, Hawaii. July I90o. (Tilden).

32. Gloeocapsa calcarea Tilden. List of fresh-water Algae collected in Minnesota during I896 and I897. Minn. Bot. Studies. 2: 29. I898. De Toni. Syll. Algar. 5: 40. 1907.

Tilden. American Algae. Cent. III. no. 299. I898.

Plant mass forming a calcareous crust, light gray to light blue-green in color, 2-3 mm. in thickness; plants 6-9 mic. in diameter; families $25-50 \mathrm{mic}$. in diameter, composed of from 4-I6 plants; sheaths colorless, somewhat thin; cell contents granular, blue-green.

Wisconsin. Forming a calcareous crust (with other lime-secreting forms) on boards where spring water from trough drips down constantly. Osceola. September I897. (Tilden).

33. Gloeocapsa zostericola Farlow. Notes on New England Algae. Bull. Torr. Bot. Club. 9:68. I882. De Toni. Syll. Algar. 5: 57. 1907.

Plant mass amorphous, gelatinous, brownish; families $40-100$ mic. in diameter; sheaths numerous, distinct (lamellose?); cells 9-II mic. in diameter, I9-26 mic. in length, flattened-hemisperical, concave on the inner surface, in families of twos or fours.

Massachusetts. On $\mathrm{Z}$ ost e r a mixed with $\mathrm{Ca}$ lot h rix. Wood's Hole. August I88r. (Farlow).

34. Gloeocapsa punctata Naegeli. Gatt. Einz. Alg. 5I. pl. I F. f. 6. I849. Snow. The Plankton Algae of Lake Erie, etc. U. S. Fish Comm. Bull. for 1902. 22: 392. 1903.

Plant mass mucous, blue-green or gray; families 23 mic. wide, containing 2-16 plants; sheaths thick, not distinctly lamellose; inner lamellae diffluent; cells $.75^{-2.8}$ mic. in diameter, spherical; cell contents homogeneous, pale blue-green.

Ohio. Put-in-Bay, Lake Erie. (Snow.) 
35. Gloeocapsa aeruginosa (Carmichael) Kuetzing. Tab. Phyc. I: pl. 2I. f. 2. I845-1849. De Toni. Syll. Algar. 5: 55. 1907.

Plate I. fig. I9.

Wolle. Fresh Water Algae. II. Bull. Torr. Bot. Club. 6: 137. I877; Fresh-Water Algae U. S. 331. pl. 210. f. 27, 28. 1887. Moebius. Ueber einige in Portorico gesammelte Süsswasser- und Luft-Algen. Hedwigia. 27: 248. I 888 .

Plant mass crustaceous, grumose or cartilaginous-mucous, blue-green or gray-green; families $16-50$ mic. in diameter; plants 4-8 mic. in diameter, spherical; sheaths thick, colorless, indistinctly lamellose; outer lamellae often sinuate, angular; cells 2-3 mic. in diameter; cell contents homogeneous, blue-green.

Greenland. (Börgesen). New York. Niagara. (Wolle). West Indies. Forming a dark green layer on stone in cave. "El Convento", near Penuelas, Porto Rico. (Sintenis). Porto Rico. (Benecke).

36. Gloeocapsa gelatinosa Kuetzing. Phyc. Gen. I74. I843. De Toni. Syll. Algar. 5: 54. 190\%.

Plate I. fig. 20.

Wolle. Fresh Water Algae. II. Bull. Torr. Bot. Club. 6: I37. 1877. West and West. A further contribution to the Freshwater Algae of the West Indies. Journ. Linn. Soc. Bot. 34:289. 1898-1900.

Plant mass lubricous, bullose, olive or green, inundated; plants 6.2-ro mic. in diameter, globose-oblong, associated in families about 25 mic. in diameter; sheaths rather narrow, colorless, lamellose when old; lamellae permanent; cells $2.5 \mathrm{mic}$. in diameter; cell contents homogeneous, bluegreen.

United States. (Wolle). West Indies. On banks. Morne Micotrin, Dominica. (Elliott).

37. Gloeocapsa conglomerata Kuetzing. Tab. Phyc. I: I6. pl. 20. f. 8. I8451849. De Toni. Syll. Algar. 5: 56. 1907.

Plate I. fig. 21.

Plant mass gelatinous, somewhat granular, expanded, dull olive-green; plants 7-II mic. in diameter, spherical, aggregated, associated in families 2245 mic. in diameter; sheaths thick, colorless, not at all or scarcely lamellose; cells $3^{-6}$ mic. in diameter; cell contents blue-green or green, becoming brownish.

Colorado. On Cladophora. (Porter, Wolle).

38. Gloeocapsa mellea Kuetzing. Tab. Phyc. I: pl. 23. f. V. I845-1849. De Toni. Syll. Algar. 5: 46. 1907.

Wolle. Fresh Water Algae. II. Bull. Torr. Bot. Club. 6: 137. 1877.

Plant mass soft, crustaceous, pale flesh-colored to yellowish; families 10-22 mic. in diameter; plants 2.5-5.5 mic. in diameter, spherical or angular, usually arranged in globose or oblong families of two or four; sheaths 
hyaline, colorless, somewhat homogeneous; cell contents flesh-colored to honey-colored. (Wolle).

Colorado. On walls and bare earth, often mixed with other algae.

39. Gloeocapsa atrata (Turpin) Kuetzing. Tab. Phyc. I: pl. 2I. f. 4. 18451849. De Toni. Syll. Algar. 5: 57. 1907.

Plate I. fig. 22.

Plant mass crustaceous, mucous, black; plants 9-14 mic. in diameter, spherical; sheaths very thick, hyaline, or pale blue, homogeneous, two or three times as wide as lumen of cell; cells 3.5-4.5 mic. in diameter; cell contents somewhat granular, pale blue-green.

Alaska. (Setchell).

40. Gloeocapsa muralis Kuetzing. Tab. Phyc. I: pl. 21. f. I. 1845-1849. De Toni. Syll. Algar. 5: 52. 1907.

\section{Plate I. fig. 23.}

Plant mass more or less expanded, delicate, gelatinous, dull olive to brownish-green; plants $13-26$ mic. in diameter, usually ellipsoid or oblong; sheaths spherical or elliptical, hyaline, colorless or yellowish, usually indistinctly lamellose; cells 5-8 mic. in diameter; cell contents somewhat granulose, blue-green.

West Indies. St. Vincent. (West).

41. Gloeocapsa rupestris Kuetzing. Tab. Phyc. I: I7. pl. 22. f. 2. I845-I849. De Toni. Syll. Algar. 5: 46. 1907 .

Tilden. American Algae. Cent. VI. no. 599. I902.

Plate I. fig. 24 .

Plant mass grayish-brown to black, crustaceous, somewhat hard; plants spherical, associated in families $15-75$ mic, wide; sheaths very thick, lamellose, yellowish or orange becoming darker; cells 6-9 mic. in diameter; cell ccntents grantiar, bite-green.

Greenland. (Boergesen). New Jersey. (Wolle). Minnesota. On moist wall growing on lime encrusted moss and on disintegrated limestone. In stene quarry. Near campus, University of Minnesota, Minneapolis. November 19or. (Lilley).

42. Gloeocapsa fusco-lutea (Naegeli) Kuetzing. Spec. Algar. 224. I849. De Toni. Syll. Algar. 5: 47. 1907.

Plant mass crustaceous, becoming black; families 50 mic. in diameter, spherical or oval; plants 4.5-5.5 mic. in diameter, globose; sheaths yellow or yellowish-brown, usually not lamellose; cells I.5-2 mic. in diameter; cell contents blue-green becoming pale.

North America. (Setchell).

43. Gloeocapsa sparsa Wood. Contr. Hist. Fresh-Water Algae North America. 13. 1872. De Toni. Syll. Algar. 5: 45. 1907. 


\section{Plate I. fig. 25.}

Plant mass mucous; plants 12 mic. in diameter, associated in families of from two to eight; cells 3-4.5 mic. in diameter, spherical, oval or oblong; sheaths having firm inner layer, homogeneous or lamellose, yellowishbrown, rarely colorless, outer layer homogeneous or lamellose, colorless or nearly so (generally scarcely visible); cell contents homogeneous.

Pennsylvania. Forming, with other algae, a rather firm, grumous or gelatinous coating of a light brown color, growing on rocks. Fairmount Water Works, near Philadelphia. (Wood).

44. Gloeocapsa gigas W. and G. S. West. On some Freshwater Algae from the West Indies. Journ. Linn. Soc. Bot. 30:276. pl. I6. f. II-I3. I895. De Toni. Syll. Algar. 5: 47. 1907.

\section{Plate I. fig. $26,27$.}

Colonies subglobose, solitary or somewhat aggregated, consisting of from four to thirty-six cells; colonial tegument subglobose, hard, often somewhat rugose on surface, yellowish or brownish; sheaths indistinct, few, pale yellowish; cells 9-I5 mic. in diameter, subglobose or oblong; cell walls smooth or finely granular; cell contents granular, blue-green.

West Indies. On damp wall of dam. St. Vincent. (Elliott).

4.5. Gloeocapsa crepidinum (Rabenhorst) Thuret. Notes Algologiques. I: 2. pl. I. f. I-3. 1876. De Toni. Syll. Algar. 5: 44. 1907.

Farlow. Marine Algae of New England. 27. pl. I. f. I. I88I. Collins. Algae of Middlesex County. I6. I888; Algae from Atlantic City, N. J. Bull. Torr. Bot. Club. I5: 309. I888. Bennett. Plants of Rhode Island. 95 . I 888. Martindale. Marine Algae of the New Jersey coast and adjacent waters of Staten Island. Mem. Torr. Bot. Club. I: 89. I889. Wolle and Martindale. Algae. Britton's Catalogue of Plants found in New Jersey. Geol. Surv. N. J. 2:6II. I889. Anderson. List of California Marine Algae, with notes. Zoe. 2:217. I89I. Collins. Algae. Rand and Redfield's Flora of Mount Desert Island, Maine. 249. I894. Collins, Holden and Setchell. Phyc. Bor,-Am. Fasc. 8. no. 351. 1897. Collins. Preliminary Lists of New England Plants.-V. Marine Algae. Rhodora. 2: 4I. Ig0o. Collins, Holden and Setchell. Phyc. Bor.-Am. Fasc. 24. no. II5I. I904. Collins. Phycological Notes of the late Isaac Holden,-I. Rhodora. 7: I72. I905.

Plate I. fig. 28.

Plant mass gelatinous, somewhat soft, olive-green (becoming black when dried); plants $5-8$ mic. in diameter, solitary or in twos or fours; sheaths yellowish-brown, not lamellose; cells 4-7 mic. in diameter.

Maine. Eastport. (Farlow.) On old logs in a salt marsh. Eagle Island, Penobscot Bay. July I896. (Collins). Common on rocks, etc. near highwater mark. (Collins). Massachusetts. Gloucester. (Farlow). On woodwork near high-water mark. Everett; Medford. (Collins). Rhode Island. Newport. (Farlow). Connecticut. On stonework; on wharf logs. Stratford Shoals. May, September. (Holden). New York. Staten Island. (Pike). New Jersey. On wharves. Atlantic City. (Morse, Martindale). 
California. On wharves at high water. On northern and middle coasts. (Anderson). Forming gelatinous masses on logs floating in salt water. Alameda. September 1903. (Osterhout, Gardner).

46. Gloeocapsa magma (Brébisson) Kuetzing. Tab. Phyc. I: I7. pl. 22. f. I. I845-1849. De Toni. Syll. Algar. 5: 35. 1907.

Dickie. Algae. in Hooker. An account of the plants collected by Dr. Walker in Greenland and Arctic America during the Expedition of Sir Francis M'Clintock, R. N., in the Yacht "Fox", 2 I June I86o. Journ. Linn. Soc. Bot. 5: 86. 186r. (Soros pora montan a Harv.); Notes on a collection of Algae procured in Cumberland Sound by Mr. James Taylor, and remarks on Arctic species in general. Journ. Linn. Soc. Bot. 9:242. 1867. Nordstedt. De Algis Aquae Dulcis et de Characeis ex Insulis Sandvicensibus a Sv. Berggren 1875 reportatis. 3. 1878 . Dickie. On the Algae found during the Arctic Expedition. Journ. Linn. Soc. Bot. 17:9. I880. Farlow. Notes on the Cryptogamic Flora of the White Mountains. Appalachia. 3:236. 1883. Wolle. Fresh-Water Algae U. S. 331. pl. 210. f. 26-3I. I887. Wolle and Martindale. Algae. Britton's Catalogue of Plants found in New Jersey. Geol. Surv. N. J. 2:612. I889. Collins, Holden and Setchell. Phyc. Bor.-Am. Fasc. 4. no. I51. I896. Collins. Algae. Flora of the Blue Hills, Middlesex Fells, Stony Brook and Beaver Brook Reservations of the Metropolitan Park Commission, Massachusetts. I26. I896. Richter. Süsswasseralgen aus dem Umanakdistrikt. Bib. Bot. Heft. 42. 3. I897. Collins. Algae of the Flume. Rhodora. 6: 229. 1904. Lemmermann. Algenfl. Sandwich-Inseln. Bot. Jahrb. 34: 6I4. 1905. Buchanan. Notes on the Algae of Iowa. Proc. Iowa Acad. Sci. 14: 9. I908.

Plate I. fig. 29.

Plant mass grumous, crustaceous, coppery-purple, becoming black when dried; families $30-70$, rarely 300 mic. in diameter; plants 6-12 mic. in diameter, spherical; sheaths lamellose, deep purple or copper-brown, usually not pellucid, the external layer very broad, globose, paler or colorless, soon diffluent; cells 4.5-7 mic. in diameter, spherical; cell contents blue-green, granular, often becoming brownish.

Dominion of Canada. Fresh water. Port Kennedy. (Walker). Cumberland Sound, Davis Strait. (Taylor). Marshes, Floeberg Beach, $82^{\circ} 27^{\prime} \mathrm{N}$. (Dickie). Greenland. Fresh water brook. Karaiak, near south end of Nunataks, Umanakdistrikt. I892, I893. (Vanhöffen). United States. Forming a purplish-brown, grumous thallus. (Wolle). New Hampshire. Common on wet stones at the top of Cabot Mountain, Shelburne. (Farlow). One of the species composing the brown coating of the wall of "The Flume." September 1904. (Collins). Massachusetts. Forming a dark purplish slimy coating on perpendicular wet rocks. Middlesex Fells. June I895. (Collins). New Jersey. On shaded rocks. (Wolle). Minnesota. On rocks. Taylor's Falls. July 1896. (Fink). Iowa. On granitic boulders. Fayette. (Fink). Hawaii. Mauna Kea. Island of Hawaii; on stones. Island of Oahu. (Berggren).

Var. itzigsohnii (Bornet) Hansgirg. Prodromus der Algenflora von Böhmen. 2: I47. I8g2. De Toni. Syll. Algar. 5: 36. 1907. 
Wolle. Fresh Water Algae. II. Bull. Torr. Bot. Club. 6: 137. 1877. (G. itzigs ohni i Bornet).

Plant mass brownish-red; families $15-60 \mathrm{mic}$. in diameter; sheaths conspicuously lamellose, the inner layers coppery-red, the outer ones paler or colorless; cells 4-5 mic. in diameter, globose or ellipsoid; cell contents greenish.

Pennsylvania. Shaded rocks. (Wolle).

47. Gloeocapsa janthina Naegeli. Gatt. Einz. Alg. 5I. pl. I F. f. 5. I849. De Toni. Syll. Algar. 5:40. 1907.

Wolle. Fresh Water Algae. II. Bull. Torr. Bot. Club. 6: 137. 1877. Collins, Holden and Setchell. Phyc. Bor.-Am. Fasc. 25. no. I205. 1905.

Plant mass crustaceous, black; plants 7.5-I2 mic. in diameter, spherical; sheaths violet or reddish-violet, outer layers paler, sometimes peeling off; cells 2-4.5 mic. in diameter; cell contents pale blue-green.

Greenland. (Boergesen). Massachusetts. On dripping masonry under railroad bridge. Melrose. August 1902. (Collins). New York. Cliffs. Niagara. (Wolle).

48. Gloeocapsa ralfsiana (Harvey) Kuetzing. Tab. Phyc. I: pl. 23. I845I849. De Toni. Syll. Algar. 5: 37. I907.

\section{Plate I. fig. 30 .}

Plant mass gelatinous, compact, dull dusky purple; plants I0-I7 mic. in diameter, associated in families of from $2-8$ cells; sheaths very thick, opaque, intensely purple, the outer layers very wide, nearly colorless, usually angular from pressure, sometimes diffluent; cell contents granular, pale blue-green.

Greenland. In Parmelia saxatilus. (Wullschlaegel).

49. Gloeocapsa thermalis Lemmermann. Algenfi. Sandwich-Inseln. Bot. Jahrb. 34: 6r4. pl. 7. f. 12-18. I905. De Toni. Syll. Algar. 5: 36. 1907.

\section{Plate I. fig. 31 .}

Plant mass mucous, hyaline or dark-purple; families $2-8$ celled, usually oblong, 8-I I mic. in length; plants, including sheath, 6-7.8 mic. in diameter, globose, often solitary; sheaths hyaline or dark purple, granular; cells I-2.6 mic. in diameter, globose, pale blue-green.

Hawaii. In hot water. Volcano of Mauna Kea. Island of Hawaii. 1896-97. (Schauinsland).

50. Gloeocapsa ambigua Naegeli in Kuetz. Spec. Algar, 220. I849. De Toni. Syll. Algar. 5: 4I. I907.

Setchell and Gardner. Algae of Northwestern America. Univ. Calif. Pub. Bot. I: 179. I903. (G. a m bigua f. fus c o lut e a Naeg.)

Plant mass crustaceous, violet becoming black; families about 62 mic. in diameter; plants $4-8 \mathrm{mic}$. in diameter, spherical; sheaths violet, usually opaque not lamellose; cells $1.8-2.5$ mic. in diameter; cell contents finely granular, blue-green. 
Alaska. In mountain stream. Orca. (Jepson).

5I. Gloeocapsa violacea (Corda) Rabenhorst. Fl. Eur. Algar. 2: 4I. I865. De Toni. Syll. Algar. 5: 39. 1907.

Tilden. American Algae. Cent. II. no. I96. I896; On some Algal stalactites of the Yellowstone National Park. Bot. Gaz. 24: I98. p1. 8. f. 5. 1897; Observations on some West American Thermal Algae. Bot. Gaz. 25: I03. I898. Collins, Holden and Setchell. Phyc. Bor.-Am. Fasc. I2. no. 551. I899. Collins. Phycological Notes of the late Isaac Holden,-II. Rhodora. 7: 235. I905.

\section{Plate I. fig. 32.}

Plant mass thin, mucous or gelatinous, dull violet or grayish-violet; families about Ioo mic. in diameter; plants 10-17 mic. in diameter, globose; sheaths not lamellose, violet or rose-colored; outer layers colorless, hyaline, very wide; cells 3.5 mic. in diameter; cell contents granular, blue-green.

Alaska. (Setchell). Connecticut. "On vertical face of moist limestone, east side of road and a few rods from it, a mile or so from the station on the road to Bull's Bridge." Gaylordsville. October r8g8. (Holden). Wyoming. Valley of the Nez Perces Creek, Lower Geyser Basin, Yellowstone National Park. June I896. (Tilden).

52. Gloeocapsa dubia Wartmann in Rabenhorst. Die Algen Europas. no. 1092. Kirchner. Algen. Kryptogamen-Flora von Schlesien. 256. I878. De Toni. Syll. Algar. 5: 34. I907.

Farlow. Notes on the Cryptogamic Flora of the White Mountains. Appalachia. 3: 236. I883.

Plant mass either grumous or widely expanded, gelatinous, firm, reddish-orange, when dried generally of a dull greenish color; plants I I-24 mic. in diameter, spherical or oblong, densely aggregated, usually associated in families of twos or fours; sheaths very thick, usually twice the diameter of the cell, not lamellose, soon peeling off; cell contents granular, brownish, when dried homogeneous and bluish-green.

Greenland. (Boergesen). New Hampshire. On rocks. Flume; Cabot Mountain, Shelburne. (Farlow).

53. Gloeocapsa sanguinea (Agardh) Kuetzing. Phyc. Gen. 174. I843. De Toni. Syll. Algar. 5: 36. 1907 .

Plant mass thin, gelatinous, extended, blood red, or thicker, somewhat crustaceous and black; families 25-50, rarely 140 mic. in diameter; sheaths very wide, not lamellose, intensely blood red, inner layers pale red, outer layers colorless or nearly colorless; cells $3.5-9$ mic. in diameter; cell contents granular, pale blue-green.

Greenland. (Boergesen).

Genus ENTOPHYSALIS Kuetz. Phyc. Gen. I77. 1843.

Plant mass globose, cartilaginous, including numerous, more or less confluent small families of cells; cells spherical, each surrounded by an elliptical sheath, associated in families. 
I Plant mass crustaceous; cells $2-5$ mic. in diameter

II Plant mass mucous; cells 4-6 mic. in diameter
E. granulosa

E. magnoliae

54. Entophysalis granulosa Kuetzing. Phyc. Gen. I77. pl. XVIII. f. 5. I843. De Toni. Syll. Algar. 5: 58. 1907.

Collins. Algae from Atlantic City, N. J. Bull. Torr. Bot. Club. I5: 309. I888. Martindale. Marine Algae of the New Jersey coast and adjacent waters of Staten Island. Mem. Torr. Bot. Club. I: 89. 1889. Wolle and Martindale. Algae. Britton's Catalogue of Plants found in New Jersey. Geol. Surv. N. J. 2:6rr. 1889. Collins. Notes on New England Marine Algae,-VI. Bull. Torr. Bot. Club. 23: I. I896. Collins, Holden and Setchell. Phyc. Bor.-Am. Fasc. 4. no. I52. I896. Collins. Preliminary Lists of New England Plants,-V. Marine Algae. Rhodora: 2: 41. 1900; Phycological Notes of the late Isaac Holden,-I. Rhodora. 7: I72. I905.

Plate I. fig. 33.

Plant mass crustaceous, up to I mm. in thickness, granular and warted, cartilaginous to fragile, brownish or black; cells 2-5 mic. in diameter; sheaths very thick, lamellose, brownish.

Maine. Forming an incrustation on edge of rocky tide pool, at extreme high water mark. Cape Rosier. July I895. (Collins). Massachusetts. (Collins). Connecticut. Forming a crust on stones between tide marks. Fresh Pond, Stratford. August 1895. (Holden). New Jersey. On old shells. Atlantic City. (Morse, Collins). "Forming a crumbly incrustation at high-water mark, and seeming to prefer lagoons or high tide-pools, where the water is quite salt and where the level does not vary much."-Collins.

55. Entophysalis magnoliae Farlow. Marine Algae of New England. 29. I881. De Toni. Syll. Algar. 5: 58. igo7.

Collins. Preliminary Lists of New England Plants,-V. Marine Algae. Rhodora. 2: 4I, 1900 .

Plant mass mucous; families densely branched; cells 4-6 mic. in diameter, dark purple, united in twos and fours, embedded in jelly.

Maine. (Collins). Massachusetts. Forming a thin slime on exposed rocks. Rare. Autumn. Magnolia Cove, Gloucester. (Farlow).

\section{Genus CHONDROCYSTIS Lemmerm.}

Abh. Nat. Ver. Bremen. 353. I899.

Plant mass cushion-shaped, widely expanded, up to $35 \mathrm{~cm}$. high, cartilaginous, soft, fragile, encrusted with lime at the base, curled up at periphery; families consisting of spherical masses of cells lying free, the membranes of which seem to be thickened into one layer.

56. Chondrocystis schauinslandii Lemmermann. Ergebn. einer Reise n. d.

Pacific. Abh. Nat. Ver. Brem. 16: 353. I899; seln. Bot. Jahrb. 34: 6I5. pl. 7. f. 22-29. I905. 5: 59. 1907 .
Algenfl. Sandwich-In-

De Toni. Syll. Algar. 
Plate I. fig. 34-36.

Plant mass rose-colored to red, thick, cushion-like, widely expanded, encrusted with lime on the under side; cells somewhat spherical or elongate, 2 mic. in diameter, 3-5 mic. in length; sheath thick.

Hawaii. On sides of lagoon. Island of Laysan. (Schauinsland).

Genus GLOEOTHECE Naegeli. Gatt. Einz. Alg. 57. 1849.

Colonies embedded in a common gelatinous tegument; cells cylindricaloblong, rounded at the ends, each surrounded by a wide mucous homogeneous or lamellose sheath; reproduction by transverse division of the cells in one direction only.

I Individual sheaths colorless

I Cells .8-2.5 mic. in diameter, 10.5-18 mic. in length

\section{G. linearis}

2 Cells $1.6-3$ mic. in diameter, 2.2-7.5 mic. in length

3 Cells 4-5.5 mic. in diameter, 6-I5 mic. in length

G. confluens

4 Cells 4-5 mic. in diameter, 6-1o mic, in length

G. rupestris

5 Cells 2.5-2.7 mic. in diameter, 4.8-5.7 mic, in length,

G. membranacea shaped with acute apices

G. lunata

II Individual sheaths partly or entirely colored

I Plant mass usually free-floating

(r) Sheaths colorless at margins; cells 3-4 mic. in diameter

G. magna

(2) Sheaths usually brownish or yellowish; cells 4-5.5 mic. in diameter, 6-I I mic. in length

G. fuscolutea

57. Gloeothece linearis Naegeli. Gatt. Einz. Alg. 58. 1849. De Toni. Syll. Algar. 5: 62. I907.

West and West. On some Freshwater Algae from the West Indies. Journ. Linn. Soc. Bot. 30: 276. 1895 .

\section{Plate II. fig. I, 2.}

Plant mass gelatinous, dull yellow becoming reddish; plants 9.5-I0.5 mic. in diameter, I0.5-18 mic. in length; sheaths very wide, colorless, hyaline, oblong or somewhat reniform; cells .8-2.5 mic. in diameter, I0.5-I8 mic. in length, linear-cylindrical, straight or curved, usually single; cell contents pale blue-green or green.

West Indies. On damp wall of dam, Sharp's River, St. Vincent. (Elliott).

58. Gloeothece confluens Naegeli. Gatt. Einz. Alg. 58. pl. I G. f. I. I849. De Toni. Syll. Algar. 5:60. 1907.

Wolle. Fresh Water Algae. III. Bull. Torr. Bot. Club. 6: I82. I877; Fresh-Water Algae U. S. 325. pl. 210. f. 6. I887. Collins. Algae of Middlesex County. I6. I888. Wolle and Martindale. Algae. Britton's Catalogue of Plants found in New Jersey. Geol. Surv. N. J. 2: 610. I889. 
Plate II. fig. 3 .

Plant mass gelatinous, amorphous, pale reddish-yellow or greenish; plants 9-10 mic. in diameter, I2-I6 mic. in length; sheaths wide, hyaline, colorless; cells I.6-3. mic. in diameter, 2.2-7.5 mic. in length, oblong-cylindrical, single or in pairs; cell contents homogeneous, greenish or becoming paler.

Massachusetts. Calcareous springs. Newton. (Farlow). New Jersey. On wet rocks. (Wolle). Pennsylvania. On wet rocks. Bethlehem. (Wolle).

59. Gloeothece rupestris (Lyngbye) Bornet. Les Algues de P. K. A. Schousboe. I77. I892. Wittrock and Nordstedt. Alg. Aq. Dulc. Exsicc. no. 399. 1880. De Toni. Syll. Algar. 5: 63. 1907.

Collins, Holden and Setchell. Phyc. Bor.-Am. Fasc. I5. no. 703. I900; Phyc. Bor.-Am. Fasc. 25. no. 1204. I905., (G. c y st if era (Hass.) Rab.)

Plate II. fig. 4 .

Families 25-45 mic. in diameter, spherical or oval, containing two, four or eight plants; plants 8-12 mic. in diameter, $12-36$ mic. in length; sheaths colorless or brownish-yellow; cells 4-5.5 mic. in diameter, 6-15 mic. in length; cell contents blue-green.

California. On dripping boards. Lake Chabot. San Leandro, Alameda County. June Igo2. (Osterhout and Gardner). Bermudas. On ground. Spanish Point. Bermuda. January 1900. (Farlow).

Var. tepidariorum (A. Br.) Hansirg. Prodromus. 2: 136. f. 46.1892. De Toni. Syll. Algar. 5: 64. 1907.

Collins, Holden and Setchell. Phyc. Bor.-Am. Fasc. I3. no. 601. I899. (G. cystifera (Hass.) Rab.).

Plant mass dusky olive or brownish blue-green, often widely expanded; families 2I-40 mic. in diameter, 30-50 mic. in length, containing usually two or four plants; cells 5-6 mic. in diameter, 5-I5 mic. in length, elliptical or long-cylindrical, after division almost spherical; cell contents finely granular, blue-green.

Rhode Island. On wood work of a dam. Centredale. April i 894. (Osterhout).

6o. Gloeothece membranacea (Rabenhorst) Bornet. Les Algues de P. K. A. Schousboe. 175. I892. De Toni. Syll. Algar. 5: 61. I907.

Plant mass membranaceous (resembling a Nos to c), dark olive green; cells 4-5 mic. in diameter, 6-1o mic. in length, always oblong before division; sheaths disappearing after third or fourth division.

North America. (Collins).

6I. Gloeothece lunata W. and G. S. West. On some Freshwater Algae from the West Indies. Journ. Linn. Soc. Bot. 30: 277. pl. I6. f. 9. I895. De Toni. Syll. Algar. 5:65. I907. 


\section{Plate II. fig. 5.}

Colonies I9 mic, in diameter, 32.5 mic. in length, oval or elliptical; cells 2.5-2.7 mic. in diameter, 4.8-5.7 mic. in length, somewhat crescent shaped, with acute apices, associated in families of two or four; cell contents homogeneous, blue-green.

West Indies. On damp wall of dam. Sharp's River. St. Vincent. May I892. (Elliott).

62. Gloeothece magna Wolle. Fresh Water Algae. II. Bull. Torr. Bot. Club. 6: 138. 1877. De Toni. Syll. Algar. 5: 62. 1907.

Plant mass large, thin, irregularly oblong, pale yellowish green: colony containing many plants; sheaths usually colorless at the margins; cells 3-4 mic. in diameter, nearly twice as long as wide.

Pennsylvania. Forming a coating on small water plants, or floating in ponds, many families joined together. Near Bethlehem. (Wolle).

63. Gloeothece fuscolutea Naegeli. Gatt. Einz. Alg. 58. 1849. De Toni. Syll. Algar. 5: 66. 1907.

Tilden. Collection of Algae from the Hawaiian Islands. Haw. Almanac and Annual for I902. II3. r9or. American Algae. Cent. V. no. 500. I90I; Algae Collecting in the Hawaiian Islands. Postelsia: The Year Book of the Minnesota Seaside Station. I: I47. I902.

Plant mass soft, gelatinous, blue-green; sheaths thick, lamellose, colorless, brownish or yellowish; cells 4-5.5 mic. wide, 6-I I mic. long, oblongcylindrical, single or associated in families of four or eight; cell contents blue-green.

Hawaii. Covering surface of water in plat in rice field. Aiea. Oahu. June Igoo. (Tilden).

\section{Genus APHANACAPSA Naeg. Gatt. Einz. Alg. 52. I849.}

Plant mass more or less expanded, colorless or blue-green, yellow or brown; plants spherical or angular from mutual pressure, single or in pairs; individual sheaths thick, very soft, colorless, not distinct, confluent into a mucous, amorphous, homogeneous colonial tegument; tegument colorless or tinted brown or blue-green; reproduction by successive division of the cells alternately in three directions.

I Plant mass colorless.

I Cells $1.5^{-2}$ mic. in diameter

A. elachista

2 Cells ro-I6 mic. in diameter

A. zanardinii

II Plant mass green or blue-green.

I Plant mass globose, gelatinous, dirty green; cells $3.2-5.6 \mathrm{mic}$, in diameter

A. grevillei

2 Plant mass hemispherical, gelatinous, blue-green; cells $5-6$ mic. in diameter

A. rivularis 
3 Plant mass amorphous, gelatinous, dirty green or olive

\section{A. virescens}

III Plant mass brown.

Cells 4.5-5.5 mic. in diameter A. brunnea

64. Aphanocapsa elachista W. and G. S. West. On some Freshwater Algae from the West Indies. Journ. Linn. Soc. Bot. 30: 276. pl. I5. f. 9, I0. I895. De Toni. Syll. Algar. 5: 73. 1907.

Plate II. fig. 6.

Colonies $26-38 \mathrm{mic}$. in diameter, not forming a distinct plant mass, very small, somewhat globose; sheaths firm, gelatinous, colorless, not lamellose, soon diffluent; cells $1.5-2$ mic. in diameter, spherical, single or in pairs, loosely arranged; cell contents homogeneous, blue-green.

West Indies. On trees. Summit of Trois Pitons (450o feet elevation). November and December I892; in stream, Grande Soufrière, Dominica. (Elliott).

"This species seems characteristically distinct by reason of its minute cells in the very small, globose colonies, which were scattered amongst other algae."-West.

65. Aphanocapsa zanardinii (Hauck) Hansgirg. De Toni. Syll. Algar. 5: 67.1907.

Plant mass colorless; cells ro-16 mic. in diameter, globose, single or in families of two or four; individual sheaths very thin, hyaline, scarcely visible; cell contents homogeneous, sometimes granular, emerald green.

Massachusetts. (Collins).

66. Aphanocapsa grevillei (Hassall) Rabenhorst. Fl. Eur. Algar, 2: 50. I865. De Toni. Syll. Algar. 5: 73. 1907.

Wolle. Fresh-Water Algae. U. S. 333. pl. 210. f. 38, 39. I887. Bennett. 'Plants of Rhode Island. I 5. I888. Buchanan. Notes on the Algae of Iowa. Proc. Iowa Acad. Sci. I4: 9. 1908.

\section{Plate II. fig. 7 .}

Plant mass gelatinous, globose, densely aggregated, more or less confluent, dirty green, when dry becoming olive or brownish; sheaths soon diffluent; cells 3.2-5.6 mic. in diameter, spherical or elliptical, rather crowded, single or in pairs; cell contents finely granular, blue-green.

Greenland. (Boergesen). Pennsylvania. Submerged stones in shallow pond water. (Wolle). Rhode Island. Benedict and other ponds. (Bennett). Iowa. Pond near R. R. Ames. 1905. (Buchanan).

67. Aphanocapsa rivularis (Carmichael) Rabenhorst. Fl. Eur. Algar. 2: 49. 1865. De Toni. Syll. Algar. 5: 69. 1907.

Wolle. Fresh Water Algae. II. Bull. Torr. Bot. Club. 6: I37. I877.

$$
\text { Plate II. fig. 8, } 9 .
$$

Plant mass hemispherical, gelatinous, tuberculose, often confluent, blu- 
ish-green becoming brownish when dry; sheaths very thick, not lamellose, colorless, soon diffluent; cells 5-6 mic. in diameter, spherical, scattered, single or in pairs; cell contents finely granular, blue-green.

Pennsylvania. In ponds attached to wood or stone. (Wolle).

68. Aphanocapsa virescens (Hassall) Rabenhorst. Fl. Eur. Algar. 2: 48. I865. De Toni. Syll. Algar. 5: 68. 1907.

Wolle. Fresh-Water Algae U. S. 333. pl. 210. f. 33. I887. Wolle and Martindale. Algae. Britton's Catalogue of Plants found in New Jersey. Geol. Surv. N. J. 2:612. I889. West. The Freshwater Algae of Maine. Journ. of Bot. 27: 207. I889.

\section{Plate II. fig. Io, II.}

Plant mass amorphous, gelatinous, more or less expanded, dirty green or olive, becoming brownish; sheaths scarcely visible, diffluent; cells about 6 mic. in diameter, globose, single or in pairs; cell contents homogeneous, often showing a central granule, pale blue-green.

Maine. (West). New Jersey. On wet stones and rocks. (Wolle).

69. Aphanocapsa brunnea Naegeli. Gatt. Einz. Alg. 52. I849. De Toni. Syll. Algar. 5: 71. 1907.

Wolle. Fresh-Water Algae U. S. 329. 1887.

Plant mass gelatinous, membranaceous, expanded, brownish; sheaths not visible; cells $4.5-5.5 \mathrm{mic}$. in diameter, spherical, in division oblong, single or in pairs, crowded; cell contents finely granular, pale yellowish brown or greenish brown.

North America. Forming brownish-olive, floating masses in stagnant waters. (Wolle). Canada. Minnesota Seaside Station, Vancouver Island. British Columbia. July Igor. (Crosby and Leavitt).

Genus APHANOTHECE Naeg. Gatt. Einz. Algar. 59. I849.

Plant mass more or less expanded, somewhat spherical or without definite shape; individual sheaths thick, not distinct, confluent into a mucous, amorphous, homogeneous colonial tegument; cells oblong; reproduction by division of the cells in one direction only.

I Plant mass without deinnite shape.

I Cells I-2 mic. in diameter

A. saxicola

2 Cells more than 2 mic. in diameter

(I) Plant mass dirty green or olive brown; cells $2.5-3$ mic. in diameter

A. conferta

(2) Growing in very salt water; cells 5 mic. in diameter, hardly longer than broad

A. utahensis

(3) Cells one to three times as long as broad

A Plant mass colorless; cells 4-4.5 mic. in diameter

A. microscopica 
B Plant mass colored

a Plant mass blue-green, olive or yellowish-brown; cells 2-3.5 mic. in diameter

A. castagnei

b Plant mass pale blue-green; cells $3-8$ mic. in diameter

A. pallida

c Plant mass pale yellowish-green or olive; cells $2-3$ mic. in diameter

A. microspora

d Plant mass yellowish-brown or olive; cells 4-4.5 mic. in diameter, irregularly scattered A. naegelii

II Plant mass more or less spherical

I Plant mass pale blue-green; cells 3-5 mic. in diameter

A. stagnina

2 Plant mass bright or dark emerald green; cells 5-6.5 mic. in diameter

A. prasina

70. Aphanothece saxicola Naegeli. Gatt. Einz: Alg. 6o. p1. I H. f. 2. I849. De Toni. Syll, Algar. 5:81. 1907.

Collins, Holden and Setchell. Phyc. Bor.-Am. Fasc. 25. no. I 203. I905; Phyc. Bor.-Am. Fasc. 27. no I30I. 1906. West and West. On spme Freshwater Algae from the West Indies. Journ. Linn. Soc. Bot. 30: 277. 1895.

Plant mass mucous-gelatinous, colorless or yellowish, without definite shape; cells I-2 mic. in diameter, $2-6$ mic. in length, somewhat cylindrical, with rounded ends, single or in pairs, sometimes surrounded by many partially dissolved sheaths; cell contents pale blue-green.

Massachusetts. Forming soft masses of irregular form, floating among other algae. Horn Pond. Woburn. September 1905. (Collins). California. Walls of reservoir. Del Monte, Monterey County. September I902. (Osterhout). West Indies. "In small masses of 70-120 mic. in diameter, amongst mosses on trees. Rather scarce." Summit of Trois Pitons (4500 feet), Dominica. November and December I892. (Elliott).

7J. Aphanothece conferta Richter in Hauck and Richter. Phykotheka Universalis. no. 487. I892. De Toni. Syll. Algar. 5: 84. I907.

Collins, Holden and Setchell. Phyc. Bor.-Am. Fasc. 24. no. II52. I904.

Plant mass gelatinous-mucous, membranaceous, expanded, dirty green or olive brown; individual sheaths colorless, diffluent; cells $2.5-3$ mic. in diameter, 4.5-5.5 mic. in length, spherical or oblong, single or in pairs, crowded in families; cell contents finely granular, pale blue-green or olive.

California. On trunk of Bay tree. Strawberry Creek, Berkeley. March Ioo3. (Gardner).

72. Aphanothece utahensis Tilden. American Algae. Cent. III. no. 297. 1898.

Plant mass $\mathrm{I}-6 \mathrm{~cm}$. in diameter, forming thin, gelatinous, brown and blue-green membranes; cells 5 mic. in diameter, oval or nearly spherical, single or in twos. 
Utah. Floating near shore of lake and washed up on beach. Garfield Beach, Great Salt Lake. July I897. (Tilden).

73. Aphanothece microscopica Naegeli. Gatt. Einz. Alg. 59. pl. I H. f. I. I849. De Toni. Syll. Algar. 5:83. 1907.

West and West. On some Freshwater Algae from the West Indies. Journ. Linn. Soc. Bot. 30: 277. 1895. Collins, Holden and Setchell. Phyc. Bor.-Am. Fasc. 12. no. 552. 1899. Saunders. The Algae. Harriman Alaska Expedition. Proc. Wash. Acad. Sci. 3:397. 190r. Collins. Algae of the Flume. Rhodora. 6: 230. I904.

\section{Plate II. fig. I2.}

Plant mass .25-2 mm. in diameter, gelatinous, colorless, globose or oblong, later irregular in shape, floating; cells 4-4.5 mic. in diameter, 6-9 mic. long, oblong-cylindrical, single or in twos; cell contents blue-green.

Greenland. (Richter, Boergesen). Alaska. Forming a slimy coating, with Chroococcus, on a perpendicular cliff over which water was trickling. Juneau. (Saunders). New Hampshire. On wall of the "Flume." (Collins). Massachusetts. On flower pots. Botanic Garden. Cambridge. February I895. (Richards). West Indies. On damp wall of dam. Sharp's River, St. Vincent; on trees, summit of Trois Pitons (450o feet), Dominica. (Elliott).

74. Aphanothece castagnei (Brébisson) Rabenhorst. F1. Eur. Algar. 2: 64. 1865. De Toni. Syll. Algar. 5: 81. 1907.

Setchell and Gardner. Algae of Northwestern America. Univ. Calif. Pub. Bot. I : I80. I903.

\section{Plate II. fig. I3.}

Plant mass gelatinous, amorphous, expanded, bluish-green, olive or yellowish-brown; sheaths not usually visible; cells 2-3.5 mic. in diameter, 3-8 mic. in length, globose, oblong or polygonal, of various sizes, somewhat crowded; cell contents pale blue.

Alaska. In sulphur waters. (Farlow, Setchell). Washington, D. C. (Farlow). Washington. In a jar of water in the laboratory. University of Washington, Seattle. (Gardner).

75. Aphanothece pallida (Kuetzing) Rabenhorst. Fl. Eur. Algar. 2: 64. I865. De Toni. Syll. Algar. 5:83. 1907.

Wolle. Fresh-Water Algae U. S. 325. pl. 210. f. 7, 8. 1887.

Plant mạs 4-6 mm. in diameter, gelatinous, soft, somewhat transparent, pale blue-greeñ; cells 3-8 mic. in diameter, 5-24 mic. in length, oblong-elliptical or cylindical, usually scattered; cell contents pale blue-green.

Pennsylvania. On wet or marshy ground. (Wolle). Minnesota. Keegan's Lake, Minneapolis. October Igo7. (Hone).

76. Aphanothece microspora (Meneghini) Rabenhorst. Fl. Eur. Algar. 2: 64. 18б5. De Toni. Syll. Algar. 5: 84. 1907.

Richter. Süsswasseralgen aus dem Umanakdistrikt. Bib. Bot. Heft. 42. 
3. I897. Saunders. The Aigae. Harriman Alaska Expedition. Proc. Wash. Acad. Sci. 3:397. 1901. Setchell and Gardner. Algae of Northwestern America. Univ. Calif. Pub. Bot. I: I80. 1903. Collins. Algae of the Flume. Rhodora. 6:230. 1904.

Plant mass amorphous, irregularly lobed, gelatinous-mucous, soft, hyaline, pale yellowish-green or olive; sheaths colorless, usually entirely dissolved; cells 2-3 mic. in diameter, 4-9 mic. in length, oblong, single or in pairs; cell contents pale blue.

Greenland. Umanak. (Vanhöffen.). Alaska. Forming with Chroococcus t u r gidus, a slimy coating on a perpendicular cliff, over which water was trickling. Juneau. (Saunders). New Hampshire. (Collins).

77. Aphanothece naegelii Wartmann in Rabenhorst. Fl. Eur. Algar. 2: 65. 1865. De Toni. Syll. Algar. 5: 77. 1907.

Tilden. Collection of Algae from the Hawaiian Islands. Haw. Alma1)ac and Annual for 1902. I13. I90I; American Algae. Cent. V. no. 497. I90I; Algae Collecting in the Hawaiian Islands. Postelsia: The Year Book of the Minnesota Seaside Station. I: I53. 1902.

\section{Plate II. fig. I4.}

Plant mass gelatinous, yellowish-brown or olive, adhering to paper when dried; sheaths diffuent; cells 4-4.5 mic. in diameter, 6.5-8 mic. in length, oblong or oval, almost spherical after division, irregularly scattered, rather densely crowded; cell contents pale blue-green.

Hawaii. Forming soft, olive-brown lumps on sides of damp cliff among mosses and liverworts. Elevation 350 feet. Kaliawaa Falls. Makao, Koolauloa, Oahu. June I90o. (Tilden).

;8. Aphanothece stagnina (Sprengel) A. Braun in Rabenhorst. F1. Eur. Algar. 2:66. 1865. De Toni. Syll. Algar. 5: 76. 1907.

Setchell and Gardner. Algae of Northwestern America. Univ. Calif. Pub. Bot. I: I80. 1903. Collins, Holden and Setchell. Phyc. Bor.-Am. Fasc. 27. no. I302. I906.

Plate II. fig. I5.

Plant mass $.5^{-2} \mathrm{~cm}$. in diameter, gelatinous, oblong, elliptical or nearly globose, hyaline, pale blue-green; cells 3-5 mic. in diameter, 5-8 mic. in length, oblong-oval; cell contents pale blue-green.

Alaska. (Farlow). Michigan. Forming firm, light green, spherical or tuberculate floating masses. Walnut Lake, Oakland County. May Igo6. (Hankinson).

79. Aphanothece prasina A. Braun in Rabenhorst. Fl. Eur. Algar. 2: 65. I865. De Toni. Syll. Algar. 5:78. I907.

Wolle. Fresh-Water Algae U. S. 325. pl. 210. f. 9, ro. 1887. ' Collins. Algae of Middlesex County. 16. r888. Wolle and Martindale. Algae. Britton's Catalogue of Plants found in New Jersey. Geol. Surv, N. J. 2:610. 1889. Collins, Holden and Setchell. Phyc. Bor.-Am. Fasc. 6. no. 25J. 1897. Tilden. Collection of Algae from the Hawaiian Islands. Haw. 
Almanac and Annual for 1902. II3. Igor; American Algae. Cent. V. no. 498. r90I; Algae Collecting in the Hawaiian Islands. Postelsia: The Year Book of the Minnesota Seaside Station. I: I46. I902.

\section{Plate II. fig. I6.}

Plant mass gelatinous, more or less globose, tuberculose or angular, bright emerald green, sometimes confluent and then lobed; sheaths diffluent; cells 5-6.5 mic. in diameter, 7.7-I I mic. long, oblong or ovoid, often spherical after division; cell contents blue-green.

Massachusetts. Cambridge. (Farlow). Connecticut. In free swimming gelatinous masses of a yellowish or bluish green color, globular when young, later becoming irregular in shape. Norwich. September 1892. (Setchell). New Jersey. Floating on ponds. (Wolle). Hawaii. Forming free-swimming, blue-green tuberculose, globose or flattened soft masses, floating in ditch in rice field near beach. Aiea, Oahu. June Igoo; in brackish, stagnant water. Meheiwi, Makao, Koolauloa, Oahu. June Igoo. (Tilden).

\section{Genus MICROCYSTIS Kuetz. Linnaea 8:372. 1833.}

Colonies spherical or somewhat spherical, solid, finally becoming hollow and lobed, single or associated in clusters, containing large numbers of cells, surrounded by a colorless, gelatinous tegument; cells spherical, oval or elliptical; cell contents green or blue-green, often showing vacuoles; reproduction by cell division in three directions.

I Cells spherical.

I Colonies more or less spherical, usually containing several daughter colonies each surrounded by its own tegument; cells 2-4 mic. in diameter

M. ichthyoblabe

2 Plant mass dull yellowish becoming olive; colonies $30-70$ mic. in diameter; cells 2.2-4 mic. in diameter

M. donnellii

3 Colonies spherical, flattered, orbicular, lens-shaped, sometimes confluent, surrounded by a thick, lamellose common tegument; cells 3-4 mic. in diameter

M. marginata

4 Colonies more or less spherical or oblong, with an indistinctly limited tegument, pale or yellowish-green; cells $4-6.5$ mic. in diameter.

M. flos-aquae

II Cells oval or oblong, sometimes almost spherical.

I Colonies spherical, oblong or flattened, sometimes containing several daughter colonies each surrounded by its own tegument; cells I-I.5 mic. in diameter, 3-5 mic. in length, oblong M. elabens

2 Plant mass pulverulent, bright glaucous or whitish blue-green; colonies spherical or oblong; cells 2-3 mic. in diameter, somewhat spherical or oval

M. pulverea

3 Plant mass irregular, firm, gelatinous, pink, brown or green, growing in very salt water; cells $2.5-4$ mic. in diameter, 6-7 mic. in length, oblong or elliptical

M. packardii

4 Plant mass mucous, floccose, amorphous, sky-blue; colonies somewhat 
spherical, distinctly limited; cells somewhat spherical or ellipsoid (size unknown)

M. piscinalis

5 Colonies irregular in shape, with an indistinctly limited tegument; cells $5-5.5$ mic. in diameter, spherical or oval

M. pallida

8o. Microcystis ichthyoblabe Kuetzing. Tab. Phyc. I: 7. pl. 8. I845-I849. De Toni. Syll. Algar. 5: 88, I907.

Wolle. Fresh-Water Algae U. S. 330. 1887. Wolle and Martindale. Algae. Britton's Catalogue of Plants found in New Jersey. Geol. Surv. N. J. 2: 6II. I889. Snow. The Plankton Algae of Lake Erie. U. S. Fish Comm. Bull. for 1902. 22: 392. I903. (Poly y st is icthioblabe Kg.)

Colonies membranaceous, thin, more or less spherical, surrounded by a common gelatinous tegument, usually containing several daughter colonies each surrounded by its own tegument, blue-green; cells $2-4$ mic. in diameter, spherical; cell contents showing vacuoles, pale blue-green.

United States. (Pike, Farlow, Collins). New Jersey. Occasional in small pools. (Wolle). Ohio. Put-in-Bay. Lake Erie. (Snow).

8I. Microcystis donnellir Wolle. Fresh Water Algae. Bull. Torr. Bot. Club. 6: 282.1879 .

Plant mass dull yellowish becoming olive; colonies $30-70$ mic. in diameter, spherical or oval, often more or less angular, green; cells $2.2-4$ mic. in diameter; cell contents granular, green.

Maryland. In soft gelatinous masses, often nine and ten inches in diameter, floating in poncls, Garrett County. July I878. (Smith).

82. Microcystis marginata (Meneghini) Kuetzing. Tab. Phyc. I: 6. p1. 8. 1845-1849. De Toni. Syll. Algar. 5: 91. I907.

Wolle. Fresh Water Algae. II. Bull. Torr. Bot. Club. 6: 137. 1877. (Anacystis marginata Menegh.); Fresh-Water Algae U. S. 329. 1887. (A. marginat a Kg.) Fanning. Observations on the Algae of the St. Paul city water. Minn. Bot. Studies. 2: 613. pl. 45. I90I. Saunders. The Algae. Harriman Alaska Expedition. Proc. Wash. Acad. Sci. 3: 397. 190i. (M. marginat a Naeg.) Setchell and Gardner. Algae of Northwestern America. Univ. Calif. Pub, Bot. I: I80. 1903. Clark. The Holophytic Plankton of Lakes Atitlan and Amatitlan, Guatemala. Proc. Biol. Soc. Wash. 21: 94. I908.

\section{Plate II. fig. I7.}

Colonies spherical, flattened or orbicular and lens-shaped, sometimes confluent, surrounded by a thick, lamellose common tegument, pale green. colorless at the margin; cells .3-4 mic. in diameter, densely crowded, spherical or sometimes angular; cell contents blue-green, becoming granular.

United States. In ponds of stagnant water. (Wolle). Alaska. Forming a slimy coating on a perpendicular cliff. Near Juneau. (Saunders); forming slimy coatings on dripping rocks. Glacier Valley, Unalaska. (Setchell and Lawson). Minnesota. St. Paul city water. (Fanning). Central America. Lake Amatitlan, Guatemala. (Meek). 
83. Microcystis flos-aquae (Wittrock) Kirchner in Engler and Prantl. Nat. Pflanz. I I a. 56. f. 49 N. Igoo. De Toni. Syll. Algar. 5: 86. 1907.

Tilden. Notes on a Collection of Algae from Guatemala. Proc. Biol. Soc. Wash. 21 : I53. 1908.

Plate II. fig. I8.

Colonies more or less spherical or oblong, with an indistinctly limited tegument, often several lying close together, pale or yellowish blue-green; cells 4-6.5 mic. in diameter, spherical, often densely crowded; cell contents showing vacuoles, pale bluish-green.

- Central America. Lake Amatitlan, Guatemala. Temperature of water $73^{\circ}$. January I906. (Kellerman, Meek and Smith).

84. Microcystis elabens (Meneghini) Kuetzing. Tab. Phyc. I: 6. pl. 8. I8451849. De Toni. Syll. Algar. 5: 88. I907.

Farlow. Marine Algae of New England. 28. I88I. (Poly cyst is e labens Kuetz.). Martindale. Marine Algae of the New Jersey Coast and Adjacent Waters of Staten Island. Mem. Torr. Bot. Club. I: 90. I889. Collins. Algae.-Rand and Redfield's Flora of Mount Desert Island, Maine. 249. I894. Collins. Preliminary Lists of New England Plants.-V. Marine Algae. Rhodora. 2: 42 . I900. Collins, Holden and Setchell. Phyc. Bor.Am. Fasc. 23. no. iroI. I903. Collins. Phycological Notes of the late Isaac Holden,-I. Rhodora. 7: I72. I905.

\section{Plate II. fig. I9.}

Colonies spherical, oblong, or flattened, membranaceous, surrounded by a common gelatinous tegument, sometimes containing several daughter colonies each surrounded by its own tegument, bluish or olive-green; cells I-I.5 mic. in diameter, 3-5 mic. in length, oblong; cell contents showing vacuoles.

Maine. On rocky sides of a tide pool at high water mark. Cape Rosier. July 1896; among small algae. Seal Harbor. (Collins). New Hampshire. (Collins). Massachusetts. "Common in summer on decaying algae, over which it forms slimy masses." Wood's Holl. (Farlow). Rhode Island. (Collins). Connecticut. On decaying algae. Fresh Pond. August. (Holden). New York. Prince's Bay, Staten Island. (Pike).

85. Microcystis pulverea (Wood) De Toni. Syll. Algar. 5: 92. 1907.

Wood. Contr. Hist. Freshwater Algae North America. 79. 1872. (Pleurococcus pulvereus Wood). Wolle. Fresh Water Algae. III. Bull. Torr. Bot. Club. 6: I82. I877. (A n a cy st is gla uc a Wolle); Fresh-Water Algae U. S. 329. pl. 210. f. 25. I887. (A. pulvereus (Wood) Wolle).

Plant mass pulverulent, bright glaucous or whitish blue-green, composed of very numerous and densely crowded colonies; colonies spherical or oblong, usually surrounded by a diffluent, hyaline tegument; cells 2-3 mic. in diameter, somewhat spherical, oval or angular, very much crowded; cell contents pale blue or olive green. 
Pennsylvania. Forming an extended stratum over the bottom of limestone spring. The stratum is in places nearly an inch in thickness and when lifted by the hand is found to be loose and crumbly. "Boiling Springs", two miles from Bellefonte, Centre County. (Wood). On bottom of limestone springs. Northampton and Lehigh Counties. (Wolle).

86. Microcystis packardii (Farlow) nob. De Toni. Syll. Algar. 5: 93. I907.

Packard. The Sea-weeds of Salt Lake. Am. Nat. 13: 70I. 1879. (Polycystis packardii Farlow). Tilden. American Algae. Cent. III. no. 298 . 1898 .

Plate II. fig. 20.

Plant mass irregular in shape, firm, gelatinous, displaying various tints of pink, brown or green; cells 2:5-4 mic. in diameter, 6-7 mic. in length, oblong or elliptical.

Utah. Forming irregularly-shaped balls or masses of a firm gelatinous structure, showing various tints of pink, brown and green. In thick masses around edge of lake for a distance of forty feet out from shore and one to two feet in depth. Often washed ashore and left in beds on sand. Garfield Beach, Great Salt Lake. July I897. (Tilden).

87. Microcystis piscinalis (Brügg.) De Toni. Syll. Algar. 5:90. I907.

Wolle. Fresh Water Algae. II. Bull. Torr. Bot. Club. 6: I37. 1877. (Polycystis piscinalis Brügg.)

Plant mass mucous, floccose, amorphous, sky-blue, becoming graygreen when dried; colonies somewhat spherical, distinctly limited, many sometimes surrounded by a more or less dissolved common tegument; cells somewhat spherical or ellipsoid; cell contents homogeneous, blue-green.

Pennsylvania. In pools. Near Bethlehem. (Wolle).

88. Microcystis pallida (Farlow) Lemmermann. Algen. Kryptogamenflora der Mark Brandenburg. 3: 77. 1907. De Toni. Syll. Algar. 5: 93.1907.

Collins. Algae from Atlantic City, N. J. Bull. Torr. Bot. Club. I5:310. I888. (P o l y c y st is pallida (Kuetz.) Farlow). Martindale. Marine Algae of the New Jersey Coast and Adjacent Waters of Staten Island. Mem. Torr. Bot. Club. I: 90. I889. Wolle and Martindale. Algae. Britton's Catalogue of Plants found in New Jersey. Geol. Surv. N. J. 2: 6II. I889. Collins. Algae.-Rand and Redfield's Flora of Mount Desert

- Island, Maine. 249. I894. Preliminary Lists of New England Plants,-V. Marine Algae. Rhodora. 2: 43. 1900.

Colonies irregular in shape, with an indistinctly limited tegument; cells 5-5.5 mic. in diameter, spherical or oval; cell contents bluish green.

Maine. Among small algae. Seal Harbor. (Collins). Massachusetts. Gloucester (Farlow). Rhode Island. Newport. (Farlow). New Jersey. On decaying algae. Atlantic City. (Morse). 


\section{Genus CLATHROCYSTIS Henfrey}

Mic. Journ. 53. pl. 4. f. 28-36. 1856.

Colonies of variable shape, at first solid soon becoming saccate and clathrate, ("fragments of the broken fronds occurring in irregularly lobed forms"), surrounded by a colorless, gelatinous, indistinctly limited integument; cells spherical, numerous.

I Cells 3-4 mic. in diameter, spherical.

II Cells 6-9 mic. in diameter, spherical or oval

C. aeruginosa

C. robusta

89. Clathrocystis aeruginosa (Kuetzing) Henfrey. Mic. Journ. 53. pl. 4. f. 28-36. 1856. De Toni. Syl1. Algar. 5: 94. 1907.

Wolle. Fresh-Water Algae U. S. 327. pl. 210. f. 17, 18. I887. Collins. Algae of Middlesex County. 16. I888. Bennett. Plants of Rhode Island. 115. I888. Jelliffe. A Further Contribution to the Microscopical Examination of the Brooklyn Water Supply. Brook. Med. Journ. 8: 592.1894. Collins, Holden and Setchell. Phyc. Bor.-Am. Fasc. 2. no. 51. I895. Collins. Algae. Flora of the Blue Hills, Middlesex Fells, Stony Brook and Beaver Brook Reservations of the Metropolitan Park Commission, Massachusetts. 126. 1896. Tilden. List of Freshwater Algae collected in Minnesota during 1895. Minn. Bot. Studies. I: 599. 1896; American Algae. Cent. I1. no. 194. 1896. Collins, Holden and Setchell. Phyc. Bor.-Am. Fasc. 24. no. II53. 1904. Buchanan. Notes on the Algae of Iowa. Proc. Iowa Acad. Sci. I4: 9. 1908.

\section{Plate II. fig. 2I, 22.}

Plant mass a bright green scum, floating in vast strata on freshwater pools, presenting to the naked eye a finely granular appearance, when dried appearing like a crust of verdigris; colonies spherical or elongate, solid, soon becoming saccate and clathrate; cells $3-4 \mathrm{mic}$. in diameter, spherical, very numerous embedded in a colorless integument.

United States. Often floating in large strata as a glaucous green scum on fresh water pools. (Wolle). Massachusetts. Horn Pond, Woburn. (Farlow). Spot Pond, Stoneham; forming a floating scum on Middle Reservoir. Middlesex Fells. (Collins). Rhode Island. Common, at times abundant. (Bennett). Mashapaug Pond, Providence. October I892. (Osterhout). New York. Brooklyn water supply. (Jelliffe). Minnesota. Covering surface of lake in sheltered bays and around edges, sometimes to a depth of three inches. In decaying forms a milky white, ill-smelling scum. Long Lake, Hennepin County. September 1895. (Shaver and Tilden). On bottom at edge of lake in very small round bunches or flat patches, fragile. Como Park, St. Paul. August I895. (Tilden). Halsted's Bay, Lake Minnetonka. November 1906. (Hill). Minneapolis city water (Corbett). Iowa. Ames. I884. (Bessey). East Okoboji Lake. October 1904. (Buchanan). Washington. Floating in Green Lake. Seattle. December 1903. (Gardner).

"The smallest fronds met with are usually roundish or ellipsoidal. When quite young they appear to be solid, but as they grow by the multiplication of the internal cells and the secretion of gelatinous matter, the 
expansion takes place chiefly near the periphery, so that the frond becomes a hollow body. The walls of the sac then give way, and, as the expansion proceeds, orifices are formed in different parts, until the whole becomes a coarsely latticed sac or clumsy net of irregularly lobed form. Then this becomes broken up into irregular fragments of all shapes and sizes each of which recommences the expanding growth, and becomes a latticed frond."-Henfrey.

9o. Clathrocystis robusta Clark. The Holophytic Plankton of Lakes Atitlan and Amatitlan, Guatemala. Proc. Biol. Wash. 2I: 94. 1908.

Colony when young dense, spherical, surrounded by a gelatinous tegument, later perforate, clathrate or broken up into elongate rounded lobes; tegument tardily deliquescent, finally wholly dissolving, leaving a densely cohering mass of cells; cells 6-9 mic. in diameter, spherical or oval; cell contents (in formalin) bright blue-green.

Central America. Forming a flocculent bright blue-green scum on surface of water. Lake Amatitlar, Guatemala. February igo6. (Meek).

Genus GOMPHOSPHAERIA Kuetz.

Alg. Exsicc. Dec. I6. no. I5I. 1836.

Colonies spherical or ellipsoid, mucous, solid, free-swimming; tegument colorless or yellowish, usually thick, soon diffluent; cells pear-shaped or heart-shaped, rarely somewhat spherical, grouped in pairs, few in numbers, disposed chiefly towards the periphery of the tegument; cell contents often granular, bluish or greenish; reproduction by cell division alternately in three directions.

I Cells 4-5 mic. in diameter, 8-I2 mic. in length G. aponina

II Cells 3.2-4 mic. in diameter, spherical; cell contents pinkish or brownish

G. rosea

乌1. Gomphosphaeria aponina Kuetzing. Alg. Exsicc. Dec. I6. no, I5I. I836. De Toni. Syll. Algar. 5: 97. 1907.

Wolle. Fresh-Water Algae United States, 328. pl. 210. f. 20-22. I887. Bennett. Plants of Rhode Island. II5. I888. Wolle and Martindale. Algae. Britton's Catalogue of Plants found in New Jersey. Geol. Surv. N. J. 2: 6II. I889. Tilden. List of Fresh-Water Algae collected in Minnesota during I893. Minn. Bot. Studies. I: 3I. I894; List of Fresh-Water Algae collected in Minnesota during I895. Minn. Bot. Studies. 600. I896; American Algae Cent. III. no. 300. I898. Lemmermann. Planktonalgen Ergebn, einer Reise. n. d. Pacific. Abh. Nat. Bremen. I6: 313. I899. Setchell. Notes on Cyanophyceae.-III. Erythea. 7: 54. I899. Bessey, Pound and Clements. Additions to the Reported Flora of the State. Bot. Surv. Nebraska. 5: I2. I90I. Snow. The Plankton Algae of Lake Erie. U. S. Fish Commission Bull. for I902. 22: 392. 1903. Setchell and Gardner. Algae of Northwestern America. Univ. Calif. Pub. Bot. I: 180. I903. Lemmermann. Algenfl. Sandwich-Inseln. Bot. Jahrb. 34: 6I6. I905. Riddle. Brush Lake Algae. Ohio Nat. 5: 268. I905. Clark. The Holophytic Plankton of Lakes Atitlan and Amatitlan, Guatemala. 
Proc. Biol. Soc. Wash. 2r: 96. 1908. Buchanan. Notes on the Algae of Iowa. Proc. Iowa Acad. Sci. 14: 9. 1908.

Plate II. fig. 23-28.

Colonies 50-90 mic. in diameter, spherical or nearly spherical, bluegreen often becoming pale; tegument colorless, rather thick, lamellose; individual sheaths colorless; cells 4-5 mic. in diameter, 8-I2 mic. in length, pear-shaped or club-shaped, stalked, surrounded by individual sheaths; stalks thick, broad, gelatinous; cell contents not showing vacuoles, bluegreen, sometimes green or orange.

United States. Frequent in small pools. (Wolle). Rhode Island. Providence. (Bennett). New Jersey. In ponds and pools. (Wolle). Ohio. Plankton. Put-in-Bay, Lake Erie. (Snow). Brush Lake, Champaign County. (Riddle). Minnesota. Pool near Lake Kilpatrick. July I893. (Ballard). In tank in Botanical laboratory. University of Minnesota, Minneapolis. October I895; in covered tank. Zoological laboratory. University of Minnesota, Minneapolis. April I898. (Tilden). Iowa. Found only once. Stagnant pool. Eagle Grove. I904. (Buchanan). Nebraska. In aquaria. Lincoln. (Bessey). Washington. Floating intermingled with other algae in brackish waters. Whidbey Island. (Gardner). California. Near Los Angeles. (Monk). Central America. Lake Amatitlan, Guatemala. (Meek). Hawaii. Among marine algae. Island of Laysan. (Schauinsland).

Var. cordiformis Wolle. Fresh-Water Algae. VI. Bull. Torr. Bot. Club 9: 25. 188z. Bot. Notiser. 61. 1882. De Toni. Syll. Algar. 98. 1907.

Colonies $60 \mathrm{mic}$. in diameter; cells 6-13 mic. in diameter, 9-16 mic. in length, usually numerous.

Pennsylvania. Small ponds near Bethlehem. (Wolle).

92. Gomphosphaeria rosea (Snow) Lemmermann. Algae. Krypt. der Mark Rrandenburg. 3: 80. I907.

Snow. The Plankton Algae of Lake Erie. U. S. Fish Comm. Bull. for 1902, 22: 387, 390, 392. pl. 4. f. I7. I903. (C o el o s phaerium roseu m).

Colonies 35-52 mic. in diameter, spherical; tegument thin, gelatinous; cells 3.2-4 mic. in diameter, spherical, without individual sheaths, stalked; stalks, gelatinous, dichotomously branched; cell contents pinkish or brownish.

Ohio. Plankton. Put-in-Bay, Lake Erie. (Snow).

Genus Coelosphaerium Naeg. Gatt. Einz. Alg. 54. 1849.

Colonies spherical, mucous, hollow, free-swimming, containing many small cells; tegument mucous, soon confluent; cells globose, elliptical or ovoid, arranged just within the periphery of the tegument; cell contents granular, with gas vacuoles; reproduction by cell division, at first in one direction, afterwards alternately in three directions.

I Colonies 30-90 mic. in diameter; cells 2-5 mic. in diameter

C. kuetzingianum

II Colonies about $150 \mathrm{mic}$. in diameter; cells $5-7$ mic. in diameter

C. dubium 
93. Coelosphaerium kuetzingianum Naegeli. Gatt. Einz. Alg. 54. pl. I. C. 1849. De Toni. Syll. Algar, 5: 100. I907.

Farlow. Notes on Fresh-Water Algae. Bot. Gaz. 8: 224. 1883. Campbell. Plants of the Detroit River. Bull. Torr. Bot. Club. 13: 93. I886. Wolle. Fresh-Water Algae U. S. 327. pl. 210. f. I6. I887. Arthur. Some Algae of Minnesota supposed to be Poisonous. Fourth Bien. Rep. Bd. Regents Univ. of Minn. Suppl. I. Rep. Dept. Agric. Univ. of Minn. Io3. 1887. Wittrock and Nordstedt. Algae Aq. Dulc. Exsicc. no. 692. I884. Bennett. Plants of Rhode Island. II5. I888. Collins. Algae of Middlesex County. I6. I888. Wolle and Martindale. Algae. Britton's Catalogue of Plants found in New Jersey. Geol. Survey. N. J. 2: 6ri. I889. Trelease. The "Working" of the Madison Lakes. Trans. Wis..Acad. Sci. Arts and Letters. 7: 122. I889. Collins. Algae. Flora of the Blue Hills, Middlesex Fiells, Stony Brook and Beaver Brook Reservations of the Metropolitan Park Commission, Massachusetts. 126. I896. Collins, Holden and Setchell. Phyc. Bor.-Am. Fasc. I2, no. 53. 1899. Fanning. Observations on the Algae of the St. Paul city water. Minn. Bot. Studies. 2: 6r2. pl. 45. fig. 24. I90I. Riddle. Algae from Sandusky Bay. Ohio Nat. 3: 317. 1902. Nelson. Observations upon some Algae which cause "Water Bloom." Minn. Bot. Studies. 3: 56. pl. 14. I903. Snow. The Plankton Algae of Lake Erie. U. S. Fish Comm. Bull. for 1902. 22: 392. r903. Collins. Phycological Notes of the late Isaac Holden,-II. Rhodora. 7: 235. 1905. Buchanan. Notes on the Algae of Iowa. Proc. Iowa Acad. Sci. I4: 9. rgo8.

Plate II. fig. 29.

Colonies 30-90 mic. in diameter, spherical; tegument colorless, thin, gelatinous, soon diffluent; cells 2-5 mic. in diameter, subspherical, oval or elongated, in twos or fours or finally irreguarly arranged; cell contents finely granular, blue-green.

United States. In ponds and pools; stagnant waters. (Wolle). Massachusetts. Framingham. I883. (Farlow). Scattered or as a scum on Spot Pond, Middlesex Fells; forming a dense scum on Winchester Reservoir, Winchester. October I898. (Collins). Connecticut. On moist rocks. Sage's Ravine, below first falls, Twin Lakes, Salisbury. October. (Holden). Rhode Island. Providence. (Lathrop). New Jersey. On stagnant pools. (Wolle). Ohio. Sandusky Bay. (Riddle). Michigan. Grosse Isle, near the mouth of the Detroit River. Summer of I885. (Campbell). Minnesota. Lake Sakatah and Lake Tetonka, Waterville. (Porter). St. Paul city water. (Fanning). Iowa. "A frequent alga in many permanent ponds, often floating in considerable quantities in the lakes." South Gar Lake, Dickinson County; Hewitt's Pond, Eagle Grove; margin of slough. Eagle Grove. I904. (Buchanan).

94. Coelosphaerium dubium Grunow in Rabenhorst. Fl. Eur. Algar. 2: 55. 1865. De Toni. Syll. Algar. 5: I02. I907.

Wood. Contr. Hist. Fresh-Water Algae North America. 13. 1872.

Colonies about I50 mic. in diameter, irregular or sometimes spherical, mucous, free-swimming; tegument colorless, thick; cells 5-7 mic. in diameter, spherical; cell contents with gas vacuoles, blue-green. 
Pennsylvania. Forming a dense scum on a stagnant brick pond, near Philadelphia. July. "The scum was of the color of 'pea-soup' and so thick was it, that I think a quart of the plants might have been readily gathered." (Wood).

\section{Genus COELOSPHAERIOPSIS Lemmermann.} Abh. Nat. Bremen. I6: 352. I899.

Colonies spherical, gelatinous, hollow; families clustered; cells spherical or elongate, arranged in a single peripheral layer; reproduction by cell division.

95. Coelosphaeriopsis halophila Lemmermann. Planktonalgen. Ergeb. einer Reise n. d. Pacific. Abh. Nat. Bremen. I6: 353. pl. 2. f. 25, 26, I899; Algenfl. Sandwich.-Inseln. Bot. Jahrb. 34: 6I6. pl. 7. f. I9-2r. 1905. De Toni. Syll. Algar. 5: 103. 1907.

Plate II. fig. 30.

Colonies 30-500 mic. in diameter, spherical, gelatinous; cells 6 mic. in diameter, 6-9 mic. in length, spherical or elongate.

Hawaii. In salt lagoon. Island of Laysan. (Schauinsland).

\section{Genus TETRAPEDIUM Reinsch.}

Algenfl. von Franken. 37. I867.

Cells solitary or occurring in families of from 2-r6 each, compressed, yuadrangular or triangular, equilateral, becoming subdivided into quadrate or wedge-shaped segments or rounded lobes, either by deep vertical or oblique incisions or by wide angular or rounded sinuses; cell contents bluegreen; reproduction by cell division. (Single cells break apart by the incisions into four daughter cells each, the daughter cells after division forming separate individuals. The direction of the incisions is either perpendicular to the lateral margin or bisects the angles.)

96. Tetrapedium trigonum. W. and G. S. West. On some Freshwater Algae from the West Indies. Journ. Linn. Soc. Bot. 30: 277. pl. I6. f. 8. I895. De Toni. Syll. Algar. 5: II3. 1907.

Plate II. fig. $3 \mathrm{~T}$.

Cells $3.6 \times 7.2$ mic., triangular, with concave sides and somewhat rotund angles, elliptical in side view; cell contents homogeneous, pale blue-green.

West Indies. On damp wall of dam. Sharp's River, St. Vincent. May I892. (Elliott).

\section{Genus MERISMOPEDIUM Meyen \\ in Wiegmann Archiv. 2: 67. 1839 .}

Colonies flat, rectangular, free-floating; tegument somewhat thick, confluent; cells spherical, before division oblong, arranged in a rectilinear series in a single layer; cell contents usually without gas vacuoles, blue- 
green, rarely violet, rose-pink or red; reproduction by division of the cells in two directions.

I Cells 5-7 mic. in diameter, 6-9 mic. in length.

I Colonies $30 \mathrm{mic}$. in diameter; cells $5 \mathrm{mic}$. in diameter, somewhat spherical; cell contents blue-green or violet. M. aerugineum

2 Cells spherical or oblong

M. elegans

3 Cells oval

M. novum

11 Cells 3-6 mic. in diameter.

I Colonies 45-150 mic. in diameter; cells spherical or oval

M. glaucum

2 Colonies large, more or less convolute; cells spherical or oblong

M. convolutum

III Cells I.3-2 mic. in diameter, somewhat spherical M. tenuissimum

9\% Merismopedium aerugineum Brébisson in Kuetzing. Spec. Algar. 472. I849; Tab. Phyc. 5: r3. pl. 38. f. 8. 1855. De Toni. Syll. Algar. 5: 107. I907.

Richter. Süsswasseralgen aus dem Umanakdistrikt. Bib. Bot. Heft. 42. 3. 1897 .

Plate II. fig. 32.

Plant mass somewhat limited, nearly colorless; colonies $30 \mathrm{mic}$. in diameter, 35-68 mic. in length, composed of from 4 to 64 cells; cells 5 mic. in diameter, somewhat spherical, crowded; cell contents blue-green.

Greenland. Umanak. (Vanhöffen).

Var. violaceum Rabenhorst. Die Algen Sachsens. no. 857. 1859. De Toni. Syll. Algar. 5: 107. 1907.

Saunders. Protophyta-Phycophyta. Flora of Nebraska. I7. I894. Tilden. List of Fresh-Water Algae collected in Minnesota during I893. Minn. Bot. Studies. I: 3I. 1894.

Cells very much crowded; cell contents violet.

Wisconsin. Trout-mere. Osceola. October I893. (MacMillan.) Nebraska. Quite common in stagnant ponds about Thedford, forming violet or purplish slimy masses sometimes reaching the size of one's hand. (Saunders).

98. Merismopedium elegans A. Braun in Kuetzing. Spec. Algar. 472. 1849.

De Toni. Syll. Algar. 5: 104. 1907.

Snow. The Plankton Algae of Lake Erie. U. S. Fish Comm. Bull. for 1902. 22: 392. I903. Buchanan. Notes on the Algae of Iowa. Proc. Iowa Acad. Sci. I4: 9. 1908.

\section{Plate II. fig. 33.}

Colonies at first mucous, more or less limited, colorless, later becoming membranaceous, expanded, containing from 64 to 1856 cells, greenish; families quadrate, finally not distinctly limited; cells 5-7 mic. in diameter, 6-9 Aic. in length, spherical or oblong; cell contents pale blue-green. 
Ohio. Plankton. Put-in-Bay, Lake Erie. (Snow). tom. Eagle Grove. I904. (Buchanan).

99. Merismopedium novum Wood. Contr. Hist. Fresh-Water Algae. N. A. 14. pl. 8. f. 8. I872. De Toni. Syll. Algar. 5: 105. 1907.

\section{Plate II. fig. 34 .}

Colonies membranaceous, distinctly limited, with straight and entire margin, composed of very numerous cells; families containing usually sixteen cells; cells up to 6 mic. in diameter, oval, sometimes constricted in the middle, closely approximated; cell contents light bluish green.

Pennsylvania. Growing adherent to or entangled in, a lot of filamentous algae. Schuylkill River, near Philadelphia. (Wood).

Without a doubt this species is identical with $M$. elegans.

ıоo. Merismopedium glaucum (Ehrenberg) Naegeli. Gatt. Einz. Alg. 55. pl. I D. f. I. I849. De Toni. Syll. Algar. 5: 105. 1907.

Nordstedt. De Algis Aquae Dulcis et de Characeis ex Insulis Sandvicensibus a Sv. Berggren 1875 reportatis. 3. 1878 . Campbell. Plants of the Detroit River. Bull. Torr. Bot. Club. I3: 93. 1886. Wolle. Fresh-Water Algae United States. 326. pl. 210. f. 12-15. 1887. Bennett. Plants of Rhode Island. II5. 1888. Mackenzie. A Preliminary List of Algae collected in the neighborhood of Toronto. Proc. Can. Inst. III. 7: 270. I89o. Saunders. Protophyta-Phycophyta. Flora of Nebraska. I6. pl. I. f. 5. I894. Jelliffe. A Further Contribution to the Microscopical Examination of the Brooklyn Water Supply. Brook. Med. Journ. 8: 592. 1894. Tilden. List of Fresh-Water Algae collected in Minnesota during I893. Minn. Bot. Studies. I: 31. I894. Fanning. Observations on the Algae of the St. Paul city water. Minn. Bot. Studies. 2: 6I2. pl. 45. r9oI. Collins, Holden and Setchell. Phyc. Bor.-Am. Fasc. 20. no. 953. I902. Riddle. Algae from Sandusky Bay. Ohio Nat. 3: 317. 1902. Lemmermann. Algenfl. Sandwich.-Inseln. Bot. Jahrb. 34: 6r7. I905. Riddle. Brush Lake Algae. Ohio Nat. 5: 268. r905. Clark. The Holophytic Plankton of Lakes Atitlan and Amatitlan, Guatemala. Proc. Biol. Soc. Wash. 21: 96. 1908. Buchanan. Notes on the Algae of Iowa. Proc. Iowa Acad. Sci. 14: 9. I908.

\section{Plate II. fig. 35 .}

Colonies 45-I50 mic. in diameter, more or less limited, with slightly sinuate-crenate margin, light blue-green or glaucous green; cells $3-6$ mic. in diameter, spherical or oval; cell contents pale blue-green or olive green.

Canada. High Park, Toronto, Ontario. (Mackenzie). United States. Not infrequent in ponds or sluggish waters. (Wolle). Maine. In a scum on a small artificial pond. Pogy Oil Factory. Round Pond. 16 July 1901. (Collins). Rhode Island. Providence. (Lathrop). New York. Brooklyn water supply. (Jelliffe). Ohio. Brush Lake, Champaign County; Sandusky Bay (Riddle). Michigan. Grosse Isle, near the mouth of the Detroit River. Summer of I885. (Campbell). Minnesota. Peat-bog near Lake Kilpatrick, July I893. (Ballard). St. Paul city water. (Fanning). Iowa. Floating in the quiet waters of ponds. Ames. I884. (M. n o va). (Bessey). Grinnell; Fayette. (Fink). Eagle Grove. Hewitt's Pond. Igo4. 
(Buchanan). Nebraska. Ponds and sluggish water. Not uncommon. (Saunders). California. In a small spring near San Pablo. September I902. (Gardner). Central America. Only one specimen noted. "Amatitlan in $85 \mathrm{ft}$. water, towed in about 75 to 65 , February I, I906, at middle of upper part of lake." (Meek). Hawaii. Island of Hawaii. (Berggren).

Var. fontinale Hansg. Phys. und. Algol. Mittheil IV. 98. I890. De Toni. Syll. Algar. 5: I06. I907.

Collins, Holden and Setchell. Phyc. Bor.-Am. Fasc. 24. no. II56. I904.

Colonies 45 mic, in diameter, gelatinous, containing 8-64 cells; cells 2.5-3 mic. in diameter, approximate, densely aggregated; cell contents distinctly granular, pale blue-green.

California. On sandy ground. Lake Merced, San Francisco. (Gardner).

Ior. Merismopedium convolutum Brébisson in Kuetzing. Spec. Algar. 472. 1849. De Toni. Syll. Algar. 5: 108. 1907.

Wood. Contr. Hist. Fresh-Water Algae North America. 15. I872. Wolle. Fresh-Water Algae U. S. 326. pl. 210. f. I4. I887. "Bennett. Plants of Rhode Island. II5. I888. Wolle and Martindale. Algae. Britton's Catalogue of Plants found in New Jersey. Geol. Surv. N. J. 2: 6II. I889. Harvey. The Fresh-Water Algae of Maine.-III. Bull. Torr. Bot. Club. I9: 124. I892. Bessey. Additions to the reported Flora of Nebraska made during I893. Bot. Surv. Nebraska. 3: 5. I894. Saunders. ProtophytaPhycophyta. Flora of Nebraska. I7. I894. Tilden. List of Fresh-Water Algae collected in Minnesota during I893. Minn. Bot. Studies. I: 3I. I894. Riddle. Algae from Sandusky Bay. Ohio Nat. 3: 317. I902. Collins, Holden and Setchell. Phyc. Bor.-Am. Fasc. 24. no. II54. I904. Riddle. Brush Lake Algae. Ohio Nat. 5: 268. I905. Brown. Algal Periodicity in Certain Ponds and Streams. Bull. Torr. Bot. Club. 35: 248. 1908.

\section{Plate II. fig. 36 .}

Cojonies I-4 mm. in diameter (visible to the naked eye), composed of very numerous cells, membranaceous, subfoliaceous, more or less convolute, greenish, bluish or yellowish; cells 4-5 mic. in diameter, 4-8 mic. in length, spherical or oblong; cell contents blue-green or yellowish.

United States. Shallow pools, forming a distinct layer upon the muddy bottom, or separating and then floating on the surface. (Wolle). Maine. Attached to spruce logs floating in the Penobscot River. Orono. October 1890. (Harvey). Rhode Island. Common. (Bennett). New Jersey. Frequent in ponds. (Wolle). Pennsylvania. "Making a distinct green layer upon the mud many feet in extent." In a very shallow, quiet, but fresh pool. Spring Mills, near Philadelphia. (Wood). Ohio. Brush Lake, Champaign County; Sandusky Bay (Riddle). Indiana. Faris Pond, Bloomington. February I907 (Brown). Minnesota. Peat-bog near Lake Kilpatrick. July r 893. (Ballard). Nebraska. At the bottom of pools or floating upon the surface. (Saunders). South Bend. (Bessey). California. Floating all through the water in such abundance as to give it a bluish color. In Stone Lake. Golden Gate Park. San Francisco. August. 1903. (Gardner.) 
I02. Merismopedium tenuissimum Lemmermann. Beitr. Kenntn. Planktonalgen. Bot. Centralb. 76: 154. 1898. De Toni. Syll. Algar. 5: 108. 1907.

Snow. The Plankton Algae of Lake Erie. U. S. Fish Comm. Bull. for ID02. 22: 392. 1903.

Plate II. fig. 37 .

Colonies quadrangular, free-floating, containing sixteen cells; cells I.3-2 mic. in diameter, somewhat spherical, crowded; cell contents pale bluish green.

Ohio. Plankton. Put-in-Bay, Lake Erie. (Snow).

\section{Genus EUCAPSIS Clements and Shantz.}

Minn. Bot. Studies. 4: I34. I909.

Colonies cubical, usually consisting of $32-128$ cells, but ranging from 8-512 cells, free-floating; tegument uniform, colorless, gelatinous; cells spherical, sometimes elliptical or flattened by mutual pressure, forming cubical families; cell contents finely granular, blue-green; reproduction by cell division in three planes.

I03. Eucapsis alpina Clements and Shantz. Minn. Bot. Studies. 4: I34. I909.

Plate II. fig. $38-40$.

Colonies $30-80 \mathrm{mic}$. in diameter, usually containing $32-128$ cells, cubical, free-floating; tegument colorless; cells 6-7 mic. in diameter, spherical, more rarely elliptic, in cubical families; cell contents blue-green.

Colorado. Alpine pond on Bald Mountain (I2,000 feet). September 1904. (Shantz).

Genus ONCOBYRSA Agardh in Flora. 10: 629. 1827.

Colonies cushion-like, hard, leathery, adherent; sheaths thick, gelatinous, confluent; cells spherical or elongated, usually regularly arranged in radial rows; cell contents blue-green or violet.
I Cells pale blue-green, sometimes violet
O. rivularis

II Cells bright blue-green

O. cesatiana

104. Oncobyrsa rivularis (Kuetzing) Meneghini. Monogr. Nostoch. Ital. 96. I846. De Toni. Syll. Algar. 5: II4. I907.

Collins, Holden and Setchell. Phyc. Bor.-Am. Fasc. 12. no. 555. I899.

Colony almost spherical, very smooth, opaque, dull brownish-green; tegument almost colorless, soon diffluent; cells $2-6$ mic. in diameter, spherical or polygonal, arranged in regular radial rows; cell contents bluegreen or violet.

United States. (Collins, Holden and Setchell).

105. Oncobyrsa cesatiana Rabenhorst. Fl. Eur. Algar. 2: 68. 1865. De Toni. Syll. Algar. 5: I16. 1907.

Setchell and Gardner. Algae of Northwestern America. Univ. Calif. Pub. Bot. I: 180. I903. 


\section{Plate II. fig. 4r.}

Colonies spherical, hard, solitary or in clusters, blue-green becoming dark-colored; tegument confluent, colorless; cells 1.2-2.5 mic. in diameter, 3 mic. in length, spherical or oblong, somewhat seriate, crowded at the periphery, few in the interior; cell contents homogeneous, light blue-green.

Alaska. Plentiful on water-moss in running fresh water. Near Iliuliuk, Unalaska. (Setchell and Lawson).

Genus CHLOROGLOEA Wille. Algol. Notizen. I-VI. 5. pl. I. Igoo.

Colonies irregularly lobed; tegument thin, not lamellose; cells spherical or oval, arranged in radiating series; reproduction by cell division in one direction.

I06. Chlorogloea tuberculosa (Hansgirg) Wille. Algol. Notizen. I-VI. 5. pl. I. I900. De Toni. Syll. Algar. 5: I I8. 1907.

Tilden. American Algae. Cent. IV. no. 382. 1900. (P t ing ș he im ia scutata cladophora e Tilden).

\section{Plate II. fig. 42.}

Colonies disc-shaped, epiphytic, greenish; cells I-1.5 mic. in diameter, 2 mic. in length; ellipsoid, after division somewhat spherical.

Canada. On Cla dophora in tide pool. Minnesota Seaside Station. Vancouver Island, British Columbia. August I898. (Tilden).

\section{Family II. CHAMAESIPHONACEAE}

Plants often showing a difference between basal and apical regions, sulitary or associated in families or colonies, usually epiphytic or attached to shells; reproduction by cell division, by division of filaments into fragments, or by means of non-motile gonidia formed by the division of the contents of a mother cell or gonidangium.

I Reproduction by cell division and by gonidia; cells usually united in colonies

I Colonies somewhat spherical or hemispherical, usually consisting of several layers of cells

Pleurocapsa

2 Colonies disc-shaped, usually consisting of a single layer of cells

3 Colonies forming branched filaments

Xenococcus

Hyella

I] Reproduction by gonidia only

I Gonidia formed by simultaneous division of the entire contents of gonidangium

Dermocarpa

2 Plants not usually united in colonies; gonidia formed by successive constrictions of apical portion of contents of gonidangium

\section{Chamaesiphon}


Genus PLEUROCAPSA Thuret in Hauck.

Die Meeresalgen Deutschlands and Oesterreichs. 515. I885.

Colonies usually crustaceous, made up of vegetative cells and gonidangia; plants united in short filaments, parallel or scarcely distinct, radiating, often dichotomously divided; cells spherical or angular, rarely oval or polyhedral; cell contents blue-green, olive, yellowish or violet; gonidangia furnished with thick sheaths, producing numerous, spherical gonidia; reproduction by cell divison in three directions, by division of filaments into fragments, and by gonidia formed by division of the contents of a gonidangium.

I Cells arranged in straight rows; growing in fresh water

Pl. concharum

II Cells not arranged in straight rows

I Growing in hot water; cells $4^{-6}$ mic. in diameter

Pl. caldaria

2 Growing in salt water

(I) Cells 5-20 mic. in diameter; cell contents golden yellow, fawncolored or dull violet

Pl. fuliginosa

(2) Cells IO-I3 mic. in diameter; cell contents violet

P1. amethystea

(3) Cells up to 15 mic. in diameter; cell contents dull blue or slate color

P1. crepidinum

107. Pleurocapsa concharum Hansgirg. Phys. und Alg. Mittheil. pl. I. f. II-I5. I890. De Toni. Syll. Algar. 5: I22. I907.

Collins, Holden and Setchell. Phyc. Bor.-Am. Fasc, 22. no. I05I. 1903.

Colonies minute; tegument moderately thin, colorless; cells 4-I7 mic. in diameter, 4-34 mic. in length, spherical, oval, ellipsoid or angular from mutual pressure, united into short, often irregularly dichotomous filaments of four to ten cells each, or into somewhat spherical masses; cell contents very finely granular, dull bluish or olive green; gonidangia $12-20$ mic. in diameter, containing 8-32 gonidia; gonidia 3-4 mic. in diameter, spherical.

California. On shells. Mountain Lake. San Francisco. June I902. (Osterhout and Gardner).

108. Pleurocapsa caldaria (Tilden) Setchell in Collins, Holden and Setchell. Phyc. Bor.-Am. Fasc. I8. no. 851. Igor. De Toni. Syll. Algar. 5: 123. $190 \%$.

Tilden. Observations on some West American Thermal Algae. Bot. Gaz. 25: 94. pl. 8. f. I8. I898; American Algae. Cent. III. no. 283. I898. (Protococcus botryoides f. caldaria Tilden); American Algae. Cent. II. no. I98. I896; Bot. Gaz. 25: I04. pl. 8. f. 21. I898. (C h r o o c o ccus varius $\mathrm{A}$. Br.)

Plate III. fig. I.

Plant mass pale or yellowish green; sheaths thin, homogeneous, hyaline; 
cells 4-6 mic. in diameter, spherical, usually solitary; cell contents homogeneous, pale green.

Wyoming. On bottom of spring. Temperature $38^{\circ}$ C. Frying Pan Basin, July I896; on rocks, near vent of geyser, sometimes heated, Norris Geyser Basin. June 1896 ; with $\mathrm{M}$ i cros por a a moena therma 1 is, lying in overflow from spring. Temperature $4 \mathrm{I}^{\circ} \mathrm{C}$. Frying Pan Basin. July I896. Yellowstone National Park. (Tilden). Forming a green coating on floor of overflow channel. Temperature $49^{\circ}$ C. Conlstant Geyser. Norris Geyser Basin; in acid waters, Green Spring, between Norris Geyser Basin and Beaver Lake. I897. Yellowstone National Park. (Weed). California. I'orming an emerald green, rather thick coating on steaming rocks above the "Devil's Kitchen," Geysers. Sonoma County. June 1900. (Setchell and Hunt).

"Clearly a member of the Cyanophyceae and forming a limited number (4) of schizospores (gonidia) which seem to relate it most closely to the genus Pleurocapsa."-Setchell.

109. Pleurocapsa fuliginosa Hauck. Die Meeresalgen Deutschlands und Oesterreichs. 515. f. 231. 1885. De Toni. Syll. Algar. 5: 122. 1907.

Collins. Notes on New England Marine Algae. V. Bull. Torr. Bot. Club. 18: 335. 1891. Collins, Holden and Setchell. Phyc. Bor.-Am. Fasc. 3. no. IOI. I895. Setchell. Notes on Cyanophyceae. III. Erythaea. 7: 54. I899. Collins, Holden, Setchell. Phyc. Bor.-Am. Fasc. I5. no. 704. 1900. Collins. Preliminary Lists of New England Plants.-V. Marine Algae. Rhodora. 2: 42. 1900; Phycological Notes of the late Isaac Holden,I. Rhodora. 7: I72. I905.

\section{Plate III. fig. 2, 3 .}

Colonies thin, crustaceous, blackish; families 50-100 mic. in diameter; sheaths colorless; cells 5-20 mic. in diameter, solitary or united in families of twos, fours or eights; cell contents homogeneous, golden yellow, fawncolored or dull violet.

Massachusetts. Forming a very thin reddish or brownish-black coating on rocks-near high water mark. Marblehead. (Collins). Rhode Island. (Collins). Connecticut. On Enteromorpha and stones between tides. Below Yellow Mill Bridge. May, August, November, December. (Holden). In dark patches on stones and woodwork, also epiphytic on Enteromorpha, mostly near high water mark. Bridgeport. December 1893. (Holden). California. Forming a smooth black covering on smooth rocks, at high water mark in exposed places. Carmel Bay, Monterey County. January I899. (Setchell and Gibbs). On piles of wharf at the Life Saving Station at the Presidio; on old timbers. Alameda. (Setchell).

Collins states that when the cells cease to divide, the contents change into small round gonidia ("Spores").

110. Pleurocapsa amethystea Kolderup-Rosenvinge. Groenlands Havalger. Medd. om Groenland. 3: 967. fig. 57. I893; Les Algues Marines du Groenland. Ann. Sci. Nat. Bot. VII. I9: I63. fig. 57. I894. De Toni. Syll. Algar. 5. I2I. 1907. 
Börgesen and Jonsson. The Distribution of the Marine Algae of the Arctic Sea and of the northernmost part of the Atlantic. Bot. Faeroes. App. XXV. 1905.

\section{Plate III. fig. 4 .}

Colonies 45 mic. or more in diameter, somewhat spherical or hemispherical, dark violet in color; cells IO-I3 mic. in diameter, hemispherical, angular, depressed or somewhat spherical, at first solitary afterwards aggregated; gonidia I-2 mic. in diameter.

Greenland. On the surface of Rhizoclonium riparium vali d u m. Littoral zone. Fiskernas. (Rosenvinge). East and west portions. (Börgesen and Jonsson).

II I. Pleurocapsa crepidinum Collins. Notes on Algae. III. Rhodora. 136. 1901. De Toni. Syll. Algar. 5: I21. I907.

Collins, Holden and Setchell. Phyc. Bor.-Am. Fasc. 24. no. II57. I904.

Cells up to 5 mic. in diameter, spherical or by mutual pressure polygonal, often remaining attached in dense masses after dividing; cell contents dull blue or slate color; gonidangia spherical, filled with small gonidia.

Maine. Occurring sparingly in a coating composed of several minute algae, on the woodwork of an old wharf. Otter Creek, Mount Desert. July I900. (Collins). Massachusetts. On B a 1 a n i and rocks. Magnolia Point. September I903. (Farlow).

Genus XENOCOCCUS Thuret. Ann. Sci. Nat. Bot. VI. I: 6. 1875.

Colonies disc-shaped or crustaceous, attached; cells somewhat spherical, or angular with rounded apices, crowded, forming a parenchymatous, onecelled layer, later several cells in thickness; tegument colorless or yellowish; cell contents homogeneous, blue-green or violet; reproduction by cell division in three directions or by means of gonidia developed in large peripheral cells; gonidia usually spherical, sometimes 32 developed in a gonidangium.

I Colonies disc-shaped, composed of one layer of cells; tegument surrounding base of cells; cells 3-4 mic. in diameter, 5.5-7 mic. long, pearshaped.

$\mathrm{X}$. laysanensis

II Colonies spherical, solitary or confluent and completely surrounding the filaments of the host; cells 4-9 mic. in diameter, spherical or flattened.

\section{X. schousboei}

III Colonies irregularly expanded, one or several layers in thickness; cells 4-6 mic. in diameter, 4-9 mic. in length.

X. kerneri

I12. Xenococcus laysanensis Lemmermann Algenf. Sandwich-Inseln. Bot. Jahrb. 34: 6r8. pl. 8. f. II-12. I905. De Toni. Syll. Algar. 5: I34. I907.

Plate III. fig. 5, 6.

Colonies epiphytic, disc-shaped, pseudo-parenchymatous, composed of 
one layer of cells; tegument hyaline, mucous, surrounding base of cells; cells 3-4 mic. in diameter at apex, 5.5-7 mic. long, pear-shaped, polygonal, crowded; cell contents bluish green.

Hawaii. On marine algae. Laysan Island. 1896-97. (Schauinsland).

II3. Xenococcus schousboei Thuret in Bornet and Thuret. Notes Algol. 2: 74. pl. 26. f. I, 2. I880. De Toni. Syll. Algar. 5: 133. 1907.

Wolle and Martindale. Algae. Britton's Catalogue of Plants found in New Jersey. Geol. Surv. N. J. 2: 6I2. I889. Martindale. Marine Algae of the New Jersey coast and adjacent waters of Staten Island. Mem. Torr. Bot. Club. I: 89. I889. Collins. Notes on New England Marine Algae V. Bull. Torr. Bot. Club. I8: 335. I89I. (D e r m o c a r pa s chous boe i). Collins, Holden and Setchell. Phyc. Bor.-Am. Fasc. I2. no. 554. I899. Setchell. Notes on Cyanophyceae. III. Erythea. 7: 54. 1899. Collins. Preliminary Lists of New England Plants,-V. Marine Algae. Rhodora. 2: 43. 1900; The Algae of Jamaica. Proc. Am. Acad. Arts Sci. 37: 239. I90I; Phycological Notes of the late Isaac Holden,-I. Rhodora. 7: 172. I905. Collins, Holden, Setchell. Phyc. Bor.-Am. Fasc. I2. no. 554. 1899.

Plate III, fig. 7 .

Colonies spherical, solitary and scattered, or grouped in confluent niasses which completely surround the filaments of the host, green or bright blue in color; cells 4-9 mic. in diameter, spherical or flattened by mutual pressure; cell contents light bluish-green.

Maine. (Collins), Connecticut. On Chantransia, Sphacelaria, Rhodochorton. Seaside Park; Black Rock; Fresh Pond; June, July, December. (Holden). Massachusetts. On Rhodochorton rothii and Rhizoclonium riparium. Nahant. (Collins). New Jersey. Growing on L y $\mathrm{ng}$ b y a. Atlantic City. (Martindale). California. On $\mathrm{C}$ aloth $\mathrm{rix}$ c r u tacea, which forms a black velvety coating on smooth rocks near high water mark. Carmel Bay, Monterey County. January I899. (Setchell and Gibbs). West Indies. On S permoth a m$\mathrm{n}$ i o n. Kingston. Jamaica. July 1900. (Pease and Butler).

II4. Xenococcus kerneri Hansgirg. Phys, und Alg. Studien. III. pl. I. f. 19. 1887. De Toni. Syll. Algar. 5: 134. 1907.

Collins, Holden and Setchell. Phyc. Bor.-Am. Fasc. 20. no. 952. I902. Lemmermann. Ueber die von Herrn Dr. Walter Volz auf seiner Weltreise gesammelten Süsswasseralgen. Abh. Nat. Ver. Brem. I8: Collins. Notes on Algae,-VI. Rhodora 5: 234. I903. Lemmermann. Algenf. SandwichInseln. Bot. Jahrb. 34: 618. I905.

\section{Plate III. fig. 8 .}

Colonies irregularly expanded, usually one layer of cells in thickness, crustaceous, about 6-9 mic. in thickness, rarely of several layers, nodulose, rough, 9-30 mic. in thickness; tegument thick, inconspictously lamellose, colorless; cells usually 4-6 mic. in diameter, 4-9 mic. in length, with rounded apices; cell contents dull blue-green or violet; gonidia about $3 \mathrm{mic}$. in 
diameter, spherical, usually as many as 32 developed in marginal gonidangia.

Massachusetts. On old plants of Cladophora in upper tide pool, rocky shore. Cohasset. October I90r. (Collins). Hawaii. Ditches and marshes, between Honolulu and Waikiki, Oahu. I896-97. (Schauinsland).

Genus HYELLA Bornet and Flahault. Journ. de Bot. I62. I888.

Colonies radiately expanded, orbicular, composed of two kinds of filaments; primary filaments horizontal, tangled, twisted, finally becoming a very densely woven felty mass; secondary filaments vertical, developed from primary; branching true; tegument septate, thicker at base of filament; narrower above; cells disconnected, not joined in chains, lower ones short, sometimes divided longitudinally, upper ones longer; reproduction by means of vegetative cells set free from tegument and by means of gonidia formed in gonidangia by successive division of contents.

I Colonies yellowish or olive, at first forming minute patches or dots, later becoming membranaceous or cushion-shaped; erect filaments usually parallel; vegetative cells usually $5-6$, sometimes up to to mic. in diameter.

\section{H. cae'spitosa}

II Colonies immersed in substance of shell, brownish-gray or bright blue; vegetative cells 5 -10 mic. in diameter

H. fontana

I15. Hyella caespitosa Bornet and Flahault. Note sur deux nouveaux Genres d'Algues perforantes. Journ. de Bot. 2: I62. I888; Sur quelques Plantes vivant dans le Test Calcaire des Mollusques. Bull. Soc. Bot. France. 36: CLXV. pl. 1o. f. 7-9; pl. II. 1889. De Toni. Syll. Algar. 5: 125. 1907.

Collins. Algae.-Rand and Redfield's Flora of Mount Desert Island, Maine. 249. I894. Collins, Holden and Setchell. Phyc. Bor.-Am. Fasc. 7. no. 302. I897. Setchell. Notes on Cyanophyceae. III. Erythea. 7: 54. I899. Collins. Preliminary lists of New England plants,-V. Marine Algae. Rhodora. 2: 42. 1900; Phycological Notes of the late Isaac Holden,-I. Rhodora. 7: 172 . I905.

\section{Plate III, fig. 9-II.}

Colonies at first forming minute patches or dots, later becoming membranaceous or cushion-shaped, I-2 mm. wide, yellowish, olive or brownish, for a time mucous, fleshy; erect filaments usually parallel, about io mic. in diameter, I00-200 mic. long; tegument simple, gelatinous, colorless; $v \in$ getative cells usually $5-6$, rarely up to 10 mic. in diameter, somewhat globose or angular, associated in filaments, sometimes irregularly branched; cell contents yellowish-olive, rarely olive to bluish-green.

Canada. In oyster shells. Malpeque, Prince Edward Island. (Faull). Maine. In dead shells. Spectacle Island, Penobscot Bay. July I894; growing in the substance of dead shells. Seal Harbor. (Collins). Rhode Island. (Collins). Connecticut. In shells. June, August. (Holden). Massachusetts. (Collins). California. On shells of the eastern oyster (Ost r a e a virginiana). Probably introduced. Bay Farm Island, Alameda. (Setchell). 
116. Hyella fontana Huber and Jadin. Sur une nouvelle Algue perforante d'eau douce, Journ. de Bot. 6: 285. pl. II. 1892. De Toni. Syll. Algar. 5: 126. 1907.

Collins, Holden and Setchell. Phyc. Bor.-Am. Fasc. 7. no. 303. I897. Collins. Some perforating and other Algae on freshwater shells. Erythea. 5: 95. 1897.

\section{Plate III. fig. I2.}

Colonies immersed in substance of sheli, dark gray or bright blue, often very dense and then through division of cells having the aspect of Chroococcus, or loosely branched; integument almost invisible; vegetative cclls 5-Io mic. in diameter, two to four times shorter than wide; gonidangia usually larger and more nearly spherical than the vegetative cells.

Connecticut. In shells in company with $\mathrm{P} l \mathrm{e} c \mathrm{t}$ on e ma $\mathrm{t}$ e $\mathrm{reb} \mathrm{rans}$, Gom ontia holdenii. Twin lakes, Salisbury, Litchfield county. August I895. (Setchell and Holden).

"Scattered through the shells, sometimes in rather dense, chroococcoidal masses, sometinies in loosely branching filaments."-Collins.

\section{Genus DERMOCARPA Crouan.}

Ann. Sci. Nat. Bot. IV. 9: 70. I858.

Colonies usually epiphytic, forming a somewhat indefinite layer; cells spherical, egg-shaped, pear-shaped, oval or oblong, solitary or united in a layer; cell contents usually blue-green or violet; reproduction by means of gonidia formed by simultaneous division of contents of the gonidangium; gonidangia oval or elongate, dissolving at apex to allow the scape of the gonidia.

I Cells somewhat oval or oblong, not contracted at base to form a stalk.

I Cell contents blue-green, green, olive or brown D. prasina

2 Cell contents rose-colored or violet
(I) Cells 4-5 mic. in diameter
D. rosea
(2) Cells 8-28 mic. in diameter
D. violacea

II Cells contracted at base to form a stalk.

I Colonies dark violet-brown; cells I8-25 mic. in diameter, 40-60 mic. in
length
D. fucicola

2 Colonies irregularly outlined; cells 8.5-I I mic. in diameter, I6.5-33.5 mic. in length $\quad$ D. smaragdinus

3 Colonies minute; cells 9.5-I7 mic. in diameter, $13-25$ mic. in length

D. olivaceus

4 Cells $18-24$ mic. in diameter, $17-24$ mic. in length
D. leibleiniae
var. pelagica

117. Dermocarpa prasina (Reinsch) Bornet and Thuret. Notes Algologique. 2: 73-77. pl. 26. f. 6-9. I880. De Toni. Syll. Algar. 5: I28. I907. 
Collins. Notes on New England Marine Algae. V. Bull. Torr. Bot. Club. 18: 335. 189I; Algae.-Rand and Redfield's Flora of Mount Desert Island, Maine. 249. I894. Collins, Holden and Setchell. Phyc. Bor.-An. Fasc. r. no. I. I895. Collins. Preliminary Lists of New England Plants,V. Marine Algae. Rhodora. 2: 41. 1900. Saunders. The Algae. Harriman Alaska Expedition. Proc. Wash. Acad. Sci. 3: 397. 190I. Setchell and Gardner. Algae of Northwestern America. Univ. of Calif. Pub. Bot. I: I82. 1903.

Plate III. fig. I3-I5.

Colonies forming a cushion-like expansion of a somewhat spherical mass; sheaths delicate; cells, 4-24 mic. in diameter, 15-30 mic. in length, cylindrical-oblong, club-shaped or spatulate, closely packed, laterally compressed; cell contents homogeneous, deep blue-green or green, becoming bluish, olive or brownish; gonidia arranged in a single row in the small cylindrical gonidangia or in several rows in the larger gonidangia.

Alaska. Abundant on Sphacelaria. From Puget Sound to the Shumagin Islands. (Saunders). New England. Grows quite abundantly in spring on the coast, on the older part of the fronds of Polys iph on ia fastigiata. (Collins). Maine. On Polysiphonia fastigiata. Near Seal Harbor. (Collins). Connecticut. (Collins). Massachusetts. On Polysiphonia fastigiata, between tides. Little Nahant. April 1891. (Setchell). Rhode Island. (Collins).

I 8. Dermocarpa (?) rosea (Reinsch) Batters. Marine Algae of Berwich. I4I. I889. Reinsch. Contrib. Algol. et Fungol. I: I8. p1. 26. f. 4. a-c. 1875. (S phaenosiphon rose us Reinsch). De Toni. Syll. Algar. 5: I30. 1907.

Farlow. Marine Algae of New England. 61. I88I.

Plate III. fig. I6-18.

Colonies $2-5 \mathrm{~cm}$. in diameter, indefinitely expanded; tegument thick, gelatinous, hyaline, surrounding the cells; individual sheaths distinct, somewhat thick; cells 4-5 mic. in diameter, ovoid-elliptical, loosely arranged; cell contents homogeneous, rose-colored.

Newfoundland. On zoophytes. Coast of Labrador. (Reinsch).

I19. Dermocarpa violacea Crouan. Note sur quelques Algues Marines nouvelles de la rade de Brest. Ann. Sci. Nat. Bot. IV. 9: 70. pl. 3. f. 2. A-D. I858. De Toni. Syll. Algar. 5: I29. 1907.

Collins, Holden and Setchell. Phyc. Bor.-Am. Fasc. I2. no. 556. I899. Collins. Preliminary Lists of New England Plants,-V. Marine Algae. Rho. dora. 2: 4I. 1900.

\section{Plate III. fig. 19-2I.}

Colonies indefinitely expanded or forming patches, rose-red; sheaths thin; cells 8-28 mic, in diameter, oval to wedge-shaped; cell contents rosered to violet.

New England. On Enteromorpha intestinalis. In company with Lyngbya lutea, Amphithrix violacea, etc. (Collins). 
Rhode Island. On Enteromorpha intestina 1 is. Easton's Point, Newport. September 1898. (Simmons).

120. Dermocarpa fucicola Saunders in Collins, Holden and Setchell. Phyc. Bor.-Am. no. 8or. rgor. De Toni. Syll. Algar. 5: I29. 1907.

Saunders. The Algae. Harriman Alaska Expedition. Proc. Wash. Acad. Sci. 3: 397. pl. 46. f. 4, 5. I90i. Setchell and Gardner. Algae of Northwestern America. Univ. Calif. Pub. Bot. I: I8I. I903. Collins, Holden and Setchell. Phyc. Bor.-Am. Fasc. 26. no. I25I. I905.

\section{Plate III. fig. 22, 23.}

Colonies 2-r2 $\mathrm{mm}$. in diameter, forming orbicular or irregular patches which become confluent into irregular masses of indefinite extent, dark riolet-brown in color; cells $18-25 \mathrm{mic}$. in diameter, 40-60 mic. in length, - ovate, clavate or spatulate, much narrowed below; gonidia abundant.

Alaska. On Fu cus. Puget Sound. (Saunders). Canada. North of Oak Bay, Victoria, British Columbia. July I898. (Tilden). Washingtot. On Irida a $1 \mathrm{a}$ min a $\mathbf{r}$ i o ides. Minnesota reef. San Juan Island. 1898. (Tilden). On Geli di u m. East Sound, Orcas Island, Washington. (Gardner.) On Fucus, Gigartina, Odonthalia, Amphiroa, West shore of Whidbey Island, Washington. (Gardner). On F u cus e va n e scens macrocephalus. Near Seattle.' June r89g. (Saunders). California. On Gelidium, middle littoral. Point Carmel. Monterey County. 3 June rgor. (Setchell).

"The present species occurs along the western coast of North America from Puget Sound to Monterey, California, and grows on all sorts of algae. In its younger and purely vegetative condition, the patches are small and the cells are long and narrow, $4-8 \mathrm{mic}$. broad and up to $28 \mathrm{mic}$. high, of equal breadth throughout. Soon they begin to broaden above giving them something of a pear-shape. In this condition they correspond closely to the description and figures given by Sauvageau (I895, p. 8 pl. 7. f. 2, 3.) of his D. biscayensis."

"Sauvageau's specimens, which grew on Sargassum, do not show conidia, but our specimens show that when the cells proceed to this condition, they become still more swollen in the upper part, while the lower part remains narrow, resembling a sort of stipe. In conidial condition the cells measure 60-65 mic. in height and $25-35$ mic. in diameter. $* * * W e$ believe that when fruiting specimens can be compared, that this species will be found to be identical with D. biscayensis Sauvageau."-Setchell.

121. Dermocarpa smaragdinus (Reinsch) nob. Reinsch. Contrib. Algol. et Fungol. I: 16. pl. 25. f. 4. I875. De Toni. Syll. Algar. 5: I3I. 1907. (Sphaenosiphon smaragdin tu Reinsch).

Farlow. Marine Algae. New England. 6r. I88I

\section{Plate III. fig. 24, 25.}

Colonies irregularly outlined; sheaths thick; cells 8.5 -Ir mic. in diameter, 16.5-33.5 mic. in length, pear-shaped or broadly wedge-shaped, rounded at the apex, prolonged at the base into a hyaline stalk about 2 mic. in diameter; cell contents slightly granular, deep bluish-green (smaragdinus). 
Canada. On Polysiphonia. Lawrence River, Anticosti Island. (Reinsch). Newfoundland. On Ploc a mi u m coc cin e u m. Labrador. (Reinsch).

I22. Dermocarpa olivaceus (Reinsch) nob. Reinsch. Contrib. Algol. et Fungol. I: I7. pl. 27. f. 2. I875. De Toni. Syll. Algar. 5: 132. I907. (S phaenosiphon olivaceus Reinsch).

Farlow. Marine Algae New England. 6r. I88I.

\section{Plate III. fig. $26,27$.}

Colonies minute, expanded or somewhat hemispherical; sheaths thick, lamellose; cells 9.5-17 mic. in diameter, 13-25 mic. in length, pear-shaped or wedge-shaped, broadly rounded at apex, contracted at base; cell contents finely granular.

Canada. On Ceramium rubrum. Anticosti Island. (Reinsch). Newfoundland. On Cera mium r u brum. Labrador. (Reinsch).

123. Dermocarpa leibleiniae (Reinsch) Bornet var. pelagica Wille. Die Schizophyceen d. Plankton Expedition. 50. pl. I. f. I, 2. De Toni. Syll. Algar. 5: 702. 1907.

Plate III. fig. 28.

Sheaths moderately thick, lamellose; cells I8-24 mic. in diameter, 17-24 mic. in length, irregularly pear-shaped, prolonged at the base into a delicate stalk.

Bermudas. (Wille).

Genus CHAMAESIPHON Braun and Grunow in Rabenhorst.

F1. Eur. Algar. 2: I48. I865.

Plants epiphytic, erect, cylindrical, somewhat filiform, club-shaped or pear-shaped, attached at base, widening upwards to free apex, solitary or aggregated; sheaths present; cell walls very thin; cell contents homogeneous, blue-green, violet or yellow; reproduction by one-celled, non-motile gonidia which are successively cut off from the upper portion of the contents of the gonidangium, gradually escaping from the open apex.
I Gonidangia usually I-2 celled.
Ch. incrustans

II Gonidangia many-celled

Ch. curvatus

124. Chamaesiphon incrustans Grunow in Rabenhorst. Fl. Eur. Algar. z: 149. 1865. De Toni. Syll. Algar. 5: I36. I907.

Möbius. Ueber einige in Portorico gesammelte Süsswasser- und LuftAlgen. Hedwigia. 27: 246. I888. Harvey. The Fresh-Water Algae of Maine.-III. Bull. Torr. Bot. Club. I9: 124. I892. Tilden. List of freshwater Algae collected in Minnesota during I895. Minn. Bot. Studies. I: 599. I896. Buchanan. Notes on the Algae of Iowa. Proc. Iowa Acad. Sci. 14: 8. I908. 
Plate III. fig. 29, 30.

Gonidangia I-2 celled, I-3 mic. in diameter at the base, 4-8 mic. in diameter at the apex, 7-30 mic. in length, club-shaped or long cylindrical, straight or curved, solitary or densely crowded in groups; tegument colorless, at first closed, later open at apex; cell contents blue-green; gonidia about 2 mic. in diameter.

Maine. Attached to filamentous algae. Spring, College meadow, Orono. (Harvey). Minnesota. In tank in Botanical Laboratory. University, Minneapolis, February I896. (Tilden). Iowa. Growing on the surface of an alga, probably an O e dog o $\mathrm{n}$ i u m. Eagle Grove. Hewitt's Pond. Igo4. (Buchanan). West Indies. Growing on an $\mathrm{O}$ e do go n i u m. In warm springs. Los Baños, near Coamo. Porto Rico. (Sintenis).

125. Chamaesiphon curvatus Nordstedt. De Algis Aquae Dulcis et de Characeis ex Insulis Sandvicensibus. 4. pl. I. f. I, 2. I878. De Toni. Syll. Algar. 5: I39. 1907.

Nordstedt. De Algis Aquae Dulcis et de Characeis ex Insulis Sandvicensibus a Sv. Berggren 1875 reportatis. 4. 1878. Lemmermann. Algenfl. Sandwich.-Inseln. Bot. Jahrb. 34: 618. 1905.

Plate III. fig. $3 \pi$.

Gonidangia many-celled, 3-10 mic. in diameter, zo-roo mic. in length, somewhat cylindrical, more or less curved, rising from a narrow base; tegu-. ment colorless; cell contents blue-green.

Hawaii. Among filaments of $\mathrm{Clad}$ ophora. Near Honolulu. Island of Oahu. (Berggren).

\section{Order II. HORMOGONEAE}

Plants multicellular, filamentous, attached to a substratum or free-floating; filaments simple or branched, ustally consisting of one or more rows of cells within a sheath; reproduction occurs by means of hormogones or resting gonidia.

Family I. Oscillatoriaceae. Filaments frequently branched, containing one or more trichomes; sheaths variable, more or less gelatinous; trichomes consisting of a simple row of cells uniform along their entire length, except for the apical cells which sometimes taper more or less; heterocysts absent; reproduction by means of vegetative division and hormogones.

Family II. Nostocaceae. Sheaths very delicate, mostly confluent, usually not visible; trichomes usually twisting and entangled, consisting of a single row of uniform cells, with heterocysts; reproduction by means of vegetative division, hormogones and gonidia.

Family III. Scytonemaceae. Filaments with a false branch system; sheaths firm and tubular; trichomes consisting of a single row of cells, but not of uniform thickness, with heterocysts; reproduction by means of vegetative division, hormogones and gonidia.

Family IV. Stigonemaceae. Filaments frequently branched; sheaths thick, firm, often irregular; trichomes consisting of one or several rows of cells, 
with heterocysts; reproduction by means of vegetative division, hormogones and gonidia.

Family V. Rivulariaceae. Filaments tapering from the base to the apex, ending in a multicellular, colorless hair; heterocysts usually present, basal; reproduction by means of vegetative division, hormogones and gonidia.

\section{Family I. OSCILLATORIACEAE}

Filaments frequently branched, containing one or more trichomes; sheaths variable, more or less gelatinous; trichomes consisting of a simple row of cells uniform along their entire length; except for the apical cells which sometimes taper more or less; heterocysts absent; reproduction by means of vegetative division and hormogones.

I Sheaths not present.

I Trichomes straight or nearly so, never forming a regular spiral

(I) Trichomes cylindrical, usually without sheaths, free; apex of trichome straight or curved

Oscillatoria

(2) Trichomes cylindrical, without sheaths, united in free-swimming scale-like masses

Trichodesmium

2 Trichomes forming a regular, more or less lax spiral
(I) Trichomes multicellular
Arthrospira
(2) Trichomes unicellular
Spirulina

Ii Sheaths present.

I Filaments simple or branched; sheaths cylindrical, firm; trichomes single within the sheath; apex of trichome straight

(1) Filaments simple, more or less agglutinated by their mucous sheaths

Fhormidium

(2) Filaments simple, free, free-floating or forming a matted mass

Lyngbya

(3) Filaments often branched, forming erect tufts; false branches solitary Symploca

(4) Filaments simple; sheaths usually purple or flesh-colored; apical cell not capitate

Porphyrosiphon

2 Filaments frequently branched; sheaths firm, lamellose, transparent or colored; trichomes several within the sheath

(I) Sheaths more or less mucous, colorless, diffluent; trichomes few within the sheath; apex of trichome capitate

\section{Hydrocoleus}

(2) Filaments prostrate, woven into a solid membranaceous mass, often slightly branched; sheaths solid, always thin, colorless; plants terrestrial or aquatic

Hypheothrix

(3) Filaments prostrate at the base, above forming erect tufts; sheaths solid, transparent; plants terrestrial

Symplocastrum

(4) Filaments tufted, often much branched; sheaths transparent or scarcely colored; plants low, aquatic

Inactis 
(5) Filaments branched; sheaths solid, closed at the apex, of various colors; trichomes densely aggregated within the sheath

\section{Schizothrix}

(6) Sheaths wide, transparent or yellowish brown; trichomes very few within the sheath, very loosely aggregated

\section{Dasygloea}

(7) Sheaths mucous, not lamellose, always transparent; trichomes many within the sheath

Microcoleus

3 Colonies somewhat spherical, elliptical or spindle-shaped; filaments solitary or aggregated in colonies; sheaths thick, gelatinous

(I) Sheaths very thick; trichomes usually single or in scattered fragments

Catagnymene

(2) Colonies somewhat spherical; sheaths thick; trichomes curved, radiating Haliarachne

Genus OSCILLATORIA Vaucher. Hist. Conferves. 165. I803.

Trichomes cylindrical, free, motile, without a sheath or rarely enclosed in a very thin, fragile, mucous sheath, often constricted at the joints; apex of trichome straight, curved, or more or less regularly spiralled, often tapering; outer wall of apical cell often thickened, forming a calyptra.

I Plants living in fresh water, floating; apex of trichome constantly straight, gradually tapering, obtuse, finally capitate; cells somewhat quadrate or shorter than the diameter, never very short.

I Plant mass purple; trichomes 2.2-5 mic. in diameter; cells somewhat quadrate or longer than the diameter $O$. prolifica

2 Plant mass light blue-green; trichomes 4-6 mic. in diameter; cells somewhat quadrate or twice as short as the diameter

O. agardhii

I] Plants living in fresh water, sometimes in hot water; trichomes large or very large; apex of trichome straight, curved or spiral, not at all or briefly tapering, obtuse; cells very short.

I Transverse walls never granulated

(I) Trichomes I6-60 mic. in diameter; apex of trichome slightly tapering, somewhat capitate, hooked

O. princeps

(2) Trichomes $12-15$ mic. in diameter; apex of trichome tapering, capitate, hooked or loosely terebriform

O. proboscidea

2 Transverse walls frequently granulated

(I) Apex of trichome straight

A Trichomes 10-20 mic. in diameter, constricted at joints; apex of trichome very briefly tapering, somewhat capitate

O. sancta

$B$ Trichomes II-20 mic. in diameter, not constricted at joints; apex of trichome neither tapering nor capitate

O. limosa 
(2) Apex of trichome spiral, rarely hooked

A Trichomes Io- $17 \mathrm{mic}$. in diameter, not constricted at joints; apex of trichome not capitate

O. curviceps

B Trichomes $18-23$ mic. in diameter; apex of trichome slightly tapering, obtusely rounded, usually straight 0 . major

C Trichomes 9-II mic. in diameter, slightly constricted at joints, here and there interrupted by inflated, refringent cells; apical cell not capitate

O. ornata

D Trichomes 6-8 mic. in diameter, not constricted at joints, here and there interrupted by inflated, refringent cells; apical cell capitate

o. anguina

III Plants living in salt water; trichomes always constricted at joints, rarely straight or spiral throughout; apex of trichome scarcely tapering, very gradually curved, obtuse.

I Trichomes twisted into a regular spiral

O. bonnemaisonii

2 Trichomes not spiral, gradually curved in apical portion, rarely straight

(I) Plant mass dull red; trichomes I6-24 mic. in diameter

(2) Plant mass olive green; trichomes I7-29 mic. in diameter

O. margaritifera

(3) Plant mass dark olive green; trichomes 7-II mic. in diameter, straight, fragile

O. nigro-viridis

(4) Plant mass thin, fragile; trichomes 9.6-II.9 mic. in diameter, sometimes spirally coiled, sometimes curved or even nearly straight

O. capitata

(5) Plants epiphytic; trichomes 6-Io mic. in diameter, flexuous, flexible

o. corallinae

IV Plants living in fresh water, sometimes in hot water; trichomes straight or curved, not tapering at the apices.

1 Trichomes 8.5 mic. in diameter, straight or slightly flexuous

O. nigra

2 Trichomes 4-Io mic. in diameter, usually slightly constricted at the joints, often curved at the apices; transverse walls usually furnished with two rows of granules

O. tenuis

3 Trichomes 2-3 mic. in diameter, not constricted at joints, curved at the apices; transverse walls commonly marked by two protoplasmic granules

O. amphibia

4 Trichomes I-I.5 mic. in diameter, straight or rolled in a circinate manner

O. subtilissima

5 Trichomes 2.3-4 mic. in diameter, curved, very much constricted at joints; transverse walls pellucid, not granulated

O. geminata

6 Trichomes 2.5 mic. in diameter, especially constricted at joints; transverse walls pellucid

O. minnesotensis 
7 Trichomes 3.5-4 mic. in diameter, not constricted at joints; transverse walls pellucid, not granulated $\quad$ o. chlorina

8 Trichomes $.6 \mathrm{mic}$. in diameter, flexible, elongate, tangled, not constricted at joints

O. angustissima

V Plants living in fresh water, hot water, rarely in salt water; trichomes tapering, more or less pointed, hooked or flexuous, not entirely spiralled (except $\mathrm{O}$. chaly bea); cells longer or shorter than the diameter, never very short.

I Apical cell capitate

(I) Trichomes 2-3 mic. in diameter; cells longer than their diameter

(2) Trichomes $2.5-5 \mathrm{mic}$. in diameter; cells somewhat quadrate

\section{O. splendida}

O. amoena

2 Apical cell not capitate

(I) Plants living in salt water

A Trichomes 4.7-6.5 mic. in diameter, flexible, undulating; apex of trichome very gradually tapering, very flexuous

\section{O. subuliformis}

B Trichomes 4 mic. in diameter, somewhat flexuous, sometimes coiled in a regular circle, very much constricted at joints; apex of trichome tapering, slightly curved, obtuse

\section{O. salinarum}

C Trichomes 3-5 mic. in diameter, fragile, straight; apex of trichome briefly tapering, hooked or undulating 0 . laete-virens

(2) Plants living in fresh water, often in hot water, rarely in brackish water

A Trichomes 3-5 mic. in diameter; apex of trichome briefly tapering, very sharply pointed, hooked; cells usually longer than their diameter

O. acuminata

B Trichomes 3-4 mic. in diameter; apex of trichome briefly tapering, very sharply pointed, hooked; cells usually shorter than their diameter

O. animalis

C Trichomes 4-4.5 mic. in diameter, straight, entangled; transverse walls granulated; cell contents violet or sky-blue

O. violacea

D Trichomes 4-6.5 mic. in diameter, here and there interrupted by inflated refringent cells; apex of trichome briefly tapering, hooked or flexuous; cells three times shorter than their diameter

O. brevis

E Trichomes 4-7 mic. in diameter; apex of trichome obtuse straight, rarely slightly curved

o. cruenta

F Trichomes 4-6 mic. in diameter, slightly constricted at joints; apex of trichome briefly and somewhat obtusely tapering, hooked; cells quadrate or one-half as long as wide

O. formosa 
G Trichomes 2.5-4 mic. in diameter, constricted at joints; apex of trichome very gradually tapering, hooked or undulating; cells quadrate or longer than the diameter O. numidica

H Trichomes 5.5-8 mic. in diameter, slightly constricted at joints; apex of trichome very gradually tapering, hooked or undulating; cells quadrate or longer than the diameter, very long near the apex

O. cortiana

1 Trichomes 5.5-9 mic. in diameter, constricted at joints; apex of trichome very gradually tapering, undulating and finally hooked; apical cell obtuse; cells shorter than their diameter

O. okeni

J Trichomes 8-r3 mic. in diameter, scarcely constricted at joints, sometimes twisted in loose spirals; apex of trichome briefly or gradually tapering and hooked; apical cell obtuse; cells shorter than their diameter

O. chalybea

$\mathrm{K}$ Trichomes 8-10 mic. in diameter, straight, somewhat constricted at joints; apex of trichome often slightly tapering, obtuse, straight or curved

O. subsalsa

L Trichomes 15.5-18.5 mic. in diameter, straight; apex of trichome usually curved, somewhat tapering, obtuse-truncate

\section{O. percursa}

VI Plants living in fresh water, sometimes in hot water; trichomes regularly terebriform in apical portion or forming a spiral throughout their entire length, more or less tapering in the apical portion.

I Trichomes 6-8 mic. in diameter, forming a lax and regular spiral through their entire length, or straight and hooked at the apex; apical cell pointed, not capitate $O$. boryana

2 Trichomes 4-6.5 mic. in diameter, flexuous, straight below, loosely spiralled and terebriform above; apical cell obtuse, not capitate

O. terebriformis

Species not well understood.

O. subtorulosa

126. Oscillatoria prolifica (Greville) Gomont. Monographie des Oscillariées. 225. pl. 6. f. 8. I893. De Toni. Syll. Algar. 5: 149. Ig07.

Farlow, Anderson and Eaton. Algae Am.-Bor. exsicc. no. 229. 1889. (O. diffusa Farlow). Trelease. The "Working" of the Madison Lakes. Trans. Wis. Acad. Sci. Arts and Letters. 7: I22. pl. I0. I889. Hauck and Richter. Phykotheka Universalis. no. 477. I892. Collins, Holden and Setchell. Phyc. Bor.-Am. Fasc. 4. no. 154. 1896. Moore. The Pollution of Water Supplies by Algae. Rhodora. I: I00. I899; The causes of the red-brown color in certain Cyanophyceae. Soc. Plant. Morph. and Phys. Sci. N. S. I3: 248. 1901. Hyams and Richards. Notes on Oscillatoria prolifica (Greville). Tech. Quart. I4: 302. I901; 15: 308. 1902; 17: 270. 1904. Olive. Notes on the occurrence of Oscillatoria prolifica (Greville) Gomont in the Ice of Pine Lake, Waukesha County, Wisconsin. Trans. Wis. Acad. Sci. I5: I24. I905. 
Plate IV. fig. I.

Plant mass expanded, floating, jurple, when dried becoming lilac; trichomes 2.2-5 mic, in diameter, straight, elongate, flexible, not constricted at joints, when old gradually tapering at apex, obtuse, capitate; cells $4^{-6}$ mic. in length, subquadrate or a little longer than wide; apical cell -slightly tapering, truncate; calyptra depressed conical; transverse walls frequently granulated; cell contents refringent, coarsely granular.

Massachusetts. Giving a pronounced purple color to the water of Jamaica Pond. 1884. (Farlow). Jamaica Pond. (Moore, Hyams and Richards). Floating freely or forming scum. Jamaica Pond, Boston. (Collins). Forming a floating scum. Jamaica Pond, Jamaica Plain. December I893. (Burrage). Wisconsin. Pine Lake, Waukesha County. August, October I900. July I905. (Olive).

I27. Oscillatoria agardhii Gomont. Monogr. Oscill. 225. 1893. De Toni. Syll. Algar. 5: 149. I907.

Collins, Holden and Setchell. Phyc. Bor.-Am. Fasc. 30. no. I45I. I908. Plate IV. fig. 2.

Plant mass widely expanded, floating, light blue-green; trichomes $4^{-6}$ mic. in diameter, straight throughout entire length, fragile, not constricted at joints, gradually tapering towards the apex, obtuse, capitate; cells $2.5-3.5$ mic. in length; apical cell slightly tapering, truncate; calyptra convex; transverse walls granulated; cell contents coarsely granular, pale blue-green.

Missouri. St. Louis. December 1906. (Hus).

I28. Oscillatoria princeps Vaucher. Hist. Conferves d'eau douce. I9o. pí. I5. f. 2. I803. Gomont. Monogr. Oscill. 226. pl. 6. f. 9. 1903. De Toni. Syll. Algar. 5: 150.1907.

Harvey. Nereis Boreali-Americana. Part III. I24. 1858. Mazé and Schramm. Essai class. Algues Guadeloupe. 17. 1870-77. Wood. Contr. Hist. Fresh-Water Algae N. A. 20. 1872. (O. im perator Wood). Farlow, Anderson and Eaton. Algae Am.-Bor. exsicc. no. I77. 1877. Wittrock and Nordstedt. Algae aq. dulc. exsicc. no. 393. 1877-87. Rabenhorst. Algen Europas. no. 2535. I878. Wolle. Fresh-Water Algae U. S. 317. pl. 207. f. 20, 22; pl. 208. f. 3, 4. I887. Collins. Flora of Middlesex County, Massachusetts. I5. I888. Möbius. Ueber einige in Portorico gesammelte Süsswasser- und Luft-Algen. Hedwigia. 27: 248. I888. Bennett. Plants of Rhode Island. II5. I888. Trelease. The "Working" of the Madison Lakes. Trans. Wis. Acad. Sci. Arts and Letters. 7: 23. 1889. Wolle and Martindale. Algae. Britton's Catalogue of Plants found in New Jersey. Geol. Surv. N. J. 2: 610. I889. Mackenzie. A preliminary list of Algae collected in the neighborhond of Toronto. Proc. of Can. Inst. III. 7: 270. I890. Saunders. Protophyta-Phycophyta Flora of Nebraska. 2i. pl. I. f. 17. I894. Tilden. List of Fresh-water Algae collected in Minnesota during I894. Minn. Bot. Studies. I: 235. I895. Collins, Holden and Setchell. Phyc. Bor.-Am. Fasc. 1. no. 2. I895. Tilden. Am. Alg. Cent. II. no. I87. 1896 ; Observations on some West American Thermal Algae. Bot. Gaz. 25: 101. pl. 9. f. 19. I898; Am. Alg. Cent. III. no. 296. I898. Collins. Preliminary Lists of New England Plants,--V. Marine Algae. Rho- 
dora. 2: 42. 1900; The Algae of Jamaica. Proc. Am. Acad. Arts Sci. 37: 239. I90I. Snow. The Plankton Algae of Lake Erie. U. S. Fish Comm. Bull. for 1902. 22: 392. I903. Setchell and Gardner. Algae of Northwestern America. Univ. Calif. Pub. Bot. I: I82. I903. Collins. Phycological Notes of the late Isaac Holden.-II. Rhodora. 7: 235. 1905. Collins, Holden and Setchell. Phyc. Bor.-Am. Fasc. 26. no. 1253. 1905. Brown. Algal Periodicity in certain ponds and streams. Bull. Torr. Bot. Club. 35: 243, 247. I908. Buchanan. Notes on the Algae of Iowa. Proc. Iowa Acad. Sci. I4: 15. 1908. Tilden. American Algae. Cent. VII. Fasc. I. no. 649. 1909.

\section{Plate IV. fig. 3 .}

Plant mass dark green or black; trichomes $16-60$ mic. in diameter, straight, rigid, fragile when dried, not constricted at joints, slightly tapering, more or less curved and somewhat truncate at apex, somewhat capitate; apical cell convex above; calyptra none; cells $3.5-7$ mic. in length; transverse walls never granulated; cell contents finely granular, rarely showing coarser granules.

Canada. High Park, Toronto. (Mackenzie). United States. Frequent in ponds and pools from Maine to Florida. (Wolle). Massachusetts. Floating on quiet pool. Saugus. (Collins). Cambridge. July I8go. (Farlow). Rhode Island. Common. (Bennett). Connecticut. Bruce's Brook; Fresh Pond. July, September, October; resting on muddy bottom and floating in considerable masses on the surface of quiet water. Parrott's Pond, Bridgeport. July I 892 . (Holden). New Jersey. Frequent in ponds and pools. Cape May; Dennisville. (Wolle). Pennsylvania. Bethlehem. August I877. (Wolle). Alabama. Auburn. May i896. (Baker). Indiana. In ponds near Bloomington. June to November. (Brown). Ohio. In washings of stones and of plants growing in lake. Lake Erie. (Snow). Wisconsin. In a brook. Near Madison. (Trelease). Minnesota. Bridal Veil Falls, Minneapolis. June I894. (Tilden). Iowa. Fayette. (Fink). Ames. (Bessey). Pond, amid dense growth of $\mathrm{L} e \mathrm{~m} n$ a. Eagle Grove. (Buchanan). Nebraska. Occasionally found among other algae in the Dismal River region and in many places in the eastern part of the state. (Saunders). Wyoming. "Forming a black, thick floating mass in mountain stream at vent of hot spring. Gradually runs out, being replaced by green at a distance of fifty feet from vent. Temperature five feet from spring $42^{\circ} \mathrm{C}$; f fifty feet from spring $38^{\circ}$ C." Mountains near Nez Perces Creek, Lower Geyser Basin. June 1896 ; forming dark green velvety mass fringing edge of small mountain creek where a hot spring flows out just underneath the bank. Temperature of water one inch below surface $19^{\circ} \mathrm{C}$; on surface $58^{\circ} \mathrm{C}$. Near Emerald Pool. Upper Geyser Basin. July I896. Yellowstone National Park. (Tilden). Washington. In pond on shore of lake. Green Lake, King County. July I897. (Tilden). West Indies. Guadeloupe. (Mazé and Schramm). In river near "Coamo." Porto Rico. (Sentenis). In mats in stream. St. Ann's Bay. Jamaica. March I893. (Humphrey). Bath, Jamaica. July rgoo. (Pease and Butler).

Forma purpurea Collins in Collins, Holden and Setchell. Phyc. Bor.- 
Am. Fasc. 16. no. 753. I900; The Algae of Jamaica. Proc. Am. Acad. Arts. Sci. 37: 239. I901. De Toni. 1. c. I52.

Plant mass bright purple; trichomes bright purple.

West Indies. Forming a stratum on a roadside brook, near the baths. Jamaica. July 1900. (Pease and Butler).

129. Oscillatoria proboscidea Gomont. Monogr. Oscill. 229. pl. 6, f. IO, II. 1893. De Toni. Syll. Algar. 5: I52. I907.

Crouan in Mazé and Schramm. Essai Class. Algues Guadeloupe. I7. I870. (O. a ntil1 a r u Crouan). Wood. Contr. Hist. Fresh-Water Algae North America. 20. pl. 2. f. 5. a, b. I872. (O. neglecta Wood). Collins. Algae of Jamaica. Proc. Am. Acad. Arts Sci. 37: 289. I901. Colliris, Holden and Setchell. Phyc. Bor.-Am. Fasc. 24. no. II59. I904. Setchell and Gardner. Algae of Northwestern America. Univ. Calif. Pub. Bot. I: 182. 1903 .

Plate IV. fig. 4.

Plant mass dark green; trichomes I2-I5 mic. in diameter, straight or somewhat flexuous, here and there spiral, not constricted at joints, sometimes mixed with other Oscillatorias; apex of trichome briefly tapering, capitate, almost truncate, curved or loosely spiralled; apical cell showing a convex, slightly thickened outer membrane; cells 2-4 mic. in length; transverse walls never granulated; cell contents finely granular.

Alaska. In a small pond of fresh water. Glacier Valley, Unalaska. I899. (Lawson). Pennsylvania. In shallow ditches along railroad track. Near Manayunk. (Wood). California. On rocks in stream. North Berkeley. March I90I. (Gardner). West Indies. Guadeloupe. (Mazé and Schramm). In a pool by "Wag Water" and in stream from reservoir. Castleton, Jamaica. April r893. (Humphrey).

I30. Oscillatoria sancta Kuetzing. Tab. Phyc. I: 30. pl. 42. f. 7. I845-I849. Gomont. Monogr. Oscill. 229. pl. 6. f. I2. I893. De Toni. Syll. Algar. 5: I53. 1907.

Tilden. Am. Alg. Cent. I. no. 73. I894. (O. 1 i m o s a). Collins, Holden and Setchell. Phyc. Bor.-Am. Fasc. Io. no. 500. I898. Setchell. Notes on Cyanophyceae.-III. Erythea. 7: 53. 1899. Tilden. Am. Alg. Cent. V. no. 495. 190I; Collection of Algae from the Hawaiian Islands. Haw. Almanac and Annual for 1902. II2. I90I; Algae Collecting in the Hawaiian Islands. Postelsia: The Year Book of the Minnesota Seaside Station. I: I66. Ig02. Setchell and Gardner. Algae of Northwestern America. Univ. Calif. Pub. Bot. I: 182, 1903.

\section{Plate IV. fig. 5.}

Plant mass dark lead-colored, becoming violet when dried and tinting paper a beautiful violet; trichomes ro-20 mic. in diameter, elongate, flexible, straight or curved, fragile when dried, constricted at joints; apex of trichome very briefly tapering, somewhat capitate, straight; cells $2.5-6$ mic. in length; wall of apical cell strongly thickened into a conspicuous convex calyptra; transverse walls marked with densely crowded coarse granules; cell contents olive green or mouse-colored. 
New York. At bottom of warm spring. Lebanon Springs. (Harrison). Minnesota. Growing in somewhat dry sheets on sides of wooden tables in greenhouse. St. Paul. November I894. (Tilden). Washington. In a small pond of fresh water. Port Townsend. (Gardner). California. At bottom of cold stream. Near Oakland. (Setchell). On earth among flower pots in conservatories. University of California. Berkeley. (Nott). Hawaii. Forming a reddish-brown skin on wet sides of cliff. Falls four miles from mouth of river. Waialuka River. Hilo, Island of Hawaii. July I900; on muddy sides of sewer ditch. Kealea Plantation, Kauai. July I9oo. (Tilden).

Var. caldariorum (Hauck) Lagerheim. Algologiska Bidrag. Bot. Notiser. 49. 1886. Gomont. 1. c. 230. I893. De Toni. 1. c. I54. I907.

Collins, Holden and Setchell. Phyc. Bor.-Am. Fasc. 22. no. I055. 1903.

Trichomes IO-I4 mic. in diameter.

California. On moist ground in conservatory. Golden Gate Park, San Francisco. December I902. (Gardner).

Var. aequinoctialis Gomont. 1. c. 230. I893. De Toni. 1. c. I54. 1907.

Collins, Holden and Setchell. Phyc. Bor.-Am. Fasc. II. no. 502. I898; Fasc. 28, no. 1352, 1907.

Trichomes 15-20 mic. in diameter.

Massachusetts. In stagnant water in claypit. West Medford. September I906. (Collins). California. Forming dark brown patches on damp soil in greenhouses. University of California, Berkeley. 1896. (Nott).

I3I. Oscillatoria limosa Agardh. Disp. Alg. Suec. 35. I8I2. Gomont. Monogr. Oscill. 230. 1893. De Toni. Syll. Algar. 5: 154. 1907.

Wolle. Fresh-Water Algae. U. S. 313. p1. 206. 1887. Collins. Algae of Middlesex County, Massachusetts. I5. I888; Marine Algae of Nantucket. 4. I888. Martindale. Marine Algae of the New Jersey coast and adjacent waters of Staten Island. Mem. Torr. Bot. Club. I: 90. I889. Wolle and Martindale. Algae. Britton's Catalogue of Plants found in New Jersey. Geol. Surv. N. J. 2: 609. 1889. (O. froelich i i Kg.). Mackenzie. A preliminary list of Algae collected in the neighborhood of Toronto. Proc. of Can. Inst. III. 7: 270. I890. Jelliffe. A preliminary list of the plants found in the Ridgewood Water Supply of the City of Brooklyn, King's County, N. Y. Bull. Torr. Bot. Club. 20: 243. 1893; A preliminary report upon the microscopical organisms found in the Brooklyn water supply. Brook. Med. Journ. 7: 602. 1893; A further contribution to the microscopical examination of the Brooklyn water supply. Brook. Med. Journ. 8: 592. 1894. Tilden. American Algae. Cent. I. no. 72. 1894. Collins. Algae. Rand and Redfield's Flora of Mount Desert Island, Maine. 248. I894. Saunders. Protophyta-Phycophyta. Flora of Nebraska. 2I. I894. Tilden. List of Freshwater Algae collected in Minnesota during I894. Minn. Bot. Studies. I: 235. r895. Collins, Holden and Setchell. Phyc. Bor.-Am. Fasc. 6. no. 253. 1897. Setchell. Notes on Cyanophyceae. -III. Erythea. 7: 53. I899. Collins. Preliminary lists of New England Plants.-V. Marine Algae. Rhodora. 2: 42. I900. Tilden. American Aigae. Cent. VI. no. 592. Ig02. Snow. The Plankton Algae of Lake Erie. U. S. Fish Comm. Bull. for I902. 22: 392. 1993. (O. froehlichii Kuetz.). 
Setchell and Gardner. Algae of Northwestern America. Univ. Calif. Pub. Bot. I: 183. I903. Collins. Phycological Notes of the late Isaac Holden. -II. Rhodora. 7: 235. I905. Riddle. Brush Lake Algae. Ohio Nat. 5: 268. 1905. Brown. Algal Periodicity in certain ponds and streams. Bull. Torr. Bot. Club. 35: 243, 247. 1908. Collins, Holden and Setchell. Phyc. Bor.-Am. Fasc. 3I. no. I503. 1908. Buchanan. Notes on the Algae of Iowa. Proc. Iowa Acad. Sci. 14: I4. Igo8. Tilden. American Algae. Cent. VII. Fasc. I. no. 648. I909.

Plate IV. fig. 6.

Plant mass dark blue-green; trichomes rI-20 mic. in diameter, crowded, straight (in dried specimens rigid and fragile), not constricted at joints; apex of trichome straight, not at all or scarcely tapering, not capitate; apical cell showing a convex, somewhat thickened outer wall; cells 2-5 mic. in diameter; transverse walls frequently granulated; cell contents bluegreen or olive.

Canada. Humber River, Toronto. (Mackenzie). United States. (Wolle). Maine. In fresh water. Mount Desert Island. (Holden). Massachusetts. Newton. (Farlow). Charles River, Newton; on wharves, Nantucket; in claypit, Glenwood, Medford, April I892. (Collins). Rhode Island. (Coilins). Connecticut. On sandy bottom and floating in fresh water ditch. May 1892; Berkshire Mill Pond (brackish), Bridgeport, May I894; stream, Stratford; Great Falls of the Housatonic; ditch below Factory Pond, floating and attached to plants; Berkshire Mill Pond; forming a dark purple stratum on plants in running water, Pequonnock River, below Factory Pond Dam. (Holden). New York. Brooklyn water supply. December and February. (Jelliffe). New Jersey. Stapleton and Tomkinsville, Staten Island. (Pike). Frequent, on wet earth. (Wolle). Texas. I90z. (Fanning.) Ohio. Brush Lake, Champaign County. 1902. (Riddle). In washings of stones and of plants growing in the lake. Put-in-Bay, Lake Erie. (Snow). Indiana. Faris Pond, Fees Pond, Monon Pond, Jordan Branch. Near Bloomington. December until May. (Brown). Minnesota. Growing mostly beneath surface of water. Current very swift. State Fish Hatcheries, St. Paul. September 1894. (Tilden). In rapidly running water, forming brown coating on decayed leaves. Minnehaha Creek, above the Falls, Minneapolis. October 190I. (Hone). Iowa. In a sulphur spring, Iowa Falls. June I904. (Gardner). Very common. Iowa City. (Hobby). Fayette. (Fink). On damp earth, forming a thin coating. Ames. (Bessey, Buchanan). Moist earth; floating in Hewitt's Pond, Eagle Grove; on moist soil in the greenhouse. Ames. (Buchanan). Nebraska. Common on damp earth, forming a blue-green coating. (Saunders). Washington. Floating on ditches of slightly brackish water. La Conner, Skagit County; Whidbey Island. (Gardner).

Var. badia Tilden. American Algae. Cent. II. no. I88. 1896. De Toni. Syll. Algar. 5: 157. 1907.

Plant mass forming a thin scum on rocks, afterwards breaking loose and floating on surface of water, brownish; trichomes 9.5 mic. in diameter; cells 5-9.5 mic. in length; cell contents drab or light brown. 

man).

Minnesota. On rocks. Grand Marais, Lake Superior. July I8g6. (Elft-

132. Oscillatoria curviceps Agardh. Syst. Alg. 68. I824. Gomont. Monogr. Oscill. 233. pl. 6. f. 14. I893. De Toni. Syll. Algar. 5: 157. 1907.

Mazé and Schramm. Essai class. Algues Guadeloupe. 16. I870-77. (O. $\mathrm{subsalsa} d \mathrm{u} 1 \mathrm{cis}$ ). Dame and Collins. Flora of Middlesex County, Massachusetts. 15. 1888. (O. froelichii viridis). Tilden. American Algae. Cent. II. no. I89. I8g6. Bessey, Pound and Clements. Additions to the reported Flora of the State. Bot. Surv. Neb. 5: I3. Igor. Collins, Holden and Setchell. Phyc. Bor.-Am. Fasc. 27. no. 1305. I906.

$$
\text { Plate IV. fig. } 7 .
$$

Plant mass light or dark blue-green; trichomes IO-I7 mic. in diameter, elongate, straight below, above curved or twisted into a loose spiral, not constricted at joints; apex of trichome not or scarcely tapering, not capitate; cells 2-5 mic. in length; outer wall of apical cell convex, sometimes slightly thickened; transverse walls sometimes marked by two rows of granules; cell contents uniformly granular or showing larger granules.

United States. (Wolle, Farlow). Massachusetts. Medford claypits. (Collins). Nebraska. On moist soil, greenhouse. Lincoln. (Bessey). Colorado. On surface of slow-flowing water in swamp. Five miles southeast of Fort Collins. July I8g6. (Cowen). California. Outlet of Lake Temescal, Oakland. July 1905. (Gardner). West Indies. (Crouan).

I33. Oscillatoria major Vaucher. Hist. Conferves d'eau douce. I92. pl. I5. f. 3. I803. De Toni. Syll. Algar. 5: I57. 1907.

Wolle. Fresh Water Algae. II. Bull. Torr. Bot. Club. 6: I38. I877. Wolle and Martindale. Algae. Britton's Catalogue of Plants found in New Jersey. Geol. Surv. N. J. 2: 609. 1889. West. The Freshwater Algae of Maine. Journ. of Bot. 29: 356. 1891.

Plant mass membranaceous, mucous, blue-green, lead-colored or dark steel-blue; trichomes 18-23 mic. in diameter, straight, often arranged longitudinally in narrow bundles; apex of trichome somewhat tapering, obtusely rounded, usually straight; cells $4.5-6$ mic. in length; transverse walls granulated on both sides.

Maine. Scarbro'. (Aubert). New Jersey. In sluggish and stagnant waters. (Wolle). Pennsylvania. Borders of ponds and pools. (Wolle).

134. Oscillatoria ornata Kuetzing. Tab. Phyc. I: 30. p1. 42. f. 9. I845-1849. Gomont. Monogr. Oscill. 234. pl. 6. f. I5. I893. De Toni. Syll. Algar. 5: 158. 1907 .

\section{Plate IV. fig. 8.}

Plant mass dark blue-green; trichomes 9-II mic. in diameter, slightly constricted at joints, here and there interrupted by inflated and refringent cells, straight below, above twisted into a loose spiral, slightly and gradually tapering; apex of trichome not capitate, obtuse; apical cell convex above; calyptra none; cells $2-5 \mathrm{mic}$. in length; transverse walls frequently granulated. 
Massachusetts. (Collins).

135. Oscillatoria anguina Bory. Dict. class. d'hist. nat. I2: 467. I827. Gomont. Monogr. Oscill. 234. p1. 6. f. I6. I893. De Toni. Syll. Algar. 5: I59. 1907.

Tilden. American Algae. Cent. I. no. 74. 1894; List of Fresh-water Algae collected in Minnesota during I894. Minn. Bot. Studies. I: 235. I895. Collins. The Algae of Jamaica. Proc. Am. Acad. Arts Sci. 37: 239. I90I. Collins, Holden and Setchell. Phyc. Bor.-Am. Fasc. 22. no. I052. I903.

Plate IV. fig. 9.

Plant mass dark blue-green; trichomes 6-8 mic. in diameter, not constricted at joints, frequently interrupted by inflated and refringent cells, straight below, above terebriform, gradually tapering; apex of trichome capitate, obtuse; outer wall of apical cell slightly thickened; cells I.5-2.5 mic. in length; transverse walls sometimes granulated.

Minnesota. On moist earth. State Fish Hatcheries, St. Paul, August I894; in stream formed by springs, Second Creek, Lake City, Wabasha County. September I894. (Tilden). California. Floating among $\mathrm{Ch}$ a $\mathrm{r}$ in a small stream. Near Richmond, Contra Costa County. November I902. (Gardner). West Indies. In still water. Roaring River, near St. Ann's Bay, Jamaica. March I893. (Humphrey).

136. Oscillatoria bonnemaisonii Crouan in Desmazieres. Pl. Crypt. France. II. no. 537. 1858. Gomont. Monogr. Oscill. 235. pl. 6. f. I7, 18. 1893. De Toni. Syll. Algar. 5: 159. 1907.

Wolle. Fresh Water Algae. II. Bull. Torr. Bot. Club. 6: I38. I877; Fresh-Water Algae. U. S. 316. pl. 207. f. I6, I7. 1887. West, W. Jun. Some Oscillarioideae from the Plankton. Journ. of Bot. 37: 337. I899. Setchell and Gardner. Algae of Northwestern America. Univ. Calif. Pub. Bot. I: I83. I903. Lemmermann. Algenfl. Sandwich-Inseln. Bot. Jahrb. 34: 6I8. 1905. Tilden. American Algae. Cent. VII. Fasc. I. no. 647. Igog.

\section{Plate IV. fig. Io.}

Trichomes $18-36$ mic. in diameter, forming loose and regular spirals, elongate, flexible, somewhat constricted at joints; apex of trichome neither tapering nor capitate; apical cell with convex outer wall, not capitate; calyptra none; cells 3-6 mic. in length; transverse walls not granulated; cell contents finely granular, uniformly strewn with larger granules.

Pennsylvania. Wet soil, recently inundated. (Wolle). Washington. In salt marshes. Whidbey Island. (Gardner). West Indies. In plankton. (Murray and Blackman). Hawaii. On marine algae. Laysan. I896-97. (Schauinsland). Mixed with other algae, floating in lagoon on beach. Seaconnot, near Hilo, Island of Hawaii. July 1900. (Tilden).

I37. Oscillatoria miniata Hauck. Die Meeresalgen Deutschlands und Oesterreichs. 508. 1885. Gomont. Monogr. Oscill. 236. I893. De Toni. Syll. Algar. 5: 160. 1907.

Mazé and Schramm. Essai Class. Algues Guadeloupe. I6. I870-1877. Murray. Catalogue of the Marine Algae of the West Indian Region. Journ. 
of Bot. 27: 26r. r889. West. Some Oscillarioideae from the Plankton. Journ. of Bot. 37 : 337. pl. 400 a. 1899.

Plant mass dull red; trichomes 16-24 mic. in diameter, straight, constricted at joints (?), apex of trichome briefly tapering, obtuse, capitate; apical cell showing a slightly convex calyptra; cells 7-II mic. in length; cell contents homogeneous or slightly granular, pale or dark red. man.)

West Indies. (Mazé and Schramm). In plankton. (Murray and Black-

138. Oscillatoria margaritifera Kuetzing. Tab. Phyc. I: 31. pl. 43. f. Io. I845. Gomont. Monogr. Oscill. 236. p1. 6. f. 19. I893. De Toni. Syll Algar. 5: 16r. I907.

Murray. Catalogue of the Marine Algae of the West Indian Region. Journ. of Bot. 27: 26r. 1889. Collins. Preliminary Lists of New England Plants.-V. Marine Algae. Rhodora. 2: 42. I90o.

\section{Plate IV. fig. II.}

Plant mass black; trichomes I7-29 mic, in diameter, straight, cor1. stricted at joints, curved gradually and for some distance from the end; apex of trichome slightly tapering, obtuse; apical cell capitate; calyptra slightly convex; cells 3-6 mic. in diameter; transverse walls lined with granules; cell contents olive green.

Massachusetts. Northern part of state. (Collins). West Indies. Guadeloupe. (Mazé).

139. Oscillatoria nigro-viridis Thwaites in Harvey. Phyc. Brit. Syn. XXXIX. no. 375. pl. 25I. A. I846-I851. Gomont. Monogr. Oscill. 237. pl. 6. f. 20. I893. De Toni. Syll. Algar. 5: I6I. 1907.

Farlow. Marine Algae of New England. 33. I88r. (O. $1 \mathrm{im}$ os a ch a$1 \mathrm{y} \mathrm{b}$ e a). West. Some Oscillarioideae from the Plankton. Journ. of Bot. 37: 337. I899. Collins. Preliminary lists of New England Plants.-V. Marine Algae. Rhodora. 2: 42. I900. Collins, Holden and Setchell. Phyc. Bor.-Am. Fasc. 22. no. 1056. 1903. Setchell and Gardner. Algae of Northwestern America. Univ. Calif. Pub. Bot. I: I83. I903.

Plate IV. fig. I2.

Plant mass very dark olive green; trichomes 7 -II mic. in diameter, moderately long, somewhat straight, fragile, constricted at joints, curved gradually and for some distance from the end; apex of trichome tapering, obtuse; apical cell somewhat capitate, with convex and slightly thickened outer wall; cells 3-5 mic. in length; transverse walls granulated; cell contents pale green or olive.

Maine. Forming a slimy layer on piles. Eastport. (Farlow). Forming a black, very thin film on muddy beams under old tide mill. Harpswell. July rgo2. (Collins). Massachusetts. Northern part of state. (Collins). Washington. In salt marshes. Whidbey Island. (Gardner). Seattle. (Foster). West Indies. In plankton. (Murray and Blackman). 
I40. Oscillatoria capitata W. West Jun. Some Oscillarioideae from the Plankton. Journ. of Bot. 37: 337. pl. 400 a. 1899. De Toni. Syll. Algar. 5: 162. 1907.

Plate IV. fig. I3-I5.

Trichomes 9.6-II.9 mic. in diameter, free or forming a delicate fragile mass, at times spirally coiled and twisted, or curved, or even nearly straight, slightly constricted at joints; apex of trichome slightly tapering; cells 4-8.5 mic. in length; apical cell 6.9-9.I mic. in diameter, 6.7-8. I mic. in length, at constriction 3.6-8 mic. in diameter; calyptra more or less convex and closely appressed; transverse walls not granulated; cell contents homogeneous or somewhat granular.

West Indies. Lat. $23^{\circ} 44^{\prime} \mathrm{N}$; 䀜g. $45^{\circ} 30^{\prime} \mathrm{W}$. (Murray and Blackman).

Wille considers this species to be a variety of $\mathrm{Catagnymene}$ s p ir a lis Lemmermann.

14I. Oscillatoria corallinae Gomont. Essai Class. Nostocacées homocystées. Morot. Journ. de Bot. 4: 356. I89o; Monogr. Oscill. 238. pl. 6. f. 21. 1893. De Toni. Syll. Algar. 5: 16z: 1907.

Collins. Preliminary lists of New England Plants.-V. Marine Algae. Rhodora. 2: 4I. 1900; The Algae of Jamaica. Proc. Am. Acad. Arts Sci. 37: 239. I9oI; Phycological Notes of the late Isaac Holden.-I. Rhodora. 7: 172. 1905. Lemmermann. Algenfl, Sandwich-Inseln. Bot. Jahrb. 34: 618. I905.

Plate IV. fig. I6.

Trichomes gregarious, forming a delicate coating on larger algae, 6-10 mic. in diameter, very long, flexuous, at times contorted, contracted at joints, curved gradually and for some distance from the end; apex of trichome scarcely tapering; cells 2.7-4 mic. in length; transverse walls not granulated; cell contents granular; apical cell somewhat capitate, with convex, slightly thickened outer wall.

Connecticut. On Gelidium. Woodmont; on Enteromorpha, below Yellow Mill Bridge, September. (Holden). West Indies. In a pellicle on coral rock. Port Antonio. March 1893. (Humphrey). Among other algae, near Kingston, Duerden. (Collins). Hawaii. Washings from marine algae. Laysan Island. (Schauinsland).

142. Oscillatoria nigra Vaucher. Hist. Conferves d'eau douce. I92. no. 3. pl. 15. f. 4. 1803. De Toni. Syll. Algar. 5: I64. I907.

Collins, Algae of Middlesex County, Massachusetts. I5. I888. Bennet. Plants of Rhode Island. II5. I888. West. The Freshwater Algae of Maine. 27: 207. I889. Wolle and Martindale. Algae. Britton's Catalogue of Plants found in New Jersey. Geol. Surv. N. J. 2: 609. 1889. Anderson. List of California Marine Algae, with notes. Zoe. 2: 217. 189r. Buchanan. Notes on the Algae of Iowa. Proc. Iowa Acad. Sci. 14: 14. rgo8.

Plant mass more or less compact, somewhat membranaceous, usually floating, lead-colored or dark olive green, glistening; trichomes 8.5 mic. in diameter, straight or slightly flexuous; apex of trichome tapering, obtusely rounded; apical cell usually straight, somewhat beak-like, bearded, 
rarely slightly curved; cells equal in length to the diameter, after division shorter; transverse walls very distinctly granulated; cell contents finely granular, pale olive,

United States. (Bailey). Maine. (West). Massachusetts. Newton. (Farlow). Malden. (Collins). Rhode Island. Common. (Bennett). New Jersey. Frequent in wet places. (Wolle). Iowa. Usually floating free in stagnant water. Iowa City. (Hobby). Ames. (Bessey, Buchanan). California. On moist cliffs above high tide. Common. (Anderson).

143. Oscillatoria tenuis Agardh. Algarum. Decades. 2: 25. I8I3. Gomont. Monogr. Oscill. 240. pl. 7. f. 23. 1893. De Toni. Syll. Algar. 5: I66. 1907.

Mazé and Schramm. Essai Class. Algues Guadeloupe. 16. I870-77. Rabenhorst. Algen Europa's, no. 2536. 1878. (O. cortiana). Dickie. On the Algae found during the Arctic Expedition. Journ. Linn. Soc. Bot. I7: 8. 1880. Farlow. Notes on the Cryptogamic Flora of the White Mountains. Appalachia. 3. 236. 1883. Wolle. Fresh-Water Algae U. S. 313. pl. 206. f. I4. 1887. Bennett. Plants of Rhode Island. II5. I888. Collins. Algae of Middlesex County, Massachusetts. I5. I888. (O. virid is). Wolle and Martindale. Algae. Britton's Catalogue of Plants found in New Jersey. Geol. Surv. N. J. 2: 609. r889. Rosenvinge. Les Algues Marines du Groenland. Ann. Sci. Nat. Bot. VII. I9: 162. I894. Tilden. American Algae. Cent. I. no. 75. I894. Saunders. Protophyta-Phycophyta. Flora of Nebraska. 2r. pl. I. f. I6. I894. Tilden. List of Fresh-water Algae collected in Minnesota during I894. Minn. Bot. Studies. I : 235. I895. Collins, Holden and Setchell. Phyc. Bor-Am. Fasc. 3. no. I02. I895. Tilden, American Algae. Cent. II. no. I90. I896. Collins. Algae. Flora of the Blue Hills, Middlesex Fells, Stony Brook and Beaver Brook Reservations of the Metropolitan Park Commission, Massachusetts. I27. I896. Rosenvinge. Deuxième Mémoire sur les Algues Marines du Groenland. Medd. om Groenland. 20: I2I. I898. Tilden. List of Fresh-water Algae collected in Minnesota during 1896 and 1897 . Minn. Bot. Studies. 2: 29. 1898. Observations on some West American Thermal Algae. Bot. Gaz. 25: I01. pi. 9. f. 20. I'898. Collins. Preliminary Lists of New England Plants,V. Marine Algae. Rhodora. 2: 42. 1900; The Algae of Jamaica. Proc. Am. Acad. Arts Sci. 37: 239. 1901. Snow. The Plankton Algae of Lake Erie. U. S. Fish Comm. Bull. for I902. 22: 393. 1903. Setchell and Gardner. Algae of Northwestern America. Univ. Calif. Pub. Bot. I: I83. I903. Collins. Phycological Notes of the late Isaac Holden.-II. Rhodora. 7: 236. 1905. Börgesen and Jonsson. The distribution of the Marine Algae of the Arctic Sea and of the Northernmost Part of the Atlantic. Botany of the Faeroes. Appendix. XXV. 1905. Brown. Algal periodicity in certain ponds and streams. Bull. Torr. Bot. Club. 35: 242, 247. r908. Buchanan. Notes on the Algae of Iowa. Proc. Iowa Acad. Sci. I4: I4. Igo8.

Plate IV. fig. I7, I8.

Plant mass thin, bright, rarely dull blue-green; trichomes 4 -ro mic. in diameter, straight, fragile, usually slightly constricted at joints; apex of trichome straight or curved, neither tapering nor capitate; apical cell convex, showing a slightly thickened outer wall; cells $2.6-5$ mic. in length; 
transverse walls usually furnished with two rows of granules; cell contents pale blue-green.

Arctic Regions. Fresh water. $82^{\circ} 27^{\prime}$ lat. N. (Dickie). Greenland. Western part, south of $6 \mathrm{I}^{\circ}$ lat. N. (Rosenvinge). Western part. (Börgesen and Jonsson). New Hampshire. On mosses. Mill Brook, Shelburne. (Farlow). Massachusetts. Newton. (Farlow). Malden and Reading. On rocks and trunks of trees. (Collins). Rhode Island. Providence. (Lathrop). New Jersey. In stagnant waters; frequent. (Wolle). (Collins). Connecticut. Bruce's Brook. October I89o; floating in pool below Factory Pond; Housatonic River, on wall of quartz mill; Fresh Pond; Pequonnock River, Bridgeport. (Holden). New York. In deep pool. Ithaca flats. April 1895. (Atkinson). Pennsylvania. Dripping, mossy rocks, pools, margins of pools, or free swimming; in hot water. (Wolle). Ohio. In plankton. Put-in-Bay, Lake Erie. (Snow). Indiana. "Three different species of Cscillatoria appeared in considerable abundance in the ponds and streams under observation. These were Oscillatoria tenuis, $O$. $1 \mathrm{imos}$ a and O. princeps. Some other species were noticed but they did not persist any length of time. O. t e $\mathrm{n} u$ is was the most abundant form both in quantity and distribution. It was abundant in stream no. I. (Jordan Branch), especially in the lower part, and in the smaller of the waterworks ponds during the greater part of the year. In stream no. I it grew on the stones in the bottom, forming a tolerably dense stratum. A similar stratum formed on the rocks at the outlet of pond no. 4 (Monon Pond) whenever sufficient water flowed over the spillway to keep them wet. Around the edge of the smaller of the water-works ponds there was usually a stratum covering the bottom in the shallow water. Whenever sufficient oxygen collected in the meshes of a mass it was loosened and floated on the surface."-Brown. Minnesota. Lining sides of tanks in Zoological Laboratory, University of Minnesota, Minneapolis. November I894. (Tilden). In arm of Mississippi River (old channel). St. Paul Park. October I897. (Freeman), Nebraska. Rocks, pools, margins of ponds, or floating free; common throughout the state. (Saunders). Wyoming. In small mountain spring in a bog, together with moss and water cress. Valley of Nez Perces Creek, Lower Geyser Basin, Yellowstone National Park. June I896. (Tilden). Washington. Floating in slightly brackish water in a ditch. La Conner, Skagit County. (Gardner). "Agrees well with O. te $n$ u is, except that it is hardly at all torulose."-Setchell. West Indies. Guadeloupe. (Mazé and Schramm). Bath. July rgoo. (Pease and Butler).

Var. natans (Kuetzing) Gomont. 1. c. 24I. De Toni. 1. c. I68.

Wolle and Martindale. Algae. Catalogue of Plants found in New Jersey. Geol. Surv. N. J. 2: 609. I889. (O. n a t a n s Kg.). Tilden. American Algae. Cent. I. no. 76. I894; List of Fresh-water Algae collected in Minnesota during I894. Minn. Bot. Studies. I: 235. I895. Snow. The Plankton Algae cf Lake Erie. U. S. Fish Comm. Bull. for 1902. 22: 393. I903. Collins. Phycological Notes of the late Isaac Holden.-II. Rhodora. 7: 236. 1905. Collins, Holden and Setchell. Phyc. Bor.-Am. Fasc. 25. no. 1207. I905; Fasc. 
Connecticut. Bruce's Brook, Bridgeport. October, December. (Holden). New Jersey. Fresh water ponds, frequent. (Wolle). Ohio. Plankton. Put-in-Bay, Lake Erie. (Snow). Wisconsin. Floating in tanks. Trout mere. Osceola. October 1894. (Tilden). California. In a stream at the outlet of Lake Chabot, San Leandro, Alameda County. May 1903. (Gardner).

Var. tergestina (Kuetz.) Rabenhorst. F1. Eur. Algar. 2: I02. 1865. Gomont. Monogr. Oscill. 241. I893. De Toni. Syll. Algar. 5: 168. 1907.

Tilden. American Algae. Cent. IV. no. 400. 1900.

Collins, Holden and Setchell. Phyc. Bor.-Am. Fasc. I4. no. 651. I900. Tilden. American Algae. Cent. VI. no. 593. I902. Setchell and Gardner. Algae of Northwestern America. Univ. Calif. Pub. Bot. I: 183. I903.

Trichomes 4-6 mic. in diameter.

Rhode Island. Forming small patches of a verdigris-green color in warm water of escape from a steam boiler. Berkeley. March I894. (Setchell and Osterhout). Minnesota. In polyzoan colony. Mississippi River, St. Paul. I898. (Freeman). In pool. Lincoln Park, Duluth. August Ig0I. (Tilden). Washington. In pool of fresh or slightly brackish water. Whidbey Island; Seattle. (Gardner).

144. Oscillatoria amphibia Agardh. Aufzähling einiger in den östreichischen Landern gefundenen neuen Gattungen und Arten von Algen. Flora. I0: 632. 1827. Gomont. Monogr. Oscill. 24I. pl. 7. f. 4, 5. 1893. De Toni. Syil. Algar. 5: I69. I907.

Wolle. Fresh Water Algae. II. Bull. Torr. Bot. Club. 6: 138. 1877. (O. ten errima Kg.); Fresh-Water Algae U. S. 3Io. pl. 205. f. 3. I887. Bessey. Miscellaneous additions to the Flora of the State, and new or noteworthy species from various localities. Bot. Surv. Nebraska. 46. 1893. Rosenvinge. Les Algues Marines du Groenland. Ann. Sci. Nat. Bot. VII. 19: I63. I894. Collins. Algae. Rand and Redfield's Flora of Mount Desert Island, Maine. 248. I894. Saunders. Protophyta-Phycophyta. Flora of Ne. braska. 20. pl. 2. f. I8. I894. Collins. Algae. Flora of the Blue Hills, Middlesex Fells, Stony Brook and Beaver Brook Reservations of the Metropolitan Park Commission, Massachusetts. I27. I896. Rosenvinge. Deuxième Mémoire sur les Algues Marines du Groenland. Medd. om Groenland. 20. I2r. I898. Tilden. Observations on some West American Thermal Algae. Bot. Gaz. 25: 102. pl. 9. f. 21. I898. Collins, Holden and Setchell. Phyc. Bor.-Am. Fasc. I5. no. 705. I900. Collins. Preliminary Lists of New England Plants,-V. Marine Algae. Rhodora, 2: 42. Igoo. Bessey, Pound and Clements. Additions to the reported Flora of the State. Bot. Surv. Nebraska. 5: I3. Ig0I. Tilden. American Algae. Cent. VI. no. 594. Ig02. Snow. The Plankton Algae of Lake Erie. U. S. Fish Comm. Bull. for 1902. 22: 392. 1903. Collins. Phycological Notes of the late Isaac Holden,-II. Rhodora. 7: 235. 1905. Börgesen and Jonsson. The distribution of the Marine Algae of the Arctic Sea and of the northernmost part of the Atlantic. Botany of the Faeroes. Appendix. XXV. I905. 
Buchanan. Notes on the Algae of Iowa. Proc. Iowa Acad. Sci. I4: 14. 1908. Tilden. American Algae. Cent. VII. Fasc. I. no. 646. 1999.

$$
\text { Plate IV. fig. I9, } 20 .
$$

Plant mass thin, of a beautiful blue-green color; trichomes 2-3 mic. in diameter, straight or curved, fragile, not constricted at joints, curved gradually at the end; apex of trichome neither tapering nor capitate; apical cell rotund above; calyptra none; cells $4-8.5$ mic. in length; transverse walls commonly marked by two protoplasmic granules; cell contents pale bluegreen.

Greenland. Western part at $60^{\circ}$ N. lat. (Rosenvinge). Eastern and western parts. (Börgesen and Jonsson). United States. Coating wood subject to hot waste water from steam engines. Temperature about $110^{\circ}$ F. (Wolle). Maine. In fresh water. (Holden). Massachusetts. On rocks and trunk of trees. (Collins). Connecticut. On muddy bottom of Bruce's Brook, Bridgeport. (Holden). Texas. Ig02. (Fanning). Ohio. Plankton. Put-in-Bay, Lake Erie. (Snow). Minnesota. In pool. Oatka Beach, Minnesota Point, Duluth. August Igor. (Tilden). Iowa. In stagnant water and on soil. Fayette. (Fink). Effluent of the filter beds of the college sewage disposal plant; on the soil in greenhouse, Ames; pond, Eagle Grove. (Buchanan). South Dakota. Floating in large dark bluegreen masses on surface of water. Lake Hendricks. August 1898. (Allen and Saunders). Nebraska. In Salt Creek; in cultures. Lincoln. (Bessey). In ditches and ponds among other algae. (Saunders). Wyoming. Lining channel of spring. Above Beehive Geyser, Upper Geyser Basin, Yellowstone National Park. 1897. (Weed). Washington. In mud at bottom of ponds. Whidbey Island. (Gardner).

145. Oscillatoria subtilissima Kuetzing. Tab. Phyc. I: 27. pl. 38. f. 7. I845-49. De Toni. Syll. Algar. 5: I7I. I907.

Bennett. Plants of Rhode Island. II5. I888. Snow. The Plankton Algae of Lake Erie. U. S. Fish Comm. Bull. for I902. 22: 392 . I903.

Trichomes I-I.5 mic. in diameter, solitary or scattered, rarely associated in a yellowish-green mass, slender, straight or rolled in a circinate manner; cell walls inconspicuous; cell conents homogeneous, yellowishgreen.

Rhode Island. Common. (Bennett). Ohio. Plankton. Put-in-Bay, Lake Erie. (Śnow).

146. Oscillatoria geminata Meneghini. Conspectus Algologiae euganeae. 9. I837. Gomont. Monogr. Oscill. 242. pl. 7. f. 6. I893. De Toni. Syll. Algar. 5: 172. 1907.

Tilden. American Algae. Cent. II. no, I9I. 1896; List of Fresh-water Algae collected in Minnesota during 1896 and 1897. Minn. Bot. Studies. 2: 28. I898; Observations on some West American Thermal Algae. Bot. Gaz. 25: 102. pl. 9. f. 22. I898; American Algae. Cent. VI. no. 595. I902. Setchell and Gardner. Algae of Northwestern America. Univ. Calif. Pub. Bot. I: I83. 1903 .

Plant mass dull yellowish-green; trichomes 2.3-4 mic. in diameter, 

joints; apex of trichome straight or curved, neither tapering nor capitate; apical cell rotund; calyptra none; cells of unequal length, 2.3-I6 mic. long: transverse walls pellucid, not granulated; protoplasm containing a few large, refringent granules.

Minnesota. In arm of Mississippi River (old channel), St. Paul Park. October 1897. (Freeman). Montana. In hot water. Lo Lo Hot Springs, Lo Lo. September I898. (Griffiths). Wyoming. Covering bottom of creek in swift current. Temperature $47.5^{\circ} \mathrm{C}$. Near Upper Geyser Basin, Yellowstone National Park. July I896. (Tilden). Washington. On mud by the roadside. La Conner, Skagit County. (Gardner).

147. Oscillatoria minnesotensis Tilden. American Algae. Cent. VI. no. 596. 1902.

\section{Plate IV. fig. 2 I.}

Plant mass thin, dark blue-green; trichomes 2-5 mic. in diameter, more or less curved, especially constricted at joints; apex of trichome straight or slightly bent, neither tapering nor capitate; apical cell rotund; calyptra none; cells 2-4 mic. in length; transverse walls pellucid; cell contents homogeneous.

Minnesota. On sides of stone quarry under dripping water. Near Campus, University of Minnesota, Minneapolis, February 1902. (Lilley).

The plant differs from $O$. geminata in the length of the cells, in the absence of granules, and in its habitat. Like that species, also it resembles a $\mathbf{P h}$ or $\mathrm{m}$ id it $\mathrm{m}$, but the trichomes when examined were oscillating rapidly thus showing conclusively that it was an Oscillatoria.

I48. Oscillatoria chlorina Kuetzing. Phyc. Gen. I85. I853. Gomont. Monogr. Oscill. 243. I893. De Toni. Syll. Algar. 5: 172. I907.

Wood. Contr. Hist. Fresh-Water Algae North America. I8. pl. I. f. I. 1872. Wolle. Fresh-Water Algae U. S. 3II. pl. 206. f. 6. 1887. Collins. Algae of Middlesex County, Massachusetts. 15. 1888. Bessey, Pound and Clements. Additions to the Reported Flora of the State. Bot. Surv. Nebraska. 5: 13. I901. Collins, Holden and Setchell. Phyc. Bor.-Am. Fasc. I9. no. 90I. I902. Setchell and Gardner. Algae of Northwestern America. Univ. Calif. Pub. Bot. I: 183. r903. Clark. The Holophytic Plankton of Lakes Atitlan and Amatitlan, Guatemala. Proc. Biol. Soc. Wash. 21: 97. 3908.

\section{Plate IV. fig. 22.}

Plant mass very thin, cobwebby, yellowish green; trichomes $3.5-4$ mic. in diameter, straight or curved, fragile, not constricted at joints; apex of trichome straight or curved, not tapering; apical cell rotund; calyptra none; cells 3.7-8 mic. in length; transverse walls pellucid, not granulated; cell contents nearly homogeneous, orange or yellowish green.

Greenland. (Richter). Massachusetts. Newton. (Farlow). Pennsylvania. In stagnant brick pond. Near Philadelphia. (Wood). Nebraska. In culture in greenhouse. Lincoln. (Bessey). Washington. Growing on decaying vegetation in a small pool, submerged about two feet. Whidbey 
Island. June IgoI. Central America. Forming a dirty green, somewhat firm mass, looking much like a fresh-water sponge. Lake Atitlan and Amatitlan, Guatemala. I905-1906. (Meek).

149. Oscillatoria angustissima W. and G. S. West. Welwitsch's African Freshwater Algae. Journ. of Bot. 300. 1897. De Toni. Syll. Algar. 5: I71. 1907 .

West. West Indian Freshwater Algae. Journ. of Bot. 42: 293. I904. Buchanan. Notes on the Algae of Iowa; Proc. Iowa Acad. Sci. I4: I4. 1908.

Plant mass expanded, blue-green; trichomes .6 mic. in diameter, not constricted at joints, flexible, elongate, entangled; apex of trichome neither tapering nor capitate; cells .9-1.2 mic. long; transverse walls not distinct; cell contents homogeneous, light blue-green.

Iowa. In pond with other algae. Ontario. (Buchanan). West Indies. Bay Estate, Barbados. (Howard).

I50. Oscillatoria splendida Greville. Flora Edinensis. 305. I824. Gomont. Monogr. Oscill. 244. pl. 7. f. 7, 8. I893. De Toni. Syll. Algar. 5: I73. 1907.

Wolle. Fresh Water Algae. II. Bull. Torr. Bot. Club. 6: 138. 1877. (O. g ra cilli ma Kg.); Fresh Water Algae. III. 1. c. 6: I83. I877; (O. 1 e p totr i c h i a Kg.); Fresh-Water Algae. U. S. 3II. pl. 206. f. 7. I887. Bennett. Plants of Rhode Island. II5. I888. Wolle and Martindale. Algae. Britton's Catalogue of Plants found in New Jersey. Geol. Surv. N. J. 2: 609. I889. Saunders. Protophyta-Phycophyta. Flora of Nebraska. 20. I894. Collins, Holden and Setchell. Phyc. Bor.-Am. Fasc. 7. no. 305. $1897 . \quad$ Setchell and Gardner. Algae of Northwestern America. Univ. Calif. Pub. Bot. I: I84. 1903. Collins, Holden and Setchell. Phyc. Bor.-Am. Fasc. 24. no. Ir6r. 1904. Collins. Phycological Notes of the late Isaac Holden.-II. Rhodora. 7: 236. 1905.

Plate IV. fig. 23-25.

Trichomes 2-3 mic. in diameter, scattered or collected in a thin mass, straight or somewhat flexuous, elongate, not constricted at the joints; apex of trichome gradually tapering, flexuous, capitate; apical cell inflated above; calyptra none; cells 3-9 mic. in length; transverse walls marked by a few protoplasmic granules; cell contents homogeneous, blue-green.

Rhode Island. Providence. (Bennett). Connecticut. On submerged leaves in quiet water. September 1895 ; in a still pool with decaying vegetable matter, bed of Pequonnock River, August, September, November. (Holden). New Jersey. On small freshwater ponds; in ditches of brackish water. (Wolle). Nebraska. On basin of artesian well (salt). Lincoln. (Saunders). Washington. On mud in fresh water pools. Seattle. (Gardner). California. In a small stream near Berkeley. September I9or. (Gardner). Hawaii. On sides of wet rocks. Laupahoehoe, Island of Hawaii. July rgoo. (Tilden).

Var. uncinata Setchell and Gardner. Algae of Northwestern America. Univ. Calif. Pub. Bot. I: I84: pl. 19. f. 22-24. 1903. De Toni. Syll. Algar. 175. I907. 
Trichomes flexuous, coiled; apical cell very long, hooked.

Washington. On damp mud at the bottom of a pool nearly dried up. Oak Harbor, Whidbey Island. (Gardner).

I5I. Oscillatoria amoena (Kuetzing) Gomont. Monogr. Oscill. 245. pl. 7. f. 9. I893. De Toni. Syll. Algar. 5: 175. I907.

Collins. Algae. Flora of the Blue Hills, Middlesex Fells, Stony Brook and Beaver Brook Reservations of the Metropolitan Park Commission, Massachusetts. 127. I896. Saunders. The Algae. Harriman Alaska Expedition. Proc. Wash. Acad. Sci. 3: 397. I9or.

Plate IV. fig. 26.

Trichomes 2.5-5 mic. in diameter, scattered or forming a mass, elongate, straight, flexible, slightly constricted at the joints; apex of trichome gradually tapering, capitate, hooked or undulate; apical cell furnished with a depressed conical calyptra; cells $2.5-4.2$ mic. long (apical cell longer); transverse walls marked by two finely granulated lines; cell contents dull bluegreen.

Alaska. Forming a soft, felt-like, dark bluish green mass, 3-ro mm. thick, of indefinite extent, lining the bottom of the outlet of a hot spring. The water in the outlet where the plant was abundant ranged from $80^{\circ} \mathrm{F}$., some distance from the spring, to $120^{\circ} \mathrm{F}$, near the spring. Near Sitka. (Saunders). Massachusetts. On rocks and trunks of trees. (Collins).

I52. Oscillatoria subuliformis Kuetzing. Diag. und Bemerk. Algenspecies. Oster-progress. 7. I863. Gomont. Monogr. Oscill. 246. I893. De Toni. Syll. Algar. 5: 176. 1907.

Farlow. Marine Algae of New England. 33. I88I. Collins. Algae of Middlesex County, Massachusetts. I5. I888; Marine Algae of Nantucket. 4. 1888. Martindale. Marine Algae of the New Jersey coast and adjacent waters of Staten Island. Mem. Torr. Bot. Club. I: 90. I889. Wolle and Martindale. Algae. Britton's Catalogue of Plants found in New Jersey. Geol. Surv. N. J. 2: 609. I889. Collins. Algae. Rand and Redfield's Flora of Mount Desert Island, Maine. 248. I894.

\section{Plate IV. fig. 27.}

Plant mass dull green; trichomes 4.7-6.5 mic. in diameter, much elongated, flexuous, undulating, not constricted at the joints; apex of trichome tapering for some distance, especially flexuous; apical cell obtuse, not capitate; calyptra none; cells 4.7-6.5 mic. in length (apical cell up to ro mic. long); cell contents finely granular, sometimes showing large refringent granules.

Maine. On rocks near Seal Harbor. (Collins). Massachusetts. Salt marshes. Charles River, Cambridge. (Farlow). Mystic River marshes; on wharves. (Collins). New Jersey. In brackish ditches and pools. Atlantic City. (Morse, Martindale). Staten Island. (Pike).

I53. Oscillatoria salinarum Collins in Collins, Holden and Setchell. Phyc. Bor.-Am. Fasc. 24. no. I160. 1904. De Toni. Syll. Algar. 5: 176. 1907. 
Collins. New species, etc., issued in the Phycotheca Boreali-Americana, Rhodora. 8: 105. 1906.

Trichomes $4 \mathrm{mic}$. in diameter, somewhat flexuous, sometimes coiled in a regular circle, very much constricted at joints; apex of trichome tapering, slightly curved, obtuse; calyptra none; cells nearly or quite as long as broad.

West Indies. Ditches of salt works. Salinas Bay, near Guanica, Porto Rico. June 1903. (Howe).

I54. Oscillatoria laetevirens Crouan. Liste des Algues marine découvertes dans le Finistère, etc. Bull. Soc. Bot. France. 7: 371. 1860. Gomont. Monogr. Oscill. 246. pl. 7. f. II. I893. De Toni. Syll. Algar. 5: I77. r907.

Collins. Preliminary Lists of New England Plants. V. Marine Algae. Rhodora. 2: 42. Igoo. Tilden. Collection of Algae from the Hawaiian Islands. Hawaiian Almanac and Annual for I902. II3. I90I; American Algae. Cent. V. no. 496. 1901. Collins, Holden and Setchell. Phyc. Bor-Am. Fasc. 22. no. 1054. 1903. Setchell and Gardner. Algae of Northwestern America. Univ. Calif. Pub. Bot. I: 184. 1903. West. West Indian Freshwater Algae. Journ. of Bot. 42: 292. 1904. Collins. Phycological Notes of the late Isaac Holden.-I. Rhodora. 7: I72. 1905. Lemmermann. Algenfl. Sandwich-Inseln. Bot. Jahrb. 34: 6I8. 1905.

\section{Plate IV. fig. 28.}

Plant mass thin, membranaceous, bright blue-green; trichomes $3-5$ mic. in diameter, straight, fragile, slightly constricted at the joints; apex of trichome briefly tapering, undulating and hooked, rarely straight; apical cell more or less obtuse or somewhat pointed, not capitate; calyptra none; cells 2.5-5 mic. in length; transverse walls granulated or cell contents uniformly granular, yellowish green.

Maine. On woodwork under old tide mill. Harpswell. July I9o3. (Collins). Rhode Island. (Collins). Connecticut. Forming a film on old grassy bottom, brackish marsh pool. Cook's Point. June. (Holden). Washington. In salt marsh. Head of Penn's Cove, Whidbey Island. (Gardner). West Indies. On roots of mangroves in brackish swamp. Near Bridgetown; Graeme Hall Swamp, Barbados. (Howard). Hawaii. Forming a delicate, bright blue-green stratum covering bottom of tide pool in rocks into which water splashes at high tide. Waianae, Oahu. May Igoo. (Tilden). Washings from marine algae. (Schauinsland).

155. Oscillatoria acuminata Gomont. Monogr. Oscill. 247. pl. 7. f. 12. I893. De Toni. Syll. Algar. 5: 177. 1907.

Collins, Holden and Setchell. Phyc. Bor.-Am. Fasc. 27. no. 1303. 1906.

$$
\text { Plate IV. fig. } 29 .
$$

Plant mass blue-green; trichomes 3-5 mic. in diameter, straight, fragile, sometimes slightly constricted at joints; apex of trichome briefly tapering, very sharply pointed, hooked or twisted, not capitate; apical cell mucronate; calyptra none; cells $5.5-8$ mic. in length; transverse walls granulated or entire cell contents filled with granules. 
California. Floating in warm salt water from a power house. Oakland. October 1905, June 1906. (Gardner).

156. Oscillatoria animalis Agardh. Aufzählung, etc. Flora. 10: 632. 1827. Gomont. Monogr. Oscill. 247. I893. De Toni. Syll. Algar. 5: I78. 1907.

Mazé and Schramm. Essai Class. Algues Guadeloupe. 16. I870-1877. (O. the rmalis Crouan).

Plate IV. fig. 30.

Plant mass blue-green; trichomes 3-4 mic. in diameter, straight, fragile, not constricted at the joints; apex of trichome briefly tapering, sharply pointed, hooked or twisted, not capitate; apical cell mucronate; calyptra none; cells 1.6-5 mic. in length; transverse walls here and there granulated; protoplasmic contents finely granular.

North America. (Farlow). West Indies. Guadeloupe. (Mazé and Schramm).

157. Oscillatoria violacea (Wallroth) Hassall. British Freshwater Algae. 254. p1. 72. f. 10. 1845. De Toni. Syll. Algar. 5: 179. 1907.

Wolle. Fresh Water Algae. III. Bull. Torr. Bot. Club. 6: 182. 1877; Fresh-Water Algae U. S. 3II. pl. 206. f. 10. 1887. Bennett. Plants of Rhode Island. II5. I888. Bessey. Miscellaneous Additions to the Flora of the State, and new or noteworthy species from various localities. Bot. Surv. Nebraska. 46. I893. Saunders. Protophyta-Phycophyta. Flora of Nebraska. 21. 1894 .

\section{Plate IV. fig. 3I.}

Plant mass membranaceous, dull green or lead-colored; trichomes 4-4.5 mic. in diameter, straight, narrow, tangled; apical cell drawn out to a thin point; cells shorter than the diameter of trichome; transverse walls granulated; cell contents finely granular, violet or sky-blue in color.

Rhode Island. Common. (Bennett). Pennsylvania. Most frequent in greenhouses. (Wolle). Nebraska. In greenhouse at University. Lincoln. (Bessey, Saunders).

158. Oscillatoria brevis Kuetzing. Phyc. Gen. I86. I843. Gomont. Monogr. Oscill. 249. pl. 7. f. I4, I5. I893. De Toni. Syll. Algar. 5: I80. 1907.

Wolle. Fresh Water Algae. II. Bull. Torr. Bot. Club. 6: 138. 1877; FreshWater Algae. U. S. 312. pl. 207. f. 8. 1887. Wolle and Martindale. Algae. Britton's Catalogue of Plants found in New Jersey. Geol. Surv. N. J. z: 609. 1889. Tilden. American Algae. Cent. I. no. 77. I894; List of FreshWater Algae collected in Minnesota during 1894 . Minn. Bot. Studies. I: 235. I895; American Algae. Century VI. no. 597. I902. Collins, Holden and Setchell. Phyc. Bor.-Am. Fasc. 24. no. II58. 1904. West. West Indian Freshwater Algae. Journ. of Bot. 42: 292. I904. (Also O. 6 u b bir e vis Schmidle?).

\section{Plate IV. fig. 32.}

Plant mass olive green; trichomes $4-6.5$ mic. in diameter, scattered or in masses, especially straight, fragile, not constricted at joints; here and 
there interrupted by inflated, refringent cells; apex of trichome somewhat pointed, briefly tapering, hooked or twisted, not capitate; calyptra none; cells I.5-2.8 mic. in diameter; transverse walls not granulated; cell contents finely granular.

New York. Forming an extended stratum on a shaded deposit of mud after an inundation. Buffalo. (Wolle). New Jersey. Fresh water, in marshes, frequent. (Wolle). Minnesota. Growing on clods of damp earth in greenhouse. St. Paul. November 1894 ; in pool coating bottom, submerged leaves and sticks, Lincoln Park, Duluth. (Tilden). California. Pool by roadside. North Berkeley. February I903. (Gardner). West Indies. (Kunze). Near Bridgetown; Bay Estate, Barbados. (Howard).

Var. neapolitana (Kuetz.) Gomont. 1. c. 249. De Toni. 1. c. I8I.

Collins, Holden and Setchell. Phyc. Bor.-Am. Fasc. 27. no. 1304. I906.

Trichomes 5-6.5 mic. in diameter; apex of trichome hooked or twisted.

California. In pool in salt marsh. Oakland, July I905. (Gardner).

159. Oscillatoria cruenta Grunow in Rabenhorst. Fl. Eur. Algar. 2: I00. 1865. De Toni. Syll. Algar. 5: 182. I907.

Wolle. Fresh-Water Algae U. S. 312. pl. 206. f. 5; pl. 207. f. I-3. I887. Clark. The Holophytic Plankton of Lakes Atitlan and Amatitlan, Guatemala. Proc. Biol. Soc. Wash. 2I: 96. 1908.

Plant mass mucous, dark purple; trichomes 4-7 mic. in diameter; apical cell obtuse, straight, rarely slightly curved; cells $2-4$ mic. in length; transverse walls granulated; cell contents pale brown or blue-green.

Pennsylvania. Imbedded in large submerged hyaline or greenish or purplish, firm gelatinous masses of irregular form, averaging about the size of a man's head. In mountain spring at about 1500 feet elevation. (Wolle). Central America. Abundant, forming a flat, gelatinous, striated stratum, brownish in color, about $4 \mathrm{~mm}$. thick, obtained from the surface between pools of hot water. Laguna. January Igo6. (Meek).

I60. Oscillatoria formosa Bory. Dict. Class. d'Hist. Nat. I2: 474. I827. Gomont. Monogr. Oscill. 250. I893. De Toni. Syll. Algar. 5: I82. 1907.

Mazé and Schramm. Essai Class. Algues Guadeloupe. I6. I870-1877. (O. $\mathrm{t}$ h e $\mathrm{rma}$ a is). Tilden. American Algae. Cent. II. no. 192. I896. Collins, Holden and Setchell. Phyc. Bor.-Am. Fasc. I5. no. 710. I900. Bessey, Pound and Clements. Additions to the Reported Flora of the State. Bot. Surv. Nebraska. 5: 13 . Igor. Collins. The Algae of Jamaica. Proc. Am. Acad. Arts Sci. 37: 239. 1901. Tilden. Algae collecting in the Hawaiian Islands. Postelsia: The Year Book of the Minnesota Seaside Station. I: I66. I902. Collins, Holden and Setchell. Phyc. Bor.-Am. Fasc. 22. no. I053. I903. Collins. Phycological Notes of the late Isaac Holden.-I. Rhodora. 7: 172. 1905.

Plate IV. fig. 33.

Plant mass dark blue-green; trichomes 4-6 mic. in diameter, straight, elongate, flexuous, usually slightly constricted at joints; apex of trichome somewhat obtuse and briefly tapering or rotund, hooked, not capitate; calyp. 
tra none; cells 2.5-5 mic, long; transverse walls sometimes finely granulated; cell contents bright blue-green.

Canada. In tufts floating in water or on muddy bottom; in great abundance in the impure water just below mouth of city sewer. Kettle Creek, St. Thomas, Ontario. November I896. (Lees). Connecticut. Floating in stagnant marsh pool near "Fresh Pond" (brackish). Stratford. May 1900. (Holden). Minnesota. University plant house, Minneapolis. January I897. (Tilden). Nebraska. In culture in greenhouse. Lincoln. (Bessey). California. Mountain lake, San Francisco. June 1902. (Osterhout and Gardner). West Indies. Guadeloupe. (Mazé and Schramm). In still water. Roaring River, near St. Ann's Bay. March I893; Castleton. April I893. (Humphrey). Hawaii. On sides of cliff at falls. Waialuka River, Hilo, Island of Hawaii. July I900. (Tilden).

16r. Oscillatoria numidica Gomont. Monogr. Oscill. 25r. I893. De Toni. Syll. Algar. 5: 183. 1907.

Tilden. American Algae. Cent. I. no. 78. 1894; List of fresh-water Algae collected in Minnesota during I894. Minn. Bot. Studies. I: 236. I895; Americán Algae: Cent. VI. no. 598. I902.

Plant mass dark blue-green; trichomes $2.5-4$ mic, in diameter, straight, fragile, constricted at joints, gradually tapering for some distance from the apex; apex of trichome curved or undulating; apical cell obtuse, not capitate; calyptra none; cells $2-8$ mic. long; transverse walls not granulated; cell contents uniformly granular; pale blue-green.

Minnesota. In tanks clinging to water plants. Greenhouse. Minneapolis. November 1894. (Tilden). On floating leaves and grasses in pool in stone quarry. Minneapolis. October Igor. (Hone).

162. Oscillatoria cortiana Meneghini. Conspectus Algol. eugan. 8. I837. Gomont. Monogr. Oscill. 25I. I893. De Toni. Syll. Algar. 5: I83. I907.

Wolle. Fresh Water Algae. III. Bull. Torr. Bot. Club. 6: 183. I877; Fresh-Water Algae U. S. 313. pl. 206. f. I5. I887.

Plate IV. fig. 34 .

Plant mass dull or dark blue-green; trichomes $5.5-8$ mic. in diameter, especially straight, fragile, slightly constricted at the joints, gradually tapering for some distance from the apex, curved or undulating at the extremity; apical cell obtuse, not capitate; calyptra none; cells 5.4-8.2 mic. in length (apical cell up to I4 mic. long); transverse walls not granulated; cell contents showing scattered protoplasmic granules, blue-green.

Pennsylvania. Floating on hot waste water at a large steam mill. Near Bethlehem. (Wolle.)

163. Oscillatoria okeni Agardh. Aufzählung, etc. Flora. 10: 633. 1827. Gomont. Monogr. Oscill. 252. pl. 7. f. 18. I893. De Toni. Syll. Algar. 5: 185.1907 .

Setchell and Gardner. Algae of Northwestern America. Univ. Calif. Pub. Bot. I: 184. 1903. 
Plate IV. fig. 35 .

Plant mass dark blue-green; trichomes 5.5-9 mic. in diameter, straight (in dried material fragile), evidently constricted at joints, gradually tapering for some distance from apex; apex of trichome undulating, hooked or curved at extremity; apical cell obtuse or somewhat pointed, not capitate; calyptra none; cells $2.7-4.5$ mic. in length; apical cell somewhat quadrate or up to $8 \mathrm{mic}$. in length; cell contents finely granular.

Washington. In pond of brackish water. Monroe's Landing, near Coupeville, Whidbey Island. (Gardner).

I64. Oscillatoria chalybea Mertens in Jürgens. Algae aquat. Decas I3. no. 4. 1822. Gomont. Monogr. Oscill. 252. 1893. De Toni. Syll. Algar. 5: 185. I907.

Wolle. Fresh-Water Algae U. S. 314. pl. 206. f. 17-21. I887. Tilden. A new Oscillatoria from California. Bull. Torr. Bot. Club. 23: 58. I896. (O. $\mathrm{trapezoidea}$ Tilden). Setchell. Oscillatoria trapezoidea Tilden. Erythea. 4: 69. 1896. Bessey, Pound and Clements. Additions to the Reported Flora of the State. Bot. Surv. Nebraska. 5: I3. Ig0r. Snow. The Plankton Algae of Lake Erie. U. S. Fish Comm. Bull. for 1902. 22: 392. I903. Collins, Holden and Setchell. Phyc. Bor.-Am. Fasc. 21. no. roor. I903. (O. chal $y^{b}$ e a genuina). Collins. Phycological Notes of the late Isaac Holden.-I. Rhodora. 7: 172. 1905.

\section{Plate IV. fig. 36.}

Plant mass dark green; trichomes 8-I3 mic. in diameter, fragile, straight, or sometimes twisted in loose spirals, slightly constricted at joints, gradually tapering for a long distance from the apex; apex hooked or curved; apical cell obtuse, not capitate; calyptra none; cells $3.6-8$ mic. long; transverse walls not at all or scarcely granulated; cell contents finely granular with scattered large refringent granules, dark blue-green.

North America. (Pike, Martindale, Farlow). Connecticut. Outlet of Fresh Pond; on woodwork, rocks and En te rom or pha, below Yellow Mill Bridge. May, June, November. (Holden). Florida. On wet ground, (Wolle). Ohio. Plankton. Put-in-Bay, Lake Erie. (Snow). Nebraska. In stagnant water. Waverly. (Bessey). California. Bottom of pond. Pasadena. October I895. (McClatchie). Lake Çhabot, San Leandro. June Igoz. (Osterhout and Gardner).

165. Oscillatoria subsalsa Agardh. Syst. Algar. 66. I824. De Toni. Syll. Algar. 187. 1907.

Kjellman. Algae of the Arctic Sea. 323. I883.

Plant mass dark blue-green, mucous, radiating; trichomes 8-ro mic. in diameter, straight, somewhat constricted at joints; apex of trichome equal or slightly tapering, obtuse, straight or curved; cells 4-5 mic. in length; cell contents granular, pale blue-green.

Greenland. "According to a label it grows 'in fossis submarinis.' Baffin Bay: Tessarmiut on the west coast of Greenland according to specimens in the herbarium of the Copenhagen Museum."-Kjellman. 
166. Oscillatoria percursa Kuetzing. Phyc. Gen. 189. I843. De Toni. Syll. Algar. 5: I87. 1907.

Mackenzie. A preliminary list of Algae collected in the neighborhood of Toronto. Proc. of Can. Inst. III. 7: 270. i 890.

Plant mass thin, green; trichomes $15.5-18.5$ mic. in diameter, sometimes solitary, straight; apex of trichome usually curved, somewhat tapering, obtuse-truncate; cells 4-6 mic. in length; dissepiments evidently grantilated; cell contents very finely granular, pale blue-green.

Canada. High Park, Toronto. (Mackenzie).

167. Oscillatoria boryana Bory. Dict. Class. d'Hist. Nat. I2: 465. I827. Gomont. Monogr. Oscill. 254. 1893. De Toni. Syll. Algar. 5: I88. I907.

Tilden. Notes on a collection of Algae from Guatemala. Proc. Biol. Soc. Wash, 21: I53. I908.

Plate IV. fig. 37,38 .

Plant mass dark lead-colored; trichomes 6-8 mic. in diameter, forming a lax and regular spiral through their entire length, or straight and hooked at the apex, flexuous, constricted at joints; apex of trichome more or less pointed, not capitate; apical cell rotund or acute conical; calyptra none; cells 4-6 mic. in length; transverse walls here and there finely granulated; cell contents showing a few protoplasmic granules.

Central America. Forming a dark velvety mass in a small stream of warm water a little distance from a hot spring on bank of river. Altitude 3,950 feet. Rio Michatoya, near Lake Amatitlan. January I906. (Kellerman).

168. Oscillatoria terebriformis Agardh. Aufzählung, etc. Flora. Io: 634. 1827. Gomont. Monogr. Oscill. 254. pl. 7. f. 24. I893. De Toni. Syll. Algar. 5: 189. 1907.

Collins. Algae. Flora of the Blue Hills, Middlesex Fells, Stony Brook and Beaver Brook Reservations of the Metropolitan Park Commission, Massachusetts. I27. 1896 .

\section{Plate IV. fig. 39.}

Plant mass dark lead-colored; trichomes 4-6.5 mic. in diameter, flextious, straight below, loosely spiralled and terebriform above, not constricted at joints; apex of trichome slightly tapering, rarely hooked; apical cell rotund or truncate; calyptra none; cells $2.5-6$ mic. in length; transverse walls usually granulated.

Massachusetts. On rocks and trunks of trees. (Collins).

I69. Oscillatoria subtorulosa (Brébisson) Farlow. Marine Algae of New England. 33. 1881. De Toni. Syll. Algar. 5: 191. I907.

Hay and Mackay. List of the Marine Algae of the Maritime Provinces of Canada, with Notes. Trans. Roy. Soc. Canada. 5: 1887. Collins. Marine Algae of Nantucket. 4. I888.

Trichomes 3-4 mic. in diameter, slightly constricted at joints; cells nearly quadrate. 
Canada. On floating balls of Polys iph onia. Pictou Harbor, Nova Scotia. (Mackay). Maine. Forming slimy patches on wharves. Eastport. (Farlow). Massachusetts. Wood's Holl. (Farlow).

\section{Genus TRICHODESMIUM Ehrenberg.}

Ann. Physik. u. Chemie. I8: 506. 1830.

Plants forming scale-like, disconnected, free-floating colonies quickly dissolving into mucous; trichomes cylindrical, without sheaths; apex of trichome straight, tapering, slightly capitate; apical cell truncate-conical, furnished with a convex calyptra.

Floating in great abundance in the ocean, especially in equatorial regions.

I Trichomes straight.

T. erythraeum

II Trichomes flexuous or spirally twisted.

I Colonies up to $6 \mathrm{~mm}$. in length; trichomes 7-16 mic. in diameter, not constricted at joints, those in center of colony having the form of twisted ropes, free at the ends $T$. thiebautii

2 Colonies spirally twisted, light yellow; trichomes $16-25$ mic. in diameter, twisted together into cords.

T. contortum

I70. Trichodesmium erythraeum Ehrenberg. Neue Beobachtungen über blutartige Erscheinungen in Aegyptien, Arabien und Siberien. In Poggendorf. Ann. Physik. u. Chem. I8: 506. I830. Gomont. Monogr. Oscill. 216. pl. 5. f. 27-30. I893. De Toni. Syll. Algar. 5: 202. I907.

Montagne. Mémoire sur le phénomène de la coloration des eaux de la Mer Rouge. Ann. Sci. Nat. Bot. III. 2: 360. pl. Io. f. d. I844. (T. h in d si i).

Plate IV. fig. 40.

Colonies very short, scarcely I $\mathrm{mm}$ in length, purplish red (when dried grayish green or dark brown); trichomes $7-11$, rarely up to 21 mic. in diameter, straight, parallel, constricted at joints, the more slender ones with apices gradually tapering, the larger ones with apices very briefly tapering; cells 5.4-I I mic. in length; cell contents coarsely granular.

Central America. In dense masses of a beautiful red color, on surface of ocean. The odor was pronounced and very disagreeable. San Salvador. $14^{\circ}$ lat. N. April I837. (Hinds).

It is interesting to note that it is the presence of this alga which has caused the Red Sea to be so named.

I7I. Trichodesmium thiebautii Gomont. Essai Class. Nostocacées homocystées. Morot. Journ. de Bot. 4: 356. I89o; Monogr. Oscill. 217. pl. 6. f. 2-4. I893. De Toni. Syll. Algar. 5: 203. I907.

West Jun., W. Some Oscillarioideae from the Plankton. Journ. of Bot. 37: 337. I899. Lemmermann. Algenf. Sandwich-Inseln. Bot. Jahrb. 34: 618. 1905 .

Plate IV. fig, 4I, 42.

Colonies up to $6 \mathrm{~mm}$. in length (in dried material dark green); trich- 
omes 7-16 mic. in diameter, not constricted at joints, those in center of colony having the form of twisted ropes, free at the ends; apex of trichome briefly tapering or sometimes inflated; cells 8-26 mic. in length, rarely somewhat quadrate; transverse walls often granulated; cell contents coarsely granular.

West Indies. Guadeloupe. (Thiebaut). In plankton. (Murray and Blackman. Hawaii. In plankton between the islands of Hawaii and Laysan. I896-I897. (Schauinsland).

I72. Trichodesmium contortum Wille in Brandt. Nordisches Plankton.

Lief. 2. Abt. 20. 18. f. I4. De Toni. Syll. Algar. 5: 204. I907.

Lemmermann. Algenf. Sandwich-Inseln. Bot. Jahrb. 34: 6I8. Ig05.

Plate IV. fig. 43.

Colonies spirally twisted, light yellow; trichomes $16-25$ mic. in diameter, twisted together into cords; cells somewhat quadrate; cell contents uniformly granular.

Hawaii. In plankton between the Islands of Hawaii and Laysan. 1896I897. (Schauinsland).

\section{Genus ARTHROSPIRA Stizenberger. Hedwigia. I: 32. I852.}

Trichomes multicellular, cylindrical, without a sheath, forming a very regular, more or less loose spiral; apex of trichome sometimes tapering; apical cell rotund; calyptra none.

I Trichomes 5-8 mic. in diameter, forming a loose spiral 9-I5 mic. in diameter, the distance between the turns being 2I-3I mic.

A. jenneri

Il Trichomes 2.5-3 mic. in diameter, forming a rather loose spiral about 6 mic, in diameter, the distance between the turns being I6-18 mic.

\section{A. gomontiana}

I73. Arthrospira jenneri (Kuetzing) Stizenberger. Spirulina and Arthrospira. Hedwigia, I: 32. I852. Gomont. Monogr. Oscill. 267. pl. 7. f. 26. 1893. De Toni. Syll. Algar. 5: 206. I907.

Wolle. Fresh-Water Algae U. S. 323. pl. 210. f. 2. I887. (S p ir ulina jenneri Kuetz.) Bennett. Plants of Rhode Island. II5. I888. Tilden. List of fresh-water Algae collected in Minnesota during I893. Minn. Bot. Studies. I: 3I. I894. Saunders. Protophyta-Phycophyta. Flora of Nebraska. 23. pl. I. f. 7. I894. Riddle. Algae from Sandusky Bay. Ohia Nat. 3: 317. I902. Brown. Algal periodicity in certain poncis and streams. Bull. Torr. Bot. Club. 35: 248. I908.

$$
\text { Plate IV. fig. } 44 .
$$

Plant mass thin; trichomes 5-8 mic. in diameter, often growing among other algae, fragile, forming a loose spiral 9-I5 mic. in diameter, sometimes slightly constricted at joints; apex of trichome not tapering, nor capitate; cells quadrate or shorter than the diameter, 4-5 mic. long; transverse walls sometimes finely granulated; cell contents scarcely granular, dark bluegreen. 
Rhode Island. Quidnessett. (Bennett). New York. In some abundance near Schenectady. (Holden). Pennsylvania. In stagnant water. (Wolle). Ohio. Sandusky Bay. (Riddle). Indiana. Edge of Monon Pond, Bloomington. (Brown). Minnesota. Home Brook, Gull Lake Biological Station, Cass County. July r893. (Tilden): In lake two miles west of Inver Grove, St. Paul. April 1908. (Misz). Nebraska. Found occasionally in stagnant water about Lincoln. (Saunders).

I74. Arthrospira gomontiana Setchell. Notes on some Gyanophyceae ot New England. Bull. Torr. Bot. Club. 22: 430. I895. De 'Toni. Syll. Algar. 5: 208. 1907.

Collins, Holden and Setchell. Phyc. Bor.-Am. Fasc. 5. no. I55. 1896. Collins. Phycological Notes of the late Isaac Holden.-II. Rhodora. 7: 235. 1905 .

Plant mass floating, verdigris-green; trichomes 2.5-3 mic. in diameter, regularly twisted into a rather loose spiral about 6 mic. in diameter, the distance between the turns being I6-I 8 mic.; apical cell not at all capitate; cells 4-5 mic. in length; transverse walls indistinct, with few granules; cell contents usually showing large vacuoles, light blue-green,

Connecticut. Floating in verdigris-green patches, on the pool below Factory Pond, Bridgeport. July 1895. (Setchell and Holden).

\section{Genus SPIRULINA Turpin.}

Dict. d'hist. nat. de Levrault. 50: 309. 1827.

Trichomes unicellular, cylindrical, without a sheath, forming a regular, more or less loose or close spiral; apex of trichome not tapering; cell contents homogeneous or slightly granular.

I Turns of the spiral not close together.

I Trichomes r.2-I.8 mic. in diameter, forming a more or less loose, somewhat irregular spiral 3,2-5 mic. in diameter, the distance between the turns being 3-5 mic.

S. meneghiniana

2 Trichomes I.2-I.7 mic. in diameter, forming a somewhat loose, regular spiral 2.5-4 mic. in diameter, the distance between the turns being 2.7-5 mic.

S. major

3 Trichomes 2 mic. in diameter, forming an especially regular spiral 5 mic. in diameter, the distance between the turns being 5 mic.

S. nordstedtii

4 Trichomes .6-.9 mic. in diameter, forming an especially regular spiral I.5-2.5 mic. in diameter, the distance between the turns being 1.2-2 mic.

S. subtilissima

5 Trichomes $.4 \mathrm{mic}$. in diameter, forming an especially regular spiral I.4-I.6 mic. in diameter, the distance between the turns being I mic.

S. tenerrima

6 Trichomes $.9 \mathrm{mic}$ in diameter, forming a very loose spiral $1.5 \mathrm{mic}$. in diameter, the distance between the turns being 3.2 mic.

\section{S. caldaria}


II Turns of the spiral close together.

I Trichomes I.2-I.8 mic. in diameter, forming a dense regular spiral 3-4.5 mic. in diameter, the turns being contiguous

\section{S. versicolor}

2 Trichomes I-2 mic. in diameter, forming a somewhat irregular dense or rareiy regular spiral 3-5 mic. in diameter, the turns being contiguous or nearly so

S. subsalsa

III Trichomes forming slender, flat, continuous bands (when untwisted forming a complete ring), normally flattened and twisted, with one to four or more turns.

S. duplex

175. Spirulina meneghiniana Zanardini. Notozie intorno alle Cellulari marine delle Lagune e de littorale di Venezia. Atti del I. R. Istituto veneto. 6: 8o. I847. Gomont. Monogr. Oscill. 270. pl. 7. f. 28. I893. De Toni. Syll. Algar. 5: 209. 1907.

Collins. Notes on New England Marine Algae.-VI. Bull. Torr. Bot. Club. 23. I: I896; Preliminary 'Lists of New England Plants.-V. Marine Algae. Rhodora. 2: 43. I900; Notes on Algae.-IV. Rhodora. 3: 289. Igor. Collins, Holden and Setchell. Phyc. Bor.-Am. Fasc. 18. no. 852. rgor.

\section{Plate IV. fig. 45.}

Plant mass compact, blue-green; trichomes I.2-I.8 mic. in diameter, flexuous, curved, twisted into a more or less loose, somewhat irregular spiral, 3.2-5 mic. in diameter, the distance between the turns being 3-5 mic.; cell contents pale blue-green.

Massachusetts. In scattered filaments among other algae in a ditch of brackish water, salt marshes. Revere. August I893; in considerable quantity in rock tide pools above high water mark, but reached by spray in stormy weather, on the Marblehead shore, near Clifton Station. July Igor. (Collins).

176. Spirulina major Kuetzing. Phyc. Gen. 183. I843. Gomont. Monogr. Oscill. 271. pl. 7. f. 29. 1893. De Toni. Syll. Algar. 5: 210. I907.

Tilden. American Algae. Cent. I. no. 79. I894. (S. s u b s a 1 s a Oersted); List of fresh-water Algae collected in Minnesota during 1894. Minn. Bot. Studies. I: 236. I895; American Algae. Cent. II. no. 193. I896; Observations. on some West American Thermal Algae. Bot. Gaz. 25: 103. 1898. Collins, Holden and Setchell. Phyc. Bor.-Am. Fasc. II. no. 50I. I898. Setchell. Notes on Cyanophyceae.-III. Erythea. 7: 54. I899. Bessey, Pound and Clements. Additions to the Reported Flora of the State. Bot. Surv. Nebraska. 5: 14: 19or. Collins, Holden and Setchell. Phyc. Bor.-Am. Fasc. 23. no. I102. 1903. Setchell and Gardner. Algae of Northwestern America. Univ. Calif. Pub. Bot. I: I82. 1903. Buchanan. Notes on the Algae of Iowa. Proc. Iowa Acad. Sci. 14: 15. I908.

\section{Plate IV. fig. 46.}

Plant mass dark blue-green; trichomes 1.2-I.7 mic. in diameter, usually scattered among other algae, more or less flexuous, twisted into a somewhat loose, regular spiral 2.5-4 mic. in diameter, the distance between the turns being $2.7-5$ mic. 
Canada. Forming a very slippery but firm brownish black stratum and also scattered among other algae. Warm sulphur spring, Banff, Alberta. June Igor. (Butler and Polley). Minnesota. Twin Lakes, Hennepin County. October I894. (Tilden). Iowa. Slough. Ontario. (Buchanan). South Dakota. In artesian water. Iroquois. September 1897. (Saunders). Nebraska. In salt creek, Lincoln. (Bessey). Wyoming. On surface of still pool into which overflow runs. Temperature $4 \mathrm{I}^{\circ} \mathrm{C}$. Mammoth Hot Springs. July I896. (Tilden). Overflow of channel of geyser. Temperature $49^{\circ}-54.5^{\circ}$ C. Spasmodic Geyser. Upper Geyser Basin. Yellowstone National Park. I897. (Weed). Utah. Forming a whitish brittle scum in hot water. Bick's Hot Spring, Salt Lake , City, July I897. (Tilden). Washington. In pools of slightly brackish water. Monroe's Landing, near Coupeville, Whidbey Island. (Gardner). California. (Parish and McClatchie). Hawaii. Mixed with other algae, on sides of wet rocks. Laupahoehoe, Hawaii. July I900. (Tilden).

This species is quite common in both the calcareous and silicious waters of Yellowstone Park. It is generally found with other algae.

177. Spirulina nordstedtii Gomont. Monogr. Oscill. 272. 1893. De Toni. Syll. Algar. 5: 212. 1907.

Collins. Preliminary Lists of New England Plants.-V. Marine Algae. Rhodora. 2: 43. I900.

Plant mass olive green; trichomes 2 mic. in diameter, fragile, twisted into an especially regular spiral $5 \mathrm{mic}$. in diameter, the distance between the turns being 5 mic.; cell contents pale blue-green.

Maine. (Collins).

178. Spirulina subtilissima Kuetzing. Phyc. Gen. I83. r843. Gomont. Monogr. Oscill. 272. pl. 7. f. 30. I893. De Toni. Syll. Algar. 5: 212. I907.

Bessey, Pound and Clements. Additions to the Reported Flora of the State. Bot. Surv. Nebraska. 5: 14. Igor. Collins, Holden and Setchell. Phyc. Bor.-Am. Fasc. 23. no. I103. I903. Lemmermann. Algenfl. Sandwich-Inseln. Bot. Jahrb. 34: 6r9. I905.

\section{Plate IV. fig. 47.}

Plant mass mucous, dark green; trichomes .6-.9 mic. in diameter, agglutinated, flexuous, twisted into an especially regular spiral $\mathbf{1 . 5 - 2 . 5}$ mic. in diameter, the distance between the turns being I.2-2 mic.; cell contents very pale green or yellowish.

Nebraska. In salt creek. Lincoln. (Bessey). California. In outflow from a sulphur spring. Mt. Diablo. Contra Costa County. July 1900. (Osterhout). Hawaii. Washings from marine algae. Laysan Island. I896-I897. (Schauinsland).

I79. Spirulina tenerrima Kuetzing. Phyc. Gen. 183. I843. Gomont. Monogr. Oscill. 272. 1893. De 'Toni. Syll. Algar. 5: 213. 1907.

Trichomes mixed with other algae, .4 mic. in diameter, twisted into an especially regular spiral 1.4-1.6 mic. in diameter, the distance between the turns being 1 mic.; cell contents very pale blue-green. 
United States. On damp earth. (Farlow).

180. Spirulina caldaria Tilden. Observations on some West Americass Thermal Algae. Bot. Gaz. 25: 103. pl. 8. f. 20. rgo8. De Toni. Syll. Algar. 5: 216. 1907.

Plate IV. fig. 48.

Plant mass widely expanded, dark blue-green; trichomes .9 mic. in diameter, short, somewhat straight and stiff, forming a very loose spiral I.5 mic. in diameter, the distance between the turns being 3.2 mic.

Canada. Forming a thick richly colored stratum on the surface of hot water very near the outlet of the springs. Natural Sulphur Springs. Banff. August 1897. (Tilden).

181. Spirulina versicolor Cohn in Rabenhorst. F1. Eur. Algar. 2: 292. I865. Gomont. Monogr. Oscill. 273. I893. De Toni. Syll. Algar. 5: 213. 1907.

Collins. Notes on New England Marine Algae--VII. Bull. Torr. Bot. Club. 23: 458. I896; Preliminary Lists of New England Plants.-V. Marine Algae. Rhodora. 2: 43. I900.

Plant mass delicate, mucous, dark purple; trichomes I.2-1.8 mic. in diameter, flexuous, twisted into a dense regular spiral 3-4.5 mic. in diameter, the turns being close together; cell contents violet-purple.

Maine. Among other algae on a mooring buoy that had been hauled up on the beach. Cape Rosier. July I896. (Collins).

Lyngbya gracilis and Spirulina versicolor "are, as far as I know, the only marine $\mathrm{N}$ os to $\mathrm{ch}$ in e a e of a red color found in America; and it is somewhat interesting that both should have been found at the same time and place. The object on which they grew gives somewhat unusual conditions for the growth of algae; practically uniform depth combined with considerable movement of the water. It would hardly be safe to draw the conclusion that these conditions tended to produce the exceptional color, but it is of interest to note that the localities given by Gomont for both species are in the Mediterranean, Adriatic and Baltic, in all of which the tidal movement is quite small."-Collins.

182. Spirulina subsalsa Oersted. Beretning om en Excursion til Trindelen, alluvial Dannelse i Odensfjord. Nat. Tidskr. I7. pl. 7. f. 4. I842. Gomont. Monogr. Oscill. 273. pl. 7. f. 32. I893. De Toni. Syll. Algar. 5: 214. I907.

Farlow, Anderson and Eaton. Algae Americae borealis exsiccatae. Fasc. I-IV. no. 478. 1877. (S. t e $\mathrm{n}$ is s i m a Kg.) Farlow. Marine Algae of New England. 3i. pl. 2. f. 4. I88I. Kjellman. The Algae of the Arctic Sea. 324. I883. Wolle. Fresh-water Algae. U. S. 323. pl. 210. f. 3. I887. Collins. Algae of Middlesex County, Massachusetts. I5. I888; Marine Algae of Nantucket. 4. I888. Martindale. Marine Algae of the New Jersey coast and adjacent waters of Staten Island. Mem. Torr. Bot. Club. I: 90. I889. Wolle and Martindale. Algae. Britton's Catalogue of Plants found in New Jersey. Geol. Surv. N. J. 2: 6Io. I889. Collins. Algae. Rand and Redfield's Flora of Mount Desert Island, Maine. 248. I894. Saunders. Protophyta-Phyco- 
phyta. Flora of Nebraska. 23. pl. I. f. 6. I894. R Marines dı Groenland. Ann. Sci. Nat. Bot. VII. 19: I63. I894. Collins, Holden and Setchell. Phyc. Bor.-Ann. Fasc. 6. no. 252. I897. Rosenvinge. Deuxième Mémoire sur les Algues Marines du Groenland. Medd. om Groenland. 20: 121. 1898. Collins. Preliminary Lists of New England Plants.V. Marine Algae. Rhodora. 2: 43. I90o. Setchell and Gardner. Algae of Northwestern America. Univ. Calif. Pub. Bot. I: 182. 1903. West. West Indian Freshwater Algae. Journ. of Bot. 42: 293. 1904. Collins. Phycological Notes of the late Isaac Holden.-1. Rhodora. 7: I72. 1905. Börgesen and Jonsson. The distribution of the Marine Algae of the Arctic Sea and of the northernmost part of the Atlantic. Botany of the Faeroes. Appendix. XXV. I905. Clark. The Holophytic Plankton of Lakes Atitlan and Amatitlan, Guatemala. Proc. Biol. Soc. Wash. 21: 96. Ig08.

Plate IV. fig. 49.

Plant mass dark blue-green or greenish-yellow; trichomes often mixed with other algae, I-2 mic. in diameter, twisted into a somewhat irregular dense (here and there loose), or rarely regular spiral, 3-5 mic. in diameter, the turns being contiguous to each other or almost so.

Greenland. Growing in cavities with brackish water among mouldering aigae. Tessarmiut, Baffin Bay. (Wormskiold). West Greenland, south of $6 r^{\circ}$ lat. N. (Rosenvinge). West Greenland and Atlantic North America. (Börgesen and Jonsson). Maine. Mixed with other algae, forming dark purple-colored patches on the wharves at low-water mark. Eastport. (Farlow). On rocks on shore near Seal Harbor. (Collins). (West). New Hampshire. (Collins). Massachusetts. Gloucester, Cambridge, Wood's Hole. (Farlow). Everett and Medford; on wharves, Nantucket. (Collins). Connecticut. In large jelly-like masses on stalks of $\mathrm{R} \mathrm{u} \mathrm{p} \mathrm{pia} \mathrm{in} \mathrm{Fresh}$ Pond (brackish), Stratford. July I892. ("Could take it up in jelly-like masses half an inch thick, pure Spiruli n a"). (Holden). - New York. Frequent in sulphur springs. Clifton. (Wolle). New Jersey. Mixed with O s cil1 a toria. Atlantic City. (Morse). Swimming River, Monmouth County. (Britton). Staten Island. (Pike). Mixed with other minute forms. Atlantic City. (Martindale). Florida. Glen Cove Spring. (Wolle). Nebraska. Irequent in salt water. Lincoln. (Saunders). Central America. Growing in very warm water. Guatemala. (Meek). West Indies. On the roots of mangroves. Near Bridgetown; Graeme Hall Swamp, Barbados. (Howard).

Forma oceanica (Crouan) Gomont. 1. c. 274. De Toni. 1. c. 215.

Collins, Holden and Setchell. Phyc. Bor.-Am. Fasc. 20. no. 954. I902.

Trichomes I mic. in diameter, somewhat straight in outline, twisted into a regular spiral.

Washington. Floating in slightly brackish water. Crocket's Lake. June I90I; in mud of pools of brackish water on salt marshes, Whidbey Island. (Gardner).

183. Spirulina duplex Wolle. Fresh-Water Algae U. S. 323. pl. 210. f. 4, 5. 1887. De Toni. Syll. Algar. 5: 216. 1907. 
Plate IV. fig. 50, $5 \mathrm{I}$.

Trichomes 2 mic. in diameter, when twisted 75-200 mic. long, having form of slender, flat, strap-like, continuous bands (when untwisted forming a complete ring), normally flattened and twisted, with one to four or more turns.

Minnesota. Frequent in pool near Minneapolis. (Wolle).

Genus PHORMIDIUM Kuetzing. Phyc. Gen. I9o. 1843.

Filaments simple, forming a woolly or felt-like layer or rarely floating, attached at the base with free ends torn and ragged; sheaths thin, transparent, mucous, agglutinated, partly or entirely diffluent; trichomes cylindrical, in some species constricted at joints, never distinctly spiral; apex of trichome often tapering, straight or curved, capitate or not capitate; outer membrane of apical cell thickened into a calyptra in many species.

I Trichomes especially constricted at joints, even moniliform; apex of trichome neither curved nor capitate.

I Trichomes scarcely 4 mic. in diameter

(I) Plants living in hot or in brackish water; trichomes 1.2-2.3 mic. in diameter; cells somewhat quadrate P. fragile

(2) Plants living in salt water; plant mass rose-colored; trichomes I.7-2 mic. in diameter; cells longer than the diameter

P. persicinum

(3) Plants terrestrial, nestling in pits in rocks; trichomes 1.5 in diameter; cells somewhat quadrate

P. foveolarum

2 Trichomes 6-8.5 mic. in diameter

P. tinctorium

II Trichomes rarely or scarcely constricted at joints; apex of trichome straight or curved, capitate in many species

I Trichomes scarcely $3 \mathrm{mic}$. in diameter

(I) Plant mass purplish violet, reddish brown or scarlet

A Filaments somewhat straight; trichomes slightly constricted at joints; transverse walls not granulated P. luridum

B Filaments somewhat straight; trichomes fragile, frequently interrupted, not constricted at joints; transverse walls rarely visible

P. rubrum

C Filaments very much twisted; trichomes not constricted at joints; transverse walls marked by four protoplasmic granules

P. purpurascens

D Filaments curved, entangled or arranged parallel with each other, trichomes not constricted at joints; apex of trichome straight, neither tapering nor capitate

P. crosbyanum

(2) Plant mass blue-green or olive.

A Plants living in hot water; plant mass expanded, lamellose, composed of many superposed papery layers; trichomes $.6-8$ mic. 
in diameter, not constricted at joints; apex of trichome straight, not tapering $P$. treleasei

B Plant mass thin, membranaceous; trichomes I-I.5 mic. in diameter, not constricted at joints; apex of trichome straight, tapering; transverse walls granulated P. laminosum

C Plant mass thin, membranaceous; trichomes I- 2 mic. in diameter, slightly constricted at joints; apex of trichome finally becoming tapered and bent; transverse walls not granulated

\section{P. tenue}

D Plant mass thick, leathery; trichomes 2-2.5 mic. in diameter, not constricted at joints; apex of trichome straight, obtuse

P. valderianum

E Plant mass lamellose; trichomes $2-2.8$ mic. in diameter, slightly constricted at joints; apex of trichome gradually tapering, bent or twisted

P. subuliforme

2 Trichomes more than 3 mic. in diameter

(I) Apex of trichome straight, not capitate

A Apical cell obtuse conical

a Plant mass encrusted with calcium carbonate

P. incrustatum

b Plant mass not encrusted with calcium carbonate

(a) Filaments somewhat straight; trichomes 3-5 mic. in diameter; transverse walls covered by protoplasmic granules

P. inundatum

(b) Filaments flexuous; trichomes 3-4.5 mic. in diameter; cells 3.4-8 mic. in length; transverse walls conspicuous

P. corium

(c) Filaments strongly flexuous; trichomes 3-5 mic. in diameter; cells $2-4$ mic. in length; transverse walls conspicuous

P. papyraceum

(d) Plant mass membranaceous, mucous; trichomes 5-6.5 mic. in diameter, interrupted; apex of trichome straight, obtuse; transverse walls sometimes finely granulated

\section{P. interruptum}

(e) Plant mass thin; trichomes I6-I8 mic. in diameter, frequently interrupted

P. naveanum

B Apical cell not or scarcely tapering, truncate

a Sheaths thin, fragile, soon diffluent; trichomes 4.5-12 mic. in diameter; cells 4-9 mic. in length

P. retzii

b Sheaths firm, or mucous and diffluent, at times thick and lamellose; trichomes 4-6 mic. in diameter; cells $1.5-2.7$ mic. in length.

P. ambiguum

(2) Apex of trichome straight, capitate

A Trichomes slightly constricted at joints

P. submembranaceum 
B Trichomes not constricted at joints

a Plants epiphytic, living in salt water; trichomes 4-4.5 mic. in diameter, irregularly curved, very rarely straight; apex of trichome gradually tapering; cells 4 -II mic. in length

P. laysanense

b Plants living in warm or fresh water; trichomes 4.5-9 mic. in diameter, elongate, flexuous; apex of trichome gradually tapering; cells 3-7 mic. in length

$P$. favosum

c Plants living in warm or fresh water; trichomes $6-8$ mic. in diameter, apex of trichome scarcely tapering; apical cell oblique, depressed, conical

P. Ealidum

d Plants living in fresh water; trichomes 5.5-II mic. in diameter, straight, fragile; apex of trichome briefly tapering; apical cell straight, conical; cells $2-4$ mic. in length

P. subfuscum

(3) Apex of trichome more or less curved, capitate

A Plant mass blue-green or dark brown

a Plants living in fresh water; trichomes 6-9 mic. in diameter; apex of trichome curved or briefly spiraled

P. uncinatum

b Plants living on damp soil or on rocks, rarely under water; trichomes 4-7 mic. in diameter; apex of trichome scarcely curved, sometimes straight

$P$. autumnale

B Plant mass dark purple

P. setchellianum

184. Phormidium fragile (Meneghini) Gomont. Monogr. Oscill. I83. pl. 4. f. I3-15. 1893. De Toni. Syll. Algar. 5: 220. 1907.

Collins. Algae. Rand and Redfield's Flora of Mount Desert Island, Maine. 248. I894. Collins, Holden and Setchell. Phyc. Bor.-Am. Fasc. Io. no. 45I. I898. Collins. Preliminary Lists of New England Plants.-V. Marine Algae. Rhodora. 2: 42. 1900. West and West. A further Contribution to the Freshwater Algae of the West Indies. Journ. Linn. Soc. Bot. 34: 289. 1898-Ig00. Bessey, Pound and Clements. Additions to the Reported Flora of the State. Bot. Surv. Nebraska. 5: r3. Igor.

Plate IV. fig. 52, 53.

Plant mass mucous, lamellose, yellowish or dark blue-green; sheaths gelatinous, fibrous, diffluent into mucous; trichomes 1.2-2.3 mic. in diameter, more or less flexuous, entangled or somewhat parallel to each other, constricted at joints; apex of trichome tapering; apical cell acute-conical; calyptra none; cells I.2-3 mic. long; cell contents not granular.

Maine. Forming a dull green, gelatinous stratum on woodwork. Near Seal Harbor; forming an encrustation in a tide pool, York Island, Penobscot Bay, July I894. (Collins). Massachusetts. Northern part. (Collins). Nebraska. In aquaria. Lincoln. (Bessey). West Indies. In stream. Wotten Waven, Dominica. (Elliott). 
I85. Phormidium persicinum (Reinke) Gomont. Monogr. Oscill. I84. I893. De Toni. Syll. Algar, 5: 220. I907.

Collins. Notes on Algae.-II. Rhodora. I: II. I900; Preliminary Lists of New England Plants.-V. Marine Algae. Rhodora. 2: 42. 1900. West. West Indian Freshwater Algae. Journ. of Bot. 42: 292. 1904. Collins, Holden and Setchell. Phyc. Bor.-Am. Fasc. 29. no. I401. I907.

Plant mass a delicate, continuous, velvety, rose-colored coating on marine shells; filaments loosely entangled; sheaths close, diffluent into an amorphous mucus; trichomes 1.7-2 mic. in diameter, especially constricted at joints; apex of trichome tapering; apical cell acute conical; calyptra none; cells $2-7 \mathrm{mic}$. in length; cell contents homogeneous.

Massachusetts. Forming a thin pink film on shells, mostly on the $S p$ irorbis which is often attached in great abundance to larger algae. Nahant. June I899. (Collins). In a jar in the Marine Biological Laboratory. Wood's Hole. May I907. (Davis). West Indies. On roots of mangroves in brackish swamp. Near Bridgetown, Barbados. (Howard).

I86. Phormidium foveolarum (Montagne) Gomont. Monogr. Oscill. I64. p1. 4. f. I6. 1893. De Toni. Syll. Algar. 5: 221. 1907.

Setchell and Gardner. Algae of Northwestern America. Univ. Calif. Pub. Bot. I: 184. 1903.

\section{Plate IV. fig. 54.}

Plant mass very thin, orbicular, "nestling" in depressions of cretaceous rocks, dark green; sheaths diffluent into an amorphous, gelatinous mucus; trichomes about $1.5 \mathrm{mic}$. in diameter, variously twisted, parallel, constricted at joints; apex of trichome not tapering; apical cell rotund; calyptra none; cells .8-2 mic. in length; cell contents not granular, pale blue-green.

Washington. Mixed with $P$. a u $\mathrm{t} \mathrm{m} \mathrm{n}$ a $\mathrm{le}$ in ditches by the roadside. Pleasant Ridge, near La Conner, Skagit County. (Gardner).

187. Phormidium tinctorium Kuetzing. Tab. Phyc. I: 35 . pl. 49. f. 3. I8451849. Gomont. Monogr. Oscill. 182. pl. 4. f. I1. I893. De Toni. Syll. Algar. 5: 218. 1907.

Wolle. Fresh Water Algae. VI. Bull. Torr. Bot. Club. 9: 25. I882; Fresh-Water Algae U. S. 30I. pl. 202. f. 22, 23. I887. (L y n g b y a t in ctori a Kg.)

\section{Plate IV. fig. 55.}

Plant mass penicillate, elongate, attached at base, waving, gelatinous, dark green, when dried yellowish purple, coloring paper violet; flaments somewhat straight, collected in fascicles, parallel; sheaths very mucous and diffluent; trichomes 6-8.5 mic. in diameter, much constricted at joints; apex of trichome straight, occasionally very gradually tapering; apical cell more or less acute conical or cylindrical conical; calyptra none; cells 5-I I mic. long; transverse walls not granulated; cells contents finely granular.

Arizona. In springs. April. (Pringle).

M. Gomont calls attention to the fact that the trichomes of this 
species resemble very much those of $\mathrm{M}$ ic rocoleus subtorulosus, but the exterior aspect of the two plants is totally different.

188. Phormidium luridum (Kuetzing) Gomont. Monogr. Oscill. I85. pl. 4. f. 17, 18. 1893. De Toni. Syll. Algar. 5: 222. I907.

West and West. A further Contribution to the Freshwater Algae of the West Indies. Joürn. Linn. Soc: Bot. 34: 289. I898-I900. West. West Indian Fresh Water Algae. Journ. of Bot. 42: 292. I904.

\section{Plate IV. fig. $56,57$.}

Plant mass membranaceous, lamellose, amethyst-purple or dark purple on the surface, gray or blue-green underneath; filaments somewhat straight; sheaths at first thin, scarcely visible, soon dissolving into a compact, gelatinous mucus; trichomes I.7-2 mic. in diameter, fragile, straight, variously entangled, slightly constricted at joints; apex of trichome neither curved nor tapering; apical cell rotund; calyptra none; cells $1.8-4.7$ mic. in length; cell contents not granular.

West Indies. Growing on sides of road, Fort Charlotte, St. Vincent. January and February r896. (West). Roseau Valley, Dominica. (Howard).

189. Phormidium rubrum Tilden. American Algae. Cent. II. no. I86. r896. Observations on some West American Thermal Algae. Bot. Gaz. 25: 10o. pl. 9. f. I8. I898. De Toni. Syll. Algar. 5: 223. 1907.

Plate IV. fig. 58 .

Plant mass forming a thin layer, scarlet in color; filaments somewhat straight; sheaths visible only under high powers; trichomes I mic. in diameter, fragile, frequently interrupted, not constricted at joints; apex of trichome neither curved nor tapering; cells I-I.2 mic. in length; transverse walls rarely visible.

Wyoming. In tepid water, in overflow from small hillside spring. Between Middle and Upper Geyser Basins, Yellowstone National Park. July I8g6. (Tilden).

J90. Phormidium purpurascens (Kuetzing) Gomont. Essai Class. Nostocacées homocystées. Morot. Journ. de Bot. 4: 355. I890; Monogr. Oscill. 186. pl. 4. f. 19. 1893. De Toni. Syll. Algar. 5: 223. 1907.

Plate IV. fig. 59.

Plant mass compact, leathery, dark violet; filaments strongly twisted, closely entangled; sheaths narrow, papery, finally becoming diffuent and agglutinated; trichómes $1.5-2.5$ mic. in diameter, not constricted at joints; apex of trichome neither tapering nor curved; apical cell rotund; calyptra none; cells 2-4.5 mic. in length; transverse walls marked by four protoplasmic granules.

Wyoming. Together with Synechococcus aeruginosus and Gl oe ocapsa violace a, forming black "stalactites," I.-I.5 dm. long and $.5 \mathrm{dm}$. in thickness, also serrated masses or extended sheets. These hung from the top and lined the walls of a small cave in which was the vent of a hot spring. At short intervals they received jets of steam and 
a spray of hot water. Valley of Nez Perces Creek, Lower Geyser Basin, Yellowstone National Park. June 1896. (Tilden).

Further study proved that the Yellowstone specimens should be placed under $\mathrm{H}$ y pheothrix calcicola (Ag.) Rab. However, since there is some possibility that the material contains a mixture of the two species, the above description is allowed to stand.

19I. Phormidium crosbyanum Tilden. American Algae. Cent. VII. Fasc. I. no. 645. Ig09.

$$
\text { Plate IV. fig. 60, 6r. }
$$

Plant mass $2 \mathrm{~cm}$. in thickness, $5 \mathrm{~cm}$. in diameter, impregnaced with lime, firm, somewhat hard, bluish green to brownish red in color; filaments curved, entangled or arranged parallel with each other; sheaths extremely delicate; trichomes I-2 mic. in diameter, not constricted at joints; apex of trichome straight, neither tapering nor capitate; apical cell conical; calyptra none; cells $\mathbf{1 . 5 - 5}$ mic. long.

Hawaii. Forming reddish brown, flattened-globose cushions on upper side of rock shelf, between tides. Waianae, Oahu, May Igoo. (Tilden).

It is usually very difficult to make out the sheaths protruding beyond the trichome, but empty sheaths are numerous.

I92. Phormidium treleasei Gomont. Sur quelques Oscillariées nouvelles. Bull. Soc. Bot. de France. 46: 37. I899. De Toni. Syll. Algar. 5: 234. 1907.

Collins, Holden and Setchell. Phyc. Bor.-Am. Fasc. 2I. no. I006. 1903. Setchell and Gardner. Algae of Northwestern America. Univ. Calif. Pub. Bot. I: 186. 1903.

Plant mass expanded, lamellose, composed of many superposed papery layers; filaments parallel, very slender, straight, rigid; sheaths very thin, transparent, mucous, agglutinated; trichomes .6-.8 mic. in diameter, not constricted at joints; apex of trichome straight, not tapering; apical cell rotund; calyptra none; cells up to $8.8 \mathrm{mic}$. in length; cell contents pale bluegreen.

Canada. Hot Sulphur Springs, Banff, Alberta. June I90I. (Butler and Polley). Arkansas. In hot springs. (Trelease).

193. Phormidium laminosum (Agardh) Gomont. Essai Class. Nostocacées homocystées. Morot. Journ. de Bot. 4: 355. I890; Monogr. Oscill. 187. p1. 4. f. 21, 22. I893. De Toni. Syll. Algar. 5: 225. I907.

Wolle. Fresh Water Algae. III. Bull. Torr. Bot. Club. 6: I83. I877. (O. e I e ga n s Ag.) Tilden. American Algae. Cent. II. no. I8r. I896, Observations on some West American Thermal Algae. Bot. Gaz. 25: 98. f. I5. I898. Bessey, Pound and Clements. Additions to the Reported Flora of the State. Bot. Surv. Nebraska. 5: I3. I9or. Saunders. The Algae. Harriman Alaska Expedition. Proc. Wash. Acad. Sci. 3: 398. I9or. Setchell and Gardner. Algae of Northwestern America. Univ. Calif. Pub. Bot. I: 185. I903. Collins, Holden and Setchell. Phyc. Bor.-Am. Fasc. 2I. no. roo3. 1903. West. West Indian Freshwater Algae. Journ. of Bot. 42: 292. I904. Tilden. Notes on a Collection of Algae from Guatemala. 
Proc. Biol. Soc. Wash. 2I: 154. I908; American Algae. Cent. VII. Fasc. I. no. 643. I909.

\section{Plate IV. fig. 62.}

Plant mass thin, membranaceous, expanded, pale blue-green, golden yellow or brick-colored; filaments flexuous, densely entangled; sheaths narrow, papery, mucous or entirely diffuent into an amorphous mucus; trichomes I-I.5 mic. in diameter, not constricted at joints; apex of trichome straight, briefly tapering, not capitate; apical cell acute conical; calyptra none; cells 2-4 mic. in length; transverse walls marked by four refringent granules, usually inconspicuous; cell contents blue-green.

Alaska. Forming a thin, membranaceous stratum on perpendicular rocks moistened by spray from a waterfall. Orca, Prince William Sound. (Saunders). Pennsylvania. Quiet waters. (Wolle). Nebraska. In runring water in greenhouse. Lincoln. (Bessey). Wyoming. In overflow water of spring where the old formation makes a hard, billowy or terraced incline. The algae extend down the incline for a distance of twenty feet, forming wide ribbons of green, alternating with bands of pink, yellow, white and a darker green. Temperature of spring $9 I^{\circ} \mathrm{C}$. Algal growth occurs at a temperature of $51-55^{\circ}$ C. Ribbon Spring, Norris Geyser Basin. June 1896; in small shallow spring, expanding at top into leaf-like masses, or tapering from bulbous head to a small tubular base, temperature $55^{\circ} \mathrm{C}$, Valley of Nez Perces Creek, Lower Geyser Basin, June I896; in grassy rivulet, temperature $30^{\circ} \mathrm{C}$., Mountain hot springs, Lower Geyser Basin, June I896; around edges of springs, forming brown and green layers which turn gray or blackish out of water, temperature $63^{\circ} \mathrm{C}$., Prismatic Lake, Middle Geyser Basin, July I896; forming 'plumy strings, white or light yellowish in color, temperature $75.5^{\circ}$ C., Solitary Spring, Upper Geyser Basin, July 1896; forming a whitish, scurfy, hardened, rather brittle scum on surface of still pool into which overflow runs, temperature $4 \mathrm{I}^{\circ} \mathrm{C}$., Mammoth Hot Springs, July 1896, Yellowstone National Park. (Tilden). Washington. In a water trough fed by a spring. San Juan Island. July I9or. (Gardner). Central America. In a pool of very warm water close to a hot spring. Near Lake Amatitlan. January 1906. (Kellerman). West Indies. Royal Botanical Gardens, St. Ann's, Trinidad. (Howard).

This species was found to be "by far the most widespread and abundant of any alga in the hot waters of the Park. Its habit of growth is extremely varied, so that it is not easily recognized. It is the only species, except Spirulina major, that, so far as $I$ know, is found in both calcareous and silicious waters in this region."-Tilden.

Forma weedii Tilden. Observations on some West American Thermal Algae. Bot. Gaz. 25: 99. p1. 9. f. 16. I898. De Toni. Syll. Algar. 5: 226. 1907.

Plant mass blue-green; filaments often strongly bent; sheaths not visible, trichomes $2.5-3$ mic. in diameter; apex of trichome sharply bent; cells I.5-2.5 mic. long; transverse walls generally distinct, sometimes marked by granules; cell contents usually granular:

Wyoming. In overflow of channel. Temperature 49-54.3 ${ }^{\circ}$. With $\mathrm{S}$ pirulina major. Spasmodic Geyser, Upper Geyser Basin, Yellowstone National Park. I897. (Weed). 
This plant is very near typical P. la minosum. The points of difference are that the filaments are slightly greater in diameter, the apex is almost invariably sharply bent, and the transverse walls may or may not be marked by granules. Sometimes the entire cell contents are granular.

194. Phormidium tenue (Meneghini) Gomont. Monogr. Oscill. I89. pl. 4. f. 23-25. I893. De Toni. Syll. Algar. 5: 227. 1907.

Wolle. Fresh-Water Algae. VI. Bull. Torr. Bot. Club. 9: 25. I882. (Oscillatoria deters a Stitz.); Fresh-Water Algae. U. S. 3Io. I887. Bennett. Plants of Rhode Island. II5. I888. Tilden. American Algae. Cent. II. no. 182. I896; Observations on some West American Thermal Algae. Bot. Gaz. 25: 100. pl. 9. f. 17. 1898. Collins, Holden and Setchell. Phyc. Bor.-Am. Fasc. I3. no. 606. I899. Bessey, Pound and Clements. Additions to the Reported Flora of the State. Bot. Surv. Nebraska. 5: r3. I90I. Setchell and Gardner. Algae of Northwestern America. Univ. Calif. Pub. Bot. I: I85. I903. West. West Indian Freshwater Algae. Journ. of Bot. 42: 292. I904. Brown. Algal Periodicity in certain Ponds and Streams. Bull. Torr. Bot. Club. 35: 248. 1908. Buchanan. Notes on the Algae of Iowa. Proc. Iowa Acad. Sci. I4: I3. I908.

\section{Plate IV. fig. 63-65.}

Plant mass thin, membranaceous, expanded, pale blue-green; filaments elongate, somewhat straight, densely entangled; sheaths thin, finally diffluent into a fibrous mucus; trichomes I-2 mic. in diameter, straight, slightly constricted at joints; apex of trichome not capitate, at first straight, afterwards becoming tapering and bent; apical cell acute-conical; calyptra none; cells 2.5-5 mic. in length; transverse walls usually indistinct; cell contents homogeneous, pale blue-green.

Alaska. In various situations, submerged and emergent, in fresh water. Walls of Amaknak Cave, Amaknak Island; Bay of Unalaska. (Setchell and I.awson). Massachusetts. In fresh water. Naushon Island. August I895. (Nott). Rhode Island. Roger Williams Park. (Bennett). New York. Stagnant waters. Rochester. (Wolle). Virginia. In a pool in Luray Cave, 260 feet below the surface. (Seipt). Indiana. Edge of pond. Near Bloomington. May, June I907. (Brown). Iowa. Frequent. Fayette. (Fink). On pots in greenhouse; in pond. Ames; in pond among decaying rushes, bottom of the margin of the slough. Eagle Grove. (Buchanan). Nebraska. On boards of mill-dam. Milford. (Bessey). Wyoming. Around edges of spring, not covered by water, but water flows in little streams through and around it. Mixed with $P$. I a $\mathrm{m}$ in o s u $\mathrm{m}$. Temperature of water $33^{\circ}$ C. Lower Geyser Basin, Yellowstone National Park. June 1896. (Tilden). Washington. Coupeville, Oak Harbor, Whidbey Island; Seattle. (Gardner). West Indies. Near Bridgetown; Bay Estate; Graeme Hall Swamp. Barbados. (Howard).

I95. Phormidium valderianum (Delponte) Gomont. Monogr. Oscill. 187. pl. 4. f. 20. I893. De Toni. Syll. Algar. 5: 223. I907.

Hariot. Algues du Golfe de Californie recueillies par M. Diguet. Journ. de Bot. 9: 169. I895. Setchell. Notes on some Cyanophyceae of New 
England. 22: 430. 1895. Collins, Holden and Setchell. Phyc. Bor.-Am. Fasc. 3. no. I03. I895. Tilden. List of fresh-water Algae collected in Minnesota during 1896 and 1897 . Minn. Bot. Studies. 2: 28. 1898. Collins. Preliminary Lists of New England Plants. V. Marine Algae. Rhodora. 2: 42. I900. Collins, Holden and Setchell. Phyc. Bor.-Am. Fasc. 23. no. I 105. 1903. Setchell and Gardner. Algae of Northwestern America. Univ. Calif. Pub. Bot. I: I84. I903. Tilden. Notes on a Collection of Algae from Guatemala. Proc. Biol. Soc. Wash. 21: I54. 1908. Tilden. American Algae. Cent. VII. Fasc. I. no. 644. I909.

\section{Plate IV. fig. 66.}

Plant mass up to $3 \mathrm{~cm}$. in thickness, slimy, expanded, lamellose, the upper layers dull green, the lower layers whitish; filaments flexuose, densely entangled; sheaths narrow, papery, finally diffluent into a tenaceous mucus and becoming agglutinated; trichomes 2-2.5 mic. in diameter, straight, not constricted at joints; apex of trichome not tapering; apical cell rotund; calyptra none; cells 3.3-6.7 mic. in length; transverse walls marked by two or four protoplasmic granules; cell contents blue-green.

Alaska. On dripping timber of old mill. Sitka. (Setchell and Lawson). Canada. Forming a thick, stratified mass. Warm sulphur spring. Banff, Alberta. June I90I. (Butler and Polley). Rhode Island. "Forming verdigris-green gelatinous sheaths, later becoming chartaceous, on stones and on leaves of $\mathrm{Ruppia} \mathrm{maritima}$ in brackish water. Watch Hill Pond, Watch Hill. September I892." (Setchell). Connecticut. (Collins). Minnesota. In arm of Mississippi River (old channel). St. Paul Park. October I897. (Freeman). Gulf of California. In thermal water at $75^{\circ}$. "Du ruisseau de l'Azufres au pied du volcan de las Virgenes." Central America. Associated with Nodularia harveyana. Laguna, Lake Amatitlan, Guatemala. Altitude 3950 feet. February I905. (Kellerman).

I96. Phormidium subuliforme Gomont. Monogr. Oscill. I89. pl. 4. f. 26. 1893. De Toni. Syll. Algar. 5: 230. I907.

Bessey, Pound and Clements. Additions to the Reported Flora of the State. Bot. Surv. Nebraska. 5: 12. I90I.

\section{Plate IV. fig. 67.}

Plant mass lamellose, yellowish green; sheaths diffluent into an amorphous, gelatinous mucus; trichomes $2-2.8$ mic. in diameter, straight, constricted at joints; apex of trichome gradually tapering, bent or twisted, not capitate; apical cell more or less acute-conical; calyptra none; cells 6-8 mic. in length; transverse walls distinct; cell contents homogeneous or coarsely granular, blue green.

Nebraska. In aquaria. Lincoln. (Bessey).

I97. Phormidium incrustatum (Naegeli) Gomont in Bornet and Flahault. Sur quelques plantes vivant dans le test calcaire des Mollusques, in Bull. Soc. Bot. France. 36: r54. I889; Monogr. Oscill. I9o. pl. 4. f. 27. 1893. De Toni. Syll. Algar. 5: 230. I907.

Tilden. American Algae. Century II. no. I83. I896; List of fresh-water 
Algae collected in Minnesota during I895. Minn. Bot. Studies. I: 599. I896. Collins, Holden and Setchell. Phyc. Bor.-Am. Fasc. 22. no. 1057. 1903.

\section{Plate IV. fig. 68.}

Plant mass encrusted with lime, crustaceous, very hard, dark red or violet; filaments curved, entangled or erect-parallel; sheaths thin, mucous, agglutinated; trichomes 4-5 mic. in diameter, not constricted at joints; apex of trichome straight, briefly tapering, not capitate; apical cell obtuseconical; calyptra none; cells 3.5-5.2 mic. in length; transverse walls usually visible, sometimes granulated; cell contents showing scattered granules.

Wisconsin. In stream. Osceola. August I895. (Tilden). California. On the sides of a water trough. Berkeley. September I902. (Osterhout and Gardner).

Var. cataractarum (Naeg.) Gomont. 1. c. I90. De Toni. 1. c. 23 I.

Wolle. Fresh-Water Algae. U. S. 302. pl. 202. f. 18, 19. 1887. Wolle and Martindale. Algae. Britton's Catalogue of Plants found in New Jersey. Geol. Surv. N. J. 2: 608. I889. Brown. Algal periodicity in certain ponds and streams. Bull. Torr. Bot. Club. 35: 248. I908. Buchanan. Notes on the Algae of Iowa. Proc. Iowa Acad. Sci. I4: r3. I908.

Filaments erect-parallel.

New Jersey. In rapid waters. (Wolle). Pennsylvania. Frequent at waterfalls, mill dams, etc., sometimes in cushion-like masses, two or three inches in thickness. (Wolle). Indiana. Jordan Branch, Bloomington. March to August 1907. (Brown). Iowa. Iowa City. (Hobby).

198. Phormidium inundatum Kuetzing. Spec. Algar. 25I. I849. Gomont. Monogr. Oscill. 192. p1. 4. f. 3I, 32. I893. De Toni. Syll. Algar. 5: 232. I907.

Wolle. Fresh-Water Algae. VI. Bull. Torr. Bot. Club. 9: 25. I882; Exsicc. no. 108. (O. a n t $1 \mathrm{i}$ a ria); Fresh-Water Algae U. S. 303. pl. 202. f. 24, 25. I887. (L. in undata Kg.) Bennett Plants of Rhode Island. I14. I888. Setchell. Notes on Cyanophyceae.-III. Erythea. 7: 53. 1899. Collins, Holden and Setchell. Phyc. Bor.-Am. Fasc. 21. no. I002. I903. Setchell and Gardner. Algae of Northwestern America. Univ. Calif. Pub. Fot. I: I85. 1903. Tilden. American Algae. Cent. VII. Fasc. I. no. 642. I909.

\section{Plate IV. fig. 69, 7o.}

Plant mass membranaceous, blue-green; filaments somewhat straight, fragile; sheaths thin, diffluent into an amorphous mucus; trichomes $3-5$ mic. in diameter, straight or curved, not constricted at joints; apex of trichome straight, briefly tapering, not capitate; apical cell obtuse conical; calyptra none; cells $4-8 \mathrm{mic}$. in length; transverse walls covered by protoplasmic granules.

United States. (Farlow). Margins of wayside ditches and the like. (Wolle). Rhode Island. Geneva. (Bennett). South Carolina. On moist earth. (Ravenel). Montana. On bottoms of dried alkali ponds. Billings. September 1898. (Williams and Griffiths). Washington. On a dripping water pipe. Seattle. May Igor. (Gardner). 
199. Phormidium corium (Agardh) Gomont. Essai Class. Nostocacées homocystées. Morot. Journ. de Bot. 4: 355. I89o; Monogr. Oscill. 192. pl. 5. f. I, 2. I893. De Toni. Syll. Algar. 5: 235. I907.

Collins. Algae. Flora of the Blue Hills, Middlesex Fells, Stony Brook and Beaver Brook Reservations of the Metropolitan Park Commission, Massachusetts. 127. I896. Collins, Holden and Setchell. Phyc. Bor.-Am. Fasc. 7. no. 304. 1897. Tilden. American Algae. Cent. IV. no. 399. I900. Collins. Preliminary Lists of New England Plants.-V. Marine Algae. Rhodora. 2: 42. I900. Bessey, Pound and Clements. Additions to the Reported Flora of the State. Bot. Surv. Nebraska, 5: I3. I90I. Setchell and Gardner. Algae of Northwestern America. Univ. Calif. Pub. Bot. I: 185. 1903. Collins. Phycological Notes of the late Isaac Holden.-II. Rhodora. 7: 236. 1905 .

\section{Plate IV. fig. $7 x, 72$.}

Plant mass widely expanded, membranaceous, leathery, dark blue-green ur black; filaments elongate, more or less flexuous, densely entangled; sheaths thin, papery, or diffluent into an amorphous mucus; trichomes 3-4.5 mic. in diameter, not constricted at joints; apex of trichome straight, briefly tapering, not capitate; apical cell obtuse conical; calyptra none; cells 3.4-8 mic. in length; transverse walls not granulated, usually consnicuous; cell contents sometimes granular, blue-green.

Greenland.'(Börgesen). Massachusetts. On cliff. Middlesex Fells. (Collins). Connecticut. On stonework of dam at R. R. crossing. Bruce's Brook; on woodwork of dam, Island Brook, below Housatonic R. R.; on stonework of dam at Moody's Pond, May 1894, Bridgeport. (Holden). South Carolina. On rocks and timbers under dam at mill. Chester County. May I898. (Green). Nebraska. In ponds. South Bend, Long Pine. (Bessey, Pound and Clements).

200. Phormidium papyraceum (Agardh) Gomont. Essai Class. Nostocacées homocystées. Morot. Journ. de Bot. 4: 355. r89o; Monogr. Oscill. 193. I893. De Toni. Syll. Algar. 5: 1907.

Collins, Holden and Setchell. Phyc. Bor.-Am. Fasc. I4. no. 653. I900. Tilden. Collection of Algae from the Hawaiian Islands. Haw. Almanac and Annual for I902. II2. Igor; American Algae. Cent. V. no. 493. I90I. Collins, Holden and Setchell. Phyc. Bor.-Am. Fasc. 21, no. I004. Ig03.

\section{Plate IV. fig. $73,74$.}

Plant mass expanded, glistening, thin, leathery, fragile when dried, lark green; filaments elongate, strongly flexuous, very densely entangled; shcaths thin, papery, sometimes diffluent; trichomes 3-5 mic. in diameter, not constricted at joints; apex of trichome straight, briefly tapering, not capitate; apical cell obtuse-conical; calyptra none; cells $2-4$ mic. in length; transverse walls usually conspicuous, not granulated; cell contents sometimes granular, blue-green.

Maine. On stones at low water mark, outlet of fresh water brook, but within.influence of tide. Cape Rosier. July Igor. (Collins). Massachusetts. In brook on stones under falling water. Medford. April r8g6. (Collins). 
Hawaii. On sides of wooden irrigation flume where water dripped through. Kahuku Plantation, Oahu. June Igoo. (Tilden).

201. Phormidium interruptum Kuetzing. Tab. Phyc. I: 33 . pl. 45. f. 7. I845. De Toni. Syll. Algar. 5: 228. I907.

Plate IV. fig. 75 .

Plant mass membranaceous, mucous, blue-green; sheaths firm; trichomes 5-6.5 mic. in diameter, flexuously curved, interrupted; apex of trichome straight, obtuse; cells $2.5-3.2 \mathrm{mic}$, in length; transverse walls sometimes finely granulated; cell contents usually homogeneous, yellowish green.

Vermont. Charlotte. (Wolle).

202. Phormidium naveanum Grunow in Nave. Vorarbeiten zu einer Kryptogamenflora von Mährens. Verhandl. der Naturforsch. Vereins in Brünn. 40. 1864. De Toni. Syll. Algar. 5: 228. 1907.

Wolle. Fresh Water Algae. Bull. Torr. Bot. Club. 6: 283. 1879; FreshWater Algae U. S. 298. pl. 20I. f. I, 2. I887.

\section{Plate IV. fig. 76.}

Plant mass thin, dull green becoming olive brown; filaments 15 -I8 mic. in diameter, more or less parallel; sheaths very wide, loosely cohering, firm, colorless; trichomes frequently interrupted; cells two or three times shorter than the diameter, indistinct; cell contents dull green.

Canada. Crystal Bay, Ontario, Lake Erie. (Wolle). Pennsylvania. Fools. (Wolle). Florida, Marsh grounds. (Smith).

203. Phormidium retzii (Agardh) Gomont. Essai Class. Nostocacées homocystées. Morot. Journ. de Bot. 4: 355. I89o; Monogr. Oscill. 195. pl. 5. f. 6-9. 1893. De Toni. Syll. Algar. 5: 24I. 1907.

Wolle. Fresh Water Algae. Bull. Torr. Bot. Club. 6: 283. 1879; FreshWater Algae U. S. 302. pl. 202. f. 9-II. 1887. (L. r e t $z$ i i Ag,, L. p a p y r in a Kirchn.) Bennett. Plants of Rhode Island. II4. 1888. Tilden. American Algae. Cent. I. no. 70. I894. List of Fresh-Water Algae collected in Minnesota during I894. Minn. Bot. Studies. I: 235. I895. Collins, Holden and Setchell. Phyc. Bor.-Am. Fasc. I. no. 3. 1895. Collins. The Algae of Jamaica. Proc. Am. Acad. Arts Sci. 37: 239. I90I. Tilden. American Algae. Cent. VI. no. 589. 1902. Setchell and Gardner. Algae of Northwestern America. Univ. Calif. Pub. Bot. I: I85. I903. Collins. The Algae of the Flume. Rhodora. 6: 230. I904; Phycological Notes of the late Isaac Holden.-II. Rhodora. 7: 236, 243. 1905. Tilden. American Algae. Cent. VII. Fasc. I. no. 640, 641. 1909.

\section{Plate V. fig. I-4.}

Plant mass thick, compact, or sometimes forming penicillate or branched tufts, attached at base, upper portions floating, bright blue-green or dark lead color; filaments more or less straight, fragile, entangled; sheaths thin, fragile, usually soon diffluent into an amorphous mucus; trichomes 4.5-I2 mic. in diameter, usually not constricted at joints, rarely somewhat monili- 
form; apex of trichome straight, not capitate; apical cell scarcely tapering, truncate, with outer membrane scarcely thickened; cells 4-9 mic. in length; transverse walls not granulated, sometimes obscured by protoplasmic igranules; cell contents granular, blue-green.

Newfoundland. On moss in stream, swift water, running into Torbay Harbor, Torbay. July I897. (Holden). New Hampshire. On walls of the "Flume" and in quieter parts of the stream. (Collins). Rhode Island. Geneva. (Bennett). Connecticut. Forming dark bluish-purple gelatinous patches, often of considerable extent, on rocks in swiftly flowing current. Quinebaug River, Lisbon. September I892. (Setchell). Stream just below paper mill. Pequonnock River; Rooster River, Bridgeport. June, July, September. (Holden). Florida. (Smith). Alabama. Auburn. March 1897. (Baker). Texas. 1902. (Fanning). Wisconsin. Forming membrane on sides of casing of spring. Osceola. September I894. (Tilden). Minnesota. In ponds. Minnesota Point, Duluth. August Igor. (Tilden). Washington. Growing on a submerged log. Green Lake, Seattle. (Gardner). West Indies. In tufts on plants. Rio Cobre, Bog Walk, Jamaica. I893. (Humphrey).

Forma fasciculatum Gomont. 1. c. I97. De Toni. 1. c. 243.

Collins, Holden and Setchell. Phyc. Bor.-Am. Fasc. 26. no. I254. I905. Collins. Notes on Algae.-VII. Rhodora. 8: I22. 1906.

Fascicles attached at base, penicillate or tufted, branched, floating.

Massachusetts. In long masses in quick running water. Inlet of Walder Pond, Lynnfield. June I905. (Collins).

Forma rupestris (Kuetz.) Gomont. 1. c. I97. De Toni. 1. c. 242.

Wolle. Fresh Water Algae. Bull. Torr. Bot. Club. 6: 283. 1879; FreshWater Algae U. S. 300. pl. 202. f. 58. 1887. Wolle and Martindale. Algae. Rritton's Catalogue of Plants found in New Jersey. Geol. Surv. N. J. 2: 608. I 889 .

Trichomes constricted at joints near the apices.

New Jersey. On rocks. Bergen, Palisades. (Wolle). Maryland. Forming a matted stratum on rocks. Garrett County. (Smith).

204. Phormidium ambiguum Gomont. Monogr. Oscill. I98. pl. 5. f. ro. 1893. De Toni. Syll. Algar. 5: 240. I907.

Tilden. List of Fresh-Water Algae collected in Minnesota during 1895 . Minn. Bot. Studies. I: 599. I896; American Algae. Cent. II. no. I84. I896. Collins, Holden and Setchell. Phyc. Bor.-Am. Fasc. 6. no. 254. I897. Collins. Preliminary Lists of New England Plants.-V. Marine Algae. Rhodora. 2: 42. I900. Bessey, Pound and Clements. Additions to the Reported Flora of the State. Bot. Surv. Nebraska. 5: I3. Igor. Setchell and Gardner. Algae of Northwestern America. Univ. Calif. Pub. Bot. I: I85. I903.

\section{Plate V. fig. 5 .}

Plant mass more or less expanded, dark or yellowish green or bluegreen; filaments elongate, flexuously curved, variously entangled; sheaths firm, or mucous and diffluent, at times thick and lamellose; trichomes 4-6 mic. in diameter, slightly constricted at joints; apex of trichome straight, 
neither tapering nor capitate; apical cell rotund, with outer membrane slightly thickened; cells $1.5-2.7$ mic. in length; transverse walls rarely granulated, occasionally obscured by protoplasmic granules; cell contents granular, blue-green.

Massachusetts. Forming a coating on stones and algae in ditch in salt marsh. Near Linden station. Revere. October I892. (Collins). Minnesota. On bottom of wooden trough through which very cold spring water flows with a swift current. State Fish Hatcheries, St. Paul. September 1895. (Tilden). Nebraska. In aquaria. Lincoln. (Bessey, Pound and Clements). Washington. Growing on a submerged log. Green Lake, Seattle. (Gardner).

205. Phormidium submembranaceum (Ardissone and Strafforello) Gomont. Monogr. Oscill. 200. pl. 5. f. I3. I893. De Toni. Syll. Algar. 244. 1907.

Collins, Holden and Setchell. Phyc. Bor-Am. Fasc. 24. no. I162. I904.

$$
\text { Plate V. fig. } 6 .
$$

Plant mass membranaceous, leathery, dark green, sheaths not present; trichomes $5 \mathrm{mic}$. in diameter, constricted at joints, densely tangled, agglutinated by an abundant amorphous mucus; apex of trichome straight, gradually tapering, capitate; apical cell showing a depressed-conical calyptra; cells somewhat quadrate, 4-Io mic. in length; cell contents homogeneous, blue-green.

California. Forming a thick layer on plants just below water mark. Alameda. September Ig03. (Osterhout and Gardner).

206. Phormidium laysanense Lemmermann. Algenfl. Sandwich.-Inseln. Bot. Jahrb. 34: 619. pl. 7. f. 4, 5. I905. De Toni. Syll. Algar. 5: 245. I907.

$$
\text { Plate V. fig. } 7,8 \text {. }
$$

Filaments 5-6 mic. in diameter; sheaths hyaline; trichomes 4-4.5 mic. in diameter, irregularly curved, very rarely straight, not constricted at joints; apex of trichome straight, gradually tapering; apical cell capitate; cells 4-II mic. in length; transverse walls not granulated; cell contents blue-green.

Hawaii. On Turbinaria. Laysan. I896-97. (Schauinsland).

207. Phormidium favosum (Bory) Gomont. Monogr. Oscill. 200. I893. De Toni. Syll. Algar. 5: 245. I907.

Dickie. On the Algae found during the Arctic Expedition. Journ. Linn. Soc. Bot. I7: 8. I88o. ( $\mathrm{H}$ y ph e oth $\mathrm{rix}$ obscur a Dickie). Collins, Holden and Setchell. Phyc. Bor.-Am. Fasc. 3. no. 20I. I895. Tilden. List of Fresh-Water Algae collected in Minnesota during 1895. Minn. Bot. Studies. I: 599. I896; American Algae. Cent. II. no. 185. 1896. Collins. Preliminary List of New England Plants. -V. Marine Algae. Rhodora. 2: 42. I900. Tilden. Collection of Algae from the Hawaiian Islands. Haw. Almanac and Annual for 1902. IÍ, I90I; American Algae. Cent. V. no. 494. 190I. Setchell and Gardner. Algae of Northwestern America. Univ. Calif. Pub. Bot. I: 186. I903. Collins. Phycological Notes of the late Isaac Holden.-II. Rhodora. 7: 236. I905. Tilden. American Algac. Cent. VII. Fasc. I. no. 639. I909. 
Plate V. fig. 9, Io.

Plant mass moderately expanded, papery or thick, attached at base, floating, dark blue-green, when dried dark lead-colored; sheaths usually not present; trichomes $4.5-9$ mic. in diameter, elongate, more or less flexuous, not constricted at joints, straight or somewhat spiral near the extremities, agglutinated by an amorphous mucus; apex of trichome gradually tapering, especially capitate; apical cell obtuse truncate, showing a somewhat hemispherical calyptra; cells 3-7 mic. in length; transverse walls marked by double rows of granules; cell contents blue-green.

Arctic Regions. Dried up pool, Distant Cape, Discovery Bay. (Dickie). Alaska. Floating or attached to wood in streams or on the ground. Glacier Valley, Unalaska. (Lawson). Juneau. (Setchell and Lawson). Massachusetts. (Farlow, Collins). Rhode Island. (Collins). Connecticut. Stratum adhering to rocks in shoal running water. Great Falls of the Housatonic, below Lovers' Leap. July. New York. On stones and earth in water flowing from a spring. Ithaca. April 1895 . (Atkinson). Texas. 1902. (Fanning). Wisconsin. In trough. Osceola. August 1895. (Tilden). Minnesota. On sides of wooden tub. Long Lake, Hennepin County. September I895. (Tilden). Hawaii. In running water in trough from rice field. Peninsula, Pearl City; on bottom of irrigating ditch in sugar cane field, Ewa Plantation, Oahu, June Igoo. (Tilden).

208. Phormidium calidum Gomont. Essai Class. Nostocacées homocystées. Morot. Journ. de Bot. 4: 355. I890; Monogr. Oscill. 202. pl. 5. f. 16. I893. De Toni. Syll. Algar. 5: 246. 1907.

Collins, Holden and Setchell. Phyc. Bor.-Am. Fasc. 28. no. I353. 1907.

Plate V. fig. II.

Plant mass thin, membranaceous, dark green; sheaths not present, trichomes 6-8 mic. in diameter, parallel, somewhat straight, not constricted at joints, agglutinated by an amorphous mucus; apex of trichome straight, scarcely tapering, very slightly capitate; apical cell showing an oblique, depressed conical calyptra; cells 3-8 mic. in length; transverse walls not granulated; cell contents dull blue-green.

California. Forming a thin layer on rocks. Stow Lake, Golden Gate Park, San Francisco. May Igo6. (Gardner).

209. Phormidium subfuscum Kuetzing. Phyc. Gen. 195. 1843. Gomont. Monogr. Oscill. 202. pl. 5. f. I7-20. I893. De Toni. Syll. Algar. 5: 247. 1907.

Wolle. Fresh-Water Algae. U. S. 300. pl. 20I. f. II-I3. I887. [L. m e mbranacea (Kg.) Thur.]. Collins, Holden and Setchell. Phyc. Bor.Am. Fasc. I3. no. 605. I899.

\section{Plate V. fig. I2-I5.}

Plant mass widely expanded, pannose, thin, lamellose, dark green or dark olive; filaments straight, fragile, short, parallel, agglutinated; sheaths diffluent into a lamellose mucus; trichomes $5.5 \mathrm{-rr}$ mic. in diameter, not constricted at joints; apex of trichome straight, capitate, more or less briefly 
tapering; apical cell showing a rotund or straight conical calyptra; cells 2-4 mic. in length; transverse walls sometimes showing two rows of granules; cell contents densely granular, dull blue-green.

Vermont. Charlotte. (Hosford). Connecticut. On rocks and boards, in old sluiceway. Still River, New Milford. May 1892, (Setchell). Mexico. Fields near Orizaba. (Müller).

Var. joannianum (Kuetz.) Gomont, 1. c. 204. De Toni. 1. c. 248.

Wolle. Fresh Water Algae. Bull. Torr. Bot. Club. 6: 283. 1879. ( $\mathrm{Ph}$. joa n i a n $\mathrm{mg}$.) Collins, Holden and Setchell. Phyc. Bor.-Am. Fasc. 8. no. 352. 1897.

Trichomes 5.5-7 mic. in diameter; apex of trichome often somewhat gradually tapering.

Rhode Island. Moshassuck River, near Woodlawn. April I894. (Osterhout). New York. Old wood. Suffern. (Austin).

210. Phormidium uncinatum (Agardh) Gomont. Essai Class. Nostocacées homocystées. Morot. Journ. de Bot. 4: 355. 1890; Monogr. Oscill. 204. pl. 5. f. 21, 22. I893. De Toni. Syll. Algar. 5: 250. 1907.

Dickie. On the Algae found during the Arctic Expedition. Journ. Linn. Soc. Bot. I7: 8. I880. (O. te $\mathrm{n}$ u is sordida Kuetz.). Collins. Algae. Flora of the Blue Hills, Middlesex Fells, Stony Brook and Beaver Brook Reservations of the Metropolitan Park Commission, Massachusetts. I27. I896. Tilden. American Algae. Cent. III. no. 295. I898. Collins, Holden and Setchell. Phyc. Bor.-Am. Fasc. Io. no. 452. I898. Bessey, Pound and Clements. Additions to the Reported Flora of the State. Bot. Surv. Nebraska. 5: 12. I901. Tilden. American Algae. Cent. VI. no. 590. 1902. Setchell and Gardner. Algae of Northwestern America. Univ. Calif. Pub. Bot. I: I86. 1903. Collins. Phycological Notes of the late Isaac Holden.-II. Rhodora. 7: 236. I905. Tilden. Notes on a Collection of Algae from Guatemala. Proc. Biol. Soc. Wash. 2I: I54. I908; American Algae. Cent. VII. Fasc. I. no. 638. Igog.

\section{Plate V. fig. 16, I7.}

Plant mass widely expanded, adherent, thin and firm, or floating, attached at base, thicker, fringed, dark green, brown or black; filaments straight or somewhat flexuous; sheaths mucous, agglutinated, distinct or diffluent into an abundant amorphous mucus; trichomes 6-9 mic. in diameter, not constricted at joints; apex of trichome briefly tapering, curved or briefly spiraled, especially capitate; apical cell showing a rotund or depressed-conical calyptra; cells 2-6 mic. in length; transverse walls frequentjy granulated; cell contents blue-green.

Arctic Regions. Fresh water. $82^{\circ} 27^{\prime}$ N. (Dickie). Alaska. Forming more or less extended blue-black layers, either submerged or on the surface of the ground. St. Michael. (Setchell); near Iliuliuk, Unalaska; Orca. (Setchell and Lawson), Greenland. (Börgesen), Maine. On stones. Cromwell Harbor Brook, Bar Harbor. July 1896. (Collins). Massachusetts. In roadside pool. Valley Street. May I908; running brook near Elm Street, Medford, Middlesex Fells. (Collins). Connecticut. Forming a purplish or copperish skin on stones in stream below dam at Moody's Pond; 
Mill River, June, July, September. (Holden). Minnesota. On rocks under water fall, Bridal Veil Falls, Minneapolis. October Igor. (Hillesheim). South Dakota. In tank of artesian waters. Aberdeen. June I896. (Griffiths). Nebraska. In aquaria. Lincoln. (Bessey, Pound and Clements). Washington. La Conner, Skagit County; Seattle. (Gardner). Central America. On rocks at edge of lake. Lake Amatitlan, Guatemala. January 1906. (Kellerman).

2II. Phormidium autumnale (Agardh) Gomont. Monogr. Oscill. 207. pl. 5. f. 23, 24. 1893. De Toni. Syll. Algar. 5: 252. I907.

Wolle. Fresh Water Algae. II. Bull. Torr. Bot. Club. 6: 183. 1877. ( $\mathrm{Ph}$. vulgare Kg.); Fresh Water Algae. III. Bull. Torr. Bot. Club. 6: 183. I877. ( $P$ h. vulgare publicum. Kg.); Fresh Water Algae. U. S. 310. pl, 206. f. 8. 1887. (O. a n t liaria Juerg.). Farlow. Notes on the Cryptogamic Flora of the White Mountains: Appalachia. 3: 236. 1883. (L. vulgar is Kirchn.). Bennett. Plants of Rhode Island. II4. I888. Wolle and Martindale. Algae. Britton's Catalogue of Plants found in New Jersey. Geol. Surv. N. J. 2: 608. I889. Mackenzie. A Preliminary List of Algae collected in the Neighborhood of Toronto. Proc. Can. Inst. III. 7: 270. I890. Saunders. Protophyta-Phycophyta. Flora of Nebraska. 22. pl. I. f. I5. pl. 2. f. 22. I894. Tilden. List of Fresh-Water Algae collected in Minnesota during I893. Minn. Bot. Studies. I: 31. I894. Collins, Holden and Setchell. Phyc. Bor.-Am. Fasc. 9. no. 40I. I 898 . Setchell. Notes on Cyanophyceae. III. Erythea. 7: 53. I899. Collins. Preliminary Lists of N'ew England Plants.-V. Marine Algae. Rhodora. 2: 42. 1900. Saunders. The Algae. Harriman Alaska Expedition. Proc. Wash. Acad. Sci. 3: 398. Igor. Tilden. American Algae. Cent. VI. no. 591. 1902. Collins, Iolden and Setchell. Phyc. Bor.-Am. Fasc. 23. no. II04. I903. Setchell and Gardner. Algae of Northwestern America. Univ. Calif. Pub. Bot. I: 186. 1903. Börgesen and Jonsson. The Distribution of the Marine Algae of the Arctic Sea and of the Northernmost Part of the Atlantic. Botany of the Faeroes. Appendix. XXV. 1905. Buchanan. Notes on the Algae of Iowa. Proc. Iowa Acad. Sci. 14: 13. Ig08.

\section{Plate V. fig. 18, 19.}

Plant mass expanded, fragile, glistening, dark blue-green, sometimes yellowish or dark-colored; filaments straight, rarely flexuous, entangled; sheaths narrow, fragile, mucous, distinct or diffluent into an amorphous mucus and agglutinated; trichomes 4-7 mic. in diameter, not constricted at ioints; apex of trichome briefly tapering, straight or scarcely curved, especially capitate; apical cell showing a rotund calyptra; cells $2-5$ mic. in length; transverse walls frequently granulated; cell contents blue-green.

Alaska. Forming a thin dark blue coating on small rocks in a rapid stream emptying into bay. Kukak Bay. (Saunders). Iliuliuk, Unalaska; Sitka. (Setchell and Lawson). Canada. Humber River. Toronto. (Mackenzie). New Hampshire. On mosses. Berlin Falls.' (Farlow). Massachusetts. On stone drinking fountain. Revere. October I897. (Collins). Rhode Island. Very common. (Bennett). Growing in a freshwater stream, on the surface of a rock frequently washed by salt water, and in a storm practically sub- 
merged. Conanicut Island. August 1894. (Richards). New Jersey. On moist soil. (Wolle). Pennsylvania. On damp earth. (Wolle). Minnesota. Gull Lake. July I893; on sides of stone basin over-flowed by spring water, between New Duluth and Fond du Lac, near Duluth, August IgoI. (Tilden). Iowa. Iowa City. (Hobby). Damp soil. Grinnell. (Fink). Nebraska. On damp soil in greenhouse; around pumps, cisterns, Lincoln. (Saunders). Washington. Coupeville, Whidbey Island; La Conner, Skagit County; Seattle. (Gardner).

212. Phormidium setchellianum Gomont. Monogr. Oscill. 2ro. pl. 5. fig. 25, 26. 1893. De Toni. Syll. Algar. 5: 254. 1907.

Collins, Holden and Setchell. Phyc. Bor.-Am. Fasc. 2. no. 52. I895.

Plate V. fig. 20, 21.

Plant mass thin, cobwebby, dark purple, when dried dark lead-colored; sheaths delicate, usually diffluent into an amorphous mucus; trichomes 4-4.8 mic. in diameter, parallel, straight or moderately flexuous, not constricted at joints; apex of trichome scarcely tapering, curved or hooked, capitate; apical cell showing a depressed-conical calyptra; cells $3-6$ mic. in length; transverse walls often showing a double row of granules; cell contents pale purple.

Connecticut. Forming arachnoid expansions on stones at the bottom or a swift brook. In the living condition the expansions are of the color of Bangia fusco-purpurea. Norwich. July I89o. (Setchell).

Genus LYNGBYA C. Agardh. Syst. Algar. XXV. I824.

Filaments free, unbranched, free-floating or forming a densely intricate floccose or expanded mass; sheaths firm, of variable thickness, sometimes lamellose, colorless or rarely yellowish brown; trichomes sometimes constricted at the joints, either obtuse or slightly tapering at the apices; outer wall of apical cell sometimes thickened forming a calyptra.

I Trichomes not more than 2 mic. in diameter.

I Plants living in salt water, epiphytic; transverse walls marked by two refringent granules

(I) Filaments 1.5 mic. in diameter; trichomes .5 mic. in diameter, cylindrical, not constricted at joints; cells 1.5 mic. in length

L. mucicola

(2) Filaments 1.5-2 mic, in diameter; sheaths very thin, scarcely visible; cells $2-7$ mic. in length L. perelegans

2 Plants living in fresh water

(I) Sheaths thin, colorless

A Filaments coiled or spiraled

a Filaments coiled; trichomes $.8 \mathrm{mic}$. in diameter, constricted at joints; cells 2.3-3.2 mic. in length $\quad$ L. rivulariarum

b Filaments more or less regularly spiraled, sometimes straight; trichomes 2 mic. in diameter; cells I.2-3 mic. in length 
B Filaments straight or curved

a Filaments 1.9 mic. in diameter; apex of trichome bluntly rounded; cells quadrate or a little longer than diameter

L. nana

b Filaments solitary and scattered; trichomes I.5-I.8 mic. in diameter, somewhat flexuous; cells up to $3.6 \mathrm{mic}$. in length

L. subtilis

c Filaments r.8 mic. in diameter, at first attached, afterwards free, short, straight or slightly curved; cells about equal in length to the diameter

L. distincta

(2) Sheaths more or less thick and gelatinous

A Plant mass ochre-yellow in color; sheaths at first thin, colorless, later thick and yellowish; trichomes .9 mic. in diameter, especially constricted at joints, frequently interrupted

L. ochracea

B Plant mass rust-colored; sheaths at first thin, colorless, later thicker and rust-colored; trichomes .8-.9 mic. in diameter, not constricted at joints, continuous

\section{L. ferruginea}

II Trichomes 2-6 mic. in diameter; sheaths usually thin and colorless, sometimes becoming thick and yellowish

I Plants living in salt water, sometimes in brackish, fresh or hot water

(r) Filaments coiled, densely entangled; sheaths thin, colorless, later becoming thick and lamellose; trichomes 2.5-6 mic. in diameter, not constricted at joints; cells $1.5-5.5$ mic. in length

\section{L. lutea}

(2) Plants living in salt water, epiphytic; sheaths thin, delicate; trichomes 3-4.5 mic. in diameter, constricted at joints; cells up to 13 mic. in length

L. holdenii

2 Plants living in fresh water; sheaths usually thin and colorless

(I) Plant mass caespitose, light green; trichomes 2-3 mic. in diameter, not constricted at joints; cells $1-3.7$ mic. in length

\section{I. digueti}

(2) Plant mass caespitose, blue-green; sheaths delicate, smooth, usually inconspicuous; trichomes 3.2-3.5 mic. in diameter, somewhat rigid, forming tufts

L. penicillata

(3) Plant mass dull blue-green; trichomes 4-6 mic. in diameter, not constricted at joints; cells $2.3-3$ mic. in length

L. aerugineo-caerulea

(4) Plants epiphytic; filaments straight or sharply curved and twisted; trichomes 5-6 mic. in diameter, not constricted at joints

L. cladophorae

(5) Plant mass at first adherent, afterwards free, rust-colored on the outside, olive green within; sheaths colorless, sometimes yellowish, slightly mucous and agglutinated, thick; trichomes 2.8-3.2 
mic. in diameter, not constricted at joints; cells $2-6.4$ mic. in length

L. versicolor

III Trichomes 5-60 mic. in diameter

I Plants living in salt water, epiphytic; plant mass caespitose

(I) Plant mass purplish-violet; trichomes 5-8 mic. in diameter; constricted at joints; cells $2.8-4.6$ mic. in length; cell contents rosecolored

L. gracilis

(2) Plant mass dull blue-green; trichomes $6.5-8$ mic. in diameter, constricted at joints; cells $2-4$ mic. in length; cell contents pale blue-green

L. meneghiniana

(3) Plant mass dark or dull yellowish green; trichomes I4-3I mic. in diameter, evidently constricted at joints; cells 4-Io mic. in length; cell contents frequently showing scattered coarse granules, olive green

L. sordida

2 Plants living in salt water; plant mass caespitose, extended, mucous, dull yellowish or dark green, when dried becoming dark violet; sheaths thick

(I) Trichomes 5-12 mic. in diameter; apex of trichome slightly tapering, capitate; cells 2-3 mic. in length $\quad$ L. semiplena

(2) Trichomes 9-25 mic. in diameter; apex of trichome not tapering, not capitate; cells $2-4$ mic. in length $L$. confervoides

3 Plants living in salt, brackish, fresh or warm water or on moist earth

(r) Trichomes 8-24 mic. in diameter; apex of trichome slightly tapering, capitate; apical cell truncate, rarely somewhat acute-conical; cells $2.7-5.6$ mic. in length

L. aestuarii

(2) Trichomes I6-60 mic. in diameter; apex of trichome not tapering, not capitate; apical cell rotund; cells $2-4$ mic. in length

L. majuscula

4 Plants living in fresh water, often in hot or warm water

(I) Plant mass caespitose, dull or dark green or blue-green

A Sheaths thickened and roughened with age; trichomes 6-Io mic. in diameter, not constricted at joints; apex of trichome not tapering, not capitate; cells I.7-3.3 mic. in length

L. martensiana

B Sheaths colorless, thin, papery; trichomes 7.5-13 mic. in diameter, especially constricted at joints; apex of trichome not tapering, not capitate; cells 3 -1o mic. in length $\quad L$. putealis

C Sheaths colorless, thick, roughened; trichomes II-I6 mic. in diameter, not constricted at joints; apex of trichome slightly tapering, somewhat capitate; cells 2-3.4 mic. in length

\section{L. major}

(2) Plant mass floating, olive green; filaments forming a regular loose spiral throughout the whole or a portion of their length; trichomes 14-16 mic. in diameter, not constricted at joints; cells 3.4$6.8 \mathrm{mic}$. in length

L. spirulinoides

(3) Plant mass formed of loosely entangled filaments, dark green; 
filaments $15^{-19} \mathrm{mic}$, in diameter; trichomes $\mathrm{I} 2.5 \mathrm{mic}$. in diameter; cells very short

L. arachnoidea

Species not well understood.

L. bicolor

L. caeruleo-violacea

L. fluitans

L. hyalina

L. pusilla

L. rubra

L. rubro-violacea

2J3. Lyngbya mucicola Lemmermann. Plankt. Schwed. Gewäss. Ark. för Bot. 70. 1904. De Toni. Syll. Algar. 5: 289. 1907.

Lemmermann. Planktonalg. Ergebnisse einer Reise n. d. Pacific. 335. I899; Algenf. Sandwich.-Inseln. Bot. Jahrb. 34: 619. I905.

Filaments 1.5 mic, in diameter, scattered, epiphytic; trichomes .5 mic. in diameter, cylindrical, not constricted at joints; cells 1.5 mic. in length; transverse walls marked by two strongly refringent granules.

Hawaii. On Chondrocystic schauinslandii. Laysan. (Schauinsland).

214. Lyngbya perelegans Lemmermann. Planktonalg. Ergebnisse einer Reise n. d. Pacific. 355. I899. De Toni. Syll. Algar. 5: 289. 1907.

Lemmermann. Algenfl. Sandwich.-Inseln. Bot. Jahrb. 34: 6I9. 1905.

Plant mass epiphytic on marine algae; filaments $\mathbf{1 . 5 - 2}$ mic. in diameter, straight or curved; sheaths very delicate, scarcely visible; cells $2-7$ mic. in length, somewhat quadrate or cylindrical; transverse walls marked by two glistening granules.

Hawaii. On marine algae. Laysan. (Schauinsland).

215. Lyngbya rivulariarum Gomont. Monogr. Oscill. I68. I893. De Toni. Syll. Algar. 5: 282. 1907 .

Lemmermann. Algenfl. Sandwich.-Inseln. Bot. Jahrb. 34: 620. 1905.

Filaments very slender, twisted or coiled; sheaths colorless, very thin, papery; trichomes .7-.8 mic. in diameter, constricted at the joints; apex of trichome not tapering; apical cell rotund; calyptra none; cells 2.3-3.2 mic. in length; transverse walls pellucid; cell contents not granular, pale bluegreen.

Hawaii. In a mass of $\mathrm{N}$ ostoc, in ditches. Between Honolulu and Waikiki, Island of Oahu. (Schauinsland).

2I6. Lyngbya lagerheimii (Möbius) Gomont. Essai Class. Nostocacées homocystées. Morot. Journ. de Bot. 4: 354. I890; Monogr. Oscill. I67. pl. 4. f. 6, 7. 1893. De Toni. Syll. Algar. 5: 287. I907.

Coilins, Holden and Setchell. Phyc. Bor.-Am. Fasc. 2. no. 53. I895. Setchell. Notes on some Cyanophyceae of New England. Bull. Torr. Bot. Club. 22: 430. I895. Collins. Preliminary Lists of New England Plants. 
-V. Marine Algae. Rhodora. 2: 42. I90o. Tilden. American Algae. Cent. VI. no. 587. I902. Collins, Holden and Setchell. Phyc. Bor,-Am. Fasc. 21. no. I008. 1903. Setchell and Gardner. Algae of Northwestern America. Univ. Calif. Pub. Bot. I: 187. I903. West. West Indian Freshwater Algae. Journ. of Bot. 42: 291. 1904. Tilden. Notes on a Collection of Algae from Guatemala. Proc. Biol. Soc. Wash. 21: I54. I908; American Algae. Cent. VII. Fasc. I. no. 636. Ig09.

\section{Plate V. fig. 22, 23.}

Filaments more or less regularly spiraled, sometimes straight; sheaths thin, hyaline; trichomes about 2 mic. in diameter; cells $\mathbf{1 . 2 - 3}$ mic. in length; transverse walls marked by two protoplasmic granules.

Maine. Forming a pale green sediment in water of a pool above high water mark, but reached by the spray. Pemaquid Point. July Igor. (Collins). Massachusetts. Little Pond, Falmouth. (Setchell). Connecticut. In brackish water in a small pool, near Norwich; in an aquarium, New Haven, November 1893. (Setchell). Minnesota. On rocks in running water in stone quarry. University campus. Minneapolis. November rgor. (Lilley). Washington. Among various filamentous algae. Whidbey Island; sulphur spring, Ravenna Park, Seattle. (Gardner). Central America. On branch of tree which had been cut off and thrown into water. Lake Amatitlan, Guatemala. January 1906. (Kellerman). West Indies. Near Bridgetown, Barbados. (Howard).

217. Lyngbya nana Tilden. American Algae. Century II. no. I79. I896. De Toni. Syll. Algar. 5: 284. 1907.

Tilden. Some new Species of Minnesota Algae which live in a Calcareous or Silicious Matrix. Bot. Gaz. 23: Ior. pl. 9. f. 5. I897; List of Fresh-Water Algae collected in Minnesota during I896 and I897. Minn. Bot. Studies. 2: 28. I898.

Plate V. fig. 24 .

Filaments I.9 mic. in diameter, straight; sheaths delicate, hyaline, smooth; trichomes bluntly rounded at apices; cells I-I.5 mic. in length; cell contents very pale steel color, or later in the season violet.

Minnesota. With other algae, forming a calcareous crust on sides of old wooden tank as far up as water line. Minneapolis. October I895. (Tilden).

218. Lyngbya subtilis W. West. Algae of the English Lake District. Journ. Roy. Micr. Soc. 741. pl. 10. f. 58. 1892. De Toni. Syll. Algar. 5: 285. 1907.

West and West. On some Freshwater Algae from the West Indies. Journ. Linn. Soc. Bot. 30: 274. 1895. West. West Indian Freshwater Algae. Iourn. of Bot. 42: 29I. I904. Collins. Notes on Algae. IX. Rhodora. Io: 162. I908.

Filaments solitary and scattered; sheaths close, colorless; trichomes I.5I. 8 mic. in diameter, somewhat flexuous, free swimming; cells up to twice as long as their diameter; cell contents homogeneous, pale blue-green. 
Maine. In salt water pools. Ragged Island, near Cape Elizabeth. (Collins). West Indies. On bed of stream in crater of Grande Soufrière, Dominica. Bay Estate, Barbados. (Howard). Hawaii. (Volz).

2I9. Lyngbya distincta (Nordstedt) Schmidle. Algologische Notizen. IV. Allg. Bot. Zeit. 3: 58. 1897. De Toni. Syll. Algar. 5: 281. 1907.

Nordstedt. De Algis Aquae Dulcis et de Characeis ex Insulis Sandvicensibus a Sv. Berggren 1875 reportatis. 4. 1878 . (L. martensiana d is t in ct a Nordstedt). Lemmermann. Algenfl. Sandwich.-Inseln. Bot. Jahrb. 34: 620. 1905. (L. k üt $\mathrm{z}$ in $\mathrm{g}$ i i d ist in cta (Nordst.) Lemm.).

Filaments I.8 mic. in diameter, at first attached, afterwards free; short, straight or slightly curved; sheaths very thin, hyaline; apex of trichome not tapering, open; cells about equal to the diameter in length; cell contents delicately granular, blue-green.

Hawaii. Among filaments of $\mathrm{P}$ ith ophora affinis. Hilo, Island of Hawaii. (Berggren). In ditches between Honolulu and Waikiki, Oahu. (Schauinsland). (Volz). Freshwater ditches, Punaluu, Hawaii. (Lauterbach).

220. Lyngbya ochracea (Kuetzing) Thuret. Essai Class. Nostochinées. Ann. Sci. Nat. Bot. VI. I: 279. I875. Gomont. Monogr. Oscill. I69. I893. De Toni. Syll. Algar. 5: 283. 1907.

Collins. Algae of Middlesex County, 14. I888. Wittrock and Nordstedt. Algae Aq. Dulc. no. I169. I893. Saunders. Protophyta-Phycophyta. Flora of Nebraska. 22. p1. 2. f. 20. I894. Tilden. American AIgae. Cent. I. no, 68. I894; List of Fresh-Water Algae collected in Minnesota during I894. Minn. Bot. Studies. I : 235. I895. Collins, Holden and Setchell. Phyc. Bor.-Am. Fasc. I. no. 4. I895. Collins. Algae. Flora of the Blue Hills, Middlesex Fells, Stony Brook and Beaver Brook Reservations of the Metropolitan Park Commission, Massachusetts. 127. I896. Tilden. American Algae. Cent. VI. no. 588. 1902. Setchell and Gardner. Algae of Northwestern America. Univ. Calif. Pub. Bot. I: 187. I903. Collins. Phycological Notes of the late Isaac Holden.-II. Rhodora. 7: 236. I905. Brown. Algal Periodicity in certain Ponds and Streams. Bull. Torr.. Bot. Club. 35: 247. 1908. Buchanan. Notes on the Algae of Iowa. Proc. Iowa Acad. Sci. 14: I3. I908.

\section{Plate V. fig. $25,26$.}

Plant mass yellowish or ochre-yellow in color; filaments very slender, more or less curved, fragile; sheaths at first thin, colorless, later becoming thicker and yellowish; trichomes .9 mic. in diameter, especially constricted at joints; frequently interrupted; apical cell rotund; calyptra none; cells .6-.8 mic. in length; transverse walls not granulated.

Canada. Hanging in a thick, jelly-like, very fragile mass, from perpendicular bank of creek. Providence Cove, near Minnesota Seaside Station, Port Renfrew, Vancouver Island, British Columbia. July rgor. (Leavitt). Massachusetts. Cambridge. (Farlow). On stonework of dam. Saugus. June I890; Cascade, Middlesex Fells; on rocks in stream, Beaver Brook. (Collins). Connecticut. Stream below paper mill; Factory Pond; outlet of Parrott's Pond, October, November; buoyed up in nebulous masses in quiet waters, 
Bridgeport, November I894. (Holden). Pennsylvania. (Wolle). Indiana. Edge of water-works reservoir, Bloomington. November I906. (Brown). Minnesota. Floating in great abundance in creeks and ditches. State Fish Hatcheries, St. Paul. September 1894. (Tilden). Iowa. "In the trough of a flowing well. It is found very commonly in the waters in this locality that are laden with iron, the sheath becoming impregnated with this substance." (Buchanan). Nebraska. Floating in fragile, ochraceous masses. (Saunders).

221. Lyngbya ferruginea G. S. West. West Indian Freshwater Algae. Journ. of Bot. 42: 292. pl. 464. f. 20. I904. De Toni. Syll. Algar. 5: 283. I907.

\section{Plate V. fig. 27-29.}

Plant mass rust-colored; filaments $1.8-2.4$ mic. in diameter; sheaths at first thin, colorless, later becoming thicker and rust-colored; trichomes .8-.9 mic. in diameter, not constricted at joints, continuous; apical cell cylindrical and obtuse; calyptra none; cells 4-5 mic. in length; transverse walls distinct, not granulated.

West Indies. Forming a yellow-brown ferrugininous stratum. Roseau Valley, Dominica. (Howard).

222. Lyngbya lutea (Agardh) Gomont. Essai Class. Nostocacées homocystées. Morot. Journ. de Bot. 4: 354. I890; Monogr. Oscill. I6I. p1. 3. f. I2, I3. I893. De Toni. Syll. Algar. 5: 275. 1907.

Mazé and Schramm. Essai Class. Algues Guadeloupe. I8. I870-1877. ( $P$ h. st ragulu m Crouan). Wolle. Fresh Water Algae. Bull. Torr. Bot. Club. 6: 283. I879. ( $\mathrm{Ph}$. julian u $\mathrm{m}$ Rab.) Farlow. Marine Algat of New England. 35. I88r. (L. t e ner rim a Thur.). Pike. Check List of Marine Algae. Bu1l. Torr. Bot. Club. 13: 105. I886. Wolle. FreshWater Algae. U. S. 30I. pl. 202. f. 20, 21. 1887. (L. j u 1 i a n a Menegh.). Collins. Algae from Atlantic City, N. J. Bull. Torr. Bot. Club. I5: 3 Io. I888. Martindale. Marine Algae of the New Jersey coast and Adjacent Waters of Staten Island. Mem. Torr. Bot. Club. I: 9I. 1889. Wolle and Martindale. Algae. Britton's Catalogue of Plants found in New Jersey. Geol. Surv. N. J. 2: 608. I889. Murray. Catalogue of the Marine Algae of the West Indian Region. Journ. of Bot. 27: 26r. I889. Collins. Algae. Rand and Redfield's Flora of Mount Desert Island, Maine. 248. I894; Preliminary Lists of New England Plants.-V. Marine Algae. Rhodora. 2: 42, I900. Collins, Holden and Setchell. Phyc. Bor.-Am. Fasc. I8. no. 854. Igor. West. West Indian Freshwater Algae. Journ. of Bot. 42; 291. I904. Börgesen and Jonsson. The Distribution of the Marine Algae of the Arctic Sea and of the Northernmost Part of the Atlantic. Botany of the Faeroes. Appendix. XXV. I905. Collins. Phycological Notes of the late Isaac Holden.-II. Rhodora. 7: 222. I905.

\section{Plate V. fig. 30, 3I.}

Plant mass somewhat gelatinous, leathery, yellowish brown or olive, when drie'd often becoming dark violet; filaments coiled, flexible, densely entangled; sheaths colorless, smooth, at first thin, later becoming thick 
( 3 mic.) and lamellose; trichomes $2.5^{-6}$ mic. in diameter, not constricted at joints; apex of trichome not tapering; apical cell showing a rotund calyptra; cells 1.5-5.5 mic. in length; transverse walls usually not distinct; cell contents granular, olive green.

Maine. Near outlet of Long Pond, (Collins). Massachusetts. On sand-covered rocks. Gloucester. (Davis). Rhode Island. At base of cliffs. Newport. (Farlow). On Enteromorpha' intestinalis, in pool at high water mark. Easton's Point, Newport. August rgor. (Simmons). Connecticut. On woodwork between tidemarks, below Yellow Mill bridge; on turfy bottom, Seaside Park; among L. a estuarii, Cook's Point; ors sandy mud, Charles Island, May, July, October. (Holden). New York. Shores of Long Island, Jamaica Bay, College Point. Summer. (Pike). New Jersey. On wharves. Atlantic City. (Morse). Florida. (Smith). Alabama. Sandy soil, somewhat influenced by marine waters. (Wolle). West Indies. Guadeloupe. (Mazé). On roots of mangroves in brackish swamp. Near Bridgetown, Barbados. (Howard).

223. Lyngbya holdenii De Toni. Syll. Algar. 5: 260. 1907.

Collins. Preliminary Lists of New England Plants.-V. Marine Algae. Rhodora. 2: 42. 1900. (L. sublilis Holden). Collins, Holden and Setchell. Phyc. Bor.-Am. Fasc. 2I. no. I007. I903; Phyc. Bor.-Am. Fasc. 24. no. II63. I904. Collins. Phycological Notes of the late Isaac Holden. -II. Rhodora. 7: 222. I905.

Filaments attached by the middle to other algae, with free ends; sheaths thin, delicate; trichomes 3-4.5 mic. in diameter, constricted at joints; apex of trichome cylindrical or somewhat tapering; apical cell rounded; cells $3-\mathrm{r} 3 \mathrm{mic}$. in length; cell contents pale green.

Maine. On bark of piles. Blake's Point. July I898. (Collins). Massachusetts. On perpendicular and overhanging rocks. Marblehead Neck. June I902. (Collins). On Enteromorpha. Magnolia. September I903. (Farlow). Connecticut. Seaside Park. December; attached to various marine algae, Bridgeport. (Holden).

224. Lyngbya digueti Gomont in Hariot. Algues du Golfe de Californie recueillies par M. Riguet. Journ. de Bot. 9: I69. I895. De Toni. Syll. Algar. 5: 284. 1907 .

Plant mass up to $2 \mathrm{~mm}$. in thickness, caespitose, light green; filaments 2.5-3 mic. in diameter, very slender, twisted and entangled in basal portions, clongate, flexible, straight in upper portions; sheaths thin, colorless, papery; trichomes 2-3 mic. in diameter, not constricted at joints; apical cell rotund; calyptra none; cells $\mathbf{I}-3.7 \mathrm{mic}$. in length.

Lower California. Adhering to insects, in fresh water. Near Santa Gertrudis. (Diguet).

225. Lyngbya penicillata Kuetzing. Diagnosen und Bemerkungen zu neuen oder kritischen Algen. Bot. Zeit. 194. 1847. De Toni. Syll. Algar. 5: 291.1907.

West and West. On some Freshwater Algae from the West Indies. Journ. Linn. Soc. Bot. 30: 274. 1895.

Plant mass caespitose, dull blue-green; sheaths delicate, smooth, ustually 
inconspicuous; trichomes $3.2-3.5 \mathrm{mic}$, in diameter, somewhat rigid, entangled and twisted into loose fascicles with penicillate apices; transverse walls marked by granules.

West Indies. On bed of stream in crater of Grande Soufrière, Dominica. (Elliott).

226. Lyngbya aerugineo-caerulea (Kuetzing) Gomont. Monogr. Oscill. 166. pl. 4. f. I-3. I893. De Toni. Syll. Algar. 5: 28I. 1907.

Jelliffe. A Preliminary List of the Plants found in the Ridgewood Water Supply of the City of Brooklyn, King's County, N. Y. Bull. Torr. Bot. Club. 20: 243. I893. Setchell. Notes on Cyanophyceae.-I. Erythea. 4: 89. 1896. West and West. A Further Contribution to the Freshwater Algae of the West Indies. Journ. Linn. Soc. Bot. 34: 289. I898-I900. Saunders. The Algae. Harriman Alaska Expedition. Proc. Wash. Acad. Sci. 3: 398, rgor. Collins, Holden and Setchell. Phyc. Bor.-Am. Fasc. 22. no. I058. I903. Setchell and Gardner. Algae of Northwestern America. Univ. Calif. Pub. Bot. I: I87. I903. Snow. The Plankton Algae of Lake Erie. U. S. Fish Comm. Bull. for 1902. 22: 392. 1903. Collins, Holden and Setchell. Phyc. Bor.-Am. Fasc. 28. no. 1355. 1907.

Plate V. fig. 32, 33.

Plant mass dull blue-green; filaments flexuous, fragile; sheaths colorless, firm, thin; trichomes $4^{-6}$ mic. in diameter, not constricted at joints, the portion protruding from the sheath very straight; apex of trichome occasionaliy capitate; apical cell depressed conical or rotund, showing a slightly thickened outer membrane; cells 2.3-3 mic. in length; transverse walls sometimes granulated; cell contents frequently coarsely granular.

Alaska. In a felt-like mass of filaments of $\mathrm{V}$ a uch e ria. Juneau; in a small pond on an island in the Muir Glacier. (Saunders). Massachusetts. Forming a blackish encrustation near the water line, in a stone drinking trough. Woburn. September I905. (Collins). In swamp. Medford. August 1906. (Lambert). Connecticut. Mt. Tom, Salisbury. (Setchell). New York. Ridgewood Water supply, Brooklyn. (Jelliffe). Ohio. Put-inBay, Lake Erie. (Snow). California. In an aquarium. Golden Gate Park, San Francisco. June I902. (Osterhout and Gardner). West Indies. On leaves in warm stream, road to Roseau Lake (2500 feet); on ground (2000300 feet) and in stream, crater of Grande Soufrière, Dominica. (Elliott).

227. Lyngbya cladophorae n. sp.

\section{Plate V. fig. 34 .}

Plants epiphytic; filaments straight or sharply curved and twisted; sheaths delicate; trichomes 5-6 mic. in diameter, not constricted at joints; apical cell rotund; transverse walls indistinct; cell contents homogeneous, blue-green.

Hawaii. Growing on Clad ophora filaments, in mountain stream. Waipio Valley, Hawaii. July igoo. (Tilden).

228. Lyngbya versicolor (Wartman) Gomont. Monogr. Oscill, 167. pl. 4 f. 4, 5. 1893. De Toni. Syll. Algar. 5: 282. 1907. 
Setchell. Notes on some Cyanophyceae of New England. Bull. Torr. Bot. Club. 22: 429. I895. Collins, Holden and Setchell. Phyc. Bor.-Am. Fasc. 2. no. 54. I895. Collins. The Algae of Jamaica. Proc. Am. Acad. Arts Sci. 37: 240. I90I. Setchell and Gardner. Algae of Northwestern America. Univ. Calif. Pub. Bot. I: I87. I903. West. West Indian Freshwater Algae. Journ. of Bot. 42: 29r. I904.

\section{Plate V. fig. 35 .}

Plant mass at first adherent, afterwards free, lubricous, somewhat soft, rust-colored on the outside, olive green within; filaments long, twisted, closely entangled; sheaths up to 2 mic. in thickness, colorless, sometimes yellowish, slightly mucous and agglutinated; trichomes $2.8-3.2 \mathrm{mic}$. in diameter, not constricted at joints; apex of trichome neither tapering nor capitate; apical cell rotund; calyptra none; cells 2-6.4 mic. in length; transverse walls pellucid, sometimes granulated.

Alaska. Floating on a deep pool of fresh water. Glacier Valley, Unalaska. (Lawson). Massachusetts. Newton. (Collins). Connecticut. At first attached to stones, later rising in a verdigris-green mass. Shores of Lake Whitney, New Haven. October I892. (Setchell). West Indies. On sides c.f basin of a fountain. Marine Garden, Kingston, Jamaica. April I893. (Humphrey). Bay Estate, Barbados. (Howard).

229. Lyngbya gracilis (Meneghini) Rabenhorst. F1. Eur. Algar. 2: I45. 1865. Gomont. Monogr. Oscill. 144. p1. 2. f. 20. 1893. De Toni. Syll. Algar. 5: 259. 1907.

Murray. Catalogue of the Marine Algae of the West Indian Region. Journ. of Bot. 27: 26r. 1889. Collins. Notes on New England Marine Algae.-VII. Bull. Torr. Bot. Club. 23: 458. I896; Preliminary Lists of New England Plants.-V. Marine Algae. Rhodora. 2: 42. Ig0o. Collins, Holden and Setchell. Phyc. Bor.-Am. Fasc. I8. no. 853. I90I.

$$
\text { Plate V. fig. } 36 \text {. }
$$

Plant mass caespitose, extensive, dense, floccose, lubricous, purplish violet, when dried often becoming colorless or dull yellow; filaments long, flexible, angular; sheaths close, smooth; trichomes 5-8 mic. in diameter, constricted at joints; apex of trichome not tapering; apical cell rotund, showing a slightly thickened outer membrane; cells $2.8-4.6$ mic. in length; cell contents finely granular, rose-colored.

Maine. Among other algae on a mooring buoy that had been hauled up on the beach. Cape Rosier. July r896. (Collins). California. On Cha et omorpha a e r a in a pool. Pacific Beach. August rgor. (Snyder). West Indies. Guadeloupe. (Mazé).

23o. Lyngbya meneghiniana (Kuetzing) Gomont. Essai Class. Nostocacées homocystées. Morot. Journ. de Bot. 4: 354. I890; Monogr. Oscill. 145. 1893. De Toni. Syll. Algar. 5: 260. 1907.

Lemmermann. Algenfl. Sandwich.-Inseln. Bot. Jahrb. 34: 620. 1905.

Plant mass up to I cm. in height, caespitose, fasciculate, mucous, dull blue-green; filaments long, somewhat straight, very flexible; sheaths thin, smooth; trichomes $6.5-8$ mic. in diameter, constricted at joints; apex of 
trichome not tapering; apical cell rotund, showing a slightly thickened outer membrane; cells 2-4 mic. in length; cell contents finely granular, pale bluegreen.

Hawaii. On marine algae. Laysan. (Schauinsland).

23r. Lyngbya sordida (Zanardini) Gomont. Monogr. Oscill. 146. pl. 2. f. 21. 1893. De Toni. Syll. Algar. 5: 260. I907.

Murray. Catalogue of the Marine Algae of the West Indian Region. Journ. of Bot. 27: 26I. I889. (L. viol a c e a Menegh.). Vickers. Liste des Algues Marines de la Barbade. Ann. Sci. Nat. Bot. VIII. I: 55. I905.

Plate V. fig. 37 .

Plant mass up to $3 \mathrm{~cm}$. in height, caespitose, fasciculate, dark or dull yellowish green, when dried usually dark violet; filaments straight, somewhat rigid; sheaths smooth; trichomes I4-3I mic. in diameter, evidently constricted at joints; apex of trichome not tapering; apical cell rotund; calyptra none; cells 4-ro mic. in length; cell contents frequently showing scattered coarse granules, olive green.

West Indies. Guadeloupe. (Mazé). Maxwell. (Vickers).

Forma bostrychicola (Crouan) Gomont. 1. c. 146.

Mazé and Schramm. Essai Class. Algues Guadeloupe. 26. I870-I877. (L. bostrychicola Crouan). Murray. Catalogue of the Marine Algae of the West Indian Region. Journ. of Bot. 27: 261. I889.

Trichomes $14-20$ mic. in diameter; cells up to Io mic. in length.

West Indies. Guadeloupe. (Mazé).

232. Lyngbya semiplena (C. Agardh) J. Agardh. Algae maris Mediterranei et Adriatici. I I. I842. Gomont. Monogr. Oscill. I58. pl. 3. f. 7-I1. I893. De Toni. Syll. Algar, 5: 273. I907.

Schramm and Mazé. Essai Class. Algues Guadeloupe. 3I. I865. (L. sordida Crouan). Mazé and Schramm. Essai Class. Algues Guadeloupe. 2I. 1870-I877. Wolle. Fresh Water Algae. II. Bull. Torr. Bot. Club. 6: 138. I877. (Ph. c ongest u m Rabenh.) Farlow. Marine Algae of New England. 35. I88r. (L. 1 u t e o-f u s c a Ag.) Pike. Check List of Marine Algae. Bull. Torr. Bot. Club. I3: I05. I886. Bennett. Plants of Rhode Island. 95. I888. Collins. Algae of Middlesex County. I4. 1888. Murray. Catalogue of the Marine Algae of the West Indian Region. Journ. of Bot. 27: 26r. 1889. (L. 1 ut e o-f u s c a Ag. and L. s ch ow ia na Kg.) Martindale. Marine Algae of the New Jersey Coast and Adjacent Waters of Staten Island. Mem. Torr. Bot. Club. I: 9r. 1889. Wolle and Martindale. Algae. Britton's Catalogue of Plants found in New Jersey. Geol. Surv. N. J. 2: 608. 1889. Collins. Algae. Rand and Redfield's Flora of Mount Desert Island, Maine. 248. I894. Collins, Holden and Setchell. Phyc. Bor.-Am. Fasc. I. no. 5. I895. Collins. Preliminary Lists of New England Plants.-V. Marine Algae. Rhodora. 2: 42. I900. Bessey, Pound and Clements. Additions to the Reported Flora of the State. Bot. Surv. Nebraska. 5: 12. I90r. Tilden. Collection of Algae from the Hawaiian Islands. Haw. Almanac and Annual for 1902. II2. I90I; American Algae. Setchell and Gardner. Algae of Northwestern America. Univ. Calif. Pub. 
I: 187. 1903. Collins, Holden and Setchell. Phyc. Bor.-Am. Fasc. 22. no. I059. 1903. Lemmermann. Algenfl. Sandwich.-Inseln. Bot. Jahrb. 34: 620. 1905. Collins. Notes on Algae.-VII. Rhodora. 8: I23. I906. Collins, Holden and Setchell. Phyc. Bor.-Am. Fasc. 30. no. 1452. 1908. Collins. Notes on Algae. IX. Rhodora. 10: 162. Ig08.

\section{Plate V. fig. 38.}

Plant mass rarely beyond $3 \mathrm{~cm}$. in height, caespitose, extensive, mucous, usually dull yellowish green or dark green, becoming dark violet when dried; filaments ascending from a decumbent and tangled base, soft, flexuous; sheaths up to 3 mic. in thickness, colorless, somewhat mucous, lamellose with age; trichomes 5-I2 mic. in diameter, not constricted at joints; apex of trichome slightly tapering, capitate; apical cell showing a depressed conical or rotund calyptra; cells $2-3$ mic. in length; transverse walls frequently granulated.

Maine. Growing in a rock pool reached only by the highest tides. Cape Rosier. July 1890; shore near Seal Harbor; in salt water pools, Ragged Island, near Cape Elizabeth. (Collins). New Hampșhire. (Collins). Massachusetts. Wood's Holl. (Farlow). Mystic River salt marshes. (Collins). Falmouth. (Nott). Forming light yellow expansions on sandy shore at low water mark. Little Harbor, Wood's Hole. August I894. (Setchell). Rhode Island. (Bennett, Collins). Connecticut. Growing in large patches on stones and woodwork between tidemarks. Stonington. (Bailey). Noank. (Farlow). New York. Shores of Long Island, Coney Island Creek. Summer. (Pike). New Jersey. Hudson, Hoboken. (Pike). On wharves between tide marks. Atlantic City. (Martindale). Nebraska. In pond. South Bend. (Bessey). Washington. Salt marsh. Whidbey Island. (Gardner). California. Pacific Beach. (Snyder). Mexico. Near Vera Cruz. (Müller). West Indies. Guadeloupe. (Mazé). Hawaii. Attached to rocks in tide pool filled at high tide. Waianae, Oahu. May Igoo. (Tilden). On marine algae. Laysan. (Schauinsland).

233. Lyngbya confervoides C. Agardh. Syst. Algar. 73. 1824. Gomont. Monogr. Oscill. 156. pl. 3. f. 5, 6. I893. De Toni. Syll. Algar. 5: 27 I. I907.

Harvey. Nereis Boreali-Americana. Part III. I02. pl. 47. c. I858. (L. n i gre sce n s Harv.). Schramm and Mazé. Essai Class. Algues Guadeloupe. $3 \mathbf{r}, 8 \mathrm{r}$. 1865 . (L e ib 1 e in ia 1 it t or a 1 is Crouan, L. ca erule ovi ol a c e a Crouan). Mazé and Schramm. Essai Class. Algues Guadeloupe. $21,23,26,28,30.1870-1877$. (L. c a e rul e o-viol a c e a Crouan, L. littora 1 is Crouan, Lyngbya cyanea Crouan, L. rufescens. Crouan, L. rubro-violacea forma crassior Crouan). Farlow. List of Marine Algae U. S. Proc. Am. Acad. Arts Sci. I0: 380. I875; Marine Algae of New England. 35. 188r. (L. 1 u t e o - $\mathrm{f}$ u s c a Ag.). Farlow, Anderson and Eaton. Algae Am. Bor-Exsicc. no. 48. I876. Pike. Check List of Marine Algae. Bull. Torr. Bot. Club. I3: 105. 1886. Martindale. Marine Algae of the New Jersey Coast and Adjacent Waters of Staten Island. Mem. Torr. Bot. Club. I: 9r. I889. Murray. Catalogue of the Marine Algae of the West Indian Region. Journ. of Bot. 27: 26I. I889. (L. c y a n e a 
Crouan). Collins, Holden and Setchell. Phyc. Bor.-Am. Fasc. 6. no. 255. 1897. Collins. Preliminary Lists of New England Plants.-V. Marine Algae. Rhodora. 2: 42. I900. Bessey, Pound and Clements. Additions to the Reported Flora of the State. Bot. Surv. Nebraska. 5: 12. I90I. Collins, Holden and Setchell. Phyc. Bor.-Am. Fasc. 23. no. rio6. 1903. Collins. Phycological Notes of the late Isaac Holden.-I. Rhodora. 7: I72. I905. Vickers. Liste des Algues Marines de la Barbade. Ann. Sci. Nat. Bot. VIII. I : 55. 1905. Lemmermann. Algenfl. Sandwich.-Inseln. Bot. Jahrb. 34: 620. 1905. Collins. Notes on Algae. IX. Rhodora. I0: I60. I908.

\section{Plate V. fig. 39.}

Plant mass about $5 \mathrm{~cm}$. in height, caespitose, extended, fasciculate, mucous, dull yellowish or dark green, when dried becoming violet; filaments ascending from a decumbent and tangled base, long, straight, somewhat rigid; sheaths up to 5 mic. in thickness, colorless, later becoming lamellose and roughened on the surface; trichomes 9-25 mic. in diameter, not constricted at joints; apex of trichome not tapering nor capitate; apical cell rotund; calyptra none; cells $2-4$ mic. in length; transverse walls usually granulated; cell contents olive or blue-green.

Maine. Salt marsh. Stover's Point, South Harpswell. (Collins.) Massachusetts. Common on Zoster a. Summer. Wood's Holl. (Farlow). Gloucester. (Davis). Rhode Island. (Collins). Connecticut. On rocks and iron work. Stratford Shoals Light, Long Island Sound, near Bridgeport. October I89ı. (Holden). New York. Sea shores or mud. Canarsic Bay, Long Island; on leaves of $Z$ ostera, Peconic Bay. (Hooper, Harvey). Prince's Bay, Staten Island; Canarsie, Bay Ridge, Long Island. (Pike). South Carolina. Charleston. (Farlow, Gibbes). Florida. On sand-covered rocks of a jetty, littoral. Anastasia Island. October Igo2. (Howe). Nebraska. In culture from salt basin. Lincoln. (Bessey, Pound and Clements). West Indies. Guadeloupe. (Mazé). Hawaii. (Farlow).

Forma violacea Collins. The Algae of Jamaica. Proc. Am. Acad. Artō Sci. 37: 240. I901. De Toni. Syll. Algar. 5: 703. I907.

Cell contents violet.

West Indies. Manchioneal Bay, Jamaica. July 1900. (Pease and Butler).

234. Lyngbya aestuarii (Mertens) Liebman. Bemerkninger og Tilläg til den danske Algeflora. Kröyers Tidskrift. 492. I84I. Gomont. Monogr. Oscill. 147. pl. 3. f. 1, 2. I893. De Toni. Syll. Algar. 5: 262. 1907.

Harvey. Nereis Boreali-Americana. Part III. I02. pl. 47. B, F. 1858 . (L. ferruginea C. Ag., L. fulva Harv.). Schramm and Mazé. Essai Class. Algues Guadeloupe. 32. 1865. (L. c o n g e s t a Crouan). Farlow. List Marine Algae U. S. Proc. Am. Acad. Arts Sci. Io: 380. I875: Farlow, Anderson and Eaton. Algae. Am. Bor. Exsicc. no. I76. 1877. Wolle. Fresh Water Algae. III. Bull. Torr. Bot. Club. 6: I83. I877. (P h. o liva c e u $\mathrm{m}$ Rab.). Wittrock and Nordstedt. Algae. Aq. Dulc. Exsicc. 110. 282. 1879. (L. a estuari a eruginosa Wolle). Wolle. Fresh Water Algae. Bull. Torr. Bot. Club. 6: 283. 1879. (L. a e r ug in os a Ag.). Farlow. Marine Algae of New England. 34. 1881. Wolle. Fresh Water Algae. VI. Bull. Torr. Bot. Club. 9:25. 1882. Pike. Check List of Marine 
Algae. Bull. Torr. Bot. Club. I3: I05. 1886.

Wolle. Fresh-Water Algae U. S. 296. pl. 200. f. II-I6, p1. 202. f. I, 2. I887. Hay and Mackay. List of the Marine Algae of the Maritime Provinces of Canada, with Notes. Trans. Roy. Soc. Can. 5: I887. Bennett. Plants of Rhode Island. II4. I88. (L. c bscura Kg., L. interrupta Kg.). Collins. Algae of Middlesex County. I4. I888; Marine Algae of Nantucket. 4. r888; Algae from Atlantic City, N. J. Bull. Torr. Bot. Club. I5: 310. 1888. Martindale. Marine Algae of the New Jersey coast and adjacent waters of Staten Island. Mem. Torr. Bot. Club. I: 9r. I889. Wolle and Martindale. Algae. Britton's Catalogue cf Plants found in New Jersey. Geol. Surv. N. J. 2: 608, 6Io. I889. (Also L. obscura Wolle and O. 1 it toralis Carm.) Murray. Catalogue of the Marine Algae of the West Indian Region. Journ. of Bot. 27: 26r. I889. (Also L. compacta Crouan). Saunders. Protophyta-Phycophyta. Flora of Nebraska. 21, 22. pl. 2. f. 25, 26. I894. Collins. Algae. Rand and Redfield's Flora of Mount Desert Island, Maine. 247. I894. Tilden. List of Fresh-Water Algae collected in Minnesota during r893. Minn. Bot. Studies. I : 3I. I894. Collins, Holden and Setchell. Phyc. Bor.-Am. Fasc. I. no. 6. I895- Collins. Preliminary Lists of New England Plants.-V. Marine Algae. Rhodora. 2: 42. 1900. Tilden. Collection of Algae from the Hawaiian Islands. Haw. Almanac and Annual for I902. II2. I90I; American Algae. Cent. V. no. 488. I90I. Collins. The Algae of Jamaica. Proc. Am. Acad. Arts Sci. 37: 240. r9or. Setchell and Gardner. Algae of Northwestern America. Univ. Calif. Pub. Bot. I: 186, 187. I903. Collins, Holden and Setchell. Phyc. Bor.-Am. Fasc. 26. no. I255. 1905. Collins. Phycological Notes of the late Isaac Holden.-I. Rhodora. 7: 772. 1905. Vickers. Liste des Algues Marines de la Barbade. Ann. Sci. Nat. Bot. VIII. I: 45. 1905. Lemmermann. Algenfl. Sandwich.-Inseln. Bot. Jahrb. 34: 620. 1905. Collins. Notes on Algae.-VII. Rhodora. 8: 123. 1906. Buchanan. Notes on the Algae of Iowa. Proc. Iowa Acad. Sci. 14: I3. I908. Collins. Notes on Algae. IX. Rhodora. Io: 160, 162. I908.

Plate V. fig. 40, 4I.

Plant' mass widely expanded, either forming a compact woolly layer on moist earth, or a floccose mass floating in water, blackish or dull bluegreen; filaments long, flexible, (sometimes branched), strongly twisted and densely crowded, or moderately flexuous or somewhat straight and loosely entangled, sometimes forming erect fascicles in inundated places; sheaths at first colorless, thin, smooth, later becoming thick, roughened on the surface, lamellose, yellowish or brownish, with layers of different colors; trichomes 8-24 mic. in diameter, not constricted at joints; apex of trichome slightly tapering and capitate, truncate, rarely somewhat acute conical; apical cell showing a slightly thickened outer membrane; cells 2.7-5.6 mic. in length; cell contents finely granular, blue-green or olive.

Canada. Forming patches on other algae. Malpeque, Prince Edward Island. (Faull). In brackish pond. Pictou Harbor. (Mackay). Maine. Very common in lagoon. Little Cranberry Isle; occasional near Seal Harbor; salt marsh, Stover's Point, South Harpswell; in salt water pools, Ragged Jsland, near Cape Elizabeth. (Collins). New Hampshire. (Collins). Massachusetts. In quite fresh water, in old claypit. West Cambridge. August 
1905; common in salt marshes. (Collins). Abundant in summer in shallow, brackish pools, covering exposed algae and $\mathrm{Z}$ os t e $\mathrm{r}$ a. Gloucester. (Davis). Rhode Island. Pocasset, Neutakonkanut. (Bennett, Collins). Connecticut. Stonington. (Farlow). On the granite masses composing the breakwater at Stonington. (Bailey). Abundant in quiet brackish water, often forming feltlike sheets. Bridgeport; Cook's Point, Fresh Pond, June, July, September, October. (Holden). In a brackish pool beside the Thames River. Norwich. September I892. (Setchell). New York. Shores of Long Island, Fort Hamilton, Bay Ridge. Summer. (Pike). New Jersey. In pools of moist earth subject to inundations from flowing tides; in ponds and pools in salt water marshes, Perth Amboy, Absecon. (Wolle). Brackish ditches at Hoboken. (Bailey). Common on marshes on floating eel-grass. Atlantic City. (Morse). In salt marshes about Newark Bay. (Pike). In salt ditches, Cape May. (Martindale). Pennsylvania. In small ponds. (Wolle). Minnesota. Gull Lake. July 1893. (Tilden). Iowa. In pond amid bladderwort. Eagle Grove. (Buchanan). Nebraska. In lakes and ponds in the eastern part of the state; in mineral water, Lincoln, Franklin. (Saunders). West Indies. Guadeloupe. (Mazé). Near Bridgetown; Bay Estate, Barbados. (Howard). In mats on stones. Kingston, Jamaica. April I893. (Humphrey). Port Antonio, Jamaica. July I89ı. (Pease and Butler). Near Kingston, Jamaica. (Duerden). Hawaii. In ditches between Honolulu and Waikiki, Oahu. 1896-97. (Schauinsland). Forming a skin growing closely attached to sand on rock. Laie Point, Koolauloa, Oahu. June Igoo. (Tilden).

Forma limicola Gomont. 1. c. I49. De Toni. 1. c. 265.

Collins, Holden and Setchell. Phyc. Bor.-Am. Fasc. I9. no. 903. I902; Fasc. 29. no. 1402. I907.

Plants living on damp soil, subject to inundation; plant mass pannose, compact, somewhat thin; filaments densely crowded and strongly twisted.

Massachusetts. Forming thin, black continuous sheets on the mud of a salt marsh. Bay Shore, Eastham. August 1907. (Collins). Washington. On mud in a salt marsh. Snakalum Point, Whidbey Island. (Gardner).

Forma natans Gomont. 1. c. I49. De Toni. 1. c. 265.

Tilden. Collection of Algae from the Hawaiian Islands. Haw. Almanac and Annual for I902. II2. Igor; American Algae. Cent. V. no. 489. I90I. Collins, Holden and Setchell. Phyc. Bor.-Am. Fasc. I9. no. 904. 1902.

Plant mass covered with water, at first attached to wet earth, later floating; filaments long, moderately flexuous or somewhat straight, loosely entangled.

Washington. Floating among $\mathrm{Ruppia}$ in a salt water pond. West coast of Whidbey Island. June Igor. (Gardner). Hawaii. In dirty tangled masses, floating in lagoon formed at mouth of river. Kealia River, Kauai. July ig00. (Tilden).

Forma symplocoides Gomont. Monogr. Oscill. I49. I893. De Toni. 1. c. 5: 265. 1907.

Collins, Holden and Setchell. Phyc. Bor.-Am. Fasc. 2I. no. 1009. 1903. 
Plant mass not covered with water; filaments decumbent and entangled at the base, above forming erect, densely coalesced fascicles.

Massachusetts. On a muddy shore near high water mark. Mattapoisett. September r902. (Collins).

Forma ferruginea Gomont. Monogr. Oscill. I50. I893. De Toni. 1. c. 5: 265.1907.

Harvey. Nereis Boreali-Americana. Part III, ro2. pl. 47 B. I858. (L. f erruginea Ag.). Kemp. A classified List of Marine Algae from the Lower St. Lawrence. Can. Nat. and Geol. 5: 30. I860. Farlow. List Marine Algae U. S. Proc. Am. Acad. Arts Sci. ro: 380 . 1875.

Plant mass dark brown; sheaths thick, lamellose, more or less intensely yellowish-brown.

Canada. On top of rocks near low water mark. Lower St. Lawrence. (Kemp). New York. On muddy shores, in tide pools and floating in ditches of salt or brackish water near the sea. Harlem River, close to the High Bridge. (Harvey). Salt ditches at Hoboken and near Greenport. (Bai1ey). Greenport, Long Island. (Farlow).

Forma aeruginosa (Ag.) Wolle in Wittrock and Nordstedt. Algae Aq. Dulc. Exsicc. no. 282. 1879. Gomont. 1. c. I50. I893. De Toni. 1. c. 265.

Tilden. American Algae. Cent. VI. no. 586. I902. Collins, Holden and Setchell. Phyc. Bor.-Am. Fasc. I9. no. 902. Ig02.

Plant mass dark blue-green; sheaths somewhat thin, colorless.

New Jersey. On ground or in brackish ditches. August 1878. (Wolle). Washington. Floating in a salt water pond. West coast of Whidbey Island. June Igoo. (Gardner). Hawaii. In shallow water of taro patch forming a bright blue-green continuous layer. Near Hauula Court House, Makao, Koolauloa, Oahu. June Igoo. (Tilden).

235. Lyngbya majuscula (Dillwyn) Harvey in Hooker. English Flora. 5: part I. 370. I833. Gomont. Monogr. Oscill. I51. pl. 3. f. 3, 4. I893. De Toni. Syll. Algar. 268. I907.

Harvey. Nereis Boreali-Americana. Part III. ıor. p1. 47 A. 1858. Mazé and Schramm. Essai Class. Algues Guadeloupe. 15, 22, 23, 24, 25. I870-1877. (Also O. corallicol a Crouan, L. 1 u t e o-f us c a Crouan, L. s h ow i a n a Crouan, L, rigidis s im a Crouan. Farlow. List Marine Algae U. S. Proc. Am. Acad. Arts Sci. I0: 380 . 1875. Hall. List of the Marine Algae growing in Long Island Sound. Bull. Torr. Bot. Club. 6: II2. I876. Dickie. Supplemental Notes on Algae collected by $H$. N. Moseley, M. A., of $H$. M. S. Challenger, from various Localities. Journ. Linn. Soc. Bot. 15: 489. I877. Farlow. Marine Algae of New England. 34. pl. I. f. 4. I88x. Pike. Check List of Marine Algae. Bull. Torr. Bot. Club. I3: I05. I886. Hay and Mackay. List of the Marine Algae of the Maritime Provinces of Canada, with Notes. Trans. Roy. Soc. Can. 5: 1887. Moebius. Ueber einige in Portorico gesammelte Süsswasser- und Luft-Algen. Hedwigia. 27: 246. I888. Hauck. Meeresalgen von Puerto-Rico. Bot. Jahrb. 9: 470. I888. Bennett. Plants of Rhode Island. 95. I888. Collins. Algae from Atlantic City, N. J. Bull. Torr. Bot. Club. 15: 310. I888. Murray. Catalogue of the Marine Algae of the West Indian Region. Journ. of Bot. 27: 26r. I889. 
(Also L. e ros a Liebm., L. a n gu in a Mont.). Martindale. Marine Algae of the New Jersey Coast and Adjacent Waters of Staten Island. Mem. Torr. Bot. Club. I: 90. I889. Wolle and Martindale. Algae. Britton's Catalogue of Plants found in New Jersey. Geol. Surv. N. J. 2: 607. I889. Anderson. List of California Marine Algae, with Notes. Zoe. 2: 218. I89r. Collins, Holden and Setchell. Phyc, Bor.-Am. Fasc. 5. no. 202. I896. Collins. Preliminary Lists of New England Plants.-V. Marine Algae. Rhodora. 2: 42. 1900. West and West. A Further Contribution to the Freshwater Algae of the West Indies. Journ. Linn. Soc. Bot. 34: 288. I898-1900. Collins. The Algae of Jamaica. Proc. Am. Acad. Arts Sci. 37: 240. I90I. Tilden. Collection of Algae from the Hawailan Islands. Haw. Almanac and Annual for I902. II2. Igor; American Algae. Cent. V. no. 492. IgoI. Vickers. Liste des Algues Marines de la Barbade. Ann. Sci. Nat. Bot. VIII. I: 55. I905.

Plate V. fig. 42.

Plant mass up to $3 \mathrm{~cm}$. in length, widely expanded, dark blue, dark blue-green, brownish or yellowish green; filaments very long, often curled, sometimes rolled in a circinate manner, rarely moderately flexuous; sheaths up to II mic. in thickness, colorless, later becoming very thick and roughened on the outside; trichomes $16-60$ mic. in diameter, not constricted at joints; apex of trichome not tapering; apical cell rotund; calyptra none; cells 2-4 mic. in length; transverse walls not granulated; cell contents finely granular, dull green, gray or lead-colored.

Canada. Pictou Harbor. (Mackay). Floating tufts, attached to other algae or to Z ostera. Malpeque, Prince Edward Island. (Faull). New Hampshire. (Collins). Massachusetts. Wood's Hole; during the later summer months forming large tufts upon $Z$ oster'a and various algae and often found floating free, Cape Cod. (Farlow). Washed ashore in large entangled masses. Wood's Hole. August 1894. (Setchell). Rhode Island. Providence. (Olney). (Collins). Connecticut. (Hall). New York. Canarsie, College Point, Long Island. Summer. (Pike). Long Island Sound. (Bailey). Peconic Bay. (Hooper). New Jersey. Newark Bay, Hudson River. (Pike). On eel-grass, Atlantic City. (Morse), Cape May. (Martindale). Florida. Key West. (Farlow, Harvey, Ashmead). California. On Z os te ra. Southern coasts. (Anderson). Mexico. (Liebman). Bermudas. (Rein). In shallow water. (Dickie). West Indies. (Hohenhacker). Guadeloupe. (Mazé). Grenada. (Murray). In warm springs. Los Baños, near Coamo; in river near Cayey; in Caguitas River, near Caguas, Porto Rico. I885. (Sintenis). Forming a film on marine algae. Port Antonio, Jamaica. July I891 (Pease and Butler) and March I803 (Humphrey). Forming extensive tufts on muddy bottom, near the mouth of a small stream. Manchioneal Bay, Jamaica. July 1900. (Pease and Butler). Shallow bays, Anguil1a. (Elliott). Barbados. (Vickers). Hawaii. Epiphytic on other algae, at low tide. Waianae, Oahu. May igoo. (Tilden).

236. Lyngbya martensiana Meneghini. Conspectus Algologiae euganeae. I2. I837. Gomont. Monogr. Oscill. I65. pl. 3. f. 17. I893. De Toni. Syll. Algar. 5: 279. 1907.

Schramm and Mazé. Essai Class. Algues Guadeloupe. 3I. I865. (L. 
a r a ch noidea Crouan).

Mazé and Schramm. Essai Class. Algues Guadeloupe. 28. $1870-1877$. (L. th e $\mathrm{rm}$ a 1 is Crouan). Tilden. Collection of Algae from the Hawaiian Islands. Haw. Almanac and Annual for 1902. II2. I90I; American Algae. Cent. V. no, 490. I90I; Algae Collecting in the Hawaiian Islands. Postelsia: The Year Book of the Minnesota Seaside Station. I: 166. I902. West. West Indian Freshwater Algae. Journ. of Bot. 42: 29I. I904. Tilden. Notes on a Collection of Algae from Guatemala. Proc. Biol. Soc. Wash. 2I: I54. I908; American Algae. Cent. VII. Fasc. I. no. 637. I909.

Plate V. fig. 43.

Plant mass caespitose, blue-green, when dried often becoming violet; filaments long, somewhat flexuous, flexible; sheaths colorless, becoming thickened and roughened with age; trichomes 6-ro mic. in diameter, not constricted at joints; apex of trichome not tapering, not capitate, apical cell rotund; calyptra none; cells I.7-3.3 mic. in length; transverse walls inconspicuous or marked by protoplasmic granules; cell contents pale bluegreen.

Central America. On stems of S c i r p u s, dead or dying, Lake Amatitlan, Guatemala. January rgo6. (Kellerman). West Indies. Guadeloupe. (Mazé and Schramm). Near Bridgetown; Graeme Hall Swamp, Barbados. (Howard). Hawaii. On twigs under dripping water. Falls four miles from mouth of river. Waialuka River, Hilo. July 1900. (Tilden).

Var. calcarea Tilden. American Algae. Cent. II. no. I78. 1896; Some new species of Minnesota Algae which live in a calcareous or silicious matrix. Bot. Gaz. 23: Ior. pl. 9. f. 4. I897; List of fresh-water Algae collected in Minnesota during 1896 and I897. Minn. Bot. Studies. 2: 28. I898. MacMillan. Minnesota Plant Life. 30. f. 8, Io. 1899. De Toni. Syll. Algar. 5: 280. I907.

\section{Plate V. fig. 44.}

Plant mass forming extended strata throughout upper portions of calcareous deposit; filaments 6.5-7.5 mic. in diameter, straight, flexible, somewhat unequal in size; sheaths very distinct, colorless, smooth or rough; trichomes 5-6.5 mic. in diameter, not constricted at joints, frequently interrupted; apex of trichome not or very rarely tapering; cells about 2.5 mic. in length; cell contents dull blue-green, violet or rarely brown.

Minnesota. Forming a part of the lime encrustation which covers sides of wooden tank. Minneapolis. October I895. (Tilden).

237. Lyngbya putealis Montagne. 2e centurie de Plantes cellulaires exotiques. Ann. Sci. Nat. Bot. II. 13: 200. 1840. Gomont. Monogr. Oscill. I63. pl. 3. f. I4. I893. De Toni. Syll. Algar. 5: 277. I907.

Schramm and Mazé. Essai Class. Algues Guadeloupe. 3r. I865. (Also Leibleinia torta Crouan, Lyngbya arachnoidea Crouan, L. putealis minor). Mazé and Schramm. Essai Class. Algues Guadeloupe. 28, 30, 31. I870-I877. (Also L. rufescens Crouan, L. b icolor Crouan, L. torta Crouan, L. fusca Crouan, L. fontana 
Crouan, L. fontan a crassior Crouan).

Collins. The Algae of

Jamaica. Proc. Am. Acad. Arts Sci. 37: 240. I901.

Plate V. fig. 45.

Plant mass up to I dm. in length, caespitose, widely expanded, elongate, penicillate, sometimes becoming dark violet or black; filaments very long, more or less flexuous and entangled at the base, above straight, parallel, rigid; sheaths colorless, thin, papery; trichomes 7.5-13 mic. in diameter, especially constricted at joints; apex of trichome not tapering; apical cell rotund; calyptra none; cells 3 -10 mic. in length; transverse walls sometimes granulated; cell contents granular, blue or blue-green.

West Indies. (Mazé and Schramm). Morant Bay, Jamaica. July Igoo. (Prase and Butler).

238. Lyngbya major Meneghini. Conspectus Algologiae euganeae. I2. I837. Gomont. Monogr. Oscill. I64. pl. 3. f. I5. I893. De Toni. Syll: Algar. 5: 279. 1907.

Wolle. Fresh Water Algae. Bull. Torr. Bot. Club. 6: 283. 1879. Murray. Catalogue of the Marine Algae of the West Indian Region. Journ. of Bot. 27: 26r. 1889. Bessey, Pound and Clements. Additions to the Reported Flora of the State. Bot. Surv. Nebraska. 5: I2. Igor. West. West Indian Freshwater Algae. Journ. of Bot. 42: 291. I904.

\section{Plate V. fig. 46.}

Filaments caespitose, elongate, straight, rigid, dark green; sheaths colorless, thick, lamellose, roughened; trichomes II-I6 mic. in diameter, not constricted at joints; apex of trichome slightly tapering, somewhat capitate; apical cell showing a slightly thickened outer membrane; cells 2-3.4 mic. in length; transverse walls granulated; cell contents dark blue-green.

Florida. St. Lucia River. (Smith). Nebraska. In aquaria. Lincoln. (Bessey, Pound and Clements). West Indies. Guadeloupe. (Mazé). Morant Bay, Jamaica. July I900. (Pease and Butler). Bay Estate, Barbados. (Howard).

239. Lyngbya spirulinoides Gomont. Essai Class. Nostocacées homocystées. Morot. Journ. de Bot. 4: 355. I89o; Monogr. Oscill. I66. pl. 3. f. I8, 19. 1893. De Toni. Syll. Algar. 5: 287. 1907.

Bessey, Pound and Clements. Additions to the Reported Flora of the State. Bot. Surv. Nebraska. 5: I3. Igor. Setchell and Gardner. Algae of Northwestern America. Univ. Calif. Pub. Bot. I: I87. I903.

$$
\text { Plate V. fig. } 47 .
$$

Plant mass floating, olive green; filaments entangled, fragile, forming a regular loose spiral throughout the whole or a portion of their length, or sometimes straight throughout; distance between turns of spiral 73-108 mic.; sheaths colorless, thin, somewhat mucous, not lamellose; trichomes 14-I6 mic. in diameter, not constricted at joints; apex of trichome not tapering; apical cell rotund; calyptra none; cells 3.4-6.8 mic. in length; 
transverse walls sometimes marked by fine granules; cell contents somewhat homogeneous or finely granular, pale blue-green.

Nebraska. On moist earth. Lincoln. (Bessey, Pound and Clements). Washington. Floating among various filamentous algae. Lake Washington, Seattle. (Gardner).

240. Lyngbya arachnoidea Kuetz. Sp. Algar. 282, I849. De Toni. Syll. Algar. 5: 266. I907.

Schramm and Mazé. Essai Class. Algues Guadeloupe. 31. 1865. Mazé and Schramm. Essai Class. Algues Guadeloupe. 28. 1870-1877.

Plant mass dark green, becoming brownish or sometimes reddish; flaments I5-I9 mic. in diameter, flexible, loosely entangled; sheaths colorless, transparent; trichomes $\mathbf{I} 2.5 \mathrm{mic}$. in diameter, interrupted in lower portions; cells very short; cell contents granular, olive or blue-green.

West Indies. In stagnant water. (Schomburgk).

Species not well understood.

241. Lyngbya bicolor Wood. Prodromus of a study of the fresh-water Algae of eastern North America. Proc. Am. Phil. Soc. II: I24. I869; Cont. Hist. Fresh-Water Algae North America. 22. pl. I. f. 7. 1872. De Toni. Syll. Algar. 5: 290. 1907.

Plant mass a blackish or bluish-green mat; filaments variously curved, closely interwoven, simple; sheaths firm, transparent, in old filaments moderately thick; trichomes sometimes constricted at joints, often interrupted; cells short; transverse walls usually not visible; cell contents mostly very granular, light blue-green.

Pennsylvania. Forming dark waving tufts, a half-inch or more in height, adherent to bottom of stream, or to plants, sticks, etc. In shallow water of the Schuylkill River, near Spring Mills, Philadelphia. (Wood).

242. Lyngbya caeruleo-violacea Crouan in Schramm and Mazé. Essai Class. Algues Guadeloupe. 38. I865. Mazé and Schramm. Essai Class. A1gues Guadeloupe. 21. 1870-1877. De Toni. Syll. Algar. 5: 292. I907.

Murray. Catalogue of the Marine Algae of the West Indian Region. Journ. of Bot. 27: 261 . I889.

"Filamentis $1 / 2-I \mathrm{~cm}$. longis, in flocculos basim ad chordae ad instar convolutis, apice liberis, articulis subtiliter granulatis, diam. 5-plo brevioribus; strato siccitate violaceo-albido."

West Indies. Guadeloupe. (Mazé).

243. Lyngbya fluitans Hering in Krauss. Pflanzen des Cap- und NatalLandes, gesammelt und zusammengestellt. Flora. 2I5. I846. De Toni. Syll. Algar. 5: 290. I907.

Murray. Catalogue of the Marine Algae of the West Indian Region. Journ. of Bot. 27 : 26r. I889.

"Filis aeruginosis, tenuissimis, flaccidis, in caespitem tripollicarem laxe implicatis."

West Indies. Guadeloupe. (Mazé). 
244. Lyngbya hyalina Harvey. Nereis Boreali-Americana. Part III. 104. pl. 47 G. 1858. De Toni. Syll. Algar. 5: 293. 1907.

Farlow. List Marine Algae U. S. Proc. Am. Acad. Arts Sci. ro: 380. I875. Bennett. Plants of Rhode Island. II5. I888. (M i c r ocole us hy a 1 in us (Kg.) Kirchn.). Murray. Catalogue of the Marine Algae of the West Indian Region. Journ. of Bot. 27: 26I. I889.

Plant mass forming indefinite, very soft and somewhat gelatinous continuous tufts or pilose strata; filaments attached by their bases, erect, straight, very slender, arachnoid, gelatinous-membranaceous, flaccid; transverse walls visible in older plants; cell contents granular, very pale yellowish green or nearly colorless.

Rhode Island. Davisville. (Bennett). Florida. On lime encrusted rocks. Key West. (Harvey).

245. Lyngbya pusilla Harvey. Nereis Boreali-Americana. Part III. Io3. p1. 47 E. I858. De Toni. Syll. Algar. 5: 293. 1907.

Farlow. List Marine Algae U. S. Proc. Am. Acad. Arts Sci. 10: 380.1875.

Plant mass minute, blackish green; filaments very slender, short, crisped, spreading in small bundles; sheaths very thin, colorless; transverse walls distinct; cell contents pale dull green.

South Carolina. Parasitic on small algae. Sullivan's Island. (Harvey).

246. Lyngbya rubra Crouan in Mazé and Schramm. Essai Class. Algues Guadeloupe. 29. 1870-1877. De Toni. Syll. Algar. 5: 293. 1907.

"Filamentis tenuissimis, in stratus maculiformes vel fasciculatos ad cm. longos consociatis, apice obtusis; articulis subquadratis, contentu subrubro repletis."

West Indies. Guadeloupe. (Mazé and Schramm).

247. Lyngbya rubro-violacea Crouan in Mazé and Schramm. Essai Class. Algues Guadeloupe. 29. 1870-I877. De Toni. Syll. Algar. 5: 293. 1907.

"Filamentis in fasciculos penicillatos, plus minusve in spiram convolutos, I-2 cm. longos conjunctis; articulis subquadratis, contentu violaceoobscuro, aetate provecta rubro."

West Indies. On madrepores. Guadeloupe. (Mazé and Schramm).

\section{Genus SYMPLOCA Kuetzing. Phyc. Gen. 201. I843.}

Filaments branched, ascending from a prostrate base, agglutinated together in erect or anastomosing fascicles, or wick-like bundles, more or less procumbent, coalescing; false branches solitary; sheaths thin, colorless, firm or somewhat mucous; apex of trichome straight, sometimes a little tapering; outer membrane of apical cell slightly thickened in some species.

I. Plants living in salt water.

I. Fascicles erect

(I) Plant mass blackish green; trichomes 4-2 mic. in diameter, constricted at joints throughout entire length $S$. atlantica 
(2) Plant mass dull or dark lead-colored; trichomes 6-14 mic. in diameter, constricted at joints near apices $\mathbf{S}$. hydnoides

2. Fascicles appressed; trichomes $\mathbf{1 . 5 - 3 . 5}$ mic. in diameter, especially constricted at joints

S. laete-viridis

II. Plants living on moist earth, or in fresh or hot water.

I. Trichomes I-3 mic. in diameter

(1) Plant mass deep blue-green; trichomes I.2-2 mic. in diameter, sometimes constricted at joints

S. thermalis

(2) Plant mass compact, fibrous; trichomes $1.5-2.5$ mic. in diameter, not constricted at joints

S. dubia

(3) Plant mass blue-green, changing to brown; trichomes 2-3 mic. in diameter

S. fuscescens

2. Trichomes 3-8 mic. in diameter

(I) Fascicles short, erect, spine-shaped; trichomes 3.4-4 mic. in diameter, not constricted at joints; cells somewhat quadrate or shorter than the diameter

S. muralis

(2) Fascicles tapering from a broad base to a loose, somewhat penicillate apex; trichomes $5.6 \mathrm{~m} . \mathrm{c}$. in diameter; cells a little longer than their diameter, after division shorter $\mathbf{S}$. borealis

(3) Fascicles elongate, usually procumbent, spine-shaped; trichomes 5-8 mic. in diameter, not constricted at joints; cells somewhat quadrate or longer than the diameter $\mathbf{S}$. muscorum

248. Symploca atlantica Gomont. Monogr. Oscill. I29. pl. 2. f. 5. I893. De Toni. Syll. Algar. 5: 302. 1907.

Collins, Holden and Setchell: Phyc. Bor.-Am. Fasc. 28. no. 1356. 1907.

Plant mass fasciculate-caespitose, blackish green; fascicles up to $I$ cm. in height, erect; filaments very densely entangled, free, unbranched; strongly and angularly twisted; sheaths thin, firm; trichomes 4-6 mic. in diameter, constricted at the joints throughout entire length; outer membrane of apical cell thickened into a depressed conical calyptra; cells $2-6$ mic. in length; transverse walls conspicuous, pellucid, not granulated; cell contents scarcely granular, greenish yellow.

California. On ground moistened by salt water. Bay Farm Island, near Alameda. November 1905. (Gardner).

249. Symploca hydnoides Kuetzing. Spec. Algar. 272. I849. Gomont. Monogr. Oscill. 126. pl. 2. f. 1-4. I893. De Toni. Syll. Algar. 5: 300. 1907.

Schramm and Mazé. Essai Class. Algues Guadeloupe. 29. I865. (S. a nt i 11 a r u Crouan). Mazé and Schramm. Essai Class. Algues Guadeloupe. I8. I870-I877. (O. hydrurimorph a Crouan, O. s y m plocarioides Crouan). Murray. Catalogue of the Marine Algae of the West Indian Region. Journ. of Bot. 27: 26r. I889. Collins, Holden and Setchell. Fhyc. Bor.-Am. Fasc. 3. no. 203. I895. Collins. Preliminary Lists of New England Plants.-V. Marine Algae. Rhodora. 2: 43. I900; Phycological Notes of the late Isaac Holden.-II. Rhodora. 7: 222, I905. Vickers. Liste des Algues Marines de la Barbade. Ann. Sci. Nat. Bot. VIII. I: 55. 1905. 
Plant mass fasciculate-caespitose, dull, rarely dark lead-colored; fascicles up to $3 \mathrm{~cm}$. in height, erect, spine-shaped, often lighter colored at base on acculnt of empty sheaths; filaments very densely entangled, somewhat agglutinated, sometimes branched, unequally and angularly twisted; 'sheaths thin, somewhat mucous; trichomes 6-I4 mic. in diameter, often constricted at joints near the apices; apical cell slightly inflated; calyptra 1ione; cells 5-I4 mic. in length; transverse walls usually indistinct; cell contents granular, blue-green.

Massachusetts. (Collins). Rhode Island. (Collins). Connecticut. In Yellow Mill Pond. August. (Holden). New York. Forming extended patches on mud left bare at low tide in the bottom of a creek. Cold spring Harbor. July i895. (Johnson). West Indies. Guadeloupe. (Mazé).

Var. genuina Gomont. 1. c. I27.

Collins, Holden and Setchell. Phyc. Bor.-Am. Fasc. I9. no. 905. I902. Collins. The Algae of Jamaica. Proc. Am. Acad. Arts Sci. 37: 240. I90r.

Trichomes 6-8 mic. in diameter; cells equal to or somewhat longer than the diameter.

Washington. Growing on old logs in a small cove. Whidbey Island. June Igor. (Gardner). West Indies. On rocks in shallow water, in small patches, not abundant. Montego Bay and Manchioneal Bay, Jamaica. 1900. (Pease and Butler).

Var. fasciculata (Kuetz.) Gomont. 1. c. 127. De Toni. 1. c. 302.

Farlow. Marine Algae of New England. I84. I88r. (S. f a s c ic u 1 a t a Kuetz.). Collins. The Algae of Jamaica. Proc. Am. Acad. Arts Sci. 37: 240. Ig0I.

Trichomes 8-14 mic. in diameter; cells scarcely as long as the diameter.

Rhode Island. On rocks between tide marks. Newport. (Farlow). West Indies. Montego Bay and Manchioneal Bay, Jamaica. (Pease and Butler).

250. Symploca laete-viridis Gomont. Monogr. Oscill. I29. pl. 2. f. 6-8. I893. De Toni. Syll. Algar. 5: 302. I907.

Setchell and Gardner. Algae of Northwestern America. Univ. Calif. Pub. Bot. I : 188. 1903.

Plate V. fig. 50.

Plant mass thin, fibrillose, light green or yellowish; fascicles up to 1 $\mathrm{mm}$. in height, slender, appressed to substratum; filaments moderately flexuous, somewhat parallel, agglutinated, not branched; sheaths wide, somewhat mucous; trichomes I.5-3.5 mic. in diameter, especially constricted at joints; apical cell conical; calyptra none; cells $2.5-6$ mic. in length; cell contents not granular, light green.

Alaska. On mud-covered rocks near the upper tide limit. St. Michael. (Setchell). Florida. Key West, Gulf of Mexico. (Farlow).

251. Symploca thermalis (Kuetzing) Gomont. Monogr. Oscill. 134. pl. 2. f. I5, 16. I893. De Toni. Syll. Algar. 5: 307. 1907.

Tilden. American Algae. Cent. III. no. 294. I898; Observations on some West American Thermal Algae. Bot. Gaz. 25: 98. pl. 9. f. I4. I 898. Collins, Holden and Setchell. Phyc. Bor.-Am. Fasc. I4. no. 652. 1900. 
Plate V. fig. $5 \mathrm{I}$.

Plant mass fasciculate-caespitose, widely expanded, dark blue-green; fascicles up to I $\mathrm{mm}$. in height, erect, approximate, somewhat thick; filaments sometimes branched, fragile, twisted and densely entangled at the base, above parallel, curled, closely crowded; sheaths very thin, sometimes mucous; trichomes I.2-2 mic. in diameter, here and there constricted at joints; apex of trichome not tapering; apical cell rotund; calyptra none, cells $1.7-5$ mic. in length; transverse walls inconspicuous, sometimes marked by two protoplasmic granules; cell contents homogeneous, rarely slightly granular, pale blue-green.

Canada. Forming extensive layers or knob-like masses on bottom of ditch. Natural Sulphur Springs, Banff, Alberta. August I897. (Tilden). New York. Adhering to bricks and stones in hot water from condensers of steam engines of the water works. Schenectady. June I893. (Holden).

252. Symploca dubia (Naegeli) Gomont. Monogr. Oscill. I35. I893. De Toni. Syll. Algar. 5: 308, I907.

\section{Plate V. fig. 52.}

Plant mass compact, fibrous, widely expanded, fasciculate on the surface, yellowish, blue-green or gray, sometimes reddish on the surface, lighter colored within on account of empty sheaths; filaments coiled, entangled at the base, forming parallel fascicles; sheaths somewhat thick, firm, irregular in outline; trichomes $\mathbf{1 . 5 - 2 . 5}$ mic. in diameter, not constricted at jcints; apical cell rotund; calyptra none; cells $3-8$ mic. in length; transverse walls inconspicuous, sometimes marked by two granules; cell contents showing protoplasmic granules arranged in lines, pale blue-green.

Mexico. (Müller).

253. Symploca fuscescens (Kuetzing) Rabenhorst. Fl. Eur. Algar. 2: I53. 1865. De Toni. Syll. Algar. 5: 307. 1907.

Wolle. Fresh Water Algae. Bull. Torr. Bot. Club. 6: 283. I879; FreshWater Algae U. S. 304. pl. 205. f. 8-I2. I887.

Plant mass blue-green, changing to brown; fascicles mucous, penicillatefert the apex, obtuse; filaments agglutinated; sheaths mucous, scarcely coofispicious cells somewhat quadrate; cell contents homogeneous or finely the pale olive or yellowish blue-green.

Peninsylvania. "Diameter of trichomes 2-3 mic." (Wolle).

254. Symploca muralis Kuetzing. Phyc. Gen. 201. 1843. Gomont. Monogr. Oscill. 132. pl. 2. f. I0. I893. De Toni. Syll. Algar. 5: 304. 1907.

Setchell. Notes on some Cyanophyceae of New England. Bull. Torr. Bot. Club. 22: 429. I895. Collins. Flora of the Blue Hills, Middlesex Fells, Stony Brook and Beaver Brook Reservations of the Metropolitan Park Commission, Massachusetts. 127. I\&g6.

Plate V. fig. 53.

Plant mass continuous, widely expanded, shaggy, dark lead-colored; fascicles up to $2 \mathrm{~mm}$. in height, spine-shaped, somewhat thick, erect; filar.ents elongate, twisted, irregularly entangled, closely crowded, decumbent 
at the base, ascending in less flexuous, somewhat parallel fascicles, not branched; sheaths thin, firm, somewhat mucous below; trichomes 3.4-4 mic. in diameter, not constricted at joints; apex of trichome slightly tapering; apical cell obtuse conical; calyptra none; cells I.5-4 mic. in length; transverse walls hardly visible, not granulateu.

Massachusetts. Forming minute green, plush-like patches on ground. Near Black Rock, Middlesex Fells. (Collins). Connecticut. Occurring abundantly on flower pots in greenhouse. New Haven. (Setchell).

255. Symploca borealis Rabenhorst. F1. Eur. Algar. 2: I56. I865. De Toni. Syll. Algar. 5: 309. I907.

Plant mass fasciculated, bright bluish or blue-green; fascicles $6-8 \mathrm{~mm}$. up to $2.5 \mathrm{~cm}$. in height, tapering from a broad lamelliform base up to a loose, somewhat penicillate apex; filaments 7-Io mic. in diameter, loosely agglutinated by a colorless mucus; sheaths close, sometimes swollen, homogeneous, very smooth, colorless, often empty in upper portions; trichomes 5-6 mic. in diameter, somewhat equal, slightly curved, erect, somewhat parallel, entangled, rarely interrupted; cells a little longer than their diameter, after division shorter; cell contents granular, bright bluegreen.

Greenland. On Bartramia ithyphylla and B. fontana. (Breute1).

256. Symploca muscorum (Agardh) Gomont. Essai Class. Nostocacées homocystées. Morot. Journ. de Bot. 4: 354. I890; Monogr. Oscill. 130. pl. 2. f. 9. I893. De Toni. Syll. Algar. 5: 303. I907.

Mazé and Schramm. Essai Class. Algues Guadeloupe. 19, 29. 1870-1877. (Ph. spadice um Croun, Ph. smaragdinu $\mathrm{m}$ Crouan, L. g r a veolen s Crouan). Wolle. Fresh Water Algae. III. Bull. Torr. Bot. Club. 6: I83. I877; ( $P$ h. 1 y n g b y a c e $u$ m Kuetz.). Fresh-Water Algae U. S. 299. pl. 20I. f. 22-26. r887. (L. phor $\mathrm{m}$ i d i $\mathrm{m} \mathrm{Kuetz.).} \mathrm{Wolle} \mathrm{and} \mathrm{Mar-}$ tindale. Algae. Britton's Catalogue of Plants found in New Jersey. Geol. Surv. N. J. 2: 608 . I889. Tilden. American Algae. Cent. I. no. 66. 1894; I-ist of fresh-water Algae collected in Minnesota during I894. Minn. Bot. Studies. I: 235. 1895. West and West. On some Freshwater. AIgaes, the West Indies. Journ, Linn. Soc. Bot. 30: 264. I895. Collins, Holden and Setchell. Phyc. Bor.-Am. Fasc. 8. no. 353. 1897. Setchelk otes Cyanophyceae. III. Erythea. 7: 53. I899. Collins, Holden and Setcelli. Phyc. Bor.-Am. Fasc. 2I: no. IOIO. Ig03. Setchell and Gardner. Algae Algae of Northwestern America. Univ. Calif. Purb. Bot. I: I88. I903. West. West Indian Freshwater Algae. Journ. of Bot. 42: 291. 1904. Collins, Holden and Setchell. Phyc. Bor.-A.m. Fasc. 25. no. 1208. T005.

Plate V. fig. 54 .

Plant mass fasciculate or mucous and Phormidium-like, extensive, blackish, dark green or blue-green; fascicles twisted, creeping, rarely erect, flaments flexible, densely crowded, at the base twisted and entangled, in upper portions less twisted, somewhat parallel; not branched; sheaths up to $2 \mathrm{mic}$. in diameter, firm, tenacious, or more or less mucous; trichomes 
5-8 mic. in diameter, not constricted at joints; apical cell rotund or obtuse conical; calyptra slightly thickened; cells 5 -I I mic. in length; transverse walls usually inconspicuous, not granulated; cell contents granular, bluegreen.

Massachusetts. On moist earth by roadside. Malden. July I904. (Collins). New Jersey. On marsh bottoms. (Wolle). Pennsylvania. On old logs partially submerged. (Wolle). Maryland. Forming tufts in an old brickyard. Baltimore. November I896. (Humphrey). Minnesota. On trunk of tree-fern. University greenhouse. Minneapolis. November I894. (Tilden). Washington. Among mosses on damp ground. Newhall, Orcas Island. (Gardner). California. In a greenhouse. Mount View Cemetery, Oakland. July 1902. (Gardner). West Indies. (Mazé and Schramm, Ramon de la Sagra). Bay Estate, Barbados. (Howard).

Var. rivularis (Wolle) Tilden. American Algae. Cent. I. no. 67. I894. (L. phormidium rivularis Wolle). Wolle. Fresh-Water Algae U. S. 299. 1887. De Toni. Syll. Algar. 5: 304. I907.

Johnson and Atwell. Fresh Water Algae. Northwestern University. Report Dept. Nat. Hist. 2r. I89o. Tilden. List of Fresh-Water Algae collected in Minnesota during 1894. Minn. Bot. Studies. I: 235. 1895.

Plant mass forming dirty aeruginous tufts $25 \mathrm{~mm}$. long; filaments Io mic. in diameter; cells $2.5-5$ mic. in length; cell contents dark steel biue or in portions yellowish green.

Pennsylvania. River Lehigh, Bethlehem. (Wolle). Illinois. Running water. Big Wood, Cook County. April. (Johnson and Atwell). Minnesota. Attached to stones in aquarium in Zoological laboratory. University of Minnesota, Minneapolis. November I894. (Tilden).

\section{Genus PORPHYROSIPHON Kuetzing.}

Tab. Phyc. 2: 7. pl. 27. f. I. I850-1852.

Filaments unbranched; sheaths firm, solid, lamellose, usually purple or flesh-colored; trichomes solitary within the sheath; apical cell not câpitate.

257. Porphyrosiphon notarisii (Meneghini) Kuetzing. Tab. Phyc. 2: 7. pl. 27. f. I. I850-1852. Gomont. Monogr. Oscill. 69. I893. De Toni. Syll. Algar. 5: 314. 1907.

Tilden. American Algae. Cent. I. no. 65 b. 1894. Collins, Holden and Setchell. Phyc. Bor.-Am. Fasc. 9. no. 402. 1898. West and West. A Further Contribution to the Freshwater Algae of the West Indies. Journ. Linn. Soc. Bot. 34: 288. 1898-1900.

\section{Plate V. fig. 55.}

Plant mass expanded, cushion-shaped, dark purple; filaments variously curved, densely entangled; sheaths purple, often colorless at the apex, sometimes showing layers of different colors, the outer ones colorless, firm, finally becoming very thick, lamellose, with the apex tapering and fibrillose; trichomes 8-19 mic. in diameter, usually constricted at joints; 
apical cell tapering, obtuse; cells 4.5-12 mic. in length; cell contents granulated, blue-green.

North America. (Trécul, Anderson). South Carolina. On clayey soil in damp "Black-jack" woods. Chester. January I898. (Green). West Indies. (Lenormand).

\section{Genus HYDROCOLEUS Kuetzing. Phyc. Gen. I96. I843.}

Plant mass forming a caespitose cushion, very rarely hardened with caicium carbonate, or caespitose but somewhat indefinite, or even not at all caespitose, but Phormidium-like; sheaths always colorless, cylindrical, somewhat lamellose, more or less mucous or somewhat amorphous, later entirely diffluent; trichomes few within the sheath, often loosely aggregated; apex of trichome straight, more or less tapering, capitate; outer membrane of apical cell thickened into a calyptra; cells shorter than the diameter of the trichome, in some species very short.

I Plants living in salt water.

I Plant mass caespitose

(I) Plant mass green becoming violet; sheaths cylindrical, moderately mucous; trichomes $14-21$ mic. in diameter

\section{H. comoides}

(2) Plant mass blackish green; sheaths irregular in outline, strongly mucous; trichomes $18-24$ mic. in diameter

H. cantharidosmus

2 Plant mass caespitose or forming an expanded mucous stratum, blackish green; sheaths irregular in outline, strongly mucous or even entirely diffuent; trichomes 8-16 mic. in diameter

H. lyngbyaceus

3 Plant mass mucous

(1) Plant mass yellowish brown or dull green; sheaths somewhat amorphous or entirely diffluent; trichomes $14-21$ mic. in diameter

H. glutinosus

(2) Plant mass pale blue-green; sheaths agglutinated, forming a diffluent, amorphous layer; trichomes $25-30 \mathrm{mic}$. in diameter

H. holdenii

II Plants living in fresh water

I Trichomes 6-8 mic. in diameter; apex of trichome gradually tapering, evidently capitate; cells somewhat quadrate or one-half the diameter of the trichome in length H. homoeotrichus

2 Trichomes I2 mic. in diameter; cells quadrate or two or three times shorter than the diameter

H. ravenelii

3 Trichomes 16-19 mic. in diameter; apex of trichome somewhat tapering, scarcely capitate; cells 2-5 times shorter than the diameter

H. heterotrichus

258. Hydrocoleus comoides (Harvey) Gomont. Monogr. Oscill. 73. pl. I2. f. 3-5. I893. De Toni. Syll. Algar. 5: 3I5. 1907. 
Mazé and Schramm. Essai Class. Algues Guadeloupe. 22. 1870-I877. (L. mucosa Crouan). Murray. Catalogue of the Marine Algae of the West Indian Region. Journ. of Bot. 27: 261. I889.

\section{Plate V. fig. 56.}

Plant mass up to $1.5 \mathrm{~cm}$. in height, cushion-shaped, hemispherical, caespitose, mucous, green becoming violet; filaments erect, often spirally twisted and entangled below, free and somewhat straight in upper portions, scarcely branched; sheaths wide, Lyngbya-like, regular in outline, lubricous, slightly mucous, sometimes lamellose and fibrillose, usually cpen at the end; trichomes $\mathbf{1 4 - 2 1}$ mic. in diameter, constricted at joints, few within the sheath, solitary in upper portion of filament; apex of trichome tapering, truncate; cells $3-5$ mic. in length; transverse walls granulated.

Bermudas. On the coast. (Farlow). West Indies. Guadeloupe. (Mazé).

259. Hydrocoleus cantharidosmus (Montagne) Gomont. Essai Class. Nostocacées homocystées. Morot. Journ. de Bot. 4: 353. I890; Monogr. Oscill. 74. p1. I2. f. 6, 7. 1893. De Toni. Syll. Algar. 5: 316. 1907.

Mazé and Schramm. Essai Class. Algues Guadeloupe. 27. 1870-1877. (L. c a n tharidosma Montagne, L. agglut in a t a Crouan, L. lati$1 \mathrm{imba}$ Crouan). Murray. Catalogue of the Marine Algae of the West Indian Region. Journ. of Bot. 27: 26r. I889. Vickers. Liste des Algues Marines de la Barbade. Ann. Sci. Nat. Bot. 1: 45. 1905.

\section{Plate V. fig. 57.}

Plant mass up to $2 \mathrm{~cm}$. in height, caespitose, lubricous, in dried specimens adhering to paper, olive or dark blue-green; filaments somewhat straight, moderately branched; false branches appressed; sheaths sometimes twice as thick as the trichome, very mucous, irregular and roughened in outline, agglutinated when dried, sometimes lamelloise, usually open at the apex; trichomes $18-24$ mic. in diameter, not constricted at joints, few within the sheath, somewhat parallel, solitary in upper portion of filament; apex of trichome tapering, truncate; cells 2-4 mic. in length; transverse walls sometimes granulated.

West Indies. Guadeloupe. (Mazé). Barbados. (Vickẹrs). Hawaii. Growing with other algae below high tide. Hanalei, Kauai. July 19oo. (Tilden).

260. Hydrocoleus lyngbyaceus Kuetzing. Species Algar. 259. I849. Gomont. Monogr. Oscill. 75. pl. I2, f. 8-Io. 1893. De Toni. Syll. Algar. 5: 317. 1907 .

Wolle. Fresh Water Algae. IV. Bull. Torr. Bot. Club. 7: 43. I880; Fresh-Water Algae U. S. 299. pl. 20r. f. 27-29. I887. (L. a I e n a ri u m (Kuetz.) Rab.). Wolle and Martindale. Algae. Britton's Catalogue of Plants found in New Jersey. Geol. Surv. N. J. 2: 608. 1889. Collins. Preliminary Lists of New England Plants.-V. Marine Algae. Rhodora. 2: 42. I900. Vickers. Liste des Algues Marines de la Barbade. Ann. Scí. Nat. Bot. VIII. I: 45. I905. 
Plate V. fig. 58.

Plant mass caespitose or mucous, widely expanded, dark green; filaments adnate, unbranched at base, branched in upper portions; false branches numerous, somewhat appressed; sheaths wide, mucous, roughened in outline, tapering or often open at apex, sometimes entirely diffluent and agglutinated; trichomes 8-16 mic. in diameter, not constricted at joints, numerous at base of filament, spirally.twisted and entangled, solitary in the branches; apex of trichome tapering, truncate; cells $2.5-4.5$ mic. in length; transverse walls granulated.

Massachusetts. (Collins). New Jersey. On moist low grounds near Atlantic City. (Wolle). Florida. (Smith). Bermudas. (Farlow). West Indies. Barbados. (Vickers).

Var. a. Gomont. 1. c. 76.

Setchell. Notes on Cyanophyceae.-I. Erythea. 4: 89. I896. Collins, Holden and Setchell. Phyc. Bor.-Am. Fasc. no. 204. 1896.

Plant mass caespitose, usually epiphytic; sheaths somewhat firm.

Massachusetts. Very abundant on the fronds of A scophyll u m nodos um in the harbor. Woods Hole. Summer of 1904. (Nott, Setchell).

Var. $\beta$ rupestre Kuetzing. 1. c. 259 . Gomont. 1. c. 76. De Toni. 1. c. 318.

Collins, Holden and Setchell. Phyc. Bor.-Am. Fasc. 5. no. 205. I8g6. Collins. Notes on New England Marine Algae.-VI. Bull. Torr. Bot. Club. 23: I. 1896. Collins. Preliminary Lists of New England Plants.-V. Marine Algae. Rhodora. 2: 42. 1900.

Plant mass expanded, mucous; sheaths entirely diffluent.

Maine. At first forming gelatinous sheaths on $\mathrm{Z}$ ostera and $\mathrm{R}$ u $\mathrm{p}$ pi a, afterwards floating masses, in warm water of tidal basin. Goose Cove, Rosier. July 1895. (Collins).

26r. Hydrocoleus glutinosus (Agardh) Gomont. Essai Class. Nostocacées homocystées. Morot. Journ. de Bot. 4: 353. I890; Monogr. Oscill. 77. 1893. De Toni. Syll. Algar. 5: 318. 1907.

Schramm and Mazé. Essai Class. Algues Guadeloupe. 30. I865. (O. f u s c o-r u bra Crouan). Mazé and Schramm. Essai Class. Algues Guadeloupe. I5. 1870-1877. Farlow. List Marine Algae U. S. Proc. Am. Acad. Arts Sci. ro: 380 . 1875. (L. nig re s cen s Harv.). Murray. Catalogue of the Marine Algae of the West Indian Region. Journ. of Bot. 27: 26r. I889. (O. g 1 ut in os a A. Br.). Collins, Holden and Setchell. Phyc. Bor.-Am. Fasc. Io. no. 453. 1898. Collins. Preliminary Lists of New England Plants.-VI. Marine Algae. Rhodora. 2: 42. I900; Phycological Notes of the late Isaac Holden.-II. Rhodora. 7: 223. I905. Vickers. Liste des Algues Marines de la Barbade. Ann. Sci. Nat. Bot. VIII. I: 45. 1905.

\section{Plate V. fig. 59.}

Plant mass not caespitose, mucous, indefinitely expanded or cylindrical in shape, yellowish brown or dull or yellowish green; sheaths very irregular in outline and somewhat amorphous, finally entirely diffluent; 
trichomes I4-2r mic. in diameter, not constricted at joints; apex of trichome tapering, truncate; cells $2.5-3.5$ mic. in length; transverse walls granulated.

Massachusetts. (Collins). Connecticut. Forming a P hor midiumlike coating on iron pillars between tide marks. Black Rock Beacon, near Bridgeport. July I892. (Holden). New York. Peconic Bay, Long Island. (Farlow). West Indies. Guadeloupe. (Mazé). Barbados. (Vickers).

262. Hydrocoleus holdenii Tilden. Rhodora. 3: 254. Igor. De Toni. Syll. Algar. 5: 319. 1907.

Holden. Two new species of Marine Algae from Bridgeport, Connecticut. Rhodora. I: 197. pl. 9. f. 7, 8. I899. (H. ma jus Holden). Collins, Holden and Setchell. Phyc. Bor.-Am. Fasc. I3. no. 602. I899. Collins. Preliminary Lists of New England Plants.-V. Marine Algae. Rhodora. 2. 42. 1900; Phycological Notes of the late Isaac Holden.-II. Rhodora. 7: 223. 1905.

Plate V. fig. 60, 6I.

Plant mass mucous, tubular, dark blue-green; sheaths agglutinated, forming mostly an amorphous, gelatinous, diffluent mass, from which the outer extermities of the trichomes project, naked or enveloped in broad ragged sheaths, or the trichomes escape entirely and become independent; trichomes 25-30 mic. in diameter, not constricted at joints; apex of trichome tapering, truncate; apical cell showing evident calyptra; cells 3-6 mic. in length; transverse walls granulated; cell contents blue-green.

Connecticut. Forming gelatinous tubular coatings on old $\mathrm{Spartina}$ stems in ditches of a salt marsh. Bridgeport. May 1896; Cook's Point, May, September. (Holden).

263. Hydrocoleus homoeotrichus Kuetzing. Phyc. Gen. 196. I843. Gomont. Monogr. Oscill. 82, pl. 13. f. 7-10. I893. De Toni. Syll. Algar. 5: 323. 1907.

Wolle. Fresh Water Algae. III. Bull. Torr. Bot. Club. 6: 183. 1877. (H. phormidioides Bulnh.). Setchell. Notes on some Cyanophyceae of New England. Bull. Torr. Bot. Club. 22: 429. I895.

$$
\text { Plate V. fig. 62, } 63 \text {. }
$$

Plant mass caespitose, floating, indefinite, expanded, lead-colored or black; filaments simple or sparingly branched, flexuous, more or less flexihle, entangled in tufts; sheaths lamellose, somewhat diffluent, cylindrical. roughened on the surface, transversely wrinkled, with open or pointed apex; trichomes 6-8 mic. in diameter, many within the sheath, parallel or twisted and entangled, sometimes solitary, not constricted at joints; apex of trichome gradually tapering, evidently capitate; apical cell depressed conical; cells 4-5.5 mic. in length; transverse walls frequently granulated; cell contents blue-green or lead-colored.

Connecticut. Growing in small short tufts on the posterior ends of shells of living fresh water mussels (A nod onta). Trading Cove Brook, 
Norwich. (Setchel1). Pennsylvania. On stones in rapid water; in sphagnum swamps. (Wolle).

264. Hydrocoleus ravenelii Wolle. Bull. Torr. Bot. Club. 6: I83. I877. De Toni. Syll. Algar. 5: 322. I907.

Plate V. fig. $64-65$.

Plant mass dark violet or blue-green; filaments 15 mic. in diameter, those containing two or more trichomes proportionately wider; sheaths of younger plants close and colorless, those of older plants thicker and firmer, golden brown in color, lamellose, with ends usually empty and sharply pointed; trichomes I2 mic. in diameter, of equal thickness, solitary or two or three somewhat twisted together in a common sheath; cells somewhat equal, or two or three times shorter than the diameter; cell contents blue-green changing to golden brown or chestnut.

Texas. Pasture grounds. Houston. (Ravenel).

265. Hydrocoleus heterotrichus Kuetzing. Gomont. Monogr. Oscill. 80. pl. 13. f. 3, 4. I893. De Toni. Syll. Algar. 5: 320. I907.

Wolle. Fresh Water Algae. Bull. Torr. Bot. Club. 6: 283. I879; FreshWater. U. S. 307. pl. 205. f. 2-5. I887.

Plate V. fig. 66.

Plant mass about $5 \mathrm{~mm}$. in height, caespitose, blackish; filaments adnate, short, in basal portion trunk-like, broadening out towards the apex, then divided and repeatedly branched; false branches more or less widely diverging, flexuous; sheaths somewhat close, somewhat mucous, irregular and roughened in outline, broadened out in middle portion of filament, gradually tapering towards the apex, pointed, open or closed, transversely wrinkled; trichomes 16 -19 mic. in diameter, many within the sheath, closely dggregated, straight or spirally tangled and twisted, sometimes solitary, not constricted at joints; apex of trichome very slightly tapering, scarcely capitate, truncate; cells $3.4-4.5$ mic. in length; cell contents finely granular.

Pennsylvania. In swamp. Near Bethlehem. (Wolle).

Genus HYPHEOTHRIX Kuetzing. Phyc. Gen. 229. I843.

Plants living on moist earth or dripping rocks; filaments prostrate, commonly slightly branched, woven into a more or less compact mass; sumetimes hardened with calcium carbonate; sheaths always colorless.

I Filaments very much twisted, scarcely flexible, ruptured if disentangled.

I Plant mass thin, somewhat gelatinous, papery-membranaceous, very hard when dry, not encrusted with calcium carbonate; sheaths firm; trichomes I-I.7 mic. in diameter, usually one or two within the sheath

H. calcicola

2 Plant mass flocculent, waving, light fawn-colored; filaments I.2-I.8 mic. in diameter; sheaths inconspicuous; transverse walls not visible

H. hinnulea 
3 Plant mass forming a small mat; filaments $1.5-2$ mic. in diameter; sheaths closely adherent, entirely diffluent

H. gloeophila

4 Plant mass thin, cushion-shaped, mucous; filaments I.8-2.2 mic. in diameter; sheaths close

H. herbacea

5 Plant mass sometimes expanded, forming loosely interwoven masses or small cushion-shaped clusters; filaments 3.5-4 mic. in diameter; sheaths firm, close

H. tenax

6 Plant mass somewhat spherical, hollow, tough, yellowish or light straw-colored; filaments 4-6 mic. in diameter; trichomes $1.5-2$ mic. in diameter

H. bullosa

7 Plant mass compact, leathery, brick-colored; filaments up to 7.5 mic. in diameter; sheaths wide, membranaceous, firm, homogeneous, smooth; trichomes 3.2-4 mic. in diameter, here and there interrupted

H. turicensis

8 Plant mass more or less expanded, olive green; filaments 8-I I mic. in diameter; sheaths moderately wide; trichomes $3.5 \mathrm{mic}$. in diameter, here and there interrupted, often constricted at joints

H. aikensis

Il Filaments long and flexible, disentangled without rupturing

I Plant mass encrusted with calcium carbonate; trichomes I-I.7 mic. in diameter; cells longer than the diameter $\mathbf{H}$. coriacea

2 Plant mass not encrusted with calcium carbonate; trichomes I.5-2 mic. in diameter; cells longer than the diameter

H. lardacea

3 Plant mass not encrusted with calcium carbonate; trichomes I.5-3 mic. in diameter; cells longer than the diameter

H. arenaria

4 Plant mass compact, leathery, roughened; trichomes 2.3-2.8 mic. in diameter; cells a little shorter than the diameter

H. vulpina

5 Plant mass membranaceous, firm, smooth, pale rose or dark red; trichomes $5.6-8.3$ mic. in diameter; cells somewhat quadrate

H. pallida

266. Hypheothrix calcicola (Agardh) Rabenhorst. F1. Eur. Algar. 2: 78. I865. Gomont. Monogr. Oscill. 45. pl. 8. f. I-3. I893. (S ch izoth rix calcicola Gom.). De Toni. Syll. Algar. 5: 327. 1907.

Anderson and Kelsey. Common and conspicuous Algae of Montana. Rull. Torr. Bot. Club. I8: 145. I89I. (L e p tothrix calcicola Kg.). Saunders. Protophyta-Phycophyta. Flora of Nebraska. 21. pl. 2. f. I9. I894 Tilden. American Algae. Cent. II. no. I80. I896; (P. purpuras cens (Kuetz.) Gom.); On some Algal Stalactites of the Yellowstone National Park. Bot. Gaz. 24: 197. pl. 8. f. 3, 4. 1897; Observations on some West American Thermal Algae. Bot. Gaz. 25: 98. I898. Collins, Holden and Setchell. Phyc. Bor.-Am. Fasc. I2. no. 557. I899. 


\section{Plate VI. fig. I-4.}

Plant mass not encrusted with calcium carbonate, somewhat gelatinous, very hard when dry, papery-membranaceous, black or rarely yellowish blue-green; filaments short, very much twisted and entangled, rarely branched; sheaths firm, somewhat cartilaginous, tapering at the apex, at first somewhat close, cylindrical, enclosing one trichome, later becoming thicker, somewhat lamellose, irregular and roughened in outline, enclosing two or rarely many trichomes; trichomes I-I.7 mic. in diameter, not constricted at joints; cells $2-6$ mic. in length; transverse walls sometimes marked by two protoplasmic granules; cell contents pale blue-green.

Massachusetts. On walls of greenhouse. Botanic Garden, Cambridge. January 1899. (Collins). Nebraska. In greenhouse at the University. (Saunders). Montana. Common everywhere all the year, on damp or dripping rocks. (Anderson and Kelsey). Wyoming. Together with Synechococcus aeruginosus and Gloeocapsa violacea, forming black "stalactites," I-T.5 dm. long and .5 dm. in diameter, or serrated, suspended masses or extended sheets. These hung from the top and lined the walls of a small cave in which was the vent of a hot spring. At short intervals they received jets of steam and a spray of hot water. Valley of Nez Perces Creek, Lower Geyser Basin, Yellowstone National Park. June I8g6. (Tilden).

267. Hypheothrix (?) hinnulea (Wolle). De Toni. Syll. Algar. 5: 336. 1907.

Wolle. Fresh Water Algae. III. Bull. Torr. Bot. Club. 6: I82. I877. (B eggiatoa hinnulea Wolle); Fresh-Water Algae U. S. 320. pl. 208. f. 5. I887. Tilden. American Algae. Cent. I. no. 69. I894. (L y n g b y a h in nule a (Wolle) (Tilden); List of fresh-water Algae collected in Minnesota during I894. Minn, Bot. Studies. I: 235. I895.

Plant mass flocculent, caespitose, waving, $6 \mathrm{~mm}$, in thickness, light fawn-colored; filaments I.2-I.8 mic. in diameter, IO-I5 $\mathrm{mm}$. in length, flexible and contractile; sheaths' inconspicuous; transverse walls not visible; cell contents colorless or light yellowish brown.

Pennsylvania. In trenches for warm waste water from steam engines. (Wolle). Minnesota. Collected in masses around the inlet pipe in tanks in Zoological laboratory. University of Minnesota, Minneapolis. November I894. (Tilden).

268. Hypheothrix gloeophila (Kuetzing) Rabenhorst. Fl. Eur. Algar. 2: 77. 1865. De Toni. Syll. Algar. 5: 331. I907.

Plant mass forming a small mat; filaments $1.5-2$ mic. in diameter, sometimes solitary, usually slightly curved and entangled; sheaths closely adherent, entirely diffluent; cells once and a half longer than their diameter; cell contents pale, almost colorless.

Greenland. (Richter).

269. Hypheothrix herbacea Kuetzing. Phyc. Gen. 199. 1843. De Toni. Syll. Algar. 5: 328. I907. 
Wolle. Fresh-Water Algae U. S. 320. pl. 208. f. 13. I887. (L e p t ot h r ix he r b a c e a Kg.).

Plant mass thin, somewhat cushion-shaped, mucous, bright green, more or less faded underneath; filaments I.8-2.2 mic. in diameter, very slender, slightly flextrously curved, entangled; sheaths very close, colorless; cells here and there distinct.

South Carolina. Very abundant on the wood-work around the artesian well. Charleston. (Wolle).

270. Hypheothrix tenax Wolle. Fresh Water Algae. Bull. Torr. Bot. Club. 6: 282. 1879; Fresh-Water Algae. U. S. 3I9. pl. 203. f. 2. I887. (L e p tothrix tenax Wolle). De Toni. Syll. Algar. 5: 329. 1907 .

Plant mass sometimes expanded, forming loosely interwoven masses $1.5 \mathrm{dm}$. or more in diameter, at other times forming small, caespitose, cushion-shaped clusters; filaments 3.5-4 mic. in diameter, slender but strong and tough, often forming firm membranes; sheaths colorless, firm, close; transverse walls not always visible; cells about as long as wide; cell contcnts primarily light blue-green, soon changing to dull yellow or light brown.

Pennsylvania. On stones in stagnant water. (Wolle).

271. Hypheothrix bullosa Wolle. Fresh Water Algae. III. Bull. Torr. Bot. Club. 6: I82. I877; Fresh-Water Algae U. S. 32I. pl. 208. f. I9. I887. (Leptothrix bullos a Wolle). De Toni. Syll. Algar. 5: 329. 1907 .

Plant mass $4-8 \mathrm{~mm}$. in diameter, somewhat spherical or oval, hollow, tough, gregarious, dilute straw color or yellowish white; filaments 4-6 mic. in diameter, unbranched, densely interwoven; sheaths colorless; trichomes 1.5-2 mic. in diameter; cell contents pale blue-green, often faded and contracted.

Pennsylvania. Shallow, sluggish water, Susquehanna River, Harrisburgh. (Wolle).

272. Hypheothrix turicensis Naegeli in Kuetzing. Spec. Algar. 269. 1849.

De Toni. Syll. Algar. 5: 333. 1907.

Wolle. Fresh Water Algae. III. Bull. Torr. Bot. Club. 6: 182. I877.

Plant mass compact, leathery, irtegularly roughened, brick-colored, within faded or dull green; filaments up to 7.5 mic. in diameter; sheaths wide, membranaceous, firm, homogeneous, colorless, very smooth, tapering at apex; trichomes 3.2-4 mic. in diameter, thick, flexuously curved, here and there interrupted; cells a little shorter than the diameter; transverse walls sometimes indistinct; cell contents sometimes granular, dark or pale blue-green.

Pennsylvania. Moist rocks. (Wolle).

273. Hypheothrix aikenensis Wolle. Fresh Water Algae. III. Bull. Torr. Bot. Club. 6: 182. I877. De Toni. Syll. Algar. 5: 329. 1907.

Plant mass more or less expanded, olive green; filaments 8-II mic. 
in diameter, tenacious, curved, very densely entangled; sheaths moderately wide, colorless, pellucid; trichomes 3.5 mic. in diameter, here and there interrupted, often constricted at joints; cells $3.5-7$ mic. in length; cell contents pale blue-green.

South Carolina. Sluggish water. Aiken. (Ravenel).

274. Hypheothrix coriacea Kuetzing. Spec. Algar. 267. I849. Gomont. Monogr. Oscill. 47. pl. 8. f. 6, 7. I893. ( $\mathrm{Schiz}$ oth $\mathrm{rix}$ coriacea Gom.). De Toni. Syll. Algar. 5: 336. 1907.

Dickie. On the Algae found during the Arctic Expedition. Journ. Linn. Soc. Bot, 17: 8. I880. Collins, Holden and Setchell. Phyc. Bor.-Am. Fasc. I4. no. 654. Igoo. ( $\mathrm{Sch}$. c ori a c a (Kg.) Gom.). Collins. The Algae of Jamaica. Proc. Am. Acad. Arts Sci. 37: 240. 1901. Collins, Holden and Setchell. Phyc. Bor.-Am. Fasc. 18. no. 855. 1901. Collins. Phycological Notes of the late Isaac Holden.-II. Rhodora. 7: 236. I905.

Plate VI. fig. 2.

Plant mass up to $1.5 \mathrm{~cm}$. in thickness; widely expanded, encrusted with calcium carbonate, crustaceous, leathery, roughened on the surface, green becoming reddish, rose- or brick-colored on the outside, faded within; filaments very densely entangled, scarcely to be separated without rupturing, very long and soft, usually moderately branched; sheaths cylindrical, firm, somewhat close, slightly roughened, not lamellose, with very gradually tapering apices; trichomes I-I.7 mic. in diameter, few within the sheath, somewhat parallel or solitary, constricted at joints; apical cell acute-conical; cells 3-6 mic. in length; transverse walls indistinct; rarely granulated; cell contents pale blue-green.

Arctic Regions. Walrus Island, 79 ${ }^{\circ} 5^{\prime}$ N. (Dickie). Connecticut. Forming a felty stratum of yellowish or orange tint, on moist limestone rocks, shore of Housatonic River, near Gaylordsville. October 1898 and April i899. (Holden). California. Mixed with other algae, forming a thin layer on the side of a watering trough. Dillon's Beach, Entrance to Tomales Bay, Marin County. December 1898. (Setchell and Gibbs). West Indies. In tufts on sides of lily tanks. Botanic Garden, Castleton, Jamaica. April I893. (Humphrey).

Forma meneghinii Kuetzing. 1. c. 268. De Toni. 1. c. 337.

Wolle. Fresh Water Algae. III. Bull. Torr. Bot. Club. 6: I82. I877.

Plant mass usually somewhat thick, pale red or flesh-colored; sheaths 2.8-4 mic. in thickness, up to four times thicker than the filaments.

New Jersey. Damp earth. (Austin).

275. Hypheothrix lardacea (Cesati) Hansgirg in Dalla Torre und Sarnth. Alg. v. Tyr. Vorarl, u. Liechtenst. 96. Gomont. Monogr. Oscill. 49. pl. 8. f. 8, 9. 1893. ( $\mathrm{Schiz}$ oth $\mathrm{rix} 1 \mathrm{ardac}$ a Gom.). De Toni. Syll. Algar. 5: 340. 1907.

Collins, Holden and Setchell. Phyc. Bor.-Am. Fasc. 3. no. 105. I895. (S. 1 a rdace a (Ces.) Gom.). Setchell. Notes on some Cyanophyceae of New England. Bull. Torr. Bot. Club. 22: 429. I895.

Tilden. American 
Algae. Cent. II. no. I76. I896; List of Fresh-Water Algae collected in Minnesota during 1896 and 1897. Minn. Bot. Studies. 2: 28. I898. Saunders. The Algae. Harriman Alaska Expedition. Proc. Wash. Acad. Sci. 3: 396. I90I. Collins, Holden and Setchell. Phyc. Bor.-Am, Fasc. 20. no. 955. 1902. Collins. Phycological Notes of the late Isaac Holden.-II. Rhodora. 7: 236. 1905.

\section{Plate VI. fig. 3 .}

Plant mass up to $3 \mathrm{~cm}$. in thickness, expanded, not encrusted with calcium carbonate, hard and elastic, composed of layers more or less uniform in color, dull or olive green or reddish; flaments soft, very long, twisted, not or but little branched, separated without rupturing; sheaths cylindrical, firm, contracted or pointed at the apex, at first close and smooth, finally becoming thicker and roughened; trichomes I.5-2 mic. in diameter, few within the sheath, frequently solitary, somewhat parallel, in living specimens not constricted at joints; cells $2-3$ mic. in length; transverse walls usually marked by protoplasmic granules; cell contents pale blue-green.

Alaska. Prince William Sound. June I899. (Saunders). Forming bloodred gelatinous patches on smooth, wet, vertical rocks. Cascades, near Iliuliuk. June I899. (Setchell and Lawson). Forming bright rose-red tufts on rocks exposed to fresh water spray. Near Orca, Prince William Sound. (Setchell). Connecticut. On vertical surface of dripping rock. East Rock, New Haven. November. (Holden). Forming rather gelatinous, rusty or dirty green patches on wet vertical faces of trap rock. East Rock, New Haven. December I89I. (Setchell). Minnesota. In a bottle of distilled water left standing for several months. Botanical Laboratory, University of Minnesota. 1896. (Determined by M. Gomont).

276. Hypheothrix arenaria (Berkeley). De Tóni. Syll. Algar. 5: 342. I907. Gomont. Monogr. Oscill. 50. pl. 8. f. II, I2. I893. (S chizot hrix arenaria Gom.).

\section{Plate VI. fig. 4.}

Plant mass thin, somewhat fragile, not encrusted with calcium carbonate, blue-green; filaments firm, strongly flexuous, closely entangled, below trunk-shaped, towards the apex divided and branched; false branches strongly twisted and entangled; sheaths firm, roughened in outline, tapering at the apex, thick and lamellose in the lower parts; trichomes $1.5-3$ mic. in diameter, few in the lower part of the filament, loosely aggregated, somewhat parallel, often solitary in the branches, constricted at the joints (in dried specimens); apical cell acute-conical; cells up to $5 \mathrm{mic}$. in length; cell contents pale blue-green.

United States. (Setchell).

277. Hypheothrix vulpina Kuetzing. Spec. Algar. 267. I849. De Toni. Syll. Algar. 5: 338. 1907.

Dickie. On the Algae found during the Arctic Expedition. Journ. Linn. Soc. Bot. I7: 8. I880.

Plant mass compact, leathery, opaque, roughened, reddish or dull olive, 
becoming darker in color; sheaths close, delicate, colorless; trichomes 2.32.8 mic. in diameter, slightly curved, loosely entangled; cells a little shortel than the diameter; transverse walls distinct, slightly granulated; cell contents pale becoming darker.

Arctic Regions. Marshy spots on land, $82^{\circ} 27^{\prime}$ N. (Dickie).

278. Hypheothrix pallida Kuetzing. Spec. Algar. 893. 1849. De Toni. Syll. Algar. 5: 339. 1907.

Wolle. Fresh Water Algae. III. Bull. Torr. Bot. Club. 6: I82. I877; Fresh-Water Algae U. S. 298. p1. 202. f. 26-3I. 1887. (L. p a 11 i da (Naeg.) Wolle). Wolle and Martindale. Algae. Britton's Catalogue of Plants found in New Jersey. Geol. Surv. N. J. 2: 608. I889.

Plant mass membranaceous, firm, somewhat smooth, pale rose or dark red in color; filaments $40-80$ mic. (?Wolle) in diameter; sheaths very wide, at first homogeneous, finally becoming lamellose and fibrillose; trichomes 5.6-8.3 mic. in diameter, rather straight or sightly curved, somewhat parallel or sometimes flexuously curved and interwoven; cells somewhat quadrate, here and there slightly swollen; cell contents faded or yellowish brown.

New Jersey. Forming reddish-brown stratum on dry ground. (Austin). On wet soil and old meadow grounds. (Wolle).

Genus SYMPLOCASTRUM Gomont. Monogr. Oscill. 52. I893.

Plants terrestrial or living on damp rocks; filaments twisted and entangled, ascending from a prostrate base, agglutinated together in erect fascicles; sheaths colorless.

I Plant mass blue-green; trichomes 1.4-2 mic. in diameter, constricted at the joints; cells shorter than the diameter $\mathbf{S}$. fragile

II Plant mass flesh-colored or reddish; trichomes I.6-2 mic. in diameter; cells usually longer than the diameter S. rubrum

III Plant mass gray or yellowish; trichomes I.9-2.3 mic. in diameter; cells longer than the diameter

S. cuspidatum

IV Plant mass blackish, olive or lead-colored; trichomes 3-6 mic. in diameter; cells somewhat quadrate or longer than the diameter

\section{S. friesii}

279. Symplocastrum fragile (Kuetzing). De Toni. Syll. Algar. 5: 347. I907. Gomont Monogr. Oscill. 52. p1. 8. f. I3, I4. I893. (S c h iz ot h rix f r a gil is ( $\mathrm{Kg}$.) Gom.).

Collins, Holden and Setchell. Phyc. Bor.-Am. Fasc. 3. no. I04. I895. Setchell. Notes on some Cyanophyceae of New England. Bull. Torr. Bot. Club. 22: 429. I895.

\section{Plate VI. fig. 5 .}

Plant mass up to I mm. in thickness, pannose, tomentose, olive or blue-green; filaments flexuous, entangled, more or less. parallel, finally becoming united into short, erect fascicles; sheaths irregular in outline, some- 
what diffuent; trichomes I.4-2 mic. in diameter, constricted at joints, at the base of the filament often numerous and closely crowded within the sheath; cells I-2.5 mic. in length; protoplasm floccose, not granular, pale blue-green.

Connecticut. Forming a reddish, closely adherent crust on stones kept moist by the spray from a waterfall, by dam across Still River, Brookfield. May I892. ("The red color was due to a unicellular organism associated with it"). (Setchell).

280. Symplocastrum rubrum (Meneghini) De Toni. Syll. Algar. 5: 350. I907. Gomont. Monogr. Oscill. 53. p1. 8. f. I5, I6. I893. (S c h izoth rix rubra Gom.).

Setchell and Gardner. Algae of Northwestern America. Univ. Calif. Pub. Bot. I: 189. 1903.

Plate VI. fig. 6.

Plant mass caespitose, flesh-colored, reddish or becoming dark colored; filaments elongate, divided and branched into numerous appressed portions, in lower parts twisted and entangled, above less flexuous, parallel, forming short, erect, pointed tufts at the apex; sheaths cylindrical, firm, wide, somewhat lamellose, slightly roughened on the surface, frequently transversely wrinkled at the base with a very long, pointed apex; trichomes I.6-2 mic. in diameter, constricted at joints (in dried specimens), few or often solitary within the sheath; apical cell rotund; cells $2-3.5$ mic. in length; transverse walls often granulated; cell contents pale reddish.

Alaska. Forming scum on deep pool of fresh water. Glacier Valley, Unalaska. (Lawson).

281. Symplocastrum cuspidatum (West and West). De Toni. Syll. Algar. 5: 349. 1907 .

West and West. On some Freshwater Algae from the West Indies. Journ. Linn. Soc. Bot. 30: 273. p1. I6. f. I-7. 1895. (S y m p lo c a c u s p i datu $\mathrm{m}$ W. and W.).

Plate VI. fig. 7-9.

Plant mass widely expanded, gray or yellowish; fascicles 8-I5 mm. in height, erect, narrow, awl-shaped, aggregated, here and there dense, becoming bluish green; sheaths colorless, transparent or forming parallel layers, often roughened in outline, narrower and often branched at the apex; trichomes $1.9-2.3$ mic. in diameter, flexuous, entangled, oftan interrupted, narrower in the mass, at the apex of the fascicles one to three included in the wide sheath, 13.5-25 mic. in diameter; cells 3.8-9 mic. in length; transverse walls distinct; cell contents blue-green.

West Indies. Specimens resembling Sphagnum cuspidatum. Occurring among mosses on trees. Summit of Trois Pitons (450o feet), Dominica. (Elliott).

Var. luteo-fusca West and West. A Further Contribution to the Freshwater Algae of the West Indies. Journ. Linn. Soc. Bot. 34: 288. I8981900. De Toni. 1. c. 349. 
Plant mass I-2 mm. in height; rust-colored, dense; fascicles 4-10 mm. in height; sheaths $15-40$ mic. in thickness, often surrounding two, three or many trichomes; trichomes 2.5-3.5 mic. in diameter.

West Indies. On rocks. Roseau Valley (1000-2000 ft.), Dominica; on tark, windward road to lake, Dominica; on the ground, mostly in old Diablotia holes, Morne Anglais (2300 ft.). (Elliott).

282. Symplocastrum friesii (Agardh) Kirchner in Engler and Prantl. Die natürlichen Pflanzenfamilien. I. I. a. 68. f. 53. I90o. Gomont. Monogr. Oscill. 54. pl. 9. f. I, 2. I893. (S chizoth rix friesii Gom). De Toni. Syll. Algar. 5: 347. 1907.

Wolle. Fresh Water Algae. II. Bull. Torr. Bot. Club. 6: I38. I877. (S y mploca 1 u c if ug a Bréb.); Fresh Water Algae. III. Bull. Torr. Bot. Club. 6: 183. I877. (Sy m ploc a friesian a Kg.); Fresh-Water Algae U. S. 303. p1. 205. f. 8; 304. pl. 205. f. I3. I887. Moebius. Ueber einegé in Portorico gesammelte Süsswasser- und Luft-Algen. Hedwigia. 27: 246. 1888. Wolle and Martindale. Algae. Britton's Catalogue of Plants found in New Jersey. Geol. Surv. N. J. 2: 608. I889. Collins, Holden and Setchell. Phyc. Bor.-Am. Fasc. II. no. 503. I898.' Collins. Notes on Algae. I. Rhodora. I: 10. 1899.

\section{Plate VI. fig. 10.}

Plant mass indefinite, expanded, black or olive or lead-colored; filaments in lower portions twisted and entangled, in upper parts somewhat straight, parallel, dichotomously divided and branched into appressed portions, forming rigid, erect, spine-shaped tufts $3 \mathrm{~cm}$. or more in height; sheaths cylindrical, firm, pointed at the apex, lamellose, smooth or a little roughened in outline; trichomes 3-6 mic. in diameter, evidently constricted at the joints, few or solitary within the sheath, parallel; apical cell truncate conical; cells 4-II mic. in length; cell contents coarsely granular (except in apical cell).

Canada, On old wood. (Macoun). United States. (Farlow). Maine. On ground in woods at the base of Mount Kineo. July 1897. (Collins). Massachusetts. On damp ground. August 1898; abundant in paths and by roadsides. Lynnwoods, Middlesex Fells. I899. (Collins). New Jersey. On shaded clay banks. Bergen. (Wolle). West Indies. Growing tipon moss. On Mt. Jimenez, Sierro de Luquillo, Porto Rico. (Sintenis).

Genus INACTIS Kuetzing. Tab. Phyc. I: 44. 1845-I849.

Plants growing in moist places or in rivers; filaments caespitose, often with numerous false branches, forming cushions which finally often hecome encrusted with calcium carbonate and hardened, zonate within, or aggregated into penicillate, floating fascicles; sheaths colorless or nearly so.

I Plant mass cushion-shaped, tufted

I Plant mass strongly encrusted with calcium carbonate, stony; fila. ments straight, somewhat simple; trichomes I-2 mic. in diameter; cells somewhat quadrate

I. pulvinata 
2 Plant mass strongly encrusted with calcium carbonate, stony; filaments slender, simple in basal portions, fasciculately branched above; trichomes 1.4-3 mic. in diameter; cells somewhat quadrate or longer than the diameter

I. fasciculata

3 Plant mass cushion-shaped or crustaceous, not hardened with calcium carbonate; filaments forming trunk at base, very much branched in upper portions; trichomes I-I.5 mic. in diameter; cells longer' than the diameter

I. lacustris

4 Plant mass somewhat hemispherical, plano-convex; filaments more or less branched, growing in tufts; cells two or three times longer than broad

I. austini

II Plant mass forming penicillate fascicles, floating.

I Plant mass submerged, attached; filaments very long; trichomes I.4-2.4 mic. in diameter, constricted at joints

\section{I. tinctoria}

2 Plant mass submerged, epiphytic on other algae; trichomes 3-6 mic. in diameter, usually constricted at joints I. simmonsiae

3 Plant mass submerged, attached; filaments very long; trichomes 6 mic. in diameter, constricted at joints I. mexicana

III Filaments solitary, growing in gelatinous mass formed by other algae; trichomes I.5-2 mic. in diameter, not constricted at joints

I. hawaiensis

283. Inactis pulvinata Kuetzing. Tab. Phyc. I: 44. pl. 77. f. 3. I845-1849. Gomont. Monogr. Oscill. 36. I893. (S chiz ot h r ix pulvinata Gom.). De Toni. Syll. Algar. 5: 350. I907.

$$
\text { Plate VI. fig. II-I3. }
$$

Plant mass cushion-shaped or crustaceous, stony, hardened with calcium carbonate, uneven or mammillate, blue-green on the outer surface, zonate within; filaments straight, rigid, parallel, coalesced or closely crowded, moderately branched; false branches entirely appressed; sheaths papery, with pointed apex; trichomes I-2 mic. in diameter, constricted at joints, more or less numerous within the sheath; cells somewhat quadrate or twice as long as broad; cell contents pale blue-green.

North America. In cataracts. (Anderson).

284. Inactis fasciculata (Naegeli) Grunow in Rabenhorst. Fl. Eur. Algar. 2: 160. I865. Gomont. Monogr. Oscill. 36. pl. 6. f. I-3. I893. (S c h izothrix fasciculat a Gom.). De Toni. Syll. Algar. 5: 35 I. 1907.

Murray. Calcareous Pebbles formed by Algae. Phyc. Mem. Part III. 74. pl. 19. 1895. Setchell. Notes on Cyanophyceae-I. Etythea. 4: 89. I896. Pennhallow. Note on Calcareous Algae from Michigan. Bot. Gaz. 2I : 215. I896. MacMillan. Minnesota Plant Life. 4r. 1899. Tilden. American Algae. Cent. VI. no. 585. I902. Powell. Observations on some Calcareous Pebbles. Minn. Bot. Studies. 3: 75. p1. I6. f. 8, 9; p1. I7. f. I-5. I903. 
Plate VI. fig. I4, I5.

Plant mass cushion-shaped, stony, hardened with calcium carbonate, becoming confluent into a crustaceous, mammillate layer, blue-green, fleshcolored or brownish on the surface, zonate within; filaments slender, flexuous, closely entangled, forming a trunk-shaped basal portion narrower at the base, thicker above, branched and divided into many parts at the apex; false branches fasciculate, somewhat appressed; sheaths somewhat thick, with pointed apex; trichomes 1.4-3 mic. in diameter, constricted at the joints, many in the trunk-shaped basal portion, few or solitary in the branches; apical cell acute conical; cells I.2-3.5 mic. in length; cell contents pale blue-green.

Connecticut. Mixed with other algae. Twin Lakes, near Salisbury. (Setchell). Michigan. Pebbles found in a pond on the shore of Lake Michigan. (Velie). Minnesota. Forming calcareous pebbles, which were found lying in from four to ten feet of clear water on sand-bars. Clearwater Lake, Wright County. June Igor. (Freeman and Lyon). "These pebbles range in size from that of a small hickory nut to two inches in diameter. Most of them are flattened, and though comparatively smooth in same cases, are often rough, corrugated and wave-worn. All are more or less hollow. In section they have a distinctly stratified appearance." * * * They "were found to be composed of a densely interwoven mass of filaments of which the most common type was that of S. fasciculata Gom."-Powell.

285. Inactis lacustris (A. Braun) De Toni. Syll. Algar. 5: 354 I907. Gomont. Monogr. Oscill. 39. pl. 6. f. 9-I2. 1893. (S c hiz ot hrix lacustris A. Br.).

Collins, Holden and Setchell. Phyc. Bor.-Am. Fasc. 15. no. 712. I900. Saunders. The Algae. Harriman Alaska Expedition. Proc. Wash. Acad. Sci. 3: 397. I90I.

Plate VI. fig. I6.

Plant mass cushion-shaped or crustaceous, not at all or scarcely hardened with calcium carbonate, dull yellowish green; filaments flexuous, closely crowded, forming a trunk-shaped basal portion narrower at the base, broadened towards the apex, branched and divided into many parts at the apex; false branches twisted, entangled, or somewhat parallel; sheaths colorless, wide, very wide in the lower part of the flament; trichomes I-I.5 mic. in diameter, constricted at the joints, many in the trunkshaped basal portion, remote, often spirally twisted, few or solitary in the branches; cells up to 4 mic. in length; cell contents pale blue-green.

Alaska. In a fresh water pool. Near Prince William Sound. June I8g9. (Saunders). Connecticut. On sandy ground near "Fresh Pond" (brackish). Stratford. December 1897. (Holden).

Var. caespitosa Gomont. 1. c. 39. De Toni. 1. c. 354 .

Hauck and Richter. Phyk. Univ. no. 74I, I886-1889. (S. 1 a c us t $\mathrm{r}$ is c a espitos a Gom.). Collins. Algae. Flora of the Blue Hills, Middlesex Fells, Stony Brook and Beaver Brook Reservations of the Metropoli- 
tan Park Commission, Massachusetts. 126. 1896.

Collins, Holden and

Setchell. Phyc. Bor.-Am. Fasc. 5. no. 206. I 896.

Filaments forming $a^{\prime}$ very thick, trunk-shaped basal portion; false branches short.

Massachusetts. On stones along the margin of Spot Pond, Middlesex Fells; on stones at the water's edge, Peabody, Suntaug Lake, August I890; Tynnfield, Suntaug Lake, September I8go. (Collins).

286. Inactis austini Wolle. Fresh Water Algae. III. Bull. Torr. Bot. Club. 6: 183. 1877. De Toni. Syll. Algar. 5: 351. 1907.

Plant mass somewhat hemispherical, plano-convex, 3-7.5 mic. in diameter, often aggregated, diffluent, brown becoming blackish green; filaments firm, cylindrical; more or less branched, growing in tufts; sheaths colorless, very close; cells two or three times longer than broad; transverse walls usually distinct; cell contents dark blue-green.

New Jersey. Wet rocks. Little Falls. 1867. (Austin).

287. Inactis tinctoria (Agardh) Thuret. Essai Class. Nostochinées. Ann.

Sci. Nat. Bot. VI. I: 379. 1875. Gomont. Monogr. Oscill. 4I. pl. 7. f. 5-7. I893. (Schizothrix tinctoria Gomont.). De Toni. Sy11. Algar. 5: 356. 1907 .

Wolle. Fresh Water Algae. III. Bull. Torr. Bot. Club. 6: I83. I877. ( $\mathrm{Hydrocoleum}$ tinctorium A. Br.); Fresh Water Algae. Bull. Torr. Bot. Club. 6: 282. 1879. (H y phe othrix tinctoria Rabenh.); Fresh-Water Algae U. S. 32I. pl. 208. f. 16. I887. (L e ptothrix tincto ria Kg.). Bessey, Pound and Clements. Additions to the Reported Flora of the State. Bot. Surv. Nebraska. 5: I3. Igor.

Plate VI. fig. I7.

Plant mass continuous, soft, mucous, attached to submerged plants, blue-green or violet; filaments very long, flaccid, floating in free tufts, with penicillate apices, unbranched in lower portions, branched above; sheaths narrow, not lamellose, somewhat diffuent; trichomes 1.4-2.4 mic. in diameter, especially constricted at the joints, in basal part of filament numercus within the sheath, more or less spirally twisted, in the branches few and straight; apical cell rotund; cells $1.4-3$ mic. in length.

Pennsylvania. On aquatic plants. (Wolle). Nebraska. On Cladophora. Fisher's Lake, Glen Rock. (Bessey, Pound and Clements).

288. Inactis simmonsiae (Collins) De Toni. Syll. Algar. 5: 356. 1907. Collins, Holden and Setchell. Phyc. Bor.Am. Fasc. 15. no. 707. 1900. (Schizothrix simmonsiae Collins). Collins. New Species, etc., issued in the Phycotheca Boreali-Americana. Rhodora. 8: 105. Ig06.

Plants living in salt water; plant mass forming a brownish tufted coating on various algae (showing reddish brown when moistened, pinkish under the microscope); tufts $\mathrm{I}-2 \mathrm{~cm}$. long; sheaths thin, distinct; trichomes $3^{-6}$ mic. in diameter, much constricted at joints, usually single within the sheath, but often several in basal portion, sometimes irregularly swollen 
and distorted as if doubling up in the sheath; cells .6-2 mic. in length; cell contents pale green.

Rhode Island. On algae in high rock pool. Easton's Point, Newport. December 1897. (Simmons).

289. Inactis mexicana (Goment) De Toni. Syll. Algar. 5: 356. I907. Gomont. Monogr. Oscill. 42. I893. ( $\mathrm{cch}$ izothrix mexicana Gom.).

Collins. The Algae of Jamaica. Proc. Am. Acad. Arts Sci. 37: 240. I901.

Plant mass continuous, soft, attached to submerged plants; filaments very long, flaccid, floating in free tufts, with penicillate apices, twisted, entangled, unbranched in lower portions, fasciculately branched, above; false branches somewhat appressed; sheaths very thin, papery, not lamellose, somewhat roughened in outline; trichomes $6 \mathrm{mic}$. in diameter, constricted at joints, in basal part of filament numerous within the sheath, densely crowded, often twisted into a cord, in the branches few or solitary; apical cell scarcely tapering, rotund; cells 2-5 mic. in length; transverse valls commonly inconspicuous; cell contents showing scattered protoplasmic granules, pale violet (in dried specimens).

Mexico. In Guatulco River. (Gomont). West Indies. On rock in "Wag Water," Castleton, Jamaica. April I893. (Humphrey).

290. Inactis hawaiensis (Lemmermann) De Toni. Syll. Algar. 5: 357. 1907.

Lemmermann. Algenfl. Sandwich.-Inseln. Bot. Jahrb. 34: 620. pl. 8. f. I9. 1905. ( $\mathrm{Sch}$ izothrix havaiensis Lemm.).

Plate VI. fig. I8.

Filaments $8-38$ mic. in diameter, solitary, growing in gelatinous mass formed by other algae; false branches present; sheaths colorless, lamellose. with pointed apices; trichomes I.5-2 mic. in diameter, not constricted at joints, parallel or flexuous, one to four within the sheath; cells 5-6 mic. in lngth; transverse walls not granulated, almost invisible; cell contents filled with vacuoles, pale blue-green.

Hawaii. With other algae in hot water. Volcano Mauna Kea, Island of Hawaii. (Schauinsland).

\section{Genus SCHIZOTHRIX Kuetzing. Phyc. Gen. 230. 1843.}

Plants living on moist earth or in water, or in inundated places, rarely entirely aquatic; filaments forming erect or prostrate, Symploca-like fascicles or a pannose stratum, rarely floating free; sheaths in the beginning colorless, finally becoming yellowish brown, purplish pink or bluish.

I Cells somewhat quadrate or shorter than the diameter.

I Plant mass thin, encrusted, often widely expanded or in tangled tufts among other algae; sheaths colorless, very transparent; trichomes I-I.5 mic. in diameter, constricted at joints; cells somewhat quadrate

S. hyalina 
2 Plant mass caespitose or appressed, semiorbicular; sheaths very thick, lamellose; trichomes 4-9 mic. in diameter, ustrally solitary within the sheath S. thelephoroides

3 Plant mass indefinite, sheaths purple, orange or rose-colored; trichomes 6-8 mic. in diameter, many within the sheath

\section{S. purpurascens}

4 Plant mass indefinite, woolly, lead-colored; sheaths very thick, lamellose; trichomes 7.5-8.5 mic. in diameter $\mathrm{S}$. chalybea

5 Plant mass not caespitose; sheaths yellowish orange; trichomes 7-I3 mic. in diameter; cells somewhat quadrate or twice as short as the diameter

S. muelleri

II Cells longer than the diameter

I Filaments very long; sheaths dark lead-colored, irregular in outline; trichomes $1.7 \mathrm{mic}$. in diameter $\mathrm{S}$. braunii

2 Filaments forming a loose, cobwebby mass within sandstone rock; sheaths cylindrical, rough, usually colorless and not lamellose, sometimes brownish and lamellose; trichomes $3.5-4.8 \mathrm{mic}$. in diameter; cells quadrate or a little longer than the diameter

\section{S. rupicola}

291. Schizothrix hyalina Kuetzing. Spec. Algar. 320. 1849. De Toni. Syll. Algar. 5: 360. 1907.

Wolle. Fresh-Water Algae U. S. 307. pl. 203. f. 3, 4. I887. (M i c r o c ole us hya 1 in us (Kg.) Kirchn.). Bennett. Plants of Rhode Island. I 5. I888. Wolle and Martindale. Algae. Britton's Catalogue of Plants found in New Jersey. Geol. Surv. N. J. 2: 609. I889.

Plant mass thin, encrusted, often widely expanded or in tangled tufts among other algae, blue-green or green; filaments $8 \mathrm{mic}$. in diameter; sheaths colorless, very transparent; trichomes I-I.5 mic. in diameter, constricted at joints, very slender, curved and entangled, few within the sheath; apex of trichome awl-shaped, pointed; cells somewhat quadrate; cell contents pale green.

Rhode Island. Davisville. (Bennett). New Jersey. In ponds on Sphagnum. (Wolle). Pennsylvania. Wet rocks. (Wolle). South Carolina. Wet ground. (Wolle).

292. Schizothrix thelephoroides (Montagne) Gomont. Monogr. Oscill. 57. pl. Io. f. 1-4. I893. De Toni. Syll. Algar. 5: 359. I907.

Moebius. Ueber einige in Portorico gesammelte Süsswasser- und LuftAigen. Hedwigia. 27: 247. pl. 9. f. 7. 1888.

\section{Plate VI. fig. I9.}

Plant mass pannose, caespitose or appressed, semiorbicular, rustcolored; filaments $.5 \mathrm{~cm}$. in height, divided and branched into appressed, somewhat dichotomous divisions, forming more or less spirally twisted tufts; sheaths firm, very thick, lamellose, the inner layers rust-colored, the outer ones colorless, very frequently dilated below the pointed apex, slightly roughened on the surface, transversely wrinkled; trichomes 4-9 mic. in diameter, usually solitary sometimes two within the sheath, parallel, 
rcmote, evidently constricted at the joints; apical cell scarcely tapering, rotund; cells in lower portion of trichome up to double the diameter in length, in the upper portion somewhat quadrate, 6-I4 mic. in length; cell contents coarsely granular, blue-green.

West Indies. Wet rocks. Summit of Mount Junque, Sierra de Luquillo, Porto Rico. (Sintenis).

293. Schizothrix purpurascens (Kuetzing) Gomont. Monogr. Oscill. 58. p1. 9. f. 6-8. I893. De Toni. Syll. Algar. 5: 36r. 1907.

$$
\text { Plate VI. fig. 20, } 2 \mathrm{I} .
$$

Plant mass indefinite, expanded, dark violet; filaments moderately long, somewhat dichotomously divided and branched into more or less divaricate portions, in lower portions entangled, in upper parts forming somewhat parallel and twisted creeping tufts; sheaths purple, orange or rose-colored, transparent at the apex, firm, solid, very thick and especially lamellose, irregular and roughened in outline, with pointed apex; trichomes 6-8 mic. in diameter, usually constricted at the joints, numerous within the sheath, somewhat remote and parallel; apical cell conical, often sharply pointed; cells $3-8$ mic. in length; cell contents coarsely granular (except in apical cell).

Var. cruenta (Lespinasse) Gomont. 1. c. 59. De Toni. 1. c. 362.

Collins, Holden and Setchell. Phyc. Bor.-Am. Fasc. II. no. 504. 1898. Collins. Notes on Algae.-I. Rhodora. I: 10. I899.

Sheaths purplish pink or peach-colored; trichomes usually constricted at joints.

Massachusetts. On moist ground near Winchester Reservoir, Middlesex Fells. August, September 1898. (Collins). South Carolina. (Ravenel).

294. Schizothrix chalybea (Kuetzing) Gomont. Monogr. Oscill. 57. p1. 9. f. 3-5. I893. De Toni. Syll. Algar. 5: 359. I907.

Plate VI. fig. 22.

Plant mass indefinite, woolly, lead-colored; filaments moderately long, branched, waving, loosely coalesced in erect tufts $2 \mathrm{~mm}$. long; false branches somewhat dichotomous, appressed; sheaths very thick, lamellose, the inner layers pale lead-colored, the outer ones transparent, firm, cylindrical, smooth or a little roughened on the outside; trichomes 7.5-8.5 mic. in diameter, very much constricted at joints; few and parallel within the sheath, or often solitary; apical cell up to II mic. in length, obtuse cr acute conical; cells 3-8 mic. in length; cell contents coarsely granular (except in apical cell), dark green in color.

Mexico. On mossy ground, near the Volcano of Orizaba. (Mueller).

295. Schizothrix muelleri Naegeli in Kuetzing. Spec. Algar. 320. I849. Gomont. Monogr. Oscill. 59. p1. Io. f. 5-7. 1893. De Toni. Syll. Algar. 5: 362. I907.

Wolle. Fresh Water Algae. II. Bull. Torr. Bot. Club. 6: I38. I877. 
(Hydrocoleum versicolor Rabenh.). Farlow. Notes on the Cryptogamic Flora of the White Mountains. Appalachia. 3: 236. I883. (Microcoleus versicolor Thur.). Collins. Aigae of Middlesex County. I5: 1888. Collins, Holden and Setchell. Phyc. Bor.-Am. Fasc. I. no. 7. I895. Collins. Algae. Flora of the Blue Hills, Middlesex Fells, Stony Brook and Beaver Brook Reservations of the Metropolitan Park Commission, Massachusetts. I26. I896. Setchell. Notes on Cyanophyceae. III. Erythea. 7: 45. I899. Collins. The Algae of the Flume. Rhodora. 6: 230. 1904.

Plate VI. fig. 23.

Filaments long, moderately flexuous, divided and branched into appressed portions, woven into an indefinite, expanded, dark or blackish green mass, or forming decumbent tufts attached to mosses, or floating free; sheaths yellowish orange, firm or somewhat diffluent, irregular in outline, with pointed apex, trichomes 7 -I3 mic. in diameter, slightly constricted at joints, solitary or few within the sheath; apical cell obtuse conical; cells 4-9 mic. in length; cell contents coarsely granular.

New Hampshire. Mt. Tumble-Down Dick. (Farlow). In thin black sheets on wall of the "Flume." (Collins). Massachusetts. Forming a black coating on wet rocks. Middlesex Fells; on perpendicular cliffs, forming sheets of considerable size, Saugus, April 1890, I893. (Collins). Connecticut. Mount Carmel. (Setchell). California. Along the banks of a small stream on Howell Mt., near St. Helena, Napa County. February i 896.

296. Schizothrix braunii Gomont. Monogr. Oscill. 63. pl. II. f. 9-I3. I893. De Toni. Syll. Algar. 5: 365. 1907.

Setchell and Gardner. Algae of Northwestern America. Univ. Calif. Pub. Bot. I: I89. I903.

\section{Plate VI. fig. 24.}

Plant mass crustaceous-floccose, adhering to paper when dried, blackish; filaments very long, densely tangled and twisted into cords, moderately branched; sheaths dark lead-colored, firm, slightly irregular in outline, not fringed, with very gradually tapering apex; trichomes 1.7 mic. in diame$t \in r$, constricted at joints, few within the sheath, often solitary, distant, parallel; apical cell tapering, obtuse; cells 2-5 mic. in length; transverse walls granulated; cell contents pale blue-green.

Alaska. On dripping rocks. Near Iliuliuk. (Setchell and Lawson). Orca. (Jepson). "Most of the sheaths are colorless, but some are of the characteristic blue-black color of this species."--Setchell and Gardner.

297. Schizothrix rupicola Tilden. American Algae. Century II. no. 175. I896; Some New Species of Minnesota Algae which live in a Calcareous or Silicious Matrix. Bot. Gaz. 23: Io3. pl. 9. f. 9. I897; List of Fresh-Water Algae collected in Minnesota during I896 and 1897. Minn. Bot. Studies. 2: 28. 1898.

Plate VI. fig. 25.

Filaments 9.6-I6 mic. in diameter, forming a loose, cobwebby mass 
within sandstone rock, as far at least as IO-I5 $\mathrm{mm}$. from surface; sheaths cylindrical, rough, usually colorless and not lamellose, but sometimes brownish and lamellose; trichomes $3.5-4.8$ mic. in diameter, not constricted at the joints, one to many in a sheath; apical cell truncate conical; cells 5-8 mic. in length; transverse walls usually invisible.

Minnesota. In bare and dry sandstone cliffs. Soldiers' Home, Minnehaha Falls. September I896. (Hall).

\section{'Genus DASYGLOEA Thwaites. Eng. Bot. pl. 294I. I848.}

Sheaths very wide, colorless or yellowish brown; trichomes very few within the sheath, very loosely aggregated; apex of trichome straight, not capitate; cells often longer than the diameter.

298. Dasygloea amorpha Berkeley in English Botany. pl. 294I. I848. Gomont. Monogr. Oscill. 84. pl. I3. f. II, I2. I893. De Toni. Syll. Algar. 5: 368. 1907 .

Wolle. Fresh Water Algae. III. Bull. Torr. Bot. Club. 6: I83. I877; Fresh-Water Algae U. S. 304. pl. 204. f. I-9. 1887. (M i c r o c o le us a morpha (Thwaites) Wolle).

Plate VI. fig. 26.

Plant mass amorphous, gelatinous; filaments twisted, entangled, divided into fringes at the apex; sheaths transparent throughout, or dull yellow within, very irregular in outline, mucous, sometimes somewhat lamellcse; trichomes 4-6 mic. in diameter, constricted at joints; apex of trichome sometimes very gradually tapered; apical cell truncate conical; cells 4-13 mic. in length; cell contents coarsely granular.

Pennsylvania. Forming a thin olive or dark blue-green membrane, skin-like, on trickling rocks in mountain ravine. Glen Onoko. (Wolle).

\section{Genus MICROCOLEUS Desmazières.}

Cat. des Plantes omises dans la Botanographie Belgique. 7. I823.

Plants living on soil, in fresh water or sometimes in salt water; filaments simple or vaguely branched, creeping on the ground, sometimes growing among other algae; sheaths colorless, more or less regularly cylindrical, not lamellose, in many species finally diffluent; trichomes many within the sheath in well developed filaments, closely crowded, often twisted into rope-like bundles; apex of trichome straight, tapering; apical cell acute, rarely obtuse conical, in one species capitate.

I Plants living in salt water; apical cell not capitate, pointed.

I Trichomes $1.5^{-2}$ mic. in diameter, constricted at joints

M. tenerrimus

2 Trichomes 2.5-6 mic. in diameter, constricted at joints M. chthonoplastes

II Plants living on soil; apical cell capitate.

M. vaginatus 
III Plants living in fresh water; apical cell not capitate

I Sheaths mucous, diffluent; trichomes 4-5 mic. in diameter, especially constricted at joints

M. lacustris

2 Sheaths somewhat mucous, not or scarcely diffuent; trichomes 5-7 mic, in diameter, not constricted at joints $\mathbf{M}$. paludosus

3 Plant mass large, cushion-like; trichomes 5-6 mic. in diameter

M. pulvinatus

4 Sheaths very mucous and agglutinated; trichomes 6-Io mic. in diameter, especially constricted at joints

M. subtorulosus

299. Microcoleus tenerrimus Gomont. Monogr. Oscill. 93. pl. I4. f. 9-II. I893. De Toni. Syll. Algar. 5: 373. Ig07.

Schramm and Mazé. Essai Class. Algues Guadeloupe. 30. 1865. Mazé and Schramm. Essai Class. Algues Guadeloupe. 20. 1870-I877. (M. o 1 i o g othrix Crouan). Murray. Catalogue of the Marine Algae of the West Indian Region. Journ. of Bot. 27: 261. r889. Collins, Holden and Setchell. Phyc. Bor.-Am. Fasc. 15. no. 706. I900. Collins. The Algae of Jamaica. Proc. Am. Acad. Arts Sci. 37: 240. 190I; Notes on Algae.-VI. Rhodora. 5: 233. I903. Setchell and Gardner. Algae of Northwestern America. Univ. Calif. Pub. Bot. I: I88. I903.

$$
\text { Plate VI. fig. } 27 .
$$

Filaments simple or slightly branched, densely entangled in a gray or blue-green mass, or mixed with various algae; sheaths wide, irregular in outline, pointed or open at the apex, sometimes entirely diffluent; trichomes I.5-2 mic. in diameter, especially constricted at the joints, long, flexuous, usually loosely aggregated, more or less numerous within the sheath; apex of trichome often gradually tapering; apical cell not capitate, very acute conical; cells 2.2-6 mic. in length; transverse walls pellucid, sometimes granulated.

Maine. In rather small quantity. At Southwest Harbor, Mount Desert Island. (Holden). Louisiana. Forming a blue-green coating on an old wooden pier. Lake Pontchartrain. November 1898. (Saunders). Washington. In a salt marsh. Whidbey Island. (Gardner). West Indies. Brackish water. Guadeloupe. (Mazé). In company with M. chth on o p last es. March I893. (Humphrey).

300. Microcoleus chthonoplastes (Flora danica) Thuret. Essai Class. Nostochinées. Ann. Sci. Nat. Bot. VI. I: 378. I875. Gomont. Monogr. Oscill. 91. pl. I4. f. 5-8. I893. De Toni. Syll. Algar. 5: 371. 1907.

Wolle. Fresh Water Algae. IV. Bull. Torr. Bot. Club. 7: 44. 1880. (M. gracilis Hass.). Farlow. Marine Algae of New England. 33. pl. 2. f. 3. 188I. Pike. Check List of Marine Algae. Bull. Torr. Bot. Club. I3: In5. I886. Wolle. Fresh-Water Algae U. S. 306. pl. 203. f. Io, II. I887. (M. gracilis Hass, M. a $\mathrm{ngu}$ if or $\mathrm{m}$ is Harv). Bennett. Plants of Rhode Island. II5. I888. Collins. Algae of Middlesex County. I4. I888; Algae from Atlantic City, N. J. Bull. Torr. Bot. Club. I5: 310. r888. Martindale. Marine Algae of the New Jersey Coast and Adjacent Waters of Staten Island. Mem. Torr. Bot. Club. I: 90. I889. Wolle and Martin- 
dale. Algae. Britton's Catalogue of Plants found in New Jersey. Geol. Surv. N. J. 2: 609. I889. Murray. Catalogue of the Marine Algae of the West Indian Region. Journ. of Bot. 27: 26r. I889. (Chthon oblastus $1 \mathrm{y} \mathrm{n} \mathrm{g} \mathrm{b} \mathrm{e} \mathrm{i} \mathrm{Kg.).} \mathrm{Johnson} \mathrm{and} \mathrm{Atwell.} \mathrm{Fresh} \mathrm{Water} \mathrm{Algae.} \mathrm{Northwestern}$ University. Report Dept. Nat. Hist. 21. I890. Collins. Algae. Rand and Redfield's Flora of Mount Desert Island. Maine. 247. I894. Collins, Holden and Setchell. Phyc. Bor.-Am. Fasc. 4. no. I53. I896. Collins. Preliminary Lists of New England Plants.-V. Marine Algae. Rhodora 2: 42. rgoo. Bessey, Pound and Clements. Additions to the Reported Flora of the State. Bot. Surv. Nebraska. 5: I3. I90I. Jamaica. Proc. Am. Acad. Arts Sci. 37: 240. I90I. Collins, Holden and Setchell. Phyc. Bor.-Am. Fasc. I9. no. 906. I902. Collins. Notes on Algae. VI. Rhodora. 5: 233. 1903. Setchell and Gardner. Algae of Northwestern America. Univ. Calif. Pub. Bot. I: I88. I903. Snow. The Plankton Algae of Lake Eric. U. S. Fish Comm. Bull. for I902. 22: 392. I903. Collins. Phycological Notes of the late Isaac Holden.-II. Rhodora. 7: 223. 1905. Tilden. American Algae. Cent. VII. Fasc. I. no. 635. I909.

\section{Plate VI. fig. 28.}

Filaments twisted, rarely branched, forming a dull or dark green, panrose, broadly expanded, compact, stratified mass, made tp of layers of different colors, or growing sparsely among other algae; sheaths cylindrical, more or less unequal and roughened in outline, with apex usually open, sometimes entirely diffluent; trichomes $2.5-6 \mathrm{mic}$. in diameter, constricted at joints, short, somewhat straight, many within the sheath, usually densely aggregated into bundles, rarely twisted into cords; apex of trichome tapering; apical cell not capitate, acute conical; cells 3.6-Io mic. in length; transverse walls not granulated.

Canada. Mixed with other algae. Malpeque, Prince Edward Island. (Faull). Maine. Very common in lagoon. Little Cranberty Isle. (Collins). Shore west of Bracy Cove. (Holden). New Hampshire. (Collins). Massachusetts. Mixed with other algae, common along the New England coast. Wood's Holl. (Farlow). Salt marshes. (Collins). Growing on sand between tide marks, salt marsh. Wood's Hole. July i895. (Osterhout). Rhode Island. Geneva. (Bennett). Connecticut. Forming a thick coating on turf near high water mark. Seaside Park; in sheets on sandy bottom between tide marks, Cook's Point, September, October. (Holden). New York. Shores of Long Island, Fort Hamilton, Greenport. Summer. (Pike). New Jersey. In brackish pools. Atlantic City. (Morse, Martindale). On moist earth. (Wolle). Texas. I902. (Fanning). Ohio. Plankton. Put-in-Bay, Lake Erie. (Snow). Illinois. Running water. Big Woods, Cook County. April. (Johnson and Atwell). Dakota. (Hobby). Washington. Growing on the mud in a salt marsh. Pen's Cove, Whidbey Island. (Gardner). West Indies. In turfs of algae. St. Ann's Bay, Jamaica. March I893. (Humphrey). Cuba. (R. de la Sagra).

301. Microcoleus vaginatus (Vaucher) Gomont. Essai Class. Nostocacées homocystées. Morot. Journ. de Bot. 4: 353. 189o; Monogr. Oscill. 93. pl. I4. f. 12. I893. De Toni. Syll. Algar. 5: 374. 1907. 
Wolle. Fresh Water Algae. II. Bull. Torr. Bot. Club. 6: I38. I877. (M. tertestris Desmaz.); Fresh-Water Algae U. S. 305. pl. 203. f. 7-9; pl. 205. f. I6, I7. I887. Collins. Algae of Middlesex County. I5. 1888. Bennett. Plants of Rhode Island. II5. I88. Wolle and Martindale. Algae. Britton's Catalogue of Plants found in New Jersey. Geol. Surv. N. J. 2: 609. 1889. Saunders. Protophyta-Phycophyta. Flora of Nebraska. 20. pl. 2. f. 21. I894; The Algae. Harriman Alaska Expedition. Proc. Wash. Acad. Sci. 3: 397. rgor. Collins. The Algae of Jamaica. Proc. Am. Acad. Arts Sci. 37: 240. 1901. Setchell and Gardner. Algae of Northwestern America. Univ. Calif. Pub. Bot. I: I89. I903. Collins, Holden and Setchell. Phyc. Bor.-Am. Fasc. 21. no. I0I1. I903. Buchanan. Notes on the Algae of lowa. Proc. Iowa. Acad. Sci. I4: I2. I908.

Plate VI. fig. 29.

Filaments creeping, rarely entangled and twisted, sometimes branched; forming a black, glistening sheet; sheaths cylindrical, more or less unequal in outline, agglutinated, pointed and closed at the apex, or open and gradually disappearing, at times entirely diffluent; trichomes $3.5-7$ mic. in diameter, not constricted at joints, many within the sheath, closely crowded, usually twisted into cords, the portion extruding from the sheath straight; apex of trichome gradually tapering and capitate; outer membrane of apical cell thickened into a depressed conical calyptra; cells $3-7 \mathrm{mic}$. in length; transverse walls frequently granulated.

Alaska. Forming, with other algae, a thin coating on damp ground, recently covered by snow. Glacier Bay. (Saunders). Massachusetts. Newton. (Farlow). Melrose. (Collins). Rhode Island. Common. (Bennett). New Jersey. On moist earth. (Wolle). Iowa. Damp ground. Grinnell. (Fink). On flower pots in greenhouse. Ames. (Buchanan). Nebraska. On damp earth in greenhouses. University. (Saunders). Washington. La Conner, Skagit County. (Gardner). California. In a gutter. Berkeley. February I902. (Gardner). West Indies. On moist rock. Rio Cobre, Bog Walk, Jamaica. April I893. (Humphrey).

302. Microcoleus lacustris (Rabenhorst) Farlow in Farlow, Anderson and Eaton. Algae. Am. Bor. Exsicc. no. 227. 1877. Gomont. Monogr. Oscill. 97. I893. De Toni. Syll. Algar. 5: 376. 1907.

Collins, Holden and Setchell. Phyc. Bor.-Am. Fasc. 7. no. 307. I897. Setchell. Notes on Cyanophyceáe. III. Erythea. 7: 52. I899. Riddle. Brush Lake Algae. Ohio Nat. 5: 268. 1905.

Filaments simple or vaguely branched, forked at the apex, twisted and entangled forming a black or blue-green layer; sheaths somewhat thin, mucous and agglutinated, sometimes diffluent, often gradually disappearing at the apex; trichomes 4-5 mic. in diameter, especially constricted at joints, somewhat parallel, the portion extruding from the sheath very straight; apical cell more or less obtuse conical, not capitate; cells 6-I2 mic. in length; transverse walls not granulated; cell contents showing scattered coarse granules, pale blue-green.

Massachusetts. Newton. (Farlow). Connecticut. In tangled felty strata and disseminated among $\mathrm{S} c \mathrm{y}$ to $\mathrm{nem}$ a $\mathrm{cr}$ is $\mathrm{pu} \mathrm{m}$, in pool. North 
Haven. November I896. (Holden). under name of $\mathrm{Phormidium}$ lected in Pennsylvania."-Setchell. ty. (Riddle).
Pennsylvania. "Distributed by Wolle c ongestum *** probably col-

Ohio. Brush Lake, Champaign Coun-

303. Microcoleus paludosus (Kuetzing) Gomont. Monogr. Oscill. 96. pl. I4. f. 13. I893. De Toni. Syll. Algar. 5: 376. I907.

Setchell. Notes on Cyanophyceae. III. Erythea. 7: 53. 1899. Bessey, Pound and Clements. Additions to the Reported Flóra of the State. Bot. Surv. Nebraska. 5: 13. I901. Am. Fasc. I7. no. 802. Ig01. Collins, Holden and Setchell. Phyc. Bor.I. no. 634. 1909 .

Tilden. American Algae. Cent. VII. Fasc.

\section{Plate VI. fig. 30.}

Filaments entangled, twisted, simple or forked at the apex, growing among other algae or forming a blackish or blue-green stratum; sheaths moderately mucous, open and disappearing at the apex or closed and pointed; trichomes 5-7 mic. in diameter, not constricted at joints, parallel, straight, or twisted into cords; apical cell not capitate; cells $4-13$ mic. in length; transverse walls not granulated; cell contents light blue-green.

Rhode Island. (Osterhout). Nebraska. On wet soil in greenhouse. Lincoln. (Bessey). California. In southern part of the state. (Parish). In conservatory. Golden Gate Park, San Francisco. September I9oo. (Gardner). In greenhouses. University of California, Berkeley. (Setchell). Hawaii. With other algae forming a layer covering rocks on bottom and sides of basin of "warm spring." Temperature at 7 a. $\mathrm{m} .3 \mathrm{I}^{\circ} \mathrm{C}$. Puna, Island of Hawaii. July Igoo. (Tilden).

304. Microcoleus pulvinatus Wolle. Fresh-Water Algae U. S. 305. pl. 204. f. IO-I4. I887. De Toni. Syll. Algar. 5: 379. I907.

Wolle and Martindale. Algae. Britton's Catalogue of Plants found in New Jersey. Geol. Surv. N. J. 2: 609. I889.

Plate VI. fig. 3I.

Plant mass large, cushion-like, often $I .5 \mathrm{dm}$. in diameter, about $5 \mathrm{~cm}$. in thickness, somewhat hollow in the center, dark olive brown, gelatinousmembranaceous; filaments $12-30$ mic. in diameter; trichomes 5-6 mic. in diameter, one, two or three in a sheath.

New Jersey." "The thalli; of all possible sizes from one to ten inches in diameter, are attached to stones and grasses, looking like boulders in tha bottom of a mill race with rapidly running water." Bamber. (Wolle).

305. Microcoleus subtorulosus (Kuetzing) Gomont. Essai Class. Nostocacées homocystées. Morot. Journ. de Bot. 4: 352. I890; Monogr. Oscill. 98. pl. I4. f. I4, I5. I893. De Toni. Syll. Algar. 5: 378. I907.

Wolle. Fresh Water Algae. Bull. Torr. Bot. Club. 6: 283. I879. (Ph. subtorulos um Bréb.); Fresh-Water Algae U. S. 300. pl. 202. f. 3, 4. 1887. (L y ng b a subtorulos a (Bréb.) Wolle). Buchanan. Notes on the Algae of Iowa. Proc. Iowa Acad. Sci. 14: 13: Ig08. 
Plate VI. fig. 32.

Plant mass lead-colored, spreading over aquatic plants and damp soil; filaments somewhat amorphous, fragile; sheaths very mucous, agglutinated; trichomes 6-Io mic. in diameter, especially constricted at joints, usually numerous within the sheath, parallel, straight; apex of trichome very gradually tapering; apical cell conical or cylindrical conical, not capitate; cells 5-Io mic. in length; cell contents showing scattered protoplasmic granules.

Florida. Moist ground. (Smith). Iowa. (Hobby).

Genus CATAGNYMENE Lemmermann.

Planktonalg. Ergebn. einer Reise n. d. Pacific. 354. I899.

Filaments multicellular, floating free, surrounded by thin, close sheaths, enclosed in widely expanded, gelatinous diffluent envelopes, separating easily into fragments through the death of cells.

I Gelatinous envelope 93-roo mic. in diameter; trichomes up to 16 mic in diameter, straight or curved.

C. pelagica

II Gelatinous envelope 150-168 mic. in diameter; trichomes 20-22 mic. in diameter, spirally coiled

C. spiralis

306. Catagnymene pelagica Lemmermann. Planktonalgen. Ergebnisse einer Reise nach dem Pacific. Abhandl. d. naturw. Verein in Bremen. 16: 354. pl. 3. f. 38-40, 42. I899; Algenfl. Sandwich.-Inseln. Bot. Jahrb. 34: 619. 1905. De Toni. Syll. Algar. 5: 38I. 1907.

Outer envelope 93-100 mic. in diameter, gelatinous, colorless; trichomes up to 16 mic. in diameter, straight or curved; apical cell rotund or possessing a calyptra; cells very short, 3-4 mic. in length.

Hawaii. In plankton, between the islands of Laysan and Hawaii. I89697. (Schauinsland).

Var. major Wille. Die Schizophyceen der Plankton-Expedition. 5I. pl. I. f. 7. I904. De Toni. Syll. Algar. 5: 382. I907.

Plate VI. fig. 33 . diameter.

Gelatinous envelope 100-165 mic. in diameter; trichomes $21-27$ mic. in

Bermudas. Plankton. Atlantic Ocean. (Wille).

307. Catagnymene spiralis Lemmermann. Planktonalgen. Ergebnisse einer Reise nach dem Pacific. Abhandl. d. naturw. Verein in Bremen. 354. pl. 3. f. 4I, 47-49. I899; Algenfl. Sandwich.-Inseln. Bot. Jahrb. 34: 6ig. 1905. De Toni. Syll. Algar. 5: 382. 1907.

Outer envelope 150-168 mic. in diameter, gelatinous, colorless; trichomes 20-22 mic. in diameter, spirally coiled; apical cell rotund; cells $3-4$ mic. in length.

Hawaii. In plankton, between the islands of Laysan and Hawaii. 1896-97. (Schauinsland). 
According to Wille, Oscillatoria capitata West should be made a variety of this species:

Var. capitata Wille. Die Schizophyceen der Plankton-Expedition. 52. pl. I. f. 8, 9. 1904 .

Plate VI. fig. 34 .

Filaments irregularly wound or twisted within an oval gelatinous envelope; trichomes Io-I 4 mic. in diameter. man).

West Indies. Lat. $23^{\circ} 44^{\prime}$ N.; long. $45^{\circ} 30^{\prime} \mathrm{W}$. (Murray and Black-

Genus HALIARACHNE Lemmermann.

Planktonalg. Ergebn. einer Reise n. d. Pacific. 353. I899.

Filaments multicellular, floating free, in somewhat globose or elongate, gelatinous colonies, arranged in two layers, radiating from the center, hooked at the apex; reproduction by division of the colony.

308. Haliarachne lenticularis Lemmermann. Planktonalgen. Ergebnisse einer Reise nach dem Pacific. Abhandl. d. naturw. Verein in Bremen. 353. pl. 2. f. 22-24. I899; Algenfl. Sandwich.-Inseln. Bot. Jahrb. 34: 6r9. I905. De Toni. Syll. Algar. 5: 385. r9o7.

Colony lenticular, 450-700 mic. in diameter; apical cell possessing a calyptra; cells about $8 \mathrm{mic}$. in diameter, 4-7 mic. in length; cell contents showing gas vacuoles.

Hawaii. In plankton, between the islands of Laysan and Hawaii. I8g697. (Schauinsland).

\section{Family II. NOSTOCACEAE}

Sheaths forming a more or less distinct mucous, gelatinous or membranaceous tegument, mostly confluent, often not present; trichomes consisting of a single row of uniform cells, with heterocysts, usually twisting and entangled, not branched, showing no differentiation of base and apex, reproduction by means of vegetative division, hormogones and gonidia.

I. Sheaths inconspicuous, or mucous and diffluent, or gelatinous, firm and thick

I Trichomes flexuous and contorted, forming a plant mass or colony of definite shape

(I) Colony usually of a rounded or expanded character, gelatinous, made up of dissolved individual sheaths, attached to the substratum or floating free in water; heterocysts intercalary

Nostoc

(2) Colony tubular, cylindrical; filaments somewhat straight, parallel, agglutinated

Wollea

2 Trichomes more or less straight, free, or forming a thin mucous layer of indefinite shape 
(I) Heterocysts and gonidia intercalary

A Trichomes free; cells disc-shaped; shorter than their diameter; gonidia seriate, remote from the heterocysts

\section{Nodularia}

B Trichomes naked, or with a thin mucous sheath, free or aggregated without order to form a flocculent mass; cells equal to or longer than their diameter; gonidia solitary, in pairs or in short series

Anabaena

C Trichomes short, aggregated in parallel bundles to form thin, feathery, plate-like masses

Aphanizomenon

(2) Heterocysts terminal and the gonidia always contiguous to them

\section{Cylindrospermum}

II Sheaths thin, membranaceous, persistent; filaments free or agglutinated in a parallel manner

I Sheaths not present; trichomes single, endophytic; heterocysts terminal

Richelia

2 Trichomes single within the sheath; heterocysts intercalary

Aulosira

3 Trichomes single within the sheath; heterocysts intercalary and terminal

Microchaete

4 Trichomes usually many within the sheath, forming a membranaceous or filamentous mass

Hormothamnion

\section{Genus NOSTOC Vaucher. Hist. Conferves, 203. I803.}

Plant mass or colony at first globose or oblong, afterwards assuming various forms (globose, foliose, filiform, bullose) in the different species, solid or hollow, mucous, gelatinous or leathery, made up of tangled trichomes and their more or less dissolved sheaths; filaments flexuous, curved, entangled, coalesced; sheaths sometimes distinct, sometimes invisible; trichomes often torulose; cells depressed spherical, barrel-shaped or cylindrical; heterocysts intercalary and (in younger plants) terminal; gonidia spherical or oblong, developed centrifugally in series between the heterocysts.

I Plants living in fresh water; forming minute, disc-shaped specks or patches on aquatic plants; plant mass growing at the periphery; filaments closely contorted.

N. cuticulare

II Plants living in fresh water, microscopic, granular, aggregated, having the appearance of Aphanocapsa; filaments very closely entangled; trichomes scarcely distinct.

N. punctiforme

JII Plants living in fresh water, very minute; trichomes $2-3.5$ mic. in diameter, distinct.

I Plant mass very minute, punctiform; filaments loosely flexuous; trichomes 3-3.5 mic. in diameter; gonidia about 4 mic. in diameter; $6-8$ mic. in length, oblong

N. paludosum 
2 Plant mass small, adherent, somewhat globose; orange or green; trichomes 2-2.5 mic. in diameter, very short, strongly curved

\section{N. aureum}

3 Plant mass small, gelatinous, membranaceous, soft, green, blue-green or brownish; trichomes 3-4 mic. in diameter, flexuously curved, somewhat densely entangled

N. comminutum

IV Plants living in fresh water; plant mass large, gelatinous, fragile, at first spherical, afterwards becoming torn and irregularly expanded.

I Filaments numerous, abruptly contorted, entangled; trichomes 3.5-4 mic. in diameter; gonidia 6-7 mic. in diameter, 7-8 mic. in length

\section{N. linckia}

2 Filaments flexuous, loosely entangled

(I) Gonidia 6-7 mic. in diameter, spherical; wall of gonidium smooth; trichomes 4 mic. in diameter

N. piscinale

(2) Gonidia oblong; wall of gonidium smooth

A Trichomes 4-4.2 mic. in diameter; gonidia 6-8 mic. in diameter, 7-ro mic. in length, contiguous; wall of gonidium becoming brownish or colorless

N. rivulare

B Trichomes 3.5-4 mic. in diameter; gonidia 6 mic. in diameter, 8-10 mic. in length, not contiguous; wall of gonidium colorless

\section{N. carneum}

C Trichomes 4 mic. in diameter; cells different in shape, some cylindrical, others barrel-shaped or spherical depressed; gonidia 6-7 mic. in diameter, 10-12 mic. in length, not contiguous; wall of gonidium colorless or becoming yellowish

N. spongiaeforme

V Plants living on soil; colonies gelatinous, soft, at first spherical, soon confluent and flattened, attached to soil or mosses

I Cells cylindrical; trichomes 4 mic. in diameter; gonidia 6-8 mic. in diameter

(I) Gonidia I4-I9 mic. in length; wall of gonidium smooth

N. ellipsosporum

(2) Gonidia 8-I4 mic. in length; wall of gonidium furnished with short spines

N. gelatinosum

2 Cells oval, spherical or spherical depressed

(I) Trichomes 3-4 mic. in diameter; gonidia 4-8 mic. in diameter, 8-I2 mic. in length, oblong, in a catenate series

N. muscorum

(2) Trichomes 2.2-3 mic. in diameter; gonidia 4 mic. in diameter, 6 mic. in length, oval

N. humifusurn

VI Plants living on soil, sometimes submerged; colonies free, at first spherical, then expanding symmetrically or irregularly; cells somewhat globose.

I Colonies gelatinous, spongy, lacunose, somewhat pellucid, green, olive or brownish; trichomes 4 mic. in diameter; gonidia 7 mic. in diame- 
ter, 7-Io mic. in length, often oval; wall of gonidium smooth, colorless

N. foliaceum

2 Colonies expanded, irregular or orbicular, very thin, small, membranaceous, pellucid, blue-green; trichomes $4 \mathrm{mic}$. in diameter

N. punctatum

3 Colonies at first spherical, afterwards becoming flattened and finally spreading out into irregular, membranaceous sheets; surrounded by a firm outer layer; trichomes 4-5.6 mic. in diameter

N. commune

4 Colonies free, spherical, becoming irregularly plicate-tuberculate, thick, solid, surrounded by a firm outer layer; trichomes 4-5 mic. in diameter; gonidia 5 mic. in diameter, 7 mic. in length, oval; wall of gonidium thick, smooth, becoming brownish

N. sphaericum

5 Colonies spherical, finally becoming flattened, membranaceous; trichomes 2.5-3 mic. in diameter

N. minutum

6 Plants living in hot water; colonies indefinitely expanded, laciniate; filaments 2 mic. (?) in diameter

N. calidarium

7 Colonies somewhat spherical, small, very hard, sometimes soft, with surface often corrugated; trichomes 6.5-8.2 mic. in diameter

N. austinii

VII Plants living on soil or in fresh water; colonies spherical, surrounded by a firm outer layer.

I Plants living on soil

(I) Colonies small; trichomes 8-9 mic. in diameter; gonidia somewhat spherical, two or three times larger than the cells; wall of gonidium thin, very smooth N. macrosporum

(2) Colonies spherical or oblong, rarely beyond I $\mathrm{cm}$. in diameter, somewhat pellucid; trichomes $5-8$ mic. in diameter; gonidia 6-? mic. in diameter, 9-I 5 mic. in length, oval N. microscopicum

(3) Colonies small or of medium size, spherical; trichomes 4-7 mic. in diameter; gonidia 6-7 mic. in diameter, exactly spherical; wall of gonidium somewhat thick, rough $\mathbf{N}$. sphaeroides

2 Plants living in fresh water

(I) Colonies irregularly somewhat orbicular, gregarious and sometimes aggregated; trichomes 5 mic. in diameter

N. depressum

(2) Colonies spherical, usually aggregated in grape-like clusters; trichomes 3.5-4 mic. in diameter

N. glomeratum

(3) Colonies gregarious, pellucid, sky blue or blue-green; trichomes 5-7 mic. in diameter; cells barrel-shaped $\mathbf{N}$. caeruleum

(4) Colonies spherical, surrounded by a leathery outer layer; trichomes 4-6 mic. in diameter

N. pruniforme

VIII Plants living in fresh water, attached; colonies somewhat spherical, bullate, rarely disc-shaped, surrounded by a firm outer layer; trich-. omes slender. 
I Trichomes 3-3.5 mic. in diameter, especially cylindrical; gonidia 5 mic. in diameter, 7 mic. in length; wall of gonidium smooth

N. verrucosum

2 Trichomes 2-3 mic. in diameter, distinctly torulose; gonidia 3-4 mic. in diameter, 5-6 mic. in length; wall of gonidium smooth, brown

N. amplissimum

3 Filaments radiating from the center, flexuous, very densely twisted and entangled near the surface; trichomes $4-4.5$ mic. in diameter; gonidia 4-5 mic. in diameter, 7-8 mic. in length, oval; wall of gonidium smooth, yellowish

N. parmelioides

309. Nostoc cuticulare (Brébisson) Bornet and Flahault. Revision des Nostocacées hétérocystées contenues dans des principaux herbiers de France. Ann. Sci. Nat. Bot. VII. 7: 187. I888. De Toni. Syll. Algar. 5: 387.1907 .

Collins, Holden and Setchell. Phyc. Bor.-Am. Fasc. 7. no. 308. 1897.

Plant mass flattened, adnate, forming thin, orbicular, confluent, dark blue-green patches; filaments closely entangled, here and there forming denser clusters; sheaths more or less distinct, wide, gelatinous, transparent; trichomes 3.8-4 mic. in diameter, torulose; cells barrel-shaped, equal to or a little longer than the diameter; heterocysts barrel-shaped, equal to or a little larger than the cells; cell cortents blue-green.

New York. On leaves of Potamogeton. Ithaca. (Atkinson).

3ro. Nostoc punctiforme (Kuetzing) Hariot. Le Genre Polycoccus Kuetzing. Morot. Journ. de Bot. 5: 29. I89I. Reinke. Zwei parasitische Algen. Bot. Zeit. 37: 473. pl. 6. f. I-5. I879. (A n a b a e n a c yc a dea rum Reinke). Bornet and Flahault. Revis. des Nostoc. Ann. Sci. Nat. Bot.' VII. 7: 189. 1888. (N. he derula e Menegh.). Sauvageau. Sur le Nostoc punctiforme. Ann. Sci. Nat. Bot. VIII. 3: 367. pl. I7. 1897. Pampaloni. I1 Nostoc punctiforme nei suoi rapporti coi Tubercoli Radicali clelle Cicadee. Nuovo Giornale Bot. Ital. N. S. 8: 626. pl. 5. I901. De Toni. Syll. Algar. 5: 388. I907.

Schneider. Mutualistic Symbiosis of Algae and Bacteria with Cycas revoluta. Bot. Gaz. I9: 25. pl. 3, 4. I894. Tilden. American Algae. Cent. II. no. I7I. I896; List of Fresh-Water Algae collected in Minnesota during I896 and I897. Minn. Bot. Studies. 2: 27. I898. Life. The Tuber-like Rootlets of Cycas revoluta. Bot. Gaz. 31: 265. I901. Lemmermann. Algenfl. Sandwich.-Inseln. Bot. Jahrb. 34: 622. I905. Buchanan. Notes on the Algae of Iowa. Proc. Iowa Acad. Sci. I4: 12. I908.

\section{Plate VI. fig. $35-37$.}

Colonies small, somewhat globose, scattered or confluent, adnate; filaments flexuous, very densely entangled; sheaths close, transparent, mucous; trichomes 3-4 mic. in diameter; cells depressed spherical or elliptical; lieterocysts $4-6.5 \mathrm{mic}$. in diameter, transparent; gonidia somewhat spherical or oblong, 5-6 mic. in diameter, 5-8 mic. in length, with thick, smooth, outer membrane; cell contents finely granular, light olive green.

Minnesota. In roots of $\mathrm{Cy}$ cas $\mathrm{r}$ e vol $\mathrm{ut}_{\mathrm{t}}$. University Plant House, 
Minneapolis. December I896. (Tilden). Iowa. In nodular thickenings on the roots of Cycas revoluta. Greenhouse. Ames. (Buchanan). Hawaii. "Sandwich Islands." r896-97. (Schauinsland).

31 I. Nostoc paludosum Kuetzing. Tab. Phyc. 2: I. pl. I. f. 2. I85o. Janczewski. Observations sur la Reproduction de quelques Nostochinées. 'Ann. Sci. Nat. Bot. V. I9: 125. pl. 9. f. B. 1874. Bornet and Flahault. Revis. des Nostoc. Ann. Sci. Nat. Bot. VII. 7: I9I. I888. De Toni. Syll. Algar. 5: 390. I907.

\section{Plate VI. fig. 38.}

Lemmermann. Algenfl. Sandwich.-Inseln. 'Bot. Jahrb. 34: 621. 1905.

Plant mass very minute, scarcely visible to the naked eye, punctiform, gelatinous; filaments loosely flexuous; sheaths wide, bullose; trichomes 3-3.5 mic. in diameter; cells barrel-shaped, 'equal in length to the diameter; heterocysts a little larger than the vegetative cells, light-colored; gonidia 4-4.5 mic. in diameter, 6-8 mic. in length, oval, 'blue-green, with a very thin, smooth, transparent outer membrane.

Hawaii. In ditches and pools between Honolulu and'Waikiki, Oahu. 1896-97. (Schauinsland).

312. Nostoc aureum Kuetzing. Tab. Phyc. 2: I. pl. I. f. 4. I850. De Toni. Syll. Algar. 5: 391. 1907.

Dickie. On the Algae found during the Arctic Expedition. Journ. Linn. Soc. Bot. I7: 9. I880.

Colonies small, adherent, somewhat globose, orange or green, soft, somewhat elastic, mucous within; trichomes $2-2.5$ mic. in diameter, very short, strongly curved, loosely entangled, sometimes nearly straight; cells sometimes crowded, sometimes separated, often continuous, somewhat globose or oblong, blue-green; heterocysts 3-4.5 mic. in diameter, spherical, single and scattered or in series.

Arctic Regions. Among mud from Floeberg, $82^{\circ} 27^{\prime} \mathrm{N}$. (Moss). "It must have been conveyed by currents from the land, or blown off shore with dust from a dried-up pool."-Dickie.

313. Nostoc comminutum Kuetzing. Tab. Phyc. 2: 3. pl. Io. f. 2. I850. De Toni. Syll. Algar. 5: 393. I908.

Wolle. Fresh-Water Algae U. S. 282. I887. Harvey. The FreshWater Algae of Maine.-I. Bull. Torr. Bot. Club. I5: I6I. I888. Britton. Catalogue of Plants found in New Jersey. Geol. Surv. N. J. 2: 606. 1889.

Plant mass small, gelatinous-membranaceous, soft, sometimes green or blue-green, sometimes becoming dull brownish; trichomes 3-4 mic. in diameter, flexuously curved, somewhat densely entangled; cells spherical or depressed spherical, strongly compressed, closely or loosely connected; heterocysts exactly spherical, up to twice the diameter of the cells, intercalary, rarely terminal; cell contents homogeneous, pale blue-green.

United States. Floating in ditches and smaller ponds. (Wolle). Maine. Abundant in a gathering made from a pool in the Penobscot at Great Works. (Merrill). New Jersey. On pond waters, frequent. (Wolle). 
314. Nostoc linckia (Roth) Bornet in Bornet and Thuret. Notes Algologiques. 86. pl. I8. f. I-I2. I880. Janczewski. Observations sur la Reproduction de quelques Nostochinées. Ann. Sci. Nat. Bot. V. 19: 127. pl. 9. f. C. 1874 . (N. $m$ in $u t$ is $\mathrm{s} i \mathrm{~m} \mathrm{u}$ Jancz.). Bornet and Flahault. Revis. des Nostoc. Ann. Sci. Nat. Bot. VII. 7: 192. 1888. De Toni. Syll. Algar. 5: 39I. I907.

Nordstedt. De Algis Aquae Dulcis et de Characeis ex Insulis Sandvicensibus a Sv. Berggren 1875 reportatis. 5. 1878 . (N. intricat u m Menegh.). Setchell. Notes on Cyanophyceae--I. Erythea. 4: 89. I8g6. Collins, Holden and Setchell. Phyc. Bor.-Am. Fasc. II. no. 507. I898. Bessey, Pound and Clements. Additions to the Reported Flora of the State. Bot. Surv. Nebraska. 5: I2. Igor. Setchell and Gardner. Algae of Northwestern America. Univ. Calif. Pub. Bot. I: 189. 1903. Lemmermann. Algenf. Sandwich.-Inseln. Bot. Jahrb. 34: 622. 1905.

Plate VII. fig. I.

Colonies of various sizes, sometimes punctiform, expanded, at first globose, soon becoming enlarged and finally clathrate-fenestrate and irregularly torn, sometimes into filiform portions, gelatinous, blue-green or violet in color, or becoming darker; filaments numerous, abruptly twisted and flexuous; sheaths distinct near the surface of the mass, within confluent and transparent; trichomes 3.5-4 mic. in diameter, pale gray-green; cells short, depressed globose; heterocysts 5-6 mic. in diameter, somewhat spherical; gonidia 6-7 mic. in diameter, 7-8 mic. in length, somewhat globose, with a smooth outer membrane becoming darker with age.

Connecticut. Occurring in Lake Saltonstall, near New Haven. (Setchell). "It forms thickish sheets of a pale green color and very much crumpled. Occasionally some trace of its original globular shape is preserver and it forms large imperfect bladders several inches in diameter."-Setchell. South Dakota. In clear running spring water. Roberts County. (Saunders). "At first forming small, solid spherical masses, attached to stones, weeds, etc, finally becoming detached and forming hollow, torn, warty, dark brown masses, sometimes Io $\mathrm{cm}$. in diameter."-Collins, Holden and Setchell. Nebraska. In ponds. South Bend. (Bessey). Washington. Floating, intermingled with other algae, on ponds of fresh water. Near Coupeville, Whidbey Island. (Gardner). Hawaii. With Conf erval sandvicensis and other algae in ponds. Paoa Valley, Oahu. I875. (Berggren).

315. Nostoc piscinale Kuetzing. Phyc. Gen. 208. I843. Bornet and Flahault. Revis. des Nostoc. Ann. Sci. Nat. Bot. VII. 7: 194. I888. De Toni. Syll. Algar. 5: 393. 1907.

McClatchie. Proc. Southern Calif. Acad. I: 346. 1897. (N. r iv u 1 a r e). Collins, Holden and Setchell. Phyc. Bor.-Am. Fasc. 8. no. 355. I897. Richter. Süsswasseralgen aus dem Umanakdistrikt. Bib. Bot. Heft. 42. 5. 1897. Collins, Holden and Setchell. Phyc. Bor.-Am. Fasc. 23. no. IIII. 1903. Lemmermann. Algenf. Sandwich-Inseln. Bot. Jahrb. 34: 622. I905. 
Plate VII. fig. 2.

Colonies at first globose, light blue-green, afterwards becoming bullose and variously tuberculate, mucous or gelatinous, dark blue-green; filaments flexuous, moderately entangled; sheaths distinct near the surface of the mass, dark-colored, those in the interior confluent, transparent; trichomes 4 mic. in diameter, pale olive green; cells depressed spherical or about twice as long as the diameter; heterocysts 4-5.6 mic. in diameter, sunewhat spherical or oblong; gonidia 6-7 mic. in diameter, globose, in a lons catenate series, approximate, with a smooth, transparent outer layer grown together with the sheath.

Greenland. Karajak. (Richter). Canada. Pool near Bow River, Laggan, Alberta. July I90I. (Butler and Polley). California. In stagnant pool. Near Pasadena. May I896. (McClatchie). Hawaii. In ditches and pools between Honolulu and Waikiki, Oahu. I896-97. (Schauinsland).

316. Nostoc rivulare Kuetzing. Tab. Phyc. 2: 3. pl. Io. f. 3. I850. Bornet and Flahault. Revis. des Nostoc. Ann. Sci. Nat. Bot. VII. 7: 195. 1888. De Toni. Syll. Algar. 5: 395. I907.

Setchell and Gardner. Algae of Northwestern America. Univ. Calif. Pub. Bot. I : i89. I903.

Colonies at first globose, of various sizes, soon becoming bullate, tuberculate, hollow, then irregularly torn and perforated, lobed, fragile, at first light green, when older becoming yellowish or of various colors; filaments loosely entangled, moderately flexuous; sheaths distinct, yellowish at the surface of the mass, those in the interior transparent and confluent; trichomes 4-4.2 mic. in diameter; cells spherical oblong, a little longer than the diameter; heterocysts 5-6 mic. in diameter, oblong; gonidia 6-8 mic. in diameter, 7-10 mic. in length, oblong or barrel-shaped, contiguous when mature, with smooth, transparent or dark-colored outer membrane.

Alaska. Forming floating masses of light brown jelly in springs and frools. Near Huntville, Unalaska. (Setchell and Lawson). Washington. Near Green Lake, Seattle. (Gardner).

317. Nostoc carneum Agardh. Syst. Algar. 22. 1824. Bornet and Flahault. Revis. des Nostoc. Ann. Sci. Bot. VII. 7: 196. 1888. De Toni. Syll. Algar. 5: 395. 1907 .

Setchell and Gardner. Algae of Northwestern America. Univ. Calif. Pub. Bot. I: I90. I903. Collins, Holden and Setchell. Phyc. Bor.-Ant. Fasc. 29. no. 1403. 1907.

Plate VII. fig. 3 .

Colonies globose when young, later bullose, tuberculate, hollow, afterwards becoming irregular in form, expanded, diffluent into a gelatinous mucus, flesh-colored, dark-colored or pale blue-green; filaments loosely entangled, moderately flexuous; sheaths indistinct, transparent; trichomes 3.5-4 mic. in diameter; cells oblong cylindrical, about twice as long as wide; heterocysts 6 mic. in diameter, oblong; gonidia 6 mic. in diameter, 8-Io 
mic. in length, oval or elliptical, separated when mature, with a smooth, transparent thin outer membrane.

Alaska. Forming brown, floating masses of jelly on surface of streams. Glacier Valley, Unalaska. (Lawson). Connecticut. Floating in a spring, in irregularly rounded masses, from the size of a pin head to $5 \mathrm{~cm}$. in diameter. Mount Carmel. October I907. (Graves). Washington. Green Lake, Seattle. (Gardner).

318. Nostoc spongiaeforme Agardh. Syst. Algar. 22. 1824. Bornet and Flahault. Revis. des Nostoc. Ann. Sci. Nat. Bot. VII. 7: 197. 1888. De Toni. Syll. Algar. 5: 397. I907.

Tilden. American Algae. Cent. I. no. 83. I894; List of Fresh-water Algae collected in Minnesota during I894. Minn. Bot. Stud. I: 236. I895. Richter. Süsswasseralgen aus dem Umanakdistrikt. Bib. Bot. 8: Heft. 42. A. 5. I897. Tilden. Am. Alg. Century VI. no. 579. I902. Collins, Holden and Setchell. Phyc. Bor.-Am. Fasc. 22, no, I064. I903. Setchell and Gardner. Algae of Northwestern America. Univ. Calif. Pub. Bot. I: Igo. I903. Lemmermann. Algenfl. Sandwich-Inseln. Bot. Jahrb. 34: 622. 1905. Tilden. American Algae. Cent. VII. Fasc. I. no. 633. 1909.

\section{Plate VII. fig. 4, 5 .}

Colonies gelatinous, at first globose, afterwards expanded, verrucose, bullose, pale blue-green-violet, or reddish; filaments flexuous, loosely entangled; sheaths in the interior confluent, those near the outside of the mass more or less distinct, yellowish or dark-colored; trichomes about 4 mic. in diameter, blue-green or violet; cells different in shape, some cylindrical, up to $7 \mathrm{mic}$. in length, others barrel-shaped or depresed-spherical; heterocysts 7-8 mic. in diameter, somewhat globose or oblong; gonidia 6-7 mic. wide, IO-I2 mic. long, oblong, separated; wall of gonidium smooth, later becoming dark-colored.

Greenland. Ikerasak. Very abundant. (Richter). Minnesota. Floating on surface of water in tank. State Fish Hatcheries, St. Paul. September I894; on mosses and weeds in stagnant pond and on muddy ground, Woodland Park, Duluth. (Tilden). Washington. Floating in a small pool of fresh water. Edge of Green Lake, Seattle. (Gardner). California. Lake Chabot, San Leandro, Alameda county. June I902. (Osterhout and Gardner). Hawaii. In bogs in Nuanu, Oahu. (Schauinsland).

319 A. Nostoc ellipsosporum (Desmazières) Rabenhorst. Fl. Eur. Algar. 2: 169. I865. Bornet and Flahault. Revis. des Nostoc. Ann. Sci. Nat. Bot. VII. 7: 198. 1888. De Toni. Syll. Algar. 5: 398. I907.

Schramm and Mazé. Essai Class. Algues Guadeloupe. 29. 1865. (Hormosiphon antillarum S. and M.). Mazé and Schramm. Essai Class. Algues Guadeloupe. I4. I870-1877. (L. a n t i 11 a r u m Crouan). Collins, Holden and Setchell. Phyc. Bor,-Am. Fasc. 2. no. 59. 1895.

\section{Plate VII, fig. 6-Io.}

Plant mass gelatinous, expanded, adhering by under surface, irregularly mammillary, reddish or dark-colored; filaments flexuous, laxiy entangled; trichomes 4 mic. in diameter, pale blue-green or olive; cells 
similar in form, cylindrical, 6-14 mic. in length; heterocysts somewhat spherical or oblong, 6-7 mic. wide, 6-14 mic. long; gonidia 6-8 mic. in diameter, I4-I9 mic. long, elliptical or oblong-cylindrical; wall of gonidia smooth, transparent or yellowish.

Michigan. Growing over grass and moss, on wet clay bank, forming reddish-brown gelatinous masses, irregularly lobed and fusing into layers. Ann Arbor. September 1892. (Johnson). Minnesota. On wet rocks. Minrehaha Falls, Minneapolis. August 1883. (Farlow). West Indies. Guadeloupe. (Mazé).

319 B. Nostoc gelatinosum Schousboe in Bornet. Deuxième Note sur les Gonidies des Lichens. Ann. Sci. Nat. Bot. V. 19: 318. 1874. Bornet and Flahault. Revis. des Nostoc. VII. 7: 199. I888. De Toni. Syll. Algar. 5: 399. I905.

\section{Plate VII. fig. II.}

Colonies more than a centimeter in diameter, gelatinous, irregularly expanded, bullate-tuberculate, brownish; filaments flexuous, loosely entangled; sheaths near the outside of colony distinct, those in the interior hyaline and confluent; trichomes 4 mic. in diameter; cells 5 -Io mic. in length, oblongcylindrical; heterocysts 5 mic. in diameter, 6-Io mic. in length, elliptical; gonidia 6-8 mic. in diameter, 8-I4 mic. in length, with truncate apices, pale brownish in color; wall of gonidium furnished with minute spines.

Minnesota. With Anthoceros on bank of ditch. Near Minneapolis. September 1904. (Hillesheim).

320. Nostoc muscorum Agardh. Dispositio. Algar. Sueciae. 44. I8I2. Bornet and Flahault. Revis. des Nostoc. Ann. Sci. Nat. Bot. VII. 7: 200. I888. De Toni. Syll. Algar. 5: 400. 1907.

Dickie. In Hooker, J. D. An Account of the Plants collected by Dr. Walker in Greenland and Arctic America, etc. Journ. Linn. Soc. Bot. 5: 86. I86I; Notes on a collection of Algae procured in Cumberland Sound by Mr. James Taylor, etc. Journ. Linn. Soc. Bot. 9: 24I. 1867. Farlow. Notes on the Cryptogamic Flora of the White Mountains. Appalachia. 3: 236. I883. Wolle. Fresh-Water Algae U. S. 282. pl. 197. f. 35. I887. Collins. Algae of Middlesex County. I63. I888. (Also N. colli i u m). Anderson and Kelsey. Common and conspicuous Algae of Montana, Bull. Torr. Bot. Club. r8: 144. r891. Saunders. Protophyta-Phycophyta. Flora of Nebraska. 18. 1894. Tilden. American Algae. Cent. IV. no. 394. Igoo. West and West. A Further Contribution to the Freshwater Algae of the West Indies. Journ. Linn. Soc. Bot. 34: 288. I898-1900. Tilden. American Algae. Cent. VI. no. 580. I902. Setchell and Gardner. Algae of Northwestern America. Univ. Calif. Pub. Bot. I: Igo. 1903. Collins, Holden and Setchell. Phyc. Bor.-Am. Fasc. 23. no. Ir ro. 1903. Collins. Algae of the Flume. Rhodora. 6: 230. I904; Phycological Notes of the late Isaac Holden.-II. Rhodora 7: 242. 1905. Collins, Holden and Setchell. Phys. Bor.-Am. Fasc. 25. no. I2II. 1905. Buchanan. Notes on the Algae of Iowa. Proc. Iowa Acad. Sci. I4: II. 1908. 
Plate VII. fig. I2-I4.

Plant mass gelatinous-membranaceous, irregularly expanded, adhering by under surface, tuberculose, dull olive or dark-colored; filaments flexuous, densely entangled; trichomes 3-4 mic. in diameter, similar, olive; cells spherical or barrel-shaped, or cylindrical, about twice as long as broad; heterocysts somewhat globose, 6-7 mic. in diameter; gonidia 4-8 mic. in diameter, 8-12 mic. in length, oblong, in a catenate series, numerous; wali of gonidium smooth, yellowish.

Arctic Regions. Fresh water. Port Kennedy. (Lat. $72^{\circ}$ N.) (Walker). Alaska. Near Iliuliuk, Unalaska. July 1899; forming soft gelatinous lumps and masses of various shapes, on rocks among mosses, Amaknak Cave, Amaknak Island, Bay of Unalaska. (Setchell and Lawson). Canada. Cumberland Sound, Davis Strait. (Taylor). In brown bunches on sides of rock among moss. Just above high tide. Baird Point. Minnesota Seaside Station, Vancouver Island, British Columbia. August I898. (Tilden). Newfoundland. Signal Hill, St. Johns. July I897. (Holden). Maine. On sand by roadside, near seashore, in company with $\mathrm{Microcoleus}$ va $\mathrm{gi}$. n at us Harpswell. July 1904. (Collins). New Hampshire. On mosses. Berlin Falls, near Shelburne. 1882, I883. (Farlow). Massachusetts. Malden swamp in Middlesex Fells, Newton. (Farlow). Minnesota. On moist ground, among mosses and liverworts. St. Louis Park, Minneapolis. October Igor. (Hone). Iowa. On the stems of mosses. Fayette. I905. (Fink). Nebraska. On wet rocks and on the moss covering them. (Saunders). Montana. Abundant on moss under dripping rocks. (Anderson and Kelsey). Washington. Moist ground just above high wate: mark. Whidbey Island. (Gardner). West Indies. Growing on sides of road. Fort Charlotte, St. Vincent Island.

321. Nostoc humifusum Carmichael sec. Harvey in Hooker's British Flora. 2: 399. 1833. Bornet and Flahault. Revis. des Nostoc. Ann. Sci. Nat. Bot. VII. 7: 201. I888. De Toni. Syll. Algar. 5: 402. 1907.

Wolle. Fresh-Water Algae U. S. 280, 282. 1887. West and West. On some Freshwater Algae from the West Indies. Journ. Linn. Soc. Bot. 30: 269. I895; A Further Contribution to the Freshwater Algae of the West Indies. Journ. Linn. Soc. Bot. 34: 288. I898-r900.

\section{Plate VII. fig. 15.}

Plant mass gelatinous or mucous, irregular, of various sizes, sometimes punctiform, sometimes widely expanded from the confluence of many colonies, tuberculate, olive or brownish in color, adherent on under surface; filaments twisted and flexuous, densely entangled; sheaths usually yellowish and distinct throughout the mass, sometimes not distinct; trichomes 2.2-3 mic. in diameter; cells somewhat globose or twice as long as the diameter; heterocysts 3 mic. in diameter, somewhat spherical; gonidia 4 mic. in diameter, 6 mic. in length, somewhat globose or oval, with smooth and yellowish outer membrane; cell contents blue-green.

Florida. Colonies "inflated even to the size of a man's head." Island of Anastatia. (Smith). West Indies. On lime-trees. Shanford Estate; on trees, summit of Trois Pitons (4500 feet), November and December 
1892; in stream, Wotten Waven, January and February I896, Dominica. (Elliott).

322. Nostoc foliaceum Mougeot. Stirpes Vogeso-Rhenanae. Fasc. I4. no. 1372. 1854. Bornet and Flahault. Revis. des Nostoc. Ann. Sci. Nat. Bot. VII. 7: 202. I888. De Toni. Syll. Algar. 5: 403. 1907.

Tilden. American Algae. Cent. V. no. 485. Igor; Collection of Algae from the Hawaiian Islands. Hawaiian Almanac and Annual for I902. II2. I90I; Algae Collecting in the Hawaiian Islands. Postelsia: The Year Book of the Minnesota Seaside Station. I: I68. 1902.

Plate VII. fig. I6.

Plant mass gelatinous, spongy, lacunose, somewhat pellucid, green or olive, becoming brownish; filaments flexuous, entangled, pale bluegreen; trichomes $4 \mathrm{mic}$. in diameter; cells spherical compressed; heterocysts 7 mic. in diameter, somewhat spherical; gonidia 7 mic. in diameter, 7 -1o mic. in length, often oval; wall of gonidium smooth, colorless.

Hawaii. In globules among mosses and liverworts on dripping cliffs at side of road. South of Laupahoehoe, Hawaii. July rgoo. (Tilden).

323. Nostoc punctatum Wood. Contr. Hist. Fresh-Water Algae North America. 32. 1874. De Toni. Syll. Algar. 5: 404. 1907.

Plant mass expanded, irregular or orbicular, very thin, small, membranaceous, pellucid, blue-green; filaments loosely interwoven, variously curved; cells 4 mic. in diameter, globose or often elliptical, mostly pellucid in the center, loosely connected; heterocysts 5 mic. in diameter, terminal or intercalary.

New Jersey. Damp Ground. September. (Austin).

324. Nostoc commune Vaucher. Histoire des Conferves d'eau douce. 222. pl. I6. f. r. r8o3. Bornet and Flahault. Revis. des Nostoc. Ann. Sci. Nat. Bot. VII. 7: 203. I888. De Toni. Syll. Algar. 5: 404. 1907.

Harvey. Nereis Boreali Americana. Part III. Ir3, II4. Suppl. II. I34. I858. (N. ver rucos u m Rabenh., N. arcticum Harv.). Dickie. Algae. Hooker. An Account of the Plants collected by Dr. Walker in Greenland and Arctic America during the Expedition of Sir Francis M'Clintock, R. N., in the Yacht "Fox." Journ. Linn. Soc. Bot. 5: 86. I86r; Notes on a Collection of Algae procured in Cumberland Sound by Mr. James Taylor, and Remarks on Arctic Species in General. Journ. Linn. Soc. Bot. 9: 240. I867. Wood. Contr. Hist. Fresh-Water Algae North America. 32, 37. 1874. Dickie. On the Algae found during the Arctic Expedition. Journ. Linn. Soc. Bot. I7: 8. I880. Campbell. Plants of the Detroit River. Bull. Torr. Bot. Club. I3: 93. I886. Wolle. FreshWater Algae U. S. 283. pl. 197. f. 8. 1887. Bennett. Plants of Rhode Island. 114. I888. Wolle and Martindale. Algae. Britton's Catalogue of Plants found in New Jersey. Geol. Surv. N. J. 2: 606. I889. Wittrock and Nordstedt. Algae Aq. Dulc. Exsicc. no. 890. I890. Anderson and Kelsey. Common and Conspicuous Algae of Montana. Bull. Torr. Bot. Club. 18: 144. 189r. Smith and Pound. Flora of the Sand Hill Region of 
Sheridan and Cherry Counties. Bot. Surv. Nebraska. 30. 1893. Saunders. Protophyta-Phycophyta. Flora of Nebraska. I7. 1894. Nelson. The Cryptogams of Wyoming. Wyoming Experiment Station. Tenth Ann. Report. 5. I900. Collins, Holden and Setchell. Phyc. Bor.-Am. Fasc. 9. no. 403. 1898. Trelease and Saunders. Plants of Yakutat Bay. Harriman Alaska Expedition. no. 502, I899. Collins. The Algae of Jamaica. Proc. Am. Acad. Arts Sci. 37: 240. I90I. Saunders. The Algae. Harriman Alaska Expedition. Proc. Wash. Acad. Sci. 3. 397. I901. Tilden. American Algae. Cent. V. no. 486. Igor; Collection of Algae from the Hawaiian Islands. Hawaiian Almanac and Annual for I902. II2. I9or; Cent. VI. no. 58I. I902; Algae Collecting in the Hawaiian Islands. Postelsia: The Year Book of the Minnesota Seaside Station. I: I69. I902. Setchell and Gardner. Algae of Northwestern America. Univ. Calif. Pub. Bot. I: 190. 1903. Collins. Phycological Notes of the late Isaac Holden.-II. Rhodora. 7: 236. 1905. Collins, Holden and Setchell. Phyc. Bor.-Am. Fasc. 25. no. I2IO. I905. Lemmermann. Algenf. Sandwich.-Inseln. Bot. Jahrb. 34: 622. I905. Brown. Algal Periodicity in Certain Ponds and Streams. Bull. Torr. Bot. Cluh 35: 247. 1908. Buchanan. Notes on the Algae of Iowa. Proc. Iowa Acad. Sci. I4: II. I908. Collins, Holden and Setchell. Phyc. Bor.-Am. Fasc. 3I. no. I504. I908.

\section{Plate VIII. fig. I.}

Plant mass gelatinous, firm, in the beginning spherical, afterwards becoming flattened, finally spreading out into undulating, folded, flesiny or membranaceous, entire or torn, often perforated sheets, leathery on the surface, blue-green, olive or brown in color; filaments flexuous, entangled; sheaths usually brownish near the surface of the mass, in the interior more or less distinct, often colorless; trichomes 4-5-6 mic. in diameter; cells depréssed spherical or barrel-shaped; heterocysts 7 mic. in diameter, somewhat sphierical, often up to three or five in number; gonidia not known.

Arctic Regions. In several localities and in varıous stages. From sea level up to Iooo feet. Prevoost Island; shores of Hayes Sound; Floeber $r$ Beach; Egerton Valley. (Dickie). On naked soil in boggy ground. Assistance Bay, Lat. $75^{\circ} 40^{\prime} \mathrm{N}$. (Sutherland). Beechey Isldnd. (Lyall). Fresh water. Port Kennedy. (Walker). Alaska. Forming thin leathery thalli of indefinite size and shape, on damp ground. Near Glacier Bay. (Saunders). Hidden Glacier, Yakutat Bay. June r899. (Trelease). Assuming various shapes, from discoid thalli to flat expansions of considerable extent, on soil or on rocks. St. Michael. (Setchell). Iliuliuk, Unalaska. (Setchell and Lawson). Greenland. On stones in fresh water stream and pools of fresh water. Disko Island. (Lyall). Canada. Various parts of the shores of the Gulf, Cumberland Sound, Davis Strait. (Taylor). Massachu. setts. On steep wet rock near Winchester North Reservoir. June Igo4. (Collins). Rhode Island. Common. (Bennett). Connecticut. On limestone. Road near Gaylordsville. October. (Holden). New Jersey. On wet ground, common. (Austin). Dripping rocks, Palisades, Bergen. (Wolle). Maryland. On a grassy bank in sandy soil. Loch Raven, Baltimore county. July 1897. (Waters). Georgia. On moist ground among various plants. Thomson, McDuffee County. August 1908. (Bartlett). Texas. On mud 
flats. Cedar Bayou, Harris County. (Ravenel). Indiana. Near Bloom. ington. (Brown). Michigan. Grosse Isle, near mouth of Detroit River. Summer of I885. (Campbell). Minnesota. On damp ground on hillside. Mendota. October I9or. (Hillesheim and Lilley). Iowa. A very common alga in the damp margins of marshy places. Iowa City. I880. (Hobby). Ames. (Bessey, Buchanan). Grinnell. I904. (Fink). Eagle Grove. I904. (Buchanan). Nebraska. On the ground and in shallow ponds in a pass between two wet valleys. Cherry County. July I892. (Smith and Pound). Frequent on damp earth and in stagnant or running water. Often found covering the ground for some distance in damp places. (Saunders). Kansas. Attached to bare patches of soil. (Parry). Montana. "Common throughout the state. On the high foot-hills (5,000-7,000 feet), on the alkaline plains and in the valleys. In inundated places, where the water is kept warm by the sun's rays, this Nostoc grows with marvelous rapidity, and frequently attains a diameter of ten inches and a half in thickness." (Anderson and Kelsey). Wyoming. Very plentiful in small pools on ledges of rock. Telephone Cañon, Albany County. April 1897. (Nelson). New Mexico. Santa Fé. (Fendler). Washington. Whidbey Island. (Gardner). Mexico. On damp soil in autumn; common after rain on dry flats. Rio Bravo (Rio Grande). (Schott). Bermudas. On the ground. Castle Point. February I898. (Richards). West Indies, In crusts on sandy soil. Constant Spring, Jamaica. April 1893. (Humphrey). Hawaii. In dense forest. Near Halfway House, Kilauea, Hawaii. (Schauinsland). Forming gelatinous, firm, flat wrinkled masses on boards of flume (not covered by water), head of flume. (2,300 feet). Pacific Sugar Mill, Hama-kua, Hawaii. July Igoo. (Tilden).

Var. flagelliforme (Berkeley and Curtis) Bornet and Flahault. 1. c. 206. Wright. Plantae Texanae. no. 3809. Harvey. 1. c. II5. Wood. 1. c. 226. De Toni. 1. c. 408.

Farlow, Anderson and Eaton. Algae Am.-Bor. Exsicc. no. 100. 1878. Anderson and Kelsey. Common and Conspicuous Algae of Montana. Bull. Torr. Bot. Club. I8: I44. I89I. Collins, Holden and Setchell. Phyc. Bor.Am. Fasc. 3I. no. I505. I908.

Plant mass filiform, up to $3-4 \mathrm{~mm}$. in width, firm; trichomes parallel.

Texas. On naked aluminous soil. San Pedro. (Wright). Montana. Very common on the alkali plains about Helena. It has the appearance of "small weather-beaten, entangled tufts of black horsehair." (Anderson and Kelsey). Mexico. On sandy soil. Mazapil, Zacatecas. (Lloyd).

325. Nostoc sphaericum Vaucher. Histoire des Conferves d'eau douce. 223. p1. 16. f. 2. I803. Bornet and Flahault. Revis. des Nostoc. Ann. Sci. Nat. Bot. VII. 7: 208. I888. De Toni. Syll. Algar. 5: 409. I907.

Wood. Contr. Hist. Fresh-Water Algae North America. 30. I872. Campbell. Plants of the Detroit River. Bull. Torr. Bot. Club. I3: 93. 1886. Wolle. Fresh-Water Algae U. S. 283. pl. I97. f. I8-20. I887. Collins. Algae of Middlesex County. I4. I888. Bennett. Plants of Rhode Island. II4. I 888. Wolle and Martindale. Algae. Britton's Catalogue of Plants found in New Jersey. Geol. Surv. N. J. 2: 606. I889. Anderson and Kelsey. Common and Conspicuous Algae of Montana. Bull. Torr. Bot. Club. 
I8: 144. I891. West and West. On some Freshwater Algae from the West Indies. Journ. Linn. Soc. Bot. 30: 269. I895. Collins. Algae. Flora of the Blue Hills, Middlesex Fells, Stony Brook and Beaver Brook Reservations of the Metropolitan Park Commission, Massachusetts. I28. I896. Tilden. American Algae. Cent. III. no. 29. I898. Collins, Holden and Setchell. Phyc. Bor.-Am. Fasc. 16. no. 755. I900. Bessey, Pound and Clements. Additions to the Reported Flora of the State. Bot. Surv. Nebraska. 5: I2. 190I. Tilden. American Algae. Cent. VI. no. 582. I902. Setchell and Gardner. Algae of Northwestern America. Univ. Calif. Pub. Bot. I: I91. 1903. Collins, Holden and Setchell. Phyc. Bor.-Am. Fasc. 30. no. I453. 1908. Buchanan. Notes on the Algae of Iowa. Proc. Iowa. Acad. Sci. I4: II. Igo8.

\section{Plate VIII. fig. 2.}

Colonies free, spherical I-I5 $\mathrm{mm}$. in diameter, finally becoming irregularly plicate-tuberculate, thick, sometimes 6-7 cm. in diameter, solid, surrounded by a firm outer layer, olive' green, yellowish or violet, bccoming brownish; filaments flexuous, densely entangled; trichomes 4 rarely 5 mic. in diameter; cells spherical compressed or barrel-shaped; heterocysts 6 mic. in diameter, somewhat spherical; gonidia 5 mic. in diameter, 7 mic. in length, oval; wall of gonidium thick, smooth, becoming brownish.

Alaska. On dripping rocks among mosses. Amaknak Island, Bay of Unalaska. (Setchell and Lawson). Maine. Minute colonies free, among various algae, in salt marsh pools. Harpswell. July 1905. (Collins). Massachusetts. In minute blackish or greenish rounded masses on wet rocks, near the Cascade. Melrose, Middlesex Fells. (Collins). Rhode Island. Providence. (Bennett). New Jersey. Abundant on wet rocks. (Wolle). Pennsylvania. Adhering to mosses and twigs in the water. Spring Mills, near Philadelphia. (Wood). North Carolina. On wet rocks with moss. Tryon. March I897. (Green). Michigan. Grosse Isle. Near mouth of the Detroit River. Summer of 1885. (Campbell). Minnesota. Among mosses on cliff overhanging stream. Dalles of the St. Louis River, Fond du Lac, near Duluth. August Igor. (Tilden). Iowa. Iowa City. (Hobby). Ames. (Bessey). Nebraska. On soil in greenhouse. Lincoln. (Bessey). Montana. Damp rocks in shady ravines, (Anderson and Kelsey). West Indies. On damp wall of dam in Sharp's River, St. Vincent. May 1892. (Elliott).

326. Nostoc minutum Desmazières. Plantes Cryptog. de France. Ist Ed. Fasc. II, no. 50. 1831. Bornet and Flahault. Revis. des Nostoc. Ann. Sci. Nat. Bot. VII. 7: 209. I888. De Toni. Syll. Algar. 5: 4II. 1907.

Setchell and Gardner. Algae of Northwestern America. Univ. Calif. Ptib. Bot. I: 191. 1903.

Plant mass minute, gregarious, spherical, finally becoming flattened, membranaceous, up to Io $\mathrm{mm}$. in diameter; filaments densely entangled; trichomes 2.5-3 mic. in diameter; cells barrel-shaped; heterocysts 4-5 mic. in diameter; gonidia unknown. 
Alaska. On dripping rocks, much mixed with other algae of a gelatinous nature. Iliuliuk, Unalaska. (Setchell and Lawson).

327. Nostoc calidarium Wood. Contr. Hist. Fresh-Water Algae North America. 34. pl. 2. f. 2. 1872. De Toni. Syll. Algar. 5: 409, 423. I907.

Plate VIII. fig. 3.

Plant mass indefinitely expanded, either membranaceous coriaceous o: gelatinous, bright or dull olive green or olive brown, irregularly and deeply sinuate, finally neatly laciniate; filaments 2 mic. (?) in diameter, unequal, sometimes flexuously curved but mostly straight and closely joined, occurring in two forms; the one small, with cylindrical cells, scatterer heterocysts and diffluent sheaths, if any; the other form very large, with globose or oblong cells and heterocysts not different from the other cells.

California. In hot springs. Temperature IIO-I $20^{\circ}$ and $124-135^{\circ}$. F. Benton's Spring, Owen's Valley, sixty miles southwest from Aurora. (Partz).

328. Nostoc austinii Wood. Contr. Hist. Fresh-Water Algae North America. 27. I872. De Toni. Syll. Algar. 5: 4II. I907.

Colonies somewhat spherical, small, mostly the size of fish eggs, but reaching the diameter of nearly. $4 \mathrm{~mm}$., sometimes very hard, sometimes much softer, with surface often corrugated, brownish or blackish; filaments variously curved, densely entangled or distantly and loosely interwoven, greenish, brownish, lead-colored or yellowish brown; sheaths often distinct in smaller colonies, those in larger ones indistinct or not visible; trichomes 6.5-8.2 mic. in diameter; cells spherical, often in pairs; heterocysts equal to diameter of cells or a little larger, spherical, intercalary or terminal, cell contents coarsely granular.

New Jersey. Growing amidst mosses on rocks. Near Gloucester. (Austin).

329. Nostoc macrosporum Meneghini. Monographia Nostochinearum ital. I 6. pl. I4. f. 2. 1843. Bornet and Flahault. Revis. des Nostoc. Ann. Sci. Nat. Bot. VII. 7: 209. 1888. De Toni. Syll. Algar. 5: 4I2. 1907.

Farlow. Notes on the Cryptogamic Flora of the White Mountains. Appalachia. 3: 236. 1883. Wolle. Fresh-Water Algae U. S. 284. 1887. Bessey, Pound and Clements. Additions to the Reported Flora of the State. Bot. Surv. Nebraska. 5: I2. Igor.

Plate VIII. fig. 4.

Colonies small, solid, spherical or oblong, blue-green or olive, becoming brownish; filaments loosely entangled, flexuously curved, or spirally rolled; sheaths often distinct, yellowish; trichomes 8-9 mic. in diameter, especially cylindrical; cells short, disc-shaped, or equalling the diameter in length, closely connected; heterocysts 9-1o mic. in diameter, somewhat spherical; gonidia (according to Borzi) "globose, angular from mutual pressure, or globose-compressed, two or three times larger than the cells; wall of gonidium thin, very smooth"; cell contents pale blue-green or olive green. 
New Hampshire. Mixed with other algae. The "Flume," Shelburne, Lake Willoughby. (Farlow).

Nebraska. On pots in greenhouse. Lincoln. (Bessey).

330. Nostoc microscopicum Carmichael. Harvey in Hooker's British Flora. 5: 399. 1833. Bornet and Flahault. Revis. des Nostoc. Ann. Sci. Nat. Bot. VII. 7: 210. I888. De Toni. Syll. Algar. 5: 413. 1907.

- Harvey. Nereis Boreali-Americana. Part III. II5. 1858. Dickie. Notes on a Collection of Algae procured in Cumberland Sound by Mr. James Taylor. Journ. Linn. Soc. Bot, 9: 24I. I867. Farlow. Notes on the Cryp. togamic Flora of the White Mountains. Appalachia. 3: 236. I883. (N. rupestre Kg.). Harvey. The Fresh-Water Algae of Maine. I. Bull. Torr. Bot. Club. I5: I6r. I888. Bennett. Plants of Rhode Island. II4. I888. Wolle and Martindale. Algae. Britton's Catalogue of Plants found in New Jersey. Geol. Surv. N. J. 2: 606. I889. Collins, Holden and Setchell. Phyc. Bor.-Am. Fasc. 6. no. 256. I897. Collins. The Algae of Jamaica. Proc. Am. Acad. Arts Sci. 37: 240. I90I. Collins, Holden and Setchell. Phyc. Bor.Am. Fasc. 23. no. Iro9. 1903. Setchell and Gardner. Algae of Northwestern America. Univ. Calif. Pub. Bot. I: I9I. Ig03. Collins. Algac of the Flume. Rhodora. 6: 230. I904. West. West Indian Freshwater Algae. Journ. of Bot. 42: 291. r904. Collins. Phycological Notes of the late Isaac Holden.-II. Rhodora. 7: 236. I905.

\section{Plate VIII. fig. 5.}

Colonies spherical or oblong, rarely beyond $\mathrm{I} \mathrm{cm}$. in diameter, soft, at first glistening, finally becoming olive or brownish; filaments loosely entangled; sheaths more or less distinct, yellowish, "contrasting with the generally uncolored jelly" (Cooke); trichomes 5-8 mic. in diameter; cells somewhat spherical; heterocysts $7 \mathrm{mic}$. in diameter, somewhat spherical; gonidia 6-7 mic. in diameter, 9-r 5 mic. in length, oval, olive; wall of gonidium smooth; cell contents sky blue or violet-green.

Canada. On stones in a small stream. Baffin's Bay. (Sutherland). Cumherland Sound. (Taylor). Maine. In a lake near Houlton. (Harvey). New Hampshire. On rocks. The "Flume." (Farlow). Vermont. On wet rocks. Ripton Gorge. September 1896. (Farlow). Massachusetts. On pebbles in rather shallow water. Suntaug Lake, Peabody. September I892. (Collins). Rhode Island. Providence. (Bennett). Connecticut. Sage's Ravine, Salisbury, below First Falls. October. (Holden). New Jersey. Frequent on moist rocks. (Wolle). Washington. Floating, intermingled with other algae. Whidbey Island; Seattle. (Gardner). West Indies. On steps into reservoir. Constant Spring. April r893. (Humphrey). "Chancery Lane Estate," Barbados. (Howard).

33r. Nostoc sphaeroides Kuetzing. Tab. Phyc. 2: 2. pl. 4. f. 1. r85o. Bornet and Flahault. Revis, des Nostoc. Ann. Sci. Nat. Bot. VII 7: 212. I888. De Toni. Syll. Algar. 5: 4I5. 1907.

Hall. List of the Marine Algae growing in Long Island Sound within 20 miles of New Haven. Bull. Torr. Bot. Club. 6: II2. I876. Collins. Algae of Middlesex County. I4. 1888. Collins, Holden and Setchell. Phyc. Bor.-Am. Fasc. ro. no. 454. r898. Saunders. The Algae. Harriman Alaska 
Expedition. Proc. Wash. Acad. Sci. 3: 398. I90r. Setchell and Gardner. Algae of Northwestern America. Univ. Calif. Pub. Bot. I: I9I. I903.

Colonies of medium size, spherical, green becoming bluish; trichomes 4-7 mic. in diameter, tapering at the apices; gonidia 6-7 mic. in diameter, exactly spherical, angular from mutual pressure, orange becoming brownish; wall of gonidium somewhat thick, rough.

Alaska. Forming a soft, bluish green coating on rocks near Juneau. (Saunders). Massachusetts. Cambridge. (Farlow), Fresh Pond, Cambridge. (Richards). Connecticut. Pools. Whitneyville and Beaver Meadows. (Eaton).

332. Nostoc depressum Wood. Contr. Hist. Fresh-Water Algae Nortin America. 30: 1872. De Toni. Syll. Algar. 5: 415. 1907.

Colonies irregularly suborbicular, gregarious and sometimes aggregated, elastic, surrounded by a firm, translucent outer layer, about the size of a mustard seed or smaller, adhering to submerged mosses, blackish in color; filaments mostly loosely interwoven; sheaths not present; trichomes 5 mic. in diameter; cells spherical, generally rather closely connected, rarely distant: heterocysts, 7 mic. in diameter, rather larger than the cells.

New Jersey. Attached to a brook moss, growing in a rapid rivulet in the northern part of the state. (Austin).

333. Nostoc glomeratum Kuetzing. Tab. Phyc. 2: 2. pl. 3. f. 5. I850. De Toni. Syll. Algar. 5: 4I5. 1907.

Wolle. Fresh Water Algae. III. Bull. Torr. Bot. Club. 6: I83. I877.

$$
\text { Plate VIII. fig. 6, } 7 \text {. }
$$

Colonies spherical, usually aggregated in grape-like clusters, leadcolored or becoming somewhat purplish, with inconspicuous outer layer; trichomes 3.5-4 mic. in diameter, more or less densely entangled, somewhat equal in thickness; cells spherical, crowded; heterocysts $7-7.7$ mic. in diameter.

California. On filaments of old Clad ophora. (Anderson).

334. Nostoc caeruleum Lyngbye. Hydrophytologia danica. 20r. p1. 68. f. B. I8I9. Bornet and Flahault. Revis. des Nostoc. Ann. Sci. Nat. Bot. VII. 7: 213. 1888. De Toni. Syll. Algar. 5: 416. 1907.

Wood. Contr. Hist. Freshwater Algae. North America. 3I. I872 Wolle. Fresh-Water Algae U. S. 284. 1887. Wolle and Martindale. Algae. Britton's Catalogue of Plants found in New Jersey. Geol. Surv. N. J. 2: 606. I889. Tilden. American Algae. Cent. I. no. 84. 1894; List of FreshWater Algae collected in Minnesota during 1894. Minn. Bot. Studies. I: 236. 1895. Setchell and Gardner. Algae of Northwestern America. Univ. Calif. Pub. Bot. I: I9I. I903. Collins, Holden and Setchell. Phyc. Bor.-Am. Fasc. 24. no. II66. I904. Buchanan. Notes on the Algae of Iowa. Proc. Iowa Acad. Sci. I4: II. 1908.

\section{Plate VIII. fig. 8.}

Colonies very small, up to 5-6 mm. in diameter, spherical, solid, 
separate or aggregated, sometimes proliferated, surrounded by a firm, tenacious outer layer, blue-green, sky blue, or becoming brownish, pellucid; filaments densely interwoven, flexuously twisted; sheaths usually indistinct; trichomes 5-7 mic. in diameter, twisted; cells barrel-shaped; heterocysts 8-10 mic. in diameter, spherical or depressed spherical; gonidia unknown.

New Jersey. Growing attached to moss. Northern part of state. (Austin). Minnesota. In small stagnant pools at edge of lake. Parker's Lake, Hennepin County. July I894. (Tilden). Floating in great quantities. Lake Zumbra. September 1903. (Butler). Iowa. Ames. I884. (Bessey). Washington. In a ditch of fresh water. Near Seattle. (Gardner).

335. Nostoc pruniforme (Linn.) Agardh. Dispositio Algar. Sueciae. 45. I812. Bornet and Flahault. Revis, des Nostoc. Ann. Sci. Nat. Bot. VII. 7: 2I5. I888. De Toni. Syll. Algar. 5: 4I8. I907.

Wood. Contr. Hist. Fresh-Water Algae North America. 28. 1872. Wolle. Fresh Water Algae. III. Bull. Torr. Bot. Club. 6: 183. I877. Rabenhorst. Die Algen Europas. no. 2530. I878. Twitchell. Remarks on a Variety of Nostoc pruniforme. Journ. Cin. Soc. Nat. Hist. 9: 253. 1886. Wolle. Fresh-Water Algae U. S. 284. I887. Atwell. A Deep-Water Nostoc. Bot. Gaz. I4: 29r. I889. Wolle and Martindale. Algae. Britton's Catalogue of Plants found in New Jersey. Geol. Surv. N. J. 2: 606. I889. Johnson and Atwell. Fresh Water Algae. Northwestern University. Report Dept. Nat. Hist. 2I. 1890. Saunders. Protophyta-Phycophyta. Flora of Nebraska. I8. pl. I. f. 4. a, b. I894. Tilden. List of Fresh-Water Algae collected in Minnesota during I893. Minn. Bot. Studies. I: 31. r894; American Algae. Cent. I. no. 85. 1894; List of Fresh-Water Algae collected in Minnesota during I894. Minn. Bot. Studies. I: 236. I895. Collins, Holden and Setchell. Phyc. Bor.-Am. Fasc. 2. no. 58. 1895; 1. c. Fasc. 14. no. 657. I900. Setchell and Gardner. Algae of Northwestern America. Univ. Calif. Pub. Bot. I: 19r. I903. Collins. Phycological Notes of the late Isaac Holden. II. 7: 237. I905. Buchanan. Notes on the Algae of Iowa. Proc. Iowa Acad. Sci. I4: II., 1908.

\section{Plate VIII. fig. 9, Io.}

Colonies spherical, attaining the size of a hen's egg, soft and watery within, at length hollow, surrounded by a leathery outer layer, olive or dark blue-green, finally becoming brownish or blackish; filaments loosely cntangled, radiating from the center; sheaths often distinct, colorless, rarely yellowish; trichomes $4-6$ mic. in diameter, cells spherical compressed or a little longer than the diameter; heterocysts 6-7 mic. in diameter, somewhat spherical.

Maine. (Leidy). Connecticut. In a stagnant pool connected with the lower of "Twin Lakes," mostly resting on the bottom, but attached when young to sticks, etc., growing to the diameter of about $5 \mathrm{~cm}$. Salisbury, Litchfield County. August I895. (Holden). New Jersey. In ponds, frequent. (Wolle). Pennsylvania. In stagnant water. Bethlehem. 1877. (Wolle). Illinois. "With the first gales of November and March each year there appears upon the shore of Lake Michigan, an abundance of 
an interesting form of Nostoc. It was first observed in 1864 by Professor Oliver Marcy. Thrown out upon the shore by the waves, it appears as small, purple and green balls or thalli." (Atwell). Thrown up in extensive "windrows" on the shore of Lake Michigan. Evanston. August I894. (Johnson). Minnesota. Lake Kilpatrick. June I893; floating free or attached to water plants in artificial lake, Minneapolis, August I894. (Tilden). Iowa. Nodules often reaching the size of a plum. (Fink). Very small, in pool near Ontario, Ames. (Buchanan). Nebraska. In still water. (Saunders). Idaho. (Twitchell). Washington. In ditches of fresh water. Near Seattle. (Gardner).

336. Nostoc verrucosum (Linn.) Vaucher. Histoire des Conferves d'eat douce. 225. pl. I6. f. 3. I803. Bornet and Flahault. Revis. des Nostoc. Ann. Sci. Nat. Bot. VII. 7: 216. I888. De Toni. Syll. Algar. 5: 4I9. I907.

Harvey. Nereis Boreali-Americana. Part III. II4. 1858. Dickie. Algae. Hooker. An Account of the Plants collected by Dr. Walker in Greenland and Arctic America during the expedition of Sir Francis M'Clintock, R. N., in the Yacht "Fox," 21 Je. I86o. Journ. Linn. Soc. Bot. 5: 79. 186r; Notes on a Collection of Algae procured in Cumberland Sound by $\mathrm{Mr}$. James Taylor. 1. c. 9: 24I. I867. Harvey. Determinations of Algae in Rothrock's Sketch of the Flora of Alaska. Ann. Rept. Bd. Regents. Smiths. Inst. for 1867. Wood. Contr. Hist. Fresh-Water Algae North America. 28. I874. Wolle. Fresh-Water Algae. U. S. 284. p1. I97. f. I, 2. 1887. Johnson and Atwell. Fresh Water Algae. Northwestern University. Report. Dept. Nat. Hist. 2 I. 1890. Anderson and Kelsey. Common and Conspicunus Algae of Montana. Bull. Torr. Bot. Club. I8: I44. I89I. Millspaugh. Contribution III. to the Coastal and Plain Flora of Yucatan. Field Columbian Museum. Bot. I: 347. I898. Tilden. American Algae. Cent. V. no. 393. I900. Bessey, Pound and Clements. Additions to the Reported Flora of the State. Bot. Surv. Nebraska. 5: 12. I9or. Collins. The Algae of Jamaica. Proc. Am. Acad. Arts Sci. 37: 240. 1901. Tilden. Collection of Algae from the Hawaiian Islands. Haw. Almanac and Annual for I902. II2. I90I; American Algae. Cent. V. no. 487. I90I; Cent. VI. no. 583. I902; Algae Collecting in the Hawaiian Islands. Postelsia: The Year Book of the Minnesota Seaside Station. I: I70. I902. Setchell and Gardner. Algae of Northwestern America. Univ. Calif. Pub. Bot. I: 19r. 1903. Brown. Algal Periodicity in Certain Ponds and Streams. Bull. Torr. Bot. Club. 35: $242,247.1908$.

\section{Plate VIII. fig. II-I6.}

Colonies often gregarious, up to $10 \mathrm{~cm}$. in diameter, at first solid, gelatinous, firm, spherical or rotund and plicate-undulate, afterwards becoming hollow, vesicular, softer, and torn, when young olive-blackish, becoming brownish green when older; filaments flexuously twisted, densely entangled near the surface; sheaths thick, often indistinct, colorless or yellowish brown; trichomes 3-3.5 mic. in diameter, especially cylindrical; cells spherical depressed, shorter than the diameter; closely connected; heterocysts $6 \mathrm{mic}$. in diameter, somewhat spherical; gonidia $5 \mathrm{mic}$. in diameter, 7 mic. in length; oval; wall of gonidium smooth, yellowish. 
Arctic Regions. Beechey Island. (Lyall). Port Kenedy. (Walker). Alaska. Fresh water pools. Port Clarence. (Harvey). Greenland. On stones in fresh water streams; in pools of fresh water, Island of Disko. (Lyall). Canada. Freshwater. Cumberland Sound. (Taylor). Pennsylvania. Growing in great abundance in very cold, large, limestone spring. Centre County. Summer of I869. (Wood). Indiana. Attached to the stone bottom of a small stream, flowing across University Campus. Jordan Branch. Bloomington. (Brown). Wisconsin. Attached to rocks in waterfall. Burkhardt. September I899. (Tilden). Illinois. Bowmanville. July. (Johnson and Atwell). Minnesota. On rocks in falls in river. Lester River, Lester Park, Duluth. August Ig0I. (Tilden). Nebraska. In cuiture in greenhouse. Lincoln. (Bessey). Montana. "Common at the Falls of the Missouri and in spring water impregnated with lime. In the fall of the year this species is torn from its hold on submerged rocks in the lipper Missouri River, rises to the surface and floats to the shore in large numbers. Sometimes watery, hollow specimens, the size of bantam eggs, are picked up." (Anderson and Kelsey). New Mexico. Santa Fé. (Fend1(r). Nevada. Attached to rocks in running water. Humboldt River, Winnemucca. July IgoI. (Griffiths). Mexico. "Found in the aguada Chulubmay, nine miles east of Izanal. March." (Millspaugh). West Indies. On rocks in "Wag Water" and in a trough in running water. Castleton, Jamaica. April I893. (Humphrey). Hawaii. Forming small, black, "shot-like" balls, covering sides of pools in falls and rapids. Head waters of flume (2,300 feet), Pacific Sugar Mill, Hamakua, Hawaii. July Igoo. (Tilden).

337. Nostoc amplissimum Setchell. Notes on Cyanophyceae. III. Erythea. 7: 50. pl. 2, 3. f. I, 2. I899. De Toni. Syll. Algar. 5: 421. 1907.

Collins, Holden and Setchell. Phyc. Bor.-Am. Fasc. I2. no. 558. I899.

Plate VIII. fig. I7-rg.

Colonies at first spherical, very early becoming hollow and lobulated, cxpanding until they become irregular, verrucose, brownish yellow sacs, measuring up to $60 \times 30 \mathrm{~cm}$.; membrane of sack of varying thickness, 2-Io $\mathrm{mm}$., composed of one to several layers of jelly in which trichomes are embedded, also containing abundant small lumps of lime; filaments very numerous, arranged somewhat variously, near upper and lower surfaces much contorted, in middle more nearly horizontal and parallel; sheaths of outer filaments conspicuous, wide, brown, those of inner filaments distinct, colorless, usually wanting in case of central filaments; trichomes 2-3 mic. in diameter, more or less torulose; cells 3.5-5 mic. in length, depressed spherical or short cylindrical; heterocysts ustally about 4 mic. in diameter; gonidia 3-4 mic. in diameter, 5-6 mic. in length, ellipsoidal, usually beginning to form in outer layer, wall of gonidium smooth, brown.

California. On stones in streams. Near Pasadena. May I8g6. (McClatchie). Floating and attached to the sides of a watering trough, supplied from an artesian well. Near Hollister. April I897. (Setchell).

Dr. Setchell calls attention to the fact that this is the largest species belonging to the Cyanophyceae. 
338. Nostoc parmelioides Kuetzing. Phyc. Gen. 206. I843. Bornet and Flahault. Revis. des Nostoc. Ann. Sci. Nat. Bot. VII. 7: 219. I888. De Toni. Syll. Algar. 5: 422. 1907.

Harvey. Nereis Boreali-Americana. Part III. II4, I34. I858. (N. crist a t u m Bailey, N. suther la ndi Dickie). Schramm and Mazé. Essai Class. Algues Guadeloupe. 29. I865. (H y d r o c o c cus g u a de 1 u pe n s is: Crouan). Mazé and Schramm. Essai Class. Algues Guadeloupe. I3. I8701877. (Oncobyrsa guadelupensis Crouan). Wood. Contr. Hist. Fresh-Water Algae North America. 29. I872. N. al p in u m Wood). Wolle. Fresh Water Algae. III. Bull. Torr. Bot. Club. 6: 183. 1877; FreshWater Algae U. S. 285. p1. 197. f. 33, 34. 1887. Setchell. Notes on somi Cyanophyceae of New England. Bull. Torr. Bot. Club. 22: 428. I895. Collins, Holden and Setchell. Phyc. Bor.-Am. Fasc. 2. no. 57. 1895. Tilden American Algae. Cent. II. no. I68. I896. Collins, Holden and Setchell. Phyc. Bor.-Am. Fasc. 5. no. 236. I896. Tilden. American Algae. Cent. VI. no. 584. 1902.

Plate VIII. fig. 20.

Colonies attached, disc-shaped or tongue-shaped, hard, sometimes. somewhat spherical, of various sizes, up to $2 \mathrm{~cm}$. in diameter; filaments radiating from the center, somewhat straight at the center, parallel, entangled, those near the surface densely twisted and entangled; sheaths of cuter filaments yellowish, distinct, those of the inner, colorless, often confluent; trichomes 4-4.5 mic. in diameter; cells spherical or spherical depressed, closely connected; heterocysts 6 mic. in diameter, somewhat spherical; gonidia 4-5 mic. in diameter, 7-8 mic. in length, oval; wall of gonidium smooth, yellowish.

Canada. South side of harbor in winter quarters. Baffin's Bay. July I85I. (Sutherland). Connecticut. Attached at one point to smooth sandstone bed of a mountain rivulet. Mt. Carmel. September I893. (Setchell). Goshen. August 1895. (Green). New York. In mountain rivulets, attached to stones under water. Near West Point. (Bailey). Crumelbow Creek, Hyde Park, New York City. (Harvey). Palisades. (Wolle). Pennsylvania. Abundant on stones on rocky bottom of river. Susquehanna River, at Harrisburgh. (Wolle). Near Harrisburgh. (Kelley). Wyoming. Attached to granitic rocks in creek about four miles from the melting snow which feeds the creek. (9,000 feet). North Fork, Clear Creek, Big Horn Mountains. August 1898. (Williams and Griffiths). Nevada. In cold. streams. Clover Mountains. (II,00o feet). (Watson).

Genus WOLLEA Bornet and Flahault. Revis. des Nostoc. 223. I888.

Plant mass or colony tubular, cylindrical, somewhat membranaceous, soft; filaments somewhat straight, parallel or slightly curved, agglutinated; sheaths confluent; heterocysts intercalary; gonidia catenate, contiguous to the heterocysts or remote from them.

339. Wollea saccata (Wolle) Bornet and Flahault. Revis. des Nostoc. Ann. Sci. Nat. Bot. VII. 7: 223. I888. Wolle. Fresh Water Algae. IV. 
Bull. Torr. Bot. Club. 7: 44. I880. ( $\mathrm{Sph}$ a e r ozyga s a c a t a Wolle). Wittrock and Nordstedt. Algae Aq. Dulc. Exsicc. no. 397. I880. Wolle. Fresh-Water Algae N. S. 290. pl. I99. f. I. I887. Wolle and Martindale. Algae. Britton's Catalogue of Plants found in New Jersey. Geol. Surv. N. J. 2: 607. 1889. De Toni. Syll. Algar. 5: 432. 1907 .

Collins, Holden and Setchell. Phyc. Bor.-Am. Fasc. I. no. 30. I895.

Plate VIII. fig: $21,22$.

Colonies 2-6 $\mathrm{mm}$. in diameter, up to $\mathrm{I} \mathrm{dm}$. in length, consisting of elongated, vertical, somewhat membranaceous, soft tubes, closed at the apex, cylindrical or variously constricted, more or less aggregated; trichomes 4-5 mic. in diameter, numerous, erect, parallel or slightly curved; cells oblong or cylindrical, closely connected; heterocysts $6 \mathrm{mic}$. in diameter, oval or somewhat spherical, yellow or pale orange; gonidia 7 mic. ill diameter, I5-22 mic. in length, numerous, cylindrical, catenate.

New Jersey. At first attached, afterwards floating free. Along the shores and in the shallow water of Cranberry Pond. (Wolle).

Genus NODULARIA Mertens.

Jürgens, Alg. Aquat. Dec. XV. no. 4. I822.

Filaments free; sheaths colorless, close, 11sually thin, mucous, sometimes diffluent; trichomes more or less straight; cells short, depressed, disc-shaped; heterocysts depressed; gonidia spherical, somewhat spherical or disc-shaped, developed in series between the heterocysts; wall of gonidium smooth.

I Trichomes less than 8 mic. in diameter.

I Filaments 4-6 mic. in diameter; gonidia 6-8 mic. in diameter, somewhat spherical

N. harveyana

2 Filaments 6-7 mic. in diameter; gonidia 7-10 mic. in diameter, spherical depressed

N. sphaerocarpa

3 Trichomes 6-8 mic. in diameter; cells short, about half as long as wide N. paludosa

II Filaments more than 8 mic. in diameter.

I Trichomes 7.5-9.5 mic. in diameter; cells nearly as long as broad before division

N. hawaiiensis

2 Filaments IO-II mic. in diameter; gonidia Io-I2 mic. in diameter, 9 mic. in length, spherical depressed, in series $\mathbf{N}$. armorica

3 Filaments 8-I8 mic. in diameter; gonidia 12-I5 mic. in diameter, 6-ro mic. in length; somewhat spherical or elliptical

N. spumigena

4 Trichomes (?) $33-38$ mic. in diameter; cells short

N. mainensis

340. Nodularia harveyana (Thwaites) Thuret. Essai Class. Nostochinées. Ann. Sci. Nat. Bot. VI. I: 378. 1875. Bornet and Flahault. Revis. 
des Nostoc. Ann. Sci. Nat. Bot. VII. 7: 243. 1888. De Toni. Syli. Algar. 5: 432. I907.

Farlow. Marine Algae New England. 31. I88ז. Collins. Algae of Middlesex County. I4. I888. Martindale. Marine Algae of the New Jersey Coast and Adjacent Waters of Staten Island. Mem. Torr. Bot. Club. I: 92. I889. Collins. Preliminary Lists of New England Plants. V. Marine Algae. Rhodora. 2: 4.2. 1900. Bessey, Pound and Clements. Additions to the Reported Flora of the State. Bot. Surv. Nebraska. 5: I2. I90I. Collins, Holden and Setchell. Phyc. Bor.-Am. Fasc. 21. no. ror3. 1903; Fasc. 22. no. I062. 1903. Setchell and Gardner. Algae of Northwestern America. Univ. Calif. Pub. Bot. I: I92. I903. West. West Indian Freshwater Algae. Journ. of Bot. 42: 29I. I904. Tilden. Notes on a Collection of Algae from Guatemala. Proc. Biol. Soc. Wash. 2I: I55. I908.

Plate IX. fig. I, 2.

Filaments 4-6 mic. in diameter, tapering at the ends, terminated by an obtuse conical cell; sheath thin, colorless, distinct; cells before division about as long as broad or a little longer; gonidia 8 mic. in diameter, somewhat spherical, yellowish brown.

Maine. In a high pool, exposed to spray only. Ragged Island, Casco Bay. July I903. (Collins). New Hampshire. (Collins). Massachusetts. Found in small quantities, mixed with $\mathrm{Spha}$ erozyga, in company with $\mathrm{Rh}$ izoclonium. Charles River, Cambridge; also in salt marshes. (Farlow). Connecticut. (Collins). New York. Mariners' Harbor. Staten Island. (Pike). Nebraska. In ponds and running water. South Bend. (Bessey). Washington. On mud by the roadside. Near La Conner, Skagit County. May Igor. (Gardner). Central America. Associated with $\mathrm{Phorm}$ idiu $\mathrm{m}$ valderianum. Laguna Lake, Amatitlan (3,950 feet). February 1905. (Kellerman).

34I. Nodularia sphaerocarpa Bornet and Flahault. Revis. des Nostoc. Ann. Sci. Nat. Bot. VII. 7: 245. I888. De Toni. Syll. Algar. 5: 433. 1907.

Collins, Holden and Setchell. Phyc. Bor.-Am. Fasc. 22, no. 1063. 1903.

$$
\text { Plate IX. fig. } 3 \text {. }
$$

Filaments 6-7 mic. in diameter, entangled; sheaths thin, colorless, finallv diffluent; cells 6 mic. in diameter, 4 mic. in length; heterocysts about as large as the cells; gonidia 7-ro mic. in diameter, depressed spherical, brownish, two to twelve in series.

California. Forming a thin layer on the moist shady side of a sandy cliff. Bolinas, Marin County. May rgo3. (Gardner).

342. Nodularia paludosa Wolle. Fresh-Water Algae U. S. 291. pl. I98. f. 3, 4. I887. De Toni. Syll. Algar. 5: 435. I907.

Bessey, Pound and Clements. Additions to the Reported Flora of the State. Bot. Surv. Nebraska. 4: 24. 1896.

$$
\text { Plate IX. fig. } 4 \text {. }
$$

Filaments single or in small clusters; sheaths rarely present, soon diffluent; trichomes 6-8 mic. in diameter, nearly straight; cells short, about 
half as long as wide; heterocysts nearly spherical, yellowish; cell contents granular, bright blue-green.

Colorado. (Wolle). Pennsylvania. (Wolle). Nebraska. In sait lake, Lincoln.

According to some authorities this species may belong to $\mathrm{A} n \mathrm{n}$ b a e $\mathrm{n} \mathrm{a}$ cupressaphila or to $N$. harveyana.

343. Nodularia hawaiiensis Tilden. American Algae. Cent. V. no. 484. rgor; Collection of Algae from the Hawaiian Islands. Hawaiian Almanac and Annual for 1902. I12. I901.

Plate IX. fig. 5 .

Plant mass stringy, dark blue-green; sheaths not evident; trichomes 7.5-9.5 mic. in diameter; cells before division nearly as long as broad, depressed spherical; heterocysts Io mic. in diameter, spherical or a little longer than broad; gonidia not known.

Hawaii. In tufts attached to other algae, on reef constantly washed over by waves. Waianae, Oahu. May Igoo. (Tilden).

The filament has neither the distinct sheath and small diameter of that of N. harvey a na nor the short Oscillatoria-like cells of N. s pumigena, the only marine forms of Nodularia described by Bornet and Flahault. Until gonidia are found in the plant its affinities cannot be dis. covered.

344. Nodularia armorica Thuret. Notes Algologiques. 2: I22. pl. 29. I880. Bornet and Flahault. Revis. des Nostoc. Ann. Sci. Nat. Bot. VII. 7: 245. 1888. De Toni. Syll. Algar. 5: 433. 1907.

Setchell and Gardner. Algae of Northwestern America. Univ. Calif. Pub. Bot. I: 193. I903. Collins, Holden and Setchell. Phyc. Bor.-Am. Fasc. 22. no. I061. 1903.

Plate IX. fig. 6.

Filaments ro-II mic. in diameter, entangled; sheaths very thin; cells compressed, one half as short as the diameter; heterocysts compressed, d little larger than the cells; gonidia I0-12 mic. in diameter, 9 mic. in length, depressed spherical, yellowish brown, arranged in series; end walls of gonidia firm, biconcave, transversely truncate.

Washington. Floating on the surfaces of quiet ponds. Near Coupeville, Whidbey Island; Port Townsend. (Gardner). California. In a shallow ditch. Oakland. May I902. (Osterhout and Gardner).

345. Nodularia spumigena Mertens in Jürgens. Algae Aquaticae. Dec. XV. no. 4. I822. Bornet and Flahault. Revis. des Nostoc. Ann. Sci. Nat. Bot. VII. 7: 245. I888. De Toni. Syll. Algar. 5: 433. 1907.

Filaments entangled in a mucous mass, or scattered, sometimes floating free, somewhat straight or curled; sheaths sometimes thin, or in other cases quite thick; cells very short, disc-shaped, three or four times shorter than the diameter; heterocysts a little larger than the cells; 
gonidia not contiguous to the heterocysts, often numerous, yellowish brown.

Var. genuina Bornet and Flahault. 1. c. 246. De Toni. 1. c. 433.

Riddle. Brush Lake Algae. Ohio Nat. 5: 268. 1905. Collins, Holden and Setchell. Phyc. Bor.-Am. Fasc. 27. no. I307. I906.

Filaments 8-12 mic. in diameter; gonidia usually I2 mic. in diameter, 8-9 mic. in length.

Maine. Among Cladophora expansa, etc., in marsh pools. Stover's Point, Harpswell. July 1906. (Collins). Ohio. Brush Lake, Champaign County. I902. (Riddle).

Var. litorea (Kuetzing) Bornet and Flahault. 1. c. 246. De Toni. 1. c. 434 .

Collins. Notes on New England Marine Algae. IV. Bull. Torr. Bot. Club. II: 130. I884; Preliminary Lists of New England Plants. V. Marine Algae. Rhodora. 2: 42. I900.

$$
\text { Plate IX. fig. 7, } 8 .
$$

Filaments I2-16 mic. in diameter; gonidia about I4 mic. in diameter. Io mic. in length.

Maine. (Collins). New Hampshire. A few filaments among other algae in marshes. Hampton. (Collins). Massachusetts. (Collins).

Var. major (Kuetzing) Bornet and Flahault. 1. c. 247. De Toni. 1. c. 435.

Collins. Preliminary Lists of New England Plants V. Marine Algae. Rhodora. 2: 42. I900. Setchell and Gardner. Algae of Northwestern America. Univ. Calif. Pub. Bot. I: 193. I903. Collins, Holden and Setchell. Fhyc. Bor.-Am. Fasc. 21. no. roI2. 1903. Collins. Phycological Notes of the late Isaac Holden.-II. Rhodora. 7: 223. 1905.

Filaments 12-I8 mic. in diameter; gonidia I4-I5 mic. in diameter, 6-7 mic. in length.

Connecticut. Scattered filaments among other blue-green algae. In marsh pool. Cook's Point. (Holden). Washington. In a pond of slightly brackish water. Penn's Cove, near Coupeville, Whidbey Island. June Igor. (Gardner).

346. Nodularia mainensis F. L. Harvey. The Fresh-water Algae of Maine. II. Bull. Torr. Bot. Club. I6: I88. 1889. De Toni. Syll. Algar. 5: 435. I907.

Sheaths distinct but close; trichomes $33-38$ mic. in diameter; cells 2-6 mic. in length; heterocysts compressed, oval, orange yellow or brownish yellow.

Maine. Found intermingled with $\mathrm{V}$ a ucheria sessilis in Pushaw Stream, a tributary of the Penobscot, near Orono. July I888. (F. L. Harvey).

Genus ANABAENA Bory. Dict. Class. I: 307. I822.

Sheaths not present or when present often diffluent; trichomes equal throughout or tapering at the apices, usually rigid and fragile, sometimes 
circinate, free or aggregated without order to form a flocculent mass; cells equal to or longer than their diameter; apical cells sometimes conical; lieterocysts numerous and intercalary; gonidia variously disposed, sometimes solitary, sometimes lying on each side of a heterocyst, rarely in short catenate series.

I Gonidia oval or spherical.

I Gonidia oval or barrel-shaped, remote from the heterocysts in catenate series

(I) Wall of gonidium smooth

A. variabilis

(2) Wall of gonidium papillose

A. hallensis

2 Gonidia spherical, contiguous to heterocysts, solitary or in short series, I2-20 mic. in diameter

A. sphaerica

II Gonidia variously disposed, sometimes contiguous to heterocysts, sometimes remote from them, cylindrical, straight or curved.

I Trichomes usually circinate; gonidia curved, obliquely truncate at the apices

(I) Gonidia 7- 13 mic. in diameter, 20-50 mic. in length, curved, oblique, inequilateral, contiguous to or rarely remote from the heterocysts; wall of gonidium smooth, colorless or yellowish; trichomes $4-8$ mic. in diameter

A. flos-aquae

(2) Gonidia 16-18 mic. in diameter, up to $30 \mathrm{mic}$. in length, curved, oblique or cylindrical, the younger ones somewhat spherical, usually remote from the heterocysts; wall of gonidium smooth, colorless; trichomes 8-I 4 mic. in diameter

A. circinalis

2 Trichomes straight; gonidia cylindrical, straight, usually remote from the heterocysts, solitary or in series

(I) Trichomes 4-5 mic. in diameter; sheaths sometimes present; gonidia $14-17$ mic. in length

A. inaequalis

(2) Trichomes 5-8 mic. in diameter; sheaths occasionally present; gonidia 7-10 mic. in diameter, up to $30 \mathrm{mic}$. and more in length

A. catenula

(3) Trichomes 4.2-6 mic. in diameter; sheaths present; gonidia 6 mic. in diameter, 14-20 mic. in length

A. laxa

III Gonidia contiguous to heterocysts on each side, developed centripetally, cylindrical or somewhat cylindrical

I Gonidia 7-12 mic. in diameter, 18-28 mic. in length, short, somewhat cylindrical, often slightly constricted in the center; apical cell conical

A. torulosa

2 Gonidia 8-10 mic. in diameter, 20-40 mic. in length, especially cylindrical; apical cells obtuse

A. oscillarioides

3 Gonidia 15-20 mic. in diameter, 50-90 mic. in length, cylindrical or more commonly tapering slightly from the middle to the rounded ends

A. bornetiana 
Species not well understood

A. azollae

A. confervoides

A. cupressophila

A. gelatinosa

A. subrigida

347. Anabaena variabilis Kuetzing. Phyc. Gen. 210. I843. Bornet and Flahault. Revis. des Nostoc. Ann. Sci. Nat. Bot. VII. 7: 226. I888. De Toni. Syll. Algar. 5: 437. 1907.

Wolle. Fresh-Water Algae U. S. 287. pl. 198. f. 29-32. I887. Bennett. Plants of Rhode Island. II4. I888. (Sphaerozyga polysperma Rab.). Wolle and Martindale. Algae. Britton's Catalogue of Plants found in New Jersey. Geol. Surv. N. J. 2: 607. 1889. Anderson and Kelsey. Common and Conspicuous Algae of Montana. Bull. Torr. Bot. Club. 18: I44. I891. Setchell. Notes on some Cyanophyceae of New England. Bull. Torr. Bot. Club. 22: 429. 1895 . Collins, Holden and Setchell. Phyc. Bor.Am. Fasc. 3. no. 107. 1895. Tilden. American Algae. Cent. II. no. I69. I896. Richter. Süsswasseralgen aus dem Umanakdistrikt. Bib. Bot. 7: Heft. 42. 5. 1897. Setchell. Notes on Cyanophyceae. III. Erythea. 7: 5I. I899. Collins, Holden and Setchell. Phyc. Bor.-Am. Fasc. 15. no. 709. 1900. Collins. Preliminary Lists of New England Plants. V. Marine Algae. Rhodora. 2: 4I. I900. Tilden. Collection of Algae from the Hawaiian Islands. Hawaiian Almanac and Annual for 1902. II2. I90I; American Algae. Cent. V. no. 483. I90I; American Algae. Cent. VI. no. 678. I902; Algae Collecting in the Hawaiian Islands. Postelsia. I: 168. 1902. Setchell and Gardner. Algae of Northwestern America. Univ. Calif. Pub. Bot. I: I9I. I903. Collins. Phycological Notes of the late Isaac Holden.-II. Rhodora. 7: 223. 1905. Collins, Holden and Setchell. Phyc. Bor.-Am. Fasc. 25. no. I209. 1905. Lemmermann. Algenfl. Sandwich-Inseln. Bot. Jahrb. 34: 622. I905. Collins, Holden and Setchell. Phyc. Bor-Am. Fasc. 31. no. 1507. I908. (A. variabilis brachyspora Collins).

\section{Plate IX. fig. 9.}

Plant mass gelatinous, spreading on damp soil or floating free, dark green; sheaths usually not present; trichomes $4-6$ mic. in diameter, flexuous, slightly constricted at joints; apical cell obtuse conical; cells 2.5-6 mic. in diameter, somewhat quadrate; heterocysts 6 mic. in diameter, 8 mic. in length, spherical or oval; gonidia 7-9 mic. in diameter, 8-14 mic. in length, oval, truncate at the apices, numerous in catenate series, remote from heterocysts, developed centrifugally; wall of mature gonidium smooth, yellowish brown.

Greenland. Umanak. (Vanhöffen). Maine. Among various floating Algae in a warm pool above high water mark. Ragged Island, Casco Bay. July 1908. (Collins). Rhode Island. Spectacle Pond. (Bennett). Forming a brownish or bluish green, gelatinous layer on the floating leaves of Ruppia maritima, in brackish water. Watch Hill Pond, Watch Hill. September I894. (Setchell). Connecticut. Fresh Pond. (Collins, Holden). 
New Jersey. Fresh water. Somerset. (Setchell). In pools, Bound Brook. (Wolle). Minnesota. In stagnant water in pools made by high waves and seepage on beach. Oatka Beach. Minnesota Point, Duluth. August rgor. (Tilden). South Dakota. Artesian water into which sewage runs. Aberdeen. August 1895. (Griffiths). Floating in large light blue-green masses on the surface of a pond supplied with artesian water. September 1898 . (Saunders). Montana. Common in open, muddy pools heated by the sun's glare; rising to the surface in small, frothy scummy masses. Ponds and semi-stagnant mud-bottomed parts of streams in the mountains and or the plains. June to November. (Anderson and Kelsey). Wyoming. On surface of water in ditch. Seven miles north of Lake Hotel, Yellowstone National Park. July I896. (Tilden). Idaho. Standing water. Near Lewiston, Nez Perces County. (800 feet). 1896. (A. A. and E. G. Heller). Washington. In ditches and ponds. Whidbey Island; Seattle. (Gardner). California. San Francisco. (Setchell). In masses of $\mathrm{R}$ u p p a maritim a in salt marsh pool. West Berikeley. August I904. (Gardner). Hawaii. On bottom of irrigation ditches in sugar cane field. Water turned on about Gnce a week. Ewa Plantation, Oahu. June I90o. (Tilden). Maluhia, Oahu. (Schauinsland).

348. Anabaena hallensis (Janczewski) Bornet and Flahault. Revis. des Nostoc. Ann. Sci. Nat. Bot. VII. 7: 227. I888. De Toni. Syll. Algar. 5: 440. I907.

Bessey, Pound and Clements. Additions to the Reported Flora of the State. Bot. Surv. Nebraska. 5: I2. I901.

\section{Plate IX. fig. IO-I3.}

Plant mass mucous, floating; sheaths gelatinous; trichomes 4-5 mic. in diameter, somewhat straight, with tapering apices; cells depressed spherical or somewhat quadrate; heterocysts 5 mic. in diameter, barrelshaped; gonidia 7-8 mic. in diameter, Io-12 mic. in length, oblong-elliptical, truncate at the apices, usually remote from the heterocysts, developed centrifugally; wall of gonidium colorless, minutely papillose; cell contents granular; blue-green.

Nebraska. In aquaria. Lincoln. (Bessey).

349. Anabaena sphaerica Bornet and Flahault. Revis. des Nostoc. Ann. Sci. Nat. Bot. VII. 7: 228. 1888. De Toni. Syll. Algar. 5: 440. 190\%.

Setchell and Gardner. Algae of Northwestern America. Univ. Calif. Pub. Bot. I: I92. I903.

Plant mass floccose, blue-green; sheaths not distinct; trichomes 5-6 mic. in diameter, moniliform, straight, agglutinated together in parallel bundles; cells spherical or spherical-truncate; heterocysts 6-7 mic. in diameter, nearly spherical; gonidia I2 mic. in diameter, I2-I8 mic. in length, spherical or somewhat oval, contiguous to heterocysts, in short series; wall of gonidium smooth, brownish yellow.

Washington. Floating on the surfaces of small ponds. Whidbey Island; Port Townsend. (Gardner).

Var. macrosperma Bornet and Flahault. 1. c. 228 . De Toni. 1. c. 440. 
Gonidia 20 mic. in diameter, spherical.

West Indies, Santa Cruz. (Hornemann).

350. Anabaena flos-aquae (Lyngbye) Brébisson in Brébisson and Godey. Algues des Environs de Falaise. 36. I835. Bornet and Flahault. Revis. des Nostoc. Ann. Sci. Nat. Bot. VII. 7: 228. 1888. De Toni. Syll. Algar. 5: 44I. 1907.

Wolle. Fresh Water Algae. III. Bull. Torr. Bot, Club. 6: I83. I877. (Trichormus incurvus Allm.). Farlow. Notes on Fresh-Water Algae. Bot. Gaz. 8: 225. I883. Wolle. Fresh-Water Algae U. S. 286. I887. Bennett. Plants of Rhode Island. I I4. I888. Trelease. The "Working" of the Madison Lakes. Trans. Wis. Acad. Sci. Arts and Letters. 7: r22. pl. Io. f. 4. I889. Wolle and Martindale. Algae. Britton's Catalogue of Plants found in New Jersey. Geol. Surv. N. J. 2: 606. I889. Saunders. Protophyta-Phycophyta. Flora of Nebraska. I8. I894. Tilden. List of FreshWater Algae collected in Minnesota during 1896 and 1897. Minn. Bot. Studies. 2: 27. 1898; American Algae. Cent. III. no. 292. I898. Fanning. Observations on the Algae of the St. Paul City Water. Minn. Bot. Studies. 2: 609. p1. 45. f. 2I. I901. Tilden. American Algae. Cent. VI. no. 576. 1902. Setchell and Gardner. Algae of Northwestern America. Univ. Calif. Pub. Bot. I: I9z. I903. Nelson. Observations upon some Algae which cause "Water Bloom." Minn. Bot. Studies. 3: 56. pl. I4. f. 3. rgo3. Moore and Kellerman. A Method of Destroying and Preventing the Growth of Algae and Certain Pathogenic Bacteria in Water Supplies. U. S. Dept. Agric. Bureau of Plant Industry. Bul1. 64. 20. I904. Riddle. Brush Lake Algae. Ohio Nat. 5: 268. I905. Clark. The Holophytic Plankton of Lakes Atitlan and Amatitlan, Guatemala. Proc. Biol. Soc. Wash. 2I: 98. 1908. Tilden. Notes on a Collection of Algae from Guatemala. Proc. Biol. Soc. Wash. 2I: I55. I908. Buchanan. Notes on the Algae of Iowa. Proc. Iowa Acad. Sci. I4: I2. I908.

Plate IX. fig. I4.

Plant mass frothy, gelatinous, lubricous, floating, bluish in color; sheaths not present; trichomes $4-8$ mic. in diameter, circinate; cells $6-8$ mic. in length, compressed spherical; heterocysts a little wider and longer than the cells; gonidia 7-I3 mic. in diameter, 20-50 mic. in length; curved, oblique, inequilateral, contiguous to or rarely remote from the heterocysts, often surrounded by a wide gelatinous sheath; wall of gonidium smooth, colorless or yellowish.

Greenland. (Börgesen). Rhode Island. Very common. (Bennett). New Jersey. Common on stagnant fresh water. (Wolle). District of Columbra. Washington. (Moore and Kellerman). Ohio. Brush Lake, Champaign County. Fall of 1902. (Riddle). Wisconsin. Forming a part of a greenish yellow scum which occurs every season in greater or less quantity on Third and Fourth Lakes (Mendota and Monona) during the hot weather of summer. (Trelease). Minnesota. (Farlow). Floating in abundance on surface of water. Cedar Lake, Hennepin County. October I897. (Fanning and Humphrey). City water supply, St. Paul. (Fanning). Forming a pale, bluish green scum. Spring Park, Lake Minnetonka, Hennepin County. October I9oI. (Nelson). Iowa. "One of the most common of the con- 
stituents of the plankton of many of our lakes at some seasons of the year. Occurs frequently in the sloughs in the northern part of the state also.' Jenning's Pond, near Boone River; slough, Eagle Grove, 1904. (Buchanan). Nebraska. Free-swimming, membranaceous, blue-green. (Saunders), Washington. Floating in great abundance on quiet water. Lake Union, Seattle. (Gardner). Central America. Very common in all the phyto-plankton from Lake Amatitlan, Guatemala. Winter of I905-1906. (Meek). Very abundant, collected with a surface net. Lake Amatitlan. Temperature of water $73^{\circ}$. January I9o6. (Kellerman, Meek and Smith).

Var. treleasei Bornet and Flahault. 1. c. 230. De Toni. 1. c. 443.

Trelease. The "Working" of the Madison Lakes. Trans. Wis. Acad. Sci. Arts and Letters. 123. pl. 10. f. 5. 1889. (A. mendotae Trelease).

Cells $4 \mathrm{mic}$. in diameter; heterocysts $5 \mathrm{mic}$. in diameter, Io mic. in length; gonidia 6 mic. in diameter, 40 mic. in length, slightly curved.

Wisconsin. Forming a copious water bloom on Lake Mendota, at Madison, especially abundant in the fall. (Farlow).

351. Anabaena circinalis Rabenhorst. Alg. Eur. Exsicc. no. 209. 1852. Bornet and Flahault. Revis, des Nostoc. Ann. Sci. Nat. Bot. VII. 7: 230. I888. De Toni. Syll. Algar. 5: 443. I907.

Wood. Contr. Hist. Fresh-Water Algae North America. 38. pl. 3. f. 5. I874. (A. gigantea Wood). Farlow. Notes on Fresh-Water Algae. Bot. Gaz. 8: 225. I883. (A. flos-a qua e c ir cinalis Kirchn.). Arthur. Some Algae of Minnesota supposed to be Poisonous. Bull. Minn. Acad. Nat. Sci. 2: (App.) I-I2. I883. Bennett. Plants of Rhode Island. Ir4. I 888. Saunders. Protophyta-Phycophyta. Flora of Nebraska, I8. pl. I. f. 12. I894. Tilden. List of Fresh-Water Algae collected in Minnesota during 1894. Minn. Bot. Studies. I: 236. 1895. Jackson and Ellms. On Odors and Tastes of Surface Waters, with Special Reference to Anabaena, a Microscopical Organism found in Certain Water Supplies of Massachusetts. Review Am. Chem. Research. 8: 410. I897. Nelson. Observations upon some Algae which cause "Water Bloom." Minn. Bot. Studies. 3: 56. p1. I4. f. 2. 1903. Moore and Kellerman. A Method of Destroying or Preventing the Growth of Algae and Certain Pathogenic Bacteria in Water Supplies. U. S. Dept. Agric. Bureau of Plant Industry. Bull. 64. 20. I904. Collins, Holden and Setchell. Phyc. Bor.-Am. Fasc. 27. no. I308. I906. Buchanan. Notes on the Algae of Iowa. Proc. Iowa Acad. Sci. I4: 12. I908.

Plate IX. fig. I5.

Plant mass frothy; sheaths often not present; trichomes 8-14 mic. in diameter, usually circinate, sometimes straight; cells a little shorter than the diameter, spherical compressed; heterocysts 8-10 mic. in diameter, somewhat spherical; gonidia I6-I $8 \mathrm{mic}$. in diameter, up to $30 \mathrm{mic}$. in length, curved, oblique or cylindrical, the younger ones somewhat spherical, usually remote from the heterocysts; wall of gonidium smooth, colorless.

Massachusetts. Horn Pond, Woburn; South Framingham, November I882. (Farlow). Ludlow Reservoir, Springfield. Fall of I895. (Jackson and Ellms). Forming a scum on a small pond. Medford. June I9o6. (Collins). 
Rhode Island. Providence. (Lathrop). R. W. Park. (Bennett). New York. Chautauqua Lake. (Wolle). Pennsylvania. Floating upon a brick pond, forming a part of a thick, dirty green, "pea-soup" colored, almost pulverulent scum. (Wood). District of Columbia. Washington. (Moore and Kellerman). Minnesota. Lake Tetonka, Waterville. I882. (Arthur). Floating on a pond. Union Park, Minneapolis. August r882. (Butler). Floating in large quantities at edge of lake. Lake Calhoun, Hennepin County. October I894. (Tilden). Spring Park, Lake Minnetonka. October I901. (Nelson). Iowa. Very common in the lakes, East Okoboji Lake; Upper Gar Lake. October 1904. (Buchanan). Nebraska. Gives a bluish green color to stagnant water, or in age forms a blue-green scum on the surface. (Saunders).

352. Anabaena inaequalis (Kuetzing) Bornet and Flahault. Revis. des Nostoc. Ann. Sci. Nat. Bot. VII. 7: 231. I888. De Toni. Syll. Algar. 5: 446. 1907 .

Collins, Holden and Setchell. Phyc. Bor.-Am. Fasc. 24. no. II65. I904.

Plate IX. fig. I6.

Plant mass floccose, floating or climbing to other algae, blue-green; sheaths distinct, especially around the gonidia; trichomes 4-5 mic. in diameter, straight, parallel, sometimes free, sometimes surrounded by a firm mucus; apex of trichome scarcely tapering; apical cell obtuse; cells spherical-truncate; heterocysts 6 mic. in diameter, spherical; gonidia 6-8 mic. in diameter, I4-I7 mic. in length, remote from the heterocysts, developed centrifugally, two or three in a series; wall of gonidium smooth, yellowish.

California. Lake Chabot, San Leandro. June I902. (Osterhout and Gardner).

353. Anabaena catenula (Kuetzing) Bornet and Flahault. Revis. des Nostoc. Ann. Sci. Nat. Bot. VII. 7: 232. I888. De Toni. Syll. Algar. 5. 447. I907.

Wolle. Fresh-Water Algae U. S. 290. pl. I99. f. I7-24. I887. (S p h a e r ozyga smithii (Thw.) Wolle). Bessey. Miscellaneous Additions to the Flora of the State. Bot. Surv. Nebraska. 46. 1893. Saunders. Protophyta-Phycophyta. Flora of Nebraska. I8. pl. I. f. 9, Io. I894. Collins. Algae. Flora of the Blue Fills, Middlesex Fells, Stony Brook and Beaver Brook Reservations of the Metropolitan Park Commission, Massachusetts. I28. 1896. Collins, Holden and Setchell. Phyc. Bor-Am. Fasc. II. no. 506. 1898. Collins. Notes on Algae.-I. Rhodora. I: 1o. I899. Setchell and Gardner. Algae of Northwestern America. Univ. Calif. Pub. Bot. I: 192. 1903.

\section{Plate IX. fig. I7.}

Plant mass gelatinous, floating, blue-green; sheaths diffluent in mature plants; trichomes 5-8 mic. in diameter, flexuous; apical cell rotund; cells barrel-shaped, usually a little shorter than the diameter; heterocysts 6-9 mic. in diameter, 9-13 mic. in length, somewhat spherical or oblong; gonidia 7 -Io mic. in diameter, I6-30 mic. in length, cylindrical, often slightly con- 
stricted in the center, with round-truncate apices, contiguous to the heterocysts or remote from them, developed centrifugally, usually in catenate series; wall of gonidium smooth, pale smoke-colored.

Alaska. Floating on shallow ponds or sluggish streams. Huntville, Unalaska. (Setchell and Lawson). Glacier Valley, Unalaska. (Lawson). Maine. In a ditch just above the beach. Eagle Island, Penobscot Bay. July I896. (Collins). Massachusetts. On dead leaves, in swamp near Bear's Den Path, Middlesex Fells; Penny Brook, Lynn Woods, July I905. (Collins). Nebraska. In moist places in greenhouses. (Bessey, Saunders). Washington. Near Coupeville, Whidbey Island; Green Lake, Seattle. (Gardner). Hawaii. In stagnant water. Kauai. July Igoo. (Tilden).

Var. americana Collins. New Cyanophyceae. Erythea. 4: II9. I896. Collins, Holden and Setchell. Phyc. Bor.-Am. Fasc. 5. no. 207. 1896. Collins. Notes on Algae.-I. Rhodora. I : Io. I899. De Toni. 1. c. 448.

Gonidia $30-60$ mic. in length, strictly cylindrical.

Massachusetts. In company with other algae, forming a scum in pools and ditches. Middlesex Fells. June I893. (Collins).

354. Anabaena laxa (Rabenhorst) A. Braun in Bornet and Flahault. Note sur le Genre Aulosira. Bull. Soc. Bot. de France. 32: I20. pl. 4. f. 2, 3. I885; Revis. des Nostoc. Ann. Sci. Nat. Bot. VII. 7: 233. I888. De Toni. Syll. Algar. 5: 451. Ig07.

Collins, Holden and Setchell. Phyc. Bor.-Am. Fasc. 30. no. I454. 1908.

Plate IX. fig. I8.

Sheaths colorless, scarcely conspicuous; filaments 7 mic. in diameter; trichomes 4.2-6 mic. in diameter; cells barrel-shaped, about as long as broad; gonidia 6 mic. in diameter, I4-20 mic. in length, cylindrical, with rotund apices; wall of gonidium smooth, colorless.

Massachusetts. Penny Brook, Lynn Woods. July 1905. (Collins).

355. Anabaena torulosa (Carmichael) Lagerheim. Bidrag till Sveriges Algflora. Oefversigt af $\mathrm{K}$. Vet.-Akad. Förhandl. 47. I88.3. Bornet and Flahault. Revis. des Nostoc. Ann. Sci. Nat. Bot. VII. 7: 236. I888. De Toni. Syll. Algar. 5: 455. I907.

Wood. Contr. Hist. Fresh-Water Algae North America. 42. pl, 3. f. 3. 1872. (Dolichospermum polysperma (Kg.) Wood). Farlow. Marine Algae United States. Proc. Am. Acad. Arts Sci. Io: 380. I875. (S phaerozyga carmichaelii Harv.); Report of the U. S. Fish Commission for 1875. 715. I876; Marine Algae of New England. 30. pl. I. f. 3. I88r. Pike. Check List of Marine Algae. Bull. Torr. Bot. Club. I3: I05. I886. Wolle. Fresh-Water Algae U. S. 289. pl. I98. f. 37, 38. 1887. (Sphaerozyga polysperma Rab.). Collins. Algae from Atlantic City, N. J. Bull. Torr. Bot. Club. 15: 310. I888; Algae of Middlesex County. I4. 1888; Marine Algae of Nantucket. 4. I888. Martindale. Marine Algae of the New Jersey Coast and Adjacent Waters of Staten Island. Mem. Torr. Bot. Club. I: 92. 1889. Wolle and Martindale. Algae. Britton's Catalogue of Plants found in New Jersey. Geol. Surv. N. J. 2: 607. I889. Saunders. Protophyta-Phycophyta. Flora of Nebraska. I8. pl. I. f. 8. I894. 
Collins, Holden and Setchell. Phyc. Bor.-Am. Fasc. 8. no. 354. I897. Co!lins. Preliminary Lists of New England Plants.-V. Marine Algae. Rhodora. 2: 4I. 1900; Phycological Notes of the late Isaac Holden.-II. Rhodora. 7: 223. 1905 .

\section{Plate IX. fig. I9.}

Plant mass mucous, thin, blue-green; trichomes $4.2-5$ mic. in diameter; apical cell acute conical; cells barrel-shaped, equal to or a little shorter than the diameter; heterocysts 6 mic. in diameter, 6-10 mic. in length, somewhat spherical or ovoid; gonidia 7-12 mic. in diameter, $18-28 \mathrm{mic}$. in length, short, somewhat cylindrical, often slightly constricted in the center, contiguous to the heterocysts, developed centripetally; wall of gonidium smooth, pale smoke-colored in mature specimens.

Maine. On Z ostera. Goose Creek marshes, Cape Rosier. July I 896. (Collins). New Hampshire. (Collins). Massachusetts. On decaying algac, looking like a shining emerald-green film. Wood's Hole; Gloucester; Cambridge; salt marshes, Everett. (Farlow). Not uncommon on mud in the harbor; on decaying Zostera marina, Mattapoisett, September 1906. (Collins). Rhode Island. (Collins). Connecticut. Noank. (Farlow). On mud on margin of marsh pools. Cook's Point; on muddy sand, near high water mark, among S partin a, shore of The Gut, June. (Holden). New York. On decayed algae. Fort Hamilton; Greenport. (Pike). Fresh water. Somerset; in pools, Bound Brook. (Wolle). New Jersey. With other algae, forming a brownish jelly, in a pool east of Camden. (Wood). Newark Bay. (Pike). Atlantic City. (Morșe, Martindale). Nebraska. In stagnant water, usually among other algae; also on damp earth, on flower pots, in greenhouses at the University. Lincoln. (Saunders).

356. Anabaena oscillarioides Bory. Dictionnaire Classique d'Histoire Naturelle. I: 308. 1822. Bornet and Flahault. Revis. des Nostoc. Ann. Sci. Nat. Bot. VII. 7: 233. I888. De Toni. Syll. Algar. 5: 45I. 190\%.

Wood. Contr. Hist. Fresh-Water Algae North America. 40. pl. 3. f. I. a, b. I872. (Cylindrospermum flexuosum Rab.). Wolle. Fresh-Water Algae U. S. 292. pl. I99. f. I3. I887. Bennett. Plants of Rhode Island. I I4. I888. Wolle and Martindale. Algae. Britton's Catalogue of Plants found in New Jersey. Geol. Surv. N. J. 2: 607. 1889. Tilden. American Algae. Cent. I. no. 87. I894. Saunders. Protophyta-Phycophyta. Flora of Nebraska. I9. 1894. Tilden. List of Fresh-Water Algae collected in Minnesota during I894. Minn. Bot. Studies. I : 236. I895. Collins. Algae. Flora of the Blue Hills, Middlesex Fells, Stony and Beaver Brook Reservations of the Metropolitan Park Commission, Massachusetts. I28. I896. Setchell. Notes on Cyanophyceae. III. Erythea. 7: 51. I899. Collins, Holden and Setchell. Phyc. Bor.-Am. Fasc. I4. no. 656. I900; Fasc. 19. no. 907. I902. Kellerman. Proposed Algological Survey of Ohio. Ohio Nat. 2: 222. 1902. Setchell and Gardner. Algae of Northwestern America. Univ. Calif. Pub. Bot. 1: 192. I903. Collins. Phycological Notes of the late Isaac Holden.-II. Rhodora. 7: 236. I905. 
Plant mass gelatinous, dark green; trichomes 4.2-6 mic. in diameter, with rotund apical cells; cells barrel-shaped, equal to the diameter in length, or a little shorter or longer; heterocysts $6-8$ mic. in diameter, spherical, or 6 mic. in diameter and ro mic. in length, ovoid; gonidia 8-1o mic. in diameter, 20-40 mic. in length, when young ovoid, finally becoming especially cylindrical, solitary or in series, with rounded apices, contiguous to the heterocysts, developed centripetally; wall of gonidium smooth, in mature specimens very pale soot-colored.

Massachusetts. On dead leaves, in swamp near Bear's Den Path, Middlesex Fells. (Collins). Wood's Hole. (Humphrey and Miyabe). In still water. West Falmouth. August 1896. (Humphrey). Rhode Island. Roger Williams Park. (Bennett). Connecticut. Pool below Factory Pond, Bridgeport. (Holden). New Jersey. In brackish ditches. (Wolle). Pennsylvania. "In a dark little grotto, formed by shelving rocks." Reading Railroad, just above the Flat Rock tunnel; on wet ground by a horse-trough, near west end of upper bridge at Manayunk; on banks of Schuylkill River, in vicinity of Philadelphia. (Wood). On dripping rocks and on wet ground. (Wolle). Ohio. (Kellerman). Illinois. Evanston. (Johnson). Minnesota. Second Creek, Lake City, Wabasha County. September I894. South Dakota. In a slough. Elm River, eight miles north of Aberdeen. May I896. (Griffiths). Nebraska. In a small creek near Lincoln. (Saunders). Montana. Helena. (Kelsey). Washington. On moist bank near bicycle path. Madrona Park, Seattle. May 190I; floating on pools and lakes, or on moist ground, Coupeville, Whidbey Island; Port Townsend. (Gardner). California. San Francisco. (Setchell).

Var. elongata (Kuetzing) Bornet and Flahault. 1. c. 236. De Toni. 1. c. 453 .

Tilden. American Algae. Cent. III. no. 293. I898.

Heterocysts 7-9 mic. in diameter, very long, 6-18 mic. in length; gonidia up to 70 mic. in length.

South Dakota. Floating in stagnant water on prairie. Columbia. June I897. (Griffiths).

Var. stenospora Bornet and Flahault. 1. c. 236 . De Toni. 1. c. 454.

Tilden. American Algae. Cent. II. no. I72. 1896; Cent. VI. no. 577. 1902. Collins, Holden and Setchell. Phyc. Bor.-Am. Fasc. 3I. no. I506. I908.

Trichomes more slender; apical cell acute conical; gonidia 5-ro mic. in diameter, 16-40 mic. in length, often two to eight in a chain; wall of gonidium smooth, colorless.

Massachusetts. Forming rather thin films on plants and boards in a ditch. Eastham. August 1908. (Collins). Minnesota. Floating on surface of shallow pool on sandy or muddy beach. Minnesota Point, Duluth. August 1901. Colorado. On aquatic plants in slowly flowing stream in swamp. Five miles southeast of Port Collins. July I896. (Cowen). 
357. Anabaena bornetiana Collins. New Cyanophyceae. Erythea. 4: I20. I896; in Collins, Holden and Setchell. Phyc. Bor.-Am. Fasc. 5. no. 208. 1896. De Toni. Syll. Algar. 5: 457. 1907.

Trichomes 12 mic. in diameter, straight or somewhat flexuous; cells spherical or slightly shorter than their diameter; heterocysts I3-I4 mic. in diameter, I3-20 mic. in length, spherical or occasionally oblong; gonidia $15-20 \mathrm{mic}$. in diameter, 50-90 mic. in length, cylindrical or more commonly tapering slightly from the middle to the rounded ends, contiguous to heterocysts on each side; wall of gonidium smooth, translucent.

Massachusetts. Occurring usually in isolated filaments among other algae in ditches and pools, often with other species of A n a b a e $\mathrm{n}$ a. Malden, Medford, Middlesex Fells. May, June I8g6. (Collins).

358. Anabaena azollae Strasburger. Das Botanische Practicum. 352. f. I24. 1884. De Toni. Syll. Algar. 5: 457. I907.

Tilden. American Algae. Cent. II. no. I70. I896; List of Fresh-Water Algae collected in Minnesota during 1896 and 1897 . Minn. Bot. Studies. 2: 27. 1898. Collins, Holden and Setchell. Phyc. Bor,-Am. Fasc. 16. no. 754. 1900 .

Sheaths not present; trichomes snake-like in shape, aggregated in small bundles; cells $5 \mathrm{mic}$. in diameter, $8 \mathrm{mic}$. in length, usually somewhat spherical or ellipsoidal, cylindrical, with rotund apices; heterocysts up to Io mic. in diameter, oval, easily distinguished from the olive contents and polar nodules ("cellulose buttons"); cell contents lead-colored-green; gonidia unknown.

Minnesota. In chambers in the leaves of $\mathrm{Azolla}$ caroliniana. University Plant House, Minneapolis. September I896. (Tilden). California. Endophytic in Azol1a caroliniana, growing in pools in the bed of Los Angeles River, Los Angeles. November I90o. (Monks).

359. Anabaena confervoides Reinsch. On Fresh-Water Algae from Kerguelen's Island, Journ. Linn. Soc. Bot. I5: 208. 1877. De Toni. Syll. Algar. 5: 46r. 1907.

Tilden. American Algae. Cent. V. no. 482. I90I; Collection of Algae from the Hawaiian Islands. Hawaiian Almanac and Annual for I902. II2. IgoI.

\section{Plate IX. fig. 2r.}

Plant mass thin; trichomes 2.2-2.8 mic. in diameter, slender, extremely long, very straight, parallel, surrounded by a common mucus; cells very distinct, rectangular, slightly longer than broad; heterocysts a little larger than the cells, elliptical; cell contents finally granular, pale blue-green; gonidia unknown.

Hawaii. Floating at edge of taro patch. Near Hauta Courthouse, Hauula, Koolauloa, Oahu. June 1900. (Tilden).

360. Anabaena cupressophila Wolle. Fresh-Water Algae U. S. 288. pl. I98. f. I, 2. I887. De Toni. Syll. Algar. 5: 458. 1907.

Wolle and Martindale. Algae. Britton's Catalogue of Plants found in 
New Jersey. Geol. Surv. N. J. 2: 607. I889.

Plate IX. fig. 22.

Plant mass gelatinous, somewhat membranaceous, deep blue-green; filaments 7-8 mic. in diameter; sheaths delicate; trichomes moniliform, slightly curved or nearly straight, more or less parallel; cells about half as long as wide, sometimes separated; heterocysts compressed globose, homogeneous, brownish yellow; cell contents granular, light blue-green.

New Jersey. On the trunks of trees, low down near the water's edge in swamps. (Wolle).

36I. Amabaena gelatinosa Wood. Contr. Hist. Fresh-Water Algae North America. 38. pl. 2. f. 4. I872. De Toni. Syll. Algar. 5: 461. 1907.

Plant mass gelatinous, mucous, indefinitely expanded, somewhat pellucid, with a brownish tinge; sheaths not present; trichomes somewhat curved, rather distant, not entangled; cells globose; heterocysts about equal to the cells in diameter, spherical or rarely oblong; cell contents homogeneous, light golden yellow or light blue-green; gonidia spherical, terminal.

Pennsylvania. Near Philadelphia. (Wood).

362. Anabaena subrigida (Wood) De Toni. Syll. Algar. 5: 46I. 1907. Wood. Contr. Hist. Fresh-Water Algae North America. 42. pl. 3. f. 2.1872. (Dolichosperm um sùrigidum Wood).

Plant mass floating; trichomes single, straight or nearly so, very small; cells cylindrical or somewhat spherical, distinct; heterocysts cylindrical, short, single, distinct; gonidia single or in pairs, slightly constricted in the center, not contiguous to heterocysts; cell contents light green.

Pennsylvania. In scum floating on ditches. Near Philadelphia. (Wood).

1

Genus APHANIZOMENON Morren.

Hist. Genre Nouv. Conf. II: II. 1838 .

Colonies thin, feathery, plate-like or spindle-shaped bundles, bluegreen, floating; sheaths not present; trichomes short, tapering at the ends, agglutinated; heterocysts scattered; gonidia cylindrical, much elongated, sclitary, developed sparingly between the heterocysts.

363. Aphanizomenon flos-aquae (Linn.) Ralfs. On the Nostochineae. Ann. Mag. of Nat. Hist. 5: 340. pl. 9. f. 6. 1850 . Bornet and Flahault. Revis. des Nostoc. Ann. Sci. Nat. Bot. VII. 7: 24I. I888. De Toni. Syll. Algar. 5: 468. 1907.

Arthur. Some Algae of Minnesota Supposed to be Poisonous. Bull. Minn. Acad. Nat. Sci. 2: (App.) I. I883. Wolle. Fresh-Water Algae U. S. 291. pl. I98. f. 7, 8. I887. Tilden. American Algae. Cent. II. no. I73. 1896; List of Fresh-Water Algae collected in Minnesota during 1895. Minn. Bot. Studies. I: 599. I896. Riddle. Algae from Sandusky Bay. Ohio Nat. 3: 317. 1902. Snow. The Plankton Algae of Lake Erie. U. S. Fish Comm. Bull. for 1902. 22: 392. I903. Collins, Holden and Setchell. Phyc. Bor.-Am. 
Fasc. 23. no. I107. 1903. Nelson. Observations upon some Algae which cause "Water Bloom." Minn. Bot. Studies. 3: 53. pl. I4. f. I. I903. Riddle. Brush Lake Algae. Ohio Nat. 5: 268. I905. Collins, Holden and Setchell. Phyc. Bor.-Am. Fasc. 28. no. 1359. 1907.

\section{Plate X. fig. I.}

Colonies small, aggregated in membranaceous flakes, fragile, blue-green; trichomes 5-6 mic. in diameter, rigid, tapering at the ends; cells somewhat quadrate, 5-15 mic. in length; heterocysts 6-7 mic. in diameter, 15-20 mic. in length, somewhat cylindrical; gonidia 7-8 mic. in diameter, 60-80 mic. in length, cylindrical, elongate, containing granular protoplasm; wall of gonidium smooth, colorless.

Massachusetts. Floating on quiet water. Medford. October I906. (Lambert). Ohio. Sandusky Bay; Brush Lake. (Riddle). Plankton. Put-in-Bay, Lake Erie. (Snow). Minnesota. Lake Tetonka, Waterville. 1882. (Arthur). Lake of the Woods. July I894. (MacMillan). Lake Minnetonka. 1895. (Crocker). On surface of water around edges in quiet bays during summer and early autumn. Long Lake, Hennepin County. September 1895. (Shaver and Tilden). In a shallow lake in the depressions of the Fergus Falls moraine, Fergus Falls. August I900. (Ballard). California. Floating on Lake Chabot, San Leandro. June 1902. (Gardner).

\section{Genus CYLINDROSPERMUM Kuetzing. Phyc. Gen. 2II. I843.}

Plant mass expanded, indefinite, mucous; sheaths not present; trichomes equal, short, embedded in an amorphous mucus; cells cylindrical, longer than their diameter; heterocysts terminal, solitary; gonidia developed from the cell or cells next the heterocyst, generally solitary, rarely seriate.

I Gonidia solitary.

I Gonidia cylindrical, up to $40 \mathrm{mic}$. in length

(I) Gonidia I0-16 mic. in diameter, 32-40 mic. in length

$$
\text { C. stagnale }
$$

(2) Gonidia II-I2 mic. in diameter, 23-24 mic. in length

\section{C comatum}

2 Gonidia oblong or ventricose-elliptical

(I) Wall of gonidium punctate

A Gonidia IO-I5 mic. in diameter, 20-38 mic. in length, ventricoseelliptical; wall of mature gonidium rough, punctate

$$
\text { C. majus }
$$

B Gonidia 6-6.5 mic. in diameter, I6-I9 mic. in length, elliptical; wall of gonidium very finely granular C. minutum

(2) Wall of gonidium smooth

A Gonidia 8-9 mic. in diameter, $18-20$ mic. in length

C. minutissimum

B Gonidia 9-I2 mic. in diameter, I8-20 mic. in length

C. muscicola 
C Gonidia I2-I4 mic. in diameter, 20-38 mic. in length

C. licheniforme

II Gonidia seriate

C. catenatum

364. Cylindrospermum stagnale (Kuetzing) Bornet and Flahault. Revis. des Nostoc. Ann. Sci. Nat. Bot. VII. 7: 250. 1888. De Toni. Syll. Algar. 5: 472. 1907 .

Wood. Contr. Hist. Fresh-Water Algae North America. 40. pl. 2. f. 7. 1872. (C. macrospermum Kg., Anabaena stagnalis Kg.) Wolle. Fresh-Water Algae U. S. 292. pl. 199. f. 6-8. 1887. Wolle and Martindale. Algae. Britton's Catalogue of Plants found in New Jersey. Geol. Surv. N. J. 2: 607. I889. Anderson and Kelsey. Common and Conspicuous Algae of Montana. Bull. Torr. Bot. Club. I8: 145. I891. Tilden. List of fresh-water Algae collected in Minnesota during 1893. Minn. Bot. Studies. I: 31. I894. (C y lindros permum 1 i mnicola Kuetz.) Collins. Notes on Algae.-IV. Rhodora. 3: 289. Igor.

Setchell. Phyc. Bor.-Am. Fasc. 18. no. 856. 190r. Tilden. American Algae. Cent. V. no. 48I. I90I; Collection of Algae from the Hawaiian Islands. Hawaiian Almanac and Annual for 1902. II2. 1901; Algae collecting in the Hawaiian Islands. Postelsia: The Year Book of the Minnesota Seaside Station. I: I68. 1902. Kellerman. Prcposed Algological Survey of Ohio. Ohio Nat. 2: 222. 1902. Clark. The Holophytic Plankton of Lakes Atitlan and Amatitlan, Guatemala. Proc. Biol. Soc. Wash. 21: 97. I908. Buchanan. Notes on the Algae of Iowa. Proc. Iowa Acad. Sci. 14: I2. Ig08.

\section{Plate X. fig. 2.}

Plant mass floccose, expanded, attached or floating; trichomes 3.8-4.5 mic. in diameter, slightly constricted at joints; cells up to three or four .times longer than their diameter; heterocysts 6-7 mic. in diameter, up to I6 mic. in length, somewhat spherical, often oblong; gonidia Io-16 mic. in diameter, 32-40 mic. in length, cylindrical, with rotund apices; wall of gonidium smooth, yellowish brown; cell contents pale blue-green.

Maine. Forming a dense bluish green or brownish scum on the surface of an artificial pond at the Pogy Oil Factory, Bristol, near Round Pond Village. July 1901. (Collins). New Jersey. Frequent in wet places on dead wood. (Wolle). South Carolina. "In bottom of shallow, slowly running streams, adhering to ground or fallen leaves, etc., gelatinous, green." Near Aiken. September. (Ravenel). Ohio. (Kellerman). Minnesota. Irving Chase Lake. July I893. (Tilden). Iowa. Iowa City. (Hobby). Montana. Ponds and semi-stagnant, mud-bottomed parts of streams in the mountains and on the plains. Common throughout. June to November. (Anderson and Kelsey). Central America. On surface of water. Lake Amatitlan, Guatemala. February 1906. (Meek). Hawaii. On wet cliffs. Laupahoehoe, Hawaii. July Igoo. (Tilden).

365. Cylindrospermum comatum Wood. Contr. Hist. Fresh-Water Algae North America. 4I. pl. 2. f. 1872. Wolle. Fresh-Water Algae U. S. 293. pl. 199. f. I6. I887. 
Buchanan. Notes on the Algae of Iowa. Proc. Iowa Acad. Sci. 14: I2. I908.

\section{Plate X. fig. 3 .}

Plant mass gelatinous, blue-green, sometimes tinged on the edges with brown; trichomes 3 mic. in diameter, flexuous, equal, intricate, not spiral; cells short cylindrical, equal to or more than twice as long as the diameter, usually separated; apical cells somewhat spherical; gonidia IO-I2 mic. in diameter, 23-24 mic. in length, oblong-cylindrical, granular, yellowish brown; wall of gonidium thick, distinctly granulate; cell contents granular, pale blue-green.

Canada. Growing upon the ground in the marshes which border the Niagara River, just above the Canadian Falls. (Wood). Iowa. Frequent on wet soil along brooks. Grinnell. (Fink).

366. Cylindrospermum majus Kuetzing. Phyc. Gen. 2I2. I843. Bornet and Flahault. Revis. des Nostoc. Ann. Sci. Nat. Bot. VII. 7: 252. I888. De Toni. Syll. Algar. 5: 474. 1907.

Collins. Algae of Middlesex County. I4. I888. Collins, Holden and Setchell. Phyc. Bor.-Am. Fasc. 3. no. I06. I895. Setchell. Notes on Cyanophyceae--III. Erythea. 7: 51. I899. Collins, Holden and Setchell. Phyc. Bor.-Am. Fasc. 15. no. 708. I900; Fasc. 23. no. II08. 1903. Collins. Phycological Notes of the late Isaac Holden.-II. Rhodora. 7: 236. I905.

Plate X. fig. 4.

Plant mass widely expanded, mucous, blackish green; trichomes 4-5 mic. in diameter, constricted at joints; cells 5-6 mic. in length, cylindrical; heterocysts a little wider than the cells, up to ro mic. in length, oblong, pale; gonidia Io-I5 mic. in diameter, 20-38 mic. in length, ventricose-elliptical; wall of mature gonidium rough, punctate.

Maine. Not immersed, but forming gelatinous masses on steep bank above the shore. South Harpswell. July 1903. (Collins). Massachusetts. Newton. (Farlow). On walls of B. and A. R. R. tunnel. (Wood). Connecticut. Investing grasses, Ut ric u l a ri a, etc., in still water. Pool below Factory Pond, Bridgeport. September I89I. (Holden). California. In a slow stream near Pasadena. (McClatchie).

367. Cylindrospermum minutum Wood. Contr. Hist. Fresh-Water Algae North America. 39. pl. 2. f. 6. 1872. De Toni. Syll. Algar. 5: 475. I907.

Wolle. Fresh-Water Algae U. S. 292. pl. 199. f. II. I887. (C. 1 i m n icola Wolle). Wolle and Martindale. Algae. Britton's Catalogue of Plants found in New Jersey. Geol. Surv. N. J. 2: 607. 1889. Bessey. Miscellaneous Additions to the Flora of the State. Bot. Surv. Nebraska. 46. I893. Saunders. Protophyta-Phycophyta. Flora of Nebraska. I9. pl. I. f. II. I894. Tilden. List of Fresh-Water Algae collected in Minnesota during 1893. Minn. Bot. Studies. I: 31. I894. 
Plate X. fig. 5 .

Plant mass rust-colored, gelatinous; trichomes 2.8 mic. in diameter, generally curved and entangled, sometimes straight, more or less constricted at the joints; cells cylindrical; heterocysts hirsute, spherical; gonidia 6-6.5 mic. in diameter, I6-I9 mic. in length, elliptical, very minutely granulate; cell contents homogeneous or granular, light blue-green.

New Jersey. Forming, with other algae, a ferruginous brown, gelatinous mass, growing in a deep, shaded, very stagnant pool. Spring Garden. (Wood). In wet places on dead wood. (Wolle). Minnesota. Irving Chase Lake. July I893. (Tilden). Nebraska. Lincoln. (Bessey). Forms light green, slimy strata on pots in greenhouse. Lincoln. (Saunders).

368. Cylindrospermum minutissimum Collins. New Cyanophyceae. Erythea.

4: I20. I896; Collins, Holden and Setchell. Phyc. Bor.-Am. Fasc.

26. no. 1256. 1905. De Toni. Syll. Algar. 5: 472 . I907.

Plant mass loose, blue-green; trichomes 2-2.5 mic. in diameter, straight, not constricted at joints; cells cylindrical, very slender, 4-5 mic. in length; heterocysts $4 \mathrm{mic}$. in diameter, $7-8 \mathrm{mic}$. in length, cylindrical-oblong; gonidia 8-9 mic. in diameter, I8-20 mic. in length; wall of gonidium smooth, translucent (in not quite ripe gonidia).

Massachusetts. Among other algae in a scum in a ditch. Malden. October 1890. (Collins).

369. Cylindrospermum muscicola Kuetzing. Phyc. Germ. I73. 1845. Bornet and Flahault. Revis. des Nostoc. Ann. Sci. Nat. Bot. VII. 7: 254. 1888. De Toni. Syll. Algar. 5: 477. I907.

Collins. Algae of Middlesex County. I4. I888. Tilden. American Algae. Cent. II. no. 174. I896. Collins. The Algae of Jamaica. Proc. Am. Acad. Arts Sci. 37: 240. 190I. Setchell and Gardner. Algae of Northwestern Amer. ica. Univ. Calif. Pub. Bot. I: I93. I903. Collins, Holden and Setchell. Phyc. Bor.-Am. Fasc. 27. no. 1306. 1906.

\section{Plate X. fig. 6.}

Plant mass expanded, mucous, blackish green; trichomes $3-4.7$ mic. in diameter, cylindrical, slightly constricted at joints; cells 4 mic. in length; heterocysts 4 mic. in diameter, 5-7 mic. in length, oblong; gonidia 9-I 2 mic. in diameter, Io-2o mic. in length, oval, orange brown; wall of goridium smooth; cell contents pale blue-green.

Maine. On steep, wet clay bank. Harpswell. July igo6. (Collins). Massachusetts. Cambridge. (Farlow). On moist ground, Medford. September I906. (Lambert). Washington. In a small stream of running water. Orcas Island. (Gardner). California. In slowly running water. Pasadena. Jecember 1895. (McClatchie). West Indies. On sides of basin. Constant Spring; on sand at edge of river, Castleton, April I893. (Humphrey).

370. Cylindrospermum licheniforme. (Bory) Kuetzing. Diagnosen und Bemerkungen. Bot. Zeit. 5: I97. I847. Bornet and Flahault. Revis. des Nostoc. Ann. Sci. Nat. Bot. VII. 7: 253. 1888. De Toni. Syll. Algar. 5: 476. 1907 . 
Collins, Holden and Setchell. Phyc. Bor.-Am. Fasc. 7. no. 309. I897. Setchell. Notes on Cyanophyceae. III. Erythea. 7: 52. I899. Tilden. American Algae. Cent. VI. no. 575. 1902. Setchell and Gardner. Algae of Northwestern America. Univ. Calif. Pub. Bot. I: I93. Ig03.

Plant mass mucous, orbicular-confluent, finally becoming widely expanded, very deep blackish green; trichomes 4.2 mic. in diameter, slightly constricted at joints; cells 4-5 mic. in length; heterocysts $5-6$ mic. in diameter, 7-I2 mic. in length, oblong; gonidia I2-I4 mic. in diameter, 20-38 mic. ir. length, oblong or ventricose-elliptical, with truncate apices; wall of gonidium smooth, brownish or reddish; cell contents pale blue-green.

New York. Ithaca. (Atkinson). Minnesota. On stones at edge of river, near quarry. St. Louis River, Fond du Lac, near Duluth. August Igor. (Tilden). Washington. On mud or moist sand. Near Oak Harbor, Whidbey Island; near Mt. Vernon, Skagit County; near Seattle. (Gardner). California. Growing upon a bank within reach of salt spray. Bolinas, Marin County. (Setchell).

371. Cylindrospermum catenatum Ralfs. On the Nostochineae. Ann. and Mag. of Nat. Hist. 5: 338. I850. Bornet and Flahault. Revis. des Nostoc. Ann. Sci. Nat. Bot. VII. 7: 254. I888. Dẹ Toni. Syll. Algar. 5: 477. I907.

Collins, Holden and Setchell. Phyc. Bor.-Am. Fasc. II. no. 505. 1898. Collins. Notes on Algae.-I. Rhodora. I: 9. I899. Tilden. American Algae. Cent. IV. no. 395. 1900. Setchell and Gardner. Algae of Northwestern America. Univ. Calif. Pub. Bot. I: 193. 1903.

\section{Plate X. fig. 7 .}

Plant mass mucous, orbicular-confluent, indefinite, blackish green; trichomes 4 mic. in diameter, constricted at joints; cells 4-5 mic. in length; 1leterocysts $4 \mathrm{mic}$. in diameter, 6-7 mic. in length, oblong; gonidia 7 -1o mic. in diameter, I3-18 mic. in length, oblong, two to eight in series; wall of gonidium smooth, orange brown.

Massachusetts. Forming a dark thin coating on the ground, looking as if a little black paint had been spilled and dried. On moist earth near Snot Pond. Middlesex Fells. August and September r897. (Collins). Washington. Floating in stagnant place in stream. Tracyton, Kitsap County. July I898. (Tilden). Hawaii. At edge of mountain stream. Kaliuwaa Stream, Makao, Koolauloa, Oaht1. June Igoo. (Tilden).

Genus RICHELIA Johs. Schm.

Vid. Medd. Nat. Foren Kjöb. I47. I901.

Sheaths not present; trichomes single, endophytic; heterocysts solitary, situated at the base of the trichome.

372. Richelia intracellularis J. Schm. Plankton fra det Röde Hav og Adenbugten. Vid. Medd. fra. d. Nat. Foren. Kjöb. I47. I90I. De Toni. Syll. Algar. 5: 480. I907. 
Plate X. fig. 8.

Trichomes 5.6-9.8 mic. in diameter, 50-105 mic. in length, short, straight or nearly straight, thickened at the apices, living as endophytes in the cells of Rhizosoleniae styliformis; heterocysts 9.8 II.2 mic. in diameter, spherical or somewhat spherical, single, basal; cells somewhat spherical or barrel-shaped; apical cell often a little larger than the others, somewhat spherical; cell contents finely granular, or showing a few large granules, pale blue-green.

Hawaii. Plankton. On Rhizosolenia and $\mathrm{Hemia}$ e $\mathrm{m}$ s delic a t u 1 us Lemm. (Schauinsland).

Genus AULOSIRA Kirchner.

Krypt. von Schles. Algen. 238. 1878 .

Filaments free, equal, scattered or in fascicles; sheaths membranaceous, close; cells cylindrical or barrel-shaped; heterocysts intercalary; gonidia developed at intervals between the heterocysts, remote from or contiguous to them, cylindrical, in catenate series.

373. Aulosira schauinslandii Lemmermann. Die Algenflora der SandwichInseln. Bot. Jahrb. 34: 622. pl. 7. f. 9-II. I905. De Toni. Syll. Algar. 5: 482. 1907 .

Plate X. fig. 9.

Filaments Io-I I mic. in diameter, flexuous or spiral; sheaths firm, colorless; trichomes $9.5 \mathrm{mic}$. in diameter, slightly constricted at joints; apical cell hemispherical, about $8 \mathrm{mic}$. in length, containing coarse granules; cells 3 mic. in length, short; heterocysts usually 9.5 mic. in diameter, I I mic. in length, always intercalary, somewhat spherical or cylindrical; gonidia not known.

Hawaii. On Turbinaria. Laysan. (Schauinsland).

Genus MICROCHAETE Thuret.

Essai Class. Nostocininées. 7. 1875.

Plants small, living in fresh or salt water, aggregated into star-shaped or cushion-shaped tufts; filaments unbranched, erect, attached at the base; sheaths present; trichomes single within the sheati; heterocysts basal and intercalary; gonidia developed from the lower cells.

I Plants living in fresh water; heterocysts basal and intercalary.

I. Filaments 4.4-5.I mic. in diameter; sheaths colorless, wide

M. tenuissima

2 Filaments Io mic. in diameter; sheaths simple, thin, close

M. tenera

3 Filaments $16-18$ mic. in diameter; sheaths at first thin, later becoming lamellose, colorless

M. robusta 
II Plants living in salt water; heterocysts basal.

I Plant mass densely caespitose; filaments 6-7 mic. in diameter, thickened into a bulb at the base M. grisea

2 Plant mass loosely caespitose; filaments 7-9 mic. in diameter, flexuous, scarcely thickened at base

\section{M. vitiensis}

374. Microchaete tenuissima W. and G. S. West. On some Freshwater Algae from the West Indies. Journ. Linn. Soc. Bot. 30: 269. pl. I4. f. 7-I I. I895. De Toni. Syll. Algar. 5: 484. 1907.

West and West. A Further Contribution to the Freshwater Algae of the West Indies. Journ. Linn. Soc. Bot. 34: 286. 1899.

\section{Plate X. fig. Io.}

Filaments 4.4-5.I mic. in diameter, very slender, somewhat entangled, twisted; sheaths transparent, colorless, wide; trichomes I-I.8 mic. in diameter; cells elongate, 5-16 mic. in length, the younger cells shorter and wider; heterocysts 2-2.4 mic. in diameter, 3.5-6.5 mic. in length, somewhat quadrate or oblong, intercalary.

West Indies. Amongst $\mathrm{Sy}$ m p loca $\mathrm{cuspidata}$ on trees, summit of Trois Pitons (4,500 feet). November and December 1892; on rocks, Castle Bruce River (2,000-3,000 feet), Dominica. January and February s896. (Elliott).

375. Microchaete tenera Thuret. Essai Class. Nostochinées. 7. 1875. Bornet and Flahault. Revis. des Nostoc. Ann. Sci. Nat. Bot. VII. 5: 84. 1887. De Toni. Syll. Algar. 5: 482. I907.

Setchell. Notes on some Cyanophyceae of New England. Bull. Torr. Bot. Club. 22: 427. IS95. Setchell and Gardner. Algae of Northwestern America. Univ. Calif. Pub. Bot. I: 194. I903.

Plate X. fig. II.

Plant mass small, star-shaped; filaments 6-7 mic. in diameter, I mm. in length, curved at the base, slightly flexuous; sheaths thin, close, uniform, colorless; trichomes $5 \mathrm{mic}$. in diameter; lower cells twice as long as their diameter, upper cells equal in length to their diameter; heterocysts basal, oblong, cylindrical, intercalary.

Alaska. Forming gray tufts on dripping rocks. Walls of Amaknak Cave, Amaknak Island, Bay of Unalaska. (Setchell and Lawson). Connecticut. Mixed with various, gelatinous algae, occurring upon dripping rocks near Norwich and New Haven. (Setchell).

376. Microchaete robusta Setchell and Gardner. Algae of Northwestern America. Univ. Calif. Pub. Bot. I: 194. I903. De Toni. Syll. Algar. 5: 483. 1907 .

Plant mass forming a tuft or star-sbaped cluster on water weeds; filaments $16-18 \mathrm{mic}$. in diameter, elongate and extremely cylindrical, decumbent at the very base, but scarcely thickened; sheaths at first thin, later becoming lamellose, colorless; trichomes I2 mic. in diameter, composed 
of cells which are quadrate or slightly longer than broad in the lower portion and shortened to one-third as long as broad in the upper part; cells G-I6 mic. in length; heterocysts basal and intercalary, the former being spherical or nearly so, while the latter are elongated and rectangular; cell contents finely granular, blue-green.

Washington. In ponds of fresh water, near Seattle. (Kincaid).

377. Microchaete grisea Thuret. Essai Class. Nostochinées. 7. 1875. Bornet and Flahault. Revis. des Nostoc. Ann. Sci. Nat. Bot. VII. 5: 85. I887. De Toni. Syll. Algar. 5: 485. 1907.

Collins. Notes on New England Marine Algae IV. Bull. Torr. Bot. Club. II: I30. I884. Collins, Holden and Setchell. Phyc. Bor.-Am. Fasc. 4. no. 158. 1896. Collins. Preliminary Lists of New England Plants. V. Marine Algae. Rhodora. 2: 42. I900; Phycological Notes of the late Isaac Holden.-II. Rhodora. 7: 223. 1905.

\section{Plate X. fig. 12.}

Plant mass densely caespitose, tomentose, orbicular, dull green, becoming violet when dried; filaments 6-7 mic. in diameter, $1 \mathrm{~mm}$. in length, curved at the bulbous base, soon becoming erect, densely crowded; sheaths thin, close, continuous, colorless; trichomes 5-6 mic. in diameter; cells shorter than their diameter; heterocysts basal, hemispherical.

Canada. Forming patches on Fucus e vanescens. Malpeque, Prince Edward Island. (Fauli). Maine. On Z $\mathrm{Z}$ ostera marin a Goose Creek, Cape Rosier. July I895. (Collins). Massachusetts. On an old pecten shell in company with Caloth $\mathrm{rix}$ c r u t a cea. West Falmouth. (Collins). Connecticut. On stranded stump. Seaside Park. November. (Holden).

378. Microchaete vitiensis Askenasy in Bornet and Flahault. Tableau synopt. des Nostochacées filamenteuses hétérocystées. 22. I885. Bornet and Flahault. Revis. des Nostoc. Ann. Sci. Nat. Bot. VII. 5: 85. 1887. De Toni. Syll. Algar. 5: 485. I97.

Lemmermann. Algenf. Sandwich.-Inseln. Bot. Jahrb. 34: 624. 1905.

Plant mass loosely caespitose, tomentose, short; filaments 7-9 mic. in diameter, scarcely attaining I $\mathrm{mm}$. in length, curved and slightly thick'ned at the base, above slightly tapering, erect, flexuous; sheaths thin, close, colorless; trichomes 5-6 mic. in diameter; cells a little shorter than their diameter; heterocysts basal.

Hawaii. Growing on Liagora coarctata. Laysan. 1896-I897. (Schauinsland).

\section{Genus HORMOTHAMNION Grunow.}

Reise d. Freg. Novara. 3i. 1867.

Plant mass formed from filaments growing together in a longitudinal manner, sometimes developing as an expanded layer, sometimes erect, filiform, torn and branched, not surrounded by a common gelatinous tegument; sheaths membranaceous, thin, often diffluent, colorless; trichomes 
moniliform; usually many within the sheath; heterocysts intercalary; gonidia not known.

I Plant mass floccose, entangled; trichomes 9-12 mic. in diameter.

\section{H. solutum}

II Plant mass erect, caespitose, resembling Symploca; trichomes 6-7 mic. in diameter

H. enteromorphoides.

379. Hormothamnion solutum Bornet and Grunow in Bornet and Flahault. Revis. des Nostoc. Ann. Sci. Nat. Bot. VII. 7: 259. 1888. De Toni. Syll. Algar. 5: 486. 1907.

Lemmermann. Algenfl. Sandwich.-Inseln. Bot. Jahrb. 34: 624. 1905.

Plant mass floccose, entangled, mucous, green or blue-green; filaments 12-15 mic. in diameter, 5-6 mm. in length, soft, flaccid, free or coalesced in numerous fascicles, erect; sheaths membranaceous, firm, colorless; trichomes 9-1 2 mic. in diameter, constricted at joints; cells disc-shaped, depressed, three or four times shorter than their diameter; heterocysts somewhat quadrate.

Hawaii. (Grunow).

380. Hormothamnion enteromorphoides Grunow. Reise seiner Majestät Fregatte Novara um die Erde. Bot. Theil. I: 31. 1867. Bornet and Thuret. Revis. des Nostoc. Ann. Sci. Nat. Bot. VII. 7: 260. 1888. De Toni. Syll. Algar. 5: 486. $190 \%$.

Schramm and Mazé. Essai Class. Algues Guadeloupe. 29. 1865. (S p h a erozyga microcoleiformis Crouan). Murray. Catalogue of the Marine Algae of the West Indian Region. Journ. of Bot. 27: 261. I889. Collins, Holden and Setchell. Phyc. Bor.-Am. Fasc. 2. no. 56. 1895. Collins. The Algae of Jamaica. Proc. Am. Acad. Arts Sci. 37: 24I. Igor. Vickers. Liste des Algues Marines de la Barbade. Ann. Sci. Nat. Bot. VIII. I: 55.1905 .

Plate X. fig. I3.

Plant mass at first mucous, confluent, agglutinated, green or blue-green, when older caespitose, formed from simple, erect, soft fascicles, rising from a prostrate base, fastigiately branched; branches tapering at the apices; filaments 7-9 mic. in diameter; sheaths mucous, colorless, delicate; trichc.mes 6-7 mic. in diameter, 7-10 mic. in length.

Florida. Key West, Tortugas. (Farlow). West Indies. Guadeloupe. (Duchassaing). In tufts from sandy bottom in shallow water. St. Ann's Bay. March 1893; on coral reef, Navy Island, Jamaica. July 1897. (Humphrey). Near Kingston, Jamaica. May rgor. (Duerden). Barbados. (Vick$\epsilon \mathrm{rs})$.

\section{Family III. SCYTONEMACEAE}

Filaments branched; false branches formed by the perforation of the sheath by the trichome which thereupon issues as one or two long, flex- 
nous branches each developing a sheath of its own; sheaths homogeneous and colorless, or lamellose and yellowish or brownish, firm, tubular; trichomes consisting of a single row of cells, one or more included in a sheath; heterocysts and gonidia variously disposed; reproduction by means of regetative division, homogones and gonidia.

I Trichomes single within the sheath

I Heterocysts not present; filaments free or forming felt-like masses, branched; false branches often in pairs

\section{Plectonema}

2 Heterocysts present

(I) False branches usually arising between two heterocysts, single or in pairs; sheaths delicate or very thick, parallel, or more or less diverging towards the apex

\section{Scytonema}

(2) False branches usually arising in the immediate region of the heterocysts, single; sheaths somewhat thin, flexible, more or less fragile

Tolypothrix

II Trichomes or filaments several within the sheath.

I Filaments straight, associated in tufits; sheaths thin; trichomes two or more within the sheath; heterocysts basal Desmonema

2 Filaments several contorted within a common tegument, associated in a gelatinous stratum; trichomes single within the sheath

Diplocolon

Genus PLECTONEMA Thuret.

Essai Class. Nostochinées. 375, 379. 1875.

Filaments free or forming felt-like masses, branched; false branches solitary or in pairs; sheaths firm, colorless or rarely yellowish orange; trichomes frequently constricted at the joints; apex of trichome straight, very rarely tapering; calyptra none.

I Plants large, caespitose; trichomes 3 mic. and more in diameter.

I Plant mass caespitose, rotund, light green; trichomes 5-Io mic. in diameter, here and there constricted at joints

\section{P. tenue}

2 Plant mass caespitose, indefinite, brownish green; trichomes II-22 mic. in diameter

P. tomasinianum

3 Plant mass widely expanded, indefinite, blackish, rarely yellowish green; trichomes $28-47$ mic. in diameter, not constricted at joints

\section{P. wollei}

II Plant mass very thin, not caespitose; trichomes I-4 mic. in diameter.

I Filaments somewhat flexuous, immersed in dead shells; trichomes .9-1.5 mic. in diameter, not constricted at joints

\section{P. terebrans}

2 Filaments somewhat straight, growing among various gelatinous algae; trichomes I-I.5 mic. in diameter

P. nostocorum

3 Filaments usually strongly flexuous, densely entangled in a rosecolored membrane; trichomes $1.2-1.8$ mic. in diameter

P. roseolum 
. 4 Filaments long, entangled, flexuous, much branched, forming a rosecolored or reddish brown mass adhering to rocks or larger algae; trichomes 1.2-2 mic. in diameter

P. golenkinianum

5 Filaments very long, entangled in dense balls; trichomes 2-2.5 mic. in diameter

P. calothrichoides

6. Filaments long, flexuous, much branched, forming a black or brownish green mass; trichomes $2-3.5 \mathrm{mic}$. in diameter

P. battersii

381. Plectonema tenue Thuret. Essai Class. Nostochinées. Ann. Sci. Nat. Bot. VI. I: 380. I875. Gomont. Monogr. Oscill. I2r. pl. I. f. 5, 6. I893. De Toni. Syll. Algar. 5: 492. 1907.

Collins. Algae. Flora of the Blue Hills, Middlesex Fells, Stony Brook and Beaver Brook Reservations of the Metropolitan Park Commission. 127. I896.

Plate XI, fig. I, 2.

Plant mass caespitose, rotund, light green; filaments graceful, elongate, much branched; false branches usually in pairs; sheaths at first colorless and very thin, later becoming thick, and yellowish orange in color; trichomes 5-Io mic. in diameter, here and there constricted at joints, tapering at the apex; apical cell tapering, obtuse conical; cells 2-6 mic. in length; transverse walls not granulated; cell contents finely granular, pale bluegreen.

Massachusetts. Spot Pond, Middlesex Fells. (Collins).

382. Plectonema tomasinianum (Kuetzing) Bornet. Les Nostocacées hétérocystées du Systema Algarum de C. Agardh (1824) et leur Synonymie actuelle. (I889). Bull. Soc. Bot. de France. 36: I55. I889. Gomont. Monogr. Oscill. II9. I893. De Toni. Syll. Algar. 5: 490. 1907.

Wood. Contr. Hist. Fresh-Water Algae North America. 59. pl. 8. f. 6. I872. (Scytonema nägelii (Kg.) Wood). Rabenhorst. Die Algen Europas. no. 2493. I877. (P. mirabile Thur.). Wolle. Fresh Water Algae. Bull. Torr. Bot. Club. 6: 285. I879. (C a 1 ot hrix mirabilis Ag.). Wittrock and Nordstedt. Algae Aq. Dulc. Exsicc. no. 39r. r88o. Wolle. Fresh Water Algae. VII. Bull. Torr. Bot. Club. I0: 20. I883; FreshWater Algae U. S. 266. pl. 18I. f. 12-I5. 1887. Bennett. Plants of Rhode Island. II4. I888. (S c y t o n e m a n a ta $\mathrm{n}$ s Bréb.). Wolle and Martindale. Algae. Britton's Catalogue of Plants found in New Jersey. Geol. Surv. N. J. 2: 603. I889. (Calothrix brebissoni $\mathrm{ig}$.). Snow. The Plankton Algae of Lake Erie. U. S. Fish Comm. Bull. for 1902. 22: 392. I903.

\section{Plate XI. fig. 3 .}

Plant mass caespitose, more or less expanded, brownish green or rarely dull blue-green, up to $2 \mathrm{~cm}$. in height; filaments entangled, flexible, usually flexuous, repeatedly branched; false branches often in pairs, issuing in an erect, spreading or oblique manner; sheaths at first thin, colorless, with age 
- becoming lamellose, yellowish brown and up to 3 mic. in thickness; trichomes II-22 mic. in diameter, constricted at the joints; apical cell rotund; cells 3-9 mic. in length; transverse walls sometimes granulated; cell contents often filled with coarse granules, blue-green.

Rhode Island. Quidnessett. (Bennett). New Jersey. Frequent on stones in ponds or floating. Hammonton. (Wolle). Pennsylvania. Forming little dark green mats, growing attached to mosses in large spring that supplies Bellefonte with water. (Wood). In spring. Bethlehem. (Wolle). Maryland. Falls of Deep Creek. (Smith). Ohio. Plankton. Lake Erie. Put-in-Bay. (Snow). Minnesota. Minneapolis. (Wolle).

383. Plectonema wollei Farlow. Remarks on some Algae found in the Water Supplies of the City of Boston. Bull. Bussey Inst. 77. 1875 . Gomont. Monogr. Oscill. pl. I. f. I. I I8. I893. De Toni. Syll. Algar. 5: 489.1907 .

Rabenhorst. Die Algen Europas. no. 2440. I876. (L y n g b y a w o $11 \mathrm{e} \mathrm{i}$ Farlow). Farlow, Anderson and Eaton. Algae Am. Bor. Exsicc. no. 46. J877-I889. Wittrock and Nordstedt. Algae Aq. Dulc. Exsicc. no. 279. 1879. Farlow. On some Impurities of Drinking-Water caused by Vegetable Growths. Supp. First Ann. Rep. Mass. State Bd. Health. I3I. I88o. Wolle. Fresh-Water Algae U. S. 297. pl. 200. f. 6-8. 1887. Collins. Algae of Middlesex County. 14. 1888 . Bennett. Plants of Rhode Island. II4. I888. Wolle and Martindale. Algae. Britton's Catalogue of Plants found in New Jersey. Geol. Surv. N. J. 2: 608. 1889. Collins, Holden and Setchell. Phyc. Bor.-Am. Fasc. 2. no. 55. I895. Tilden. American Algae. Cent. II. no. 177. 1896; List of Fresh-Water Algae collected in Minnesota during r895. Minn. Bot. Studies. I: 599. 1896. Collins. The Algae of Jamaica. Froc. Am. Acad. Arts Sci. 37: 240. 1901. Snow. The Plankton Algae of Lake Erie. U. S. Fish Comm. Bull. for 1902. 22: 392. I903. Collins. Phycological Notes of the late Isaac Holden.-II. Rhodora. 7: 236. 1905.

$$
\text { Plate XI, fig. 4, 5. }
$$

Plant mass caespitose, floating, blackish, rarely yellowish green; filaments woolly, entangled, fragile (in dried specimens), somewhat straight or variously curved, slightly branched; false branches solitary, rarely in pairs, issuing in an oblique manner; sheaths colorless, sometimes yellowish orange, lamellose with age, roughened in outline, up to ro mic. in thickness; trichomes 28-47 mic. in diameter, not constricted at joints; apical cell rotund; cells 4-9 mic. in length; transverse walls not granulated; cell contents finely granular, blackish or blue-green.

Massachusetts. Attached to stones in rivers. (Wolle). Washed ashore in large quantities. Horn Pond, Woburn; August I890; Lake Quannapowitt, Wakefield. (Collins). Rhode Island. Providence. (Bennett). Connecticut. Attached to stones in swift water. Housatonic River, below Great Falls, near New Milford. October I890. (Holden). New Jersey. "The floating mass was fully ten yards long, 2-3 yards wide, a foot or more in thickness, and so densely matted, it was impossible to break through with a row-boat." In pond near Stanhope; Sussex; Lake Hopatcong, Swarts- 
wood Pond. (Wolle). Pennsylvania. Bethlehem. (Wolle). Florida. (Wolle). South Carolina. Strouds. August, October 1896. (Green). Ohio. Plankton. Lake Erie, Put-in-Bay. (Snow). Minnesota. Forming large masses, dark, nearly black in color, on surface of stagnant lake. Long Lake, Hennepin County. September 1895 . (Shaver and Tilden). Central America. Nicaragua. (Agardh). West Indies. In rapid current of stream. "Roaring River,' St. Ann's, Jamaica. March 1893. (Humphrey). Morant Bay. August I894. (Pease and Butler).

384. Plectonema terebrans Bornet and Flahault. Sur quelques Plantes vivant dans le Test Calcaire des Mollusques. Bull. Soc. Bot. de France. 36: CLXIII. pl. Io. f. 5, 6. I889. Gomont. Monogr. Oscill. 123. I893. De Toni. Syll. Algar. 5: 497. I907.

Collins. Some Perforating and other Algae on Fresh-Water Shells. Erythea. 5: 95. 1897. Collins, Holden and Setchell. Phyc. Bor.-Am. Fasc. 7. no. 306. I897. Collins. Preliminary Lists of New England Plants.-V. Marine Algae. Rhodora. 2: 42. I900; Phycological Notes of the late Isaac Holden.-II. Rhodora. 7: 223. I905. Collins, Holden and Setchell. Phyc. Bor.-Am. Fasc. 28. no. 1357. 1907.

\section{Plate XI. fig. 6.}

Filaments slender, elongate, flexuous, branched; false branches often solitary; sheaths very thin, colorless, cylindrical; trichomes .9-1.5 mic. in diameter, not constricted at joints; cells $2-6$ mic. in length; apical cell rotund; transverse walls marked by two refringent granules; cell contents pale blue-green.

Maine. In live shells of Littorina, in company with $\mathrm{Hyella}$ ca espitos a. Cape Rosier. July Igoi. (Collins). Rhode Island. (Collins). Connecticut. In U n i o shells. Twin Lakes, Salisbury, Litchfield County. August 1895 . (Setchell and Holden). "Very abundant all through the shells, and when the latter were decalcified, formed a dense mat which made it rather difficult to distinguish the other algae that grew in company with it."-Collins. In marine shells with other algae. Harbor. September, October. (Holden).

385. Plectonema nostocorum Bornet in Bornet and Thuret. Notes Algologiques. 2: I37. I880. Gomont. Monogr. Oscill. I22. pl. I. f. I 1. I893. De Toni. Syll. Algar. 5: 495. I907.

Collins. Notes on Algae.-III. Rhodora. 3: I33. Igor; The Algae of Jamaica. Proc. Am. Acad. Arts Sci. 37: 240. I90I; Algae of the Flume. Rhodora. 6: 230. 1904. Collins, Holden and Setchell. Phyc. Bor.-Am. Fasc. 24. no. II64. I904. Lemmermann. Algenfl. Sandwich.-Inseln. Bot. Jahrb. 34: 624. I905.

Plate XI. fig. 7 .

Filaments graceful, elongate, somewhat straight, at first much branched, later sparingly branched; false branches solitary or in pairs; sheaths colorless, very thin, cylindrical; trichomes I-I.5 mic. in diameter, constricted at 
joints; apical cell rotund; cells $2-2.5$ mic: in length; transverse walls not granulated.

Maine. In the gelatine of a small Nostoc, growing in a watering trough by the side of the road from Seal Harbor to Jordan Pond, Mount Desert. July 1900. (Collins). New Hampshire. In a gelatinous mass on a wet cliff. Wanalancet Falls, Tamworth. August 1903; with other algae in masses of translucent gelatine, on walls of the "Flume," September I904. (Collins). West Indies. Among G lo e o c a s a quaternat a. Bath, Jamaica. July 1900. (Pease and Butler). Hawaii. In hot water. Kilauea, Hawaii. (Schauinsland).

386. Plectonema roseolum (Richter) Gomont. Monogr. Oscill. I22. pl. I. f. 9, I0. 1893. De Toni. Syll. Algar. 5: 494. I907.

Setchell and Gardner. Algae of Northwestern America. Univ. Calif. Pub. Bot. I: I88. I903.

Plate XI. fig. 8 .

Plant mass gelatinous, rose-colored, when dried becoming papery, adhering to the paper; filaments densely entangled, strongly tortuous and abundantly branched, sometimes less tortuous and sparingly branched; false branches solitary or in pairs; sheaths colorless, usually thick, firm, irregular in outline; trichomes 1.2-I.8 mic. in diameter, not constricted at joints; apical cell rotund; transverse walls marked by two protoplasmic granules; cell contents very pale rose-color.

Alaska. On dripping rocks. West shore of Amaknak Island. Bay of Unalaska. (Setchell and Lawson).

387. Plectonema golenkinianum Gomont. Sur quelques Oscillariées Nouvelles. Bull. Soc. Bot. de France. 46: 35. pl. I. f. II. I899. De Toni. Syll. Algar. 5: 494. I907.

Collins, Holden and Setchell. Phyc. Bor.-Am. Fasc. I3. no. 603. I899. Collins. Preliminary Lists of New England Plants.-V. Marine Algae. Rhocora. 2: 42. 1900; Notes on Algae.-VI. Rhodora. 5: 233. 1903.

$$
\text { Plate XI. fig. } 9 .
$$

Forming a rose-colored or reddish brown mass, adhering to rocks or larger algae; filaments entangled, elongate, flexuous, abundantly and repeatedly branched; false branches spreading, elongate, in pairs, more slender than the primary filament; sheaths colorless, somewhat thick; trichomes I.2-2 mic. in diameter, constricted at joints; apical cell rotund; cells shorter than their diameter; cell contents homogeneous, rose-colored.

Maine. Forming a reddish brown coating on wet cliffs, and especially in "grottoes." Eagle Island, Penobscot Bay. July 1893. (Collins).

388. Plectonema calothrichoides Gomont. Sur quelques Oscillariées Nouvelles. Bull. Soc. Bot. de France. 46: 30. pl. I. f. 6-1o. 1899. De Toni. Syll. Algar. 5: 496. 1907.

Collins, Holden and Setchell. Phyc. Bor.-Am. Fasc. 13. no. 604. I8gg. 
Collins. Preliminary Lists of New England Plants.-V. Marine Algae. Rhodora. 2: 42. 1900.

Plate XI. fig. Io.

In a crust formed by various blue-green algae; filaments scarcely elongate, entangled in dense balls, radial because of pressure, strongly tortuous, tapering at the apices, branched; false branches in pairs, spreading, often parallel; sheaths thick and orange brown in the middle portion of the filament, gradually becoming thinner and faded at the ends; trichomes 2-2.5 mic. in diameter, constricted at joints; apical cell rotund; cells shorter than their diameter, cell contents pale blue-green.

Massachusetts. Marblehead. January I889; with other algae, on rocks near high water mark, Nahant, June 1889. (Collins).

389. Plectonema battersii Gomont. Sur quelques Oscillariées Nouvelles. Bull. Soc. Bot. de France. 46: 36. I899. De Toni. Syll. Algar. 5: 495. 1907.

Collins. An Algologist's Vacation in Eastern Maine. Rhodora. 4: I77. I902; Notes on Algae.-VI. Rhodora. 5: 233. I903. Collins, Holden and Setchell. Phyc. Bor.-Am. Fasc. 22. no. 1060. 1903.

Plant mass blackish or brownish green; filaments elongate, flexuous, abundantly and repeatedly branched; false branches usually in pairs, more slender than the main filaments; sheaths colorless, somewhat thick in the main filaments; trichomes 2-3.5 mic. in diameter, constricted at joints, with somewhat tapering apices; apical cell rotund; cells shorter than their diameter; cell contents homogeneous, pale blue-green.

Maine. In a runway on rocks from upper pools. Brownie Island, Jonesport. July I902; Harpswell. (Collins). Massachusetts. Marblehead Neck. August I902. (Collins).

Genus SCYTONEMA Agardh. Syst. Algar. 26. 1824.

Filaments branched; false branches usually arising between two heterocysts, solitary or in pairs, formed by the lateral perforation of the sheath by the trichome; trichomes single within the sheath, straight; hormogones terminal, solitary; gonidia spherical or oval, observed in a few species; wall of gonidium thin, smooth.

I Sheaths homogeneous or formed of parallel layers.

I Plants living in fresh water

(I) Filaments 5-8 mic. in diameter

S. conchophilum

(2) Filaments 12-16 mic. in diameter

S. arcangelii

(3) Filaments $18-24$ mic. in diameter

S. coactile

(4) Filaments about $30 \mathrm{mic}$. in diameter

S. rivulare

(5) Filaments $36 \mathrm{mic}$. in diameter

S. occidentale

(6) Filaments $16-36 \mathrm{mic}$. in diameter

S. crispum

2 Plants living in warm water

(I) Filaments I6 mic. in diameter

S. caldarium 

(2) Filaments 25 mic. in diameter
S. azureum

3 Plants living on soil, rocks, or bark, not submerged
(I) Filaments 7-I5 mic. in diameter
S. hofmanni
(2) Filaments 9-I5 mic. in diameter
S. varium
(3) Filaments 12-I5 mic. in diameter
S. javanicum
(4) Filaments 10-18 mic. in diameter
S. ocellatum
(5) Filaments up to $20 \mathrm{mic}$. in diameter
S. intertextum
(6) Filaments $15-20$ mic. in diameter
S. austinii
(7) Filaments I5-21 mic. in diameter; cells compressed
(8) Filaments I5-2I mic. in diameter; cells somewhat quadrate or elongate
S. guyanense
(9) Filaments $19-24$ mic. in diameter
S. amplum
(I0) Filaments 20-25 mic. in diameter
S. wolleanum
(II) Filaments $16-30 \mathrm{mic}$. in diameter
S. stuposum

II Sheaths lamellose, with diverging layers; plants usually living on soil or rocks, not submerged.

I Filaments IO-I5 mic. in diameter

S. tolypotrichoides

2 Filaments 12 -I 8 mic. in diameter

S. flavo-viride

3 Filaments I5-2I mic. in diameter

S. mirabile

4 Filaments $18-36$ mic. in diameter

S. myochrous

5 Filaments 40-75 mic, in diameter

S. badium

III Sheaths thick, lamellose, forming wings or membranaceous expansions (ocreae); branches in basal portion of filament issuing in pairs, those in the upper portion solitary.

I Plants living in water

(I) Plants living in salt water; filaments 28-50 mic. on diameter

S. fuliginosum

(2) Plants living in fresh water, on dripping rocks or submerged

S. alatum

2 Plants living on damp rocks or ('n bark
(I) Filaments I2-I6 mic. in diameter
S. junipericolum
(2) Filaments $15-30 \mathrm{mic}$. in diameter
S. crustaceum
(3) Filaments 24-40 mic. in diameter
S. densum

Species not well understood
S. bornetianum
S. dubium
S. hirtulum
S. immersum
S. polymorphum
S. rubrum
S. simplex 
390. Scytonema conchophilum Humphrey in Collins. The Algae of Jamaica. Proc. Am. Acad. Arts Sci. 37: 24I. Igor. Collins, Holden and Setchell. Phyc. Bor.-Am. Fasc. 2. no. 52. 1895.

Plant mass having the form of gray, postular roughenings on shells; filaments 5-8 mic. in diameter, irregularly branched; false branches single or in pairs, with rounded apices; sheaths rather thin, deep yellow, homogeneous, when old rough on the outside, colorless and thin at growing tips; trichomes 2.7-4.5 mic. in diameter; cells two-thirds to twice as long as. hroad; heterocysts 5 mic. in diameter, spherical or slightly elongated, rarely two or three together, intercalary; cell contents pale bluish green.

West Indies. On old conch shell, Mastigocoleus testarum occurring on inside of same shell. Port Antonio. March 1893; Kingston, Jamaica. June I897. (Humphrey).

39I. Scytonema arcangelii Bornet and Flahault. Revis. des Nostoc. Ann. Sci. Nat. Bot. VII. 5: 92. I887. De Toni. Syll. Algar. 5: 502. I907.

Collins. The Algae of Jamaica. Proc. Am. Acad. Arts Sci. 37: 241. I901.

Plant mass cushion-shaped, 3-4 mm. in height, expanded, gray or greenish; filaments $12-16 \mathrm{mic}$. in diameter, entangled in fascicles; false branches long, flexuous; sheaths membranaceous, thin, colorless; trichomes. JO-I4 mic. in diameter; cells disc-shaped or somewhat quadrate; heterocysts somewhat quadrate, colorless or yellowish.

West Indies. On moist rocks by spring. Castleton, Jamaica. April I893. (Humphrey).

392. Scytonema coactile Montagne in Kuetzing. Spec. Algar. 305. I849. Bornet and Flahault. Revis. des Nostoc. Ann. Sci. Nat. Bot. VII. 5: 90. 1887. De Toni. Syll. Algar. 5: 501. 1907.

Schramm and Mazé. Essai Class. Algues Guadeloupe. 32. 1865. Mazé and Schramm. Essai Class. Algues Guadeloupe. 34-36. I870-1877. (S. c o a ctile radians Crouan, S. elegans antillarum Crouan, Toly pothrix guadelupensis Crowan). Murray. Catalogue of the MarineAlgae of the West Indian Region. Journ. of Bot. 27: 26I. I889.

Plant mass caespitose, woolly, silky, radiately expanded, green or bluegreen, up to $15 \mathrm{~cm}$. in diameter; filaments $18-24$ mic. in diameter, $4 \mathrm{~cm}$. and more in length; false branches long, erect, spreading; sheaths firm, membranaceous, colorless or yellowish; trichomes $12-18 \mathrm{mic}$. in diameter; cells somewhat quadrate or longer than the diameter; heterocysts somewhat rare, somewhat quadrate.

West Indies. At first attached, finally floating free in stagnant water (Perrottet, Montagne).

393. Scytonema rivulare Borzi. Morfologia e Biologia delle Alghe Ficocromacee. Nuovo Giorn. Bot. Ital. I I : 373. 1879. Bornet and Flahault. Revis. des Nostoc. Ann. Sci. Nat. Bot. VII. 5: 91. 1887. De Toni. Syll. Algar. 5: 501. 1907.

Tilden. American Algae. Cent. V. no. 479. I90r; Collection of Algae from the Hawaiian Islands. Haw. Almanac and Annual for Ig02. III. I901. 
Plate XI. fig. II, I2.

Plant mass widely expanded, woolly, blackish, verging towards red; filaments about $30 \mathrm{mic}$. in diameter, sparingly branched, variously flexuous or curved; sheaths firm, close, homogeneous, "glassy," up to 5 mic. in thickness; cells quadrate or shorter than wide; heterocysts having the form and size of the vegetative cells, orange or yellowish; gonidia spherical, blackish or lead-colored; wall of gonidium firm, smooth; cell contents distinctly granular, lead-colored becoming purple.

Hawaii. Forming dark brownish or purplish red cushions on stones in mountain stream. Kaliawaa stream, Makao, Koolauloa, Oahu. June 1900. (Tilden).

394. Scytonema occidentale Setchell. Notes on Cyanophyceae.-III. Erythea. 7: 49. I899. De Toni. Syll. Algar. 5: 503. 1907.

Plate XI. fig. I3, I4.

Forming tufts of a somewhat rigid consistency and of a black color; filaments 36 mic. in diameter, decumbent at base, branched; false branches 21-27 mic. in diameter, usually in pairs, erect, flexuous, free or included for a longer or shorter distance within a common sheath; sheaths thick, gelatinous, roughened, made up of parallel layers; trichomes I8-30 mic. in diameter; cells $9-12$ mic. in length, those in the hormogones much shorter, 3 mic. in length; cell contents grayish violet.

California. Growing upon bare smooth rock bed of La Jota Creek, just above the Falls, on Howell Mt., near St. Helena, Napa County. (Setchell).

395. Scytonema crispum (Agardh) Bornet. Les Nostocacées hétérocystées du Systema Algarum de C. Agardh (1824) et leur Synonymie actuelle (1889). Bull. Soc. Bot. de France. 36: 156. 1889. Bornet and Flahault. Revis. des Nostoc. Ann. Sci. Nat. Bot. VII. 5: 89. 1887. (S. c in cinnatum Thur.) De Toni. Syll. Algar. 5: 498. I907.

Dickie. Fresh-water Algae. Brown's Florula Discoana. Contributions to the Phyto-Geography of Greenland within the Parallels of $68^{\circ}$ and $70^{\circ}$ North Latitude. Trans. Bot. Soc. Edinburgh. 9: 464. I868. (L. c in c in n a t a Kg.) Wolle. Fresh Water Algae. III. Bull. Torr. Bot. Club. 6: 183. I877. Nordstedt. De Algis Aquae Dulcis et de Characeis ex Insulis Sandvicensibus a Sv. Berggren 1875 reportatis. 6. 1878 . Wolle. Fresh Water Algae. V. Rull. Torr. Bot. Club. 8: 38. 188I; Fresh-Water Algae U. S. 254. pl. 185. f. 8-1o. I887. Johnson and Atwell. Fresh Water Algae. Northwestern University. Report Dept. Nat. Hist. 20. r89o. Setchell. Notes on some Cyanophyceae of New England. Bull. Torr. Bot. Club. 22: 428. I895. Collins, Holden and Setchell. Phyc. Bor.-Am. Fasc. 2. no. 60. I895; Fasc. I4. no. 655. 1900. Bessey, Pound and Clements. Additions to the Reported Flora of the State. Bot. Surv. Nebraska. 5: I4. Igor. Collins. The Algae of Jamaica. Proc. Am. Acad. Arts Sci. 37: 241. 1901. Tilden. American Algae. Cent. V. no. 480. I90r; Collection of Algae from the Hawaiian Islands. Hawaiian Almanac and Annual for I902. 112. rgor. Collins. Phycological Notes of the late Isaac Holden.-II. Rhodora. 7: 237. I905. Lemmer- 
mann. Algenfl. Sandwich-Inseln. Bot. Jahrb. 34: 624. 1905.

Tilden. American Algae. Cent. VII. Fasc. I. no. 632. 1909.

Plate XI. fig. I5.

Plant mass caespitose, entangled, woolly, green, becoming brown or olive; filaments 16-36 mic. in diameter, $3 \mathrm{~cm}$. and more in length, curled, hranched; sheaths firm, membranaceous, colorless, rarely becoming brownish; trichomes 14-30 mic. in diameter; cells three times shorter than their diameter; heterocysts depressed or quadrate, sometimes numerous, sometimes almost none.

Greenland. Abundant in "Lyngemarken Spring, September." (Dickie). Rhode Island. In abundance near Providence. (Osterhout). Connecticut. Near Lanesville; on rock below Factory Pond; ditch at North Haven. September, November. (Holden). Forming extensive dark green woolly masses in stagnant water. North Haven. October I89I. (Setchel1). Pennsylvania. In a pond near Bethlehem. (Wolle). Florida. (Coe). Illinois. Takeside, Cook County. May (Johnson and Atwell). Minnesota. Lily Lake, near Stillwater, Washington County. August I908. (Tilden). Nebraska. In ponds. Nebraska City. (Bessey). Colorado. (Brandegee). West Indies. In reservoir. Botanic Garden, Castleton, Jamaica; on sides of trough, Constant Spring; in basin, Kingston. April I893. (Humphrey). Hawaii. In ponds. Nuanu, Oahu. (Berggren). Floating in mats on surface of stagnant water among roots of Water Hyacinth, on beach. Meheiwa, Makao, Koolauloa, Oahu. June 1900. (Tilden).

"The filaments vary very much. Sometimes both branches and heterocysts are rare and the species looks very much like a $\mathrm{L}$ y $\mathrm{ng}$ b a, very cften the scanty branches occur single and adjacent to a heterocyst and it resembles greatly a Tolypoth $\mathrm{T} i \mathrm{x}$, while the geminate branches midway between two heterocysts, characteristic of Sc y t o n e $\mathrm{m}$ a are generally found only after long and careful search."-Setchell.

396. Scytonema caldarium Setchell. Notes on Cyanophyceae.-III. Erythea. 7: 48. pl. 3. f. 3. 1899. Collins, Holden and Setchell. Phyc. Bor.-Am. Fasc. 12. no. 559. 1899.

Plate XII. fig. I.

Plant mass forming more or less extended tufts; filaments 16 mic. in diameter, decumbent or even horizontal at base, more or less entangled, branched; false branches in pairs, erect, twisted together into Symplocalike tufts, 8-I5 mm. high; erect filaments $12-16 \mathrm{mic}$. in diameter, seldom or only singly branched; sheaths firm, lamellose, with parallel layers, colorless, soon becoming a deep yellowish brown; trichomes 4-8 mic. in diameter; cells 3-I2 mic. in length; heterocysts discoid to quadrate in the younger portions of the filaments, cylindrical in older portions, colorless; cell contents uniformly coarsely granular, olive or yellowish green.

California. Growing on cooler portions of the rocks from which the hot water drips. Temperature of the tufts $27^{\circ} \mathrm{C}$. Waterman Hot Springs, near San Bernadino. April 1897. (Parish). 
397. Scytonema azureum Tilden. American Algae. Cent. VII. Fasc. I. no. 630. 1909.

\author{
Plate XII. fig. 2, 3 .
}

Filaments 25 mic. in diameter, flexuous, sparingly branched; false branches usually in pairs, occasionally originating at the heterocysts as in Tolypothrix; sheaths narrow, straight, smooth; trichomes 17 mic. in diameter, often constricted at joints; cells quadrate or shorter than broad; heterocysts somewhat spherical or quadrate, yellowish green; cell contents more or less deep bluish purple (cyaneus, azureus) in color.

Hawaii. With other algae forming a layer covering rocks on bottom and sides of basin of "warm spring." Temperature at 7 a. m. $3 \mathrm{I}^{\circ} \mathrm{C}$. Puna, Hawaii. July 1900. (Tilden).

398. Scytonema hofmanni Agardh. Synopsis Algar. Sueciae. 117. 1817. Bornet and Flahault. Revis. des Nostoc. Ann. Sci. Nat. Bot. VII. 5: 97. 1887. De Toni. Syll. Algar. 5: 513. 1907.

Wood. Prodromus of a Study of the Fresh-Water Algae of Eastern North America. I30. 1869. Mazé and Schramm. Essai Class. Algues Guadeloupe. 32. I870-1877. (S. julianum Menegh., S. cinereum Crouan). Wood. Contr. Hist. Fresh-Water Algae North America. (S. cortex Wood). 64. I872. Farlow. Notes on the Cryptogamic Flora of the White Mountains. Appalachia. 3: 236. I883. (S y m phy os iphon li of ma n i Kg.). Wolle. Fresh-Water Algae U. S. 262. pl. I89. f. 3. 1887. Moebius. Ueber einige in. Portorico gesammelte Süsswasser- und I uft-Algen. Hedwigia. 27: 245. I888. Wolle and Martindale. Algae. Britton's Catalogue of Plants found in New Jersey. Geol. Surv. N. J. 2: 605. I889. Bessey. Additions to the Reported Flora of Nebraska, made duiing 1893. Bot. Surv. Nebraska. 5. 1894. Saunders. Protophyta-Phycophyta. Flora of Nebraska. 24. I894. Collins, Holden and Setchell. Phyc. Bor.Am. Fasc. 9. no. 404. I898. West and West. A Further Contribution to the Fresh-water Algae of the West Indies. Journ. Linn. Soc. Bot. 34: 287. I898-I900. Collins. The Algae of Jamaica. Proc. Am. Acad. Arts Sci. 37: 24I. 190I. Collins, Holden and Setchell. Phyc. Bor.-Am. Fasc. I7. no. 803. 190I. Setchell and Gardner. Algae of Northwestern America. Univ. Calif. Pub. Bot. I: I95. I903. Collins. Phycological Notes of the late Isaac Holden.-II. Rhodora. 7: 237. I905. Collins, Holden and Setchell. Phyc. Bor.-Am. Fasc. 26. no. 1258. 1905.

\title{
Plate XII. fig. 4.
}

Plant mass cushion-shaped, widely expanded, I-3 mm. in thickness, blackish or blue-green, sometimes impregnated with calcium carbonate, then purple or green or bluish gray; filaments 7-I5 mic. in diameter, coalesced in vertical fascicles; false branches aggregated; sheaths firm, membranaceous; trichomes 5 -10 mic. in diameter, olive or blue-green; cells unequal in length; heterocysts oblong.

Alaska. On dripping rocks. Iliuliuk, Unalaska. (Setchell and Lawson). New Hampshire. On rocks near the brook. Tuckerman's Ravine, near Shel- 
burne. (Farlow). Massachusetts. Newton. (Farlow). On shaded rocks. High Ledge, Melrose. April I892. (Collins). Connecticut. On old stumps. Shore of upper Twin Lake, Salisbury. October. (Holden). New Jersey. On moist earth, wood and rocks. (Wolle). Nebraska. On damp wood, in greenhouses. State University, Lincoln. (Bessey, Saunders). California. On rocks. North side of Bolinas Ridge, Marin County. June I8g6. (Setche11). West Indies. Forming violet-colored masses among mosses on limestone rocks in mountains near Utuado, Porto Rico. (Moebius). On steps of Court House, Port Antonio. April I893; on leaves of trees, Bath, Jamaica. (Humphrey). Head of Castle Bruce River, Dominica. January and February 1896. (E1liott).

Forma brunnea Wolle. Fresh-Water Algae U. S. 258. I887; Fresh Water Algae. Bull. Torr. Bot. Club. 6:284. 1879. (S. c or tex br u n e m Wolle). De Toni. 1. c. 515 .

Plant mass dark brown; filaments covered with apparently "sub-spherical, resinous cells."

South Carolina. (Ravenel). Florida. (Ravenel, Smith, Austin).

Var. symplocoides (Reinsch) Bornet and Flahault. 1. c. 99. De Toni. 1. c. 515 .

Mazé and Schramm. Essai Class. Algues Guadeloupe. 36. 1870-1877. (Calothrix conferta Crouan).

Sheaths colorless; cell contents pale blue-green.

West Indies. (Mazé).

Var. calcicolum Hansgirg. Physiologische und Algologische Mittheilungen. pl. 3. f. 35. I890; Prodromus der Algenflora von Böhmen. 2: 33- I892. De Toni. 1. ᄂ. 516 .

Plant mass smooth, brown or black, rarely almost soft, gelatinous, often expanded; filaments 6-I2 mic. in diameter, more or less branched, curved, often associated in dense floccose masses; false branches somewhat more slender, single or in pairs, approximate, usually issuing between two heterocysts, erect; sheaths close, somewhat thickened with age, yellow or yellowish orange, rarely almost colorless; trichomes 4-6 mic. in diameter; cells almost inconspicuous, somewhat quadrate or twice as short as wide, heterocysts somewhat quadrate, single or in pairs, a little shorter or longer than their diameter; cell contents granular, dull blue-green, green, olive or yellowish.

South Carolina. (Ravenel). Florida. (Smith, Austin, Ravenel).

399. Scytonema varium Kuetzing. Spec. Algar. 307. I849. Bornet and Flahault. Revis. des Nostoc. Ann. Sci. Nat. Bot. VII. 5: 97. I887. De Toni. Syll. Algar. 5: 512. 1907.

Mazé and Schramm. Essai Class. Algues Guadeloupe. 34. I870-I877. Wolle. Fresh Water Algae. II. Bull. Torr. Bot. Club. 6: I39. I877. (S. chrysochlor u m Kg.); Fresh-Water Algae U. S. 253. I887. Saunders. The Algae. Harriman Alaska Expedition. Proc. Wash. Acad. Sci. 3: 398. I901. Setchell and Gardner. Algae of Northwestern America. Univ. 
Calif. Pub. Bot. I: 195. 1903. Lemmermann. Algenf. Sandwich.-Inseln. Bot. Jahrb. 34: 625. I905.

\section{Plate XII. fig. 5.}

Plant mass 2-3 mm. in height, cushion-shaped, bluish-green or brownish; filaments 9-I5 mic. in diameter, tortuous, entangled; sheaths gelatinous, below colorless, pellucid, in upper portions yellowish; trichomes 5-7 mic. in diameter; cells somewhat quadrate, scarcely distinct; heterocysts somewhat quadrate or longer than the diameter, colorless; cell contents densely granular, blue-green or yellowish.

Alaska. On rocks moistened by spray from a waterfall. Near Juneau. (Saunders). Canada. Shaded rocks. Niagara. (Wolle). Florida. Anastatia Island, St. Augustine. (Wolle). Hawaii. (Schauinsland).

400. Scytonema javanicum (Kuetzing) Bornet in Bornet and Flahault. Notes Algologiques. 148, 1880. Bornet and Flahault. Revis. des Nostoc. Ann. Sci. Nat. Bot. VII. 5: 1887. De Toni. Syll. Algar. 5: 506. 1907.

West and West. On some Freshwater Algae from the West Indies. Journ. Linn. Soc. Bot. 30: 269. pl. I4. f. I2-I5. I895. Setchell. Notes on some Cyanophyceae of New England. Bull. Torr. Bot. Club. 22: 428. I895. Collins. The Algae of Jamaica. Proc. Am. Acad. Arts Sci. 37: 241. I90I.

Plate XII. fig. 6.

Plant mass cushion-shaped, $2-4 \mathrm{~mm}$. in thickness, deep blue-green or reddish; filaments I2-I5 mic. in diameter, coalesced in vertical fascicles; false branches long, flexuous, aggregated; sheaths firm, thin, colorless, becoming yellowish; trichomes 9-12 mic. in diameter; cells compressed or quadrate; heterocysts somewhat quadrate; cell contents green becoming krown or violet.

Massachusetts. Growing on trunks of trees in Middlesex Fells, Melrose. (Setchell). West Indies. On lime trees. Shanford Estate; Anguilla; on walls, Roseau, Dominica, November, December I892. (Elliott). On flower pot in garden. Castleton, Jamaica. April 1893. (Humphrey).

Var. hawaiiense Lemmermann. Algenfl. Sandwich-Inseln. Bot. Jahrb. 34: 624. pl. 7. f. 6-8. 1905. De Toni. 1. c. 507.

\section{Plate XII. fig. 7 .}

Plant mass cushion-shaped, dark blue-green; filaments 9.5-II mic. in diameter, coalesced into vertical fascicles; sheaths firm, thin, always colorless; trichomes 5.5-8 mic. in diameter; cells 5.5-14 mic. in length, cylindrical, sometimes quadrate (younger cells compressed); heterocysts 7-9.5 mic. in diameter, 9.5-I4 mic. in length, usually cylindrical, rarely somewhat quadrate, sometimes yellowish; cell contents homogeneous, pale blue-green, the cells in younger branches being filled with reddish bodies (gas vacuoles).

Hawaii. Among mosses. Crater of Kilauea, Hawaii. (Schauinsland).

40r. Scytonema ocellatum Lyngbye. Hydrophytologia Danica. 97. pl. 28 A. 
1819. Bornet and Flahault. Revis. des Nostoc. Ann. Sci. Nat. Bot. VII. 5: 95. I887. De Toni. Syll. Algar. 5: 509. I907.

Mazé and Schramm. Essai Class. Algues Guadeloupe. 33. I870-1877. (S. torridum Agardh, S. pariet in um Crouan). Wolle. FreshWater Algae U. S. 258. pl. I88. f. I-4, IO-I4. I887. (S. c in er e u m Menegh.). Wolle and Martindale. Algae. Britton's Catalogue of Plants found in New Jersey. Geol. Surv. N. J. 2: 605. 1889. Saunders. ProtophytaPhycophyta. Flora of Nebraska. 24. pl. 2. f. 24. I894. Bessey. Additions to the Reported Flora of Nebraska made during I893. Bot. Surv. Nebraska. 3: 5. I894. Setchell. Notes on Cyanophyceae.-I. Erythea. 4: 88. I896. Wittrock, Nordstedt, and Lagerheim. Algae Aq. Dulc. Exsicc. no. I322. I896. Collins, Holden and Setchell. Phyc. Bor.-Am. Fasc. 5. no. 210. 1896; Fasc. I5. no. 7II. I900. Bessey, Pound and Clements. Additions to the Reported Flora of the State. Bot. Surv. Nebraska. 5: I4. I90I. Collins. The Algae of Jamaica. Proc. Am. Acad. Arts Sci. 37: 24I. I90I; Algae of the Flume. Rhodora. 6: 230. 1904; Phycological Notes on the late Isaac Holden.-II. Rhodora. 7. 237. I905. Lemmermann. Algenfl. Sandwich.Inseln. Bot. Jahrb. 34: 625. I905.

\section{Plate XII. fig. 8.}

Plant mass cushion-shaped, black or gray becoming bluish; filaments IO-I 8 mic. in diameter, up to $3 \mathrm{~mm}$. in length, entangled, branched; false branches short; sheaths firm, becoming brownish; trichomes 6-I4 mic. in diameter, cells shorter than the diameter or quadrate, heterocysts somewhat quadrate, yellowish; cell contents olive green.

New Hampshire. One of the three species composing the brown coating on the wall of the "Flume." September I904. (Collins). Massachusetts. Forming a dark brown felt upon rocks just above the surface of the water. Massapoag Brook, at Sharon. April 1891. (Setchell). Connecticut. On dripping rocks. Sage's Ravine, Salisbury. August. (Holden). New York. (Wolle). New Jersey. On moist rocks. Bergen, Godwinville. (Austin). Pennsylvania. On moist rocks and shaded walls. (Wolle). Florida. (Wolle). Nebraska. On flower pots in greenhouse. University, Lincoln. (Bessey, Saunders). Bermudas. On sand dunes. Paget. January I9o0. (Farlow). West Indies. On bark of trees. Near Constant Spring, Kingston, Jamaica. December I892. (Lagerneim). On old palm stems. Castleton, Jamaica. April r893. (Humphrey). Hawaii. (Berggren, Schauinsland).

402. Scytonema intertextum (Kuetzing) Rabenhorst. Fl. Eur. Algar. 2: 263. 1865. De Toni. Syll. Algar. 5: 511. I907.

Wolle. Fresh Water Algae. Bull. Torr. Bot. Club. 6: 284. 1879; FreshWater Algae U. S. 258. pl. 186. f. I0-17. I887.

\section{Plate XII. fig. 9 .}

Plant mass more or less thick, cushion-shaped, compact, dark brown or olive; filaments up to 20 mic. in diameter, ascending; false branches fasciculate, flexuously curved, densely entangled; sheaths somewhat thick, sometimes a little swollen, distinctly lamellose, yellowish or flesh-colored, 
rarely brownish, the external layers sometimes diffluent into colorless fibrils; trichomes I2-I6 mic. in diameter, here and there irregularly constricted at joints; cells equal to or a little longer than their diameter; heterocysts oblong or somewhat spherical, very pale brown in color, solitary or in pairs at the base of the false branches; cell contents granular.

Florida. On old wood. (Smith).

403. Scytonema austinii Wood. Contr. Hist. Fresh-Water Algae North America. 58. I874. De Toni. Syll. Algar. 5: 5II. 1907.

Wolle. Fresh-Water Algae U. S. 26r. pl. I89. f. 5. I887. (S y m p h y osiphon austinii Wood). Wolle and Martindale. Algae. Britton's Catalogue of Plants found in New Jersey. Geol. Surv. N. J. 2: 605. I889.

Plant mass cushion-shaped and somewhat turfy, brown or black; filaments i 5-20 mic. in diameter, ascending, mostly unbranched, curved; sheaths reddish or yellowish brown at the apex, colorless and transparent, firm, indistinctly lamellose, with rough surface; trichomes 4-Io mic. in diameter, blue-green or dark-colored, often very much thickened at the ends; cells shorter or longer than their diameter; heterocysts short, cylindrical, somewhat quadrate or spherical, sometimes strongly compressed and much shorter than broad.

New Jersey. Forming a sort of miniature turfy cushion upon the rocks. Little Falls. (Austin). Pennsylvania. On rocks. (Wolle)

404. Scytonema millei Bornet in Bornet and Thuret. Notes Algologiques. 147. I880. Bornet and Flahault. Ann. Sci. Nat. Bot. VII. 5: 93. 1887. De Toni. Syll. Algar. 5: 505. I907.

Hohenacker. Algae Marinae Siccatae. no. 458. I862. (S. 1 e p rie u ri i Kg.). Collins, Holden and Setchell. Phyc. Bor.-Am. Fasc. 29. no. I405. 1907.

Plant mass cushion-shaped, woolly, widely expanded, $\mathrm{r}-5 \mathrm{~mm}$. thick, ciark green, becoming brown; filaments $15-21$ mic. in diameter, flexuous, entangled, branched; false branches erect, spreading; sheaths firm, brownish; trichomes IO-I5 mic. in diameter; cells compressed; heterocysts compressed, brown, shorter than the diameter of the trichome.

West Indies. On earth. St. Thomas. (Hohenacker). On earth and rocks. Mavis Bank Road, Jamaica. June Igo6. (Lewis).

405. Scytonema guyanense (Montagne) Bornet and Flahault. Revis. des Nostoc. Ann. Sci. Nat. Bot. VII. 5: I887. De Toni. Syll. Algar. 5: 506. 1907.

Montagne. Histoire de l'Ile de Cuba. Io. pl. 2. f. 2. 1838. (S. by ssoidfum corticale Mont.). Wood. Prodromus of a Study of the Fresh-Water Algae of Eastern North America. Proc. Am. Phil. Soc. II: 130. I869. Mazé and Schramm. Essai Class. Algues Guadeloupe. 33: I87077. (Calothrix indica Crouan). Wood. Contr. Hist. Fresh-Water Algae North America. 64. pl. 5. f. 4. 1872. (S. raveneli i Wood). Wood. Fresh Water Algae. II. Bull. Torr. Bot. Club. 6: I39. I877. (S y m p h y osiphon wollei Born.). Nordstedt. De Algis Aquae Dulcis et de Characeis ex insulis Sandvicensibus a Sv. Berggren 1875 reportatis. (S. 
pu 1 vinatum Nordst.). Wolle. Fresh Water Algae. Bull. Torr. Bot. Club. 6: 283. I879. (M a stigon e ma velut in u m Wolle); Fresh-Water Algae U. S. 257. pl. 186. f. I-6. I887. (S. c ortex raveneli i Wolle). Collins. Algae of Middlesex County. I3. I888. Lemmermann. Algenf. Sandwich.-Inseln. Bot. Jahrb. 34: 624. I905.

Plant mass dense, cushion-shaped, I-2 mm. in thickness, widely expanded, blackish green; filaments $15-21$ mic. in diameter, coalesced in vertical fascicles; false branches long, flexuous, aggregated; sheaths firm, membranaceous, lamellose, yellowish brown; trichomes I0-I6 mic. in diameter; cells somewhat quadrate or elongate; cell contents olive green.

Massachusetts. In a greenhouse. Newton. (Farlow). New Jersey. Forming an extended olive green stratum, a little above the water level, on the plank sides of a neglected basin of sea water. Perth Amboy. July I878. (Wolle). Pennsylvania. On calcareous rocks. (Wolle). South Carolina. Forming little turfy spots of a greenish color on bark. Growing on twigs of a $\mathrm{Ce} 1 \mathrm{t}$ is and on bark of a willow. (Ravenel). Florida. On trunks of various trees. (Smith). Hawaii. On volcanic gravel, Oahu. (Berggren, Schauinsland).

406. Scytonema amplum West and West. On some Freshwater Algae from the West Indies. Journ. Linn. Soc. Bot. 30: 270. p1. I6. f. I4-I6. I895; A Further Contribution to the Freshwater Algae of the West Indies. 1. c. 34: 287. 1900. De Toni. Syll. Algar. 5: 512. 1907.

\section{Plate XII. fig. Io, II.}

Plant mass small, woolly, 3-5 $\mathrm{mm}$. in diameter, brownish; filaments 19-24 mic. in diameter, densely. entangled; false branches 13.5 -I6 mic. in diameter, rare, usually in pairs but sometimes single, more slender than the main filament; sheaths very wide, formed of parallel layers, in outer portions gelatinous, colorless or somewhat yellowish, in the interior abruptly yellowish or brownish; trichomes $3.5-4$ mic. in diameter, narrow; cells up to six times longer than the diameter; heterocysts oblong, several times longer than their diameter; cell contents yellowish green.

West Indies. On trees. Summit of Trois Pitons (4,500 feet). November, December. I892; on rocks, Castle Bruce River (2,000-3,000 feet), Dominica. January, February i896. (Elliott).

407. Scytonema wolleanum De Toni. Syll. Algar. 5: 513. 1907. Wolle. Fresh Water Algae. Bull. Torr. Bot. Club. 6: 284. 1879; FreshWater Algae U. S. 255. pl. 187. f. I-3. 1887. (S. m i r a bil e Wolle). Plate XII. fig: 12.

Plant mass more or less widely expanded, olive becoming brownish; filaments 20-25 mic. in diameter, strongly curved and flexuous; false branches I2.5-I5 mic. in diameter, numerous, usually in pairs, adhering usually without separation of the trichome at the end; sheaths firm, smooth, olive or yellowish, rarely nearly colorless; trichomes often somewhat moniliform; cells two to three times shorter than their diameter.

Florida. On bark of Cypress trees. (Ravenel).

408. Scytonema stuposum (Kuetzing) Bornet in Bornet and Thuret. Notes 
Algologiques. I46. 1880. Bornet and Flahault. Revis. des Nostoc. Ann. Sci. Nat. Bot. VII. 5: 92. I887. De Toni. Syll. Algar. 5: 503. 1907 .

Mazé and Schramm. Essai Class. Algues Guadeloupe. 34. 1870-1877. (S. c y an escens Crouan).

Plate XII. fig. I3, I4.

Plant mass cushion-shaped, woolly, widely expanded, blackish violet or becoming reddish; filaments $16-30 \mathrm{mic}$. in diameter, 5-10 $\mathrm{mm}$. long, free, branched; false branches approximate, solitary or in pairs; sheaths thick, gelatinous; trichomes I2-I8 mic. in diameter; cells somewhat quadrate or two or three times shorter than their diameter; heterocysts equalling the cells in diameter; cell contents olive or violet.

West Indies. (Mazé).

409. Scytonema tolypotrichoides Kuetzing. Spec. Algar. 307. I849. Bornet and Flahault. Revis. des Nostoc. Ann. Sci. Nat. Bot. VII. 5: Ioo. 1887. De Toni. Syll. Algar. 5: 516. I907.

Wood. Contr. Hist. Fresh-Water Algae North America. 6r. pl. 6. f. 2. 1872. (S. c a lotrichoides Wood). Wolle. Fresh Water Algae. II. Bull. Torr. Bot. Club. 6: I39. 1877; Fresh-Water Algae U. S. 250. pl. 182. f. 4-Ir. I887. Wolle and Martindale. Algae. Britton's Catalogue of Flants found in New Jersey. Geol. Surv. N. J. 2: 604. I889. Setchell. Notes on Cyanophyceae.-II. Erythea. 4: 192. I896.

\section{Plate XIII. fig. I.}

Plant mass caespitose, floating, spherical, one $\mathrm{cm}$. in diameter, brown or green in color, filaments 10-15 mic. in diameter, 5-6 $\mathrm{mm}$. long, radiating from the center, repeatedly branched; sheaths colorless, becoming orange brown, lamellose; the outer layers often colorless; trichomes 8-I2 mic. in diameter; cells somewhat quadrate or oblong, scarcely distinct; heterocysts varied, some short, some long, rose-colored; cell contents densely granular, olive or yellowish.

New York. In gelatinous masses on dripping rocks. Niagara Falls; on wet or moist carth on the banks of rivers. (Wolle). New Jersey. Frequent on wet rocks. (Wolle). South Carolina. In wet, boggy places, on rotten pine boards. September I869. (Ravenel).

4 IO. Scytonema flavo-viride (Kuetzing) Bornet and Flahault. Revis. des Nostoc. Ann. Sci. Nat. Bot. VII. 5: Iоr. 1887. De Toni. Syll. Algar. 5: 517.1907.

Plant mass caespitose, entangled, floating, yellowish green; filaments 12-18 mic. in diameter, $2 \mathrm{~cm}$, and more in length, rigid, very sparingly branched; sheaths colorless, thick, lamellose; trichomes 6-ro mic. in diameter, cylindrical, equal, constricted at joints; cells twice as long as wide, sometimes up to I5 mic. in diameter and shorter than the diameter; heterocysts quadrate or oblong, colorless; hormogones very long; cell contents blue-green.

Mexico. In swamps. Near Vera Cruz. (Miller).

4II. Scytonema mirabile (Dillwyn) Bornet. Les Nostocacées hétérocystées du Systema Algarum de C. Agardh (1824) et leur Synonymie ac- 
tuelle (1889). Bull. Soc. Bot. de France. I2. I889. Bornet and Flahault. Revis. des Nostoc. Ann. Sci. Nat. Bot. VII. 5: IOI. 1887. (S. figurat u m Ag.) De Toni. Syll. Algar. 5: 517. 1907.

Wood. Contr. Hist. Fresh-Water Algae North America. 60, 61. pl. 5. i. I, 2. 1872. (S. therinale Kg., S. calotrichoides Kg.). Nordstedt. Die Algis Aquae Dulcis et de Characeis ex Insulis Sandvicensibus a Sv. Berggren 1875 reportatis. 6. I878. Wolle. Fresh-Water Algae U. S. 251. pl. I83. f. 5-7. I887; 259. 1887. Wolle and Martindale. Algae. Britton's Catalogue of Plants found in New Jersey. Geol. Surv. N. J. 2: 604. 1889. West and West. On some Fresh-water Algae from the West Indies. Journ. Linn. Soc. Bot. 30: 271. 1895. Setchell. Notes on CyanoFhyceae.-I. Erythea. 4: 89. 1896; Notes on Cyanophyceae.-II. Erythea. 4: 193. I896. Tilden. American Algae. Cent. III. no. 290. I898. (S. m y ochrous (Dillw.) Ag.). West and West. A Further Contribution to the Freshwater Algae of the West Indies. Journ. Linn. Soc. Bot. 34: 287. I898-1900. Setchell. Notes on Cyanophyceae.-III. Erythea. 7: 48. r899. Tilden. American Algae. Cent. IV. no. 396. 1900. Collins, Holden and Setchell. Phyc. Bor.-Am. Fasc. 18. no. 857. Igor. Saunders. The Algae. Harriman Alaska Expedition. Proc. Wash. Acad. Sci. 3: 398. 190r. Tilden. Algae Collecting in the Hawaiian Islands. Postelsia: The Year Book of the Minnesota Seaside Station. I: 166. 1902. Setchell and Gardner. Algae of Northwestern America. Univ. Calif. Pub. Bot. I: 195. I903. Collins. Phycological Notes of the late Isaac Holden.--II. Rhodora. 7: 237. I905. Lemmermann. Algenfl. Sandwich.-Inseln. Bot. Jahrb. 34: 625. I905. Tilden. American Algae. Cent. VII. Fasc. I. no. 631. I909.

\section{Plate XIII. fig. 2-5.}

Plant mass woolly, widely expanded, spongy-tomentose, brownish black or blackish green; filaments I5-2I mic. in diameter, turtuous, entangled, 2-4 mm. or I cm. in thickness; sheaths lamellose, yellowish brown; layers of the sheath scarcely diverging; trichomes 6-I2 mic. in diameter; hasal cells long, cylindrical, the upper ones disc-shaped; heterocysts somewhat quadrate or longer than the diameter, brownish; cell contents yellowish green.

Alaska. On moist ground near Glacier Bay; in a freshwater stream emptying into Glacier Bay; on the perpendicular surface of a rock moistened by dripping water, Kukak Bay, July I899. (Saunders). Connecticut. Coating moist limestone rocks. On shore of Housatonic River, near Gaylordsville. June, October Igor. (Holden). New York. Forming a dark brown ccating on wet rocks. Niagara. (Wolle). New Jersey. Frequent on submerged sticks in ponds. (Wolle). South Carolina. Damp surface of liard clay; in wet boggy places on rotten pine boards, September I869. (Ravenel). Sandy soil near Aiken. (Wolle). Minnesota. On sides of rocks in stone quarry. Minneapolis. May I899. (Crosby). Iowa. On cliffs. Fayette. I897. (Fink). Colorado. In pannose layers upon the "Pillars of Hercules," South Cheyenne Cañon, near Manitou. (Setchell). Mexico. (Müller). West Indies. On damp wall of dam. Sharp's River, St. Vincent. May I892; on trees, summit of Trois Pitons (4,500 feet), November and December 1892 ; on rocks, Hamstead Valley (850 feet), Do- 
minica, January and February 1896 . (Elliott). Hawaii. In stagnant water. Mauna Kea, Hawaii. (Berggren, Schauinsland).

Var. leprieurii (Montagne) Bornet and Flahault. 1. c. 103. De Toni. 1. c. 520 .

Schramm and Mazé. Essai Class. Algues Guadeloupe. 32. r865. Mazé and Schramm. Essai Class. Algues Guadeloupe. 34. 1870-1877. Collins, Holden and Setchell. Phyc. Bor.-Am. Fasc. 21. no. Ior4. 1903.

Outer layers of sheath gelatinous, colorless.

Canada. Warm sulphur springs, Banff, Alberta. June Igor. (Butler and Polley). West Indies. (Mazé and Schramm).

4I2. Scytonema myochrous (Dillwyn) Agardh. Dispositio Algar. sueciae. 38. I8I2. Bornet and Flahault. Revis. des Nostoc. Ann. Sci. Nat. Bot. VII. 5: I04. I887. De Toni. Syll. Algar. 5: 521. 1907.

Dickie. In Hooker. An Account of the Plants collected by Dr. Walker in Greenland and Arctic America during the Expedition of Sir Francis M'Clintock, R. N., in the Yacht "Fox." Journ. Linn. Soc. Bot. 5: 86. I86I; Notes on a Collection of Algae procured in Cumberland Sound by Mr. James Taylor, and Remarks on Arctic Species in General. 1. c. 9: 242. I867. Wood. Prodromus of a Study of the Fresh-Water Algae of Eastern North America. Proc. Am. Phil. Soc. Ix: I29. I869. (S. c a ta ta cta e Wood); Contr. Fresh-Water Algae North America. 62. pl. 7. f. I. I872. Rabenhorst. Die Algen Europas. no. 2492. 1877. Wolle. Fresh-Water Algae. 6: I84. I877. (S. b r a n d e ge i Wolle); Fresh-Water Algae U. S. 252, 253. p1. I82. f. I-3; pl.I83. f. I-4; p1. I85. f. I-7. I887. (S. gra cile Kg., S. t t rfos u m Kg.). Bennett. Plants of Rhode Island. Ir4. I888. Wolle and Martindale. Algae. Britton's Catalogue of Plants found in New Jersey. Geol. Surv. N. J.-2: 605. 1889. Collins, Holden and Setchell. Phyc. Bor.Am. Fasc. 3. no. I09. I895. Setchell. Notes on Cyanophyceae-II. Erythea. 4: 192, I93. 1896. Collins. Some Perforating and other Algae on Fresh-Water Shells. Erythea. 5: 96. I897. Saunders. Algae. Harriman Alaska Expedition. Proc. Wash. Acad. Sci. 3: 398. I901. Setchell and Gardner. Algae of Northwestern America. Univ. Calif. Pub. Bot. I: I95. 1903. Collins. Phycological Notes of the late Isaac Holden.-II. Rhodora. 7: 237. 1905. Buchanan. Notes on the Algae of Iowa. Proc. Iowa Acad. Sci. I4: I0. Ig08.

\section{Plate XIII. fig. 6.}

Plant mass woolly, widely expanded, spongy-tomentose, brownish black or blackish green; filaments $18-36$ mic. in diameter, 2-I5 $\mathrm{mm}$. long, tortuous, entangled; sheaths lamellose, yellowish brown; layers of the sheath diverging; trichomes 6-12 mic. in diameter; basal cells long, cylindrical, the upper ones disc-shaped; heterocysts somewhat quadrate or longer than their diameter, brown; gonidia spherical, yellowish brown; cell contents yellowish green.

Alaska. Forming small tufts on rocks in a brook emptying into Glacier Bay. (Saunders). Greenland. (Börgesen). Canada. Fresh water. Port Kennedy. (Walker). Cumberland Sound. (Taylor). Forming broad turf- 
like coating on the rocks below the great cataract. Niagara Falls. (Wood). Dark brown coating on wet rocks. Niagara. (Wolle). Rhode Island. New Providence. (Bennett). Connecticut. Forming dark brownish patches on submerged limestone rocks. Twin Lakes, Salisbury. August, October I892. (Holden). Growing on outside of $\mathrm{U} n$ i o shells. Twin Lakes, Salisbury, Litchfield County. August 1895. (Setchell and Holden). New Jersey. On rocky shores of Morris Pond. (Wolle). On moist ground. Closter, Bergen. (Austin). Pennsylvania. Moist ground in extended patches and on dripping rocks. (Wolle). North Carolina. Moist ground. (Ravenel). Iowa. Fayette. I905. (Fink). Colorado. Wet rocks. (Brandegee). Bermudas. (Farlow).

413. Scytonema badium Wolle. Fresh Water Algae. III. Bull. Torr. Bot. Club. 6: 184. 1877. De Toni. Șyll. Algar. 5: 524. 1907.

Plant mass thin, brown (b a dius); filaments 40-75 mic. in diameter, somewhat erect, appressed, short; false branches flaccid, divaricate, single or in pairs; sheaths wide, yellowish olive; trichomes 2-2.5 mic. in diameter, sometimes continuous, sometimes showing distinct transverse walls; cells about as long as wide; heterocysts scattered or situated at the base, somewhat spherical or oblong; cell contents pale blue-green.

New York. On old wood. Herkimer County. (Austin).

4I4. Scytonema fuliginosum Tilden. American Algae. Cent. VII. Fasc. I. no. 629. Ig09.

$$
\text { Plate XIII. fig. } 7,8 .
$$

- Plant mass thin, bluish green; filaments 28-50 mic. in diameter; sheaths folded into many layers or laminations; layers much dilated, dark brown in thicker parts; trichomes 10-20 mic. in diameter; cells $1.4-5$ mic. in length; heterocysts I2-I6 mic. in diameter, spherical, oval or somewhat quadratc; cell contents gray green.

Hawaii. Forming a thin layer on bottom of small shallow tide pool just below high tide. Pahala Plantation beach, south shore of Hawaii. July 1900. (Tilden).

4I5. Scytonema alatum (Carmichael) Borzi. Morfologia e Biologia delle Alghe Ficocromacee. Nuovo Giorn. Bot. Ital. II: 373. I879. Bornet and Flahault. Revis. des Nostoc. Ann. Sci. Nat. Bot. VII. 5: i Io. I887. De Toni. Syll. Algar. 5: 528. 1907.

Harvey. Nereis Boreali-Americana. Part III. 99. pl. 48. A. f. I-4. 1858. (Petalonema a I t u m Berk.). Wood. Contr. Hist. Fresh-Water Algae North America. 66. 1872 . Wolle. Fresh-Water Algae U. S. 267. pl. 188. f. 15, 16. I887. Setchell. Notes on Cyanophyceae.-II. Erythea. 4: 193. 1896. Hone. Petalonema alatum in Minnesota. Minn. Bot. Studies. 3: 47. p1. 13. 1903 .

Plate XIII. fig. 9.

Plant mass caespitose, mucous, black or brown; $24-66$ mic. in diameter, 4-8 mm. in length, flexuous, erect or appressed; false branches short, spreading, irregular in outline; sheaths forming lamellose wings or mem- 
branaceous expansions, the outer layers white, somewhat transparent, the internal layers bright yellow, contracted at the heterocysts, very smooth on the surface; trichomes 9-I5 mic. in diameter; cells shorter than the diameter; heterocysts spherical, brownish; cell contents blue-green or green.

New York. On dripping rocks under Biddle Stairs, Niagara Falls. 1849. (Harvey). "The only locality hitherto discovered for this plant is on the high cliff, near the Cave of the Winds, Niagara Falls. 'Twas found there twenty-five years since and it may be gathered there to-day." (Wolle). Minnesota. On gravel bed of a quiet stream, the outlet of an old tank near the Government Dam works. Near Minneapolis. October I9or, Hone.

416. Scytonema junipericolum Farlow in Collins, Holden and Setchell. Phyc. Bor.-Am. Fasc. I6. no. 756. 1900. De Toni. Syll. Algar. 5: 525. 1907 .

Plant mass forming indefinite, pulvinate, tomentose, black expansions .2-.3 mm. high; basal filaments . I4-I6 mic. in diameter, nearly prostrate; upper filaments I2-I4 mic. in diameter; false branches in pairs, numerous, erect, soon dividing into Tolypothrix-like, tortuous, corymbose branchlets; sheaths about 2 mic. in thickness, lamellose, with diverging layers, with obtuse apex; cells at the base disc-shaped, the upper ones becoming cuboidal and often torulose; heterocysts II-I2 mic. in diameter, 6-7 mic. in length.

Bermudas. Common, forming dark velvety patches on the bark of juniperus bermudian a. "Fairyland." January rgoo. (Farlow).

417. Scytonema crustaceum Agardh. Syst. Algar. 39. I824. Bornet and Flahault. Revis. des Nostoc. Ann. Sci. Nat. Bot. VII. 5: I06. I887. De Toni. Syll. Algar. 5: 525. 1907.

Wolle. Fresh-Water Algae U. S. 263. 1887. (S y m phyos ip hon crust a ce s Kg.) Collins, Holden and Setchell. Phyc. Bor.-Am. Fasc. 28. no. I358. 1907 .

\section{Plate XIII. fig. Io-I2.}

Plant mass cushion-shaped, black, .5-2 $\mathrm{mm}$. in thickness; filaments I5-30 mic. in diameter, thick, short, erect, aggregated, often slightly thickened and decumbent, with numerous branches; false branches ascending, short, in pairs, coalesced at the base, finally becoming free; sheaths gelatinous, yellowish brown, lamellose, the layers diverging; trichomes 6-8 mic. in diameter; cells somewhat quadrate or depressed; heterocysts oblong, blue-green.

Connecticut. On limestone rock. Salisbury. November Ig06. (Phelps). Pennsylvania. Not infrequent, on wet cliffs. (Wolle).

Var. incrustans (Kuetzing) Bornet and Flahault. 1. c. I07. De Toni. 1. c. 526 .

Wolle. Fresh Water Algae. II. Bull. Torr. Bot. Club. 6: I39. 1877; (Symphyosiphon incrustans Kg.). A Nostoc the Matrix of Scytonema. Bull. Torr. Bot. Club. 217. 1878. Setchell. Notes on Cyanophyceae.-II. Erythea. 4: I9I. I8g6. 
False branches in pairs, included within a common sheath as far as the apex; gonidia spherical or oval; wall of gonidium deep brown.

New York. Common on rocks exposed to spray. Niagara Falls. (Wolle).

4I8. Scytonema densum (A. Braun) Bornet in Bornet and Thuret. Notes Algologiques. I52. 1880. Bornet and Flahault. Revis. des Nostoc. Ann. Sci. Nat. Bot. VII. 5: 109. 1887. De Toni. Syll. Algar. 5: 527. 1907.

West and West. On some Freshwater Algae from the West Indies. Journ. Linn. Soc. Bot. 30: 271. I895. Setchell. Notes on Cyanophyceae.II. Erythea. 4: 19I. 1896; Notes on Cyanophyceae.-III. Erythea. 7: 48. 1899. Collins. The Algae of Jamaica. Proc. Am. Acad. Arts Sci. 37: 241. I90r.

\section{Plate XIII. fig. I3.}

Plant mass dense, cushion-shaped, brown or black; filaments $24-40$ mic. in diameter, I mm. in length, entangled; false branches erect, appressed; sheaths yellowish brown, gelatinous, lamellose, the younger ones pale yellow; trichomes 6-I2 mic. in diameter; heterocysts somewhat quadrate; cell contents green.

New York. On rocks. Niagara. August 1876. (Wolle). California. Twin Oaks, San Diego County. (Koch). West Indies. Amongst S. Javanicum on lime-trees. Shanford Estate, Dominica. November and December I892, (Elliott). In turfs in moist places. Port Antonio, Jamaica. April 1893. (Humplirey).

419. Symphyosiphon bornetianum Wolle. Fresh-Water Algae U. S. 261. pl. I89. f. 4. I887. De Toni. Syll. Algar. 5: 536. 1907.

Plate XIII. fig. I4.

Plant mass thin, with smooth surface, brownish or reddish brown; filaments I2-I5 mic. in diameter, short, thick, with the branches forming a close, upright growth; sheaths close; cells somewhat longer or shorter than the diameter; heterocysts scattered, yellowish; cell contents brown or slightly blue-green.

South Carolina. On old bricks. Port Royal; on clay cliffs. (Wolle).

420. Scytonema dubium Wood. Contr. Hist. Fresh-Water Algae North America. 63. pl. 6. f. 3. I872. De Toni. Syll. Algar. 5: 533. I907.

Plant mass immersed; filaments 6-1o mic. in diameter, very long, closely interwoven, variously curved, usually sparingly branched; false branches usually single, more or less distant, moderately short, sometimes very short, abortive and somewhat crowded; sheaths close, usually rather thick and firm, transparent, colorless; trichomes often contained in distinct, cell-like apartments, sometimes continuous, with indistinct transverse walls; heterocysts cylindrical, two to six times longer than broad; cell contents finely granular, usually pale bluish green, sometimes bright blue-green.

New Jersey. On leaves of Ranuculus aquatilis. In Shepherd's 
Mill Pond, near Greenwich, Cumberland County. I869. (Wood).

421. Scytonema hirtulum (Kuetzing) Rabenhorst. Fl. Eur. Algar. 2: 265. 1865. De Toni. Syll. Algar. 5: 531. I907.

Wolle. Fresh-Water Algae U. S. 26I. pl. I89. f. 7. I887. (S y m p h y osiphon histulus $\mathrm{Kg}$.).

\section{Plate XIII, fig. I5.}

Plant mass expanded, cushion-shaped, olivaceous-black, consisting of spine-shaped, wick-like bundles of filaments; filaments and false branches IO-I5 mic. in diameter, ascending, slightly curved, parallel and more or less densely agglutinated below, usually free at the apices, obtusely rounded; sheaths colorless or yellowish, transparent, the external layers a little swollen with age, roughened, 20 mic. in thickness; trichomes 8-Io mic. in diameter; transverse walls distinct; cells equal to the diameter or a little shorter; heterocysts both basal and intercalary, single or in pairs, oblong, brown in color.

United States. On moist rocks and damp earth. (Wolle).

422. Scytonema immersum Wood. Contr. Hist. Fresh-Water Algae North America. 59. pl. 2. f. 9. 1872. De Toni. Syll. Algar. 5: 530. 1907.

Intermingled with other algae and adhering to aquatic plants; filaments about Io mic, in diameter, elongate; false branches mostly in fairs, more or less distant, short or elongate; sheaths wide, transparent, colorless; apex of trichome obtusely rounded; transverse walls sometimes distinct, sometimes invisible; cells quadrate or shorter than the diameter; heterocysts distinct, single, intercalary, somewhat cylindrical, sometimes half as long as broad, sometimes nearly twice as long; cell contents bright blue-green.

New Jersey. Forming a flocculent, greenish black, slimy coating to the stems and finely dissected leaves of $R$ an $u n c u l u s$ a quatilis. In Shepherd's Mill Pond, near Greenwich, Cumberland County. 1869. (Wood).

423. Scytonema polymorphum Naegeli. Rabenhorst. Fl. Eur. Algar. 2: 257. 1865. De Toni. Syll. Algar. 5: 532. 1907.

Moebius. Ueber einige in Portorico gesammelte Süsswasser- und LuftAlgen. Hedwigia. 27: 245. I888.

Plant mass cushion-shaped, dark blue-green or blackish; filaments 7-27 mic. in diameter, variously curved, loosely entangled, sparingly branched; false branches single or in pairs; sheaths colorless or yellowish brown, transparent, lamellose; trichomes 5.8-14.5 mic. in diameter; transverse walls visible or invisible; cells shorter or up to three times longer than their diameter; heterocysts oblong, colorless or pale brown; cell con$t \in n t s$ light blue-green or lead-colored.

West Indies. Porto Rico. (Moebius).

424. Scytonema rubrum Montagne. Première Centurie de Plantes Cellulaires Exotiques. Ann. Sci. Nat. Bot. II. 8: 349. I837; Histoire de l'Ile de Cuba. 9. I838. De Toni. Syll. Algar. 5: 532. 1907. 
Filaments decumbent, reddish, dichotomously branched, entangled; false branches spreading, abruptly bent; cells shorter than their diameter.

West Indies. On fallen leaves. Cuba. (Montagne).

425. Scytonema simplex Wood. Contr. Hist. Fresh-Water Algae North America. 57. I872. Wolle. Fresh-Water Algae U. S. 259. 1887. (S. s im plic e Wood !!). De Toni. Syll. Algar. 5: 536. 1907.

Plant mass moderately thick, somewhat cushion-like, blackish green; filaments IO-I5 mic. in diameter, very long, flexuously curved, sparingly branched or without branches; false branches in pairs or single, usually elongate; sheaths thick, transparent, often colorless, sometimes pale yellowish brown, mostly open and truncate at apex; trichomes $3-6$ mic. in diameter; cells equal to seven times as long as broad (?), often separated, apical cells very short; heterocysts cylindrical, scattered, two to five times longer than their diameter; cell contents sparsely granular, pale greenish.

South Carolina. Adhering to the wet sides of a wooden gutter leading water from a spring. Aiken. September 1869. (Ravenel).

\section{Genus TOLYPOTHRIX Kuetzing. Phyc. Gen. 227. I843.}

Filaments branched; false branches usually arising in the immediate region of the heterocysts, rarely between two heterocysts, single; sheaths somewhat thin, flexible, more or less fragile; gonidia spherical, oval or elliptical, often many in a series; wall of gonidium smooth, thin.

I Sheaths thin.

I Plants living in water

(I) Filaments 8-1o mic, in diameter T. tenuis

(2) Filaments 9-12.5 mic. in diameter T. lanata

(3) Filaments 10-15 mic. in diameter $T$. distorta

(4) Filaments I2-I7 mic. in diameter $T$. penicillata

2 Plants living in moist places

(I) Filaments IO-I5 mic. in diameter T. byssoidea

(2) Filaments $15-25$ mic. in diameter $T$. ravenelii

II Sheaths thick.

I Plants living in water

(r) Filaments 5-6 mic. in diameter T. setchellii

(2) Filaments 12-I5 mic. in diameter T. limbata

2 Plants living in moist places; filaments $12-15$ mic. in diameter

T. rupestris

Species not well understood

T. glacialis

426. Tolypothrix tenuis Kuetzing. Phyc. Gen. 228. 1843. Bornet and Flahault. Revis. des Nostoc. Ann. Sci. Nat. Bot. VII. 5: I22. I887. De Toni. Syll. Algar. 5: 545. 1907. 
Wolle. Fresh-Water Algae. VII. Bull. Torr. Bot. Club. Io: 20.1883. Wolle and Martindale. Algae. Britton's Catalogue of Plants found in New Jersey. Geol. Surv. N. J. 2: 605. 1889. West and West. On some Freshwater Algae from the West Indies. Journ. Linn. Soc. Bot. 30: 27I. 1895. Setchell. Notes on Cyanophyceae.-II. Erythea. 4: I93. I896. Collins. Algae. Flora of the Blue Hills, Middlesex Fells, Stony Brook and Beaver Brook Reservations of the Metropolitan Park Commission, Massachusetts. 128. 1896. Collins, Holden and Setchell. Phyc. Bor.-Am. Fasc. 6. nu. 257. 1897. Tilden. American Algae. Century IV. no. 397. I900. Saunders. The Algae. Harriman Alaska Expedition. Proc. Wash. Acad. Sci. 3: 398. 190I. Setchell and Gardner. Algae of Northwestern America. Univ. Calif. Pub. Bot. I: I96. 1903. Tilden. American Algae. Cent. VII. Fasc. I. no. 628. 1909.

Plant mass caespitose-floccose, rarely extended in a cushion-like layer, blue-green, becoming brownish with age; filaments 8-10 mic. in diameter, $2 \mathrm{~cm}$. in height, repeatedly branched; false branches erect, spreading, flexuously curved; sheaths membranaceous, thin, usually inflated at the base of the branches, colorless or yellowish; trichomes 6-8 mic. in diameter, cylindrical; cells equal to or longer than the diameter; heterocysts one to five, often colorless; cell contents blue-green.

Alaska. Forming brownish or blue-green tufts, attached to rocks in fresh water. Glacier Bay; Popof Islands. (Saunders). Massachusetts. On mosses and various small plants. Spot Pond, Middlesex Fells. (Collins). New Jersey. Often very abundant, in ponds. (Wolle). Plainfield. (Balen). Maryland. On grasses in pools in abandoned brickyard. Baltimore. October I896. (Humphrey). Michigan. Ann Arbor. (Reighard). Minnesota. In tank. Botanical Department, University of Minnesota, Minneapolis. March Igog. (Tilden). South Dakota. Forming blue-green tufts or coatings on reeds, finally becoming loosened and floating. Big Stone Lake. August I898. (Saunders). Washington. Near Newhall, Orcas Island; Green Lake, Seattle. (Gardner). West Indies. On damp wall of dam. Sharp's River, St. Vincent. May I892. (Elliott).

Forma bryophila Rabenhorst. F1. Eur. Algar. 2: 273. 1865. De Toni. 1. c. 547 .

Wolle. Fresh-Water Algae U. S. 265. pl. I8I. f. 5-7. I887.

Forming a widely extended, thin, papery layer; trichomes $2.5-3 \mathrm{mic}$. in diameter.

New Jersey. Often very abundant in ponds. (Wolle). Pennsylvania. (Wolle).

427. Tolypothrix lanata (Desvaux) Wartmann in Rabenhorst. Die Algen Sachsens. no. 768. 1858. Bornet and Flahault. Revis. des Nostoc. Ann. Sci. Nat. Bot. VII. 5: 120. 1887. De Toni. Syll. Algar. 5: 542. 1907.

Wood. Contr. Hist. Fresh-Water Algae North America. 66. pl. 8. f. I I872. (' $T$. dis t o r t a var. Wood). Wolle. Fresh Water Algae. IV. Bull. Torr. Bot. Club. 7: 44. 1880. (T. a e g a gr o pila Kg.); Fresh-Water Algae U. S. 263-265. pl. I80. f. 5-7, I4-I6; pl. I8I. f. I-4. I887. (T. m u s c i c o 1 a Kg., 
T. pulchra Kg., T. flaccida Kg.). Collins. Algae of Middlesex County. I3. I888. Harvey. The Fresh-Water Algae of Maine.-I. Bull. Torr. Bot. Club. 15: I6r. I888. Wolle and Martindale. Algae. Britton's Catalogue of Plants found in New Jersey. Geol. Surv. N. J. 2: 605. I889. Anderson and Kelsey. Common and Conspicuous Algae of Montana. Bull. Torr. Bot. Club. I8: I44. I8gI. Johnson. Fresh Water Algae. Northwestern University. Report Dept. Nat. Hist. 22. 189I. Collins, Holden and Setchell. Phyc. Bor.-Am. Fasc. 5. no. 209. 1896; Fasc. 20. no. 956. 190\%. Setchell and Gardner. Algae of Northwestern America. Univ. Calif. Pub. Bot. I: 195. 1903. Collins. Phycological Notes of the late Isaac Holden.-II. Rhodora. 7: 237. I905.

\section{Plate XIV. fig. I.}

Plant mass caespitose-floccose, rarely extended in a cushion-like layer, blue-green, becoming brownish with age; filaments 9-12.5 mic. in diameter, $\therefore \mathrm{cm}$. in height, repeatedly branched; false branches erect, spreading, flexuously curved, sheaths membranaceous, thin, usually inflated at the base of the branches, colorless or yellowish; trichomes about ro mic. in diameter, cylindrical; cells equal to or longer than the diameter; heterocysts cne to four, often colorless; cell contents blue-green.

Alaska. Forming blackish brown felt-like mats in shallow, running water. Unalaska. June 1899; forming dark brown, felt-like layers on rocks or on the bottom of shallow, fresh water or dried streams, Iliuliuk. (Setchell and Lawson). Maine. Old well, College Farm, near Orono. 1887. (Harvey). Massachusetts. Spot Pond, Stoneham; floating in clay pits, Medford, April I893. (Collins). Connecticut. Lime Rock. (Adam). Mostly on aquatic mosses in summer and autumn, in quiet water. Pequonnock River, Bridgeport. November 189o; Lake Saltonstall, near New Haven, September to December. (Holden). New Jersey. Clusters torn from attachment by storm. Budd's Lake. August r88r. (Wolle). Pennsylvania. Forming little bright green balls, adherent to aquatic plants in an aquarium. Philadelphia. (Wood). In ponds. (Wolle). Indiana. In shallow ponds. Edgemoor, Lake County. August 1890. (Johnson). Montana. On dripping rocks and on wet wood-work of dams, flumes, etc., in springs and streams. July to October. (Anderson and Kelsey). Washington. Near Seattle. (Kincaid). West Indies. (Mazé).

Var. hawaiiensis Nordstedt. De Algis Aquae Dulcis et de Characeis ex Insulis Sandvicensibus a Sv. Berggren 1875 reportatis. 6 . 1878 . (T. m us c ic o 1 a). De Toni. 1. c. 545 .

Lemmermann. Algenfl. Sandwich.-Inseln. Bot. Jahrb. 34: 625. 1905.

Filaments 9- 14 mic. in diameter; trichomes $6-8$ mic. in diameter; cells 4-7 mic. in length; heterocysts 9 mic. in diameter, IO-15 mic. in length.

Hawaii. Adhering to leaves in stagnant water. Mauna Kea, Hawaii. (Berggren).

428. Tolypothrix distorta (Hofman-Bang) Kuetzing. Phyc. Gen. 228. I843. Bornet and Flahault. Revis. des Nostoc. Ann. Sci. Nat. Bot. VII. 5: I19. 1887. De Toni. Syll. Algar. 5: 541. 1907.

Wood. Contr. Hist. Fresh-Water Algae North America. 65. I872. 
Wolle. Fresh-Water Algae U. S. 263. pl. I80. f. I-3. I887. Bennett. Plants of Rhode Island. II4. I888. (S c y t o n e m a $\mathrm{grac}$ il e $\mathrm{Kg}$.). Wolle and Martindale. Algae. Britton's Catalogue of Plants found in New Jersey. Geol. Surv. N. J. 2: 605. I889. Anderson and Kelsey. Common and Conspictuous Algae of Montana. Bull. Torr. Bot. Club. 18: 144. I891. Tilden. American Algae. Cent. I. no. 82. 1894; List of Fresh-Water Algae collected in Minnesota during I894. Minn. Bot. Studies. I : 236. I895; American Algae. Cent. V. no. 478. I90I; Collection of Algae from the Hawaiian Islands. Hawaiian Almanac and Annual for I902. III. I90I; Algae Collecting in the Hawaiian Islands. Postelsia: The Year Book of the Minnesota Seaside Station. I: I53. I902. Setchell and Gardner. Algae of Northwestern America. Univ. Calif. Pub. Bot. I: I95. I903.

Plate XIV. fig. 2-4.

Plant mass caespitose-floccose or extended in a cushion-like layer, blue-green or brownish; filaments ro-I5 mic. in diameter, I-3.cm. in length, repeatedly branched; false branches erect, spreading, flexuously curved; sheaths membranaceous, thin, here and there inflated at the base of the branches, colorless, rarely yellowish; trichomes 9-12 mic. in diameter, sometimes constricted at joints; cells equal to or shorter than the diameter; heterocysts solitary, rarely in twos or threes; cell contents blue-green.

Alaska. Floating or attached to plants or stones in quiet, fresh water. Cape Nome. (Setchell). Vermont. Pond waters. East Charlotte. (Wolle). Rhode Island. (Thwaites). Warden's Pond. (Wood). North Providence. (Bennett). New York. Reservoir Pond, West Point. (Wood). New Jersey. On rocky shores of Morris Pond, Morris. (Wolle). Wisconsin. Fourth Lake, Madison. (Bailey). Minnesota. Artificial lake. Minneapolis. August I894. (Tilden). Montana. Everywhere in flowing water, growing caespitose on the rocks. July to October. (Anderson and Kelsey). Washington. Fidalgo Island; Lake Washington, Seattle. (Gardner). Hawaii. Forming tiny bluish green tufts or cushions on rocks in mountain stream. Kaliawaa Stream, Makao, Koolauloa, Oahu. June I90o. (Tilden).

429. Tolypothrix penicillata (Agardh) Thuret. Essai Class. Nostochinées. Ann. Sci. Nat. Bot. VI. I: 380. I875. Bornet and Thuret. Revis. des Nostoc. Ann. Sci. Nat. Bot. VII. 5: I23. I887. De Toni. Syll. Algar. 5: 549. 1907.

Farlow. Notes on the Cryptogamic Flora of the White Mountains. Appalachia. 3: 236. 1883. Wolle. Fresh-Water Algae U. S. 252. pl. I83. f. II-I3. 1887. (S cytonema naegeli $\mathrm{Kg}$.). Wolle and Martindale. Algae. Britton's Catalogue of Plants found in New Jersey. Geol. Surv. N. J. 2: 604. I889.

\section{Plate XIV. fig. 5.}

Plant mass penicillate-caespitose, deep brown in color; filaments I2-I7 mic. in diameter, $2 \mathrm{~cm}$. in length, repeatedly branched; false branches erect at the base, flexuously curved, elongate; sheaths firm, membranaceous, at first colorless, afterwards becoming brownish; trichomes about io mic. in diameter, cylindrical; cells 4-12 mic. in length; heterocysts usually solitary, yellowish; cell contents blue-green. 
New Hampshire. On submerged mosses. Mill Brook, Shelburne. (Farlow). New Jersey. On moist rocks. Closter and Godwinville. (Austin).

430. Tolypothrix byssoidea (Hassall) Kirchner in Engler and Prantl. Nat. Pflanz. I. Ia. 80. I900. Bornet and Flahault. Revis, des Nostoc. Ann. Sci. Nat. Bot. VII. 5: II6. I887. (H as sallia by s oidea Hass.) De Toni. Syll. Algar. 5: 55I. 1907.

Wood. Contr. Hist. Fresh-Water Algae North America. 68. pl. 9. f. I. 1872. (Sirosiphon scytonematoides Wood). Wolle. FreshWater Algae U. S. 266. pl. I8I. f. 8-II. I887. (T. t r u n ci cola (Rab.) Wolle). Collins. Algae of Middlesex County. I3. I888. Setchell. Notes on some Cyanophyceae of New England. Bull. Torr. Bot. Club. 22: 428. 1895. Collins. Algae. Flora of the Blue Hills, Middlesex Fells, Stony Brook and Beaver Brook Reservations of the Metropolitan Park Commission, Massachusetts. I28. I896. Collins, Holden and Setchell. Phyc. Bor.-Am. Fasc. 6. no. 258. I897. West and West. A Further Contribution to the Freshwater Algae of the West Indies. Journ. Linn. Soc. Bot. 34: 287. I898-Igoo.

\section{Plate XIV. fig. 6.}

Plant mass woolly, cushion-like, brownish or black; filaments IO-I5 mic. in diameter, I $\mathrm{mm}$. in length, irregularly branched; false branches short, erect, spreading; sheaths close, thin, orange or brown, fragile, tubular, continuous; trichomes 9-II mic. in diameter, constricted at joints; cells two or three times shorter than the diameter; heterocysts, basal, one or two; cell contents olive.

Massachusetts. Newton. (Farlow). Among other algae. Cascade, Middlesex Fells. (Collins). Connecticut. Growing on rocks at the water's edge. Quinebaug River, Lisbon. (Setchell). South Carolina. Growing on the limbs of M y rica cerifera. February. (Ravene1). West Indies. On leaves. Wotten Waven, Dominica. (Elliott).

Forma saxicola Grunow. Bornet and Flahault. 1. c. II7. De Toni. 1. c. 552.

Setchell and Gardner. Algae of Northwestern America. Univ. Calif. Pub. Bot. I: 195. 1903.

Filaments I4-I8 mic. in diameter; sheaths often striated and corrugated; trichomes 12 mic. in diameter.

Alaska. Among mosses on dripping rocks. Amaknak Island, Bay of Unalaska. (Setchell and Lawson).

Forma cylindrica Tilden. American Algae. Cent. IV. no. 398. I900. ( $\mathrm{Hassa} 11$ ia byssoidea cylindrica).

Trichomes 5-6 mic. in diameter, cylindrical; heterocysts basal or intercalary.

Canada. On vertical rocks just above high tide. Baird Point, Strait of Juan de Fuca, Minnesota Seaside Station, Vancouver Island, British Columbia. August 1898. (Tilden). 
431. Tolypothrix ravenelii Wolle. Fresh Water Algae. Bull. Torr. Bot. Club. 6: 285. I879; Fresh-Water Algae U. S. 265. pl. I8o. f. 8-Io. I887. De Toni. Syll. Algar. 5: 542. Ig07.

Plate XIV. fig. 7.

Plant mass thin, more or less expanded, reddish brown; filaments 1 5-25 mic. in diameter, elongate, false branches elongate; sheaths thin, close, yellowish or dark-colored; trichomes often interrupted; cells equal to or twice as short as their diameter; transverse walls distinct; heterocysts basal or intercalary, usually single, oblong, yellowish; cell contents finely granular, yellowish or reddish.

Florida. On sandstone rock. Gainesville. December I877. (Ravenel).

432. Tolypothrix setchellii Collins. Some Perforating and other Algae on Freshwater Shells. Erythea. 5: 96. pl. 4. I897. Collins, Holden and Setchell. Phyc. Bor.-Am. Fasc. 7. no. 310. 1897. De Toni. Syll. Algar. 5: 548. I897.

Setchell and Gardner. Algae of Northwestern America. Univ. Calif. Pub. Bot. I: 196. 1903.

Plate XIV. fig. 8 .

Filaments 5-6 mic. in diameter, up to $7 \mathrm{dm}$. in length, scattered or arranged in parallel series and forming a layer, flexuous, occasionaily thickened, repeatedly branched; false branches spreading; sheaths thick, gelatinous, refractive, colorless or yellowish; trichomes 4 mic. in diameter, constricted at joints; cells equal to or longer than the diameter; heterocysts disc-shaped; cell contents blue-green.

Alaska. "A dwarf species." On Ch a r a. Near Iliuliuk, Unalaska. (Lawson). Connecticut. On shells. Twin Lakes, Salisbury, Litchfield County. August 1897. (Setchell and Holden).

433. Tolypothrix limbata Thuret in Bornet and Flahault. Revis. des Nostoc. Ann. Sci. Nat. Bot. VII. 5: I24. I887. De Toni. Syll. Algar. 5: 550. I907.

Setchell and Gardner. Algae of Northwestern America. Univ. Calif. Pub. Bot. I: I96. I903.

Plant mass floccose-caespitose, blue-green; filaments $12-15 \mathrm{mic}$. in diameter, $2-3 \mathrm{~mm}$. in length, repeatedly branched; false branches erect, spreading, flexuously curved; sheaths refringent, colorless, lamellose, with the outer layers mucous; trichomes 6-9 mic. in diameter, constricted at joints; cells equal to or a little longer than the diameter; heterocysts one to two; cell contents dull blue-green.

Washington. Growing on the side of a jar in the botanical laboratory. University of Washington, Seattle. (Gardner).

434. Tolypothrix rupestris Wolle. Fresh Water Algae. III. Bull. Torr. Bot. Club. 6: 185. I877; in Rabenhorst. Die Algen Europas. no. 2573. 1879; Fresh-Water Algae U. S. 265. pl. I8o. f. II-I3. I887. 
Plate XIV. fig. 9.

Plant mass expanded, variously tinged with red, purple and black; filaments I2-I5 mic. in diameter, loosely interwoven, much branched; sheaths wide, yellowish, or colorless; cells as long or twice as long as their diameter; heterocysts spherical or oblong, two or three in series; cell contents granular, dull blue-green.

Pennsylvania. On dripping, gelatinous, exposed rocks. Delaware Water Gap. July. (Wolle).

435. Tolypothrix glacialis Dickie. On the Algae found during the Arctic Expedition. Journ. Linn. Soc. Bot. I7: 8. 188o. De Toni. Syll. Algar. 5: 556. 1907.

Plant mass caespitose, brown; filaments 15 mic. in diameter, rigid; sheaths somewhat lamellose; transverse walls indistinct.

Arctic Regions. Forming a brownish crust on decayed N o s t o c. Edge of Glacier Lake, Cape Baird. (300 feet), $8 \mathrm{I}^{\circ} 30^{\prime} \mathrm{N}$. (Dickie).

Genus DESMONEMA Berkeley and Thwaites.

English Botany. I849.

Plant mass caespitose, penicillate; filaments somewhat dichtomously divided, straight; sheaths thin; trichomes two or more within the sheath; heterocysts basal; gonidia large, oval or elliptical, single or in short series; wall of gonidium somewhat thick.

436. Desmonema wrangelii (Agardh) Bornet and Flahault. Revis. des Nostoc. Ann. Sci. Nat. Bot. VII. 5: 127. I887. De Toni. Syll. Algar. 5: 558. 1907.

Wolle. Fresh-Water Algae U. S. 237. pl. I68. f. 3, 4. I887. (C a 1 o th rix d i $11 \mathrm{w}$ y n i i Hass.) Wolle and Martindale. Algae. Britton's Catalogue of Plants found in New Jersey. Geol. Surv. N. J. 2: 603. I889. (Also C. radios a (Kg.) Kirchn.). Setchell. Notes on some Cyanophyceae of New England. Bull. Torr. Bot. Club. 22: 428. 1895. Collins, Holden and Setchell. Phyc. Bor.-Am. Fasc. 3. no. I08. I895. Saunders. The Algae. Harriman Alaska Expedition. Proc. Wash. Acad. Sci. 3: 398. rgor. Setchell and Gardner. Algae of Northwestern America. Univ. Calif. Pub. Bot. J : 196. I903.

\section{Plate XIV. fig. Io.}

Plant mass $5-6 \mathrm{~mm}$. in height, caespitose, formed of penicillate fascicles, gelatinous, dark green; filaments erect, somewhat flexuous, repeatedly subdichotomously branched; sheaths thin, continuous, colorless or yellowish; trichomes 9-1o mic. in diameter, constricted at the joints; cells three times shorter than the diameter; heterocysts one, two or none; cell contents blue-green.

Alaska. In a clear brook, emptying into Glacier Bay; in brook, Popof Island. (Saunders). On stones in brooks or lakes, or even in pools on the tundra. St. Michael. (Setchell). Near Iliuliuk, Unalaska. (Setchell and Lawson). Connecticut. Very abundant. Forming small tufts or extended 
patches of a blackish green color on stones in the swiftest currents of Roaring Brook, Cheshire. May 1894. (Setchell). New Jersey. Swamps; Morris Pond, Morris. (Wolle). Maryland. Garrett County. (Wolle).

\section{Genus DIPLOCOLON Naegelii in Itzigsolın.}

Phykologische Studien. Part I. I60. I857.

Plant mass gelatinous, terrestrial; colonies irregular in shape, constricted, somewhat club-shaped; filaments several, contorted within a common tegument, branched; false branches solitary or in pairs, usually arising between two heterocysts, but rarely in the immediate region of the heterocysts; trichomes single within the sheath.

437. Diplocolon heppii Naegeli in Itzigsohn. Phykologische Studien. Nova Acta Acad. Leopold-Carolin. der Nat. 26: Part I. r6o. pl. II. (excl. f. 8-12). I857. Bornet and Flahault. Revis. des Nostoc. Ann. Sci. Nat. Bot. VII. 5: I29. I887. De Toni. Syll. Syll. Algar. 5: 56r. r907.

Wolle. Fresh-Water Algae. II. Bull. Torr. Bot. Club. 6: I39. I877; FreshWater Algae. U. S. 260. pl. 195. f. I-9. I887. (S c y t o ne ma he p pi i (Naeg.) Wolle). Setchell. Notes on Cyanophyceae.-II. Erythea. 4: 193. I 896.

\section{Plate XIV. fig. II.}

Plant mass caespitose, grumous-gelatinous, brownish becoming black; coionies club-shaped, gelatinous, irregularly dilated, up to I $\mathrm{mm}$. in thickness, yellowish brown; common tegument lamellose, yellowish brown; flaments 20-28 mic. ill diameter, repeatedly branched within the common tegument, flexwously curved and densely interwoven; trichomes constricted at joints; cells and heterocysts 6-10 mic. in diameter, somewhat spherical; cell contents blue-green.

New York. Forming a blackish brown gelatinous stratum upon rocks. Niagara Falls. (Wolle). Florida. On old wood. March 1878. (Wolle).

\section{Family IV. STIGONEMACEAE}

Filaments free, rarely laterally aggregated, scattered, frequently branched; sheaths thick, firm, often irregular; trichomes consisting of one or several rows of cells, with heterocysts; heterocysts often lateral, sometimes intercalary; reproduction by means of vegetative division, hormogones and gonidia.

I Sheaths distinct, definite.

I Filaments free

(1) Trichomes consisting of one row of cells

A Branches of two kinds, the one cylindrical, the other flagelliform; heterocysts terminal or lateral

Mastigocoleus

B Branches unilateral, usually tapering at the apex; heterocysts intercalary

Hapalosiphon 
(2) Trichomes consisting of one to several rows of cells

A Branches unilateral, thin, finally forming hormogones

Fischerella

B Branches scattered; hormogones formed in the apices of the branches or in special short branches Stigonema

2 Filaments growing together forming a cushion-like mass

Capsosira

II Sheaths confluent into a gelatinous amorphous mass

Nostochopsis

Genus MASTIGOCOLEUS Lagerheim. Notarisia. I : 65 . I886.

Filaments free, irregularly branched; branches of two kinds, the one cylindrical, the other flagelliform, tapering off into a hair-like apex; sheaths continuous; trichomes, except in the branches, single within the sheath; heterocysts single, rarely in pairs, terminal or lateral, sometimes intercalary; gonidia unknown; reproduction by means of hormogones; cell contents homogeneous.

438. Mastigocoleus testarum Lagerheim. Note sur le Mastigocoleus, Nouveau Genre des Algues Marines de 1'Ordre des Phycochromacées. Notarisia. I: 65. pl. I. 1886. Bornet and Flahault. Revis. des Nostoc. Ann. Sci. Nat. Bot. VII. 5: 54. 1887. 'De Toni. Syll. Algar. 5: 564. Ig07.

Collins. Algae. Rand and Redfield's Flora of Mount Desert Island, Maine. 247. I894. Collins, Holden and Setchell. Phyc. Bor.-Am. Fasc. 5. no. 213. 1896. Setchell. Notes on Cyanophyceae--III. Erythea. 7: 47. 1899. Collins. Preliminary Lists of New England Plants.-V. Marine Algae. Rhodora, 2: 42. I900; The Algae of Jamaica. Proc. Am. Acad. Arts Sci. 37: 24I. I90I; Phycological Notes of the late Isaac Holden.-II. Rhodora. 7: 223. 1905 .

\section{Plate XIV. fig. I2.}

Filaments 6-ro mic. in diameter, variously curved; sheaths thin, colorless; trichomes 3.5-6 mic. in diameter; cells cylindrical or nearly so; heterocysts exceeding the diameter of the trichome, 6-I 8 mic. wide and long; cell contents greenish.

Canada. In oyster shells. Malpeque, Prince Edward Island. (Faull). Maine. Growing in the substance of dead shells. Seal Harbor. (Collins). Massachusetts. In shells of $\mathrm{M}$ y a a r e $\mathrm{n}$ a $\mathrm{I}$ i a on a sandy beach below low water mark. Quisset. July I893, I895. (Setchell). Rhode Island. (Collins). Connecticut. In shells. Fresh Pond. August, September. (Holden). California. In shells of the Eastern oyster. Near Bay Farm Island, Alameda County. (Setchell). West Indies. In old shells. Kingston, Jamaica. I897. (Humphrey). Jamaica. (Flahault).

Genus HAPALOSIPHON Naegeli in Kuetzing. Spec. Algar. 894. I849.

Plant mass caespitose-floccose, thin, aquatic; filaments free, not grow- 
ing together laterally, branched, consisting of a single row of cells, rarely of twa rows, enclosed within a sheath; branches erect, usually about the same thickness as the creeping primary filament, commonly unilateral, long, flexuous, very slightly tapering; sheaths continuous, strong, of uniform thickness; sheaths of the branches thinner than those of primary filaments, lisually colorless; heterocysts intercalary; wall of gonidium thick, yellowish brown.

I Plants living in fresh water.

I Filaments decumbent, branched on all sides; branches 6-8 mic. in diameter; cells elliptical depressed

H. flexuosus

2 Plant mass caespitose, orange brown; primary filaments II.5-I2.5 mic. in diameter; trichomes $7.5-8 \mathrm{mic}$. in diameter $H$. aureus

3 Plant mass floccose, caespitose, dull blue-green; primary filaments $2 \mathrm{I}-24$ mic. in diameter

H. fontinalis

II Plants living in hot water

I Plant mass cushion-like, irregular or expanded, blue-green; primary filaments 3-6 mic. in diameter

H. laminosus

2 Plant mass widely expanded, bright blue-green; trichomes 3-II mic. in diameter

H. major

III Plants living on bark of trees

I Plant mass caespitose, small, blue-green; filaments 4-7 mic. in diameter

$\mathrm{H}$. intricatus

2 Filaments 7 -10 mic. in diameter; trichomes 7-9.5 mic. in diameter

H. arboreus

439. Hapalosiphon flexuosus Borzi. Alghe d'Acqua Dolce della Papuasia. La Nuova Notarisia. 43. I892. De Toni. Syll. Algar. 5: 570. I907.

West and West. On some Freshwater Algae from the West Indies. Journ. Linn. Soc. Bot. 30: 272. I 895.

Filaments decumbent, branched on all sides, consisting of a single row of cells; branches 6-8 mic. in diameter, about equally thick in all parts, flexuously interwoven; sheaths thin, smooth; cells elliptical depressed; heterocysts similar to vegetative cells in form and size.

West Indies. In stream. Grande Soufrière, Dominica. November, December I892. (Elliott).

440. Hapalosiphon aureus West and West. Welwitsch's African Freshwater Algae. Journ. of Bot. 241. 1897. De Toni. Syll. Algar. 5: 57I. 1907.

West. West Indian Freshwater Algae. Journ. of Bot. 42: 29I. I904.

Plant mass caespitose, densely interwoven, orange brown, growing among other algae; primary filaments II.5-12.5 mic. in diameter, tortuous and interwoven, formed of a single series of cells; sheaths firm, tenacious, thick, orange brown, transparent, finally becoming punctulate; trichomes 7.5-8 mic. in diameter; cells somewhat quadrate or spherical, shorter than the diameter and somewhat ellipsoid, or oblong and seven or eight times as long as broad; branches $6.5-9.5$ mic. in diameter, frequently unilateral, 
single or in pairs, long and flexuous, more slender than the primary filament, sometimes branched; sheaths thick and usually colorless; cells of the branches variable, 4-6.5 mic. in diameter, similar to those in the primary filament, often indistinct; heterocysts up to 6 mic. in diameter, 7-2I mic. in length, rectangular, oblong, intercalary; gonidia not known; cell contents finely granular, pale blue-green.

West Indies. Bay Estate, Barbados. (Howard).

44I. Hapalosiphon fontinalis (Agardh) Bornet. Les Nostocacées Hétérocystées du Systema Algarum de C. A. Agardh (1824) et leur Synonymie actuelle (1889). Bull. Soc. Bot. de France. 36: I3. I889. Bornet and Flahault. Revis. des Nostoc. Ann. Sci. Nat. Bot. VII. 5: 6r. 1887. (H. p u mil u s Kirchn.). De Toni. Syll. Algar. 5: 568. I907.

Nordstedt. De Algis Aquae Dulcis et de Characeis ex Insulis Sandvicensibus a Sv. Berggren 1875 reportatis. 7. 1878. ( $\mathrm{H}$. b r a u $\mathrm{n}$ i i Naeg.). Wolle. Fresh-Water Algae. V. Bull. Torr. Bot. Club. 8: 39. I88I. (H. brebis s on i i Kg.) ; Fresh-Water Algae U. S. 275, 277. pl. I96, f. 2-4, 22, 23. r887. (H. bra un i Kg., H. f u cescens Kg.). Harvey. The FreshWater Algae of Maine.--I. Bull. Torr. Bot. Club. 15. I6I. I888. Bennett. Plants of Rhode Island. II4. I888. Wolle and Martindale. Algae. Britton's Catalogue of Plants found in New Jersey. Geol. Surv. N. J. 2: 606. I889. Tilden. List of Fresh-Water Algae collected in Minnesota during I893. Minn. Bot. Studies. I: 30. I894. Collins. Algae. Flora of the Blue Hills, Middlesex Fells, Stony Brook and Beaver Brook Reservations of the Metrojolitan Park Commission, Massachusetts. 128. I896; The Algae of Jamaica. Froc. Am. Acad. Arts Sci. 37: 24I. I90I. Saunders. The Algae. Harriman Alaska Expedition. Proc. Wash. Acad. Sci. 3: 399. I90I. Setchell and Gardner. Algae of Northwestern America. Univ. Calif. Pub. Bot. I: 196. 1903. Lemmermann. Algenfl. Sandwich.-Inseln. Bot. Jahrb. 34: 625. 1905. Tilden. American Algae. Cent. VII. Fasc. I. no. 627. Ig09.

Plate XIV. fig. I3.

Plant mass floccose, caespitose, dull blue-green, $3 \mathrm{~mm}$. in height; primary filaments $2 \mathrm{I}-24$ mic. in diameter, creeping, interwoven, densely branched on the upper side, containing a single row of cells, rarely two or three, somewhat equal in diameter; sheaths somewhat thick, septate; secondary filaments 9-12 mic. in diameter, long, simple; sheaths continuous; trichomes consisting of a row of single, cylindrical cells; heterocysts intercalary; hormogones 6 mic. in diameter, I00-300 mic. in length, made up of from I4-5o cells.

Alaska. In a freshwater pond near Seldovia, Cook Inlet. (Saunders). Maine. Old well. College Farm, near Orono. (Harvey). Massachusetts. On the under side of $\mathrm{N} \mathrm{p} \mathrm{p}$ a $\mathrm{r}$ leaves. Spot Pond and Shiner Pool, Middlesex Fells. (Collins). Rhode Island. Spectacle Pond. (Bennett). New Jersey. On submerged plants in ponds. Dennisville, Atsion, Hammonton. (Wolle). Minnesota. Lake Kilpatrick. June I893. (Tilden). On perpendicular rocks in stone quarry. Near campus, University of Minnesota, Minreapolis. September I904. (Lippold). West Indies. On rock. "Wag 
Water," Castleton, Jamaica. April I893. (Humphrey). Hawaii. Adhering to leaves, in stagnant water. Mauna Kea, Hawaii. (Berggren).

Var. tenuissimus (Grunow) Collins and Setchell. Phyc. Bor.-Am. Fasc. 5. no. 212. 1896. De Toni. Syll. Algar. 5: 570. 1907.

Wolle. Fresh Water Algae. V. Bull. Torr. Bot. Club. 8: 39. I88r. (H. te nuis im us Grun.); Fresh-Water Algae U. S. 277. pl. 196. f. 20, 2 . 1887. Bennett. 1. c. I I4. Wolle and Martindale. 1. c. 606.

Plant mass floccose; filaments irregularly branched in a squarrose manner; branches spreading; sheaths very close, colorless, transparent; trichomes 3-4.2 mic. in diameter, often interrupted, variously curved, with indistinct, transverse walls; nearly equal in length to the diameter.

Massachusetts. Spot Pond, Medford. September I890. (Collins). Khode Island. Blackamore Pond. (Bennett). Connecticut. Attached to under side of $\mathrm{N}$ u p har leaves. Mill Pond, Lantern Hill, Ledyard. Septemher 1892. (Setchell). New Jersey. (Wolle). Pennsylvania. (Wolle). Florida. (Wolle). Minnesota. (Wolle).

442. Hapalosiphon laminosus (Kuetzing) Hansgirg. Ueber den Polymorphismus der Algen. Bot. Centralblatt. 22: 48. 1885. Bornet and Flahault. Revis. des Nostoc. Ann. Sci. Nat. Bot. VII. 5: 55. 1887. De Toni. Syll. Algar. 5: 565. I907.

Setchell. Notes on Cyanophyceae.-III. Erythea. 7: 47. I899. Collins. Holden and Setchell. Phyc. Bor.-Am. Fasc. I8. no. 858. I90I. Setchell. The Upper Temperature Limits of Life. Science. I7: 395. 1903.

$$
\text { Plate XIV. fig. I4, I5. }
$$

Plant mass irregular or expanded, carneous-spongiose or compact, partly hardened with calcium carbonate, blue-green; filaments interwoven, showing great variety of form; mature flaments 6 mic. in diameter, with distinct sheath, often constricted at joints, containing a single row of cells, rarely two rows, the cells being spherical depressed, barrel-shaped or cylindrical, branched; branches unilateral, erect, more slender than the primary filament, composed of long, cylindrical cells; young filaments similar th those of Anabaena, either with or without sheaths, crowded, with a somewhat parallel arrangement, torulose in middle portion, tapering at the ends, sometimes simple, sometimes branched; branches single or in pairs, abruptly bent, with long, narrow cells; heterocysts intercalary, often wider than the vegetative cells, spherical or oblong.

California. In long, dark, emerald green, penicillate tufts, waving in a stream of hot water (temperature $49-50^{\circ}$ C.). Arrowhead Hot Springs, near San Bernadino. April 1898. (Setchell).

"Within the strictly thermal limits (waters over $43^{\circ}-45^{\circ} \mathrm{C}$.), only one member of the higher and heterocysted Cyanophyceae has been noted, viz., Hapalosiphon 1 a minos us."-Setchell.

Note.-H. major grows luxuriantly in water of a temperature of $54^{\circ}$ C., and even higher.

443. Hapalosiphon major Tilden. American Algae. Century II. no. I67. 
1896; Observations on some West American Thermal Algae. Bot. Gaz. 25: 97. pl. 9. f. I0-18. 1898. De Toni. Syll. Algar. 5: 565. I907.

\section{Plate XV. fig. I-4.}

Plant mass widely expanded, bright blue-green in color; filaments branched; branches single or in pairs, sometimes abruptly bent; trichomes 3-6 mic. in diameter, sometimes cylindrical with indistinct transverse walls, sometimes consisting of very long cells or short somewhat quadrate cells or even spherical cells, the latter up to II mic. in diameter; heterocysts 8 mic. in diameter, 8-16 mic. in length, intercalary, oblong, barrel-shaped.

Wyoming. Completely coating bed of very swift mountain rivulet, at vent of hot spring. Temperature of spring $6 \mathrm{I}^{\circ} \mathrm{C}$. The growth of the plant begins here and disappears at a distance of fifty-five feet from spring where the temperature is $5 \mathrm{I}^{\circ} \mathrm{C}$. The most luxuriant growth is thirty-five feet from the spring at a temperature of $54^{\circ} \mathrm{C}$. On a mountain near Lower Geyser Basin, Yellowstone National Park. June 1896 . (Tilden). Oregon. I 1 hot spring. Temperature $55^{\circ}$ C. Cascade Mountains, lat. $45^{\circ} 20^{\prime}$. 1895 . (Lloyd).

"The filaments of $\mathrm{H}$. major are nearly twice the diameter of $H$. $1 \mathrm{a}$ minosus Hansg. An important character of the latter plant is its habit of forming crystals of lime, according to Cohn who studied the plant at Carlsbad. The Yellowstone species occurred in silicious waters only, at least it was not discovered at Mammoth Hot Springs, where the waters contain calcium carbonate."-Tilden.

444. Hapalosiphon intricatus West and West. On some Freshwater Algae from the West Indies. Journ. Linn. Soc. Bot. 30:-27I. I895; A Further Contribution to the Freshwater Algae of the West Indies. 1. c. 34: 286. I899. De Toni. Syll. Algar. 5: 57I. I907.

\section{Plate XV. fig. 5.}

Plant mass caespitose, small, blue-green; filaments 4-7 mic. in diameter, densely interwoven and variable, sparingly branched, containing a single row of cells; branches single, unilateral, flexuous, similar to the primary filament, with or without a sheath; mature sheaths close, usually distinct; cells variable, up to three times longer than their diameter, often equal and somewhat rotund, or elongate; heterocysts 3.8-5.5 mic. in diameter, one to three times longer than diameter, somewhat quadrate or oblong, scattered.

West Indies. In little intricate tufts among the leaves of $\mathrm{L}$ e $\mathfrak{c} \mathrm{co}$ b r y u m, on trees, summit of Trois Pitons (4,500 feet), Dominica. November, December 1892; in stream, Wotten Waven, Dominica, January, February 1896 . (Elliott).

445. Hapalosiphon arboreus West and West. On some Freshwater Algae from the West Indies. Journ. Linn. Soc. Bot. 30: 272. 1895. De Toni. Syll. Algar. 5: 572. 1907. 
Plate XV. fig. 6, 7 .

Primary filaments 7 -Io mic. in diameter, flexuous, here and there branched on one side, formed from a single row of cells; sheaths close, thin, colorless; branches short, resembling the primary filaments, but more slender; cells 7-9.5 mic. in diameter, 7-19 mic. in length; heterocysts 6-9 mic. in diameter, 9-I I mic. in length, quadrate or oblong, intercalary.

West Indies. On trees. Summit of Trois Pitons (4,500 feet), Dominica. November, December I892. (Elliott).

\section{Genus FISCHERELLA (Bornet and Flahault) Gomont. Journ. de Bot. I. I895.}

Plant mass forming a continuous, more or less expanded layer, terrestrial; filaments of two kinds; primary filaments creeping, containing one or two rows of cells, unilaterally very much branched; branches or secondary filaments erect, elongate, more slender than the primary, containing very long hormogones within the sheath.

1 Plants living in moist places; primary filaments 6-9 mic. in diameter

\section{F. ambigua}

II Plants living in moist places or in hot water; primary filaments Io-13 mic. in diameter F. thermalis

446. Fischerella ambigua (Naegeli) Gomont. Note sur le Scytonema ambiguum Kuetz. Morot. Journ. de Bot. 9: 49. pl. 3. I895. Bornet and Flahault. Revis. des Nostoc. Ann. Sci. Nat. Bot. VII. 5: I00. 1887. (Scytonema a mbigu um Kg.). De Toni. Syll. Algar. 5: 576. 1907 .

Wolle. Fresh-Water Algae U. S. 262. pl. I89. f. 2. 1887 . (S y m p h y osiphon a mbigu u $\mathrm{m}$ Naeg.). Collins. Algae of Middlesex County. J3. I888. West and West. On some Freshwater Algae from the West Indies. Journ. Linn. Soc. Bot. 30: 270. 1895; A Further Contribution to the Freshwater Algae of the West Indies. 1. c. 34: 286. 1899. Setchell and Gardner. Algae of Northwestern America. Univ. Calif. Pub. Bot. I: 196. I903. Lemmerman. Algenfl. Sandwich.-Inseln. Bot. Jahrb. 34: 625. I905.

\section{Plate XV. fig. 8, 9.}

Plant mass crustaceous, orbicular, up to I $\mathrm{mm}$. in thickness, brown becoming black; filaments 6-9 mic. in diameter, very slender, densely coalesced in vertical fascicles; false branches aggregated; sheaths gelatinous, colorless, finally becoming brownish; trichomes 2-3 mic. in diameter, thicker at the apices; cells and heterocysts elongate; hormogones very long; cell contents pale greenish or yellowish brown.

United States. Frequently intermingled with larger algae, on moist rocks, wet earth, etc. (Wolle). Massachusetts. Newton. (Farlow). Mexico. (Lenormand). West Indies. On trees, summit of Trois Pitons (4,500 feet). November, December 1892; on the ground, mostly in old "Diablotia" holes, Morne Anglais (2,300 feet), July I892; on banks near 
summit. Couliabon (3,700 feet), Dominica, January, February I896. (Elliott). Hawaii. (Berggren).

In speaking of Tolypothrix bys oidea cylindrica Tilden, Dr. Setchell states that "although the basal stratum and fasciculi of branchlets are not well developed, yet the branches seem to indicate this species (F. a mbigua) rather than the one to which Miss Tilden has referred it." Further investigation is needed to settle this point.

447. Fischerella thermalis (Schabe) Gomont. Note sur le Scytonema ambiguum Kuetz. Morot. Journ. de Bot. 9: 52. 1895. Bornet and Flahault. Revis. des Nostoc. Ann. Sci. Nat. Bot. VII. 5: 66. I887. De Toni. Syll. Algar. 5: 574. 1907.

Farlow, Anderson and Eaton. Algae Am. Bor. Exsicc. no. 223. I877. (Scytonema thermale Borzi). Farlow. Notes on the Cryptogamic Flora of the White Mountains. Appalachia. 3: 236. I883. (F is ch e ra thermalis a mericana Farlow). Collins, Holden and Setchell. Phyc. Bor.-Am. Fasc. 5. no. 21 I. I896. Lemmermann. Algenfl. Sandwich.Inseln. Bot. Jahrb. 34: 625. 1905. (S t ig o n e ma thermale (Schabe) Borzi).

\section{Plate XV. fig. Io, II.}

Plant mass $.5 \mathrm{~mm}$. in thickness, cushion-shaped, woolly, expanded, blackish olive or blue-green; primary filaments IO-I3 mic. in diameter, creeping, interwoven, constricted at joints, very much branched on the upper side; cells somewhat spherical, surrounded by a close, colorless or yellowish sheath; branches 7-9 mic. in diameter, erect, cylindrical, or sometimes inflated and torulose; cells somewhat quadrate, separated; hormogones of three to six cells, showing vacuolar cell contents; sheaths close, continuous; heterocysts intercalary and lateral.

New Hampshire. On stone in damp woods. Shelburne, Lake Willoughby; on granite rocks near Shelburne. (Farlow). Hawaii. In hot water. Crater of Kilauea, Hawaii. (Schauinsland).

Var. mucosa Lemmermann. 1. c. 626. p1. 8. f. I6-18. 1905. De Toni. 1. c. 575 .

Plate XV. fig. I2.

Filaments I4-2I mic. in diameter, slightly or not at all constricted at joints, almost regularly dichotomously branched; sheaths wide, transparent, mucous, trichomes constricted at the joints; cells quadrate, cylindrical or disc-shaped; apical cell hemispherical, with less granular contents; heterocysts not known; hormogones consisting of four to six cells, filled with vacuoles, surrounded by a gelatinous sheath; protoplasmic contents (in preserved material) spindle-shaped or spherical, in contact with that of adjoining cells by means of protoplasmic threads passing through the transverse walls.

Hawaii. In hot water. Kilauea, Hawaii. (Schauinsland). 
Genus STIGONEMA Agardh. Syst. Algar. 20. 1824.

Plants terrestrial or aquatic; plant mass rigid, blackish brown, or cushion-like and soft; filaments free, rarely laterally aggregated, scattered; trichomes, in the larger filaments, consisting of two or several rows of cells; heterocysts often lateral, here and there intercalary, hormogones developed in the apices of vegetative branches or in short special branches.

I Trichomes in the mature filaments consisting usually of a single row of cells

I Filaments 7-I5 mic. in diameter; sheaths usually colorless

S. hormoides

2 Filaments 25 mic. in diameter; cells 14 mic. in diameter, 6-8 mic. in length

S. aerugineum

3 Filaments 24-26 mic. in diameter; sheaths thick, lamellose

S. panniforme

4 Filaments $14-38$ mic. in diameter; sheaths yellowish brown

S. tomentosum

5 Filaments 24-45 mic. in diameter; sheaths thick, lamellose, colorless or yellowish brown

S. ocellatum

II Trichomes in the mature filaments consisting usually of two or severai rows of cells

I Filaments up to 35 mic. in diameter

(I) Filaments $18-28$ mic. in diameter; cells often surrounded by a special darker colored envelope S. minutum

(2) Filaments 27-37 mic. in diameter; cells throughout the entire length of the filament uniformly divided $\mathbf{S}$. turfaceum

2 Filaments 40-90 mic. in diameter

(I) Hormogones 45 mic. in length, terminal, solitary or in series

$\mathrm{S}$. informe

(2) Plants rigid; hormogones 45 mic. in length, lateral

S. mamillosum

Species not well understood

\section{S. brandegeei}

448. Stigonema hormoides (Kuetzing) Bornet and Flahault. Revis. des Nostoc. Ann. Sci. Nat. Bot. VII. 5: 68. I887. De Toni. Syll. Algar. 5: 577. 1907 .

West and West. On some Freshwater Algae from the West Indies. Journ. Linn. Soc. Bot. 30: 272. I895. Collins. Algae. Flora of the Blue Hills, Middlesex Fells, Stony Brook and Beaver Brook Reservations of the Metropolitan Park Commission, Massachusetts. I28. I896. Collins, Holden and Setchell. Phyc. Bor.-Am. Fasc. 6. no. 259. I897. West and West. A Further Contribution to the Freshwater Algae of the West Indies. 1. c. 34: 286. 1899. Setchell. Notes on Cyanophyceae.-III. Erythea. 7: 47. I899. Collins. Algae of the Flume. Rhodora. 6: 230. 1904.

Plant mass thin, somewhat woolly, brownish black; filaments 7-15 
mic. in diameter, 3 decimill. long, decumbent, slender, densely interwoven, irregularly and sparingly branched; branches erect, flexuous, somewhat torulose, equal in diameter to the primary filament; sheaths thick, colorless or yellowish; cells somewhat spherical, loosely arranged in a single row, rarely in two rows; heterocysts scattered; cell contents pale blue-green.

New Hampshire. One of the species composing the brown coating on the wall of the "Flume." (Collins). Massachusetts. In gelatinous masses, on dripping rocks. Cascade, Middlesex Fells. April I8g6. (Collins). West Indies. On trees. Summit of Trois Pitons (4,500 feet); on rocks, Roseau Valley (I,000-2,000 feet), June I892; abundant on banks, Morne Micotrin; on roadside and on bank near Roseau Lake (2,700 feet); on rocks, Castle Bruce River (2,000-3,000 feet), Dominica, January, February I896. (Elliott).

Var. tenue West and West. 1. c. 30: 273. pl. 15. f. 4-8. 1895. De Toni. 1. c. 578 .

Plate XV. fig. I3.

Filaments more slender, 5.5-7 mic. in diameter.

West Indies. With the typical form but much more abundant. (Elliott).

Var. rhizodes (Kuetzing) Hansgirg. Prodromus der Algenflora von Böhmen. 2: 25. I892. De Toni. 1. c. 578 .

Wolle. Fresh-Water Algae U. S. 274. 1887.

Plant mass brownish black; filaments 8-12 mic. in diameter; branches tinilateral, slightly tapering or thickened at the apices.

Vermont. On moist rocks. Charlotte. (Wolle).

449. Stigonema aerugineum n. sp.

Plate XV. fig. I4.

Plant mass forming a brown, membranous layer; filaments 25 mic. in diameter, rounded at apices, rare, mixed with other algae; branches short, straight, spreading; sheaths thick, homogeneous, colorless; cells 14 mic. in diameter, 6-8 mic. in length, oval or depressed globose, crowded, usually forming a single row; heterocysts 8 mic. in diameter, somewhat spherical; cell contents bright blue-green.

Hawaii. Covering bottom of pool. On Puna Road, thirteen miles from Hilo, Hawaii. July Igoo. (Tilden).

450. Stigonema panniforme (Agardh) Kirchner. Algen KryptogamenFlora von Schlesien. 230. 1878. Bornet and Flahault. Revis. des Nostoc. Ann. Sci. Nat. Bot. VII. 5: 7I. I887. De Toni. Syll. Algar. 5: 580. 1907.

Wood. Contr. Hist. Fresh-Water Algae North America. 73. pl. 9. f. 3. 1872. (Sirosiphon argillaceus Wood). Wolle. Fresh Water Algae. III. Bull. Torr. Bot. Club. 6: 185. 1877; Fresh-Water Algae U. S. 273. 11. I93. f. I2, 13. I887. Bennett. Plants of Rhode Island. II4. I888. (Sirosiphon pulvinatus Bréb.). Wolle and Martindale. Algae. Britton's Catalogue of Plants found in New Jersey. Geol. Surv. N. J. 2: 6r5. I889. Hauck and Richter. Phykotheka Universalis. Fasc. 4. no. 645. I889. West and West. On some Freshwater Algae from the West Indies. 
Journ. Linn. Soc. Bot. 30: 273. I895.

Collins, Holden and Setchell. Phyc. Bor.-Am. Fasc. 2. no. 61. 1895. Collins. Algae. Flora of the Blue Hills, Middlesex Fells, Stony Brook and Beaver Brook Reservations of the Metropolitan Park Commission, Massachusetts. 128. 1896; Phycological Notes of the late Isaac Holden.-II. Rhodora. 7: 237. I905.

Plant mass caespitose, expanded, olive-black; filaments 24-36 mic. in. diameter, up to I $\mathrm{mm}$. in length, decumbent, flexuous, intricate, tapering at the apices, irregularly branched; branches erect, agglutinated laterally in fascicles, as thick as the primary filament; sheaths thick, yellowish or yellowish-brown, roughened on the surface; cells short, separated, usually iu one series; heterocysts scattered; hormogones terminal, $20 \mathrm{mic}$. in diameter, about 100 mic. in length.

Maine. Growing on rocks and moss just above high water mark, but wet by spray in rough weather. Cape Rosier. July I894. (Collins). New Hampshire. In crevices of rocks. Shelburne. August I894. (Farlow). Massachusetts. Wet rock. Middlesex Fells. (Collins). Rhode Island. Pocasset Brook. (Bennett). Connecticut. On vertical faces of trap rocks. Sargent's River, Woodbridge. November 189I. (Setchell). On moist rocks. Sage's Ravine, below first falls, Salisbury. October. (Holden). New Jersey. Frequent, on moist rocks. (Wolle). Pennsylvania. Wet mountain cliff. Pike County. (Wolle). South Carolina. On a moist clay bank near Aiken. August 1869. (Ravenel). West Indies. On trees. Summit of Trois Fitons (4,500 feet); on rocks, Roseau Valley (I,000-2,000 feet), Dominica. (Elliott).

45I. Stigonema tomentosum (Kuetzing) Hieronymus. Bemerkungen ueber einige Arten der Gattung Stigonema Ag. Hedwigia. 34: I66. 1895. De Toni. Syll. Algar. 5: 58r. I907.

Wolle. Fresh-Water Algae U. S. 269. pl. I9I. f. I-20; pl. I95. f. I6. I887. (Sirosiphon pulvinatus alpinus (Kg.) Wolle).

Plant mass compact, woolly, up to $2 \mathrm{~mm}$. in height, often cracked, crustaceous, brownish black; filaments $14-38$ mic. in diameter; primary filaments decumbent, giving off numerous elongate, erect, flexuous branches; branches often densely agglutinated into fascicles; sheaths yellowish or brownish; trichomes for the most part consisting of a single row of cells rarely of two rows; cells of the older filaments somewhat quadrate or spherical, rarely somewhat cylindrical, each surrounded by a special, deeper colored envelope; cells of the younger filaments IO-I2 mic. in diameter, often compressed, wider than long, with blue-green contents; heterocysts not rare, lateral or oftener intercalary, somewhat quadrate or spherical, oftener compressed, wider than long, yellowish; hormogones Io mic. in diameter, 40-100 mic. in length.

West Virginia. Wet rocks. Black Water Creek. (Wolle).

452. Stigonema ocellatum (Dillwyn) Thuret. Essai Class. Nostochinées. 380. 1875. Bornet and Flahault. Revis. des Nostoc. Ann. Sci. Nat. Bot. VII. 5: 69. I887. De Toni. Syll. Algar. 5: 578. 1907.

Mazé and Schramm. Essai Class. Algues Guadeloupe. 36. I870-1877. (Sirosiphon pluviale Crouan). Wood. Contr. Hist. Fresh-Water 
Algae North America. 69, 7r. pl. 8. f. 2, 3. 1872. (S ir os iph on pellucidulus Wood, S. neglectus Wood). Wolle. Fresh Water Algae. III. Bull. Torr. Bot. Club. 6: I85. 1877. (S i r os i p h on c r a m e r i Brügg). Nordstedt. De Algis Aquae Dulcis et de Characeis ex Insulis Sandvicensibus a Sv. Berggren 1875 reportatis. 7. I878. Wolle. Fresh Water Algae. Bull. Torr. Bot. Club. 6: 285. I879. (S ir os iphon ocellat us Kg.) Farlow. Notes on the Cryptogamic Flora of the White Mountains. Appalachfa. 3: 236. 1883. Wittrock and Nordstedt. Algae Aq. Dulc. Exsicc. no. 668. I883. Wolle. Fresh-Water Algae U. S. 272. pl. I94. f. r-3, II-I6. 1887. Bennett. Plants of Rhode Island. I14. 1888. Wolle and Martindale. Algae. Britton's Catalogue of Plants found in New Jersey. Geol. Surv. N. J. 2: 605. I889. Collins, Holden and Setchell. Phyc. Bor.-Am. Fasc. Io. no. 455. 1898. Setchell. Notes on Cyanophyceae.-III. Erythea. 7: 48. I899. Saunders. The Algae. Harriman Alaska Expedition. Proc. Wash. Acad. Sci. 3: 399. I90I. Setchell and Gardner. Algae of Northwestern America. Univ. Calif. Pub. Bot. I: I96. I903. Collins. Algae of the Flume. Rhodora. 6: 230. 1904. Lemmermann. Algenfl. Sandwich.-Inseln. Bot. Jahrb. 34: 625. 1905. Collins, Holden and Setchell. Phyc. Bor.-Am. Fasc. 27. no. I309. Ig06. Tilden. Notes on a collection of Algae from Guatemala. Proc. Biol. Soc. Wash. 21: I55. 1908; American Algae. Cent. VII. Fasc. I. no. 626. Igog.

\section{Plate XV. fig. I5-I7.}

Plant mass caespitose or cushion-like, woolly, brownish; filaments $3^{-8}$ $\mathrm{mm}$. long, erect, decumbent at the base, irregularly branched; branches scarcely more slender than the primary filaments, $35-45$ mic. in diameter, elongate, straight, spreading, all bearing hormogones; sheaths thick, lamellose, colorless or yellowish brown; trichomes consisting of one, rarely two rows of cells; cells $20-30 \mathrm{mic}$. in diameter, of various sizes, often wider than long, each surrounded by a special, darker colored envelope; heterocysts rare, lateral; hormogones $15 \mathrm{mic}$. in diameter, 50-65 mic. in length.

Alaska. On rocks in a rapid stream emptying into Glacier Bay; floating in a quiet freshwater pool, Prince William Sound, June I899. (Saunders). New Hampshire. Common on the wet rocks of the Flume and Berlin Falls. (Farlow). One of the species composing the brown coating on wall of Flume. September 1904; among decaying vegetation on bottom of lake. Lake Chocorua. September 1906. (Collins). Massachusetts. Attached to Sedges in freshwater swamp. Falmouth. August I897. (Moore). Rhode Island. Quidnessett. (Bennett). New York. Forming, with minute mosses, a blackish, turfy coating to a steep slope of bare rock (5,000 feet), over portions of which water is continually dripping. Near top of Mount Tahawus, Adirondack Mountains. (Wcod). New Jersey. Forming, with various other species of algae, a gelatinous blue-green or brown stratum; in a. very stagnant pool; on submerged sticks in swampy places, "in dark brown waving tufts, about one-half inch in length"; Bamber Lake, I883. (Wolle). Florida. In a marsh pool. Near Hibernia. (Canby). Central America. Growing on edges of steam-holes on side of Volcano Santa Maria, near Lake Atitlan. February 1906. (Kellerman). West Indies. On 
rocks. Castle Bruce River (2,000-3,000 feet), Dominica. January, February r896. (Elliott). Hawaii. In stagnant water. Mauna Kea, Hawaii. (Berggren, Lemmermann).

453. Stigonema minutum (Agardh) Hassall. History of the British Freshwater Algae. I: 230. pl. 67. f. 3, 4. I845. Bornet and Flahault. Revis. des Nostoc. Ann. Sci. Nat. Bot. VII. 5: 72. I887. De Toni. Syll. Algar. 5: 582. 1907.

Wood. Prodromus of a Study of the Freshwater Algae of Eastern North America. 133. I869; Contr. Hist. Fresh-Water Algae North America. 72, 74. pl. 9. f. 2. 1872. (Sirosiphon acervatus Wood, S. 1 ignico1 a Wood). Wolle. Fresh-Water Algae U. S. 273. pl. I93. f. I-II. I887. West and West. On some Freshwater Algae from the West Indies. Journ. Linn. Soc. Bot. 30: 273. 1895; A Further Contribution to the Freshwater Algae of the West Indies. 1. c. 34: 286. 1899. Collins, Holden and Setchell. Phyc. Bor.-Am. Fasc. I5. no. 7I3. I900. Saunders. The Algae. Harriman Alaska Exped. Proc. Wash. Acad. Sci. 3: 399: I90I. Setchell and Gardner. Algae of Northwestern America. Univ. Calif. Pub. Bot. I: I97. I903. Collins. Algae of the Flume. Rhodora. 6: 230. I904; Phycological Notes of the late Isaac Holden.-II. Rhodora. 7: 237. 1905. Lemmermann. A1genfl. Sandwich.-Inseln. Bot. Jahrb. 34: 627. I905.

Plate XV. fig. I8, 19.

Plant mass crustaceous or cushion-like, thin, fragile, blackish; filaments 18-28 mic. in diameter, about I $\mathrm{mm}$. in length, decumbent at the base, ascending, flexuously curved, branched; branches sometimes long, similar to the primary filaments, sometimes very short, bearing hormogones, often very much crowded on one side; sheaths yellowish or yellowish brown, lamellose, the special envelope surrounding each cell frequently of a deeper color; trichomes in the basal portion of the filament usually consisting of one row of cells, those in the middle and upper portions often composed of two to four rows; heterocysts numerous, lateral or intercalary; hormogones Iz-I5 mic. in diameter 25-35 mic. in length.

Alaska. Forming a thin brown coating with $\mathrm{Ch}$ roococcus rufesc e $\mathrm{n}$ s, on damp rocks, several hundred feet above sea level. Prince William Sound. (Trelease). Greenland. (Börgesen). New Hampshire. One of the species composing the brown coating on wall of the Flume. September 1904. (Collins). Massachusetts. On wet cliff. Cascade, Melrose. April I900. (Collins). Connecticut. On submerged rocks in Plantain Pond, Salisbury. October. (Holden). South Carolina. On old boards. April; on boards over which spring water was constantly running, August; growing on bark of I l ex op a ca; on old wood and on trunks of trees. (Ravenel); West Indies. On damp wall of dam. Sharp's River, St. Vincent; on trees, summit of Trois Pitons (4500 feet); on lime-trees, Shanford Estate; in stream, Wotten Waven, Dominica. (Elliott). Hawaii. On gravelly volcanic soil. Hilo, Hawaii. (Berggren, Schauinsland). c. 584 .

Var. saxicola (Naegelii) Bornet and Flahault. 1. c. 73. De Toni. 1. 
Nordstedt. De Algis Aquae Dulcis et de Characeis ex Insulis Sandvicensibus a Sv. Berggren 1875 reportatis. 7. 1878 . (Sirosiphon saxicola Naeg.). Farlow. Notes on the Cryptogamic Flora of the White Mountains. Appalachia. 3: 236. I883. Wittrock and Nordstedt. Algae Aq. Dulc. Fixsicc. no. 669. 1884 .

Plant mass usually thin, crustaceous; filaments $\mathbf{1 5 - 2 1}$ mic. in diameter; sheaths brown or brownish yellow; cells usually compressed, spherical in the primary filaments, short and often dense in the branches, in the apex truncate and forming a single row.

New Hampshire. On exposed rocks and on Stereocaulon. Top of Cabot Mountain, Shelburne. (Farlow). Pennsylvania. (Wolle). Hawaii. On gravelly volcanic soil. Hilo, Hawaii. (Berggren)

45. Stigonema turfaceum (Berkeley) Cooke. British Fresh-Water Algae 272. pl. III. f. 2. I882-I884. Bornet and Flahault. Revis. des Nostoc. Ann. Sci. Nat. Bot. VII. 5: 74. I887. De Toni. Syll. Algar. 5: 584. 1907.

Wood. Contr. Hist. Fresh-Water Algae North America. 75. I872. (Sirosiphon pulvinatus Bréb.). West. The Freshwater Algae of Maine. Journ. of Bot. 27:207. I889. Richter. Süsswasseralgen aus dem Umanakdistrikt. Bib. Bot. 7: Heft. 42. 4. I897.

Plate XV. fig. 20.

Plant mass cushion-like, deep olivaceous black; filaments 27-37 mic. in diameter, up to $\mathrm{I} \mathrm{mm}$. in length, decumbent at the base, ascending, variously curved, much branched; branches resembling the primary filament, erect, bearing hormogones at the apex; sheaths thick, lamellose, yellowish brown; trichomes consisting of from two to four rows of cells; heterocysts collateral; hormogones 12 mic. in diameter, $45 \mathrm{mic}$. in length.

Greenland. East coast. Summers of 1892 and I893. (Vanhöffen). Maine. (West). New Jersey. Growing on exposed face of rocks. (Austin). Pennsylvania. On rocks. Near Philadelphia. (Wood).

Var. parvus Wood. Contr. Hist. Fresh-Water Algae North America. 75. pl. Io. f. I. I872. De Toni. 1. c. 585 .

Filaments closely interwoven into a deep olive black, turfy mass, very thick, irregularly. and frequently branched, yellowish brown; branches polymorphous, their apices usually obtusely rounded, containing from one to four rows of cells; sheaths thick, light yellowish brown, sometimes colorless; trichomes consisting usually of several row of cells, cell contents granular, usually deep brown, sometimes light green.

Pennsylvania. On the face of dripping rocks along the Wissahickon Creek, near Philadelphia. (Hunt).

455. Stigonema informe Kuetzing. Spec. Algar. 3I9. r849. Bornet and Flahault. Revis. des Nostoc. VII. 5: 75. I887. De Toni. Syll. Algar. 5: 585 . I907.

Wood. Contr. Hist. Fresh-Water Algae North America. 73. pl. 8. f. 4. 1872. (Sirosiphon gut tula Wood). Wolle. Fresh Water Algae. III. 
Bull. Torr. Bot. Club. 6: 185 . 1877. (S i r os iphon coralloides Kg., S.: la cu'stris Rab.); Fresh-Water Algae U. S. 270. pl. I9I. f. 2I; pl. I92. f. 9-12. 1887. Wolle and Martindale. Algae. Britton's Catalogue of Plants found in New Jersey. Geol. Surv. N. J. 2: 605. 1889. West and West. On some Freshwater Algae from the West Indies. Journ. Linn. Soc. Bot. 30. 273. I895. Setchell. Notes on Cyanophyceae.-I. Erythea. 4: 88. I896; Notes on Cyanophyceae.-II. Erythea. 4: I9I. I8g6.

$$
\text { Plate XV. fig. } 2 \text { I. }
$$

Plant mass expanded, caespitose or crustaceous, somewhat mucous, brownish or black; filaments $40-70 \mathrm{mic}$. in diameter, $1-2 \mathrm{~mm}$. in length, erect from a decumbent base, irregularly branched; branches $45 \mathrm{mic}$. in diameter, straight or bent, branched on upper side, all bearing hormogones; sheaths thick, lamellose, yellowish brown; cells I5-I 8 mic. in diameter; heterocysts numerous, collateral; hormogones $\mathrm{I} 8 \mathrm{mic}$. in diameter, $45 \mathrm{mic}$. in length, solitary or in series.

Vermont. Wet rocks. Mt. Mansfield. (Wolle). Connecticut. In small quantity in Long Pond, Lantern Hill, Ledyard. (Setchel1). New Jersey. On stones constantly washed by the waves, along the rocky shores of Green Pond, Morris. (Wolle). On dry rocks and on moist rocks. (Austin.) South Carolina. Growing on the bark of $\mathrm{T}$ a $\mathrm{x}$ o d i u $\mathrm{m} \mathrm{d}$ is $\mathrm{tich} \mathrm{um}$. Aiken. (Ravenel). West Indies. On trees. Summit of Trois Pitons (4500 feet). Dominica. (Elliott).

456. Stigonema mamillosum (Lyngbye) Agardh. Syst. Algar. 42. I824. Bornet and Flahault. Revis. des Nostoc. Ann. Sci. Nat. Bot. VII. 5: 77. 1887. De Toni. Syll. Algar. 5: 587. 1907.

Wood. Contr. Hist. Fresh-Water Algae North America. 77. 1872. Farlow. Marine Algae New England. 40. 1882; Notes on the Cryptogamic Flora of the White Mountains. Appalachia. 3: 236. I883. Collins. Algae. Rand and Redfield's Flora of Mount Desert Island, Maine. 247. I894; Algae. Flora of the Blue Hills, Middlesex Fells, Stony Brook and Beaver Brook Reservations of the Metropolitan Park Commission, Massachusetts. I28. 1896. Collins, Holden and Setchell. Phy. Bor.-Am. Fasc. 8. no. 356. 1897. Collins. Algae of the Flume. Rhodora. 6: 230. 1904; Phycological Notes of the late Isaac Holden.-II. Rhodora. 7: 237, 243. I905.

\section{Plate XV. fig. 22.}

Plant mass cushion-like, woolly, up to $12 \mathrm{~mm}$. in thickness; filaments up to $65 \mathrm{mic}$. in diameter, erect, rigid, interwoven, very much branched at the base; branches $45-50 \mathrm{mic}$. in diameter, gradually tapering at the ends, erect, spreading, with numerous branchlets; some branchlets sterile, long and thick, others bearing hormogones, mammilliform, short, spreading, shorter than the diameter of the branch, 24 mic. in diameter; sheaths thick, lamellose, often torulose, yellowish brown; hormogones short, 15 mic. in diameter, 45-50 mic. in length; heterocysts collateral.

Newfoundland. On submerged stones in a pond at the foot of Windsor Lake, near St. John's. July 1897. (Holden). Maine. On rocks in outlet of Hadlock Lower Pond. (Holden). New Hampshire. On submerged stones 
in the Androscoggin River, Shelburne. (Farlow). On rocks just outside the Flume. (Collins). Massachusetts. In a brook which empties into the sea at Rafe's Chasm, Magnolia Cove, in Gloucester. (Farlow). On pebbles at margin of Spot Pond, Cascade, Middlesex Fells. (Collins). Connecticut. On damp rocks in Mill River, near Samp Mortar Rock; on stones in Pequonnock River. July. (Holden). New York. Round Pond, near West Point. (Bailey).

457. Sirosiphon brandegeei Wolle. Fresh-Water Algae U. S. 274. pl. I94. f. 17-27. 1887. De Toni. Syll. Algar. 5: 590. 1907.

Filaments 12-20 mic. in diameter, with somewhat pointed apices, reddish brown; cells in one, two or three rows.

Colorado. On "shores" of a soda spring. Cannon City (Brandegee).

Genus CAPSOSIRA Kuetzing. Spec. Algar. 344. 1849.

Plant mass hemispherical, cushion-like, attached by lower surface, formed of filaments growing together laterally, aquatic; filaments erect, branched, composed of a single row of cells; sheaths septate; heterocysts intercalary and lateral; hormogones composed of from Io-20 cells; gonidia spherical; wall of gonidium thick, brownish.

458. Capsosira brebissonii Kuetzing. Spec. Algar. 344. 1849. Bornet and Flahault. Revis. des Nostoc. Ann. Sci. Nat. Bot. VII. 5: 79. I887. De Toni. Syll. Algar. 5: 592. Ig07.

Wolle. Fresh Water Algae. Bull. Torr. Bot. Club. 6: 283. I879. Setchell. Notes on some Cyanophyceae of New England. Bull. Torr. Bot. Club. 22: 427. I895. Collins, Holden and Setchell. Phyc. Bor.-Am. Fasc. 26. no. 1257. 1905 .

\section{Plate XVI. fig. I.}

Plant mass crustaceous-confluent or hemispherical, I-3 mm. thick, gelat.. inous, hard, blackish green, within showing concentric zones of green and yellowish tints; filaments 7.5 mic. in diameter, straight, densely crowded, irregularly branched, torulose; branches appressed, close, upright, fastigiate; sheaths thick, gelatinous, not lamellose, colorless or yellowish; cells 4-5 mic. in diameter, somewhat globose, distant; heterocysts lateral.

New Hampshire. On shells. Lake Chocorua. September I904. (Farlow). Connecticut. Growing on a large rock on the eastern side of Round Pond at Lantern Hill, near Mystic. (Setchell).

\section{Genus NOSTOCHOPSIS Wood.}

Prodr. Fresh-Water Alg. N. A. 126. 1869.

Plant mass or colony gelatinous, definite, aquatic; trichomes formed of a single row of cells, branched; heterocysts intercalary and lateral, pedicellate or sessile.

459. Nostochopsis lobatus Wood. Prodromus of a Study of the FreshWater Algae of Eastern North America. 127. 1869; Contr. Hist. Fresh-Water Algae North America. 45. pl. 3. f. 6. 1872. Bornet 
and Flahault. Revis, des Nostoc. Ann. Sci. Nat. Bot. VII. 5: 80. I887. De Toni. Syll. Algar. 5: 592. I907.

Farlow. Notes on Fresh-Water Algae. Bot. Gaz. 8: 225. 1883. Collins, Holden and Setchell. Phyc. Bor.-Am. Fasc. 3. no. IIo. I895. Setchell. Notes on some Cyanophyceae of New England. Bull. Torr. Bot. Club. 22: 427. I895. Collins. Phycological Notes of the late Isaac Holden.-II. Rhodora. 7: 237. 1905.

\section{Plate XVI. fig. 2.}

Colony vesicular, lobed, up to $2 \mathrm{~cm}$. in diameter, hollow, blue-green or yellowish green; trichomes 4-9 mic. in diameter, I mm. in length, branched from the base, loose, elongate, flexuous, often constricted at joints; branches unilateral, fastigiate, cylindrical below, torulose in upper portions, somewhat club-shaped; cells up to twice as long as wide; heterocysts lateral, exserted, or intercalary.

Vermont. Forming expansions of several inches in water courses. Ferrisburg. (Faxon and Hosford). Connecticut. Forming irregular, firmly gelatinous balls growing upon stones in more or less rapid water in a brook just west of the "head" of the mountain. Mt. Carmel, about seven miles north of New Haven. September I893 and I895. (Setchell). In brook. Mt. Carmel. September. (Holden).

Pennsylvania. Floating. Schuylkill River, just above Manayunk. (Wood).

\section{Family V. RIVULARIACEAE}

Filaments tapering from base to apex, ending in a colorless hair, simple or branched; false branches due to development of new trichome from a cell of the main trichome, usually occurring immediately under an intercalary heterocyst-rarely by the perforation of the sheath between two heterocysts by the trichome, as in Scytonema-either separating immediately and forming a new sheath, or remaining for some time within the origirial sheath; heterocysts usually present, usually basal, occasionally intercalary; reproduction by means of vegetative division, hormogones and gonidia.

I Heterocysts not present

\section{Amphithrix}

\section{Heterocysts present}

I Filaments free, simple or coalesced into a branched plant mass

(I) Sheaths cylindrical

A Filaments simple or branched; false branches distinct, free

\section{Calothrix}

B Filaments branched; false branches several (two to six) remainnng within the original sheath or common tegument

\section{Dichothrix}

C Filaments branched; false branches many (up to a hundred) remaining within the original sheath or common tegument

Polythrix

(2) Sheaths thick, saccate

Sacconema 
2 Filaments coalesced into a crustaceous, spherical or hemispherical, mucous or gelatinous plant mass or colony

(I) Heterocysts basal

A Filaments simple, parallel, associated in a crustaceous layer

Isactis

B Filaments branched, radially arranged, associated in a spherical or hemispherical colony

(2) Heterocysts intercalary

Rivularia

Brachytrichia

Genus AMPHITHRIX Kuetzing. Phyc. Gen. 220. I843.

Plant mass crustaceous or caespitose, thin, expanded, of a purple or violet color, consisting of two layers: the lower layer composed of densely interwoven filaments or of minute, radiately disposed series of cells; the upper layer consisting of simple erect filaments, closely packed together and tapering to fine points; sheaths thin, close, continuous; hormogones solitary or in series; heterocysts not present.

460. Amphithrix janthina (Montagne) Bornet and Flahault. Revis. des Nostoc. Ann. Sci. Nat. Bot. VII, 3: 344. 1886 . De Toni. Syl.. Algar. 5: 60I. 1907.

Collins. Notes on New England Marine Algae--VI. Bull. Torr. Bot. Club. 23:2. 1896; Preliminary Lists of New England Plants.-V. Marine Algae, Rhodora. 2: 4I. I900; Phycological Notes of the late Isaac Holden. --II. Rhodora. 7: 237. I905.

\section{Plate XVI. fig. 3 .}

Plant mass crustaceous, thin, purple; filaments $1.5-2.2$ mic. in diameter, 3-5 decimill. in length, erect, close, purplish; sheaths thin, unfform, very close; cells equal to the diameter in length; hormogones $20 \mathrm{mic}$. in length; cell contents pale blue-green.

Massachusetts. On wet cliffs just above high water mark. Rockport. (Collins). Connecticut. Coating stones in Island Brook, below R. R. October. (Holden).

Var. torulosa (Grunow) Bornet and Flahault. 1. c. 344. De Toni. 1. c. 6or.

Collins. Notes on New England Marine Algae. VI. Bull. Torr. Bot. C.lub. 23: 2. I896. Collins, Holden and Setchell. Phyc. Bor.-Am. Fasc. 6. no. 262. 1897. Collins. Preliminary Lists of New England Plants.-V. Marine Algae. Rhodora. 2: 4I. I900.

Filaments up to $5 \mathrm{~mm}$. in length; trichomes torulose.

Massachusetts. Forming a purplish coating on stone in ditch in salt marsh near Linden Station, Revere. September I892. (Collins).

46r. Amphithrix violacea (Kuetzing) Bornet and Flahault. Revis. des Nostoc. Ann. Sci. Nat. Bot. VII. 3:344. 1886. De Toni. Syll. Algar. 5: 602. 1907 . 
Collins, Holden and Setchell. Phyc. Bor.-Am. Fasc. 5. no. 218 . I8g6. Collins. Preliminary Lists of New England Plants.-V. Marine Algae. Rhodora. 2: 4I. I900; Phycological Notes of the late Isaac Holden.-II. Rhodora. 7: 223. I905.

Plate XVI. fig. 4.

Plant mass caespitose, brownish red or violet; filaments $2-3$ mic. in drameter, I-3 mm. in length, erect, fasciculate; sheaths thin, uniform; trichomes constricted at the joints; cells shorter than their diameter; cell contents granular.

Maine. On cliffs at high water mark. Eagle Island, Penobscot Bay. July I892. (Collins). Rhode Island. (Collins). Connecticut. On stones. Fresh Pond. November. (Holden).

Genus CALOTHRIX Agardh. Syst. Algar. 24. 1824.

Plant mass consisting of penicillate tufts or a soft velvety expansion; filaments simple or slightly branched; heterocysts basal or intercalary, absent in a few species; gonidia basal, seriate.
I Heterocysts not present.
C. juliana

II Heterocysts present.

I Plants living in salt water

(I) Heterocysts basal

A Plants fasciculate or penicillate, parasitic
a Filaments $12-15$ mic. in diameter
C. confervicola
b Filaments 2I-29 mic. in diameter
C. consociata

B Plants caespitose, often growing on rocks

a Filaments 8-I2 mic. in diameter; cell contents violet

C. fusco-violacea

b Filaments Io-r 8 mic. in diameter; cell contents olive green
C. scopulorum

c Filaments 9-I5 mic. in diameter; cell contents olive green

C. contarenii

d Filaments 15-20 mic. in diameter; cell contents olive green

C. pulvinata

e Plants parasitic; filaments 9-I 5 mic. in diameter, thickened into a bulb at the base; cell contents blue-green

\section{C. parasitica}

(2) Heterocysts basal and intercalary

A Filaments 9-12 mic. in diameter, scarcely thickened at base
C. aeruginea

B Filaments I5-I8 mic. in diameter; false branches solitary

C. prolifera

C Filaments I2-2I mic. in diameter; false branches fasciculate at the apex of the filament

C. fasciculata 
D Filaments 12-24 mic. in diameter; false branches in pairs, arising between two heterocysts

C. vivipara

E Filaments Io-40 mic. in diameter, interwoven at base, decumbent

C. pilosa

F Filaments I2-40 mic. in diameter, not branched; sheaths yellowish brown

C. crustacea

2 Plants living in fresh water

(I) Plants epiphytic

A Filaments 5-7.5 mic. in diameter; trichomes 3.4-4 mic. in diameter

C. epiphytica.

B Filaments 7-8 mic. in diameter; heterocysts basal, usually in pairs

C. scytonemicola

C Filaments 8-1o mic, in diameter; trichomes 6-9 mic. in diameter, especially constricted at joints; heterocysts basal, in pairs

\section{C. stagnalis}

D Filaments IO-I2 mic. in diameter, curved and bulbous-inflated at the base; trichomes $7-8$ mic. in diameter

\section{C. fusca}

E Filaments 5-I5 mic. in diameter, sometimes thicker at the base; trichomes $3.5-5.5 \mathrm{mic}$. in diameter

\section{C. sandwicensis}

F Filaments 15-16 mic. in diameter at base; sheaths thick, lamellose, finally becoming brownish black; cells very short

C. breviarticulata

G Filaments I5-I8 mic. in diameter; sheaths wide, often truncate, almost colorless; trichomes 7-9 mic. in diameter

\section{C. violacea}

H Filaments I8-24 mic. in diameter; sheaths thick, gelatinous, lamellose, finally ocreate

C. adscendens

(2) Flants living in warm or hot water

A Filaments 8-10 mic. in diameter; sheaths somewhat thick, uniform, transparent, sometimes yellowish at base; heterocysts basal, rarely intercalary

c. thermalis

B Filaments 8-Io mic. in diameter; sheaths close, ocreate, transparent, becoming yellowish brown; heterocysts basal and intercalary, spherical or quadrate

C. calida

C Filaments IO-II mic. in diameter; sheaths close, thick, lamellose, ocreate, transparent and yellowish C. kuntzei

(3) Plants living on stones and wood

A Filaments 9-ro mic. in diameter; sheaths narrow, close, uniform, colorless; trichomes 6-7 mic. in diameter C. braunii

B Filaments IO-12 mic. in diameter; sheaths thick, close, uniform or ocreate, yellowish brown

C. parietina

C Filaments I2-I3 mic. in diameter; sheaths thin, close, uniform, colorless or yellowish

C. castellii 
Species not well understood
C. donnellii
M. elongatum
M. fertile
M. fibrosum
M. halos
C. lacucola
S. obscurus
M. pardoxum
C. rhizosoleniae
M. sejunctum
M. turgida

462. Calothrix juliana (Meneghini) Bornet and Flahault. Revis. des Nostoc. Ann. Sci. Nat. Bot. VII. 3: 348. I886. De Toni. Syll. Algar. 5: 605. 1907.

Setchell. Notes on some Cyanophyceae of New England. Bull. Torr. Bot. Club. 22: 425. I895. Collins, Holden and Setchell. Phyc. Bor.-Am. Fasc. 3. I895. Tilden. American Algae. Century II. no. 163. I896. Collins. The Algae of Jamaica. Proc. Am. Acad. 37: 241. 1901. Brown. Algal periodicity in certain ponds and streams. Bull. Torr. Bot. Club. 35: 247. J908.

\section{Plate XVI. fig. 5.}

Filaments scattered or forming an interrupted, olivaceous layer, densely crowded, erect, simple, rigid, often thickened at the base, 10-15 mic. in diameter, $2 \mathrm{~mm}$. in length; sheaths thin, close, not lamellose, colorless; trichomes 9-I2.5 mic. in diameter, ending in a long, tapering, fragile hair; cells three times shorter than their diameter; hormogones 4 or 5 times longer than their diameter.

United States. (Farlow). Massachusetts. Massopoag Brook, Sharon. (Setchell). Connecticut. Growing on wood and on stones. Trading Cove Brook, Norwich; Quinebaug River, Lisbon. (Setchell). Forming small isolated blackish tufts (I-3 mm. in diameter), on smooth stones in shallow water. Trading Cove Brook, Norwich. September I892. (Setchell). Indiana. Bloomington. (Brown). California. On stones in stream. Pasadena. January I896. (McClatchie). West Indies. On stones in stream. Roaring River, St. Ann's Bay, Jamaica. March I893. (Humphrey).

463. Calothrix confervicola (Roth) Agardh. Syst. Algar. 70. I824. Bornet and Flahault. Revis. des Nostoc. Ann. Sci. Nat. Bot. VII. 3: 340. I886. De Toni. Syll. Algar. 5: 606. 1907.

Harvey. Nereis Boreali-Americana. Part III. 105. 1858. Farlow. List Marine Algae United States. Proc. Am. Acad. Arts Sci. 10: 380. I875. Hall. List of the Marine Algae growing in Long Island Sound within 20 miles of New Haven. Bull. Torr. Bot. Club. 6: II2. 1876. Farlow. Marine Algae of New England. 36. pl. I. f. 6. I88r. Pike. Check List of Marine 
Algae. Bull. Torr. Bot. Club. 13: 105. 1886. Bennett. Plants of Rhode Island. 95. I888. Collins. Algae from Atlantic City, N. J. Bull. Torr. Bot. Club. I5: 310. I888; Marine Algae of Nantucket. 5. I888; Algae of Middlesex County. I3. r888. Martindale. Marine Algae of the New Jersey coast and adjacent waters of Staten Island. Mem. Torr. Bot. Club. I: 9I, I889. Wolle and Martindale. Algae. Britton's Catalogue of Plants found in New Jersey. Geol. Surv. N. J. 2: 602. I889. Anderson. List of California Marine Algae, with notes. Zoe. 2: 218. I89I. Collins, Holden and Setchell. Phyc. Bor.-Am. Fasc. I. no. 9. I895. Collins. Preliminary lists of New England Plants.-V. Marine Algae. Rhodora. 2: 4I. I900; The Algae of Jamaica. Proc. Am. Acad. 37: 24I. I90I. Lemmerman, E. Algenfl. Sandwich.-Inseln. Bot. Jahrb. 34: 627. I905. Collins. Phycological Notes of the late Isaac Holden.-II. Rhodora. 7: 223. I905.

\section{Plate XVI. fig. 6-8.}

Filaments gregarious, stellately fasciculate, attached to larger algae, rigid, not thickened at the base, blackish green or lead-colored, I2-25 mic. in diameter, 2-3 $\mathrm{mm}$. in length; sheaths close, very often entirely colorless, sometimes yellowish brown in lower parts, homogeneous, soft, gelatinous in upper portions; trichomes IO-I8 mic. in diameter; cells four or five times shorter than their diameter; heterocysts one or two, basal; hormogones numerous in the sheath, four to six times longer than their diameter.

Canada. On other algae. Malpeque, Prince Edward Island. (Faull). New England. On algae of all kinds. Very common in summer. (Farlow). Maine. (Collins). New Hampshire. (Cóllins). Massachusetts. On Enteromorpha intestinalis in ditches in salt marshes. Wood's Hole. July I892. (Setchel1). "Parasitic" on various algae at Brant Point; on Ulva in salt water, Medford, Everett. (Collins). Rhode Island. On the filiform marine algae. (Bailey, Olney, Hunt). Connecticut. On R u ppia, Fresh Pond, August. (Holden). New York. Shores of Long Island. In fresh and salt water. Bay Ridge, Fort Hamilton. Summer. Staten Island. (Pike). New Jersey. On rockweed. Atlantic City. (Morse, Martindale). Hudson: Hoboken and Communipaw. (Pike). New York Bay. (Hooper). California. Common. (Anderson). West Indies. On various algae. Port Antonio. Jamaica. March r893. (Humphrey). Hawaii. On marine algae. Laysan. I896-1897. (Schauinsland).

Var. purpurea Bornet and Flahault. 1. c. 350. De Toni. 1. c. 607.

Collins, Holden and Setchell. Phyc. Bor.-Am. Fasc. 30. no. I456. I908.

Trichomes purple.

Maine. On Cladophora expansa (Kuetz). In marsh pools. Stover's Point. Harpswell. I3 July rgo5. (Collins).

464. Calothrix consociata (Kuetzing) Bornet and Flahault. Revis. des Nos toc. Ann. Sci. Nat. Bot. VII. 3: 35I. 1886. De Toni. Syll. Algar. 5: 607. 1907 .

Setchell and Gardner. Algae of Northwestern University. Univ. Calif. Pub. Bot. I: 197. 1903. 
Plate XVI. fig. 9.

Filaments gregarious and stellately fasciculate, attached to filiform algae, curved, decumbent and slightly thickened at the base, blackish green, 2I-29 mic. in diameter, $.5 \mathrm{~mm}$. in length; sheaths close, membranaceous, brownish, with dilated, funnel-shaped apex, the outside layers colorless; trichomes 12 mic. in diameter; cells three times shorter than the diameter; heterocysts basal; cell contents olive.

Washington. On grasses in a salt marsh. Head of Penn's Cove, near Coupeville, Whidbey Island. (Gardner).

465. Calothrix fusco-violacea Crouan in herb. Thuret and Mus. Paris. Bornet and Flahault. Revis. des Nostoc. Ann. Sci. Nat. Bot. VII. 3: 352. I886. De Toni. Syll. Algar. 5: 608. I907.

Setchell. Notes on Cyanophyceae.-I. Erythea. 4: 87. 1896. Collins, Holden and Setchell. Phyc. Bor.-Am. Fasc. 5. no. 217. I896. Collins. Preliminary Lists of New England Plants.-V. Marine Algae. Rhodora. 2: 4I. I900.

\section{Plate XVI. fig. Io.}

Filaments 8-I2 mic. in diameter, .5 mm. in length, gregarious, forming a velvety, indefinite or violet mass, bent and thickened at the base; sheaths close, thin, colorless, uniform, gelatinous and diffluent in upper parts; trichomes 7-8 mic. in diameter, constricted at joints, at first ending in a short hair which falls off when hormogones are formed, leaving apex truncate; cells shorter than their diameter; heterocysts basal, often worn out; hormogones many within the sheath, up to ten times longer than their diameter.

Massachusetts. Forming orbicular velvety patches, reddish purple to dark blue-green in color, on $\mathrm{P}$ unctaria p la n t a gin ea. Wood's Hole. Summer of I895. (Nott).

466. Calothrix scopulorum (Weber and Mohr) Agardh. Syst. Algar. 70. I824. Bornet and Flahault. Revis. des Nostoc. Ann. Sci. Nat. Bot. VII. 3: 353. I886. De Toni. Syll. Algar. 5: 608. 1907.

Harvey. Nereis Boreali-Americana. Part III. 105. 1858. Farlow. List Marine Algae United States. Proc. Am. Acad. Arts Sci. Io: 380 . 1875. Kjellman. Algae of the Arctic Sea. 322. I883. Pike. Check List of Marine Algae. Bull. Torr. Bot. Club. I3: 105. I886. Collins. Algae from Atlantic. City, N. J. Bull. Torr. Bot. Club. 15: 3I0. I888. Bennett. Plants of Rhode Island. 95. I888. Martindale. Marine Algae of the New Jersey coast and Adjacent Waters of Staten Island. Mem. Torr. Bot. Club. I: 9I. I889. Wolle and Martindale. Algae. Britton's Catalogue of Plants found in New Jersey. Geol. Surv. N. J. 2: 603. I889. Collins. Algae--Rand and Redfield's Flora of Mount Desert Island, Maine. 246. I894. Rosenvinge. Les Algues Marines du Groenland. Ann. Sci. Nat. Bot. VII. I9: I62. I894; Deuxième Mémoire sur les Algues marines du Groenland. Medd. om Groenland. 20: 121. 1898. Collins. Preliminary Lists of New England Plants.V. Marine Algae. Rhodora. 2: 4I. I900. Saunders. The Algae. Harriman Alaska Expedition. Proc. Wash. Acad. Sci. 3: 399. I901. Collins, Holden and Setchell. Phyc. Bor.-Am. Fasc. I7. no. 805. I901. Setchell and Gard- 
ner. Algae of Northwestern America. Univ. Calif. Pub. Bot. I: 197. 1903. Collins. Phycological Notes of the late Isaac Holden.-II. Rhodora. 7: 223, 243. 1905. Börgesen and Jonsson. The Distribution of the Marine Algae cf the Arctic Sea and of the Northernmost Part of the Atlantic. Bot. Faeroes. App. XXV. I905.

\section{Plate XVI. fig. II, I2.}

Plant mass caespitose, velvety, widely expanded, dark green or olive; filaments IO-I $8 \mathrm{mic}$. in diameter, up to $1 \mathrm{~mm}$. in length, twisted and curled, moderately thickened at the base; sheaths somewhat thick, colorless, yellowish brown, or forming yellowish and colorless zones, lamellose in the larger filaments, variously dilated and expanded; trichomes 8-15 mic. in diameter, ending in a hair; heterocysts one to three, basal; hormogones numerous in the sheath, four or five times longer than their diameter.

Greenland. Forming "in conjunction with several other algae, a thin stratum over stones within the upper part of the littoral zone. It is scarce here (in the Polar Sea), and nowhere occurs in great masses. It has been found both on exposed and sheltered coasts." Greenland Sea; West coast of Spitzbergen. (Kjellman). Forming a gelatinous cushion upon rocks in the littoral region. (Sorenson). East and west portions. (Börgesen and Jonsson). Newfoundland. On rocks between tides. Quidi Vidi. July I897. (Holden). Maine. Very common on rocks. Seal Harbor; Little Cranberry Isle (Collins); Sea Wall (Holden). New Hampshire. (Collins). Massachusetts. On rocks near high water mark. Marblehead. June Igor. (Collins). Rhode Island. Rocks near high water mark. (Bailey and O1ney.) Connecticut. On rocks. Stratford Shoals. July, September. (Holden). New York. Shores of Long Island. Greenport, Little Egg Harbor. Summer. (Pike). Staten Island. (Pike). New Jersey. Hoboken, Beesley's Point. (Pike). On wharves. Atlantic City. (Morse, Martindale). On woodwork. (Morse). New Jersey. Marine. Hudson: Hoboken; Cape May; Beesley's Point. (Pike). On wharves, Atlantic City. (Morse). Washington. In salt water. Puget Sound. (Saunders).

467. Calothrix contarenii (Zanardini) Bornet and Flahault. Revis. des Nostoc. Ann. Sci. Nat. Bot. VII. 3: 355. I886. De Toni. Syll. Algar. 5: 610. 1907.

Collins. Notes on New England Marine Algae. V. Bull. Torr. Bot. Club. I8: 335. I89 ; The Algae of Jamaica. Proc. Am. Acad. 37: 241. Igor. Collins, Holden and Setchell. Phyc. Bor.-Am. Fasc. 23. no. III3. 1903.

\section{Plate XVI. fig. I3.}

Plant mass crustaceous, compact, orbicular, smooth, glistening, blackish green; filaments 9 - $15 \mathrm{mic}$. in diameter, up to $\mathrm{I} \mathrm{mm}$. in length, very densely crowded, parallel, erect, moderately flexuous; decumbent and thickened at the base; sheaths somewhat thick, colorless or yellowish, dilated into lamellose, funnel-shaped expansions; trichomes 6-8 mic. in diameter, ending in a slender long hair; cells equal to or shorter than their diameter; heterocysts, one to two, basal. 
Massachusetts. On stones more or less embedded in the sand, a little above low water mark. Revere Beach. January and February. (Collins). West Indies. On wreck on beach. Port Morant, Jamaica. March I893. (Humphrey). On Ga la xa ura, etc. Santurce, Porto Rico. May 1903. (Howe).

468. Calothrix pulvinata (Mertens) Agardh. Syst. Algar. 7I. I824. Borner and Flahault. Revis. des Nostoc. Ann. Sci. Nat. Bot. 3: 356. 1886. De Toni. Syll. Algar. 5: 6ro. 1907.

Farlow. Marine Algae of New England. 37. 1881. Pike. Check List of Marine Algae. Bull. Torr. Bot. Club. I3: 106. I886. Collins. Algae from Atlantic City, N. J. Bull. Torr. Bot. Club. I5: 310. I888. Bennett. Plants of Rhode Island. 95. I888. Martindale. Marine Algae of the New Jersey Coast and Adjacent Waters of Staten Island. Mem. Torr. Bot. Club. I: 91. I889. Wolle and Martindale. Algae. Britton's Catalogue of Plants found in New Jersey. Geol. Surv. N. J. 2: 603. 1889. Collins. Algae. Rand and Redfield's Flora of Mount Desert Island, Maine. 247. I894; Preliminary Lists of New England Plants.-V. Marine Algae. Rhodora. 2: 4I. 1900. Collins, Holden and Setchell. Phyc. Bor.-Am. Fasc. 20. no. 957. 1902. Setchell and Gardner. Algae of Northwestern America. Univ. Calif. Pub. Bot. I: I97. I903. Collins. Notes on Algae.-V. Rhodora. 5: 208. I903; Phycological Notes of the late Isaac Holden.-II. Rhodora. 7: 223. 1905.

\section{Plate XVI. fig. I4.}

Plant mass sponge-like, porous, fasciculate, hairy on the surface, dull green, widely expanded; filaments $15-18$ mic. in diameter, 2-3 mm. in length, erect, flexuous, scarcely thickened at the base, agglutinated into irregular fascicles, sparingly branched; branches often opposite; sheaths thick, firm, lamellose, colorless or brownish; trichomes 8-12 mic. in diameter, tapering into a short hair; cells two or three times shorter than their diameter; hormogones four to six times longer than broad, often developed within the sheath; cell contents olive.

Maine. Growing in extensive sheets on beams and posts under old tide mill. Harpswell. July I902; on piles of bridge, outlet of Long Pond. "Rare; the most northern station for this species yet reported." (Collins). Massachusetts. On wharves. Wood's Hole. (Farlow). Rhode Island. Newport. (Farlow). Connecticut. On woodwork at or above high water mark. Black Rock; Stratford Shoals; on old hulk, Cook's Point, August, October. (Holden). New York. Shores of Long Island: Greenport, Little Egg Harbor. (Pike). New Jersey. On wharves. Atlantic City. (Morse, Martindale). Washington. In salt marsh on sticks and old wood. Whidbey Island. August r899. (Gardner).

469. Calothrix parasitica (Chauvin) Thuret. Essai Class. Nostochinées. Ann. Sci. Nat. Bot. VI. I: 38r. I875. Bornet and Flahault. Revis. des Nostoc. Ann. Sci. Nat. Bot. VII. 3: 357. I886. De Toni. Syll. Algar. 5: 612, 1907.

Farlow. Marine Algae of New England. 37. I88r. Collins. Notes on New England Marine Algae. II. Bull. Torr. Bot. Club, 10: 55. I883. Pike. Check List of Marine Algae. Bull. Torr. Bot. Club. 13: 106. I886. Collins, Holden and Setchell. Phyc. Bor.-Am. Fasc. 3. no. III. 1895. Setchell. 
Notes on Cyanophyceae.-III. Erythea. 7: 46. r899. Collins. Preliminary Lists of New England Plants.-V. Marine Algae. Rhodora. 2: 4I. Ig0o; Phycological Notes of the late Isaac Holden.-II. Rhodora. 7: 223. I905.

Plate XVI. fig. 15, 16.

Filaments 9-15 mic. in diameter, $.5 \mathrm{~mm}$. in length; gregarious, immersed in the outer cells of Nemalion, blue-green, bulbous and curved at the base (bulb up to 24 mic. in diameter); sheaths thin, colorless, often dilated and funnel-shaped at the apex; trichomes $7-8$ mic. in diameter, ending in a very long, flexuous hair; cells short; heterocysts basal; hormogones many in the sheath, four or five times longer than the diameter.

Maine. (Co1lins). New Hampshire. (Collins). Massachusetts. Completely covering $\mathrm{Nemalion} m \mathrm{~m} l \mathrm{t}$ if id um growing at low water mark between the Oak Bluff and the Camp Meeting landings, at Cottage City. (Collins). Epiphytic on the fronds of $\mathrm{Nem}$ alion multifidum. Wood's Holl. July I895. (Nott). Rhode Island. On Ne mali on. Newport. (Farlow). Connecticut. On Nemalion. Stratford Shoals. July. (Holden).

470. Calothrix aeruginea (Kuetzing) Thuret. Essai Class. Nostochinées. Ann. Sci. Nat. Bot. VI. I: Io. I875. Bornet and Flahault. Revis. des Nostoc. Ann. Sci. Nat. Bot. VII. 3: 358. r886. De Toni. Syll. Algar. 5: 612. 1907 .

Schramm and Mazé. Essai Class. Algues Guadeloupe. 30. 1865. (L e i ble in i a flaccida Crouan). Mazé and Schramm. Essai Class. Algues Guadeloupe. 20. $1870-1877$. (L y $\mathrm{ng}$ b a $\mathrm{n}$ e mali o $\mathrm{n}$ is Crouan). Collins. Notes on New England Marine Algae. V. Bull. Torr. Bot. Club. 18: 336. 1891; Preliminary Lists of New England Plants. V. Marine Algae. Rhodora. 2: 4I. 1900; The Algae of Jamaica. Proc. Am. Acad. Arts Sci. 37: 241. Igor. Collins, Holden and Setchell. Phyc. Bor.-Am. Fasc. 17. no. 804. Igor. Collins. Phycological Notes of the late Isaac Holden.-II. Rhodora. 7: 223. 1905. Vickers. Liste des Algues Marines de la Barbade. Ann. Sci. Nat. Bot. VIII. I: 55. 1905. Börgesen and Jonsson. The Distribution of the Marine Algae of the Arctic Sea and of the Northernmost Part of the Atlantic. Botany of the Faeroes. Appendix. XXV. 1905.

Plate XVII. fig. I.

Filaments 9-12 mic. in diameter, $.5 \mathrm{~mm}$. in length, forming a somewhat continuous light blue-green layer on the surfaces of larger algae, decumbent and slightly thickened at the base; sheaths somewhat thick, very often entirely colorless, rarely yellowish in lower parts, uniform, soft, and gelatinous in the upper portions; trichomes $7-9$ mic. in diameter, ending in a gradually tapering hair; cells short; heterocysts one or two at the base, $\mathrm{f} f \mathrm{w}$ or none intercalary, hormogones numerous within the sheath, four to six times longer than wide.

Maine. Cape Rosier. July 1890; among other algae on woodwork of old wharf, Otter Creek, Mount Desert Island. July rgoo. (Collins). Massachusetts. (Collins). Connecticut. Forming a coating on iron piles between tide marks. Black Rock Beacon. August, October. (Holden). West Indies. On Dasya a rbuscula. Montego Bay, Jamaica. June Igoo. 
(Pease and Butler). Rocky Bay, Hastings, Barbados. (Vickers). Hawaii. Growing on other algae. In pools at half tide. Waianae, Waikiki and Laie Point, Oahu. May and June Ig00. (Tilden).

471. Calothrix prolifera Flahault in Bornet and Flahault. Revis. des Nostoc. Ann. Sci. Nat. Bot. VII. 3: 36I. I886. De Toni. Syll. Algar. 5: 615. 1907 .

Collins, Holden and Setchell. Phyc. Bor.-Am. Fasc. 24. no. II68. 1904. (Calothrix crustacea forma prolifera (Flah.) Collins). Collins. New species, etc., issued in the Phycotheca Boreali-Americana. Rhodora. 8: 105. 1906.

Plant mass expanded, velvety, brownish green; filaments $15-18$ mic. in diameter, $2 \mathrm{~mm}$. in length, somewhat flexuous, curved and distinctly thickened at the base, here and there branched; branches issuing in the region of the heterocyst as in Tolypothrix; sheaths thick, lamellose, firm, colorless in upper portions, yellowish below, ocreate; ocreae dilated and torn; trichomes 8-12 mic. in diameter, tapering at the apex into a hair; cells three or four times shorter than their diameter; heterocysts one or two at the base, many scattered through the trichome.

California. Among other algae, on boards wet with salt water. Alameda. January 1904. (Gardner).

472. Calothrix fasciculata Agardh. Syst. Algar. 71. 1824. Bornet and Flahault. Revis. des Nostoc. Ann. Sci. Nat. Bot. VII. 3: 36I. 1886. De Toni. Syll. Algar. 5: 6I5. I907.

Collins. Notes on New England Marine Algae. V. Bull. Torr. Bot. Club. I8: 336. I89I. Collins, Holden and Setchell. Phyc. Bor.-Am. Fasc. 6. no. 261. I897. Collins. Preliminary Lists of New England Plants.-V. Marine Algae. Rhodora. 2: 4I. I900.

Plant mass caespitose, velvety, expanded, blackish green; filaments I22 I mic. in diameter, $2-3 \mathrm{~mm}$. in length, erect, somewhat flexuous, a little thickened at the base, when young unbranched, later branched; false branches formed in two ways: sometimes scattered and lateral, solitary or in pairs, sometimes fasciculately crowded on one side of the middle portion of the filament; sheaths moderately thick, lamellose, firm, uniform or dilated, colorless or with age becoming yellowish brown; trichomes 8-I2 mic. in diameter, ending in a hair; cells two or three times shorter than the diameter; heterocysts basal and, in mature filaments, few or numerous throughout the trichome; cell contents blue-green.

Maine. On rocks between tide marks. Cape Rosier. July 1889; on dead shells, Cape Rosier, July 1895. (Collins). Massachusetts. (Collins). Rhode Island. (Collins).

Forma incrustans Collins. Notes on Algae.-I. Rhodora. I: I3. I899. De Toni. 1. c. 6 i6.

Collins. Notes on New England Marine Algae. V. Bull. Torr. Bot. Club. I8: 336. I89r. (C. c ontaren i Collins). Collins, Holden and Setchell. Phyc. Bor.-Am. Fasc. 12. no. 561. 1899. Collins. Notes on Algae. -II. Rhodora. I: I3. I900; Preliminary Lists of New England Plants.-V. Marine Algae. Rhodora. 2: 4I. 1900. 
Plant mass crustaceous, flattened; filaments 8-12 mic. in diameter, more slender than in the typical form.

Massachusetts. On rocks in littoral zone. Revere Beach. September :895. (Collins).

473. Calothrix vivipara Harvey. Nereis Boreali-Americana. Part III. I06. 1858. Bornet and Flahault. Revis. des Nostoc. Ann. Sci. Nat. Bot. VII. 3: 362. 1886. De Toni. Syll. Algar. 5: 616. 1907.

Farlow. List Marine Algae U. S. Proc. Am. Acad. Arts Sci. Io: 380. I875; Marine Algae of New England. 37. 188I. Wittrock and Nordstedt. Algae Aq. Dulc. Exsicc. no. I307. I896. Collins, Holden and Setchell. Phyc. Bor.-Am. Fasc. I2. no. 560. I899. Collins. Preliminary Lists of New England Plants.-V. Marine Algae. Rhodora. 2: 4I. Igoo.

Plant mass widely expanded, velvety, blackish green; filaments I2-24 mic. in diameter, $3-5 \mathrm{~mm}$. in length, decumbent and interwoven at the base, becoming erect, somewhat flexuous, branched; false branches in pairs, issuing from the filament as in Scytonema; sheaths thick, gelatinous, uniform, yellowish brown, somewhat opaque; trichomes 9-I5 mic. in diameter, tapering very gradually from base to apex, ending in a hair; cells equal to or shorter than their diameter; heterocysts basal and a few scattered through the trichome; cell contents olive green.

Massachusetts. Forming patches on rocks and growing also on other algae. Nahant; Wood's Holl. (Farlow). In upper tide pools on smooth rocks. Marblehead. August 1895. (Collins). Rhode Island. (Bailey). Seaconnet Point. (Farlow).

474. Calothrix pilosa Harvey. Nereis Boreali-Americana. Part III. Io6. pl. 48 C. 1858. Bornet and Flahault. Revis. des Nostoc. Ann. Sci. Nat. Bot. VII. 3: 363. 1886. De Toni. Syll. Algar. 5: 614. 1907.

Murray. Catalogue of the Marine Algae of the West Indian Region. Journ. of Bot. 27: 261. 1889. (S c y t on e ma s u b marinu m Crn.). Collins, Holden and Setchell. Phyc. Bor.-Am. Fasc. I8. no. 859. 19or. Collins. The Algae of Jamaica. Proc. Am. Acad. 37: 242. Igor. Collins, Holden and Setchell. Phyc. Bor.-Am. Fasc. 24. no. I I67. I904.

Plant mass caespitose, widely expanded, black or dark blue-green; filaments ro-40 mic. in diameter, 2-10 $\mathrm{mm}$. in length, decumbent and interwoven at the base, erect at the apices, elongate, rigid, free or growing together laterally in fascicles, distinctly thicker in upper portions; sheaths hard, thick, at first orange, finally yellowish brown, opaque, uniform; trichomes ro-20 mic. in diameter, briefly tapering at the apex; terminating in a hemispherical cell, here and there interrupted by heterocysts; cell contents olive brown.

Florida. Forming blackish or dark brown, pilose strata of indefinite extent. On rocks between tide marks. Key West. (Harvey). California. Forming a black velvety covering on the bottoms of small pools in the rocks above high water mark, but filled with salt water from the spray and higher waves, though often much concentrated by the sun. Near Point Carmel, Monterey County. June Igor. (Setchell). West Indies. Guadeloupe. (Mazé). On Bostrychia tenella. Port Antonio, Jamaica. 
August I894. (Pease and Butler). On rocks, etc., littoral. Porto Rico. May I903. (Howe).

475. Calothrix crustacea Thuret. Notes Algologiques. I: I3. pl. 4. I878. Bornet and Flahault. Revis, des Nostoc. Ann. Sci. Nat. Bot. VII. 3: 359. I886. De Toni. Syll. Algar. 5: 613. I907.

Mazé and Schramm. Essai Class. Algues Guadeloupe. 31. I870-1877. Farlow, Anderson and Eaton. Algae Am. Bor. Exsicc. no. 49. 1877. Farlow. Marine Algae of New England. 36. I88I. Pike. Check List of Marine Algae, Bull. Torr. Bot. Club. 13: 105. I886. Collins. Algae from Atlantic City, N. J. Bull. Torr. Bot. Club. I5: 310. I888; Algae of Middlesex County. I3. I888; Marine Algae of Nantucket. 5. I888. Bennett. Plants of Rhode Island. 95. I888. Martindale. Marine Algae of the New Jersey coast and Adjacent Waters of Staten Island. Mem. Torr. Bot. Club. I: 9I. I889. Wolle and Martindale. Algae. Britton's Catalogue of Plants found in New Jersey. Geol. Surv. N. J. 2: 602. I889. Murray. Catalogue of the Marine Algae of the West Indian Region. Journ. of Bot. 27: 26I. 1889.(S c hiz osiphon pilosus Crn.). Anderson. List of California Marine Algae, with Notes. Zoe. 2: 218. I891. Collins, Holden and Setchell. Phyc. Bor.Am. Fasc. I. no. I0. I895. Collins. Preliminary Lists of New England Plants.-V. Marine Algae. Rhodora. 2: 41. 1900. Setchell and Gardner. Algae of Northwestern America. Univ. Calif. Pub. Bot. I: 197. 1903. Collins, Holden and Setchell. Phyc. Bor.-Am. Fasc. 25. no. I212. I905. Collins. Phycological Notes of the late Isaac Holden.-II. Rhodora. 7: 223. 1905 .

\section{Plate XVII, fig. 2-6.}

Plant mass caespitose, velvety, widely expanded, blackish green or brownish; filaments I2-40 mic. in diameter, I-2 mm. in length, erect, densely crowded, a little thickened at the base; sheaths somewhat thick, colorless or yellowish brown, in the older filaments lamellose, variously dilated and expanded in upper portions; trichomes 8-15 mic. in diameter, ending in a long hair; cells short; heterocysts one to three at the base, often many scattered through the trichome; hormogones many within the sheath, four or five times longer than wide; gonidia oblong, cylindrical, smooth, in series.

Canada: On other algae. Malpeque, Prince Edward Island. (Faull). Maine, (Collins). New Hampshire. (Collins). Massachusetts. On U1va in salt water. Medford; Everett; Brant Point and Polpis. (Collins). On algae of all kinds and on rocks. Wood's Holl. (Farlow). Rhode Island. Narragansett Bay. (Bennett). (Collins). Connecticut. Clothing fronds of $\mathrm{Cladophora,} \mathrm{Enteromorpha} \mathrm{and} \mathrm{other} \mathrm{algae,} \mathrm{also} \mathrm{on}$ rocks. Woodmont. July 1892 ; on algae and rocks, Stratford Shoals; Cook's Point, July, September, October. (Holden). New York. Shores of Long Island: Bay. Ridge, Fort Hamilton. Summer. (Pike). New Jersey. On rockweed. Atlantic Ocean. (Morsc, Martindale). Florida. (Harvey, Melville). Washington. Floating, on rocks, clay banks, wood, etc., in brackish lagoon. Whidbey Island; Keyport, Kitsap County. (Gardner). California. Common. On rocks, wharves and other algae. (Anderson). On grass and weeds, salt marsh. Alameda. April I904. (Gardner). West 
Indies. Guadeloupe. (Mazé). Hawaii. On other algae. In tide pools at lialf tide. Waianae, Oahu. May Igoo. (Tilden).

Forma simulans Collins in Collins, Holden and Setchell. Phyc. Bor.-Am. Fasc. 29. no. 1406. I907.

Filaments stout; color from light blue-green to purple or dull rose.

Massachusetts. On Z os te r a. Mattapoisett. October 1906. Appearing like C. confervicola (Roth) Ag., but with intercalary heterocysts. (Collins).

476. Calothrix epiphytica West and West. Welwitsch's African Freshwater Algae. Journ. of Bot. 35: 240. 1897. De Toni. Syll. Algar. 5: 62I. 1907.

West and West. Journ. Linn. Soc. Bot. 34: 285. I898-1900.

Filaments 5-7.5 mic. in diameter at the base, 250 mic. rarely up to 350 mic. in length, minute, attached to larger algae, solitary or somewhat gregarious, gradually tapering from base to apex; sheaths somewhat thick, transparent and colorless; trichomes 3.5-4 mic. in diameter at the base, cnding in a very thin hair at the apex; cells equal to the diameter, in length, or at the base a little shorter; heterocysts basal, solitary, small.

West Indies. Epiphytic on Toly poth rix. Dominica. (Elliott).

477. Calothrix scytonemicola n. sp.

\section{Plate XVII. fig. 7.}

Filaments 7-8 mic. in diameter, isolated or in small groups, the lower portion attached to host, the remainder erect and free, ending in a hair point; sheaths not distinct; heterocysts 8 mic. in diameter, basal, usually two in number, somewhat globose.

Hawaii. Growing on filaments of Scytonema crispum. Very abundant. In stagnant water in pool on beach, among roots of Water hyacinth. Meheiva, Makao, Koolauloa, Oahu. June Igoo. (Tilden).

478. Calothrix stagnalis Gomont. Note sur un Calothrix sporifère. (C a 1 othrix stagnalis sp. n.). Morot. Journ. de Bot. 9: 197. f. I, 2. I895. De Toni. Syll. Algar. 5: 619. Ig07.

Collins, Holden and Setchell. Phyc. Bor.-Am. Fasc. 23. no. III4. I903. Collins. Notes on Algae.-VII. Rhodora. 8: I23. 1906.

\section{Plate XVII. fig. 8, 9.}

Filaments 8-1o mic. in diameter in the middle portions, up to I $\mathrm{mm}$. in length, gregarious, radiating, decumbent and thickened at the base, erect, sickle-shaped; sheaths thin, close, papery, transparent; trichomes 6-9 mic. in diameter, especially constricted at joints, gradually tapering into a hair; cells 6-to mic. in diameter, unequal, usually subquadrate or longer than the diameter; heterocysts in pairs, basal, yellowish, spherical or somewhat quadrate; gonidia IO-II mic. in width (with sheath I2-I4 mic. wide), 26-40 mic. in length, yellowish; wall of gonidium smooth.

Massachusetts. In stellate tufts, rather sparsely distributed on various filamentous algae, in swamp. Medford. August 1903. (Collins).

479. Calothrix fusca (Kuetzing) Bornet and Flahault. Revis. des Nostoc. Ann. Sci. Nat. Bot. VII. 3: 364. 1886. De Toni. Syll. Algar. 5: 617. I907. 
Mazé and Schramm. Essai Class. Algues Guadeloupe. 3I. I877. (M a s$\mathrm{t} i \mathrm{chothrix}$ longissima Crowan). Wolle. Fresh Water Algae. II. Bull. Torr. Bot. Club. 6: 138. 1877. (M a stigonema fus ca Wolle). Fresh Water Algae III. Bull. Torr. Bot. Club. 6: 184. 1877. (M a stigothrix a e ruginea Kuetz. Bennett. Plants of Rhode Island. II4. 1888. ( $\mathrm{M}$ a stigon e ma a e r uginos um (Kg.) Kirchn.). Collins. Algae of Middlesex County. I3. I888. (M a stigon e ma a e rugine u m Kirchn.). Tilden. List of Fresh-Water Algae collected in Minnesota during I893. Minn. Bot. Studies. I: 30. I894. Collins, Holden and Setchell. Phyc. Bor.-Am. Fasc. I. no. II. I895. Collins. Algae. Flora of the Blue Hills, Middlesex Fells, Stony Brook and Beaver Brook Reservations of the Metropolitan Park Commission, Massachusetts. 127. I896. Collins. The Algae of Jamaica. Proc. Am. Acad. 37: 24I. 190I. Saunders. The Algae. Harriman Alaska Expedition. Proc. Wash. Acad. Sci. 3: 399. I90I. Snow. The Plankton Algae of Lake Erie. U. S. Fish Comm. Bull, for 1902. 22: 392. 1903. Setchell and Gardner. Algae of Northwestern America. Univ. Calif. Pub. Bot. I: 197. 1903. Collins. The Algae of the Flume. Rhodora, 6: 230. 1904. Lemmermann. A1genfl. Sandwich.-Inseln. Bot. Jahrb. 34: 627. 1905. Collins. Phycological Notes of the late Isaac Holden.-II. Rhodora. 7: 237. 1905. Collins, Holden and Setchell. Phyc. Bor.-Am. Fasc. 29. no. 1407. 1907.

\section{Plate XVII. fig. IO, II.}

Filaments Io-12 mic. in diameter, 2-3 decimill. in length, scattered or gregarious, living within the colonies of gelatinous algae, curved and bulbous-inflated at the base (bulb 15 mic. in diameter); sheaths thick, colorless, gelatinous, diffluent at the apex; trichomes $7-8$ mic. in diameter, ending in a long hair; cells short; heterocysts one or two at the base.

Alaska. Embedded in the gelatinous coating of $\mathrm{B}$ a t r a ch os p e $\mathrm{m} \mathrm{um}$ r a g u m from a freshwater pond. Cook Inlet; Kadiak Island. (Saunders). Occurring singly or few together in the jelly of other species of algae. Near Iliuliuk, Unalaska. (Setchell and Lawson). New Hampshire. On B a trachospermum vagum. Lake Chocorua. September I906; on wall of Flume. (Collins). Massachusetts. On B a t r a chos permu m. Billerica. (Faxon). Among other algae on rocks at Cascade, Middlesex Fells. (Collins). Rhode Island. Easton's Pond, Newport. (Bennett). Connecticut. On fiat $\mathrm{rach}$ os perm u $\mathrm{m}$ v $\mathrm{g}$ u m. Pool below Factory Pond Dam. October. (Holden). New Jersey. October 1892. (Peters). Pennsylvania. (Wolle). Ohio. In plankton. Lake Erie. Put-in-Bay. (Snow). Minnesota. In pool near Lake Kilpatrick. June 1893. (Ballard). West Indies. Guadeloupe. (Conquérant). Hawaii. In ditches between Honolulu and Waikiki, Oaht. I896-I897. (Schauinsland).

480. Calothrix sandvicensis (Nordstedt) Schmidle. Zur Entwickelung einer Zygnema und Calothrix. Flora. 84: I7o. pl. 5. f. I2-I4. I897. De Toni. Syll. Algar. 5: 6I8. I907.

Nordstedt. De Algis Aquae Dulcis et de Characeis ex Insulis Sandvicensibus a Sv. Berggren 1875 reportatis. 5. pl. I. f. 3. I878. (L o p hopodiu m s a ndvi c en s e Nordst.). Lemmermann. Algenfl. Sandwich.Inseln. Bot. Jahrb. 34: 627. 1905. 
Plate XVII. fig. 12.

Filaments 5-I5 mic. in diameter, sometimes thickened in lower portion; trichomes 3.5-5.5 mic. in diameter; heterocysts equal to or exceeding the basal cells in diameter; gonidia $8 \mathrm{mic}$. in diameter, 8-10 mic. in length, single, rarely in pairs, somewhat quadrate, angular-convex, rotund.

Hawaii. On filaments of $\mathrm{P}$ it hoph or a a f in is. Near Hilo, Hawaii. July I889. (Lauterbach).

481. Calothrix breviarticulata West and West. Welwitsch's African Freshwater Algae. Journ. of Bot. 35: 240. I897. De Toni. Syll. Algar. 5: 620. 1907 .

West. West Indian Freshwater Algae. Journ. of Bot. 42: 293. I904.

Filaments $15-16$ mic. at the base, Ir.5-12.5 mic. in middle portions, up to $380 \mathrm{mic}$. in length, solitary or gregarious, gradually tapering from base to apex; sheaths thick, lamellose, becoming brownish black in old plants; trichomes 8.5 mic. in diameter at the base, $5.5-7.5$ mic. in middle portions; cells disc-shaped, four or five times shorter than their diameter; heterocysts solitary, basal, hemispherical; cell contents pale blue-green.

West Indies. Epiphytic on $\mathrm{Vaucheria}$ species. Royal Botanical Gardens, St. Ann's, Trinidad. (Howard).

482. Calothrix violacea (Wolle) De Toni. Syll. Algar. 5: 6r9. 1907.

Wolle. Fresh Water Algae. II. Bull. Torr. Bot. Club. 6: 138. 1877. (Mastigonema violacea Wolle).

Filaments $15-18$ mic. in diameter, parasitic, usually in clusters, ten or twelve arising from each base, "a sort of warty excrescence," when young blue-green, changing when mature to purplish iron or amethyst color, finally becoming olivaceous brown; sheaths wide, often truncate, almost colorless; trichomes 7-9 mic. in diameter; lower cells short, two or four times shorter than the diameter, upper cells longer, finally four or six times as long as wide; heterocysts more or less compressed.

Pennsylvania. "Parasitic on P 1 e ct o n e ma in shallow river waters." (Wolle).

483. Calothrix adscendens (Naegeli) Bornet and Flahault. Revis. des Nostoc. Ann. Sci. Nat. Bot. VII. 3: 365. I 886 . De Toni. Syll. Algar. 5: 620. I907.

Wolle. Algae Exsicc. no. 83. (M astigonema parasiticum Wolle). Setchell. Notes on Cyanophyceae. III. Erythea. 7: 46. I899.

\section{Plate XVII. fig. I3, I4.}

Filaments $18-24$ mic. in diameter, $1 \mathrm{~mm}$. in length, scattered or gregarious, light blue-green in dried material, tapering from base to apex; sheaths thick, gelatinous, lamellose, finally becoming ocreate, transparent; trichomes 12 mic. in diameter in the middle portions; cells equal to the diameter in length or shorter; heterocysts basal.

Pennsylvania(?). (Wolle). 
484. Calothrix thermalis (Schwabe) Hansgirg. Beiträge zur Kenntniss der Böhmisch. Thermalalgenflora. Oesterr. Bot. Zeitschrift. 34: 279. 1884. Bornet and Flahault. Revis. des Nostoc. Ann. Sci. Nat. Bot. VII. 3: 368, 1886. De Toni. Syll. Algar. 5: 625. 1907.

Weed. Formation of Travertine and Silicious Sinter by the Vegetation of Hot Springs. U. S. Geol. Survey. 9th Ann. Report. 665. I889. (M a s t i$\mathrm{g}$ onema $\mathrm{th}$ ermale Schwabe). Tilden. American Algae. Cent. III. no. 287. 1898. Observations on some West American Thermal Algae. Bot. Gaz. 25: 94. pl. 9. f. I-5. I898.

\section{Plate XVIII. fig. I-5.}

Plant mass mucous, smooth, more or less expanded, deep olive green, when dried blue-green; filaments 8-1o mic. in diameter, up to $3 \mathrm{~mm}$. in longth, interwoven, flexuous, densely crowded; sheaths somewhat thick, uniform, transparent, sometimes yellowish at the base; trichomes 5-8 mic. in diameter, tapering at the apex into a long hair, here and there constricted at the joints; cells equal to or three times shorter than the diameter; heterocysts basal and rarely intercalary.

Wyoming. Olive colored, forming sinter. Crater of Excelsior Geyser; overflow of channel of geyser, temperature $49-54.5^{\circ} \mathrm{C}$., Spasmodic Geyser; forming cedar-colored fur on overflow channel of Old Faithful Geyser, Upper Basin, 1897. (Weed). With other algae in rivulets. Temperature $49-50^{\circ}$. C. Fountain Hotel Geyser Basin. June 1896; very common in colder portions of overflows, temperature $34^{\circ}$ C., Emerald Pool, Upper Geyser Basin, July I896, Yellowstone National Park. (Tilden).

485. Calothrix calida P. Richter in Kuntze. Revisio Generum Plantarum. Part III. II. 388. f. a, b. I898. De Toni. Syll. Algar. 5: 626. I907.

Plate XVIII. pl. 6, 7 .

Plant mass $6 \mathrm{~mm}$. in thickness, dry, spongy or crustaceous, widely expanded, flattened, olivaceous; filaments 8-1o mic. in diameter, interwoven flexuous, aggregated; sheaths close, yellowish brown, when young transparent, thick, ocreate, ocreae here and there dilated; trichomes 3-6 mic. in diameter, pale blue-green, tapering into a long hair; cells spherical or elliptical, equal to their diameter, or three times longer, the lower ones spherical depressed or barrel-shaped; transverse walls often inconspicuous; heterocysts basal and intercalary, spherical or quadrate.

Wyoming. In warm water from a geyser. Temperature $+50^{\circ} \mathrm{R}, \mathrm{I} 874$. Yellowstone National Park. (Kuntze).

486. Calothrix kuntzei P. Richter in Kuntze. Revisio Generum Plantarum. Part III. II. 388. f. a-c. I898. De Toni. Syll. Algar. 5: 625. 1907.

Plant mass dry, crustaceous, pulvinate, mammillose, stony, expanded, faded within, blue-green on the surface, lamellose, up to $5 \mathrm{~mm}$. in thickness; filaments IO-I 1 mic. in diameter, free, usually agglutinated in irregular fascicles, parallel or flexible; sheaths close, thick, transparent and yellowish, lamellose, ocreate; trichomes thickened at the base, especially when young, bright bluish in color; basal cells hemispherical or spherical, barrelshaped or disc-shaped, those in upper portion of trichome oval or spheri- 
cal, somewhat quadrate or shorter or longer than their diameter; basal heterocysts spherical; intercalary heterocysts quadrate or cylindrical, sometimes in series, equalling the diameter in length, or up to seven times longer than wide.

\section{Plate XVIII. fig. 8-Io.}

Wyoming. In running, hot geyser water. October 1874 . Yellowstone National Park. (Kuntze).

487. Calothrix braunii Bornet and Flahault. Revis. des Nostoc. Ann. Sci. Nat. Bot. VII. 3: 368. I886. De Toni. Syll. Algar. 5: 624. I907.

Setchell. Notes on some Cyanophyceae of New England. Bull. Torr. Bot. Club. 22: 426. 1895. Collins, Holden and Setchell. Phyc. Bor.-Am. Fasc. 3. no. II2. I895. Tilden. American Algae. Century III. no. 286. I898. Setchell. Notes on Cyanophyceae.-III. Erythea. 46. I899. Setchell and Gardner. Algae of Northwestern America. Univ. Calif. Pub. Bot. I: 198. 1903. Collins. Phycological Notes of the late Isaac Holden. -II. Rhodora. 7: 237. I905.

\section{Plate XVIII. fig. II.}

Plant mass caespitose, velvety, blue-green; filaments 9-10 mic. in diameter, $.5 \mathrm{~mm}$. in length, densely crowded, parallel, straight, curved and thickened at the base; sheaths narrow, close, uniform, colorless; trichrimes 6-7 mic. in diameter, equal, tapering into a very long hair, often constricted at joints; cells a little shorter than their diameter; heterocysts basal.

Massachusetts. Growing on stones in a small brook. Sharon; forming extended patches on rounded stones in a small rivulet, Cataumet. (Setchell). Connecticut. On stones in shallow water. Bridgeport. October I893; forming a coating on stones, side stream of Pequonnock River, below Factory Pond Dam, October. (Holden). Washington. On dead floating stems of Scirpus. Lake Washington, Seattle. July I897; on pebbles at edge of Lake Union, Seattle, June I897. (Tilden).

488. Calothrix parietina (Naegeli) Thuret. Essai Class. Nostochinées. Ann. Sci. Nat. Bot. VI. I : 381. I875. Bornet and Flahault. Revis. des Nostoc. Ann. Sci. Nat. Bot. VII. 3: 366. I886. De Toni. Syll. Algar. 5: 621. 1907 .

Wolle. Fresh Water Algae. II. Bull. Torr. Bot. Club. 6: I38. I877. (Mastigonema caespitos um Kg.); Fresh Water Algae. 1. c. 6: 284. 1879, ( $\mathrm{Sch}$ izosiphon crustif ormis Naeg.). Farlow. Marine Aigae of New England. 40. I88I. Wolle. Fresh-Water Algae U. S. 237, 245. p1. I73. f. 2, 3; pl. I76. f. 5; p1. I78. f. I-3; p1. 205. f. 6, 7. I887. (C a 1 othrix gracilis Rab., Is a c t is caes pitos a (Kg.) Wolle, including f. tenuior viridis Rab.). Wolle and Martindale. Algae. Britton's Catalogue of Plants found in New Jersey. Geol. Surv. N. J. 2: 603. I889. Collins, Holden and Setchell. Phyc. Bor.-Am. Fasc. I. no. I2. I895. Tilden. American Algae. Cent. I. no. 65. 1894. (P or phy r o s iph o n not a r is i i Kg.). Cent. II. no. I64. I896. Collins. Algae.' Flora of the Blue Hills, Middlesex Fells, Stony Brook and Beaver Brook Reservations of the 
Metropolitan Park Commission, Massachusetts. I27. I896. Richter. Süsswasseralgen aus dem Umanakdistrikt. Bib. Bot. 7: Heft. 42. 4. I897. Tilden. List of Fresh-Water Algae collected in Minnesota during 1896 and I897. Minn. Bot. Studies. 2: 27. 1898. Setchell. Notes on Cyanophyceae. III. Erythea. 7: 45. I899. Setchell and Gardner. Algae of Northwestern America. Univ. Calif. Pub. Bot. I: 198. I903. Collins. Phycological Notes of the late Isaac Holden.-II. Rhodora. 7: 237. 1905. Collins, Holden and Setchell. Phyc. Bor.-Am. Fasc. 28. no. 1360. 1907. Brown. Algal Periodicity in certain Ponds and Streams. Bull. Torr. Bot. Club. 35: 243, 248. I908. Buchanan. Notes on the Algae of Iowa. Proc. Iowa Acad. Sci. 14: 15. 1908 .

Plate XVIII. fig. I2.

Filaments IO-I2 mic. in diameter, up to $\mathrm{I} \mathrm{mm}$. in length, scattered or aggregated into a crustaceous, thin, brown or black mass, erect or decumbent, flexuously contorted, uniform or somewhat thicker at the base; sheaths close, somewhat thick, yellowish brown, opaque, fragile, sometimes uniform, sometimes ocreate; ocreae wide and fringed in upper portions; trichomes 5-ro mic. in diameter, ending in a thin hair I mic. in diameter; cells short, two or three times wider than long; heterocysts a little wider at the base, intercalary heterocysts rare; hormogones few in the sheath, three times longer than wide.

Alaska. Forming reddish brown patches on dripping rocks. Amaknak Cave, Amaknak Island, Bay of Unalaska. (Setchell and Lawson). Greenland. Umanak. (Richter). Vermont. Northern part. (Wolle). Massachusetts. In Nobska Pond, near Wood's Hole. (Farlow). Forming minute tufts on rocks near Bear's Den, Middlesex Fells. (Collins). Rhode Island. Forming a calcareous incrustation on perpendicular walls of a limestone quarry. Lincoln. April 1906. (Collins). Connecticut. On stone dam of Factory Pond; on dripping rocks between Canaan and Twin Lakes, Salisbury; on dripping rock, East Rock, New Haven; on sandy ground, shore of Fresh Pond, October, November; forming a close coating on stone work of dam, Pequonnock River, Bridgeport, October 1892. (Holden). New Jersey. On submerged stones in shallow water. (Wolle). Indiana. Abundant on stones in Stone Spring Branch the entire year. Bloomington. (Brown). Minnesota. Growing in damp sand in stone quarry. Minneapolis. August 1894 . (Anderson). On stone sides of fountain. Kenwood, Minneapolis. August 1895. (Tilden). Iowa. On stem of P h r a g m it es. Ontario. (Buchanan). Colorado. Wet rorcks. Cannon City. (Brandegee). California. On the sides of a water trough near Berkeley. July I905. (Osterhout and Gardner). On clay bank of a small stream. North Berkeley. September I905; on the sides of a water tank, Berkeley, February I906. (Gardner).

Dr. Setchell considers the specimen under the name of $\mathrm{Cal}$ oth $\mathrm{rix}$ the $\mathrm{rma} \mathrm{is}$, in Tilden. Am. Alg. no. 287 , to belong to C. pariet in a. This scarcely seems possible.

"C. parietin a may be entirely free from incrustation, or it may be very thoroughly incrusted with either lime or silica. It is seldom, if ever, branched, but the hormogonia in the incrusted specimens attach themselves 
very often to the sheaths of the older filaments and resemble branches very strongly indeed. Intercalary heterocysts do occur in C. parietina, but they are not at all common. The species is usually readily distinguished by its lamellose, brown and more or less ochreate sheath, but these characters may be at times more or less obscure."-Setchell.

489. Calothrix castellii (A. Massalongo) Bornet and Flahault. Revis. des Nostoc. Ann. Sci. Nat. Bot. VII. 3: 369. I886. De Toni. Syll. Algar. 5: 627. 1907.

Wolle. Fresh-Water Algae U. S. 255. p1. I82. f. 8-1o; pl. I84. f. 35, 38-40; 187. f. 3-33. (S c y to ne ma castelli i Mass.); 262. pl. I89. f. 1. 1887.

Plant mass spongy, cushion-shaped, widely expanded, the surface pubescent or hirsute by the projecting ends of the filaments, dull bluegreen; filaments I2-13 mic. in diameter, $4-8 \mathrm{~mm}$. in length, curved, flexuous, densely crowded, sometimes agglutinated, erect, decumbent and bulbous at the base; sheaths thin, close, firm, uniform, transparent or yellowish; trichomes 8-10 mic. in diameter, tapering into a very long hair; cells two to four times shorter than their diameter; heterocysts basal.

Pennsylvania. On shelves, walls and flower pots in greenhouse. Harrisburg. (Wolle).

490. Calothrix donnellii (Wolle) De Toni. Syll. Algar. 5: 629. 1907. Wolle. Fresh Water Algae. Bull. Torr. Bot. Club. 6: 283. I879. (M a stigonema donnellii Wolle).

Plant mass caespitose, mucous, olivaceous; filaments 6-I2 mic. in diameter, at the base sometimes $15-20$ mic. in diameter, simple or branched, flagelliform; very gradually tapering, sometimes thin and flaccid, sometimes strong and rigid, slightly curved, densely interwoven; sheaths very thin, colorless, at first drawn out into a hair, afterwards often truncate and open; trichomes frequently interrupted; cells usually four or five times shorter than their diameter; transverse walls distinct; heterocysts basal, rarely intercalary; cell contents pale or bright blue-green, sometimes brownish.

Pennsylvania? On wood in salt water, submerged. (Wolle).

49I. Mastigonema elongatum Wood. Contr. Hist. Fresh-Water Algae North America. 53. pl. 5. f. I. I872. Wolle. Fresh-Water Algae U. S. 243. pl. I74. f. 9. I887. De Toni. Syll. Algar. 5: 631. $190 \%$.

Plant mass at first somewhat spherical, afterwards frequently spindleshaped, slippery, firm, blackish green; filaments up to 6 mic. in diameter, very elongate, sometimes truncate at the apex, but generally produced into a long, flexuous, translucent hair; sheaths close, transparent, frequently truncate at the apex; trichomes sometimes strongly constricted at joints; cells short; transverse walls sometimes not visible; heterocysts somewhat spherical.

Pennsylvania. On brook moss in an aquarium. (Wood).

492. Mastigonema fertile Wood. Contr. Hist. Fresh-Water Algae North America. 54. pl. 5. f. 3. 1872 . Wolle. Fresh-Water Algae U. S. 244. 1887. De Toni. Syll. Algar. 5: 630. 1907. 
Plant mass caespitose; filaments up to 14 mic. in diameter, elongate, flexuously curved, not branched, truncate at the apex; sheaths moderately close, firm, thick, colorless, with truncate and open apex; trichomes often interrupted; cells three to five times as long as their diameter; transverse walls sometimes distinct, sometimes inconspicuous; heterocysts spherical or compressed, about as wide as the trichome; gonidia up to $4 \mathrm{mic}$. in diameter, cylindrical, often many in series in one filament; cell contents green.

Pennsylvania. In a stagnant pool in "Bear Meadows," forming a filamentous, felty mass with other algae. Allegheny Mountains, Centre County. (Wood).

493. Mastigonema fibrosum (Wood) Wolle. Fresh-Water Algae U. S. 244. pl. r74. f. 8. 1887. Wood. Contr. Hist. Fresh-Water Algae North America. 54. pl. 5. f. 3. 1827. De Toni. Syll. Algar. 5: 63I. 1907.

Plant mass light bluish green or olive; filaments Io-II mic. in diameter, with apex prolonged into a long, hyaline hair; sheaths transparent, in the immature filament distally broad and distinct, although hyaline, below rather thick and close, in the mature filament below close, indistinct, above dissolved in fibrillae and wanting at the apex; transverse walls distinct; heterocysts spherical, sometimes in pairs.

Pennsylvania. In a thick jelly, with other algae, on wet dripping rocks. Near Manayunk. (Wood).

494. Mastigonema halos Wood. Contr. Hist. Fresh-Water Algae North America. 52. pl. 5. f. 2. I872. De Toni. Syll. Algar. 5: 630. 1907.

Plant mass caespitose; filaments up to 12 mic. in diameter, unbranched, in mature state greatly elongate and with the sheath truncate and open, in the young condition shorter and often ending in a rather short hair; sheaths firm, rather thick, often distinctly lamellose, colorless; trichomes 7 mic. in diameter, continuous or interrupted; cells short; heterocysts somewhat spherical; cell contents finely granular.

Connecticut. Growing in little tufts in salt or brackish water. Stonington Inlet. (Wood).

495. Calothrix lacucola Wolle. Fresh Water Algae. V. Bull. Torr. Bot. Club. 8: 39. I88I; Fresh-Water Algae U. S. 239. pl. I72. f. I. I887. Wolle and Martindale. Algae. Britton's Catalogue of Plants found in New Jersey. Geol. Surv. N. J. 2: 603. I889. De Toni. Syll. Algar. 5: 629. I907.

\section{Plate XVIII. fig. 13.}

Plant mass floating, dull yellow or brownish; filaments $15-20$ mic, in diameter at the base, very much branched; false branches somewhat spreading, not concrete, moderately tapering, with obtuse, slightly bent apices, elongate, interwoven; sheaths close, colorless or yellowish; trichomes thin, homogeneous or with distinct transverse walls; cells equal to or two or three times shorter than their diameter; heterocysts spherical, usually single at the base of the branches, equalling the trichome in diameter.

New Jersey. Split Rock Pond, Morris. (Wolle). 
496. Schizosiphon obscurus Dickie. Notes on some Algae found in the North Atlantic Ocean. Journ. Linn. Soc. Bot. II: 459. f. 5. I87I. De Toni. Syll. Algar. 5: 633. 1907.

\section{Plate XVIII. fig. I4.}

Filaments straight, gradually tapering upwards from the large, somewhat spherical basal cell (heterocyst?); sheaths distinct, obscurely lamellose; trichomes shorter than the sheath, usually torulose throughout.

West Indies ?. Forming a thin stratum on drift wood. (Mitchell). "The contents of the bottle were collected in the North Atlantic on the 24th of November, I867. * * * Considering our position, I concluded that the substance must have come from some part of the American continent or the West Indies within the influence of the Gulf Stream."-Dickie.

497. Mastigonema paradoxum Kuetzing. Phyc. Gen. 233. pl. 5. f. 3. I843. De Toni. Syll. Algar. 5: 632. I907.

Wolle. Fresh Water Algae. III. Bull. Torr. Bot. Club. 6: 184. 1877.

$$
\text { Plate XVIII. fig. I5. }
$$

Filaments somewhat solitary; sheaths wide, colorless or yellowish brown, transparent, homogeneous; trichomes up to 13 mic. in diameter, simple or sometimes branched, often moniliform, flaccid or flexuously curved, long; heterocysts spherical, two to four times shorter than the diameter of the trichome.

Pennsylvania. On wet sides of wooden water box. (Wolle).

498. Calothrix thizosoleniae Lemmermann. Planktonalg. in Ergebn. ein Reise n. d. Pacific. 355. 1899. De Toni. Syll. Algar. 5: 630. 1907.

Lemmermann. Algenfl. Sandwich.-Inseln. Bot. Jahrb. 34: 627. pl. 7 . f. 2, 3. I905.

Filaments up to 3 mic. in diameter, slightly thickened at the base, slightly tapering at the apex; sheaths transparent, close; trichomes 2.5 mic. in diameter; cells 1.5 mic. in length.

Hawaii. In plankton on Rhizosolenia and Hemiaulus delic a $t$ u 1 u s Lemm. Between Hawaii and Laysan. r896-1897. (Schauinsland).

499. Mastigonema sejunctum Wood. Contr. Hist. Fresh-Water Algae North America. 53. pl. 4. f. 2: I872. De Toni. Syll. Algar. 5: 631. 1907.

Plant mass somewhat caespitose, soft, parasitic; filaments unbranched, tapering at the apex; sheaths usually wide and distinct, hyaline, often strongly undulate, the apex mostly much amplified and dissolved into fibrillae; trichomes continuous or more rarely interrupted; cells short or lcng; cell contents granular, yellowish olive or greenish; heterocysts about equal to the filament in diameter.

Michigan. In bog growing on edges of minute leaves so as to form little prominences or thickenings of the margin.

500. Mastigothrix turgida Wolle. Fresh Water Algae. III. Bull. Torr. Bot. Club. 6: 184. 1877. De Toni. Syll. Algar. 5: 632. 1907. 
Filaments I5-20 mic. in diameter at the base, swollen, often curved; trichomes elongated into a colorless, transparent, pointed hair, with long cells; cells in basal portion of trichome somewhat quadrate, becoming when old three or four times shorter than the diameter; cell contents at first blue-green, later violet or yellowish; heterocysts compressed spherical or concave-convex.

Pennsylvania. Scattered, or in small clusters, in gelatinous coatings on submerged timbers. (Wolle).

\section{Genus DICHOTHRIX Zanardini.}

Plant. Maris Rubri Enum. 89. 1858.

Plant mass caespitose, penicillate or pulvinate; filaments more or less dichotomously branched; trichomes often several (two to six) enclosed within the original sheath or common tegument; heterocysts sometimes basal, sometimes intercalary, in one species not present.

I Plants living in fresh water.

I Sheaths close, gradually tapering at the apex

(I) Plants living in hot water; filaments $15-25$ mic. in diameter, trichomes $5-6$ mic. in diameter

D. montana

(2) Filaments IO-I2 mic. in diameter, flexuous, erect, radiating

D. orsiniana

(3) Plant mass encrusted with calcium carbonate; filaments 9-I2.5 mic. in diameter, prostrate, not rigid

D. calcarea

(4) Plants living in fresh or rarely salt water; filaments about 15 mic. in diameter; trichomes 5-9 mic. in diameter, constricted at joints

D. baueriana

(5) Filaments $12-15$ mic. in diameter; trichomes 10-15 mic. in diameter, not constricted at joints

D. olivacea

2 Sheaths lamellose, funnel-shaped at apex

(I) Filaments 9-12 mic. in diameter; trichomes 6 mic. in diameter D. compacta

(2) Filaments 13 mic. in diameter; trichomes 6.5-7.5 mic. in diameter D. meneghiniana

(3) Plant mass usually encrusted with calcium carbonate; filaments I5-18 mic. in diameter; trichomes 6-8 mic. in diameter

D. gypsophila

(4) Filaments 25-28 mic. in diameter; trichomes IO-I2 mic. in diameter, bulbously inflated at the bases of the branches; heterocysts light blue in color

D. hosfordii

II Plants living in salt water.

I Filaments 1 5-22 mic. in diameter; trichomes 7-9 mic. in diameter; heterocysts basal

D. rupicola

2 Filaments 20-30 mic. in diameter; trichomes $17-22$ mic. in diameter; heterocysts basal and intercalary $\quad$ D. fucicola 
3 Filaments 25-35 mic. in diameter; trichomes 15 mic. in diameter; heterocysts oblong, solitary

D. penicillata

4 Filaments 22-30 mic. in diameter; trichomes 7.5-12.5 mic. in diameter; heterocysts basal and intercalary

D. utahensis

50r. Dichothrix montana Tilden. American Algae. Cent. VI. no. 572. I902. De Toni. Syll. Algar. 645. 1907.

Plant mass expanded, blue-green; filaments $15-25$ mic. in diameter; sheaths hyaline; trichomes 5-6 mic. in diameter, sometimes constricted at joints, drawn out into a long hair; cells quadrate or longer than their diameter; heterocysts hemispherical.

Montana. On rocks in hot water. Lo Lo Hot springs, Lo Lo. September I898. (Griffiths).

The plant closely resembles D. ba u e riana, but its filaments are much wider and its habitat quite different. Being very plainly a $\mathrm{D}$ i c h oth $\mathrm{rix}$, it cannot be included under $\mathrm{Ca}$ loth $\mathrm{rix}$ thermalis, and it is therefore made a new species.

502. Dichothrix orsiniana (Kuetzing) Bornet and Flahault. Revis. des Nostoc. Ann. Sci. Nat. Bot. VII. 3: 376. I886. De Toni. Syll. Algar. 5: 641. 1907.

Wolle. Fresh Water Algae. II. Bull. Torr. Bot. Club. 6: I38. I877. ( $M$ astigonema orsiniant m Kg.); 6: 284. 1879. ( $\mathrm{Sch}$. cat a a ct a e Naeg.); Fresh-Water Algae U. S. 236. pl. 168. f. I, 2. I887. (C a 1 othrix orsiniana Thur.). Tilden. List of Fresh-Water Algae collected in Minnesota during 1895. Minn. Bot. Studies. I: 599. I896. Collins, Holden and Setchell. Phyc. Bor.-Am. Fasc. 9. no. 405. I898. Collins. Phycological Notes of the late Isaac Holden.-II. Rhodora. 7: 238. I905.

\section{Plate XVIII. fig. I6.}

Plant mass caespitose, made up of penicillate fascicles 2-3 $\mathrm{mm}$. in height, gelatinous, dark green; filaments ro-r2 mic. in diameter (in ultimate branches), flexuous, erect, radiating; false branches appressed, enclosed for some distance in a common tegument; sheaths thick, close, soft, uniform, yellow, in lower portions becoming brownish and somewhat opaque; trichcmes 6-7.5 mic. in diameter, tapering into a hair; cells shorter than their diameter; cell contents olive green; heterocysts basal.

Connecticut. Forming gelatinous tufts on rocks at the base of a dam. Pequonnock River, Bridgeport. July 1894. (Holden). New York. On rocks in rapids of Niagara River, Niagara Falls. (Wolle). Florida. (Wolle), Minnesota. Kenwood, Minneapolis. August 1895. (Tilden).

503. Dichothrix calcarea Tilden. American Algae. Cent. II. no. I65. I896. De Toni. Syll. Algar. 5: 645. 1907; Some New Species of Minnesota Algae which live in a Calcareous or Silicious Matrix. Bot. Gaz. 23: 100. pl. 9. f. I-3. I897; List of Fresh-Water Algae collected in Minnesota during 1896 and 1897. Minn. Bot. Studies. 2: 27. 1898. MacMillan. Minnesota Plant Life. 30, 41. f. 8, 10. 1899. 


\section{Plate XVIII. fig. I\%.}

Forming extended strata either on surface of calcareous matrix, giving it a pinkish brown or pale blue-green tinge, or in layers throughout the matrix; filaments 9-12.5 mic. in diameter, prostrate, not rigid; false branches appressed; sheaths rather thin, not lamellose, hyaline; trichomes up to Io mic. in diameter, for the most part constricted at joints in lower portions, tapering to a hair point; cells in lower portion of filament equal in length to their diameter, shorter in upper portions; heterocysts basal, spherical or depressed, equal to or a little smaller than the diameter of the filament.

Minnesota. Together with $\mathrm{Ch}$ a et ophora calcarea, Lyng bya martensiana calcarea and L. na'n a, forming the lime encrustation which covers sides of wooden tank. Minneapolis. October 1895. (Tilden).

504. Dichothrix baueriana (Grunow) Bornet and Flahault. Revis. des Nostoc. VII. 3: 375. I886. De Toni. Syll. Algar. 5: 640. 1907.

Wolle. Fresh Water Algae. Bull. Torr. Bot. Club. 6: 284. I879. (S c h izosiphon ba uerian um Grun.). Setchell. Notes on Cyanophyceae. -I. Erythea. 4: 88. I896. Collins, Holden and Setchell. Phyc. Bor.-Am. Fasc. 5. no. 216. 1896. Setchell and Gardner. Algae of Northwestern America. Univ. Calif. Pub. Bot. I: 198. I903. Collins, Holden and Setchell. Phyc. Bor.-Am. Fasc. 24. no. II69. I904.

Plate XVIII. fig. I8.

Filaments 55 mic. in diameter (in ultimate branches), caespitose-penicillate or forming a widely expanded layer up to a centimeter in thickness, flexuous; sheaths close, gelatinous, soft, uniform, transparent or yellowish; trichomes 5-9 mic. in diameter, constricted at joints, gradually tapering into a long hair; cells shorter than or equal to their diameter; cell contents green or brown; heterocysts somewhat spherical or hemispherical.

Alaska. On dripping rocks or stones in running or quiet water. Near Iliuliuk, Unalaska. (Setchell and Lawson). Orca. (Jepson). Rhode Island. Forming an uninterrupted coating on submerged limestone rocks in quiet water. Lime Rock. October 1894 . (Osterhout). On stones at border of lily pond. Newport. Connecticut. Round Pond, Lantern Hill, Ledyard; on stones about edges of lake, Lake Whitney, in Hamden, near New Haven. (Setchell). Florida. On submerged wood. (Smith). Washington. Whatcom. (Gardner). West Indies. On rocks, littoral. Porto Rico. May 1903. (Howe). "The present specimens appear to be the first recorded from a strictly marine station."-Collins.

505. Dichothrix olivacea (Hooker) Bornet and Flahault. Revis. des Nostoc. Ann. Sci. Nat. Bot. VII. 3: 375. I886. De Toni. Syll. Algar. 5: 639. 1907 .

Mazé and Schramm. Essai Class. Algues Guadeloupe. 36. I877. (C a 1 othrix submarina Crouan). Murray. Catalogue of the Marine Algae of the West Indian Region. Journ. of Bot. 27: 26r. 1889. 
Plant mass caespitose, erect, pulvinately expanded, olive or black; filaments $12-15$ mic. in diameter (in the ultimate branches), up to $2 \mathrm{~cm}$. in length, slightly flexuous; false branches very long, equal; sheaths close, thin, uniform, hyaline or yellowish; trichomes I0-I5 mic. in diameter, not constricted at joints, tapering into a hair; cells quadrate or longer than their diameter; cell contents blue-green or olive; heterocysts basal, often in pairs.

West Indies. Guadeloupe. (Mazé).

506. Dichothrix compacta (Agardh?) Bornet and Flahault. Revis. des Nostoc. Ann. Sci. Nat. Bot. VII. 3: 378. I886. De Toni. Syll. Algar. 5. 643. 1907 .

Setchell. Notes on Cyanophyceae.-III. Erythea. 7: 45. 1899.

Plant mass caespitose; filaments 9-I2 mic. in diameter, up to $1 \mathrm{~mm}$. in length, very densely aggregated, erect, penicillate; the upper false branches appressed, often included, for some distance within the common tegument; sheaths lamellose, smooth, uniform or ocreate, orange becoming brownish; ocreae dilated and torn at the apex; trichomes 6 mic. in diameter, ending in a hair at the apex; cells as long as broad, or half as long; cell contents pale olive; heterocysts basal.

California. San Bernardino. (Parish).

"Dichothrix compacta (Ag.) B. and F. is not always readily to be distinguished from D. gypsophila. It is said to resemble Calothrix parietina in every way except that it has the branching of the genus Dichothrix. It is shorter than D. gypsophila, and has the cells of the trichome usually shorter, rather than longer, than broad. $* * *$ The sheaths are yellowish-brown, lamellose, more or less dilated towards the summit, but, at the very summit, are usually contracted again very suddenly."-Setchell.

507. Dichothrix meneghiniana (Kuetzing) De Toni. Syll. Algar. 5: 64r. Ig07.

Wolle. Fresh Water Algae. Bull. Torr. Bot. Club. 6: 284. I879. (S c h jz osiphon meneghinianus Kuetz.); Fresh-Water Algae U. S. 238. pl. I70. f. 5-7. I887. Wolle and Martindale. Algae. Britton's Catalogue of Plants found in New Jersey. Geol. Surv. N. J. 2: 603. 1889. (Calothrix meneghinia n a Kirchn.).

\section{Plate XIX. fig. I.}

Plant mass composed of small deep blue-green or green dense tufts; filaments 13 mic. in diameter, short, simple in the beginning, later much and compactly branched; sheaths distinctly lamellose, yellow or brown in lower portions, colorless and torn into fine fibres at the apices; trichomes 6.5-7.5 mic. in diameter; cells somewhat quadrate, or twice as short as the diameter; heterocysts usually single, about as large as the cells.

New Jersey. Frequent on submerged wood in fresh water. (Wolle). Florida. Forming a gelatinous stratum on old wet wood. (Smith). 
508. Dichothrix gypsophila (Kuetzing) Bornet and Flahault. Revis. des Nostoc. Ann. Sci. Nat. Bot. VII. 3: 377. I886. De Toni. Syll. Algar. 5: 642. 1907 .

Wolle. Fresh-Water Algae U. S. 237. pl. I68. f. 5. I887. (C a 1 ot h rix gy p ophila $\mathrm{Kg}$.). Wolle and Martindale. Algae. Britton's Catalogue of Plants found in New Jersey. Geol. Surv. N. J. 2: 603. I889. Weed. Formation of Travertine and Silicious Sinter by the Vegetation of Hot Springs. U. S. Geol. Survey. 9th Ann. Report. 665. 1889. Setchell. Notes on Cyanophyceae.-I. Erythea. 4: 88. 1896. Tilden. American Algae. Cent. II. no. 200 B. I896. Collins, Holden and Setchell. Phyc. Bor.-Am. Fasc. I2. no. 562. I899. Collins. Phycological Notes of the late Isaac Holden.-II. Rhodora. $7: 238$. I905.

\section{Plate XIX. fig. 2 .}

Filaments caespitose, scattered or forming a somewhat continuous layer, very often "nestling" among filaments of $\mathrm{H}$ y p heotrich u m and I. e p ot $\mathrm{r}$ i c h $\mathrm{m} \mathrm{m}$, and encrusted with calcium carbonate (calareous tufa), I5-I8 mic. in diameter (in the ultimate branches), about $2 \mathrm{~mm}$. in length, erect, penicillate; upper false branches appressed, included within the common tegument; sheaths thick, lamellose, smooth, orange becoming brown, finally opaque, ocreate; ocreae dilated, truncate, and torn at the apices; trichomes 6-8 mic. in diameter, gradually tapering into a hair; cells equal to or a little longer than the diameter; cell contents green or olive.

Connecticut. Forming gelatinous yellow masses upon rocks and small stones about the edge of Long Pond, at Lantern Hill, in Ledyard. September 1892. (Setchell). Incrusted on limestone, shore of Housatonic River, near Gaylordsville. October 1898. (Holden). New Jersey. Fresh Water. Morris; rocky shores of Lake Hopatcong. (Wolle). Florida. Adams Kay. July 1895. (Curtiss.) Wyoming. Forming a finely fibrous sinter, consisting of layers one-sixteenth of an inch to half an inch thick, each stratum resembling a very fine thick white fur. In overflow channels of geysers. Upper Geyser Basin, Yellowstone National Park. (Weed). Taken from wall of Excelsior crater. Weed affirms that it is due "to the growth of the little alga-Calothrix gypsophila-or the young form, Mastigonema therma 1 e." Middle Geyser Basin, Yellowstone National Park. June ז896. (Tilden).

509. Dichothrix hosfordii (Wolle) Bornet in Setchell. Notes on Cyanophyceae.-II. Erythea. 4: I90. 3896. Wolle. Fresh-Water Algae. V. Bull. Torr. Bot. Club. 8: 38. I88I. (C a loth $\mathrm{rix}$ h os fordi Wolle); Fresh-Water Algae U. S. 239. pl. I69. f. I-4; pl. I70. f. 3, 4. 1887 .

Collins, Holden and Setchell. Phyc. Bor.-Am. Fasc. 5. no. 215. I896. Collins. Some Perforating and other Algae on Fresh-Water Shells. Erythea. 5: 96. I897; Phycological Notes of the late Isaac Holden.-II. Rhodora. 7: 238. I905. Collins, Holden and Setchell. Phyc. Bor.-Am. Fasc. 29. no. 1408. 1907. 
Plate XIX. fig. 3 .

Plant mass olivaceous; filaments $25-28 \mathrm{mic}$. in diameter; sheaths wide, distinctly lamellose, yellow towards the base, colorless and hyaline towards the end; trichomes IO-I2 mic. in diameter, aggregated, subdichotomously branched, bulbously inflated at the bases of the branches; branches flagelliform, tapering to a fine, colorless hair point; cells four or five times shorter than their diameter; heterocysts depressed hemispherical ("skull-cap" shaped), light blue in color.

Vermont. Charlotte. (Hosford). Massachusetts. On pebbles. Shores of Pranker's Pond, Saugus. September I893; epiphytic on flowering plants ir: shallow water, Herring Pond, Eastham, August 1907. (Collins). Conrecticut. On smooth red sandstone in running water. Wintergreen Falls, Hampden, near New Haven. November I891. (Setchell). On stones on border of pool below Factory Pond, Pequonnock River. June, July, October, November. Bridgeport. (Holden). Growing on outside surface of Unio shells. Twin Lakes, Salisbury, Litchfield County. (Setchell and Holden). New York. Growing upon submerged stones. Lake George. October I892. (Jelyffe). Michigan. Ann Arbor. (Johnson).

510. Dichothrix rupicola Collins. Notes on Algae.-IV. Rhodora. 3: 290. I9or. Collins, Holden and Setchell. Phyc. Bor.-Am. Fasc. 20. no. 958. 1902. De Toni. Syll. Algar. 5: 644. 1907.

Plant mass caespitose, I $\mathrm{mm}$. in thickness; filaments $15-22$ mic. in diameter, erect, penicillate, branched; ultimate branches flexuous, divaricate, acute; sheaths lamellose, yellow brown with dilated and lacerate ocreation near the tip; trichomes 7-9 mic. in diameter, terminating in a hair; cells about equal to the diameter in length; heterocysts basal; cell contents bluegreen to pale olive.

Maine. Forming a coating on sloping rocks, exposed to the full force of the surf. Pemaquid Point. July Igor. (Collins).

5II. Dichothrix fucicola (Kuetzing) Bornet and Flahault. Revis. des Nostoc. Ann. Sci. Nat. Bot. VII. 3: 379. I886. De Toni. Syll. Algar. 5: 644. 1907.

Mazé and Schramm. Essai Class. Algues Guadeloupe. 32. 1877. (M a s$\mathrm{t}$ ichonema sargassi Crouan). Murray. Catalogue of the Marine Algae of the West Indian Region. Journ. of Bot. 27: 26I. I889.

Plant mass caespitose, made up of penicillate, olive green fascicles, 5-8 $\mathrm{mm}$. in height; filaments $20-30 \mathrm{mic}$. in diameter (in the ultimate branches), erect, rigid; false branches appressed, strict, fastigiate, included for some distance within the common tegument; sheaths close, thin, uniform, hyaline or yellowish; trichomes $17-22$ mic. in diameter, ending in a long hair; upper cells quadrate or one-half as long as wide, lower cells two or three times longer than wide; cell contents pale green; heterocysts basal and intercalary.

West Indies. Guadeloupe. (Mazé). 
512. Dichothrix penicillata Zanardini. Plantarum Maris Rubri Enumeratio. 89. pl. 12. f. 3. 1858. Bornet and Flahault. Revis. des Nostoc. Ann. Sci. Nat. Bot. VII. 3: 379. I886. De Toni. Syll. Algar. 5: 644. 1907.

Collins, Holden and Setchell. Phyc. Bor.-Am. Fasc. 2. no. 62. I895. Collins. The Algae of Jamaica. Proc. Am. Acad. Arts Sci. 37: 242. I90I. Collins, Holden and Setchell. Phyc. Bor.-Am. Fasc. 23. no. III2. Igo3.

Plant mass caespitose, fastigiate-penicillate, scattered or gregarious, dark green; filaments 25-35 mic. in diameter, (in ultimate branches), $2 \mathrm{~mm}$. in length, short, flexuous; sheaths thick, gelatinous, soft, uniform, hyaline; trichomes I5 mic. in diameter; cells shorter than the diameter; cell contents olive; heterocysts oblong, solitary.

Mexico. Gulf of Mexico. (Hooper). West Indies. Guadeloupe. (Mazé). In tufts at joints of Cymopolia barbata. Port Maria, Jamaica. March 1893. (Humphrey). On Dict y ot a dichoto ma. (Pease and Butler). On Digenia simplex. Santurce, Porto Rico. May I903. (Howe).

513. Dichothrix utahensis Tilden. American Algae. Cent. III. no. 288. I898.

Setchell. Notes on Cyanophyceae.-III. Erythea. 7: 45. I899.

Plant mass impregnated with calcium carbonate, light blue-green, -5-I $\mathrm{cm}$. in thickness; filaments $22-30 \mathrm{mic}$. in diameter, generally thickened at the base; false branches appressed, included below in the common tegument; sheaths thick, lamellose, colorless or brownish; trichomes 7.5-12.5 mic. in diameter, sometimes constricted at joints, tapering into a long hair; cells in lower portions equal to the diameter in length, in upper Iarts shorter than the diameter; cell contents olive green; heterocysts basal and intercalary, the former one to three in number.

Utah. Forming a calareous crust on an old board and on stones in a small stream running from a brackish pond into Great Salt Lake, one mile northeast from Black Rock, Garfield Beach. July I897. (Tilden).

The above species resembles D. gypsophila and $D$. calcarea in its habit of forming a calcareous crust and in some minor characters; like Calothrix scopularum it has the basal portion of the filament thickened and often shows two or three basal heterocysts. Dr. Setchelr refers it to $\mathrm{Ca} l o t h \mathrm{rix}$ parietina, but the filaments are much too large for that species, there are numerous intercalary heterocysts, and it differs in several other important characteristics.

Genus POLYTHRIX Zanardini. Phyc. Indic. Pugillus. 32. I872.

Plant mass filiform, branched, consisting of numerous filaments fasciculately arranged, included within a common tegument; filaments densely crowded, branched; heterocysts terminal and intercalary.

514. Polythrix corymbosa (Harvey) Grunow in herb. Bornet and Flahault. Revis. des Nostoc. Ann. Sci. Nat. Bot. VII. 3: 380. I886. Harvey. Nereis Boreali-Americana. Part. III. 109. pl. 28 B. r858. (M icrocoleus corymbosus Harv.). De Toni. Syll. Algar. 5: 645. 1907. 
Farlow. List Marine Algae U. S. Proc. Am. Acad. Arts Sci. Io: 380. 1875. Murray. Catalogue of the Marine Algae of the West Indian Region. Journ. of Bot. 27: 261. I889. Collins, Holden and Setchell. Phyc. Bor.-Am. Fasc. 21. no. IoI6. I903.

Plant mass caespitose, pulvinate, expanded, made up of rigid, fastigiate, twisted tufts $\mathrm{I}-3 \mathrm{~cm}$. in height, dichotomously or irregularly branched; common tegument transparent or yellowish; trichomes 5-6 mic. in diameter, tapering into a thin hair at the apex; heterocysts somewhat spherical.

Florida. On mud flats near high water mark. Key West. (Harvey, Farlow). Forming a turf, I cm. thick, on rocks just below low water mark. Key West. October 1902. (Howe).

\section{Genus SACCONEMA Borzi.}

Morfologia, etc. N. Giorn. Bot. Ital. I4: 282, 298. I882.

Plant mass or colony small, gelatinous, lobed or torn; common tegument lamellose, very much folded and saccate, finally dissolved at apices, containing from two to many trichomes; trichomes irregularly aggregated, somewhat caespitose; false branches short, moniliform, not coalesced; heterocysts basal, spherical; gonidia present.

5I5. Sacconema rupestre Borzi. Note alla Morfologia e Biologia delle Alghe Ficocromacee. Nuovo Giorn. Bot. Ital. I4: 282, 298. pl. 16, I7. f. 9-12. 1882. Bornet and Flahault. Revis. des Nostoc. Ann. Sci. Nat. Bot. VII. 3: 381. I886. De Toni. Syll. Algar. 5: 646. I907.

Hauck and Richter. Phyk. Univ. no. 74I. I89I. Wittrock, Nordstedt and Lagerheim. Algae Aq. Dulc. Exsicc. no. 1309. I896.

\section{Plate XIX. fig. 4.}

Trichomes 8 mic. in diameter; heterocysts basal, spherical; gonidia I5 mic. in diameter; wall of gonidium roughened.

Massachusetts. Suntaug Lake, Tynnfield. September I89o. (Collins).

\section{Genus ISACTIS Thuret. Essai Class. Nostochinées. II. I885.}

Plant mass flat, crustaceous, orbicular, thin, adhering by the lower surface, growing at the margin; filaments parallel, erect, unbranched or rarely sparingly branched; heterocysts basal; gonidia unknown.

I Filaments decumbent at base; trichomes 7-9 mic. in diameter

$$
\text { I. plana }
$$

II Filaments slightly swollen at base; trichomes 8-To mic. in diameter

\section{I. centrifuga}

516. Isactis plana (Harvey) Thuret. Essai Class. Nostochinées. II. I885. Bornet and Flahault. Revis. des Nostoc. Ann. Sci. Nat. Bot. VII. 4: 344. I886. De Toni. Syll. Algar. 5: 646. 1907.

Wolle. Fresh Water Algae. II. Bull. Torr. Bot. Club. 6: 138. 1877. (Mastigon ema plana Rab.). Farlow. Marine Algae of New Eng- 
land. 39. p1. I. f. 2. I88I. Bot. Club. I3: 106. I886.

Pike. Check List of Marine Algae. Bull. Torr. Collins. Marine Algae of Nantucket. 5. I888; Algae from Atlantic City, N. J. Bull. Torr. Bot. Club. 15: 310. I888. Martindale. Marine Algae of the New Jersey Coast and Adjacent Waters of Staten Island. Mem. Torr. Bot. Club. I: 91. I889. Wolle and Martindale. Algae. Britton's Catalogue of Plants found in New Jersey. Geol. Surv. N. J. 2: 603. I889. Collins, Holden and Setchell. Phyc. Bor.-Am. Fasc. 4. no. I56. I896. Collins. Preliminary Lists of New England Plants.-V. Miarine Algae. Rhodora. 2: 42. 1900; Phycological Notes of the late Isaac Holden.-II. Rhodora. 7 : 224. 1905.

\section{Plate XIX. fig. 5.}

Plant mass green. becoming brown or black, showing dark purple tints when dried; filaments decumbent at the base, up to $.5 \mathrm{~mm}$. in length, crowded; sheaths close, transparent, sometimes yellowish, scarcely distinct; trichomes 7-9 mic. in diameter, produced at the apex into a very long, thin hair; cells shorter than their diameter; cell contents blue-green or greenish violet.

New England. Very common on rocks and on other algae, forming dark green spots scarcely raised above the substance on which it is growing. (Farlow). Massachusetts. On Fucus vesiculosus at half tide. Cuttyhunk. August 1894. (Setchell). On shells. Polpis. (Collins). Connecticut. On stones. Charles Island. September. (Holden). New York. Wet rocks. Portage. (Wolle). On shells at and below low water mark. Cold Spring Harbor. August I895. (Johnson). Shores of Long Island. On Fucus. Fort Hamilton, Jamaica Bay. (Pike). New Jersey. On stones and old oyster shells. Atlantic City. (Morse, Martindale).

Var. fissurata Bornet and Flahault. 1. c. 345. De Toni. 1. c. 647.

Setchell and Gardner. Algae of Northwestern America. Univ. Calif. Pub. Bot. I: 198. 1903 .

Plant mass zonate; filaments branched, closely cohering; especially rock-loving.

Alaska. On stones. Captains Bay, Unalaska. (Lawson).

5I7. Isactis centrifuga Bornet in Collins. Notes on Algae.-III. Rhodora. 3: 136. Igor. Collins, Holden and Setchell. Phyc. Bor-Am. Fasc. I6. no. 757. 1900. De Toni. Syll. Algar. 5: 647. 1907.

Plant mass up to $4 \mathrm{~cm}$. in diameter, the growth marginal, the central portion of the mass becoming detached from the substratum and rounding upwards, while the margin remains closely attached, dark green or nearly biack; filaments 8-12 mic. in diameter, slightly swollen at base, reaching a length of a millimeter; sheaths firm, usually translucent, sometimes brownish and opaque; trichomes 8-Io mic. in diameter; cells one-third to onehalf as long as wide; heterocysts basal, spherical or depressed, rarely intercalary and spherical or elongate.

Rhode Island. On soft crumbling rocks, at low water mark. Ochre Point, Newport. May, June I90o. (Collins). 
Genus RIVULARIA (Roth) Agardh. Syst. Algar. 19. I824.

Colonies spherical, hemispherical or inflated and lobed, solid or hollow, sometimes confluent into an indefinite mass; filaments radiating from the center, repeatedly branched; sheaths conspicuous near the base of the trichomes, near the periphery of the colony gelatinous and confluent; heterocysts basal; gonidia more or less cylindrical and elongate, not known in all species.

I Filaments flagelliform, tapering towards the apex; gonidia present

I Colonies hard; trichomes 4-7 mic. in diameter; gonidia 9-15 mic. in diameter, especially cylindrical

R. pisum

2 Colonies soft; trichomes 7-9 mic. in diameter; gonidia 10-18 mic. in diameter, larger at the base

R. natans

3 Colonies firm, solid, light green; gonidia cylindrical, ifrequently curved, about nine times as long as broad

$\mathbf{R}$. incrustata

4 Colonies soft, solid; trichomes 8-1o mic. broad at the base; gonidia 8-I8 mic. in diameter, cylindrical, straight or slightly curved

R. echinulata

II Filaments gradually tapering; gonidia unknown

I Colonies hollow when old

(I) Colonies soft; trichomes 4-5 mic. in diameter in lower portion, somewhat constricted at joints $\quad R$. polyotis

(2) Colonies soft; trichomes 2-5 mic. in diameter, cylindrical

2 Colonies solid

R. nitida

(I) Colonies not encrusted with calcium carbonate

A Plants living in fresh water
a Trichomes 4 mic. in diameter
R. borealis
b Trichomes 6-10 mic. in diameter
R. compacta
c Trichomes 9-12.5 mic. in diameter
R. minutula

d Trichomes continuous or indistinctly divided; heterocysts ro-I2 mic. in diameter

R. paradoxa

B Plants living in salt water; trichomes 2.5-5 mic. in diameter

R. atra

(2) Colonies encrusted with calcium carbonate

A Colonies hemispherical, finally confluent and forming a hard, stony crust; trichomes $4-7.5$ mic. in diameter

R. haematites

D Colonies small, somewhat hard; trichomes 4-9 mic. in diameter

R. dura

C Colonies at first hemispherical, afterwards forming a gelatinous crust, indurated with calcium carbonate in the interior; trichomes 5-9 mic. in diameter

R. coadunata

D Colonies spherical, hard; trichomes 4-I6 mic. in diameter

$R$. bornetiana 
Species not well understood

\author{
R. mexicana \\ R. microscopica \\ $Z$ minutula \\ Z. mollis
}

518. Rivularia pisum Agardh. Syst. Algar. 25. 1824. Bornet and Flahault. Revis. des Nostoc. Ann. Sci. Nat. Bot. VII. 4: 366. 1886. (Gl o e otrichia pisum Thur.). De Toni. Syll. Algar. 5: 653. 1907.

Wood. Contr. Hist. Fresh-Water Algae North America. 47. pl. 2. f. 9. 1872. (R. cartilaginea Wood). Wolle. Fresh Water Algae. II. Bull. Torr. Bot. Club. 6: 138. 1877. Campbell. Plants of the Detroit River. Bull. Torr. Bot. Club. I3: 93. I886. (R. e ch in at a Eng. Bot.). Arthur. Some Algae of Minnesota supposed to be Poisonous. Fourth Bien. Report Bd. Regents. Suppl. ז. 99. 1887; Second Report on some Algae suppused to be Poisonous. 1. c. I09. I887. (G I. p i s u m (Ag.) Thur.). Collins. Algae of Middlesex County. I3. I888. Wolle and Martindale. Algae. Britton's Catalogue of Plants found in New Jersey. Geol. Surv. N. J. 2: 604. I889. Anderson and Kelsey. Common and Conspicuous Algae of Montana. Bull. Torr. Bot. Club. I8: 143. I89r. Saunders. ProtophytaPhycophyta. Flora of Nebraska. 25. pl. 3. f. 33. 1894. Collins, Holden and Setchell. Phyc. Bor.-Am. Fasc. 7. no. 3II. 1897. Tilden. List of Fresh-Water Algae collected in Minnesota during 1896 and 1897. Minn. Bot. Studies. 2: 27. I898. Kellerman. Proposed Algological Survey of Chio. Ohio Nat. 2: 222. Igo2. Nelson. Observations upon some Algae which cause "Water Bloom." Minn. Bot. Studies. 3: 52, 56. 1903. Collins. Phycological Notes of the late Isaac Holden.-II. Rhodora. 7: 238. I905. Collins, Holden and Setchell. Phyc. Bor.-Am. Fasc. 27. no. I310. 1905.

Plate XIX. fig. 6.

Colonies small, I-2 mm., rarely up to I $\mathrm{cm}$. in diameter, spherical, hard, blackish green; filaments crowded; trichomes 4-7 mic. in diameter, ending in a hair; cells somewhat quadrate; cell contents olive; gonidia 9-I5 mic. in diameter, 60-400 mic. in length, surrounded by a special sheath.

Massachusetts. Medford, Newton. (Farlow). On stems of flowering plants. Lake Quannapowitt, Wakefield. September 1906. (Collins). Connecticut. Floating on the surface, forming a verdigris-green scum. Twin L.akes, Salisbury. October I892. (Setchell and Holden). New Jersey. "Parasitic" on aquatic plants in ponds and pools. (Wolle). Ohio. (Kellerman). Michigan. Attached to leaves of water plants in marsh. Northern part of state. (Wood). Grosse Isle, near mouth of Detroit River. Summer of I885. (Campbell). Minnesota. Lake Phalen, near St. Paul. August I882; Lake Tetonka, at Waterville. July I883; Lake Minnetonka. August 1883. (Farlow and Arthur). Abundant on water plants. Vermilion Lake. July I886. (Arthur, Bailey and Holway). Floating on surface of water in large quantity. Lake Minnewaska, Glenwood. August 1897. (Foss). Iowa. On Utricularia. East Okoboji Lake. July 1883. (Farlow and Arthur). 
Nebraska. On water plants. Minden. (Saunders). Montana. On leaflets of Myriophy $11 \mathrm{um}$. Common in Sand Coulee Creek. (Anderson and Kelsey).

519. Rivularia natans (Hedwig) Welwitsch. Synopsis Nostochinearum Austriae Inferioris. 17. 1836. Bornet and Flahault. Revis. des Nostoc. Ann. Sci. Nat. Bot. VII. 4: 369. i886. De Toni. Syll. Algar. 5: 648. 1907 .

Wood. Contr. Hist. Fresh-Water Algae North America. 47. I872. (G1o eotrichia angulos a Rab.). Wolle. Fresh Water Algae. II. Bull. Torr. Bot. Club. 6: 138. I877; Fresh-Water Algae U. S. 246. pl. 178. f. 4-20; pl. 179. f. IO, II. I887. Rabenhorst. Algen Europa's. no. 2539. (G1 o i otrichia parvula Rabenh.). Bennett. Plants of Rhode Island. Ir4. I888. Wolle and Martindale. Algae. Britton's Catalogue of Plants found in New Jersey. Geol. Surv. N. J. 2: 604. 1889. Saunders. Protophyta-Phycophyta. Flora of Nebraska. 24. pl. 3. f. 32. I894. Tilden. American Algae. Cent. I. no. 80. I894; List of Fresh-Water Algae collected in Minnesota during I894. Minn. Bot. Studies. I: 236. I895. Collins, Holden and Setchell. Phyc. Bor.-Am. Fasc. 5. no. 214. I896. Collins. The Algae of Jamaica. Proc. Am. Acad. 37 : 242. I90I. Tilden. American Algae. Cent. VI. no. 569. 1902. Kellerman. Proposed Algological Survey of Ohio. Ohio Nat. 2: 222. 1902. Clark. The Holophytic Plankton of Lakes Atitlan and Amatitlan. Guatemala. Proc. Biol. Soc. Wash. 21: 98. 1908.

\section{Plate XIX. fig. 7, Plate XX. fig. I-3.}

Colonies up to ro $\mathrm{cm}$. in diameter, spherical, bullate, hollow, soft, dull olive green; filaments loosely associated; trichomes 7-9 mic. in diameter, tapering into a thick hair; lower cells barrel-shaped, about as long as wide, upper cells shorter than the diameter; cell contents olive; heterocysts 6-I2 mic. in diameter, usually spherical; gonidia without sheath IO-I 8 mic. in diameter, $40-250 \mathrm{mic}$. in length; external sheaths up to $40 \mathrm{mic}$. in diameter, often wide, folded and wrinkled, transparent or brownish, with smooth surface.

Rhode Island. (Bailey). New York. Attached to water plants, in pools. Buffalo. (Wolle). When young attached to stones and weeds, aftervards floating free. Shore of Cayuga Lake, Ithaca. September I895. (Atkinson). New Jersey. In small ponds and pools. (Wolle). Pennsylvania. On water plants. Bethlehem. July 1877. (Wolle). Ohio. (Kellerman). Minnesota. Floating near edge of artificial lake Minneapolis. August I894; on pondweeds in pond. Woodland Park, Duluth. August rgor. (Tilden). Nebraska. Minden. (Saunders). Central America. Among sponges. (Meek). West Indies. Under $\mathrm{N} \mathrm{y} \mathrm{m} \mathrm{ph}$ a e a leaves. Botanic Garden, Castleton, Jamaica. April r893. (Humphrey). Hawaii. Forming soft brown velvety masses, appearing spherical in the water, collapsing when taken out. In lower terrace water of rice field, with Chara. Aiea, Oahu. June I9oo. (Tilden).

520. Rivularia incrustata (Wood) De Toni. Syll. Algar. 5: 656. rgo7. Wood. Contr. Hist. Fresh-Water Algae North America. 45. pl. 3. f. 4. 1872. (Gloeotrichia incrustata Wood). 
Tilden. American Algae. Cent. I. no. 81. 1894; List of Fresh-Water Àlgae collected in Minnesota during 1894. Minn. Bot. Studies, I: 236. I896.

Colonies spherical or somewhat oval, firm, solid, about the size of a very small pea, crystal-bearing, light green; filaments straight or slightly curved, produced into long hairs, not regularly articulated; apex of filam.ent straight or slightly curved, mostly indistinctly articulate, frequently interrupted; sheaths ample, transparent, saccate, sometimes strongly constricted; lower cells in the mature filament short and generally compressed; gonidia cylindrical, frequently curved, about nine times as long as broad.

Pennsylvania. Growing attached to small water plants. Schuylkill River, near Spring Mills, Philadelphia. (Wood). Minnesota. Attached to Chara. Lake Minnetonka, Hennepin County. August 1894. (MacDougal).

52I. Rivularia echinulata (Smith) Bornet and Flahault. Sur la Determination des Rivulaires qui forment des Fleurs d'Eau. Bull. Soc. Bot. de France. 31: 76. I884. De Toni. Syll. Algar. 5: 657. I907.

Farlow. Notes on Fresh-Water Algae. Bot. Gaz. 8: 224. 1883. (R. fluit a ns Cohn); 8: 246. I883. (Echinella articulata Ag.). Wittrock and Nordstedt. Algae. Aq. Dulc. Exsicc. no. 664. 1884. Wolle. Fresh-Water Algae U. S. 249. pl. I79. f. 4. 188\% Richter. Bot. Gaz. I9: 425. I894. Tilden. List of Fresh-Water Algae collected in Minnesota iuring I894. Minn. Bot. Studies. I: 236. I895. Collins, Holden and Setchell. Phyc. Bor.-Am. Fasc. 7. no. 3II. 1897. (G1. p is um (Ag.) Thur.). Howe. A Note on the "Flowering" of the Lakes in the Adirondacks. Torreya. 3: 150. 1903.

\section{Plate XX. fig. 4 .}

Colonies solid, free swimming, soft, firm when dried, $.5-1.5 \mathrm{~mm}$. in liameter, especially spherical, sometimes lenticular, straight or recurved, cylindrical, with the surface villous from the protruding trichomes; filaments radiately arranged, loosely associated; trichomes 8-10 mic. broad at the base, ending in a long hair; lower cells spherical, those in the middle of the trichome quadrate, upper cells long cylindrical, the end cell pointed; cell contents showing sulphur granules or vacuoles; heterocysts 9-Io mic. in diameter, oblong or spherical; gonidia 8-18 mic. in diameter, 44-50 mic. it length, cylindrical, straight or slightly curved, with granular contents.

New York. Honnedaga Lake, Herkimer County. Altitude 2,200 feet. August; Chilson Lake, Essex County, June to August. (Smith). Minnesota. Lake Sakatah and Lake Tetonka, Waterville. (Porter). Lake Minnetonka. August I883; Waterville, June r884. (Arthur). Lake Minnetonka. August I883. (Farlow). Lake Chisago, Chisago County. July I894. (MacDougal and Anderson).

Note: See also the two articles by Professor Arthur under R. p is u m.

522. Rivularia polyotis (Agardh) Bornet and Flahault. Revis. des Nostoc. Ann. Sci. Nat. Bot. VII. 4: 360. 1886. De Toni. Syll. Algar. 5: 659. 1907.

Collins. Algae from Atlantic City, N. J. Bull. Torr. Bot. Club. I5: 310. 
I888. (R. h o s p it a Thur.). Martindale. Marine Algae of the New Jersey Coast and Adjacent Waters of Staten Island. Mem. Torr. Bot. Club. I: 9I. I889. Wolle and Martindale. Algae. Britton's Catalogue of Plants found in New Jersey. Geol. Surv. N. J. 2: 604. I889. Collins, Holden and Setchell. Phyc. Bor.-Am. Fasc. 21. no. I015. I903.

\section{Plate XX. fig. 5, 6.}

Colonies up to $3 \mathrm{~cm}$. in diameter, at first hemispherical, pulvinate, gregarious, finally becoming bullate, hollow, soft, dull blackish green; sheaths wide, lamellose, ocreate, funnel-shaped, dilated, the outer layers confluent into an amorphous gelatin, becoming yellowish brown with age; trichomes 4-5 mic. in diameter in lower portion, above 8-13.5 mic. in diameter, somewhat constricted at joints, tapering into a thick hair; lower cells about twice as long as their diameter, upper cells twice as short as the diameter.

New Jersey. On roots of Spartin a and on oyster shells. (Morse). Florida. On pneumatophores of the black mangrove (Avicennia nit ii a), just above low water mark. Key West. October Igo2. (Howe).

523. Rivularia nitida. Agardh. Dispositio Algarum Sueciae. 44. 1817. Bornet and Flahault. Revis. des Nostoc. Ann. Sci. Nat. Bot. VII. 4: 357. I887. De Toni. Sy11. Algar. 5: 661. I907.

Farlow. Marine Algae of New England. 38. I88r. (R ivularia plic a t a Carm.). Pike. Check List of Marine Algae. Bull. Torr. Bot. Club. I3: 106. I886. Martindale. Marine Algae of the New Jersey Coast and Adjacent Waters of Staten Island. Mem. Torr. Bot. Club. I: 9I. I88g. Collins. Algae.-Rand and Redfield's Flora of Mount Desert Island, Maine. 247. I894. Collins, Holden and Setchell. Phyc. Bor--Am. Fasc. 6. no. 260. I897. Collins. Preliminary Lists of New England Plants.-V. Marine Algae. Rhodora. 2: 43. I900. Tilden. American Algae. Cent. VI. no. 57 I. I902. Setchell and Gardner. Algae of Northwestern America. Univ. Calif. Pub. Bot. I: I98. I903. Collins. Phycological Notes of the late Isaac Holden.-II. Rhodora. 7: 224. I905.

Colonies up to $3 \mathrm{~cm}$. in diameter, spherical or expanded, plicate-corrugate, soft, hollow, olive green; filaments crowded; sheaths close, narrow, scarcely distinct, in the lower portion of the filament expanded, transparent or yellowish brown; trichomes 2-5 mic. in diameter, cylindrical, ending in a very thin, very long hair; lower cells three or four times longer than their diameter, upper cells shorter; cell contents olive.

Alaska. On mud near high water mark. St. Michael. (Setchell). Canada. In stream attached to roots of higher plants. Minnesota Seaside Station, Port Renfrew, Vancouver Island, British Columbia. July Igor. (Leavitt and Crosby). Nova Scotia. (Collins). Maine. On woodwork, rare. (Collins). New Hampshire. (Collins). Massachusetts. On mud and Spartina roots. Cohasset Narrows; Wood's Holl. (Farlow). On woodwork. Wellington, Medford. October i8g2. (Collins). On roots of S p a rt in a. Quamquisset Harbor, Falmouth. July and August I89r. (Setcheli). Rhode Island. (Collins). Connecticut. On bank of outlet. Fresh Pond. Tuly to September. (Holden). New York. Prince's Bay, Staten Island; shores of Long Island, Jamaica Bay, Canarsie. (Pike). 
524. Rivularia borealis P. Richter. Süsswasseralgen aus dem Umanakdistrikt. Bib. Bot. 7: Heft. 42. 4. f. I. I897. De Toni. Syll. Algar. 5: 664. I907.

\section{Plate XX. fig. 7,8.}

Colonies up to $.5 \mathrm{~mm}$. in diameter, small, spherical or hemispherical, gregarious, sometimes confluent into an indefinite mass, soft, not indurated with calcium carbonate; filaments up to $200 \mathrm{mic}$. in length, loosely associated; sheaths in the interior of the mass close, those near the periphery expanded, narrow at the apex, diffluent with age; trichomes $4 \mathrm{mic}$. in diameter, ending in a hair; lower cells depressed, shorter than the diameter, upper cells quadrate; heterocysts 4 mic. in diameter, spherical.

Greenland. On.submerged plants and especially on M y r i o p h y $11 \mathrm{um}$ e p i phy tica, in a lake. Umanak. (Vanhöffen).

525. Rivularia compacta Collins in Collins, Holden and Setchell. Phyc. Bor.-Am. Fasc. II. no. 508. 1898; Notes on Algae.-I. Rhodora. I: Io. 1899.

Colonies spherical or somewhat spherical, firm, not encrusted with lime, smooth, minute, seldom over $2 \mathrm{~mm}$. in diameter, dark green or blackish; filaments I5-20 mic. in diameter, closely packed; sheaths more or less expanded above, colorless or yellowish; trichomes 6-10 mic. in diameter, constricted at joints, tapering gradually to a hair-like termination; cells about as long as broad below, one-third to one-quarter as long above; heterocysts basal, spherical or oblong.

Massachusetts. On stones, shore of Spot Pond, Middlesex Fells. September I89o. (Collins). Connecticut. Norwich. (Setchell).

This species "resembles R. m in u $\mathrm{t} \mathrm{u} \mathrm{la} \mathrm{(Kuetz.)} \mathrm{Born.} \mathrm{\&} \mathrm{Flah.,} \mathrm{but} \mathrm{the}$ thalli are much firmer, and not at all encrusted with lime; the trichomes are slenderer, and the filaments more densely packed. In some particulars it agrees with the description of R. beccariana (De Not.) Born. \& Flah., Revis. des Nost., part 2, p. 56; but the latter has more slender trichomes, with longer articulations and much narrower sheaths."-Collins.

526. Rivularia minutula (Kuetzing) Bornet and Flahault. Revis. des Nostoc. Ann. Sci. Nat. Bot. VII. 4: 348. I886. De Toni. Syll. Algar. 5: 672. 1907.

Wolle. Fresh-Water Algae. V. Bull. Torr. Bot. Club. 8: 38. I881. (R. radians minutula Kirchn.). Stalker. Report on the Waterville Cattle Disease. Fourth Bien. Rep. Bd. Regents Univ, of Minn. Suppl. I. Rep. Dept. Agric. Univ. of Minn. 105, 108. r887. ( $\mathrm{L}$ i m n a c t is $\mathrm{m}$ in u $\mathrm{t}$ 1 a Kuetz.). Collins. Algae of Middlesex County. I3. I888. (R. r a dian s Thur.). Richter in Kuntze. Revisio Generum Plantarum. Part III. II. 389. 1898 .

\section{Plate XX. fig. 9.}

Colonies up to $8 \mathrm{~mm}$. in diameter, spherical or hemispherical, sometimes confluent, soft or indurated with calcium carbonate, blue-green or brownish; filaments loosely associated; sheaths 27 mic. in thickness, wide, 
lamellose, ocreate, hyaline or brownish; ocreae funnel-shaped, dilated above; trichomes 9-12.5 mic. in diameter, gradually tapering into a thick hair with short cells; lower cells somewhat quadrate, upper cells three or four times shorter than their diameter; heterocysts oblong or hemispherical.

Massachusetts. Spot Pond, Stoneham. (Collins). Minnesota. "Very abundant, covering the surface of the lake for a considerable extent. 'The natives cortsider it to be grass seed washed into the lake." July I88o. (Hobbe). Iowa. In West Okoboji Lake, Dickinson County. (Stalker). Montana. On water plants. 1874. (Kuntze).

527. Rivularia paradoxa (Wolle) De Toni. Syll. Algar. 5: 672. 1907. Wolle. Fresh Water Algae. II. Bull. Torr, Bot. Club. 6: i38. I877. (Z o n otrichia paradoxa Wolle); Fresh Water Algae. III. 1. c. I84.

Colonies hemispherical, gelatinous, bright blue-green; younger filaments flagelliform, older ones often contracted in the middle, or narrow below and gradually widened more than half the length, then tapering to a fine point (filaments of the latter form are usually much longer, double the length of the former); trichomes continuous or indistinctly divided; cells quadrate to three 'times as long as wide, very variable; cell contents f. Tanular, green tinged with brown; heterocysts 10-12 mic. in diameter.

Pennsylvania. Wolle.

528. Rivularia atra Roth. Catalecta Botanica. 3: 340. 1806. Bornet and Flahault. Revis. des Nostoc. Ann. Sci. Nat. Bot. VII. 4: 353. I886. De Toni. Syll, Algar. 5: 664. 1907.

Wood. Contr. Hist. Fresh-Water Algae North America. 50. 1872. (Z.o notrichia minutula Rab.). Farlow. List Marine Algae United States. Proc. Am. Acad. Arts Sci. 10: 380. I875. Farlow. Marine Algae of New England. 38. p1. 2. f. 2. I88I. Kjellman. Algae of the Arctic Sea. 321. i883. (Rivularia hemispherica (L.) Aresch). Farlow. Notes on Fresh-Water Algae. Bot. Gaz. 8: 224. I883. Pike. Check List of Marine Algae. Bull, Torr. Bot. Club. I3: 106. I886. Collins. Marine Algae of Nantucket. 5. 1888. Wolle and Martindale. Algae. Britton's Catalogue of Plants found in New Jersey. Geol. Surv. N. J. 2: 604. 1889. Martindale. IMarine Algae of the New Jersey Coast and Adjacent Waters of Staten Island. Mem. Torr. Bot. Club. I: 9r. I889. Anderson. List of California Marine Algae, with Notes Zoe. 2: 218. I89I. Collins. Algae.-Rand and Redfield's Flora of Mount Desert Island, Maine. 247. I894. Rosenvinge. Les Algues Marines du Groenland. Ann. Sci. Nat. Bot. VlI. 19: I62. I894 Collins, Holden and Setchell. Phyc. Bor-Am. Fasc. 8. no. 357. I897. Rosenvinge. Deuxième Mémoire sur les Algues Marines du Groenland. Medd. om Groenland. 20: I21. I898. Collins. Preliminary Lists of New England Dlants.-V. Marine Algae. Rhodora. 2: 43. Ig0o; Phycological Notes of the late Isaac Holden.-II. Rhodora. 7: 224. 1905. Börgesen and Jonsson. The Distribution of the Marine Algae of the Arctic Sea and of the North. crnmost Part of the Atlantic. Bot. Faeroes. App. XXV. 1905.

\section{Plate XX. fig. Io.}

Colonies up to $4 \mathrm{~mm}$. in diameter, spherical, solitary or .confluent, dark 
green; filaments crowded; sheaths close, narrow, scarcely distinct, above widened, hyaline or yellowish; trichomes $2.5-5 \mathrm{mic}$. in diameter, ending in a thin hair; lower cells scarcely longer than the diameter, upper cells shorter; cell contents blue-green.

Greenland. In upper part of littoral zone on sheltered coasts, gregariotis, but in small numbers. West coast; Baffin Bay, at Tessarmiut, Ameralik, Pikitsok. (Kjellman). Western part. (Börgesen and Jonsson). Eastern part, south of $70^{\circ}$ lat. N. (Rosenvinge). Canada. On rocks and other aigae. Malpeque, Prince Edward Island. (Faull). New England. Common along the whole coast, on stones, algae and stalks of Spart in i. (Farlow). Maine. Common in upper tide pools, (Collins). Sea Wall. (Holden). New Hampshire. (Collins). Massachusetts. On shells in larbor; on sides of rock pools, Marblehead, August 1897. (Collins). Rhode Island. (Collins). Connecticut. On turf of S p a rtin a. Charles Island. September. (Holden). New York. Shores of Long Island. Hell Gate, Flushing Bay. (Pike). New Jersey. Marine. On stones. Atlantic City. (Martindale). California. Common. On stones, algae and other material. (Anderson).

Var. confluens (Kuetzing) Bornet. Les Algues de Schousboe. 29. I892. De Toni. 1. c. 666.

Colonies confluent forming a layer or mass.

Maine. On ground between tide marks. Cape Rosier. July I897. Connecticut. On turf of $\mathrm{S} p$ a $\mathrm{r} t$ in a roots. Charles Island, near Milford. September I896. (Holden).

529. Rivularia haematites (DC.) Agardh. Syst. Algar. 26. I824. Bornet and Flahault. Revis. des Nostoc. Ann. Sci. Nat. Bot. VII. 4: 350. 1886. De Toni. Syll. Algar. 5: 668. 1907.

Wood. Contr. Hist. Fresh-Water Algae North America. 49. I872. (Zonotricha parcezonata Wood). Wolle. Fresh Water Algae. III. Bull. Torr. Bot. Club. 6: 184. 1877. ( $Z$ o not $r$ ic.h ia ha e mat it es Rabenh.). Dickie. On the Algae found during the Arctic Expedition. Journ. Linn. Soc. Bot. I7: 8. I880. ( $Z$ o not $r$ ich ia $f 1$ u viat $i 1$ is Kuetz.). Campbell. Plants of the Detroit River. Bull. Torr. Bot. Club. I3: 93. I886, (Rivalaria calcarea Eng. Bot.). Wolle and Martindale. Algae. Britton's Catalogue of Plants found in New Jersey. Geol. Surv. N. J. 2: 603. I889. (I s a ct is f 1 uviatilis (Rab.) Kirchn.). Saunders. Protophyta-Phycophyta. Flora of Nebraska. 25. pl. 3. f. 3I. I894. Setchell. Notes on Cyanophyceae.-I. Erythea. 4: 88. I896, Tilden. American AIgae. Cent. III. no, 289. 1898; Observations on some West American Thermal Algae. Bot. Gaz, 25: 96. pl. 9. f. 6-9. I898.

\section{Plate XX. fig. II-I4.}

Colonies hemispherical, finally confluent and forming a hard, stony crust, up to a centimeter in thickness, green or olive in colos, blue-green when dried, zoned in the interior; filaments dense; sheaths close, hyaline or rarely yellowish, fragile, strongly refringent, above ocreate, funnelshaped, dilated; trichomes 4-7.5 mic. in diameter, ending in a very long 
hair; lower cells twice as long as the diameter, those in the middle of the trichome quadrate, the upper ones half as long as wide.

Arctic Regions. "Forming firm, gelatinous bosses on pebbles in running water." In streams from a lake, winter-quarters. $82^{\circ} 27^{\prime} \mathrm{N} ., 6 \mathrm{I}^{\circ} 22^{\prime} \mathrm{W}$. (Moss). Canada. Forming a calcareous crust on botton of ditch. Natural Silphur Springs, Banff, Alberta. I3 August I897. (Tilden). New York. Forming a slippery grayish, or grayish flesh-colored coating on rocks kept wet and glistening with foam and spray. "Cave of the Winds," Niagara Falls. (Wood). "Growing on rocks as glossy blackish, very hard and slippery fronds or masses, which varied in size from that of very small shot to nearly half an inch in length." (Wood). New Jersey. Rocky margins of Green Pond, Morris. (Wolle). Pennsylvania. Stones. Sus quehanna River. (Wolle). Michigan. Grosse Isle, near the mouth of the Detroit River. Summer of 1885. (Campbell). Nebraska. Minden. (Saunjers). Colorado. Forming a reddish crust upon dripping rocks. Bridal Veil Falls, Williams Cañon, near Manitou. (Setchell).

530. Rivularia dura Roth. Neue Beiträge zur Botanik. 273. I802. Bornet and Flahault. Revis, des Nostoc. Ann. Sci. Nat. Bot. VII. 4: 347. 1886. De Toni. Syll. Algar. 5: 674. 1907.

Wood. Contr. Hist. Fresh-Water Algae North America. 50. pl. 4. f. 5. 1872. (D a s y a t is mollis Wood). Campbell. Plants of the Detroit River. Bull. Torr. Bot. Club. I3: 93. I886. Wolle. Fresh-Water Algae U. S. 249. pl. I79. f. I-3. I887. Bennett. Plants of Rhode. Island. I I4. 1888. Collins. Algae of Middlesex County. I3. 1888. (R. radians Thur.). Wolle and Martindale. Algae. Britton's Catalogue of Plants found in New Jersey. Geol. Surv. N. J. 2: 604. I889. Mackenzie. A Preliminary List of Algae collectcd in the Neighborhood of Toronto. Proc. Can. Inst. III. 7: 270. 1890. Snow. The Plankton Algae of Lake Erie. U. S. Fish Comm. Bull. for 1902. 22: 392. I903.

\section{Plate XX. fig. I5.}

Colonies small, $5 \mathrm{~mm}$. in diameter, somewhat hard, indurated with calcitum carbonate, blackish green; filaments dense; sheaths close, not lamellose, uniform, hyaline; trichomes 4-9 mic. in diameter, ending in a long, very thin hair; lower cells equal in length to the diameter, upper ones almost three times shorter than wide; cell contents blue-green, sometimes changing to violet when dried.

Canada. High Park, Toronto. (Mackenzie). Massachusetts. (Collins). Rhode Island. Not uncommon. (Bennett). New Jersey. Atlached to aquatic plants in ponds. (Wolle). Ohio. Plankton. Lake Erie. Put-in-Bay. (Snow). Michigan. Attached to water plants in a small bog near mouth of Carp River in northern part of state. (Wood). Grosse Isle, near the mouth of the Detroit River. Summer of 1885. (Campbell).

531. Rivularia coadunata (Sommerfelt) Foslie. Contributions to Knowledge of the Marine Algae of Norway. II. Tromsoe Mus. Aarsheft. 14: 21. I891. Bornet and Flahault. Revis. des Nostoc. Ann. Sci. Nat. 
Bot. VII. 4: 352. I886. (R. b i a s o let t i a n a Menegh.). De Toni. Syll. Algar. 5: 667. I907.

Collins. Notes on New England Algae. Bull. Torr. Bot. Club. 9: 69 . 1882. (Rivularia warreniae Thur.). Setchell. Notes on some Cyanophyceae of New England. Bull. Torr. Bot. Club. 22: 427. 1895. Tilden. American Algae. Cent. II. no. I66. I896. Collins, Holden and Setchell. Phyc. Bor.-Am. Fasc. 8. no. 358. I897. Tilden. List of FreshWater Algae collected in Minnesota during 1896 and 1897 . Minn. Bot. Studies. 2: 27. 1898. Collins. Preliminary Lists of New England Plants. -V. Marine Algae. Rhodora. 2: 43. I900. Collins, Holden and Setchell. Phyc. Bor.-Am. Fasc. I8. no. 860. I90I. Saunders. The Algae. Harriman Alaska Expedition. Proc. Wash. Acad. Sci. 3: 399. I901. Tilden. American Algae. Cent. VI. no. 570. 1902. Setchell and Gardner. Algae of Northwestern America. Univ. Calif. Pub. Bot. I: I98. I903.

\section{Plate XX. fig. I6, I7.}

Colonies at first hemispherical, afterwards expanded into an olive or blackish, gelatinous, crustaceous, cushion-like layer, 2-8 $\mathrm{mm}$. in thickness, indurated with calcium carbonate in the interior; filaments about 18 mic. 11 diameter, approximate; sheaths wide, lamellose, colorless or yellowish, ur showing transverse zones, ocreate; ocreae dilated, funnel-shaped; trichomes 5-9 mic. in diameter, ending in a very thin, long, flexuous hair; lower cells a little shorter than the diameter, the upper ones one-third as long as broad; cell contents blue-green; heterocysts oblong, basal, one to three, rarely intercalary.

Alaska. On dripping rocks, on roots, etc., in fresh or brackish water. West shore of Amaknak Island, Bay of Unalaska; at mouth of creek, Iliuliuk, Unalaska. (Setchell and Lawson). Forming minute, hard, dark bluish green thalli, I-3 mm. in diameter, which finally become agglutinated into liollow, indefinite masses. On rocks in freshwater streams. Juneau; Glacier Bay. (Saunders). Canada. On sandstone rocks just above high tide, but submerged or at least washed by waves during storms. Minnesota Seaside Station, Port Renfrew, Vancouver Island, British Columbia. December igor (Tilden). New Hampshire. (Collins). Massachusetts. Growing on a rock, above high water mark but where the spray formed little pools in rough weather. Marblehead. September I88I; in moist places just above high water mark. Marblehead. June Igor. (Collins). Rhode Island. (Collins). Connecticut. Occurring in fairly typical form in perfectly fresh water. Gardner's Lake. Eastern part of the state. (Setchell). South Dakota. On rocks at edge of lake. Big Stone Lake. October I895. (Griffiths). Washington. East Sound, Orcas Island. (Gardner). California. On dripping vertical faces of the cliff, just above high water mark. Carmel Bay, Monterey County. December I 896 . (Nott and Setchell).

532. Rivularia bornetiana Setchell. Notes on some Cyanophyceae of New England. Bull. Torr. Bot. Club. 22: 426. 1895. De Toni. Syll. Algar. 5: 666. I907.

Collins, Holden and Setchell. Phyc. Bor.-Am. Fasc. 4. no. I57. I 896. 
Collins. Preliminary Lists of New England Plants.-V. Marine Algae. Rhodora. 2: 43. rgoo.

Colonies I mm. to more than a centimeter in diameter, solid, spherical, sometimes coalescing into a cylindrical mass $5-8 \mathrm{~cm}$. long, rather firm, deep bluish black when young, later becoming light olive green or pale yellow, not incrusted with lime; filaments 8-20 mic. in diameter, radiating from the center, flexuous in older colonies; sheaths wide, conspicuous, colorless to deep brown in color, very much lamellose and ocreate above; trichomes usually 4 mic. in diameter, occasionally reaching 16 mic., very torulose when young, very little so when older; terminal hairs long and slender in younger plants, almost wanting in the older ones; cells from one-half to five times as long as broad; transverse walls distinct in younger trichomes, very obscure in older specimens; cell contents provided with a few scattered granules, light blue; heterocysts 6-8 mic. in diameter, basal, depressed spherical or ellipsoidal in shape.

Nova Scotia. (Holden, Setchell), Rhode Island. Forming globular thalli on Ruppia maritima in brackish water. Watch Hill Pond, Watch Hill. September I892. (Setchell).

533. Rivularia mexicana (Kuetzing) Rabenhorst. F1. Eur. Algar. 2: 222. 1865. De Toni. Syll. Algar. 5: 676. I907.

Colonies soft, gelatinous, somewhat spherical or irregular, pale green, at first attached, finally floating free; trichomes 8-Io mic. in diameter, loose1y. entangled, flagelliform, tapering into a çolorless hair at the apex.

Mexico. In stagnant water. (Müller).

534. Rivularia microscopica Dickie. Notes on the Algae. Sutherland's Journal of a Voyage in Baffin's Bay and Barrow Straits in the Years I850-51. 2: 193. 1852. De Toni. Syll. Algar. 5: 677. 1907.

Kjellman. Algae of the Arctic Sea. 322. 1883 .

Arctic Regions. Growing on Enteromorpha compressa. American Arctic Sea; Assistance Bay and "other localities." (Dickie).

535. Zonotrichia minutula Wood. Contr. Hist. Fresh-Water Algae North America. 50. 1872. De Toni. Syll. Algar. 5: 675. 1907.

Colonies very small, somewhat spherical, not distinctly zoned, rather soft, not impregnated with calcium carbonate, blackish green; internal filaments very distinctly fasciculately branched; sheaths thick, ample, often pale orange brown, with their apices mostly colorless, torn and open; trichomes 3-5 mic. in diameter; cells short; heterocysts 6 mic. in diameter, ovate to spherical.

New York. Forming very small, blackish green, subglobo'se masses, attached to mosses. Clear Pond, Adirondack Mountains. (Wood).

536. Zonotrichia mollis Wood. Contr. Hist. Fresh-Water Algae North America. 48. p1. 4. f. 3. I872. De Toni. Syll. Algar. 5: 675. 1907.

Colonies somewhat hemispherical, gregarious, often confluent into a mammillose stratum, somewhat soft, grey or flesh-colored, slightly 
zoned; filaments up to $4.2 \mathrm{mic}$. in diameter, very long, narrow, flexuous; sheatlus close, colorless, firm, not fibrous; trichomes up to 2 mic. in diameter, often interrupted; transverse walls visible; cells equal to up to four times longer than broad; heterocysts single, spherical.

New York. On dripping rocks. Cave of the Winds, Niagara. (Wood).

\section{Genus BRACHYTRICHIA Zanardini.}

Phyc. Indic. Pugillus. 24. 1872 .

Colonies at first solid, finally becoming hollow, made up of Nostoclike filaments embedded in gelatin; filaments flexuously curved, parallel. above tapering and drawn out into a hair at the apex, very much branched; sheaths distinct in the young filaments, tubular, finally becoming confluent and invisible; heterocysts intercalary, arranged without any order.

537. Brachytrichia quoyi (Agardh) Bornet and Flahault. Revis. des Nostoc. Ann. Sci. Nat. Bot. VII. 4: 373. I886. De Toni. Syll. Algar. 5: 680. 1907.

Farlow. List of the Marine Algae of the United States. 25. 1876. (R iv u1aria nitida?). Bornet in Farlow, Anderson and Eaton. Algae Am. Bor. Exsicc. no. 45. 1876. ( $\mathrm{H}$ or mact is $\mathrm{farl}$ to $\mathrm{wi}$ Born.); in Farlow. Marine Algae of New England. 39. pl. 2. f. I. I88r. (H. r m a c t is qu o y i (Ag.) Bornet). Pike. Check List of Marine Algae. Bull. Torr. Bot. Club. 13: 106. 1886. Martindale. Marine Algae of the New Jersey Coast and Adjacent Waters of Staten Island. Mem. Torr. Bot. Club. I: 9I. I889. Wolle and Martindale. Algae. Britton's Catalogue of Plants found in New Jersey. Geol. Surv. N. J. 2: 604. I889. Hauck and Richter. Phyk. Univ. no. 681. 1890. Schiveley. Hormactis quoyii. Proc. Phil. Acad. I890: 497. I891. Wittrock and Nordstedt. Algae Aq. Dulc. Exsicc. no. II97. 1893. Collins, Holden and Setchell. Phyc. Bor.-Am. Fasc. I. no. 8. I895. Collins. Preliminary Lists of New England Plants.-V. Marine Algae. Rhodora. 2: 4I. 1900 .

\section{Plate XX. fig. 18 .}

Colonies up to $5 \mathrm{~cm}$. in diameter, plicate-expanded and bullate, confluent, blackish green.

Massachusetts. Growing on $F u c u s$ at half tide. Wood's Holl. (Farlow). Falmouth; Wood's Holl. July I8g2. (Collins). Forming bladders on stems of old Fucus vesiculosus L. Quamquisset Harbor, Falmouth. August 1890. (Setchell). New York. Shores of Long Island. Greenport. July. (Pike), New Jersey. Atlantic City. (Morse). California. Pacific Ocean. (Grunow).

\section{Families and Genera not well understood.}

Genus ASTEROTHRIX Kuetzing. Phyc. Gen. 200. I843.

Filaments very rigid, nude, with cuspidate, obtuse or acute ends, somewhat genuflexuous, branched at right angles; transverse walls usually indistinct; propagation unknown. 
538. Asterothrix creginii Wolle. Fresh-Water Algae U. S. 322. pl. 209. f. 22-25. I887. De Toni. Syll. Algar. 5: 683. I907.

Bennett. Plants of Rhode Island. II5. I 888.

$$
\text { Plate XX. fig. I9, } 20 .
$$

Filaments 2-4 mic. in diameter, short, pale blue-green; branches given oft at right angles, cross-like; trichomes often moniliform; transverse walls usually evident.

Rhode Island. Pocasset. (Bennett). Kansas. Norton. (Cregin).

\section{Genus GONIOTRICHUM Kuetzing. Phyc. Gen. 244. I843.}

Colonies erect, filamentous, dichotomously or rarely unilaterally branched; filaments at first unbranched, finally branched, by the repeated division of cells at right angles; branches more or less regularly branched; cells showing a central star-shaped chromatophore, a central pyrenoid, and an eccentric nucleus; cell walls diffluent into a gelatinous mucus which forms a thick, gelatinous envelope surrounding each cell.

I Colonies filamentous, solid, gelatinous, occasionally branched

\section{G. humphreyi}

II Filaments single or associated in rose-red bundles (colonies), usually thickened at the base, tapering above

G. elegans

539. Goniotrichum humphreyi Collins in Collins, Holden and Setchell. Phyc. Bor.-Am. Fasc. 9. no. 42r. 1898; The Algae of Jamaica. Proc. Am. Acad. Arts Sci. 37: 25I. I90I. De Toni. Syll. Algar. 5: 688. I907.

Colonies filamentous, solid, gelatinous, occasionally forking or dividing into several branches, the terminal portion consisting of a single series of cells, the older part containing numerous cells irregularly placed near the surface of the filament; lateral branches abundant, simple, issuing nearly at a right angle, composed of a single series of cells.

West Indies. On woodwork of wreck. St. Ann's Bay. March I893. (Humphrey).

540. Goniotrichum elegans (Chauvin) Zanardini. Notizie intorno alle Cellulari Marine delle Lagune e dei Litorali de Venezia. Atti R. Ist. Ven. I. 6: 69. I847. De Toni. Syll. Algar. 5: 687. 1907.

Collins. The Algae of Jamaica. Proc. Am. Acad. Arts Sci. 37: 251. I9or.

Filaments $20 \mathrm{mic}$, in diameter, $.3-6 \mathrm{~mm}$. in length, single or associated in rose-red bundles or colonies, usually thickened at the base, above tapering, rarely unbranched, often somewhat dichotomously branched; cells 7-ro mic. in diameter, in one or many series, spherical or elliptical; cell contents violet or reddish changing to green. 
Canada. In tufts on Chondrus $\mathrm{c} r$ is p us. Malpeque, Prince Edward Island. (Faull). West Indies. Among other algae on $\mathrm{L}$ a $\mathrm{u}$ r e $\mathrm{n}$ c i a o bt us a. Near Kingston. (Duerden.).

Genus ASTEROCYTIS Gobi. Kurzer Bericht Algol. Excur. St. Petersb. Gesellsch. Nat. 10: 93. 1879.

Colonies erect, filamentous, branched; cells ellipsoid, irregularly arranged, reproduction by means of non-motile, naked gonidia; sexual reproduction unknown.

54I. Asterocytis ramosa (Thwaites) Gobi. Kurzer Bericht über die im Summer 1878 ausgeführte Algologische Excursion. St. Petersb. Gesellsch. d. Naturf. I0: 93. I879. De Toni. Syll. Algar. 5: 690. 1907.

Collins. Notes on New England Marine Algae. V. Bull. Torr. Bot. Club. 18: 336. I89I. (Gon iot i c h u m ramos um (Thwaites) Hauck).

$$
\text { Plate XX. fig. } 21 \text {. }
$$

Filaments $12-20$ mic. in diameter, I-Io $\mathrm{mm}$. long, associated in green or lead-colored fascicles; branching somewhat dichotomous or unilateral; cells 5-8 mic. in diameter, 8-20 mic. in length, in a single series, cylindricalrotund or elongate; cell contents lead-colored or green.

Massachusetts. In small quantity among other algae. Quincy. (Collins).

\section{Genus GLAUCOCYSTIS Itzigsohn in Rabenhorst.}

De Algen Europas. no. x935. 1866.

Cells elliptical, oval, rarely elongate-elliptical, associated in spherical or elliptical, microscopical families of from two to eight cells, surrounded by a colorless, thin and soon diffluent common tegument; cell contents at first blue in color, finally displaying a blue-green or green chromatophore; reproduction by division of cells in one direction.

542. Glaucocystis nostochinearum Itzigsohn in Rabenhorst. De Algen Europas. no. 1935. I866. De Toni. Syll. Algar. 5: 693. 1907.

Lagerheim. Ueber einige Algen aus Cuba, Jamaica and Puerto-Rico. Bot. Notiser. I99. 1887.

Plate XX. fig. 22.

Cells ro-I8 mic. in diameter, I8-28 mic. in length, solitary or in families of from two to eight cells; families elliptical or somewhat spherical; cell contents light blue-green or green; cell walls thin.

West Indies. Fajardo, Porto Rico. (Sintenis, Moebius).

\section{Genus PORPHYRIDIUM Naegeli. Gatt. Einzell. Alg. I39. 1849.}

Plant mass irregularly expanded, thin, gelatinous, crustaceous; cells jumerous, spherical or more or less angular by compression; cell contents . reddish purple, with a central pyrenoid and an eccentric nucleus; individual 
sheaths at first thin, becoming thick, finally diffluent into a gelatinous mucus; reproduction by cell division in all directions.

543. Porphyridium cruentum (Agardh) Naegeli. Gatt. Einzell. Alg. I39. pl. 4. I849. De Toni. Syll. Algar. 5: 697. I907.

Buchanan. Notes on the Algae of Iowa. Proc. Iowa Acad. Sci. I4: 9. 1908.

\section{Plate XX. fig. 23.}

Plant mass often widely expanded, membranaceous, mucous, of a dark red color, sometimes becoming greenish; cells $6.5-9$ mic. in diameter, spherical or angular by mutual pressure; cell contents reddish purple.

Iowa. (Buchanan).

\section{Family II. CRYPTOGLENACEAE}

Plants unicellular, blue-green, floating free in water; vegetative cells elliptical, oval or almost wedge-shaped, bearing two cilia of equal length, not motile; cell walls thin, close, colorless; chromatophores disc-shaped, adhering to the wall, enclosing somewhat spherical pyrenoids.

Genus CRYPTOGLENA Ehrenberg.

Abhandl. Akad. Wiss, zu. Berlin. I50. 1832.

Cells marked by a conspicuous red pigment spot; cell wall often separated from the protoplasm, forming a sac.

544. Cryptoglena americana Davis. Notes on the Life History of a Bluegreen Motile Cell. Bot. Gaz. I9: pl. II. I894. De Toni. Syll. Algar. 5: 700. 1907 .

Collins. Preliminary Lists of New England Plants.-V. Marine Algae. Rhodora. 2: 4I. 1900.

Plate XX. fig. 24, 25.

Motile cells 5-6 mic. in diameter, 8-1o mic. in length, broadly elliptical, hyaline on one end, slightly truncate, with a depression from which arises a pair of cilia of unequal length, the longer one about as long as the cell is wide; cell contents blue-green, with six to ten disc-shaped chromatophores arranged around the periphery, and with one or two bright red pigment spots placed on the periphery, near the middle of the cell; nonmotile cells 6-7 mic. in diameter, 7-9 mic. in length, arranged in groups of twos and fours in a closely packed Polycystis-like colony, almost uniformly colored blue-green, with six to ten disc-shaped chromatophores and one or two brownish red pigment spots near the middle of the cell at the periphery; nucleus near the middle of the cell.

Massachusetts. On stems of grass and larger algae. Salt marshes of the Charles River, Cambridge. Autumn. (Davis). 


\section{GLOSSARY}

Adherent, clinging to, or united with Adnate, touching closely or broadly Agglutinated, glued together

Aggregated, forming a mass or collection, but not cohering

Amorphous, structureless

Anastomose, to run together in a netlike manner

Angular, having angles; sharp cornered

Apex, the end opposite the point of attachment; tip

Appressed, pressed closely against

Approximate, near, about

Aquatic, living in water

Arachnoid, cobwebby

Articulate, jointed with cells

Asexual, without sex

Base, the point of attachment

Brackish, somewhat salty

Bulbous, with a bulb

Bullate, swollen

Bullose, swollen

Caespitose, in tufts or dense bunches

Calcareous, composed of or containing lime

Calyptra, a cap or lid

Capitate, furnished with a globose head

Carneous, fleshy

Cartilaginous, firm and tough like cartilage

Catenate, joined in a contintuous series; in a chain

Cell, a closed sac, surrounded by a wall of cellulose, containing protoplasm and a single nucleus

Cell sap, the watery fluid of a cell which separates from the protoplasm as one or more vacuoles

Cell wall, the membrane enclosing the cell contents

Cellulose, the cell wall substance of plants

Centrifugally, from the center

Centripetally, toward the center

Chlorophyll, the green coloring matter contained in plants green

Chromatophore, a plastid, containing a coloring matter
Cilium (p1. cilia), one of the vibratile, protoplasmic processes which serves to propel zoogonidia through the water

Circinate, rolled from the end

Clathrate, with openings like lattice work

Clavate, club-shaped

Coalesced, grown together, united

Coalescence, the complete union of similar things

Collateral, side by side, secondary

Colony, a group of independent cells surrounded by a common investment; a mass of plants of more or less definite shape, large enough to be detected by the naked eye

Concentric, with a common center

Confluent, growing or running together

Conidium, gonidium; a gonidium which is abstricted from the apex of a stalk

Constricted, narrowed in certain places

Contiguous, near or in contact

Contorted, twisted

Contractile, able to contract

Convolute, rolled together

Coriacious, leathery, tough

Crenate, wavy

Crisped, curled

Crustaceous, crust-like

Cuspidate, pointed, with a tooth

Decumbent, lying down

Deliquescent, dissolving.

Dense, crowded together

Depressed-globose, globular, with the poles slightly flattened

Dichotomous, two-forked; furcate

Dichotomy, division into two branches

Diffluent, dissolving

Disc, any flat circular area

Disc-shaped, flat and circular

Dissepiment, cross wall

Distal, pertaining to the apex

Divaricate, spreading

Diverging, separating 
Eccentric, without a common center

Elongate, lengthened, very long

Endophyte, a plant living within another organism, usually as a parasite

Entire, not toothed

Epiphyte, a plant growing upon the outside of another plant, but not nourished by it

Equilateral, with equal sides

Family, a mass of plants of microscopic size and somewhat definite shape quite evidently arising from the division of a single cell

Fascicle, bundle

Fasciculate, in bundles

Fastigiate, tapering to a point

Fenestrate, window-like

Fibrillae, little threads

Fibrillose, made up of small fibers

Fibrous, of fibers

Filament, the trichome together with its sheath; a fine thread

Filamentous, thread-like, composed of filaments

Filiform, thread-shaped

Fission, splitting; cell division in which the cell separates into two nearly equal portions, especially as a mode of reproduction

Flaccid, soft, flabby

Flagelliform, whip-like

Flexuous, flexible

Floccose, composed of matted, woolly hairs

Flocculent, woolly

Foliaceous, leaf-like

Foliose, leaf-like

Gelatinous, jelly-like

Geminate, paired

Geniculate, bent abruptly like a berit knee

Genuflexuous, bent abruptly

Glaucous, sea-green, gray-green

Globose, like a ball

Globular, spherical or nearly so

Gonidangium, the cell in which gonidia are produced

Gonidium, a reproductive cell developed asexually; a specialized reproductive cell capable by itself, of giving rise to a new organism.

Granular, with granules

Granule, a small grain

Granulose, with granules

Gregarious, growing in association, but not matted together

Grumose, grumous, like a cluster of grains
Habit, the general appearance or characteristic manner of growth of a plant

Habitat, the locality or region, or the kind of situation in which a plant is naturally found

Heterocyst, a cell uniformly larger than its neighbors, but of doubtful function.

Hirsute, with coarse hairs

Homogeneous, uniform in character or substance.

Host, a plant which supports a parasite (or an epiphyte?)

Hyaline, clear and colorless, transparent

Immersed, sunken below the surface Impregnated, filled with

Indurated, hardened

Inequilateral, with unequal sides

Inflated, swollen

Integument, any outer covering

Intercalary, inserted between

Intricate, tangled, involved

Inundated, flooded

Investment, a covering

Laciniate, torn

Lacunose, hollowed

Lamelliform, plate-like

Lamellose, with plates or blades

Lenticular, lens-shaped

Lubricous, slippery, slimy

Lumen, cavity

Mammillate, mammillose, with nipple-like projections

Mammilliform, nipple-like

Marginal, at the edge

Membranaceous, papery

Moniliform, chain-like

Motile, able to move

Mucilaginous, jelly-like

Multicellular, of several to many cells

Nodule, a little knot or lump

Nucleus, a differentiated round or oval body embedded in the protoplasm of a cell

Obovate, ovate, but with the point of attachment at the lower end

Ocrea, a sheath

Ocreated, sheathed

Orbicular, circular

Oval, elliptical

Ovoid, egg-shaped

Pannose, ragged

Papillose, with a little point or nipple 
Parasite, a plant that lives on or in some other organism from which it derives its nourishment for the whole or a part of its existence

Parenchyma, the soft, thin-walled cellular tissue of plants.

Pedicel, a small or delicate supporting stalk

Pedicellate, stalked

Pellucid, clear

Penicillate, like a brush

Periphery, edge

Phycocyanin, a blue pigment contained in the chromatophores of the blue-green algae

Pigment spot, a specialised mass of cytoplasm permeated by a red coloring matter, present in the motile cells of many algae; eye-spot

Piliferous, bearing hairs

Pilose, hairy

Plant, in the coccogoneae a single cell; in the HORMOGONEAE a single trichome

Plant mass, the usually shapeless mass of individual plants remaining in close proximity to each other after their formation, either because nothing occurs to separate them or because they are definitely held together by a gelatinous excretion

Plicate, folded or ridged

Polar, at the end

Polygonal, many-sided

Polyhedral, many-angled

Polymorphous, of many forms

Proliferated, grown out

Protoplasm, the viscid, contractile, semiliquid, more or less granular, substance that forms the principal portion of an animal or vegetable cell

Prostrate, flat, lying down

Pseudo-parenchymatous, like parenchyma

Pubescent, finely hairy

Pulverulent, powdery

Pulvinate, cushion-like

Punctate, dotted

Punctiform, dot-like

Pustular, like a swelling

Pyrenoid, a small colorless mass of proteid substance seen in many algae, which may be regarded as reserve material

Quadrate, square, in fours

Radial, pertaining to a radius, as of a circle or sphere

Rectilinear, straight
Refractive, refringent, bending or turning aside as a light ray

Reniform, kidney-shaped

Reproduction, the development of one or more new organisms from the whole or from a part of the protoplasm of a parent organism

Rotund, round

Rugose, furrowed, roughened

Saccate, sack-like

Segment, one of the parts into which an object is naturally divided

Septate, divided by partitions

Seriate, in a row

Sessile, without a stalk

Sheath, a gelatinous, usually tubular, envelope surrounding a plant

Silicious, containing silica

Sinuate, snake-like, twisted

Sinus, a gulf or indentation

Spatulate, shaped like a spoon

Spherical, ball-like

Spongiose, spongy

Stellate, star-like

Stratified, in layers

Stratum, a layer

Striated; having fine markings

Sub, slightly, somewhat

Submerged, sunken

Substratum, surface on which the plant grows

Superposed, placed one above another

Tegument, covering

Tenacious, firm, tough

Terebriform, screw-like

Terminal, end

Terrestrial, growing on the ground

Thallus, a plant-body without true root, stem or leaf; used incorrectly instead of "plant mass"

Tomentose, closely hairy

Tortuous, twisted

Torulose, chain-like

Trichome, the entire number of cells of a multicellular plant, not including the sheath

Truncate, cut off abruptly

Tuberculate, tuberculose, warted

Tubular, tube-like

Ultimate, last, end

Uncinate, hooked at the end

Undulate, wavy

Unicellular, one-celled

Unilateral, one-sided

Vacuole, a cavity in the protoplasm of a cell containing a watery fluid 
Ventricose, a swelling out on one Vesicular, bladdery side or in the middle Villous, long hairy

Verrucose, warted

Vesicle, a small bladder-like cavity Zonate, disposed in the form of zones

Note: The proper terms to be used in connection with the bluegreen algae have not yet become definitely established. The terms and definitions given in this treatise are merely provisional, in case better ones can be found. Some difficulty has been experienced with the terms: "plant mass," "colony," "family," "thallus," etc. The definition of each, as the author conceives the meaning, is given in the glossary.

Plant mass, the usually shapeless mass of individual plants remaining in close proximity to each other after their formation, either because nothing occurs to separate them or because they are definitely held together by a gelatinous excretion

Colony, a mass of plants of more or less definite shape, large enough to be detected by the naked eye

Family, a mass of plants of microscopic size and somewhat definite shape, quite evidently arising from the division of a single cell

Plant, in the cocCOGONEAE a single cell; in the HORMOGONEAE a single trichome. In the latter case it may be thought better. by some to consider "plant" and "filament" as synonymous terms. 


\section{ERRATA}

Page 8, after line 26 insert Plate I, fig. 6

Page 26, line 23, for Hansirg read Hansgirg

Page 27 , line 27 , for APHANACAPSA read APHANOCAPSA

Page 39, line 37, for Coelosphaerium read COELOSPHAERIUM

Page 52, line 35, for smaragdinus read smaragdina

Page 52, line 37 , for olivaceus read olivacea

Page 54, line 38, for smaragdinus read smaragdina

Page 55, line 4 , for olivaceus read olivacea

Page 55, line 16, after 2. insert 1904.

Page III, line 18 , for Chondrocystic read Chondrocystis

Page II5, line 19, for sublilis read subtilis

Page 122, line 44, for symplocoides read symplocoidea

Page 129, after line 25, insert Plate V. fig. 48.

Page $\mathrm{I} 3 \mathrm{O}$, before first line, insert Plate V. fig. 49

Page I40, first line, for I-4 read I

Page 160 , line 3, after capitata insert (E. West Jun.)

Page 168 , line 25 , for depresed-read depressed-

Page 170, line 18 , for natus Harpswell. read natus. Harpswell

Page 180 , line 32 , for sack read sac

Page 18I, line 9, before N. insert (

Page 19I, line I8, for climbing read clinging

Page 265, first line, for Indies read Indies 



\section{Lists of Hosts and Associates}

Amphiroa 54

Anodonta 137

Anthoceros 169

Avicennia nitida 287

Azolla caroliniana I95

Balani 49

Bartramia fontana ${ }^{32}$

Bartramia ithyphylla 132

Batrachospermum vagum 266

Bostrychia tenclla 263

Celtis 22I

Ceramium rubrum 55

Chaetomorpha aerea II 7

Chaetophora calcarea 276

Chantransia 50

Chara 68, 234, 286

Chondrus crispus 295

Cladophora 18, 46, 56, II6, I49, I77, 264

Cladophora expansa 185,257

Conferva sandvicensis I66

Cycas revoluta 164,165

Cymopolia barbata 280

Dasya arbuscula 26I

Dictyota dichotoma 280

Digenia simplex 280

Enteromorpha 48, 70, II5, 264

Enteromorpha compressa 293

Enteromorpha intestinalis $53,54,115$, 257

Fucus 54, 294

Fucus evanescens 54,204

Fucus vesiculosus 282, 294

Galaxaura 260

Gelidium 54, 70

Gigartina 54

Gomontia holdenii 52

Hemiaulus delicatulus 202, 273

Iridaea laminarioides 54

Juniperus bermudiana 226

Laurencia obtusa 295

Leucobryum 24I

Liagora coarctata 204

Littorina 209
Mussels 137

Mya arenaria 237

Myrica cerifera 233

Myriophyllum 285

Myriophyllum epiphytica 288

Nemalion multifidum 26I

Nuphar 239, 240

Nymphaea 285

Odonthalia 54

Oedogonium 56

Ostraea virginiana $5 \mathbf{r}$

Parmelia saxatilis 22

Phragmites 270

Pithophora affinis 113,267

Plocamium coccineum 55

Polysiphonia 55, 84 .

Polysiphonia fastigiata 53

Punctaria plantaginea $25^{8}$

Ranunculus aquatilis 227,228

Rhizoclonium $\mathrm{I}_{3}$

Rhizoclonium riparium 5o

Rhizoclonium riparium validum 49

Rhizosolenia 202, 273

Rhodochorton 50

Rhodochorton rothii 50

Ruppia 90, 122, 136, 187, 257

Ruppia maritima 99, 188, 293

Sargassum 54

Scirpus 125, 269

Spartina 137, 193, 287, 29o

Spermothamnion 50

Sphacelaria 50, 53

Sphagnum 138, 151

Spirorbis 94

Stereocaulon 249

Taxodium distichum 250

Turbinaria 104, 202

Ulva 257,264

Unio 209

Utricularia 8, r99, 284

Vaucheria II6, 267

Zostera r 7, 120, 122, 124, 136, 193, 265

Zostera marina 193,204 



\section{INDEX}

acervatus Wood (Sirosiphon) 248 acuminata Gomont (Oscillatoria) 60, 78

adscendens (Naeg.) Born. and Flah. (Calothrix) 255, 267

aegagropila Kuetz. (Tolypothrix) 230

aeruginea (Kuetz.) Thur. (Calothrix) $254,26 \mathrm{I}$

aeruginea Kuetz. (Mastigothrix) 266

aerugineo-caerulea (Kuetz.) Gom. (Lyngbya) 109, i 16

aerugineum Kirchn. (Mastigonema) 266

aerugineum Bréb. (Merismopedium) 42

var. violaceum $R a b .42$

aerugineum n. sp. (Stigonema) 244, 245

aeruginosa (Kuetz.) Henfr. (Clathrocystis) 37

aeruginosa (Carm.) Kuetz. (Gloeocapsa) 14,18

a eruginosa C. Ag. (Lyngbya) I 20

aeruginosum (Kuetz.) Kirchn: (Mastigonema) 266

aeruginosus Naeg. (Synechococcus) II, 95, I 40

aestuarii (Mertens) Liebm. (Lyngbya) IIO, II5, 120

forma aeruginosa Wolle I20

forma aeruginosa. (Ag.) Wolle 123

forma ferruginea Gom. I 23

forma limicola Gom. 122

forma natans Gom. I22

forma symplocoidea Gom. I22,

agardhii Gom. (Oscillatoria) 58, 62 agglutinata Crouan (Lyngbya) I35

aikenensis Wolle (Hypheothrix) I39, I4I

alatum Berk. (Petalonema) 225

alatum (Carm.) Borzi (Scytonema) 212,225

alpina Clements and Shantz (Eucapsis) 45

alpinum Wood (Nostoc) I8r

ambigua (Naeg.) Gom. (Fischerella) 242

ambigua Naeg. (Gloeocapsa) I5, 22

forma fusco-lutea Naeg. 22

ambiguum Gom. (Phormidium) 92, IO3

ambiguum Kuetz. (Scytonema) 242 ambiguum Naeg. (Symphyosiphon) 242

americana Davis (Cryptoglena) 297 amethystea Kolderup - Rosenvinge (Pleurocapsa) 47,48

amphibia Ag. (Oscillatoria) 59, 73

Amphithrix Kuetzing 252, 253

amplissimum Setch. (Nostoc) I64, I80

amplum W. and G. S. West (Scytonema) $212,22 I$

amoena (Kuetz.) Gom. (Oscillatoria) 60,77

amorpha Berk. (Dasygloea) I54

amorpha (Thwaites) Wolle (Microcoleus) I 54

Anabaena Bory 161,185

anguiformis Harv. (Microcoleus) I55

anguina Mont. (Lyngbya) 124

anguina Bory (Oscillatoria) 59, 68 angulosa $\mathrm{Rab}$. (Gloeotrichia) 285

angustissima $W$. and G. S. West (Oscillatoria) 60,76

animalis Ag. (Oscillatoria) 60, 79

antillarum $\mathrm{S}$. and $\mathrm{M}$. (Hormosiphon) 168

antillarum Crouan (Lyngbya) I68

antillarum Crouan (Oscillaria) 64

antillarum Crouan (Symploca) I 29

antliaria Juerg. (Oscillaria) IOO, I07

Aphanizomenon Morren 16I, 196

Aphanocapsa Naegeli 2,27

Aphanothece Naegeli 2, 29

aponina Kuetz. (Gomphosphaeria) 38

var. cordiformis Wolle 39

aquatilis Sauv. (Synechocystis) Io

arachnoidea Crouan (Lyngbya) 125

arachnoidea Kuetz. (Lyngbya) III, 127

arboreus W. and G. S. West (Hapalosiphon) $238,24 \mathrm{I}$

arcangelii Borp. and Flah. (Scytonema) $2 I I, 2 I 3$

arcticum Harv. (Nostoc) I7I

arenaria (Hass.) Rab. (Gloeocapsa) I3, 16

arenaria (Berk.) De Toni (Hypheothrix) I39, I43

arenaria Gom. (Schizothrix) $\mathrm{r} 43$

arenaria (Kuetz.) Rab. (Lyngbya) I 35

argillaceus Wood (Sirosiphon) 245

armorica Thur. (Nodularia) J82, I84

Arthrospira Stizenberger 57,85

articulata Ag. (Echinella) 286

Asterocytis Gobi 296

Asterothrix Kuetzing 294

atlantica Gom. (Symploca) 128, 129 atra Roth (Rivularia) 283,289

var. confluens (Kt1etz.) -Born. 290 
atrata (Turp.) Kuetz. (Gloeocapsa) 14, I9

Aulosira Kirchner I6I, 202

aureum Kuetz. (Nostoc) 162, 165

aureus W. and G. S. West (Hapalosiphon) 238

austini Wolle (Inactis) I47, I49

austinii Wood (Nostoc) I63, I75

austinii Wood (Scytonema) 212, 220

austinii Wood (Symphyosiphon) 220

autumnale (Ag.) Gom. (Phormidium) 93, 94, 107

azollae Strasb. (Anabaena) I87, 195

azureum Tilden (Scytonema) 212, 216

badium Wolle (Scytonema) 212, 225

battersii Gom. (Plectonema) 206, 2 II baueriana (Grun.) Born. and Thur. (Dichothrix) $274,275,276$

bauerianum Grum. (Schizosiphon) 276

beccariana (De Not.) Born. and Flah. (Rivularia) 288

biasolettiana Menegh. (Rivularia) 292

bicolor Crouan (Lyngbya) III, I25

bicolor Wood (Lyngbya) I27

bonnemaisonii Crouan (Oscillatoria) 59,68

borealis Rab. (Symploca) I29, I32

borealis Richt. (Rivularia) 283, 288

bornetiana Collins (Anabaena) I86, I95

bornetiana Setchell (Rivularia) 283 , 292

bornetianum Wolle (Symphyosiphon) 2 I 2,227

boryana Bory (Oscillatoria) 6r, 83

bostrychicola Crouan (Lyngbya) II 8

botryoides (Kuetz.) Kirchn. (Protococcus)

forma caldarius Tilden 47

Brachytrichia Zanardini 253, 294

brandegei Wolle (Sirosiphon) 244, $25 \mathrm{I}$

brandegei Wolle (Scytonema) 224

braunii Born. and Flah. (Calothrix) 255,269

braunii Kuetz. (Hapalosiphon) 239

brannii Naeg. (Hapalosiphon) 239

braunii Gom. (Schizothrix) I53

brébissonii Kuetz. (Calothrix) 207

brébissonii Kuetz. (Capsosira) 25I

brébissonii Kuetz. (Hapalosiphon) 239

breviarticulata $W$. and G. S. West (Calothrix) 255, 267

brevis Kuetz. (Oscillatoria) 60, 79

var. neapolitana (Kuetz.) Gom. 80

brunnea Naeg. (Aphanocapsa) 28, 29

bullosa Wolle (Hypheothrix) I39, I4 I

bullosa Wolle (Leptothrix) I4I byssoidea Hass. (Hassallia) 233

var. cylindrica Tilden 233

byssoidea (Hass.) Kirchn. (Tolypothrix) 229,233

forma cylindrica Tilden 233, 243

forma saxicola Grun. 233

byssoideum Ag. (Scytonema)

var. corticale Mont. 220

caeruleo-violacea Crouan (Leibleinia) I I9

caeruleo-violacea Crouan (Lyngbya) I I , I27

caeruleum Lyngb. (Nostóc) I63, I77

caespitosa Born. and Flah. (Hyella) $5 \mathrm{I}, 209$

caespitosa (Kuetz.) Wolle (Isactis) 269

forma tenuior viridis Rab. 267

caespitosum Kuetz. (Mastigonema) 269

calcarea Tilden (Dichothrix) 274, 275, 280

calcarea Tilden (Gloeocapsa) I3, I7 calcarea Eng. Bot. (Rivularia) 290

calcicola (Ag.) Rab. (Hypheothrix) $96, \quad 138,139$

calcicola Kuetz. (Leptothrix) I39

calcicola Gom. (Schizothrix) I39

caldaria (Tilden) Setchell (Pleurocapsa) 8,47

caldaria Tild. (Spirulina) 86, 89

caldarium Setchell (Scytonema) 2II, 2 I 5

calida P. Richter (Calothrix) 255, 268 calidarium Wood (Nostoc) 163, I75

calidum Gom. (Phormidium) 93, I05

Calothrix Agardh 17, 252, 254

calotrichoides Gom. (Plectonema) 206, 210

calotrichoides Kuetz, (Scytonema) 223

calotrichoides Wood (Scytonema) 222

cantharidosma Mont. (Lyngbya) I34, 135

cantharidosmus (Mont.) Gom. (Hydrocoleus) I35

capitata W. West Jun. (Oscillatoria) $59,70,160$

Capsosira Kuetzing 237, 25I

carmichaelii Harv. (Sphaerozyga) r92 carneum Ag. (Nostoc) I62, I67

cartilaginea Wood (Rivularia) 284

castagnei (Bréb.) Rab. (Aphanothece) $30,3 \mathrm{I}$

castellii (A. Massalongo) Born. and Flah. (Calothrix) 255, 27r

castellii Mass. (Scytonema) 27I

Catagnymene Lemmermann 58, I 59

cataractae Naeg. (Schizosiphon) 275 cataractae Wood (Scytonema) 224 
catenatum Ralfs (Cylindrospermum) I98, $20 I$

catenula (Kuetz.) Born. and Flah. (Anabaena) 186, I9I

var. americana Collins 192

centrifuga Bornet (Isactis) 28I, 282 cesatiana Rab. (Oncobyrsa) 45

chalybea Mert. (Oscillatoria) 6I, 82 var. genuina Collins, Holden and Setchell 82

chalybea (Kuetz.) Gom. (Schizothrix) I 52

Chamaesiphon Braun and Grunow 46 , 55

Chamaesiphonaceae 2,46

chlorina Kuetz. (Oscillatoria) 60, 75

Chlorogloea Wille 3,46

Chondrocystis Lemmermann 2, 24

Chroococcaceae I, 2

Chroococcus 2, 3, 3 I

Chroothece Hansgirg 2, I2

chrysochlorum Kuetz. (Scytonema) 217

chthonoplastes (F1. Dan.) Thur. (Microcoleus) 155

cincinnata Kuetz. (Lyngbya) 214

cincinnatum Thur. (Scytonema) 2I4

cinereum Crouan (Scytonema) 2I6

cinereum Menegh. (Scytonema) 219

circinalis Rab. (Anabaena) I86, 190

cladophorae n. sp. (Lyngbya) I09, I 16

Clathrocystis Henfrey 3,37

coactile Mont. (Scytonema) 2II, 2I3

var, radians Crouan (Scytonema) $2 \mathrm{I} 3$

ccadunata (Sommerfelt) Foslie (Rivularia) $283,29 \mathrm{I}$

Coccogoneae I

Coelosphaeriopsis Lemmermann 3, 4I

Coelosphaerium Naegeli 3, 39

cohaerens (Bréb.) Naeg. (Chroococcus) 4,9

collinum Kuetz. (Nostoc) I69

comatum Wood (Cylindrospermum) 197, 198

comminutum Kuetz. (Nostoc) I62, I65 commune Vaucher (Nostoc) I63, I7I

var. flagelliforme (Berk. and Curtis) Born. and Flah. I73

comoides (Harv.) Gom. (Hydrocoleus) 1.34

compacta (Ag. ?) Born. and Flah. (Dichothrix) 274, 277

compacta Crouan (Lyngbya) I 2 T

compacta Collins (Rivularia) 283, 288 concharum Hansg. (Pleurocapsa) 47 conchophilum Humph. (Scytonema) 211,213

conferta Richt. (Aphanothece) 29, 30 conferta Crouan (Calothrix) 2 I7 confervicola (Roth) Ag. (Calothrix) $254,256,265$

var. purpurea Born. and Flah. 257 confervoides Reinsch (Anabaena) I87, 195

confervoides C. Ag. (Lyngbya) IIo, I I9

forma violacea Collins I20

confluens Naeg. (Gloeothece) 25

congesta Crouan (Lyngbya) I20

congestum Rab. (Phormidium) II8, I 58

conglomerata Kuetz. (Gloeocapsa) I4, 18

consociata (Kuetz.) Born. and Flah: (Calothrix) 254, 257

contarenii (Zanard.) Born. and Flah. (Calothrix) 254, 259

contarenii Collins (Calothrix) 262

contortum Wille (Trichodesmium) 84,85

convolutum Bréb. (Merismopedium) 42,44

corallicola Crouan (Oscillaria) I 23

corallinae Gom. (Oscillatoria) 59, 70

coralloides Kuetz. (Sirosiphon) 250

coriacea Kuetz. (Hypheothrix) I39, 142

forma meneghinii Kuetz. I42

coriacea Gom. (Schizothrix) I42

coriacea (Kuetz.) Gom. (Schizothrix) I 42

corium (Ag.) Gom. (Phormidium) 92, IOI

cortex Wolle (Scytonema) 22I

forma ravenelii Wolle 22I

cortex Wood (Scytonema) 216

cortiana Menegh. (Oscillatoria) 6r, $7 \mathrm{I}, 8 \mathrm{I}$

corymbosa (Harv.) Grun. (Polythrix) 280

corymbosus Harv. (Microcoleus) 280 crameri Brügg. (Sirosiphon) 247

creginii Wolle (Asterothrix) 295

crepidinum (Rab.) Thur. (Gloeocapsa) 14,20

crepidinum Collins (Pleurocapsa) 47, 49

crispum (Ag.) Born. (Scytonema) I57, $2 \mathrm{II}, 2 \mathrm{I} 4,265$

cristatum Bailey (Nostoc) I8I

crosbyanum Tilden (Phormidium) 9I, 96

cruenta Grun. (Oscillatoria) 6o, 8o

cruentum (Ag.) Naeg. (Porphyridium) .296

crustacea Thur. (Calothrix) 50, 204, 255,264

forma prolifera (Flah.) Collins 262

forma simulans Collins 265 
crustaceum Ag. (Scytonema) 212, 226 var. incrustans (Kuetz.) Born. and Flah, 226

crustaceus Kuetz. (Symphyosiphon) 226

crustiformis Naeg. (Schizosiphon) $260^{\circ}$

cryptarum Farl. (Chroothece ?) I2

Cryptoglena Ehr. 297

Cryptoglenaceae 297

cupressophila Wolle (Anabaena) I84, I87, 195

curtus Setchell (Synechococcus) I I

curvatus Nordst. (Chamaesiphon) 55, 56

curviceps Ag. (Oscillatoria) 59,67

cuspidata W. and G. S. West (Symploca) 145

cuspidata (Symploca) 203

cuspidatum (W. and G. S. West) De Toni (Symplocastrum) I44, I45

var. luteo-fusca $W$. and G. S. West 145

cuticulare (Bréb.) Born. and Flah. (Nostoc) I6I, I64

cyanea Crouan (Lyngbya) II9

cyanescens Crouan (Scytonema) 222

Cyanophyceae I

cycadearum Reinke (Anabaena) I64

Cylindrospermum Kuetz. 16I, I97

cystifera (Hass.) Rab. (Gloeothece) 26

Dasygloea Thwaites 58, 154

decorticans $\mathrm{A}$. Br. (Chroococcus) 4,8

densum (A. Br.) Born. (Scytonema) 212,227

depressum Wood (Nostoc) 163, I77

Dermocarpa Crouan 46,52

Desmonema Berk, and Thwaites 206, 235

detersa Stiz. (Oscillaria) 98

Dichothrix Zanard. 252, 274

diffusa Farlow (Oscillaria) 6r

digueti Gom. (Lyngbya) rog, I I 5

dillwynii Hass. (Calothrix) 235

Diplocolon Naeg. 206, 236

distincta (Nordst.) Schmidle (Lyngbya) 109, II 3

distorta (Hofman-Bang) Kuetz. (Tolypothrix) 229, 23I

distorta var. Wood (Tolypothrix) 230

donnellii (Wolle) (Calothrix) 256, 27 I

donnellii Wolle (Mastigonema) 27I

donnellii Wolle (Microcystis) 33, 34 dubia Wartm. (Gloeocapsa) I5, 23

dubia (Naeg.) Gom. (Symploca) 129, I3I

dubium Grun. (Coelosphaerium) 39, 40

dubium Wood (Scytonema) 212, 227 duplex Wolle (Spirulina) 87, 90

dura Roth (Rivularia) 283, 291

echinata Eng. Bot. (Rivularia) 284 echinulata (Smith) Born, and Flah. (Rivularia) 283, 286

elabens (Menegh.) Kuetz. (Microcystis) 33,35

elabens Kuetz. (Polycystis) 35

elachista W. and G. S. West (Aphanocapsa) 27,28

elegans (Chauv.) Zanard. (Goniotrichum) 295

elegans A. Br. (Merismopedium) 42, 43

elegans Ag. (Oscillatoria) 96

elegans Kuetz. (Scytonema)

var. antillarum Crouan 2/3

ellipsosporum (Desm.) Rab. (Nostoc) $162, \quad$ I 68

elongatum Wood (Mastigonema) 256, 271

enteromorphoides Grun. (Hormothamnion) 205

Entophysalis Kuetz. 2, 23

epiphytica West and West (Calothrix) 255, 265

erosa Liebm. (Lyngbya) 124

erythraeum Ehr. (Trichodesmium) 84

Eucapsis Clements and Shantz 3, 45

farlowii Born. (Hormactis) 294

fasciculata Ag. (Calothrix) 254, 262

forma incrustans Collins 262

fasciculata (Naeg.) Grun. (Inactis) 147

fasciculata Gom. (Schizothrix) I47, I 48

favosum (Bory) Gom. (Phormidium) 93, 104

fenestralis Kuetz. (Gloeocapsa) 13, I6

ferruginea C. Ag. (Lyngbya) 109, r20, 123

ferruginea G. S. West (Lyngbya) II4 fertile Wood (Mastigonema) 256, 27I fibrosum (Wood) Wolle (Mastigonema) 256,272

figuratum Ag. (Scytonema) 223

Fischerella (Born. and Flah.) Gom. 237,242

flaccida Crouan (Leibleinia) 26r

flaccida Kuetz. (Tolypothrix) $23 \mathrm{I}$

flavo-viride (Kuetz.) Born. and Flah. (Scytonema) 212, 222

flexuosum Rab. (Cylindrospermum) 193

flexuosus Borzi (Hapalosiphon) 2.38

flos-aquae (Lyngb.) Bréb. (Anabaena) 186 , 189 
flos-aquae (Linn.) Ralfs (Aphanizomenon) 196

var. treleasei Born. and Flah. I9o var. circinalis Kirchn. I90

flos-aquae (Wittr.) Kirchn. (Microcystis) 33,35

fluitans Her. (Lyngbya) III, I27

fluitans Cohn (Rivularia) 286

fluviatilis (Rab.) Kirchn. (Isactis) 290

fluviatilis Kuetz. (Zonotrichia) 290

foliaceum Moug. (Nostoc) I63, I7I

fontana Huber and Jadin (Hyella) 51,52

fontana Crouan (Lyngbya) I25

forma crassior Crowan 126

fontinalis (Ag.) Born. (Hapalosiphon) 238,239

var. tenuissimus (Grun.) Collins and Setchell) 240

formosa Bory (Oscillatoria) 60, 80

foveolarum (Mont.) Gom. (Phormidium) 9I, 94

fragile (Menegh.) Gom. (Phormidium) 9I, 93

fragile (Kuetz.) De Toni (Symplocastrum) I44

fragilis (Kuetz.) Gom. (Schizothrix) 144

friesiana Kuetz. (Symploca) I46

friesii Gom. (Schizothrix) I46

friesii (Ag.) Kirchn. (Symplocastrum) $\mathrm{I} 44,146$

froelichii Kuetz. (Oscillaria) 65

fucicola Saunders (Dermocarpa) 52, 54

fucicola (Kuetz.) Born. and Flah. (Dichothrix) 274, 279

fuliginosa Hauck (Pleurocapsa) 47,48

fuliginosum Tilden (Scytonema) 212, 225

fulva Harv. (Lyngbya) I 20

fusca (Kuetz.) Born. and Flah. (Calothrix) 255,265

fusca Crouan (Lyngbya) 125

fusca Wolle (Mastigonema) 266

fuscescens Kuetz. (Hapalosiphon) 239

fuscescens (Kuetz.) Rab. (Symploca) I29, I3I

fusco-lutea (Naeg.) Kuetz. (Gloeocapsa) 14 , 19

fusco-lutea Naeg. (Gloeothece) 25, 27

fusco-rubra Crouan (Oscillatoria) I 36

fusco-violacea Crouan (Calothrix) 254,258

gelatinosa Wood (Anabaena) 187, r96 gelatinosa Kuetz. (Gloeocapsa) I4, 18 gelatinosum Schousb. (Nostoc) 162, 169

geminata Menegh. (Oscillatoria) 59, 74,75

gigantea Wood (Anabaena) I9o

gigas W. and G. S. West (Gloeocapsa) 14,20

glacialis Dickie (Tolypothrix) 229, 235

glauca Wolle (Anacystis) 35

Glaucocystis Itzig. 296

glaucum (Ehr.) Naeg. (Merismopedium) 42,43

var. fontinale Hansg. 44

Glococapsa Kuetz, 2, I3

gloeophila (Kuetz.) Rab. (Hypheothrix) 139,140

Gloeothece Naeg. 2, 25

glomeratum Kuetz. (Nostoc) I63, I77

glutinosa A. Br. (Oscillaria) I36

glutinosus (Ag.) Gom. (Hydrocoleus) I34, I36

golenkinianum Gom. (Plectonema) 206, 210

gomontiana Setch. (Arthrospira) 85, 86

Gomphosphaeria Kuetz. 3, 38

Goniotrichum Kuetz. 295

gracile Kuetz. (Scytonema) 224, 232

gracilis Rab. (Calothrix) 269

gracilis (Menegh.) Rab. (Lyngbya) 89 , IIO, II7

gracilis Hass. (Microcoleus) I55

gracillima Kuetz. (Oscillaria) 76

granosa (Berk.) Kuetz. (Gloeocapsa) 13,15

granosa Rab. (Gloeothece) I5

granulosa Kuetz. (Entophysalis) 24

graveolens Crouan (Lyngbya) I32

grevillei (Hass.) Rab. (Aphanocapsa) 27,28

grisea Thur. (Microchaete) 203, 204

guadelupensis Crouan (Hydrococcus) I8I

guadelupensis Crouan (Oncobyrsa) I8I

guadelupensis Crouan (Tolypothrix) $2 \mathrm{r} 3$

guttula Wood (Sirosiphon) 249

guyanense (Mont.) Born. and Flah. (Scytonema) 212, 220

gypsophila Kuetz. (Calothrix) 278

gypsophila (Kuetz.) Born. and Flah. (Dichothrix) 274, 277, 278, 280

haematites (DC.) Ag. (Rivularia) 283, 290

haematites Rab. (Zonotrichia) 290

Haliarachne Lemm. 58, 160

hallensis (Jancz.) Born., and Flah. (Anabaena) I86, I 88 
halophila Lemm. (Coelosphaeriopsis) $4 \mathrm{I}$

halos Wood (Mastigonema) 256, 272

Hapalosiphon Naeg. 236, 237

harveyana (Thwaites) Thur. (Nodularia) $99,182,184$

hawaiensis Lemm. (Schizothrix) I50

hawaiensis (Lemm.) De Toni (Inactis) 147,150

hawaiiensis Tilden (Nodularia) I82, 184

hederulae Menegh. (Nostoc) I64

helveticus Naeg. (Chroococcus) 4,8

hemisphaerica (L.) Aresch. (Rivula. ria) 289

heppii Naeg. (Diplocolon) 236

heppii (Naeg.) Wolle (Scytonema) 236

herbacea Kuetz. (Hypheothrix) I39, 140

herbacea Kuetz. (Leptothrix) I4I

heterotrichus Kuetz. (Hydrocoleus) I34, 138

hindsii Mont. (Trichodesmium) 84

hinnulea Wolle (Beggiatoa) I40

hinnulea (Wolle) De Toni (Hypheothrix ?) 138, I 40

hinnulea (Wolle) Tilden (Lyngbya) I40

hirtulus Kuetz. (Symphyosiphon) 228

hirtulum (Kuetz.) Rab. (Scytonema) 212,228

hofmanni Ag. (Scytonema) 212, 216

forma brunnea Wolle 2I7

var. calcicolum (Hansg.) 217

var. symplocoides (Reinsch) Born. and Flah. 2 I7

hofmanni Kuetz. (Symphyosiphon) 216

holdenii Tilden (Hydrocoleus) I34, I37

holdenii De Toni (Lyngbya) I09, Ir 5

homoeotrichus Kuetz. (Hydrocaleus) I34, I37

Hormogoneae I, 56

hormoides (Kuetz.) Bornet and Flah. (Stigonema) 244

var. rhizodes (Kuetz.) Hansg. 245

var. tenue West and West 245

Hormothamnion Grun. 16r, 204

hosfordii Wolle (Calothrix) 278

hosfordii (Wolle) Born. (Dichothrix) 274,278

hospita Thur. (Rivularia) 287

humifusum Carm. (Nostoc) I62, I70

humphreyi Collins (Goniotrichum) 295

hyalina Harv. (Lyngbya) III, I 28

hyalina Kuetz. (Schizothrix) I50, I5I

hyalinus (Kuetz.) Kirchn. (Microcoleus) I28, I5I

hydnoides Kuetz. (Symploca) iza

var. fasciculata (Kuetz.) Gom. I30 var. genuina Gom. 130
Hydrocoleus Kuetz. 57, I34

hydrurimorpha Crouan (Oscillaria) 129

Hyella Bornet and Flahault 46, 51

Hypheothrix Kuetzing 57, I38

ichthyoblabe Kuetz. (Microcystis) 33, 34

icthyoblabe Kuetz. (Polycystis) 34

immersum Wood (Scytonema) 212, 228

imperator Wood (Oscillaria) 62

Inactis Kuetzing 57,146

inaequalis (Kuetz.) Born. and Flah. (Anabaena) 186, 19I

incrustans Grun. (Chamaesiphon) 55

incrustans Kuetz. (Symphyosiphon) 226

incrustata Wood (Gloeotrichia) 285

incrustata (Wood) De Tóni (Rivularia) 283,285

incrustatum (Naeg.) Gom. (Phormidium) 92,99

var. cataractarum (Naeg.) Gom. IOO incurvus Allm. (Trichormus) 189

indica Crouan (Calothrix) 220

informe Kuetz. (Stigonema) 244, 249

interrupta Kuetz. (Lyngbya) I2I

interruptum Kuetz. (Phormidium) 92, $\mathrm{r} 02$

intertextum (Kuetz.) Rab. (Scytonema) 212,219

intracellularis J. Schm. (Richelia) $20 \mathrm{I}$

intricatum Menegh. (Nostoc) I66

intricatus West and West (Hapalosiphon) $238,24 \mathrm{I}$

inundata Kuetz. (Lyngbya) 100

inundatum Kuetz. (Phormidium) 92, IOO

Isactis Thuret $253,28 \mathrm{I}$

itzigsohnii Born. (Gloeocapsa) 22

janthina (Mont.) Born. and Flah. (Amphithrix) 253

var. torulosa (Grun.) Born. and Flah. 253

janthina Naeg. (Gloeocapsa) I4, 22

javanicum (Kuetz.) Born. and Flah. (Scytonema) 212, 218

var. hawaiiense Lemm. 218

jenneri (Kuetz.) Stiz. (Arthrospira) 85

jenneri Kuetz. (Spirulina) 85

joannianum Kuetz. (Phormidium) 106 juliana (Menegh.) Born. and Flah. (Calothrix) 254, 256

julianum Rab. (Phormidium) II4 julianum Menegh. (Scytonema) 216 junipericolum Farl. (Scytonema) 212, 226 
kerneri Hansg. (Xenococcus) 49, 50 kuetzıngıanum Naeg. (Coelospnaerıum) 39,40

kuetzingiı Schmidle (Lynbya)

var. distincta (Nordst.) Lemm. II3

kuntzei P. Richter (Calothrix) 255, 200

lacucola Wolle (Calothrix) 256, 272

lacustris (A. Br.) De Toni (112actis) I47, 148

var. caespitosa Gom. I48

lacustris (Kab.) Farlow (Microcoleus) 157

lacustris A. Br. (Schizothrix) 148

lacustris Kab. (Sirosiphon) 250

laetevirens Crouan (Oscillatoria) 60, 78

laete-viridis Gom. (Symploca) I29, 130

lagerheimii (Möb.) Gom. (Lyngbya) IOS, 111

laminosum (Ag.) Gom. (Phormidium) $92,96,98$

forma weedii 'Tilden 97

laminosus (Kuetz.) Hansg. (Hapalosiphon) $238,240,24 \mathrm{I}$

lanata (Desv.) Wartm. (Tolypothrix) 229,230

var. hawaiensis Nordst. $23 \mathrm{I}$

lardacea (Cesati) Hansg. (Hypheothrix) 142

lardacea (Ces.) Gom. (Schizothrix) I 39, I 42

latilimba Crouan (Lyngbya) I35

laxa (Rab.) A. Br. (Anabaena) 186, I92

laysanense Lemm. (Phormidium) 93, 104

laysanensis Lemm. (Xenococcus) 49

leibleiniae (Reinsch) Bornet (Dermocarpa)

var. pelagica Wille 52,55

lenticularis Lemm. (Haliarachne) 160

leprieurii Kuetz. (Scytonema) 220

leptotrichia Kuetz. (Oscillaria) 76

licheniforme (Bory) Kuetz. (Cylindrospermum) 198, 200

lignicola Wood (Sirosiphon) 248

limbata Thur. (Tolypothrix) 229, 234

limneticus Lemm. (Chroococcus) 4, Io

limnicola Wolle (Cylindrospermum) I99

limosa Ag. (Oscillatoria) 58, 64, 65, 72

var. badia Tilden 66

var. chalybea Crouan 69

linckia (Roth) Born. (Nostoc) I62, I66

linearis Naeg. (Gloeothece) 25

littoralis Crouan (Leibleinia) IIg littoralis Carm. (Oscillatoria) I2 I

lobatus Wood (Nostochopsis) 25I

longissima Crouan (Mastichothrix) 266

lucifuga Bréb. (Symploca) I46

lunata W. and G. S. West (Gloeothece) 25,26

luridum (Kuetz.) Gom. (Phormidium) 91,95

lutea (Ag.) Gom. (Lyngbya) 53, 109, I 4

luteo-fusca Ag. (Lyngbya) II8, II9

luteo-fusca Crouan (Lyngbya) 123

Lyngbya C. Ag. 50, 57, I08, 215

lyngbyei Kuetz. (Chthonoblastus) I 56

lynbyaceum Kuetz. (Phormidium) I32

lyngbyaceus Kuetz. (Hydrocoleus) I34, I35

var. a Gom. 136

var. $\beta$ rupestre Kuetz. 136

macrococcus (Kuetz.) Rab. (Chroococcus) 3,5

macrospermum Kuetz. (Cylindrospermum) I98

macrosporum Menegh. (Nostoc) I63,

magma (Bréb.) Kuetz. (Gloeocapsa) I4, 2 I

var. itzigsohnii (Born.) Hansg. 2J magna Wolle (Gloeothece) 25, 27

magnoliae Farlow (Entophysalis) 24 mainensis F. L. Harv. (Nodularia) 182,185

major Tilden (Hapalosiphon) 238, 240

major Menegh. (Lyngbya) I I0, I26

major Vauch. (Oscillatoria) 59, 67

major Kuetz. (Spirulina) 86, 87, 97

majus Kuetz. (Cylindrospermum) 197, 199

majus Hold. (Hydrocoleus) 137

majuscula (Dillw.) Harvey (Lyngbya) II0, 123

mamillosum (Lyngbye) Ag. (Stigonema) 244,250

margaritifera Kuetz. (Oscillatoria) 59,69

narginata Menegh. (Anacystis) 34

marginata (Menegh.) Kuetz. (Micro. cystis) $6,33,34$

marginata Naeg. (Microcystis) 34

martensiana Menegh. (Lyngbya) I10, 124

var. calcarea Tilden 125,276

var. distincta Nordst. II3

Mastigocoleus Lagerh. 236, 237

mellea Kuetz. (Gloeocapsa) I3

mellea Kuetz. (Gloeocapsa) I4, I8

membranacea (Rab.) Born. (Gloeothece) 25,26

membranacea (Kuetz.) Thur. (Lyngbya) 105 
membraninus (Menegh.) Naeg. (Chroococcus) 4, Io

mendotae Trelease (Anabaena) rgo

meneghiniana Kirchn. (Calothrix) 277

meneghiniana (Kuetz.) De Toni (Dichothrix) 274, 277

meneghiniana (Kuetz.) Gom. (Lyngbya) I10, II7

meneghiniana Zan. (Spirulina) 86, 87 meneghinianus Kuetz. (Schizosiphon) 277

Merismopedium Meyen. 3, 4I mexicana (Gom.) De Toni (Inactis) I 47, I 50

mexicana (Kuetz.) Rab. (Rivularia) 284,293

mexicana Gom. (Schizothrix) I50

Microchaete Thuret I6I, 202

microcoleiformis Crouan (Sphaerozyga) 205

Microcoleus Desmazières 58 , I 54

Microcystis Kuetz. 3, 33

microscopica Naeg. (Aphanothece) 29, $3 \mathrm{I}$

microscopica Dickie (Rivularia) 284. 293

microscopicum Carm (Nostoc) I63, 176

microspora (Menegh.) Rah. (Aphanothece) 30,31

millei Born. (Scytonema) गT2, 220

miniata Hauck (Oscillatoria) 59, 68 minnesotensis Tilden (Oscillatoria) 59,75

minor (Kuetz.) Naeg. (Chroococcus) 4,9

forma minima W. and G. S. West 9 minutissimum Collins (Cylindrospermum) 197,200

minutula Kuetz. (Limnactis) 288

minutula (Kuetz.) Born. and Flah. (Rivularia) 283, 288

minutula Rab. (Zonotrichia) 284, 289

minutula Wood (Zonotrichia) 293

minutum Wood (Cylindrospermum) I97, 199

minutum Desm. (Nostoc) I63, I74

minutum (Ag.) Hass. (Stigonema) 244,248

var. saxicola (Naeg.) Born. and Flah. 248

minutus (Kuetz.) Naeg. (Chroococcus) 4,7

mirabile Thur. (Plectonema) 207

mirabile (Dillw.) Born. (Scytonema) 212,222

var. leprieurii (Mont.) Born. and Flah. 224

mirabile Wolle (Scytonema) 22I

mirabilis Ag. (Calothrix) 207

mollis Wood (Dasyactis) 29I mollis Wood (Zonotrichia) 284, 293 monococca (Kuetz.) Hansg. (Chroothece) 12

var. mellea (Kuetz.) Hansg. I3 montana Tilden (Dichothrix) 274, 275 montana Kuetz. (Gloecapsa) I3, I6 var. caldarii Sur. 16 montana Harv. (Sorospora) 2 I mucicola Lemm. (Lyngbya) I08, III mucosa Crouan. (Lyngbya) I35 muelleri Naeg. (Schizothrix) I52 multicoloratus Wood (Chroococcus) 4,7

muralis Kuetz. (Gloeocapsa) 14, I9 muralis Kuetz. (Symploca)' 129, I3I muscicola Kuețz. (Cylindrospermum) I97, 200

muscicola Kuetz. (Tolypothrix) 230

muscorum Ag. (Nostoc) 162 , I69

muscorum (Ag.) Gom. (Symploca) I 29,132

var. rivularis (Wolle) Tilden I33 myochroum (Dillw.) Ag. (Scytonema) 212, 224

Myxophyceae I

naegelii Wartm. (Aphanothece) 30, 32

naegelii Kuetz. (Scytonema) 232

naegelii (Kuetz.) Wood (Scytonema) 207

nana Tild. (Lyngbya) Iog, II 2

natans Kuetz. (Oscillaria) 72

ratans (Hedw.) Welw. (Rivularia) 283,285

natans Bréb. (Scytonema) 207

naveanum Grun. (Phormidium) 92, $\mathrm{ro2}$

neglecta Wood (Oscillatoria) 64

neglectus Wood (Sirosiphon) 247

nemalionis Crouan (Lyngbya) $26 \mathrm{I}$

nigra Vauch. (Oscillatoria) 59,70

nigrescens Harv. (Lyngbya) I19, 136

nigro-viridis Thw. (Oscillatoria) 59, 69

nitida Ag. (Rivularia) 283, 287

nitida ? (Rivularia) 294

Nodularia Mertens $16 \mathrm{I}, 182$

nordstedtii Gom. (Spirulina) 86, 88

Nostoc Vaucher 7, III, I60, I6I, 210, 235

Nostocaceae 56,160

nostochinearum Itzig. (Glaucocystis) 296

Nostochopsis Wood 237, 25 I

nostocorum Born. (Plectonema) 206, 209

notarisii Kuetz. (Porphyrosiphon) 269 notarisii (Menegh.) Kuetz. (Porphyrosiphon) I33 
novum Wood (Merismopedium) 42, 43

numidica Gom. (Oscillatoria) 6I, 8I

obscura Dickie (Hypheothrix) I04

obscura Kuetz. (Lyngbya) I2I

obscura Wolle (Lyngbya) I2I

obscurus Dickie (Schizosiphon) 256, 273

occidentale Setch. (Scytonema) 2II, 214

ocellatum Lyngb. (Scytonema) 2I2, 2 I 8

ocellatum (Dillw.) Thur. (Stigonema) 244,246

ccellatus Kuetz. (Sirosiphon) 247

ochracea (Kuetz.) Thur. (Lyngbya) I09, II3

okeni Ág. (Oscillatoria) 6I, 8I

oligothrix Crouan (Microcoleus) 155

olivacea (Hooker) Born. and Flah. (Dichothrix) 274, 276

olivacea (Reinsch) nob. (Dermocarpa) 52,55

olivaceum Rab. (Phormidium) I20

olivaceus Reinsch (Sphaenosiphon) 55

Oncobyrsa Ag. 3, 45

ornata Kuetz. (Óscillatoria) 59, 67 orsiniana Thur. (Calothrix) 275

orsiniana (Kuetz.) Born. and Flah. (Dichothrix) 274, 275

orsinianum Kuetz. (Mastigonema) 275

oscillarioides Bory (Anabaena) I86, 193

var. elongata (Kuetz.) Born. and Flah. I94

var. stenospora Born. and Flah. I94

Oscillatoria Vaucher $57,58,90$

Oscillatoriaceae 56,57

packardii (Farlow) nob. (Microcystis) 33,36

packardii Farlow (Polycystis) 36

pallida (Kuetz.) Rab. (Aphanothece) $30,3 \mathrm{I}$

pallida Kuetz. (Hypheothrix) I39, I44 pallida (Naeg.) Wolle (Lyngbya) I44 pallida (Farlow) Lemm. (Microcystis) 34,36

pallida (Kuetz.) Farlow (Polycystis) 36

pallidus Naeg. (Chroococcus) 4, 9 paludosa Wolle (Nodularia) I 82, I 83 paludosum Kuetz. (Nostoc) I6I, I65 paludosus (Kuetz.) Gom. (Microcoleus) 158

panniforme (Ag.) Kirchn. (Stigone-ma) 244,245

papyraceum (Ag.) Gom. (Phormidium) 92 , IOI papyrina Kirchn. (Lyngbya.) IO2

paradoxa (Wolle) De Toni (Rivularia) 283,289

paradoxa Wolle (Zonotrichia) 289

paradoxum Kuetz. (Mastigonema) 256,273

parasitica (Chauvin) Thur. (Calothrix) 254, 260

parasiticum Wolle (Mastigonema) 267

parcezonata Wood (Zonotrichia) 290 parietina (Naeg.) Thur. (Calothrix) $255,269,280$

parietinum Crouan (Scytonema) 2 I9

parmelioides Kuetz. (Nostoc) I64, I8I

parvula Rab. (Gloiotrichia) 285

pelagica Lemm. (Catagnymene) I59

var. major Wille 159

pellucidulus Wood (Sirosiphon) 247

penicillata Zanard. (Dichothrix) 275, 280

penicillata Kuetz. (Lyngbya) I09, I 5

penicillata (Ag.) Thur. (Tolypothrix) 229,232

percursa Kuetz. (Oscillatoria) 6r, 83

perelegans Lemm. (Lyngbya) I08, I I I

persicinum (Reinke) Gom. (Phormidium) 9I, 94

phormidioides Buinh. (Hydrocoleus) 137

Phormidium Kuetzing. 57, 9I

phormidium Kuetz. (Lyngbya) 132

phormidium Rab. (Lyngbya)

var. rivularis Wolle $\mathrm{I} 33$

pilosa Harv. (Calothrix) 255, 263

pilosus Crouan (Schizosiphon) 264

piscinale Kuetz. (Nostoc) I62, I66

piscinalis (Brügg.) De Toni (Microcystis) 34,36

piscinalis (Brügg.) (Polycystis) 36

pisum Thur. (Gloeotrichia) 284

pisum (Ag.) Thur. (Gloeotrichia) 284,286

pisum Ag. (Rivularia) 283, 284, 286

plana (Harv.) Thur. (Isactis) $28 \mathrm{I}$

var. fissurata Born. and Flah. 282

plana Rab. (Mastigonema) 28I

Plectonema Thuret 206, 267

Pleurocapsa Thuret 46, 47

plicata Carm. (Rivularia) 287

pluviale Crouan (Sirosiphon) 246

polydermatica Kuetz. (Gloeocapsa) I3, I5

polymorphum Naeg. (Scytonema) 212,228

polyotis (Ag.) Born. and Flah. (Rivularia) 283,286

polysperma Rab. (Sphaerozyga) I87, I92 
polyspermum (Kuetz.) Wood (Dolichospermum) I92

Polythrix Zanardini 252, 280

Porphyridium Naegeli 296

Porphyrosiphon Kuetzing 57, I33

prasina A. Br. (Aphanothece) 30, 32 prasina (Reinsch) Born. and Thuret (Dermocarpa) 52

princeps Vauch. (Oscillatoria) 58, 62, 72

forma purpurea Collins 63

proboscidea Gom. (Oscillatoria) 58, 64

prolifera Flah. (Calothrix) 254, 262

prolifica (Grev.) Gom. (Oscillatoria) $58,6 \mathrm{I}$

pruniforme (Linn.) Ag. (Nostoc) I63, I78

pulchra Kuetz. (Tolypothrix) 23I

pulverea (Wood) De Toni (Microcystis) 33,35

pulvereus (Wood) Wolle (Anacystis) 35

pulvereus Wood (Pleurococcus) 35 pulvinata (Mert.) Ag. (Calothrix) 254,260

pulvinata Kuetz. (Inactis) I46, I47

pulvinata Gom. (Schizothrix) I47

pulvinatum Nordst. (Scytonema) 22I

pulvinatus Wolle (Microcoleus) 158

pulvinatus Bréb. (Sirosiphon) 245, 249

forma alpinus (Kuetz.) Wolle 246

punctata Naeg. (Gloeocapsa) I4, I7

punctatum Wood (Nostoc) I63, I7I

punctiforme (Kuetz.) Har. (Nostoc) I6I, I64

purpurascens (Kuetz.) Gom. (Phormidium) 9I, 95

purpurascens (Kuetz.) Gom. (Phormidium) 139

purpurascens (Kuetz.) Gom. (Schizothrix) I52

var. cruenta (Lesp.) Gom. I52 purpureus Snow (Chroococcus) 4, to pusilla Harv. (Lyngbya) III, I28

putealis Mont. (Lyngbya) IIO, I25

var. minor Crouan 125

quaternata (Bréb.) Kuetz. (Gloeocapsa) I3, I7, 210

quoyi (Ag.) Born. and Flah. (Brachytrichia) 294

quoyi (Ag.) Born. (Hormactis) 294

racemosus Wolle (Synechococcus) II

radians Thur. (Rivularia) 288

var. minutula Kirchn. 288

radiosa (Kuetz.) Kirchn. (Calcthrix) 235

ralfsiana (Harv.) Kuetz: (Gloeocapsa) 15,22

ramosa (Thwaites) Gobi (Asterocytis) 296 ramosum (Thwaites) Hauck (Goniotrichum) 296

ravenelii Wolle (Hydrocoleus) I34, I 38

ravenelii Wood (Scytonema) 220

ravenelii Wolle (Tolypothrix) 229, 234

refractus Wood (Chroococcus) 4,8

retzii Ag. (Lyngbya) 102

retzii (Ag.) Gom. (Phormidium) 92, IO2

forma fasciculatum Gom. ro3.

forma rupestris (Kuetz.) Gom. I03 rhizosoleniae Lemm. (Calothrix) 256, 273

Richelia Johs. Schm. I6I, 201

richteriana Hansg. (Chroothece) 12

rigidissima Crouan (Leibleinia) I23

rivulare Kuetz. (Nostoc) 166

rivulare Kuetz. (Nostoc) 162, 167

rivulare Borzi (Scytonema) 2II, 2I3

Rivularia (Roth) Agardh. 253, 283

Rivulariaceae 57,252

rivulariarum Gom. (Lyngbya) I08. I I I

rivularis (Carm.) Rab. (Aphanocapsa) $27 ; 28$

rivularis (Kuetz.) Menegh. (Oncobyrsa) 45

robusta Clark (Clathrocystis) $37, \cdot 38$

robusta Setchell and Gardner (Microchaete) 202, 203

rosea -(Reinsch) Batters (Dermocarpa ?) 52,53

rosea (Snow) Lemm. (Gomphosphaeria) 38,39

roseolum (Richter) Gom. (Plectonema) 206,210

rubra Crouan (Lyngbya) III, r28

rubra Gom. (Schizothrix) I45

rubrapunctus Wolle (Chroococcus) 4 , 5

rubro-violacea Crouan (Lyngbya) II , 128

forma crassior Crouan II9

rubrum Tild. (Phormidium) 9I, 95

rubrum Mont. (Scytonema) 212, 228

rubrum (Menegh.) De Toni (Symplocastrum) I44, 145

rufescens (Bréb.) Naeg. (Chroococcus) 248

rufescens Crouan (Lyngbya) II9, I25

rupestre Kuetz. (Nostoc) I76

rupestre Borzi (Sacconema) 28I

rupestris Kuetz. (Gloeocapsa) I4, r9 rupestris (Lyngbye) Born. (Gloeothece) 25,26

var. tepidariorum (A. Br.) Hansg. 26

rupestris Wolle (Tolypothrix) 229, 234

rupicola Collins (Dichothrix) 274, 279

rupicola Tilden (Schizothrix) I53 
saccata (Wolle) Born. and Flah. (Wollea) 18I

saccata Wolle (Sphaerozyga) 182

Sacconema Borzi 252, 28I

salinarum Collins (Oscillatoria) 6o, 77

sancta Kuetz. (Oscillatoria) 58, 64

var. aequinoctialis Gom. 65

var. caldariorum (Hauck) Lag. 65

sandvicense Nordst. (Lophopodium) 266

sandvicensis (Nordst.) Schmidle (Calothrix) 255, 266

sanguinea (Ag.) Kuetz. (Gloeocapsa) 15,23

sargassi Crouan (Mastichonema) 279

saxicola Naeg. (Aphanothece) 29, 30

saxicola Naeg. (Sirosiphon) 249

schauinslandii Lemm. (Aulosira) 202

schauinslandii Lemm. (Chondrocystis) 24

schizodermaticus West (Chroococcus) 4,6

Schizophyceae I

Schizothrix Kuetzing 58, I50

schousboei (Dermocarpa) 50

schousboei Thur. (Xenococcus) 49, 50

schowiana Crouan (Leibleinia) I23

schowiana Kuetz. (Lyngbya) II8

scopulorum (Weber and Mohr) Ag. (Calothrix) 254, 258, 280

scutata cladophorae Tilden (Pringsheimia) 46

Scytonema Agardh 206, 21 I

Scytonemaceae 56, 205

scytonematoides Wood (Sirosiphon) 233

scytonemicola n. sp. (Calothrix) 255, 265

sejunctum Wood (Mastigonema) 256, 273

semiplena (C. Ag.) J. Ag. (Lyngbya) I I, 118

setchellianum Gom. (Phormidium) 93, 108

setchellii Collins (Tolypothrix) 229, 234

simmonsiae (Collins) De Toni (Inactis) 147,149

simmonsiae Collins (Schizothrix) 149 simplex Wood (Scytonema) 2I2, 229 simplice Wood (Scytonema) 229

smaragdina (Reinsch) nob, (Dermocarpa) 52,54

smaragdinum Crouan (Phormidium) 132

smaragdinus Reinsch (Sphaenoșiphon) 54

smithii (Thw.) Wolle (Sphaerozyga) I9I solutum Born. and Grun. (Hormothamnion) 205

sordida Crouan (Lyngbya) IIo, I I8

sordida (Zanard.) Gom. (Lyngbya I 18

forma bostrychicola (Crouan) Gom. I 18

spadiceum Crouan (Phormidium) $\mathrm{I}^{2}$

sparsa Wood (Gloeocapsa) I4, I9

sphaerica Born. and Flah. (Anabaena) 186,188

var. macrosperma Born. and Flah. I 88

sphaericum Vauch. (Nostoc) I63, I73

sphaerocarpa Born. and Flah. (Nodularia) 182,183

sphaeroides Kuetz. (Nostoc) 163,176

Sphaerozyga Agardh 183

spirális Lemm. (Catagnymene) 7o, I59

var. capitata (W. West Jun.) Wille I 60

Spirulina Turpin 57,86

spirulinoides Gom. (Lyngbya) IIO, I 26

splendida Grev. (Oscillatoria) 60, 76

var. uncinata Setch. and Gard. 76

spongiaeforme Ag. (Nostoc) 162, I68

spumigena Mert. (Nodularia) 182, I84

var. genuina Born. and Flah. I85

var. litorea (Kuetz.) Born. and Flah. 185

var. major (Kuetz.) Born. and Flah. I85

stagnale (Kuetz.) Born. and Flah. (Cylindrospermum) 197,198

stagnalis Kuetz. (Anabaena) 198

stagnalis Gom. (Calothrix) 255, 265

stagnina (Spreng.) A. Br. (Aphanothece) 30,32

Stigonema Agardh 237, 244

Stigonemaceae 56,236

stragulum Crouan (Phormidium) II4

stuposum (Kuetz.) Born. (Scytonema) $2 \mathrm{I} 2,22 \mathrm{I}$

subbrevis Schmidle (Oscillatoria) 79

subfuscum Kuetz. (Phormidium) 93, I05

var. joannianum (Kúetz.) Gom. I06 submarina Crouan (Calothrix) 276 submarinum Crouan (Scytonema) 263 submembranaceum (Ard. and Straff.) Gom. (Phormidium) 92, IO4

subrigida (Wood) De Toni (Anabaena) 187,196

subrigidum Wood (Dolichospermum) I96

subsalsa Ag. (Oscillatoria) 6r, 82 var. dulcis Crouan 67

subsalsa Oerst. (Spirulina) 87 
subsalsa Oerst. (Spirulina) $87,89,90$

forma oceanica (Crouan) Gom. 90 subtilis Holden (Lyngbya) IO9, II 5 subtilis W. West (Lyngbya) II2

subtilissima Kuetz. (Oscillatoria) 59, 74

subtilissima Kuetz. (Spirulina) 86, 88 subtorulosa (Bréb.) Farlow (Oscillatoria) $6 \mathrm{I}, 83$

subtorulosum Bréb. (Phormidium) I 58

subtorulosus (Kuetz.) Gom. (Microcoleus) 95,158

subuliforme Gom. (Phormidium) 92, 99

subuliformis Kuetz. (Oscillatoria) 60, 77

sutherlandi Dickie (Nostoc) I8I

Symploca Kuetzing 57, I28

symplocarioides Crouan (Oscillaria) 129

Symplocastrum Gomont 57

Synechococcus Naegeli 2, I I

Synechocystis Sauvageau 2, 10

tenax Wolle (Hypheothrix) I39, I4I tenax Wolle (Leptothrix) I4I

tenera Thur. (Microchaete) 202, 203

tenerrima Thur. (Lyngbya) II4

tenerrima Kuetz. (Oscillaria) 73

tenerrima Kuetz. (Spirulina) 86, 88

tenerrimus Gom. (Microcoleus) I 55

tenue (Menegh.) Gom. (Phormidium) 92,98

tenue Thur. (Plectonema) 206, 207

tenuis Kuetz. (Oscillaria)

var. sordida Kuetz. 106

tenuis Ag. (Oscillatoria) 59, 7 I, 72

var. natans (Kuetz.) Rab. 73

var. tergestina (Kuetz.) Rab. 73

tenuis Kuetz. (Tolypothrix) 229

forma bryophila Rab. 230

tenuissima $W$. and G. S. West (Microchaete) 202, 203

tenuissima Kuetz. (Spirulina) 89

tenuissimum Lemm. (Merismopedium) 42,45

tenuissimus Grun. (Hapalosiphon) 240

terebrans Born. and Flah. (Plectonema) $52,206,209$

terebriformis Ag. (Oscillatoria) 61, 83

terrestris Desmaz. (Microcoleus) I57

testarum Lagerh. (Mastigocoleus) 213,237

Tetrapedium Reinsch 3, 4I

thelephoroides (Mont.) Gom. (Schizothrix) I5I

thermale Schwabe (Mastigonema) 268,278

thermale Borzi (Scytonema) 243

thermale Kuetz. (Scytonema) 223 thermale (Schabe) Borzi (Stigonema) 243

thermalis (Schwabe) Hansg. (Calothrix) $255,268,270,275$

thermalis Schwabe (Fischera)

var. Americana Farl. 243

thermalis (Schabe) Gom. (Fischerel. la) 242,243

var. mucosa Lemm. 243

thermalis Lemm. (Gloeocapsa) 15, 22

thermalis Crouan (Lyngbya) I25

thermalis Crouan (Oscillaria) 79

thermalis (Kuetz.) Gom. (Symploca) I 29, I 30

thermophilus Wood (Chroococcus) 4,7

thiebautii Gom. (Trichodesmium) 84

tinctoria Rab. (Hypheothrix) I49

tinctoria (Ag.) Thur. (Inactis) 147, I 49

tinctoria Kuetz. (Leptothrix) I49

tinctoria Kuetz. (Lyngbya) 94

tinctoria Gom. (Schizothrix) I49

tinctorium A. Br. (Hydrocoleum) I49

tinctorium Kuetz. (Phormidium) 9I, 94

Tolypothrix Kuetzing 206, 2I5, 229, 265

tolypotrichoides Kuetz. (Scytonema) 212,222

tomasinianum (Kuetz.) Born. (Plectonema) 206,207

tomentosum (Kuetz.) Hier. (Stigonema) 244,246

torridum Ag. (Scytonema) 219

torta Crouan (Leibleinia) 125

torta Crouan (Lyngbya) 125

torulosa (Carm.) Lagerh. (Anabaena) I86, 192

trapezoidea Tilden (Oscillatoria) 82 treleasei Gom. (Phormidium) 92, 96 Trichodesmium Ehrenberg 57, 84

trigonum W. and G. S. West (Tetrapedium) $4 \mathbf{I}$

truncicola (Rab.) Wolle (Tolypothrix) 233

tuberculosa (Hansg.) Wille (Chlorogloea) 46

turfaceum (Berk.) Cooke (Stigonema) 244, 249

var. parvum Wood 249

turfosum Kuetz. (Scytonema) 224

turgida Wolle (Mastigothrix) 256, 273

turgidus (Kuetz.) Naeg. (Chroococcus) $4,5,32$

var. fuscescens (Kuetz.) De Toni 6

turicensis (Naeg.) Hansg. (Chroococcus) 3,5

turicensis Naeg. (Hypheothrix) I39, I4I 




\title{
LIST OF ILLUSTRATIONS
}

\author{
(Magnification: 500-700 diameters) \\ PLATE I.
}

Fig. I. Chroococcus macrococcus (Kuetż) Rab. (After Hassall)

Fig. 2. Chroococcus turicensis (Naeg.) Hansg. (After Hảnsgirg)

Fig. 3. Chroococcus turgidus (Kuetz.) Naeg. (After West)

Fig. 4. Chroococcus schizodermaticus West. (After W. and G. S. West)

Fig. 5. Chroococcus multicoloratus Wood. (After, Wood)

Fig. 6. Chroococcus refractus Wood. (After Wood)

Fig. 7. Chroococcus minor (Kuetz.) Naeg. (After W, and G. S. West)

Fig. 8. Chroococcus limneticus Lemm. (After Lemmermann)

Fig. 9. Chroococcus purpureus Snow. (After'Snow)

Fig. I0. Synechocystis aquatilis Sauv. (After Engler and Prantl)

Fig. II. Synechococcus aerüginosus Naeg. (After Engler and Prantl)

Fig. 12. Chroothece richterianá Hansg. (After Engler and Prantl)

Fig. I3. Gloeocapsa granosa (Berkeley) Kuetz. (After Hassall)

Fig. I4. Gloeocapsa polydermatica Kuetz. (After. West)

Fig. I5. Gloeocapsa fenestralis Kuetz. (After Kuetzing)

Fig. I6. Gloeocapsa arenaria (Hass.) Rab. (After Saunders)

Fig. 17. Gloeocapsa montana Kuetz. (After Kuetzing)

Fig. 18. Gloeocapsa quaternata (Bréb.) Kuetz. (Original)

Fig. 19. Gloeocapsa aeruginosa (Carm.) Kuetz. (After Cooke)

Fig. 20. Gloeocapsa gelatinosa Kuetz. (After Kuetzing)

Fig. 21. Gloeocapsa conglomerata Kuetz. (After Kuetzing)

Fig. 22. Gloeocapsa atrata (Turp.) Kuetz. (After Cooke)

Fig. 23. Gloeocapsa, muralis. Kuetz. (After Kuetzing)

Fig. 24. Gloeocapsa rupestris Kuetz. (After Cooke)

Fig. 25. Gloeocapsa sparsa. Wood. (After Wood)

Fig. 26, 27. Gloeocapsa gigas. W. and G. S. West. (After W. and G. S. West.t):

Fig. 28. Gloeocapsa crepidinum (Rab.) Thur. (After Bornet and Thuret)

Fig. 29. Gloeocapsa magma (Bréb.) Kuetz. (After Lemmermann)

Fig. 30. Gloeocapsa ralfsiana (Harv.) Kuetz. (After Cooke)

Fig. 3I. Gloeocapsa thermalis Lemm. (After Lemmermann)

Fig. 32. Gloeocapsa violacea (Corda) Rab. (Original)

Fig. 33. Entophysalis granulosa Kuetz. (After Engler and Prantl)

Fig. 34-36. Chondrocystis schauinslandii Lemm. (After Lemmermann)

PLATE II.

Fig. I, 2. Gloeothece linearis Naeg. (After W. and G. S. West)

Fig. 3. Gloeothece confluens Naeg. (After West).

Fig. 4. Gloeothece rupestris (Lyngb.) Born. (After Cooke)

Fig. 5. Gloeothece lunata W, and G. S. West. (After W. and G. S. West)

Fig. 6. Aphanocapsa elachista W. and G. S. West. (After W. and G. S. West)

Fig. 7. Aphanocapsa grevillei (Hass.) Rab. (After West)

Fig. 8, 9. Aphanocapsa rivularis (Carm.) Rab. (After Cooke).

Fig. 10, II. Aphanocapsa virescens (Hass.) Rab. (After Hansgirg)

Fig. 12. Aphanothece microscopica Naeg. (After West)

Fig. 13. Aphanothece castagnei (Bréb.) Rab. (After Engler and Prantl)

Fig. I4. Aphanothece naegelii Wartm. (Original)

Fig. I5. A phanothece stagnina (Spreng.) A. Br. (After Lemmermann)

Fig. I6. Aphanothece prasina A. Br. (Original) 
Fig. 17. Microcystis marginata (Menegh.) Kuẹtz. (After West)

Fig. 18. Microcystis flos-aquae (Witt.) Kirchn. (After Engler and Prantl)

Fig. 19. Microcystis labens (Menegh.) Kuetz. (After Lemmermann)

Fig. 20. Microcystis packardii (Farlow) Tilden. (Original)

Fig. 2I, 22. Clathrocystis aeruginosa (Kuetz.) Henfr. (After Engler and Prant1)

Fig. 23-28. Gomphosphaeria aponina Kuetz. (After West)

Fig. 29. Coelosphaerium kuetzingianum Naeg. (After West)

Fig. 3o. Coelosphaeriopsis halophila Lemm. (After Lemmermann)

Fig. 3I. Tetrapedium trigonum W. and G. S. West. (After W. and G. S. West)

Fig. 32. Merismopedium aerugineum Bréb. (After Kuetzing)

Fig. 33. Merismopedium elegans A. Br. (After West)

Fig. 34. Merismopedium novum Wood. (After Wood)

Fig. 35. Merismopedium glaucum (Ehr.) Naeg. (After West)

Fig. 36. Merismopedium convolutum Bréb. (After Hansgirg)

Fig. 37. Merismopedium tenuissimum Lemm. (After Lemmermann)

Fig. 38-40. Eucapsis alpina Clements and Shantz. (After Shantz)

Fig. 4I. Oncobyrsa cesatiana Rab. (After Lemmermann)

Fig. 42. Chlorogloea tuberculosa (Hansg.) Wille. (After Wille)

\section{PLATE III.}

Fig. I. Pleurocapsa caldaria (Tilden) Setchell. (Original)

Fig. 2, 3. Pleurocapsa fuliginosa Hauck. (After Hauck)

Fig. 4. Pleurocapsa amethystea Kolderup-Rosenvinge. (After Kolderup-Rosenvinge)

Fig. 5, 6. Xenococcus laysanensis Lemm. (After Lemmermann)

Fig. 7. Xenococcus schousboei Thur. (After Engler and Prantl)

Fig. 8. Xenococcus kerneri Hansg. (After Hansgirg)

Fig. 9-II. Hyella caespitosa Born. and Flah. (After Engler and Prantl)

Fig. I2. Hyella fontana Buber and Jadin. (After Lemmermann)

Fig. 13-I5. Dermocarpa prasina (Reinsch) Born, and Thur. (After Bornet and Thuret)

Fig. I6-I8. Dermocarpa (?) rosea (Reinsch) Batters. (After Reinsch)

Fig. 19-2r. Dermocarpa violacea Crouan. (After Crouan)

Fig. 22, 23. Dermocarpa fucicola Saunders. (After Saunders)

Fig. 24, 25. Dermocarpa smaragdina (Reinsch) Tilden. (After Reinsch)

Fig. 26, 27. Dermocarpa olivacea (Reinsch) Tilden. (After Reinsch)

Fig. 28. Dermocarpa leibleiniae (Reinsch) Born. var. pelagica Wille (After Wille)

Fig. 29-30. Chamaesiphon incrustans Grun. (After West)

Fig. 3I. Chamaesiphon curvatus Nordst. (After Nordstedt)

PLATE IV.

Fig. I. Oscillatoria prolifica (Grev.) Gom. (After Gomont)

Fig. 2. Oscillatoria agardhii Gom. (After Lemmermann)

Fig. 3. Oscillatoria princeps Vauch. (After Gomont)

Fig. 4. Oscillatoria proboscidea Gom. (After Gomont)

Fig. 5. Oscillatoria sancta Kuetz. (After Gomont)

Fig. 6. Oscillatoria limosa Ag. (After Gomont)

Fig. 7. Oscillatoria curviceps Ag. (After Gomont)

Fig. 8. Oscillatoria ornata Kuetz. (After Gomont)

Fig. 9. Oscillatoria anguina Bory. (After Gomont)

Fig. 10. Oscillatoria bonnemaisonii Crouan. (After Gomont)

Fig. II. Oscillatoria margaritifera Kuetz. (After Gomont)

Fig. I2. Oscillatoria nigro-viridis Thwaites. (After Gomont)

Fig. I3-15. Oscillatoria capitata W. West Jun. (After West)

Fig. I6. Oscillatoria corallinae Gom. (After Gomont)

Fig. 17-18. Oscillatoria tenuis Ag. (After Gomont)

Fig. 19, 20. Oscillatoria amphibia Ag. (After Gomont)

Fig. 2I. Oscillatoria minnesotensis Tilden. (Original)

Fig. 22. Oscillatoria chlorina Kuetz. (After Wood) 
Fig. 23-25. Oscillatoria splendida Grev. (After Lemmermann, Setchell and Gardner)

Fig. 26. Oscillatoria amoena (Kuetz.) Gom. (After Gomont)

Fig. 27. Oscillatoria subuliformis Kuetz, (After Gomont)

Fig. 28. Oscillatoria laetevirens Crouan. (After Gomont)

Fig. 29. Oscillatoria acuminata Gom. (After Gomont)

Fig. 30. Oscillatoria animalis Ag. (After Gromont)

Fig. 31. Oscillatoria violacea (Wallr.) Hass.

Fig. 32. Oscillatoria brevis Kuetz. (After Gomont)

Fig. 33. Oscillatoria formosa Bory. (After Gomont)

Fig. 34. Oscillatoria cortiana Menegh. (After Gomont)

Fig. 35. Oscillatoria okeni Ag. (After Gomont)

Fig. 36. Oscillatoria chalybea Mert. (After Gomont)

Fig. 37, 38. Oscillatoria boryana Bory. (After Gomont)

Fig. 39. Oscillatoria terebriformis Ag. (After Gomont)

Fig. 40. Trichodesmium erythraeum Ehr. (After Gomont)

Fig. 4I, 42. Trichodesmium thiebautii Gom. (After Gomont)

Fig. 43. Trichodesmium contortum Wille. (After Wille)

Fig. 44. Arthrospira jenneri (Kuetz.) Stiz. (After Gomont)

Fig. 45. Spirulina meneghiniana Zan. (After Gomont)

Fig. 46. Spirulina major Kuetz. (After Gomont)

Fig. 47. Spirulina subtilissima Kuetz. (After Gomont)

Fig. 48. Spirulina caldaria Tilden. (Original)

Fig. 49. Spirulina subsalsa Oerst. (After Gomont)

Fig. 50, 5I. Spirulina duplex Wolle. (After Wolle)

Fig. 52, 53. Phormidium fragile (Menegh.) Gon. (After Gomont)

Fig. 54. Phormidium ' foveolarum (Mont.) Gom. (After Gomont)

Fig. 55. Phormidium tinctorium Kuetz. (After Gomont)

Fig. 56, 57. Phormidium luridum (Kuetz.) Gom. (After Gomont)

Fig. 58. Phormidium rubrum Tilden. (Original)

Fig. 59. Phormidium purpurascens (Kuetz.) Gom. (After Gomont)

Fig. 60, 6r. Phormidium crosbyanum Tilden. (Original)

Fig. 62. Phormidium laminosum (Ag.) Gom. (After Gomont)

Fig. 63-65. Phormidium tenue (Menegh.) Grom. (After Gomont)

Fig. 66. Phormidium valderianum (Delp.) Gom. (After Gomont)

Fig. 67. Phormidium subuliforme Gom. (After Gomont)

Fig. 68. Phormidium incrustatum (Naeg.) Gom. (After Gomont)

Fig. 69, 70. Phormidium inundatum Kuetz. (After Gomont)

Fig. 71, 72. Phormidium corium (Ag.) Gom. (After Gomont)

Fig. 73, 74. Phormidium papyraceum (Ag.) Gom. (After Gomont)

Fig. 75, Phormidium interruptum Knetz. (After Wolle)

Fig. 76. Phormidium naveanum Grun. (After Wolle)

PLATE V.

Fig. I-4. Phormidium retzii (Ag.) Gom. (After Gomont)

Fig. 5. Phormidium ambiguum Gom. (After Gomont)

Fig. 6. Phormidium submembranaceum (Ar. and Straff.) Gom. (After Gomont)

Fig. 7, 8. Phormidium laysanense Lemm. (After Lemmermann)

Fig. 9, Io. Phormidium favosum (Bory) Gom. (After Gomont)

Fig. Ir. Phormidium calidum Gom. (After Gomont)

Fig. 12-15. Phormidium subfuscum Kuetz. (After Engler and Prantl)

Fig. 16, I7. Phormidium uncinatum (Ag.) Gom. (After Gomont)

Fig. 18, 19. Phormidium autumnale (Ag.) Gom. (After Gomont)

Fig. 20, 21. Phormidium setchellianum Gomont. (After Gomont)

Fig. 22, 23. Lyngbya lagerheimii (Möb.) Gom. (After Gomont)

Fig. 24. Lyngbya nana Tilden. (Original)

Fig. 25, 26. Lyngbya ochracea (Kuetz.) Thur. (After Bornet)

Fig. 27-29. Lyngbya ferruginea G. S. West. (After West)

Fig. 30, 3I. Lyngbya lutea (Ag.) Gom. (After Gomont)

Fig. 32, 33. Lyngbya aerugineo-caerulea (Kuetz.) Gom. (After Gomont)

Fig. 34. Lyngbya cladophorae Tilden. (Original) 
Fig. 35. Lyngbya versicolor (Wartm.) Gom. (After Gomont)

Fig. 36. Lyngbya gracilis (Menegh.) Rab. (After Gomont)

Fig. 37. Lyngbya sordida (Zan.) Gom. (After Gomont)

Fig. 38. Lyngbya semiplena (C. Ag.) J. Ag. (After Gomont)

Fig. 39. Lyngbya confervoides C. Ag. (After Gomont)

Fig. 40, 4I. Lyngbya aestuarii (Mert.) Liebm. (After Gomont)

Fig. 42. Lyngbya majuscula (Dillw.) Harv. (After Gomont)

Fig. 43. Lyngbya martensiana Menegh. (After Gomont)

Fig. 44. Lyngbya martensiana var. calcarea Tilden. (Original)

Fig. 45. Lyngbya putealis Mont. (After Gomont)

Fig. 46. Lyngbya major Menegh. (After Gomont)

Fig. 47. Lyngbya spirulinoides Gom. (After Gomont)

Fig. 48. Symploca atlantica Gom. (After Gomont)

Fig. 49. Symploca hydnoides Kuetz. (After Gomont)

Fig. 50. Symploca laete-viridis Gom. (After Gomont)

Fig. 5I. Symploca thermalis (Kuetz.) Gom. (After Gomont)

Fig. 52. Symploca dubia (Naeg.) Gom. (After Kuetzing)

Fig. 53. Symploca muralis Kuetz. (After Gomont)

Fig. 54. Symploca muscorum (Ag.) Gom. (After Gomont)

Fig. 55. Porphyrosiphon notarisii (Menegh.) Kuetz. (After Gomont)

Fig. 56. Hydrocoleus comoides (Harv.) Gom. (After Gomont)

Fig. 57. Hydrocoleus cantharidosmus (Mont.) Gom. (After Gomont)

Fig. 58. Hydrocoleus lyngbyaceus Kuetz. (After Gomont)

Fig. 59. Hydrocoleus glutinosus (Ag.) Gom. (After Kuetzing)

Fig. 60, 6I. Hydrocoleus holdenii Tilden. (After Holden)

Fig. 62, 63. Hydrocoleus homoeotrichus Kuetz. (After Gomont)

Fig. 64, 65. Hydrocoleus ravenelii Wolle. (After Wolle)

Fig. 66. Hydrocoleus heterotrichus Kuetz. (After Gomont)

\section{PLATE VI.}

Fig. I. Hypheothrix calcicola (Ag.) Rab. (After Gomont)

Fig. 2. Hypheothrix coriacea Kuetz. (After Gomont)

Fig. 3. Hypheothrix lardacea (Ces.) Hansg. (After Gomont)

Fig. 4. Hypheothrix arenaria (Berk.) De Toni. (After Gomont)

Fig. 5. Symplocastrum fragile (Kuetz.) De Toni. (After Gomont)

Fig. 6. Symplocastrum rubrum (Menegh.) De Toni. (After Gomont)

Fig. 7-9. Symplocastrum cuspidatum (West and. West) De Toni. (After W. and G. S. West)

Fig. Io. Symplocastrum friesii (Ag.) Kirchn. (After Gomont)

Fig. II-I3. Inactis pulvinata Kuetz. (After Kuetzing)

Fig. I4, I5..Inactis fasciculata (Naeg.) Grun. (After Gomont)

Fig. I6. Inactis lacustris (A. Br.) De Toni. (After Gomont)

Fig. I7. Inactis tinctoria (Ag.) Thur. (After Gomont)

Fig. I8. Inactis hawaiensis (Lemm.) De Toni. (After Lemmermann)

Fig. I9. Schizothrix thelephoroides (Mont.) Gom. (After Gomont)

Fig. 20, 2I. Schizothrix purpurascens (Kuetz.) Gom. (After Gomont)

Fig. 22. Schizothrix chalybea (Kuetz.) Gom. (After Gomont)

Fig. 23. Schizothrix muelleri Naeg. (After Gomont)

Fig. 24. Schizothrix braunii Gom. (After Gomont)

Fig. 25. Schizothrix rupicola Tilden. (Original)

Fig. 26. Dasygloea amorpha Berk. (After Gomont)

Fig. 27. Microcoleus tenerrimus Gom. (After Gomont)

Fig. 28. Microcoleus chthonoplastes (Fl. Dan.) Thur. (After Gomont)

Fig. 29. Microcoleus vaginatus (Vauch.) Gom. (After Gomont)

Fig. 30. Microcoleus paludosus (Kuetz.) Gom. (After Gomont)

Fig. 31. Microcoleus pulvinatus Wolle (After Wolle)

Fig. 32. Microcoleus subtorulosus (Kuetz.) Gom. (After Gomont)

Fig. 33. Catagnymene pelagica Lemm. (After Wille)

Fig. 34. Catagnymene spiralis Lemm. (After Wille)

Fig. 35-37. Nostoc punctiforme (Kuetz.) Hariot (After Sauvageau)

Fig. 38. Nostoc paludosum Kuetz. (After Janczewski) 


\section{PLATE VII.}

Fig. 1. Nostoc linckia (Roth) Born. (After Bornet and Thuret)

Fig. 2. Nostoc piscinale Kuetz. (After Cooke)

Fig. 3. Nostoc carneum Ag. (After Lemmermann)

Fig. 4, 5. Nostoc spongiaeforme Ag. (After Cooke)

Fig. 6-Io. Nostoc ellipsosporum (Desm.) Rab. (After Bornet and Thuret)

Fig. II. Nostoc gelatinosum Schousb. (Original)

Fig. 12-r4. Nostoc muscorum Ag. (After Bornet and Thuret)

Fig. I5. Nostoc humifusum Carm. (After Cooke)

Fig. I6. Nostoc foliaceum Moug. (Original)

\section{PLATE VIII.}

Fig. I. Nostoc commune Vauch. (After Hansgirg)

Fig. 2. Nostoc sphaericum Vauch. (After Cooke)

Fig. 3. Nostoc calidarium Wood. (After Wood)

Fig. 4. Nostoc macrosporum Menegh. (After Cooke)

Fig. 5. Nostoc microscopicum Carm. (After Cooke)

Fig. 6, 7. Nostoc glomeratum Kuetz. (After Kuetzing)

Fig. 8. Nostoc caeruleum Lyngbye (Original)

Fig. 9, ro. Nostoc pruniforme (Linn.) Ag. ((After Cooke)

Fig. I I-I6. Nostoc verrucosum (Linn.) Vauch. (After Thuret)

Fig. I7-I9. Nostoc amplissimum Setch. (After Setchell)

Fig. 20. Nostoc parmelioides Kuetz. (After Gomont)

Fig. 2I, 22. Wollea saccata (Wolle) Born. and Flah. (After Engler and Prantl)

\section{PLATE IX.}

Fig. I, 2. Nodularia harveyana (Thwaites) Thur. (After Bornet and Thuret)

Fig. 3. Nodularia sphaerocarpa Born. and Flah. (After West)

Fig. 4. Nodularia paludosa Wolle. (After Wolle)

Fig. 5. Nodularia hawaiiensis Tilden. (Original)

Fig. 6. Nodularia armorica Thur. (After Bornet and Thuret)

Fig. 7, 8. Nodularia spumigena var. litorea (Kuetz.) Born. and Flah. (After Bornet and Thuret)

Fig. 9. Anabaena variabilis Kuetz. (After Hansgirg)

Fig. Io-I3. Anabaena hallẹnsis (Jancz.) Born. and Flah. (After Janczewski)

Fig. I4. Anabaena flos-aquae (Lyngb.) Bréb. (After Engler and Prantl)

Fig. I5. Anabaena circinalis Rab. (After Hansgirg)

Fig. 16. Anabaena inaequalis (Kuetz.) Born. and Flah. (After West)

Fig. 17. Anabaena catenula (Kuetz.) Born, and Flah. (Original)

Fig. I8. Anabaena laxa (Rab.) A. Br. (After Bornet and Flahault)

Fig. I9. Anabaena torulosa (Carm.) Lag. (After Cooke)

Fig. 20. Anabaena oscillarioides Bory. (After Hansgirg)

Fig. 2I. Anabaena confervoides Reinsch. (Original)

Fig. 22. Anabaena cupressớphila Wolle. (Âfter Wolle)

\section{PLATE $X$.}

Fig. I. Aphanizomenon flos-aquae (Linn.) Ralfs. (After Engler and

Fig. 2. Cylindrospermum stagnale (Kuetz.) Born. and Flah. (After

Fig. 3. Cylindrospermum comatum Wood. (After Wood)

Fig. 4. Cylindrospermum majus Kuetz. (After Gomont)

Fig. 5. Cylindrospermum minutum Wood. (After Wolle)

Fig. 6. Cylindrospermum muscicola Kuetz. (After Kuetzing)

Fig. 7. Cylindrospermum catenatum Ralfs. (Original)

Fig. 8. Richelia intracellularis J. Schm. (After Lemmermann)

Fig. 9. Aulosira schauinslandii Lemm. (Áfter Lemmermann) 
Fig. Io. Microchaete tenuissima W. and G. S. West. (After W. and G. S. West)

Fig. II. Microchaete tenera Thur. (After Bornet and Thuret)

Fig. I2. Microchaete grisea Thur. (After Bornet and Thuret)

Fig. 13. Hormothamnion enteromorphoides Grun. (After Engler and Prantl)

\section{PLATE XI.}

Fig. I, 2. Plectonema tenue Thur. (After Gomont)

Fig. 3. Plectonema tomasinianum (Kuetz.) Born. (After Bornet and Thuret)

Fig. 4, 5. Plectonema wollei Fart. (After Gomont)

Fig. 6. Plectonema terebrans Born. and Flah. (After Bornet and Flahault)

Fig. 7. Plectonema nostocorum Born. (After Gomont)

Fig. 8. Plectonema roseolum (Richter) Gom. (After Gomont)

Fig. 9. Plectonema golenkinianum Gom. (After Gomont)

Fig. Io. Plectonema calotrichoides Gom. (After Gomont)

Fig. I1, 12. Scytonema rivulare Borzi. (Original)

Fig. I3, I4. Scytonema occidentale Setchell. (After Setchell)

Fig. 15. Scytonema crispum (Ag.) Born. (Original)

PLATE XII.

Fig. I. Scytonema caldarium Setch. (After Setchell)

Fig. 2, 3. Scytonema azureum Tilden. (Original)

Fig. 4. Scytonema hofmanni Ag. (After Engler and Prantl)

Fig. 5. Scytonema varium (Kuetz.) (After Kuetzing)

Fig. 6. Scytonema javanicum (Kuetz.) Born. (After W. and G. S. West)

Fig. 7. Scytonema javanicum var, hawaiiense Lemmermann (After Lemmermann)

Fig. 8. Scytonema ocellatum Lyngb. (After Wolle)

Fig. 9. Scytonema intertextum (Kuetz.) Rab. (After Wolle)

Fig. IO, II. Scytonema amplum W. and G. S. West. (After W. and G. S. West)

Fig. I2. Scytonema wolleanum De Toni. (After Wolle)

Fig. I3, I4. Scytonema stuposum (Kuetz.) Born. (After Kuetzing)

\section{PLATE XIII.}

Fig. I. Scytonema tolypotrichoides Kuetz. (After Wood)

Fig. 2-5. Scytonema mirabile (Dillw.) Born. (After West)

Fig. 6. Scytonema myochroum (Dillw.) Ag. (After Bornet and Thuret)

Fig. 7, 8. Scytonema fuliginosum Tilden. (Original)

Fig. 9. Scytonema alatum (Carm.) Borzi. (After Hone)

Fig. 10-I2. Scytonema crustaceum Ag. (After Kuetzing)

Fig. I3. Scytonema densum (A. Br.) Born. (After Kuetzing)

Fig. I4. Symphyosiphon bornetianum Wolle. (After Wolle)

Fig. I5. Scytonema hirtulum (Kuetz.) Rab. (After Wolle)

\section{PLATE XIV.}

Fig. I. Tolypothrix lanata (Desv.) Wartm. (After West)

Fig. 2-4. Tolypothrix distorta (Hofman-Bang) Kuetz. (Original)

Fig. 5. Tolypothrix penicillata (Ag.) Thur. (After Engler and Prantl)

Fig. 6. Tolypothrix byssoidea (Hass.) Kirchn. (After Cooke)

Fig. 7. Tolypothrix ravenelii Wolle. (After Wolle)

Fig. 8. Tolypothrix setchellii Collins. (After Collins)

Fig. 9. Tolypothrix rupestris Wolle. (After Wolle)

Fig. Io. Desmonema wrangellii (Ag.) Born. and Flah. (After Engler and Pranti)

Fig. II. Diplocolon heppii Naeg. (After Engler and Prantl)

Fig. I2. Mastigocolets testarum Lag. (After Engler and Prantl) 
Fig. I3. Hapalosiphon fontinalis (Ag.) Born. (After Lemmermann)

Fig. 14, 15. Hapalosiphon laminosus (Kuetz.) Hansh. (After Buscalioni)

\section{PLATE XV.}

Fig. I-4. Hapalosiphon major Tilden. (Original)

Fig. 5. Hapalosiphon intricatus W. and G. S. West. (After W. and G.

Fig. 6, 7. Hapalosiphon arboreus W. and G. S. West. (After W. and G. S. West)

Fig. 8, 9. Fischerella ambigua. (Naeg.) Gom. (After W. and G. S. West)

Fig. I0, II. Fischerella thermalis (Schabe) Gom. (After Lemmermann)

Fig. I2. Fischerella thermalis var. mucosa Lemm. (After Lemmermann)

Fig. 13. Stigonema hormoides (Kuetz.) Born. and Flah. (After W. and G. S. West)

Fig. 14. Stigonema aerugineum Tilden, (Original)

Fig. I5-17. Stigonema ocellatum (Dillw.) Thur. (After West)

Fig. I8, I9. Stigonema minutum (Ag:) Hass. (After West)

Fig. 20. Stigonema turfaceum (Berk.) Cooke. (After Engler and Prantl)

Fig. 2I. Stigonema informe Kuetz. (After Kuetzing)

Fig. 22. Stigonema mamillosum (Lyngb.) Ag. (After Gomont)

\section{PLATE XVI.}

Fig. I. Capsosira brebissonii Kuetz. (After Engler and Prantl)

Fig. 2. Nostochopsis lobatus Wood. (After Engler and Prantl)

Fig. 3. Amphithrix janthina (Mont.) Born. and Flah. (After Engler and Prantl)

Fig. 4. Amphithrix violacea (Kuetz.) Born. and Flah. (After Kuetzing)

Fig. 5. Calothrix juliana (Menegh.) Born. and Flah. (After Kuetzing)

Fig. 6-8. Calothrix confervicola (Roth) Ag. (After Bornet and Thuret)

Fig. 9. Calothrix consociata (Kuetz.) Born. and Flah. (After Kuetzing)

Fig. Io. Calothrix fusco-violacea Crouan. (After Crouan)

Fig. II, I2. Calothrix scopulorum (Web. and Mohr) Ag. (After Bornet and Thuret)

Fig. I3. Calothrix contarenii (Zan.) Born. and Flah. (After Kuetzing)

Fig. I4. Calothrix pulvinata (Mert.) Ag. (After Bornet and Thuret)

Fig. I5, I6. Calothrix parasitica (Chauv.) Thur. (After Bornet and Thuret)

\section{PLATE XVII.}

Fig. I. Calothrix aeruginea (Kuetz.) Thur. (After Bornet and Thuret)

Fig. 2-6. Calothrix crustacea Thur. (After Bornet and Thuret)

Fig. 7. Calothrix scytonemicola Tilden. (Original)

Fig. 8, 9. Calothrix stagnalis Gom. (After Lemmermann)

Fig. Io, Ir. Calothrix fusca (Kuetz.) Born. and Flah. (After Teodoresco)

Fig. I2. Calothrix sandvicensis (Nordst.) Schmid. (After Schmidle)

Fig. 13, 14. Calothrix adscendens (Naeg.) Born. and Flah. (After Teodoresco)

\section{PLATE XVIII.}

Fig. 1-5. Calothrix thermalis (Schwabe) Hansg. (Original)

Fig. 6, 7. Calothrix calida P. Richter. (After Richter)

Fig. 8-10. Calothrix kuntzei P. Richter. (After Richter)

Fig. II. Calothrix braunii Born. and Flah. (After Lemmermann)

Fig. 12. Calothrix parietina (Naeg.) Thur. (After West)

Fig. 13. Calothrix lacucola Wolle. (After Wolle)

Fig. I4. Schizosiphon obscurus Dickie. (After Dickie)

Fig. I 5. Mastigonema paradoxum Kuetz. (After Kuetzing)

Fig. I6. Dichothrix orsiniana (Kuetz.) Born. and Flah. (After West)

Fig. 17. Dichothrix calcarea Tilden. (Original)

Fig. I8. Dichothrix baueriana (Grun.) Born. and Flah. (After Lemmermann) 
PLATE XIX.

Fig. I. Dichothrix meneghiniana (Kuetz.) De Toni. (After Wolle)

Fig. 2. Dichothrix gypsophila (Kuetz.) Born. and Flah. (After Engler and Prant1)

Fig. 3. Dichothrix hosfordii (Wolle) Bornet. (After Wolle)

Fig. 4. Sacconema rupestre Borzi. (After Engler and Prantl)

Fig. 5. Isactis plana (Harv.) Thur. (After Bornet and Thuret)

Fig. 6. Rivularia pisum Ag. (After Cooke)

Fig. 7. Rivularia natans (Hedw.) Welw. (After Teodoresco)

PLATE XX.

Fig. I-3, Rivularia natans (Hedw.) Welw. (Original)

Fig. 4. Rivularia echinulata (Smith) Born, and Flah. (After Lemmermann)

Fig. 5, 6. Rivularia polyotis (Ag.) Bornet and,Flah. (After Bornet and Thuret)

Fig. 7-8. Rivularia borealis P. Richter. (After Richter)

Fig. 9. Rivularia minutula (Kuetz.) Born, and Flah. (After West)

Fig. Io. Rivularia atra Roth. (After Wille)

Fig. II-I4. Rivularia haematites (DC) Ag. (Original)

Fig. I5. Rivularia dura Roth. (After Cooke)

Fig. I6, I7. Rivularia coadunata (Sommerf.) Foslie. (After West)

Fig. 18. Brachytrichia quoyi (Ag.) Born, and Flah. (After Gomont)

Fig. 19, 20. Asterothrix creginii Wolle. (After Wolle)

Fig. 2I. Asterocytis ramosa (Thwaites) Gobi. (After Wille)

Fig. 22. Glaucocystis nostochinearum Itzig. "(After Lagerheim)

Fig. 23. Porphyridium cruentum. (Ag.) Naeg. (After Cooke)

Fig. 24, 25. Cryptoglena americana Davis, (After Davis) 



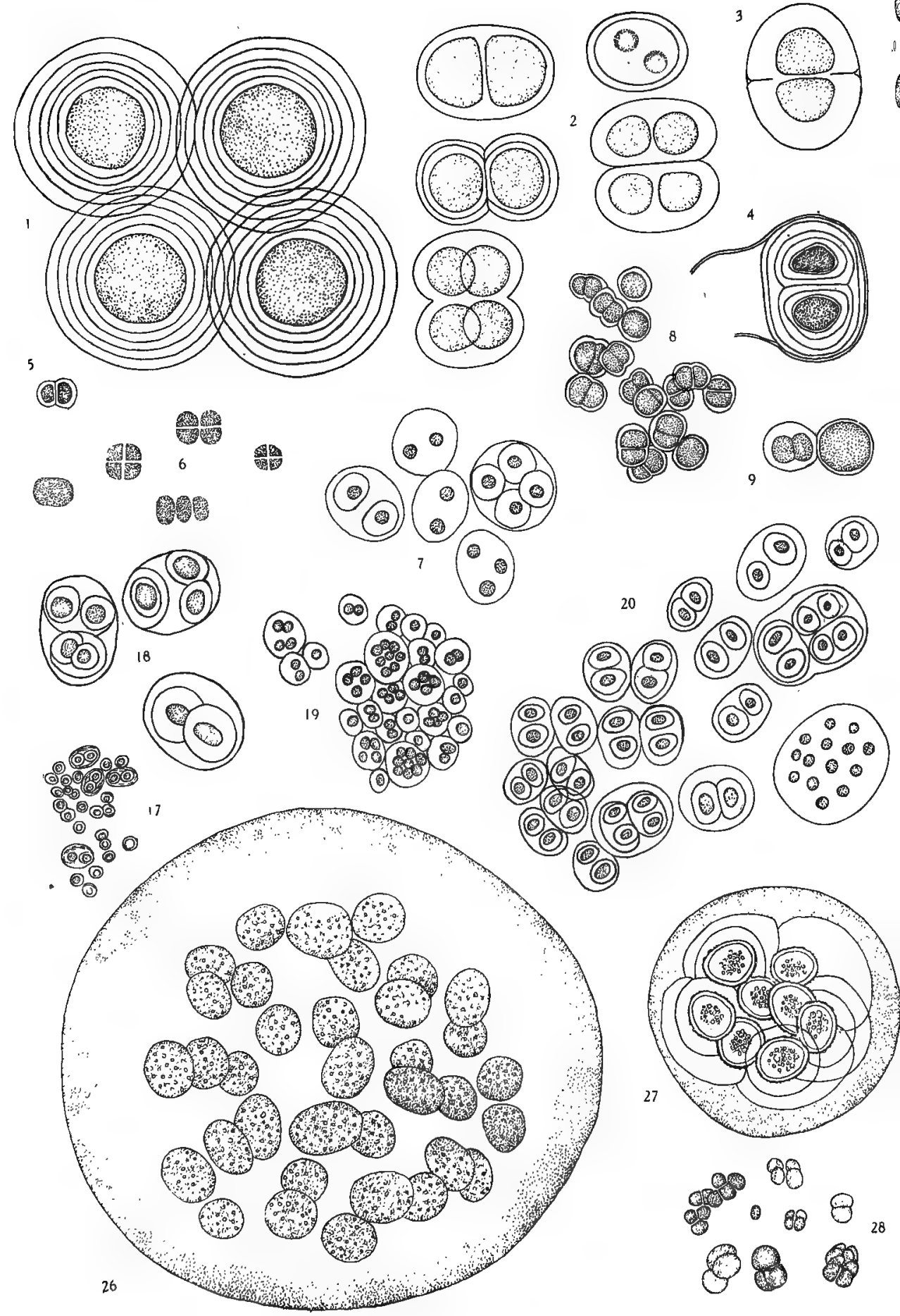


108

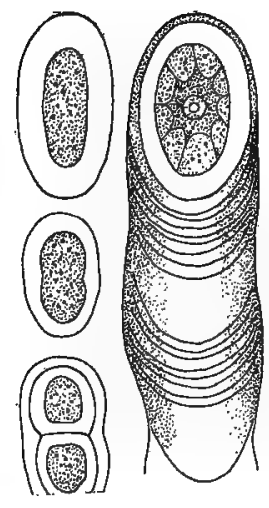

12
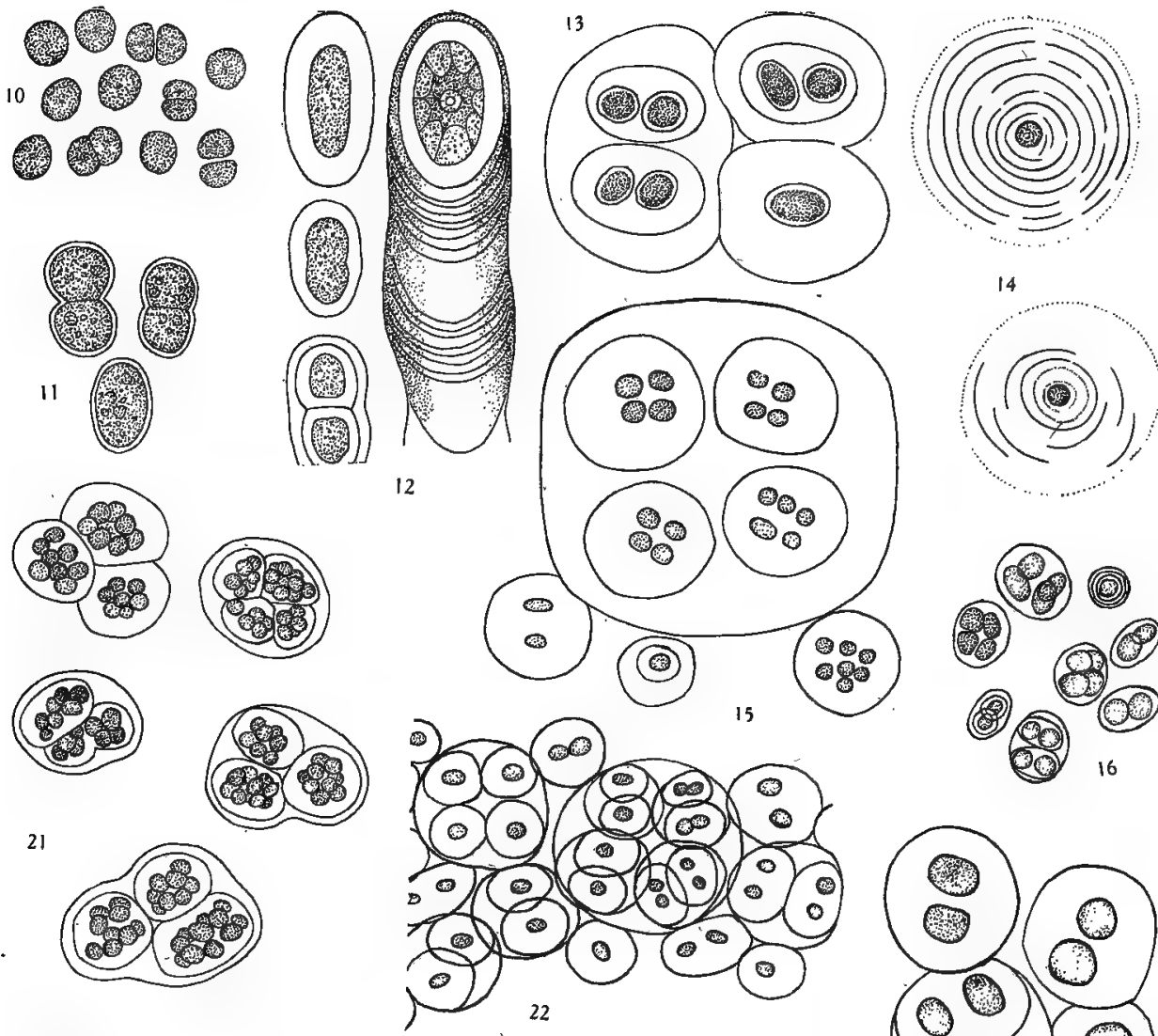

2
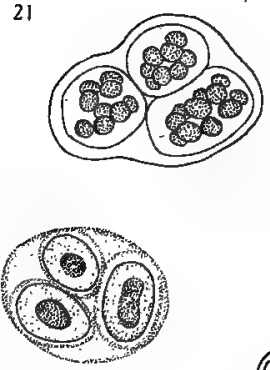

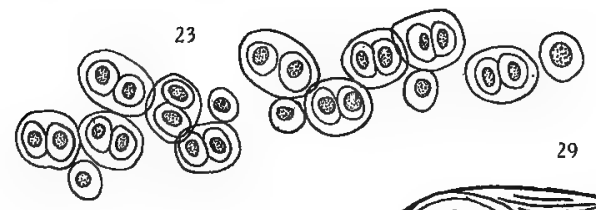

(6)

25

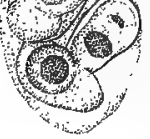

(2) (80) Am, 3.7.

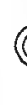
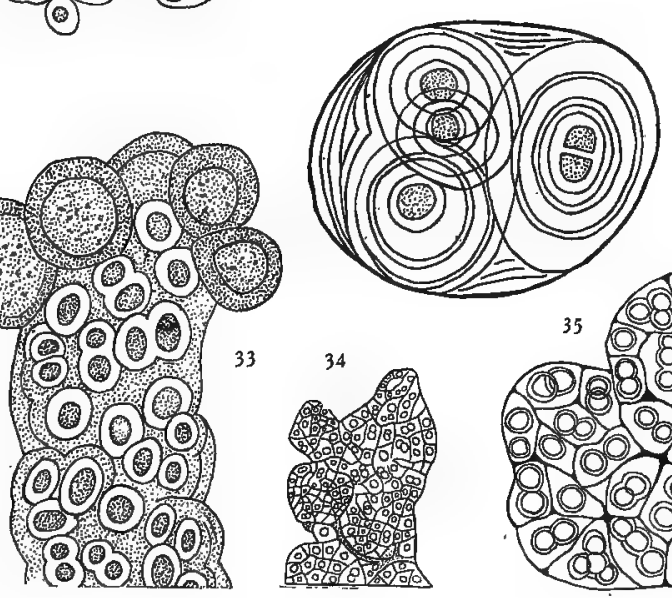

35 (0) (O) 8010

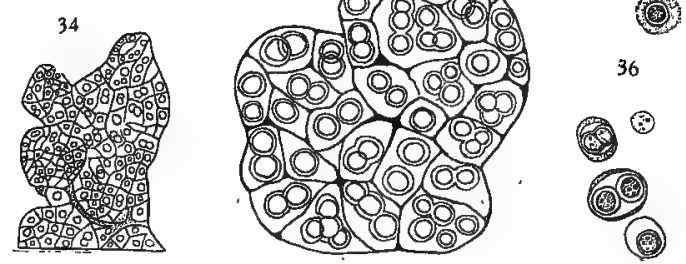

1680

(4)

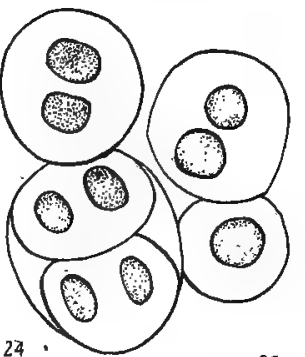
(2) (웅ㅇㅇ (6) (00) (6) (0)(ㅇ) (3) (3) 




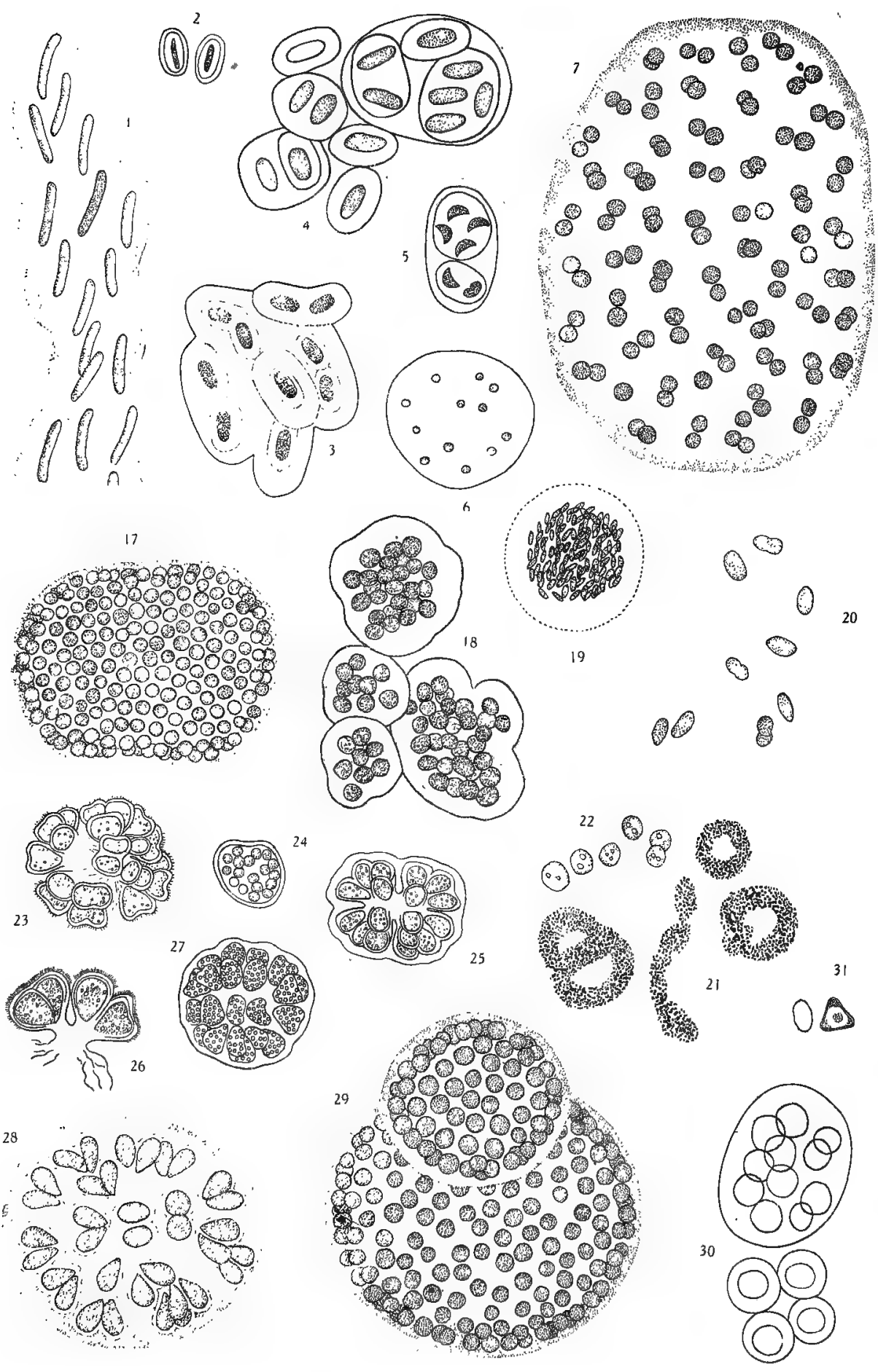



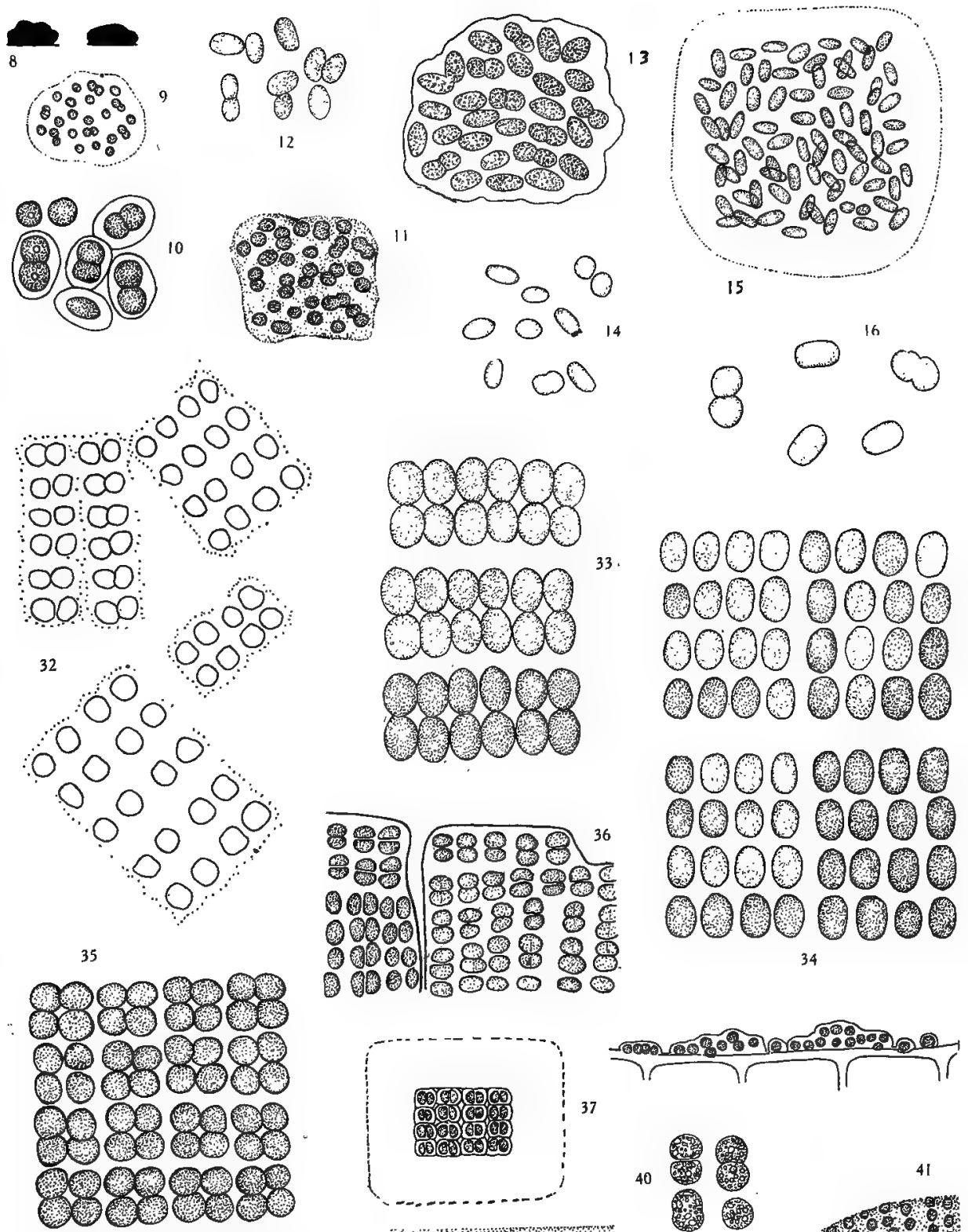

10000010 30000 0000098 020140 0800808 00 8009

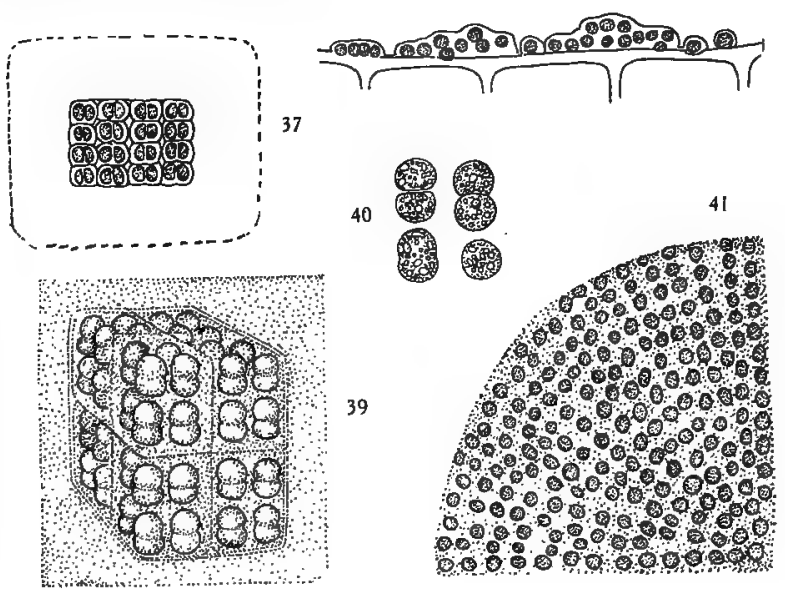






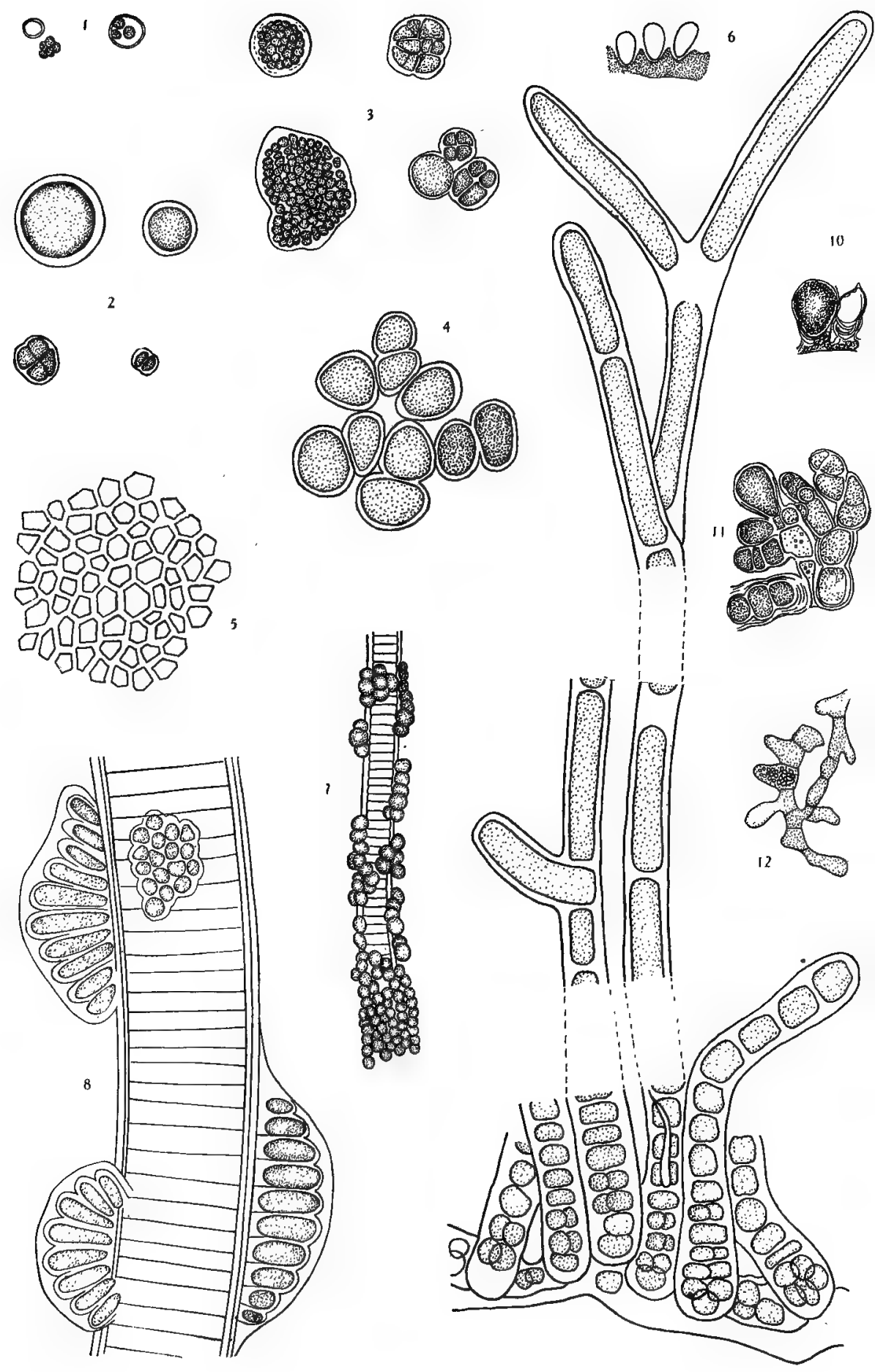



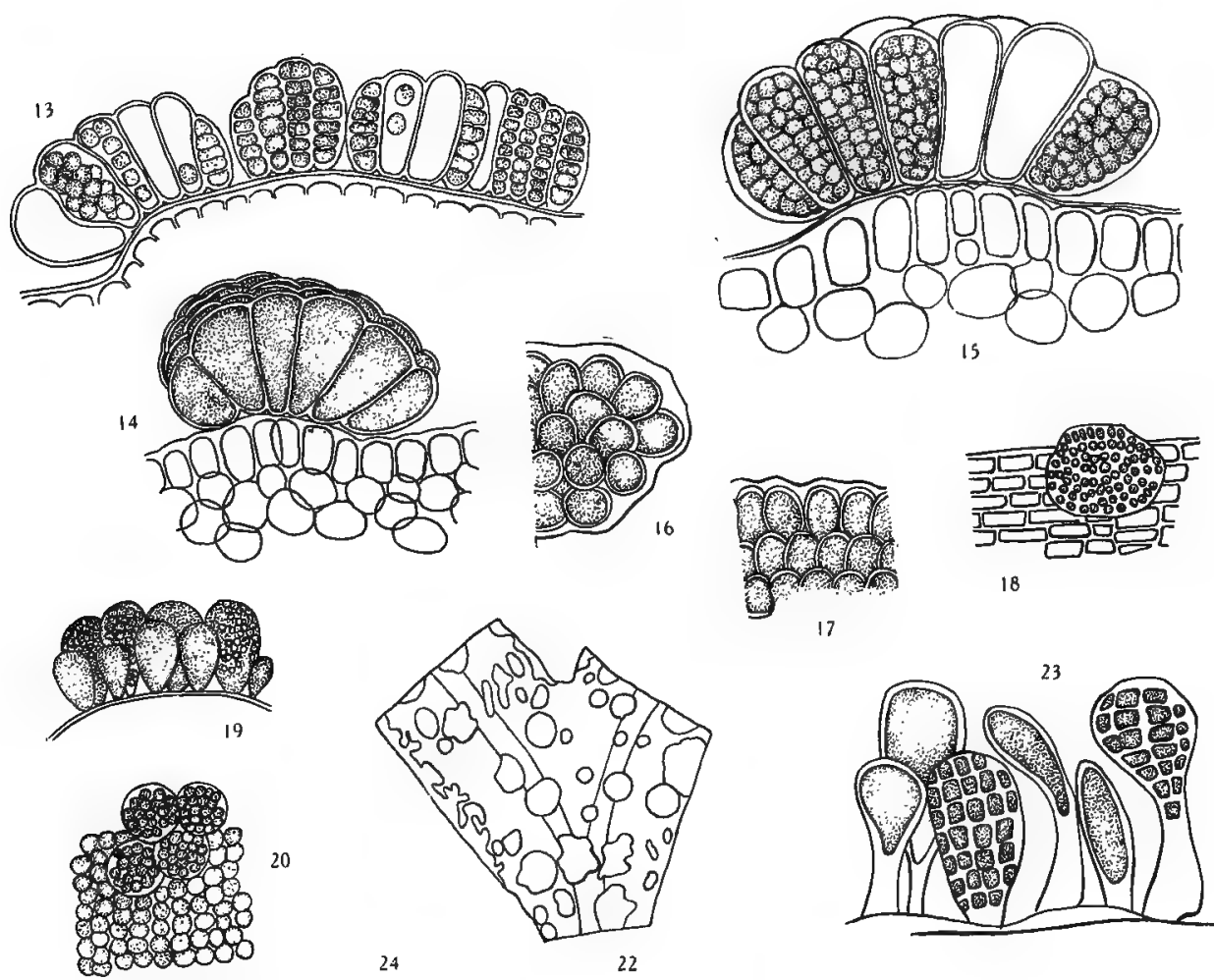

17
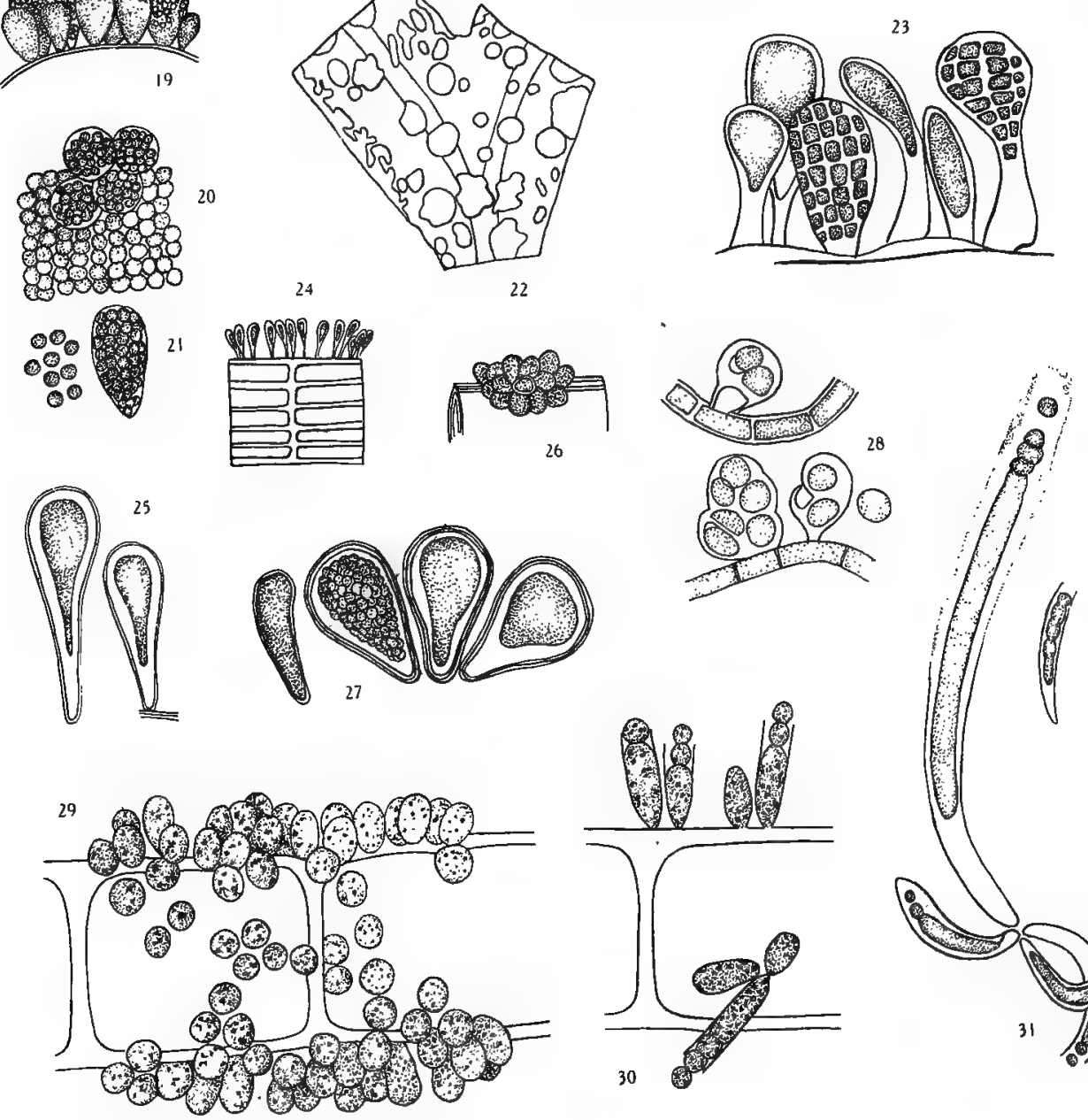



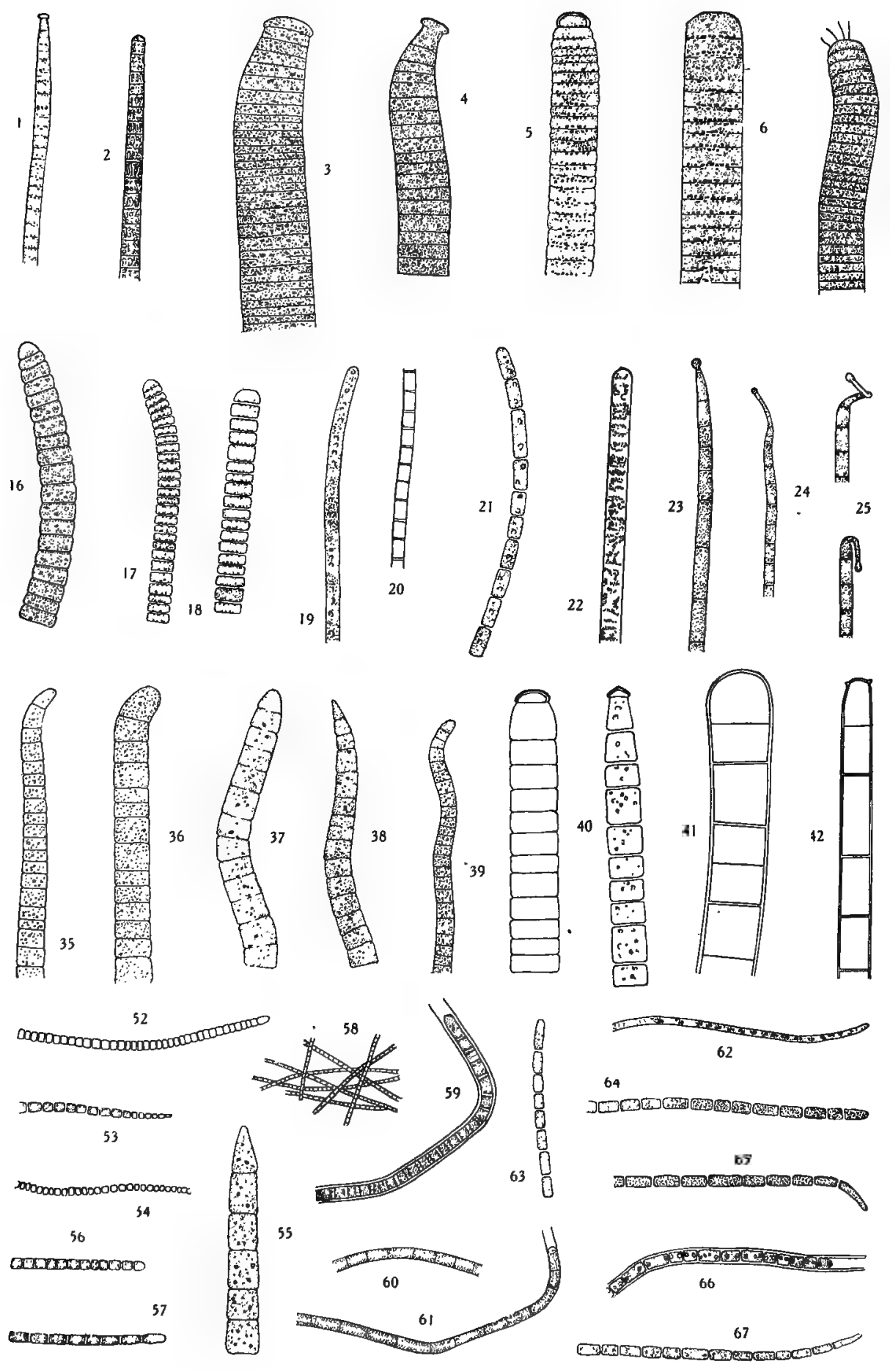

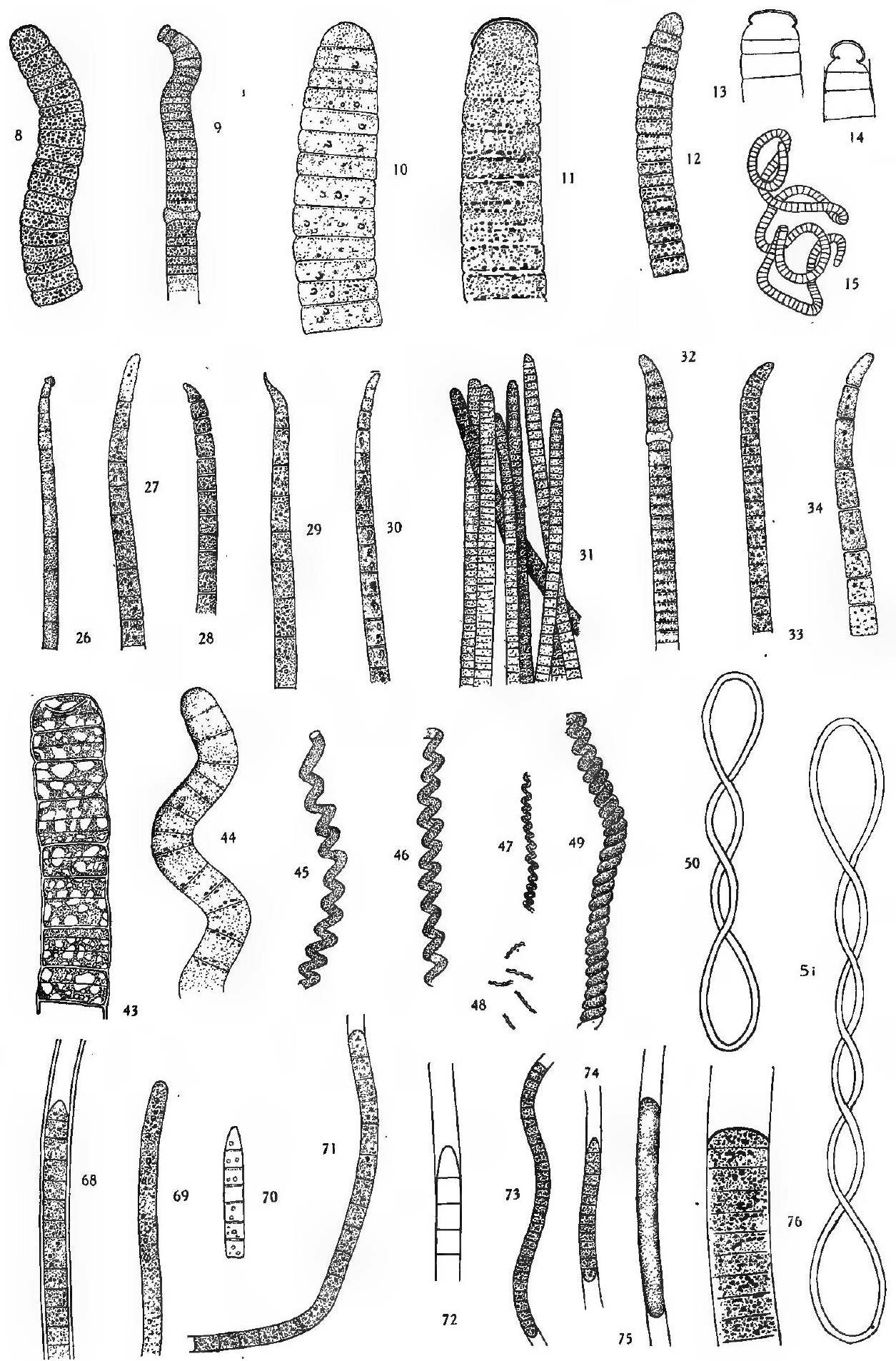




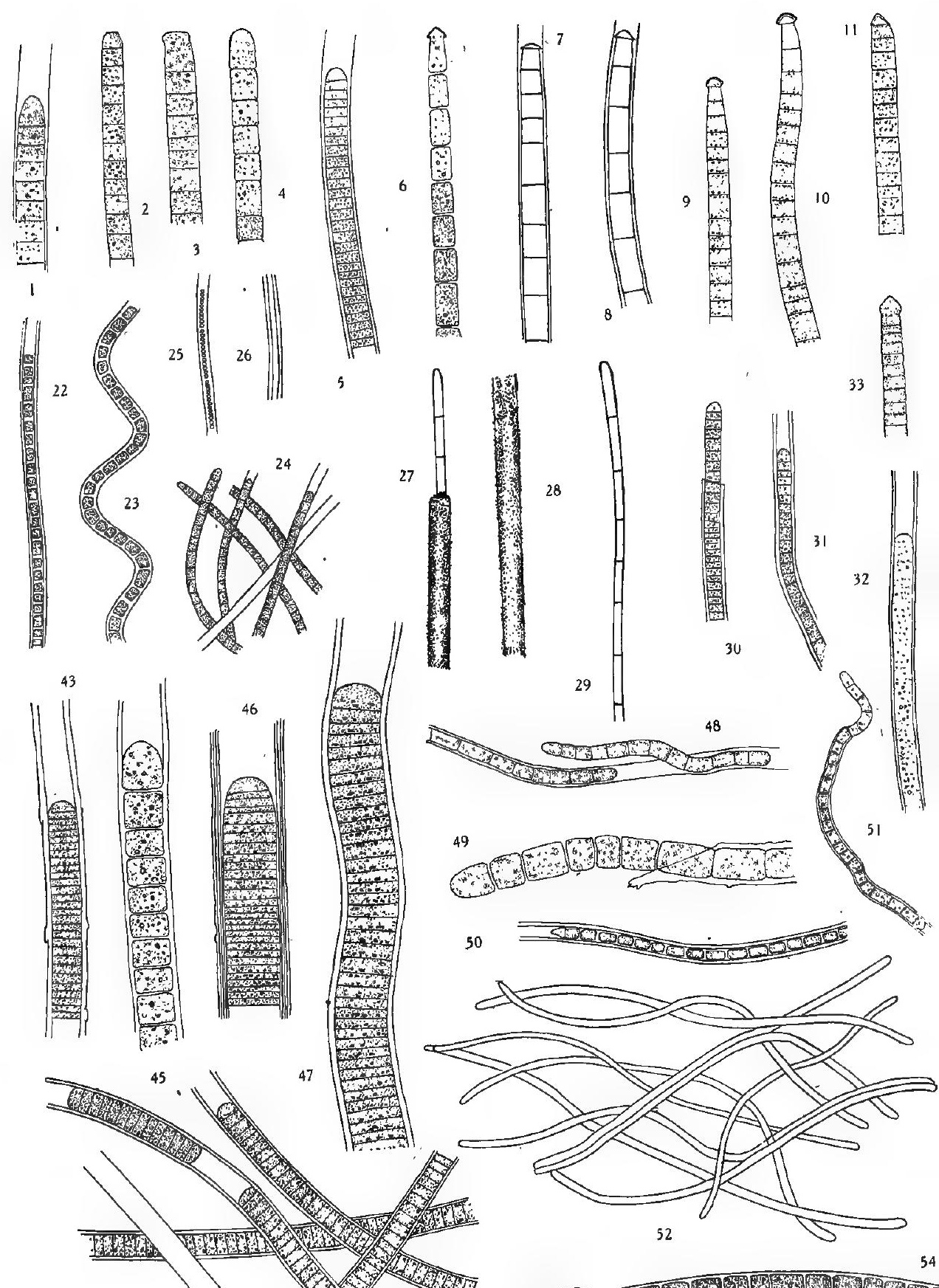

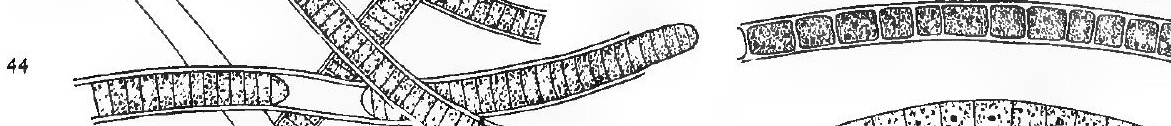
1 


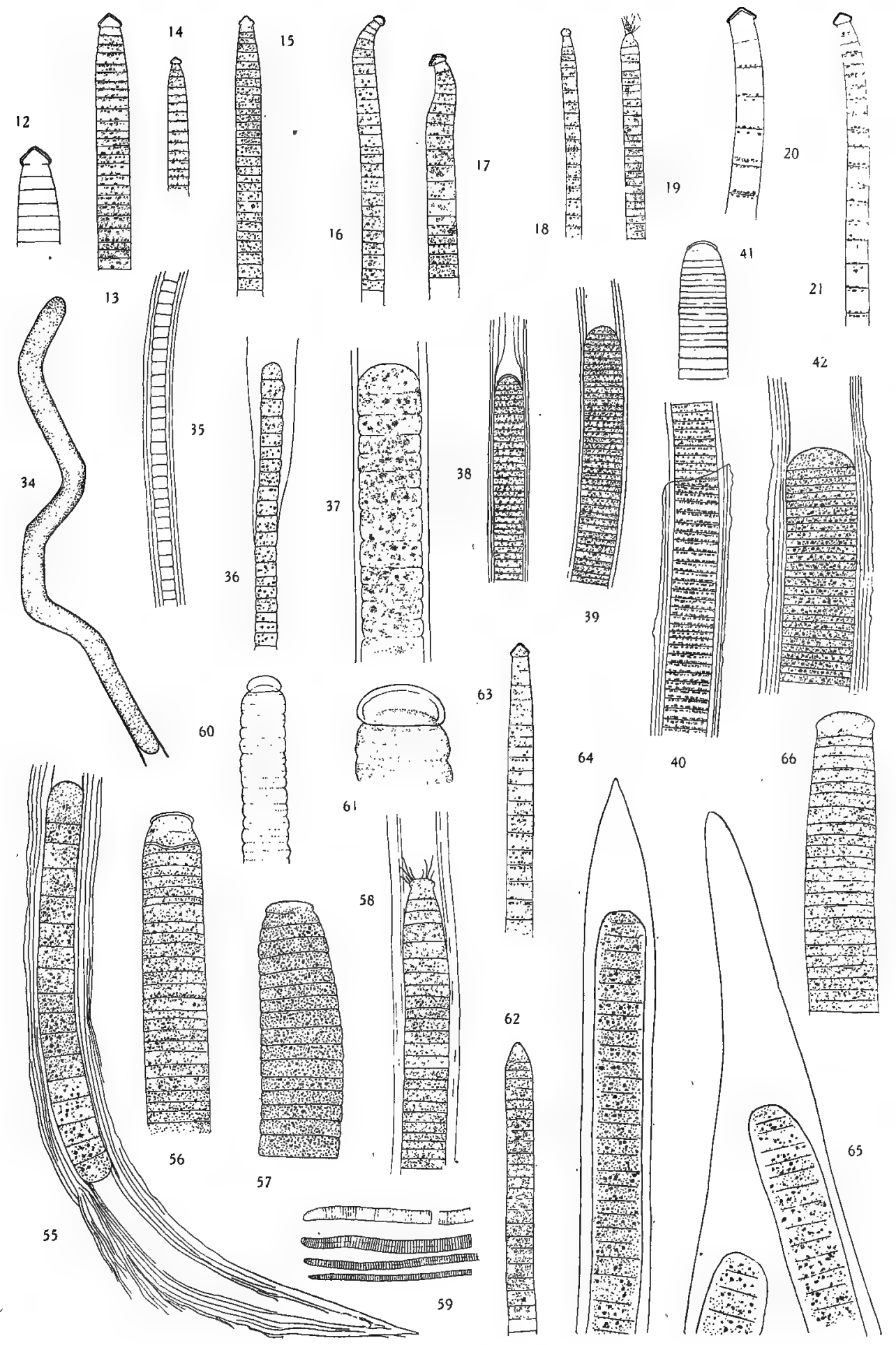


- 



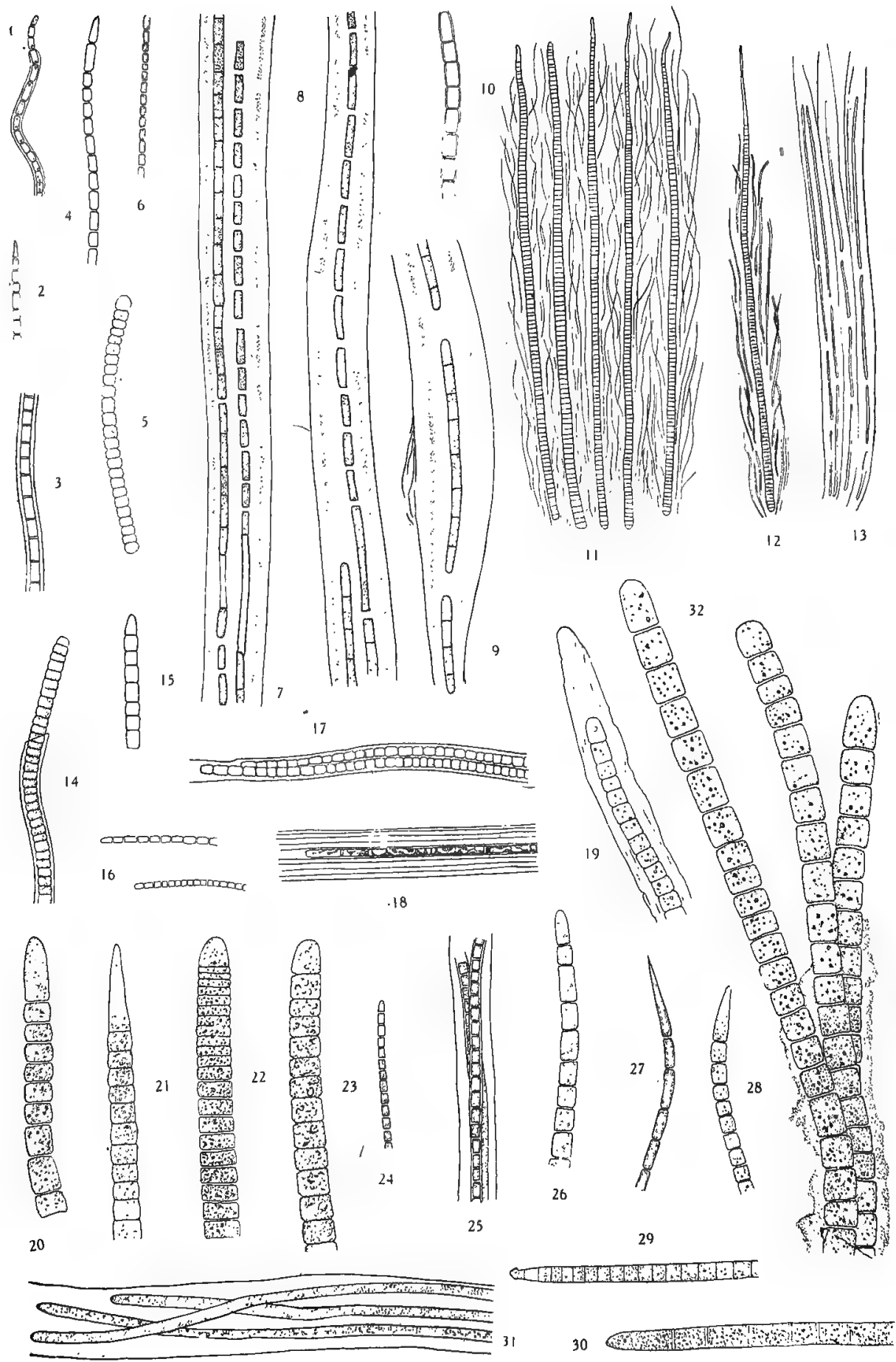




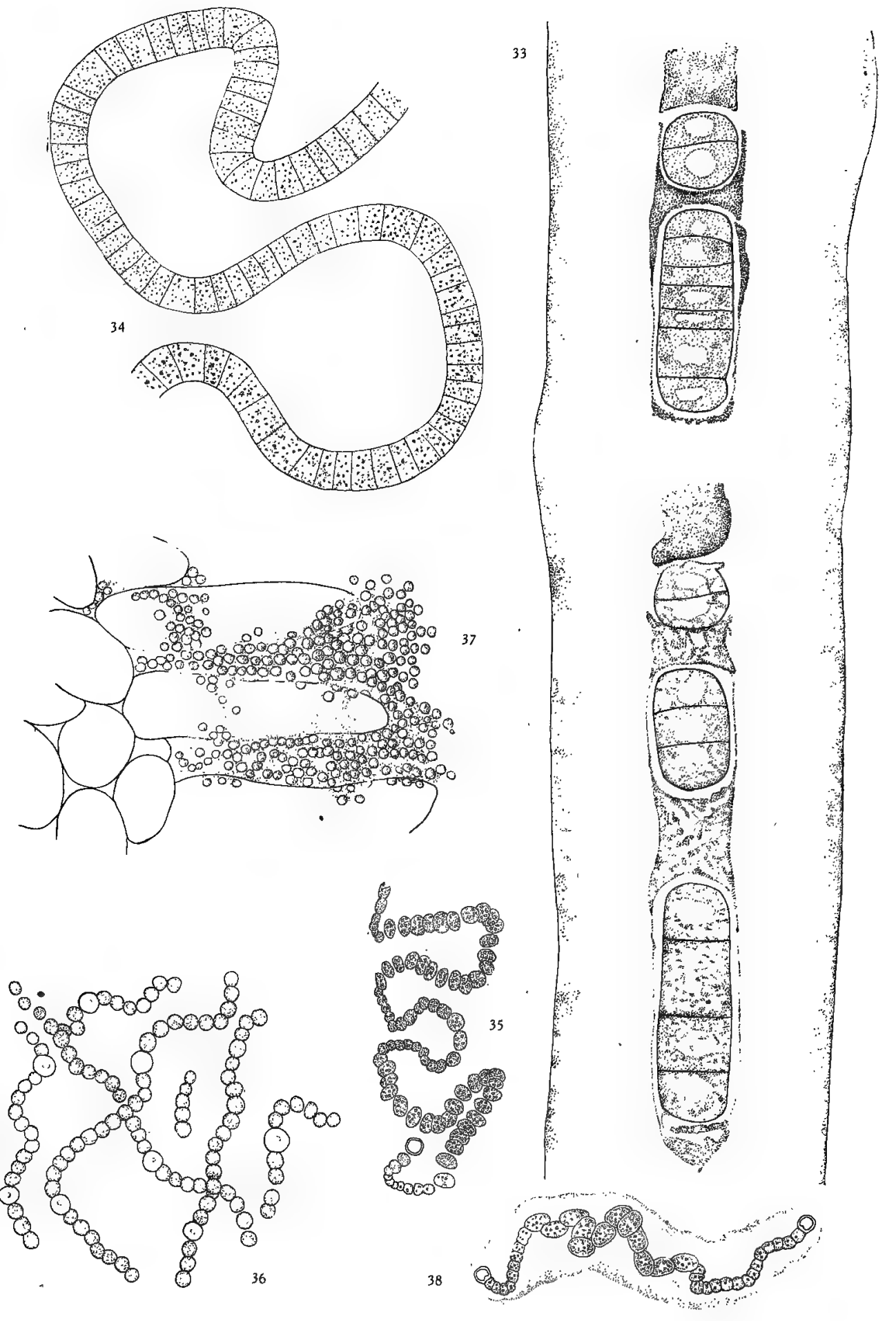






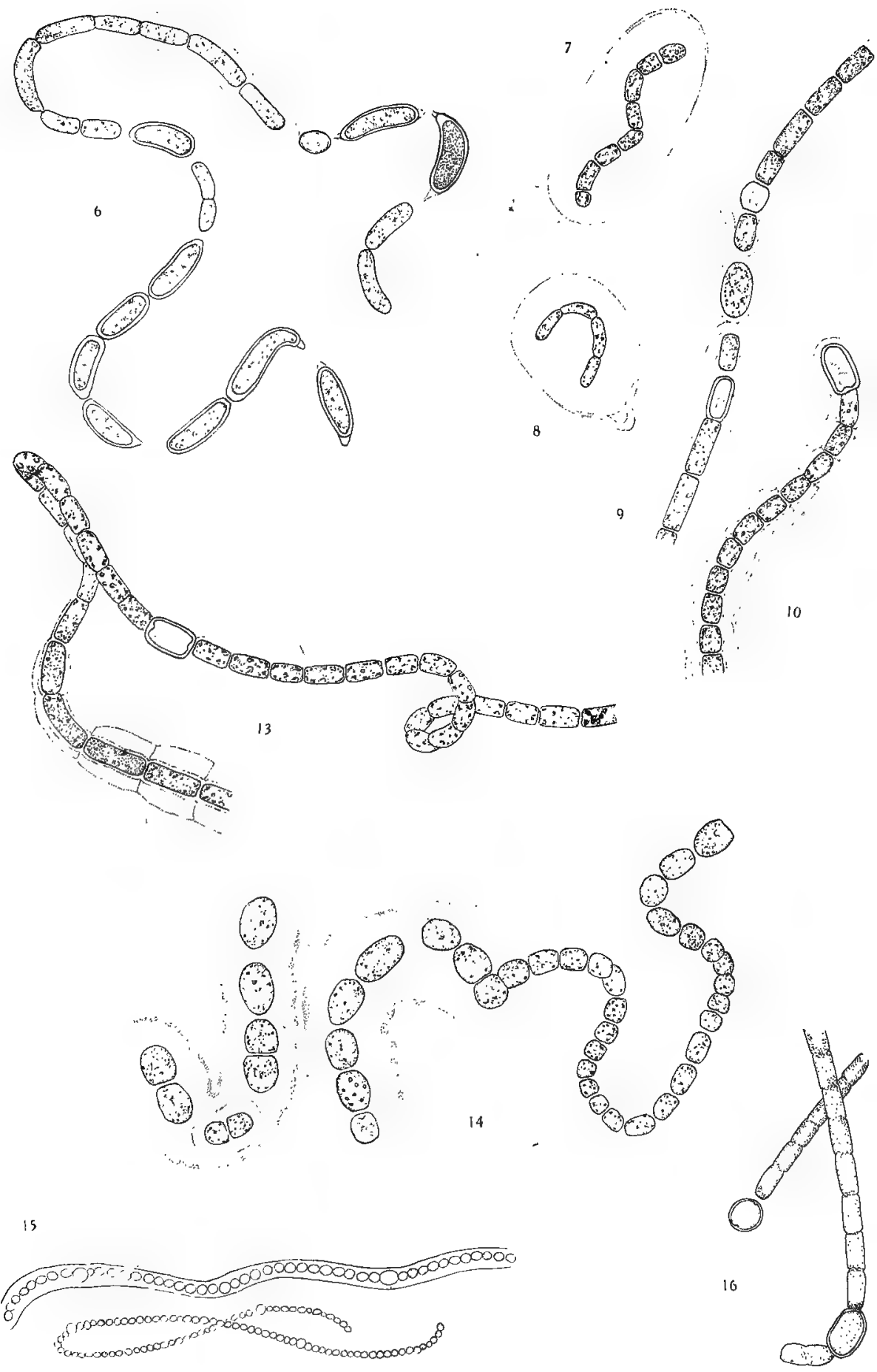

Plat 




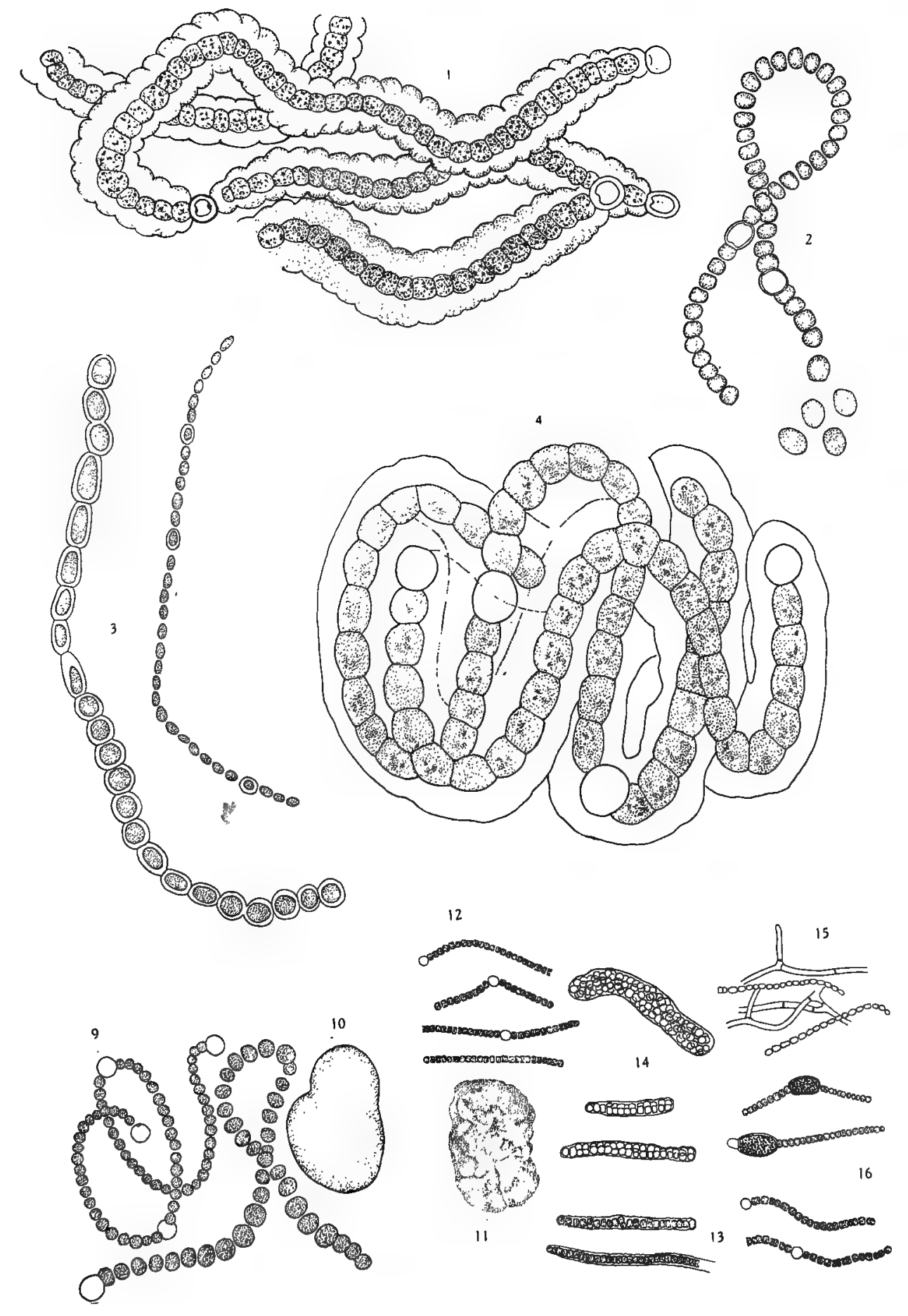



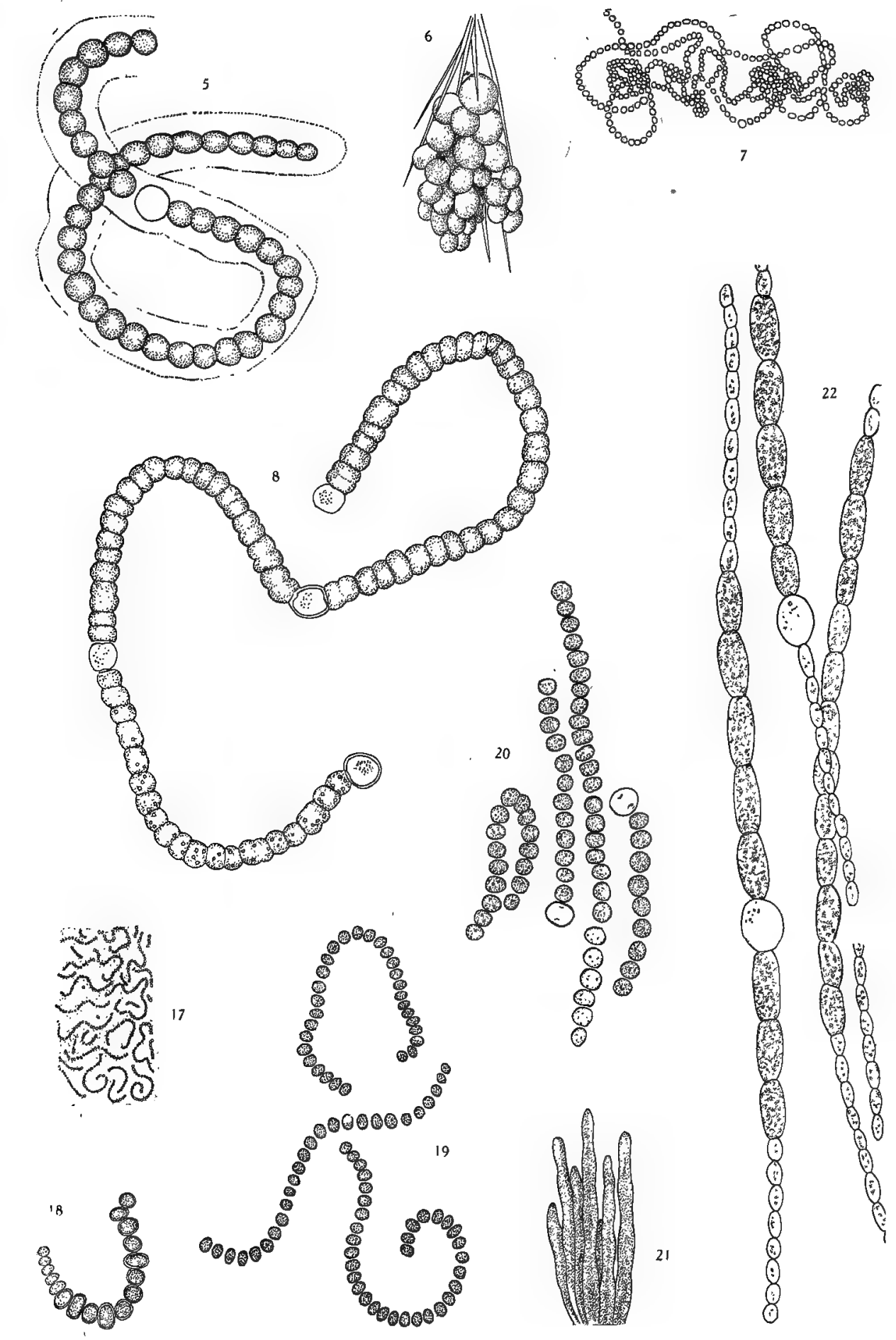

IIII. 



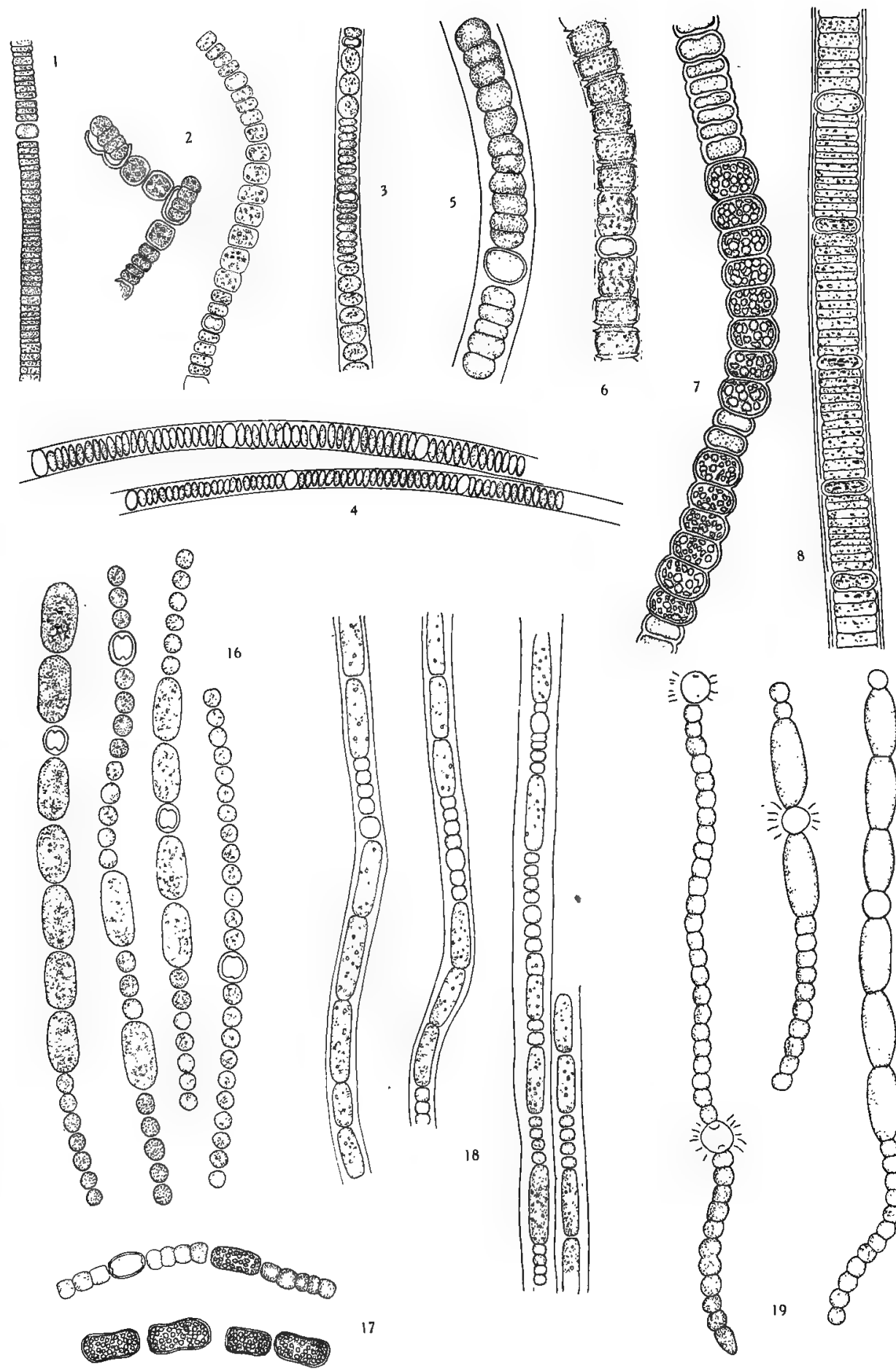

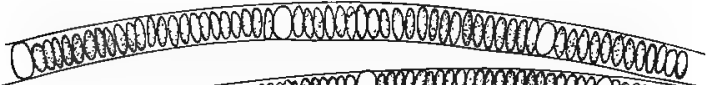

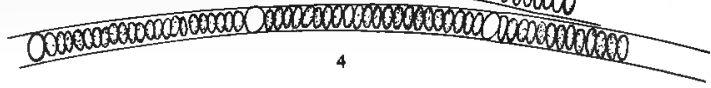




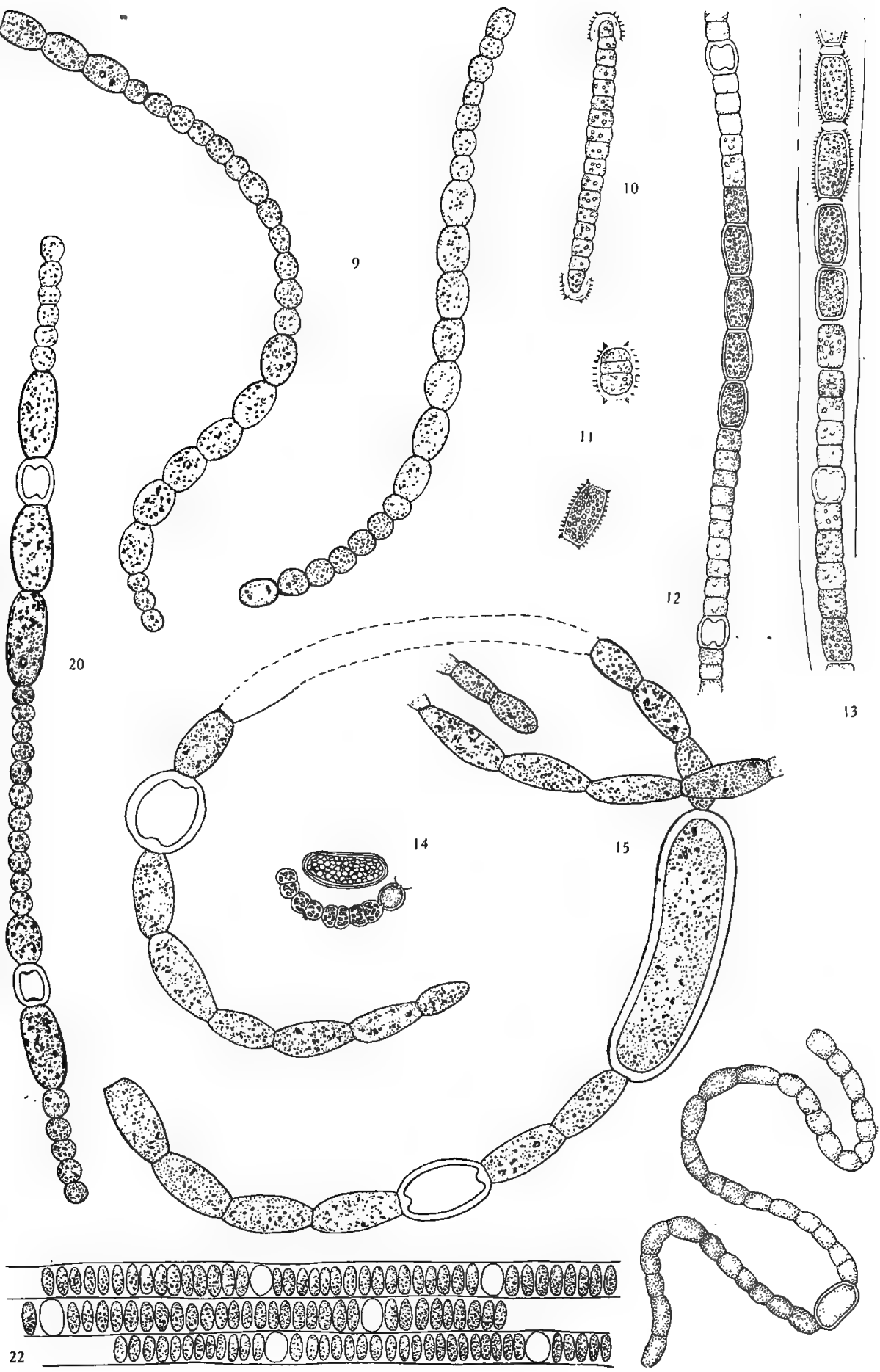





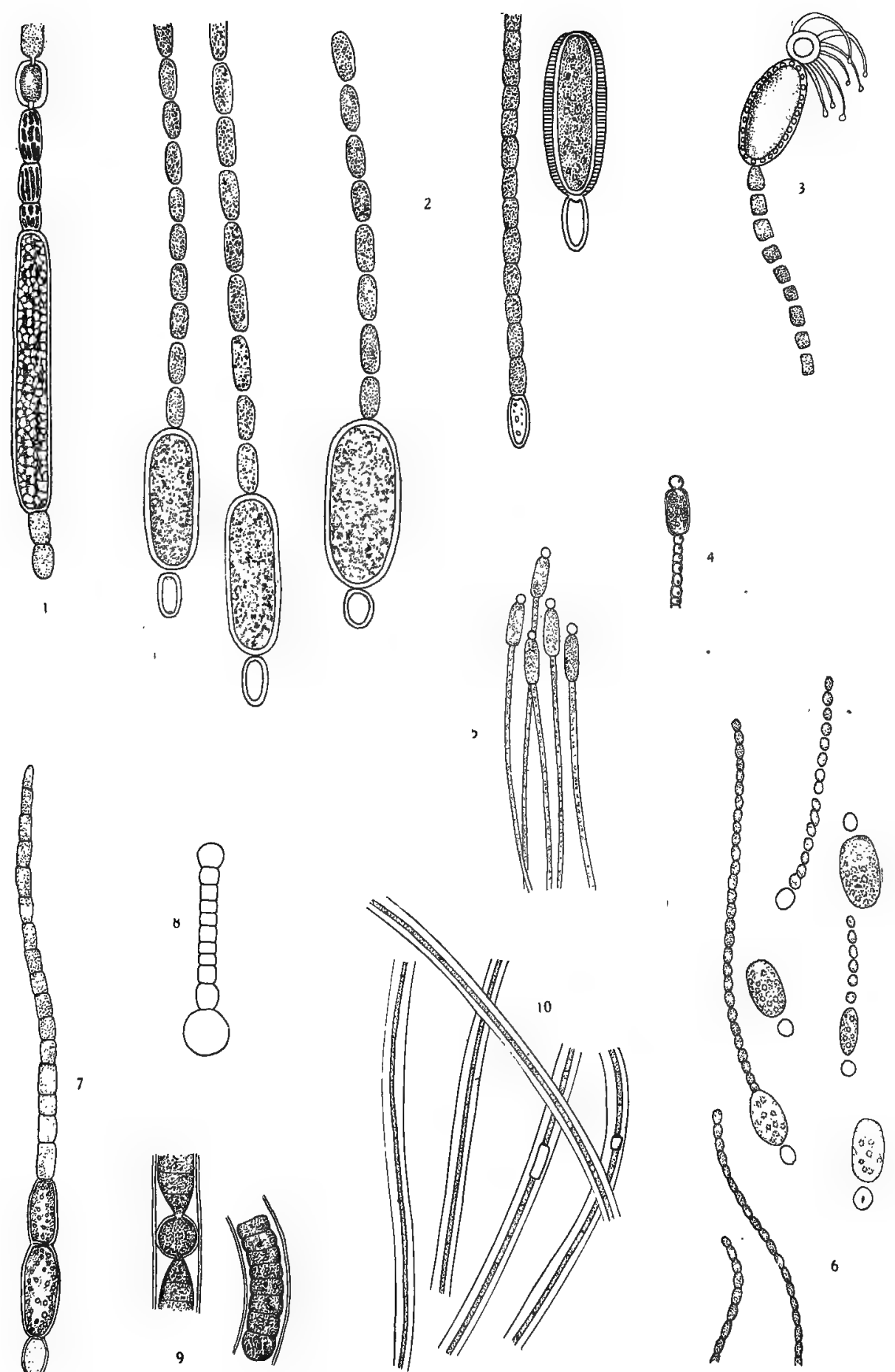

Plate 

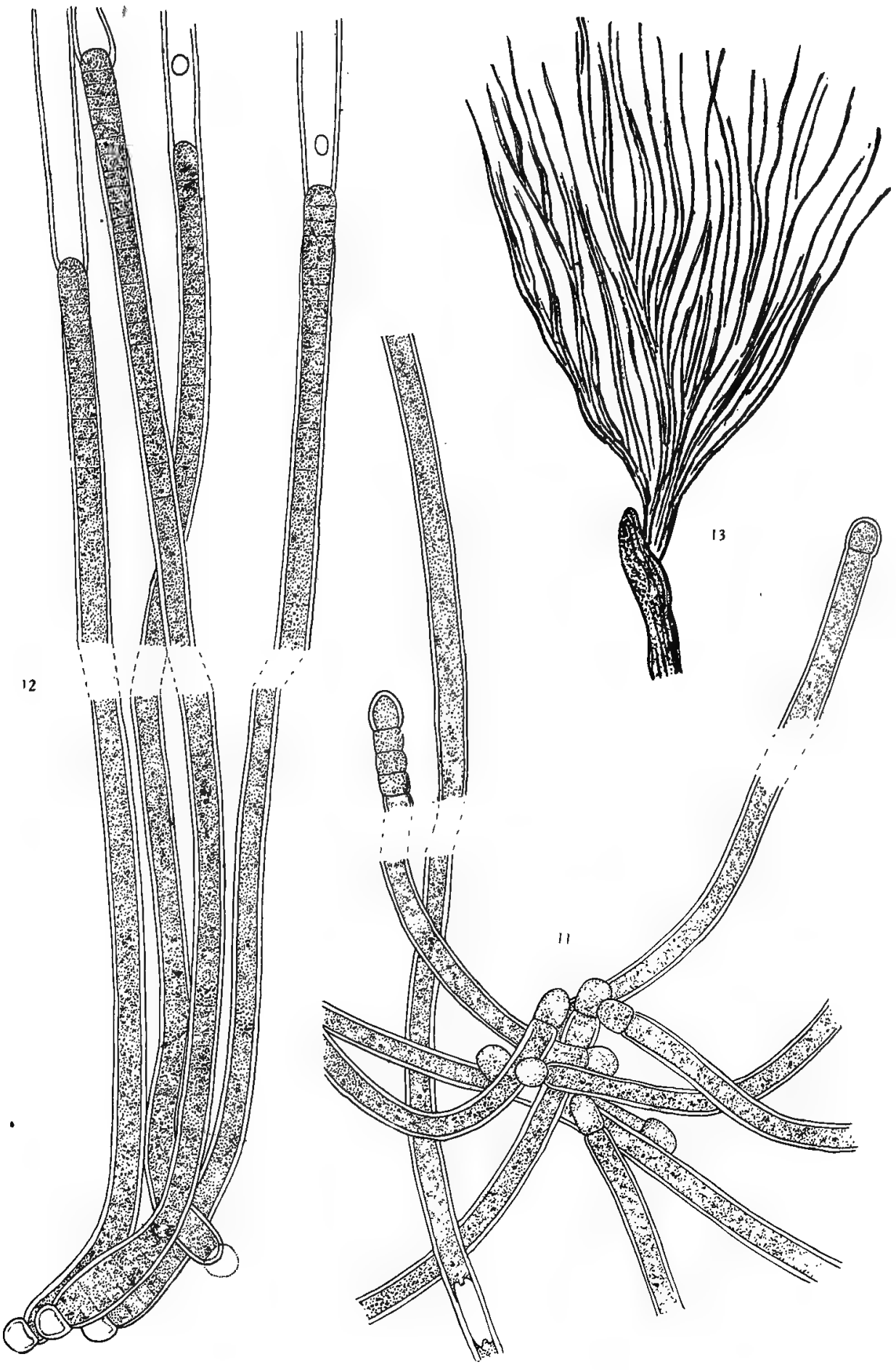



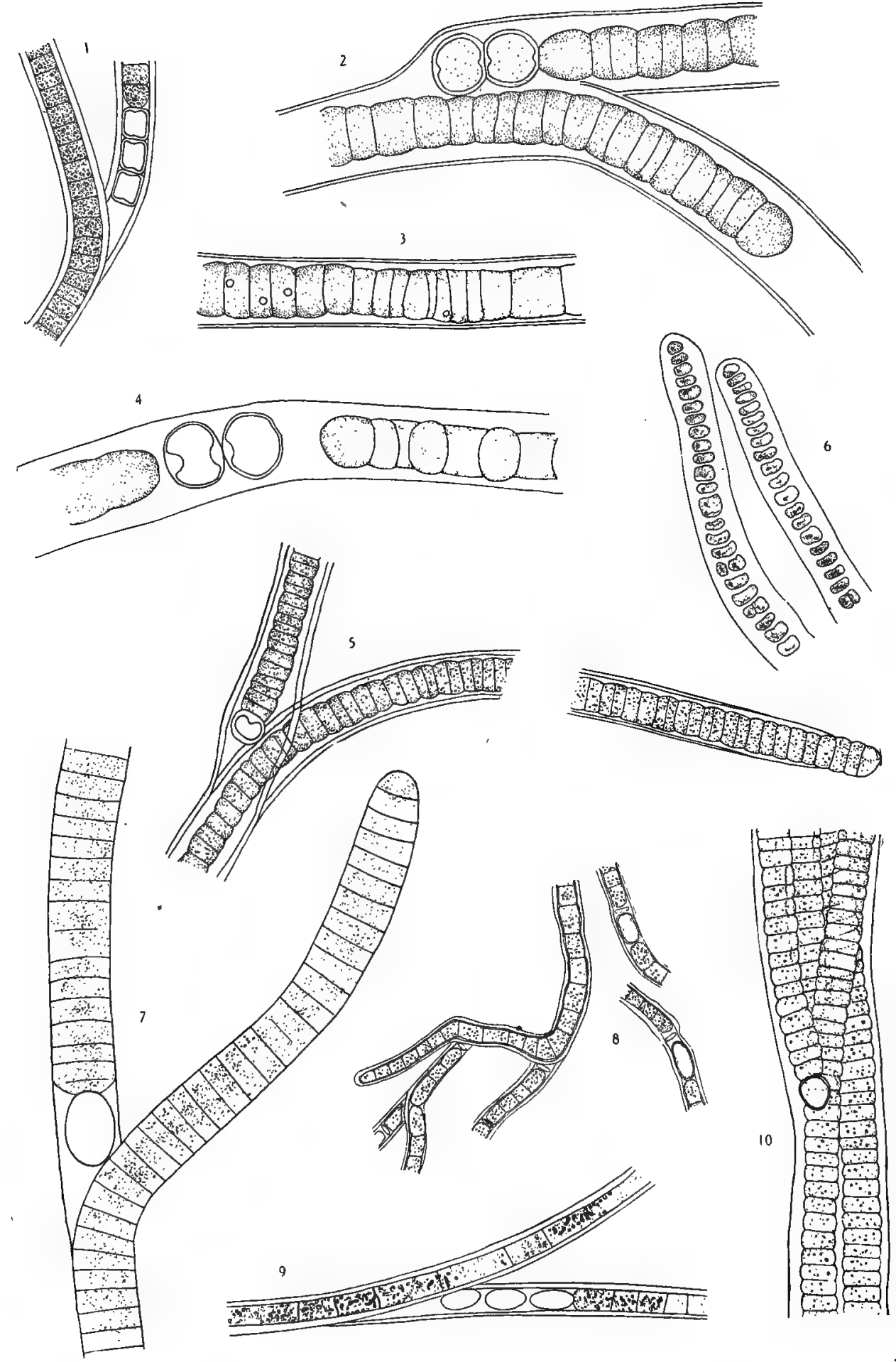


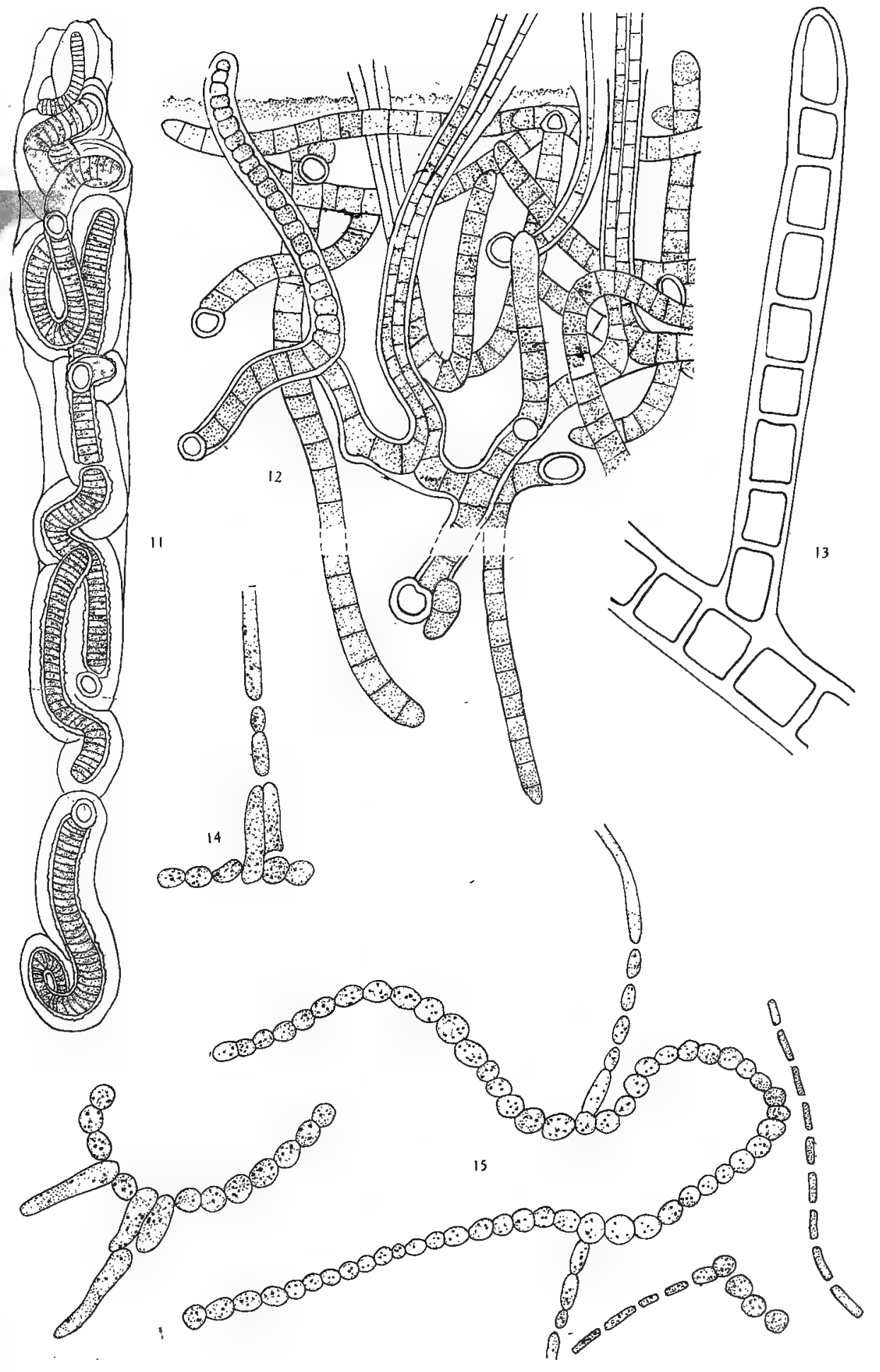

XIV. 




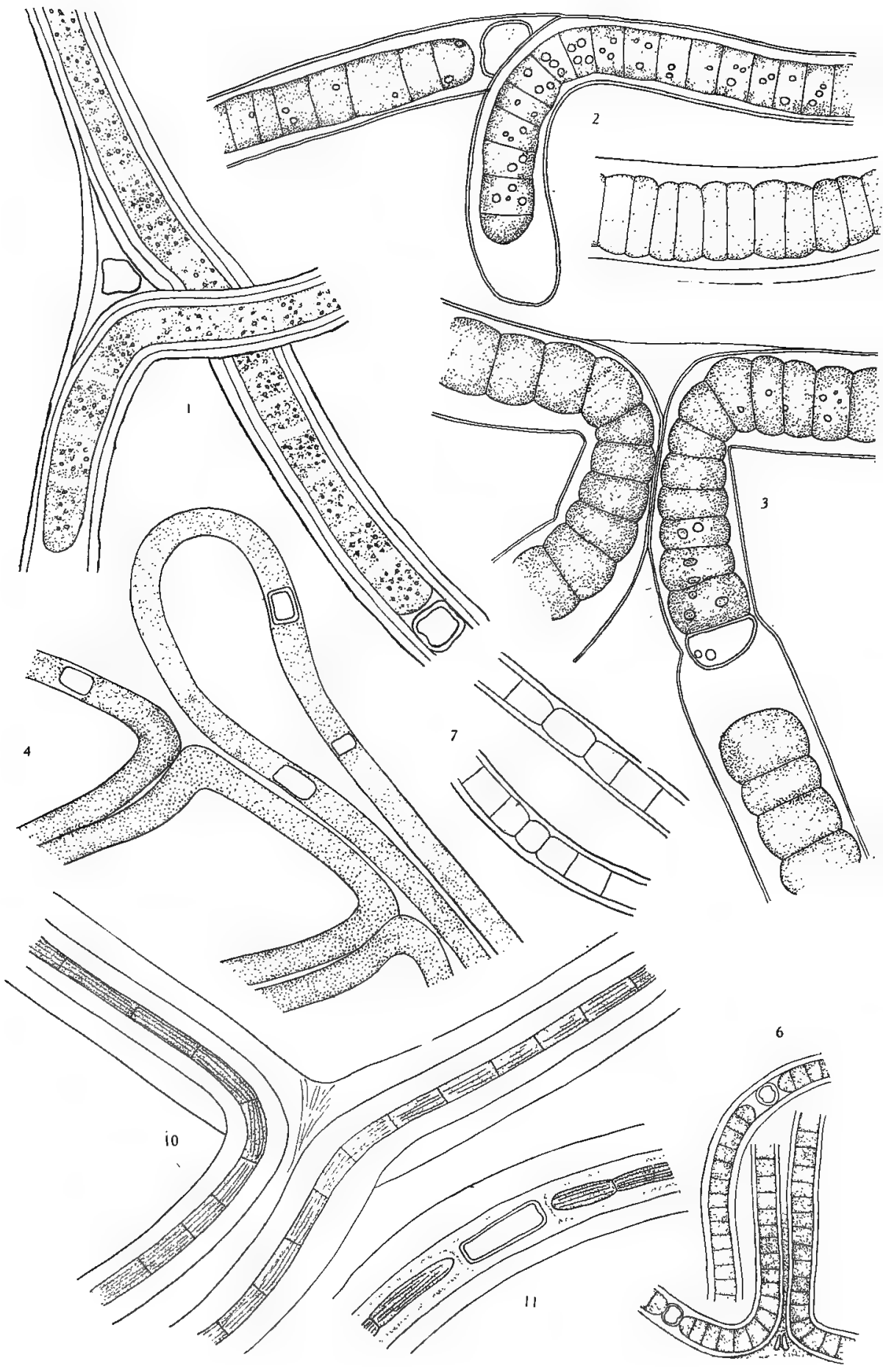

$\mathrm{Pla}$ 


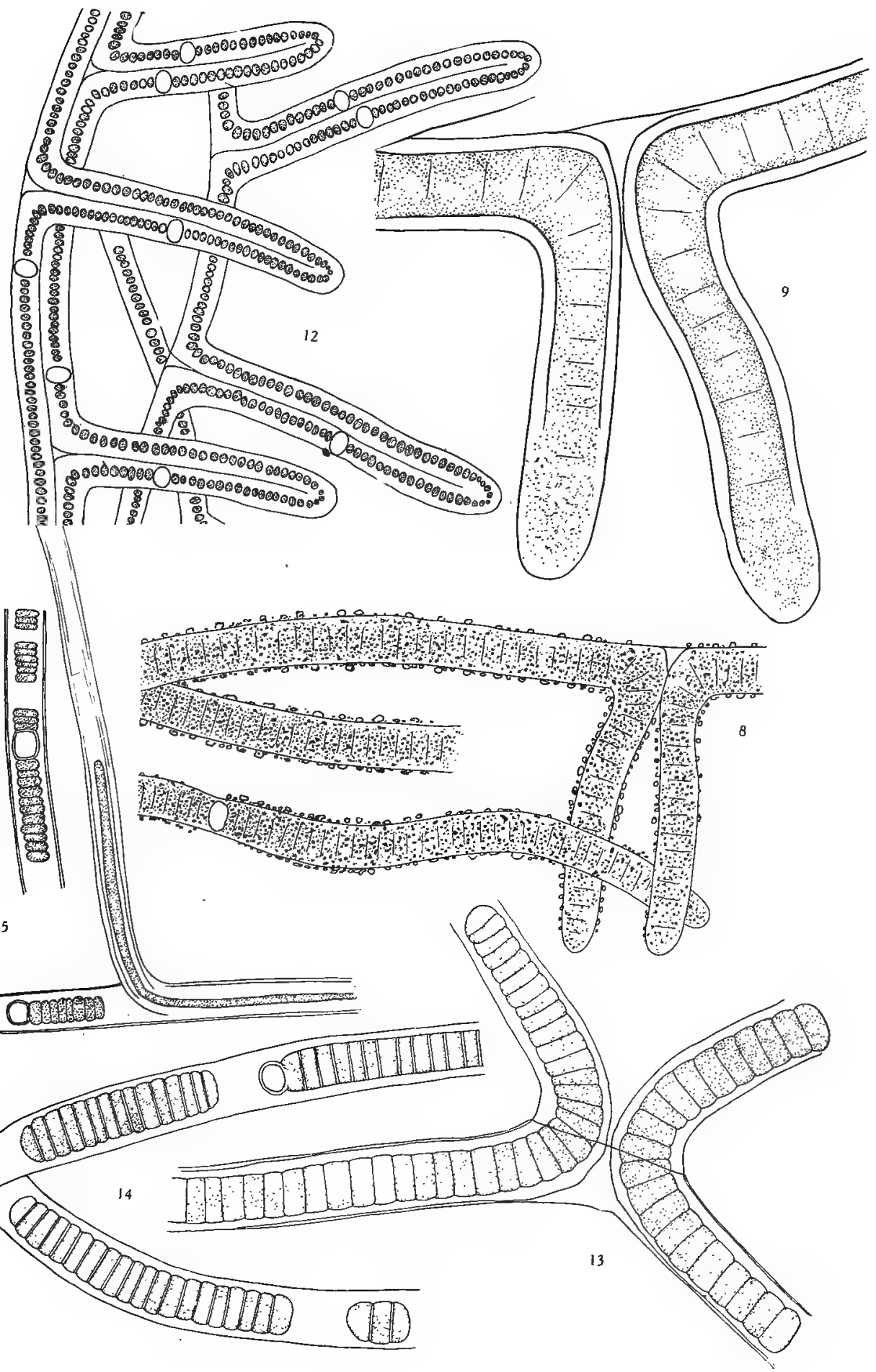






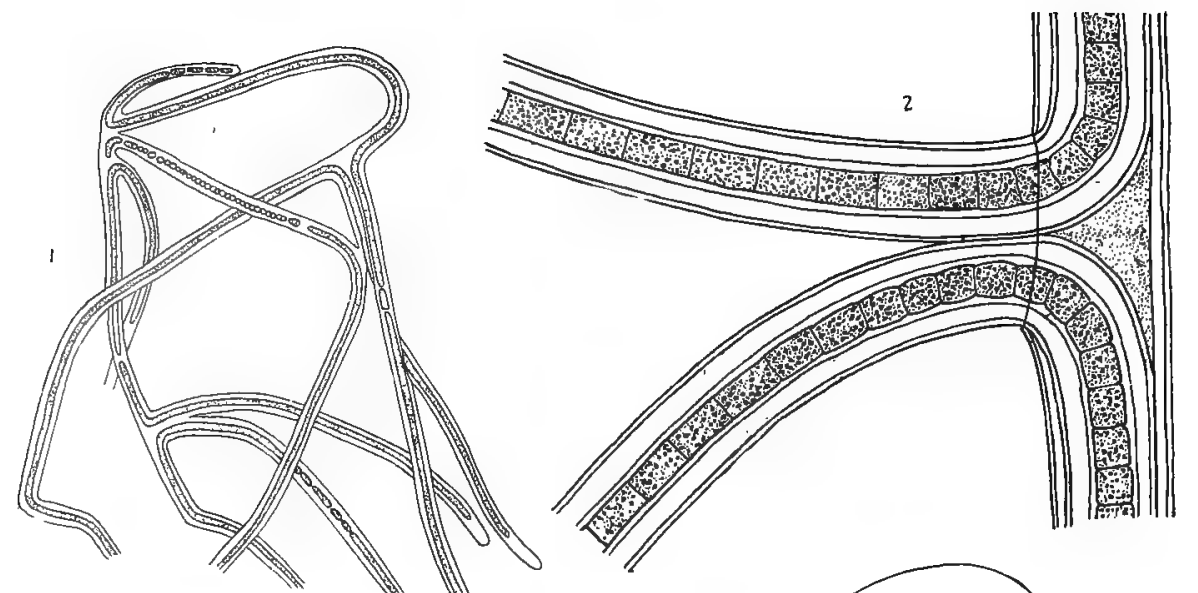

3
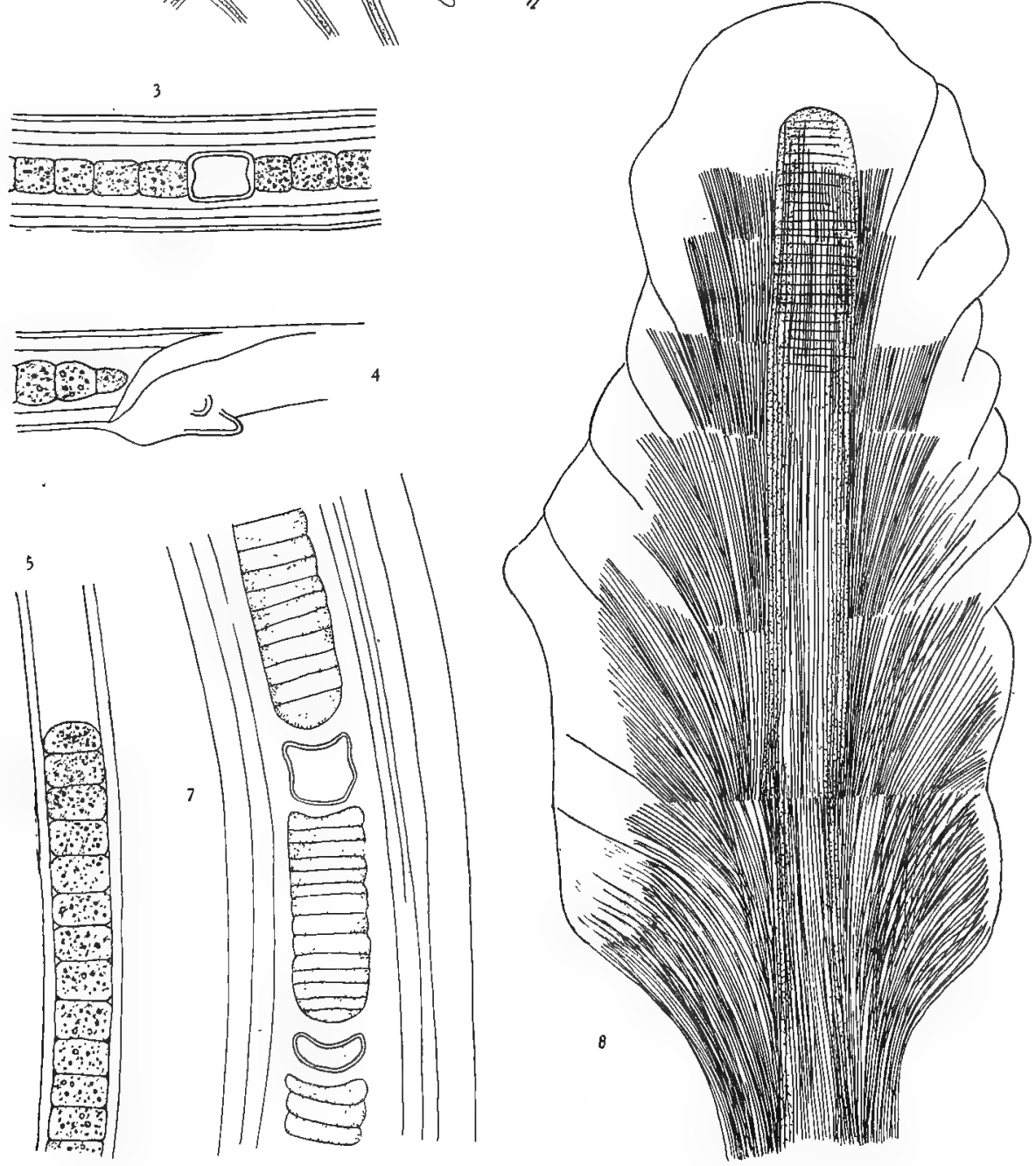


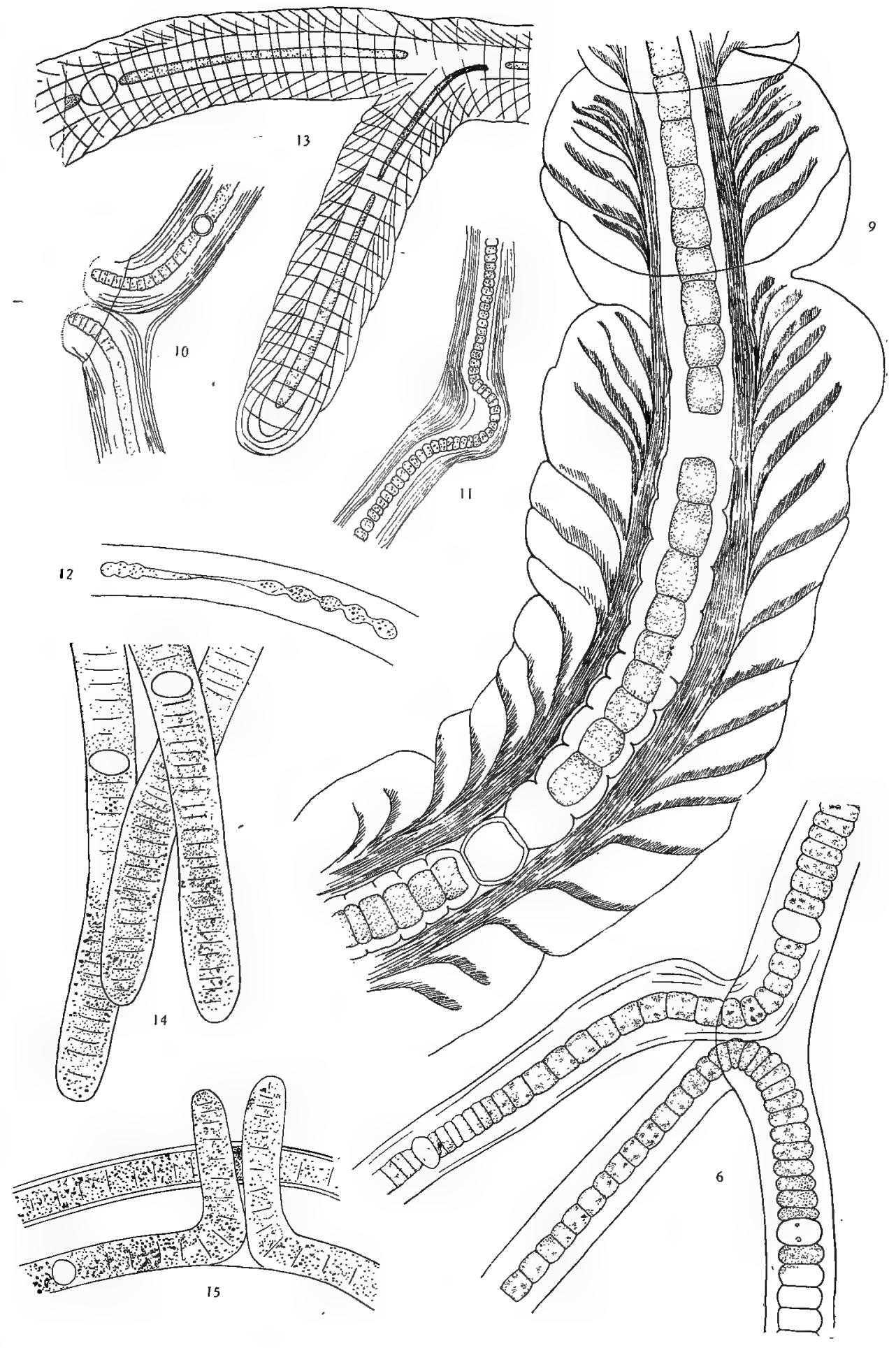

XIII. 




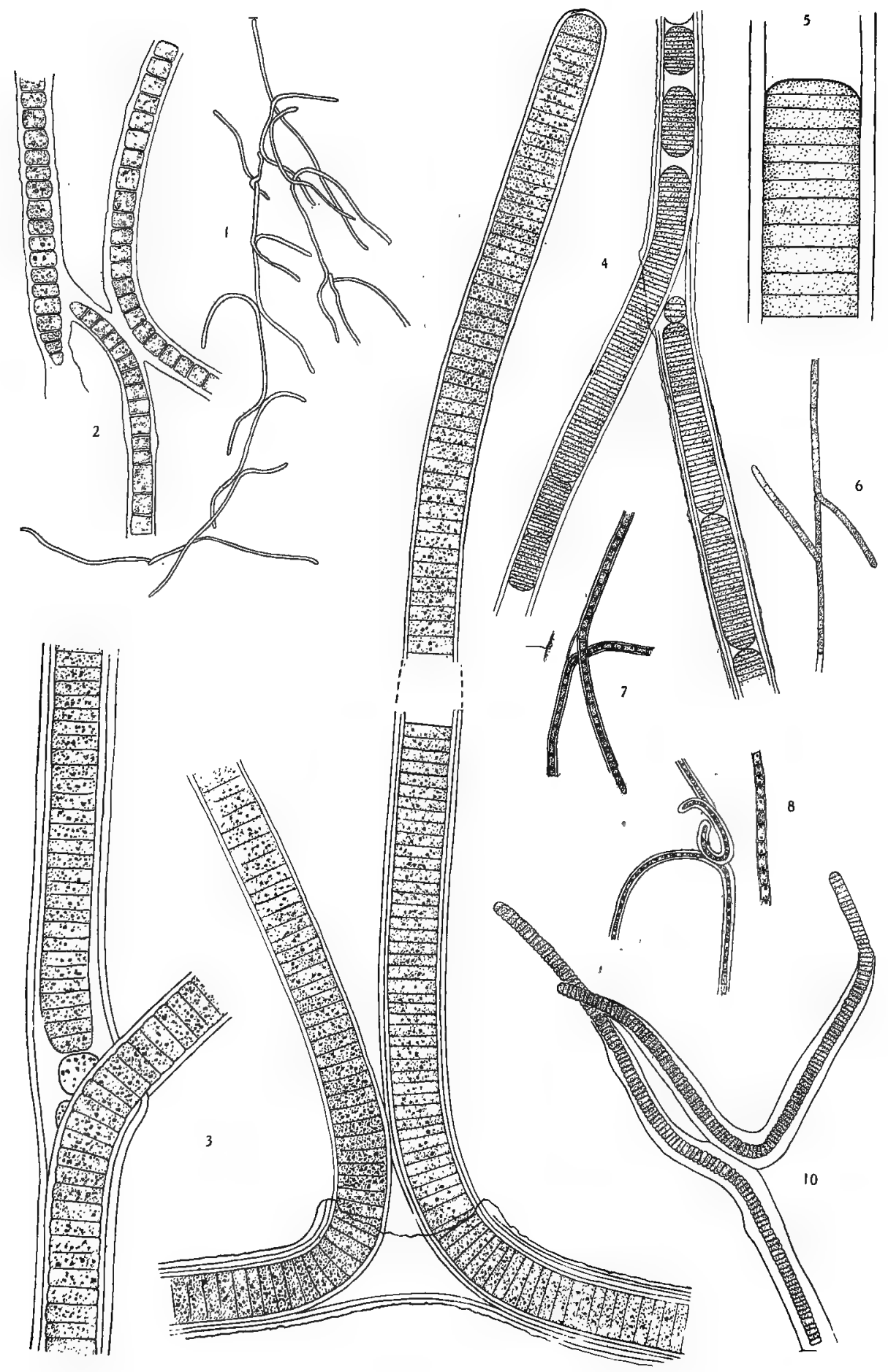




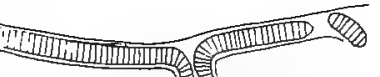
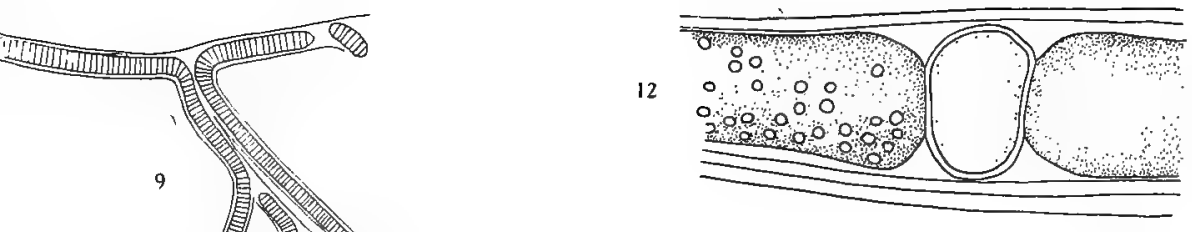

2
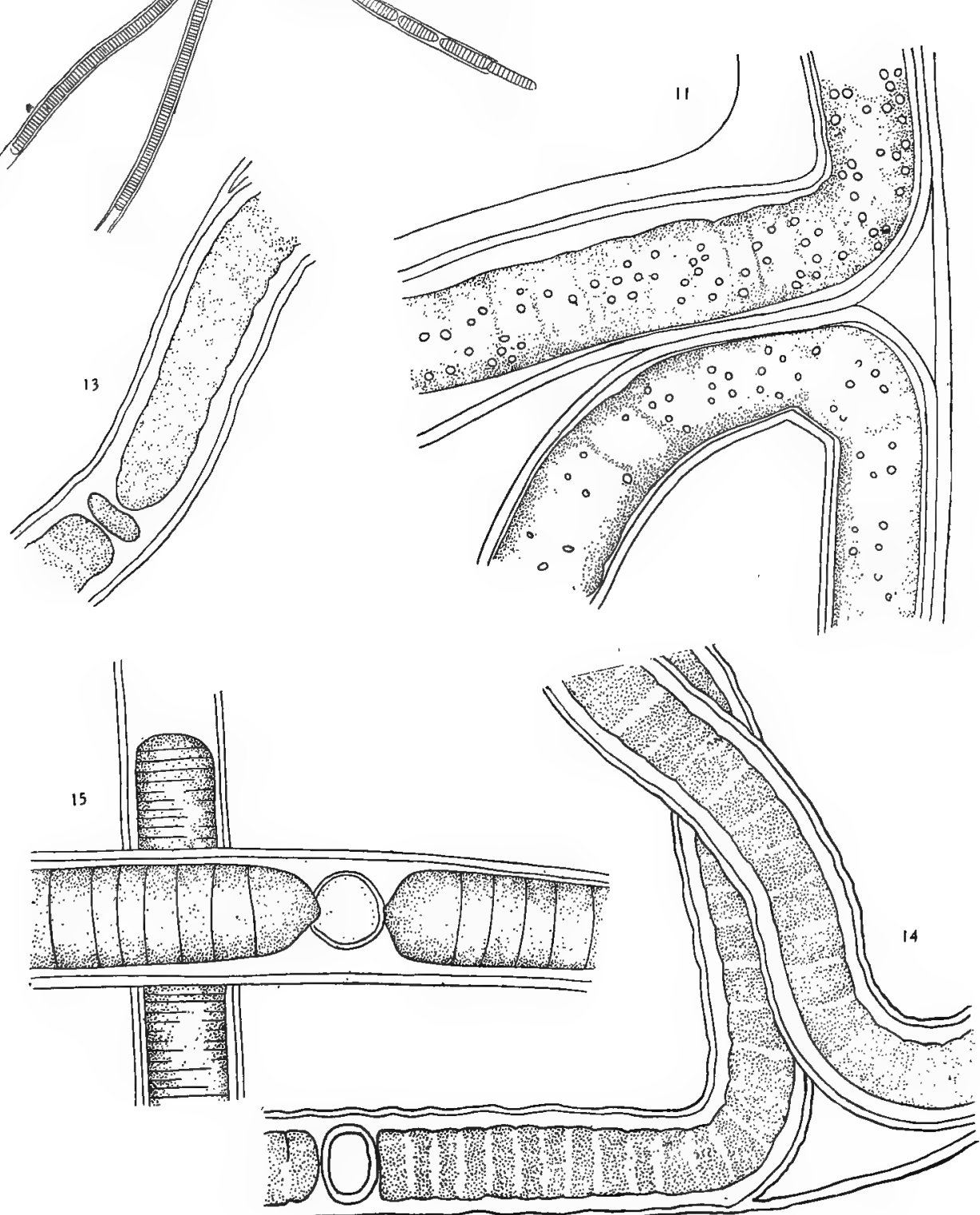




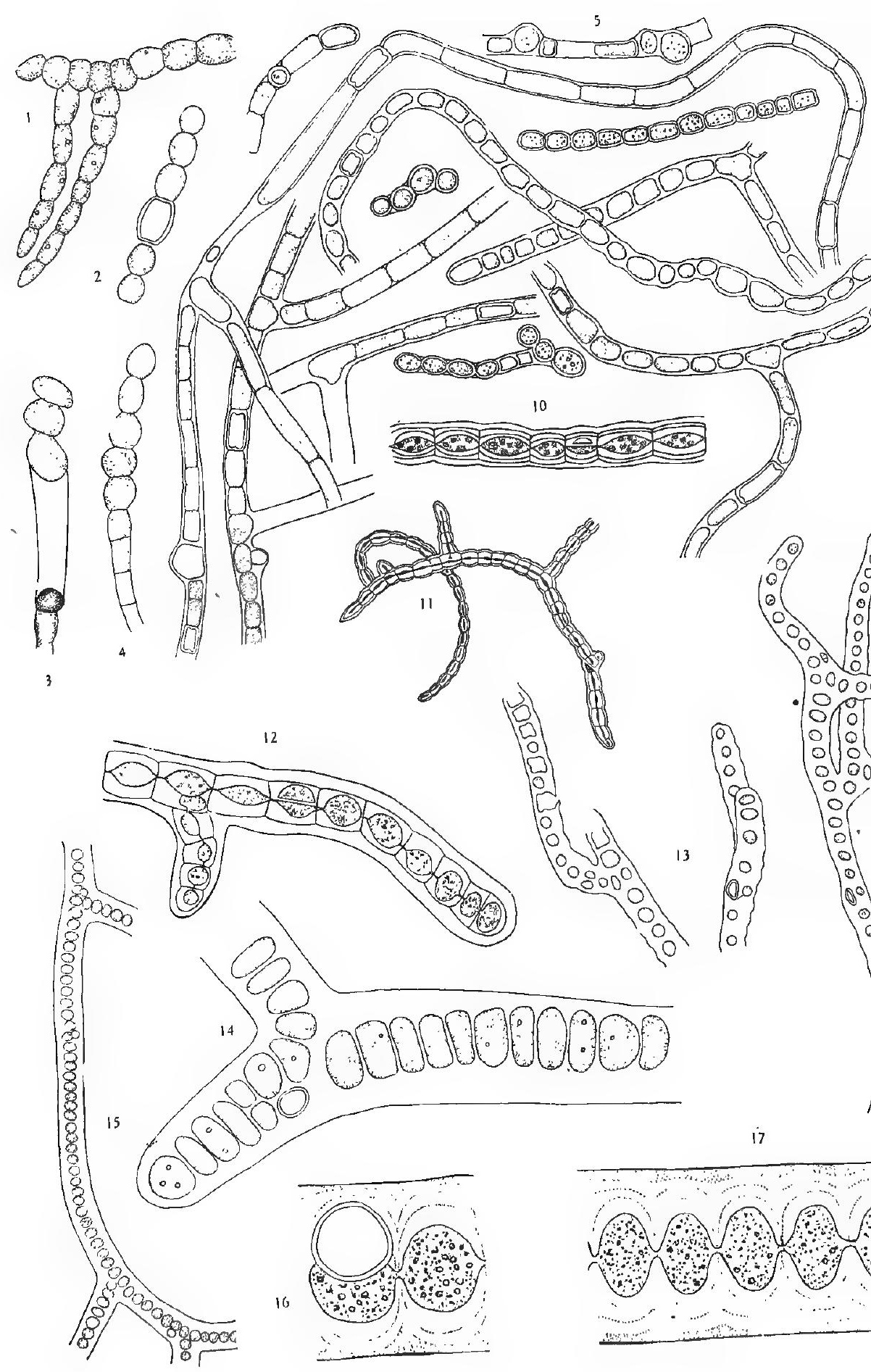



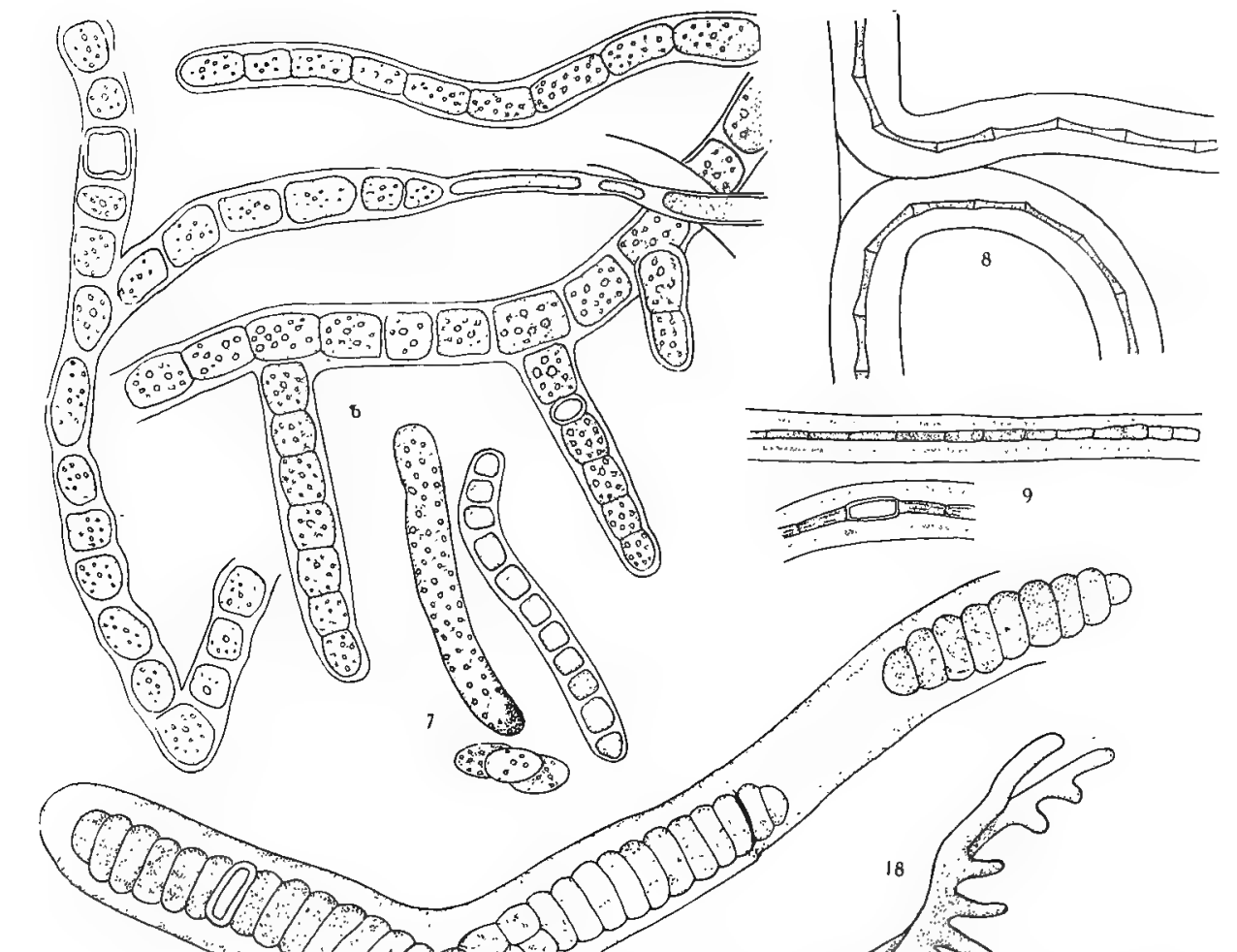



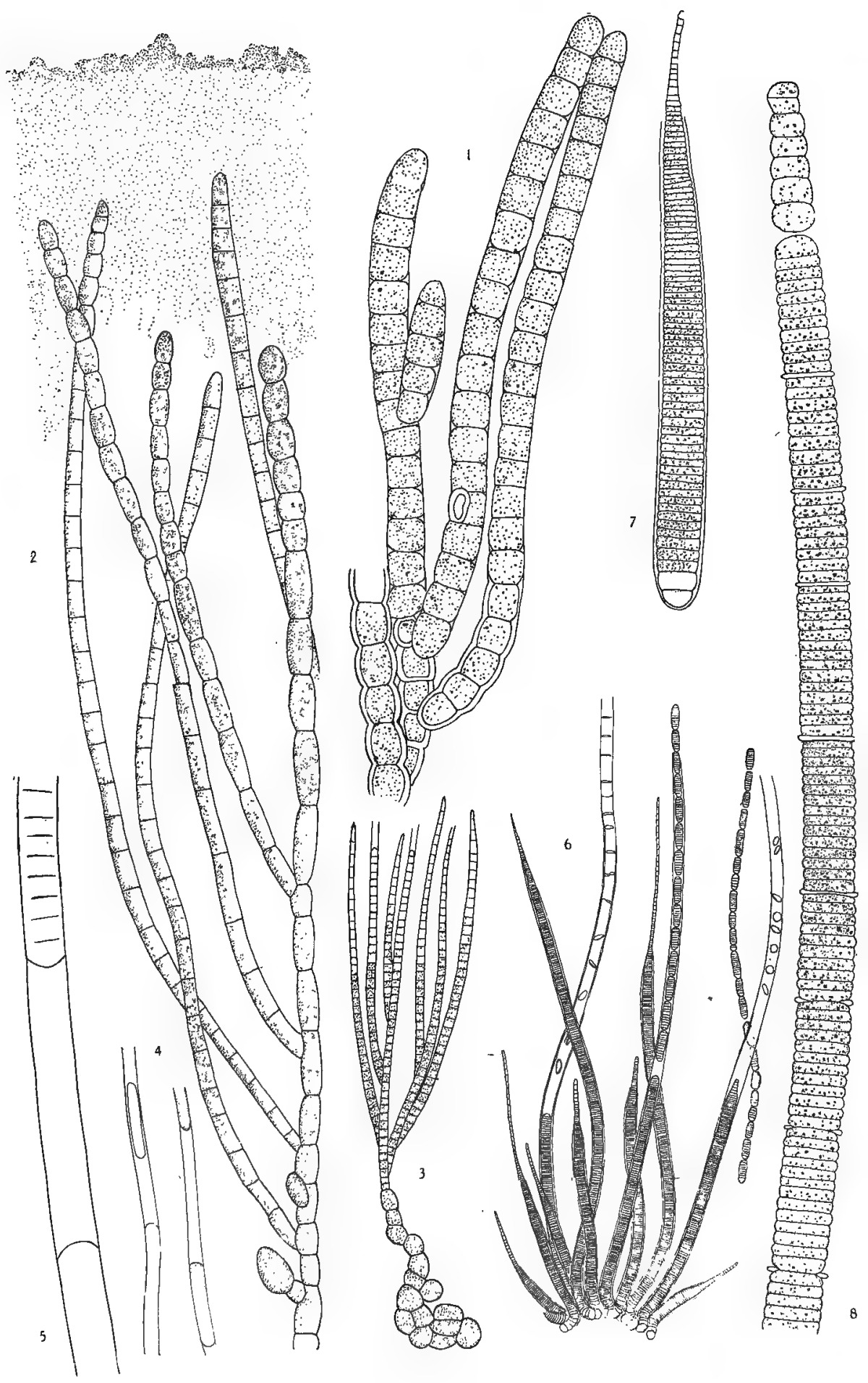

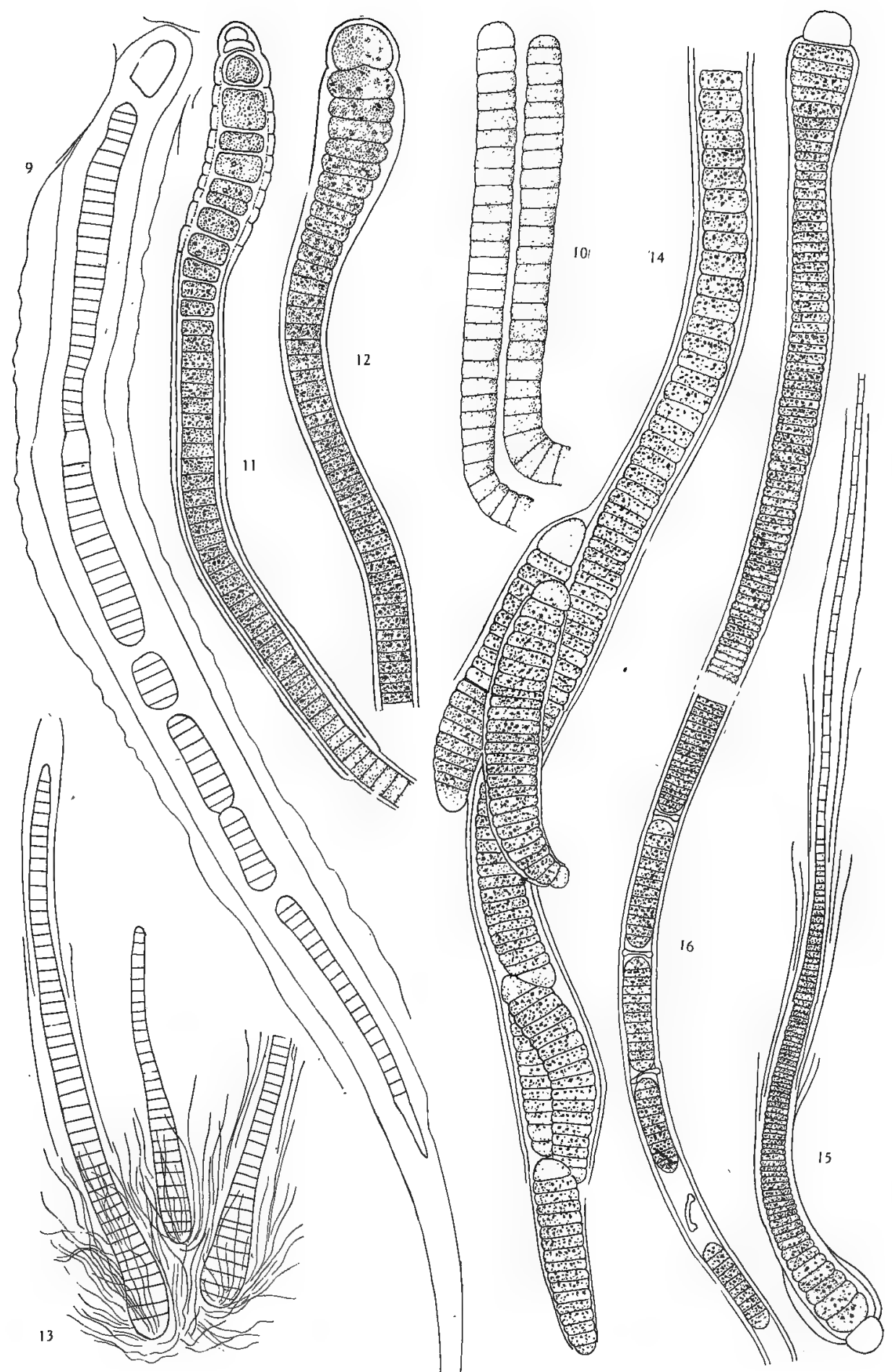




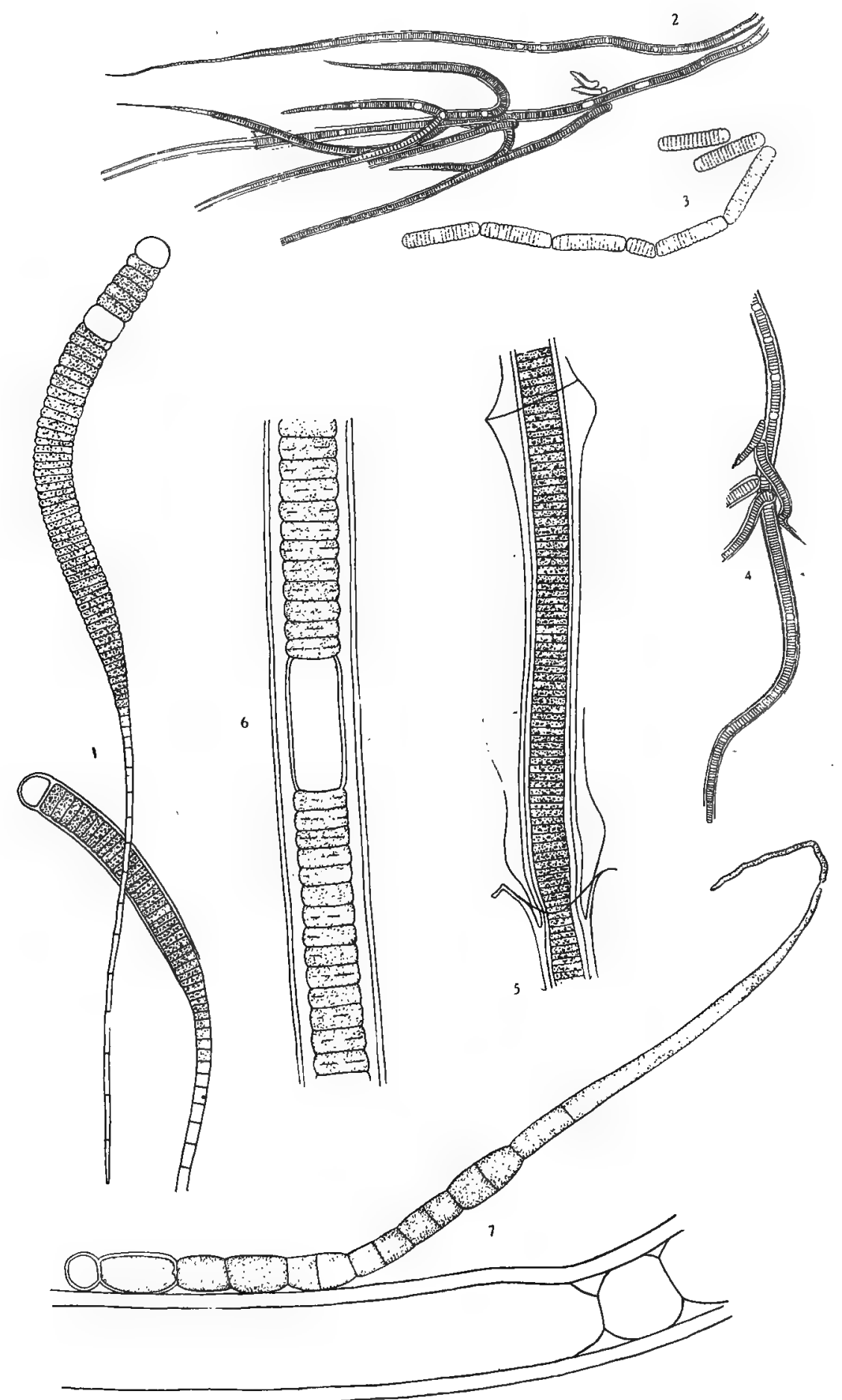

P 


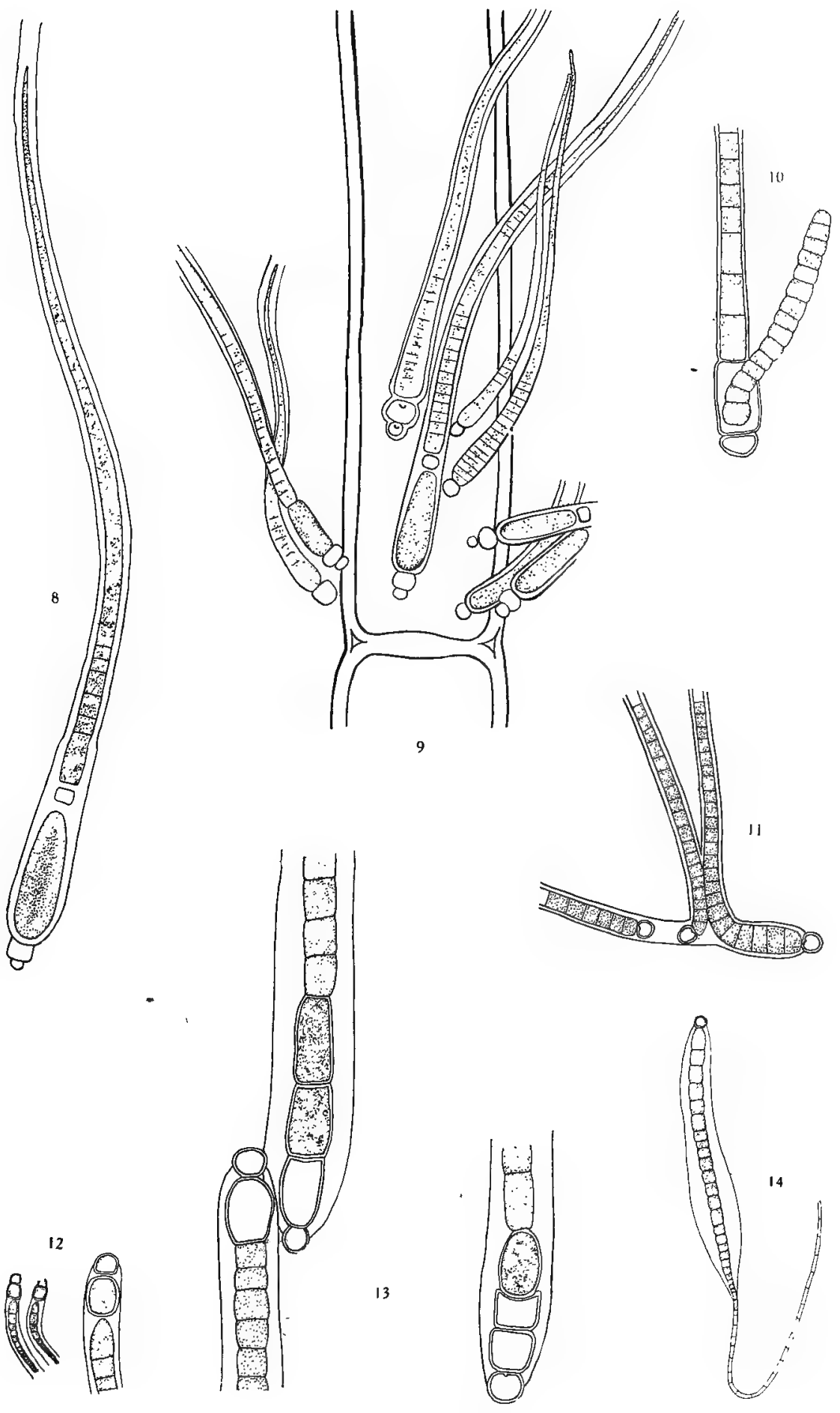

XVII. 




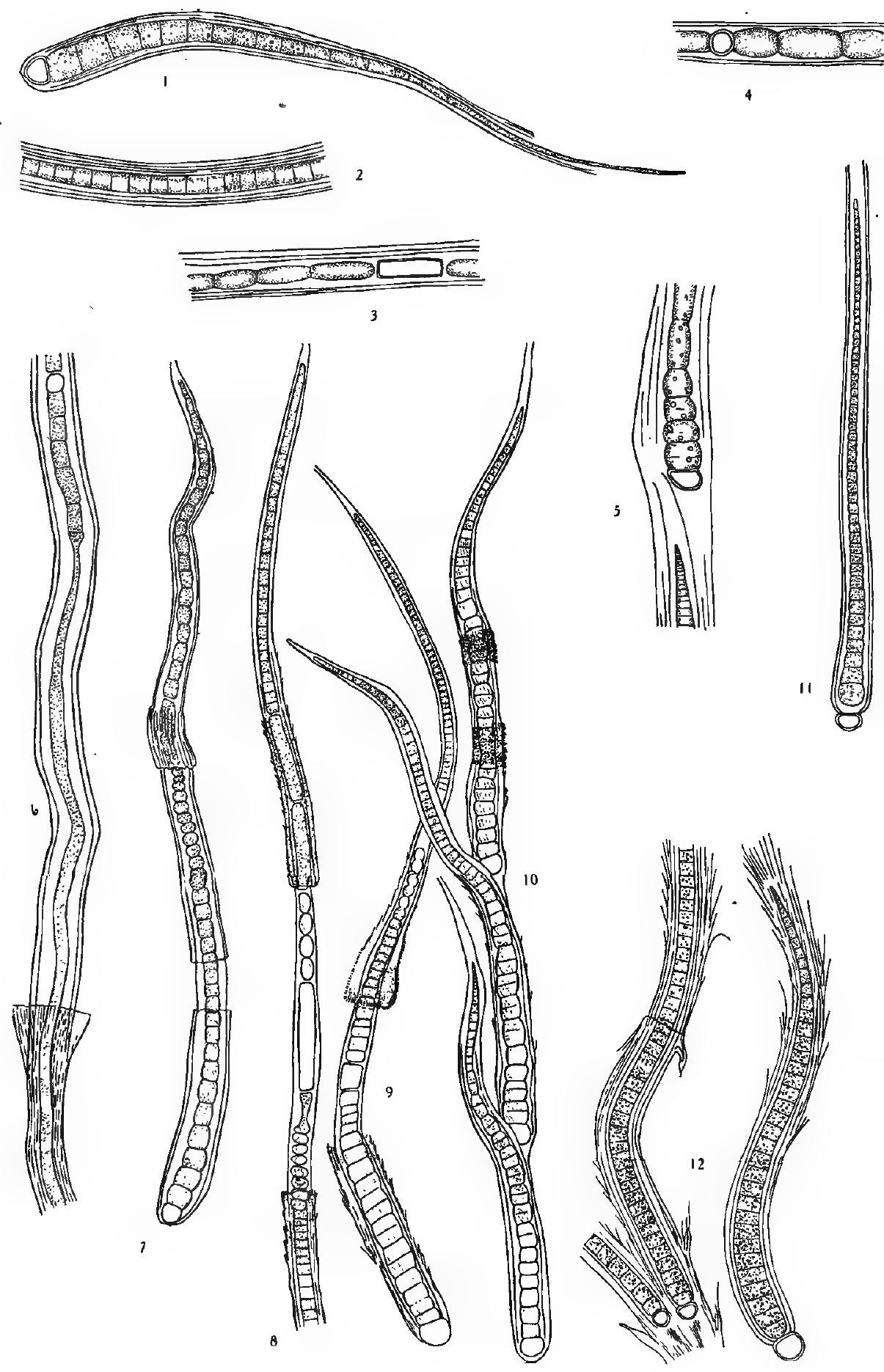



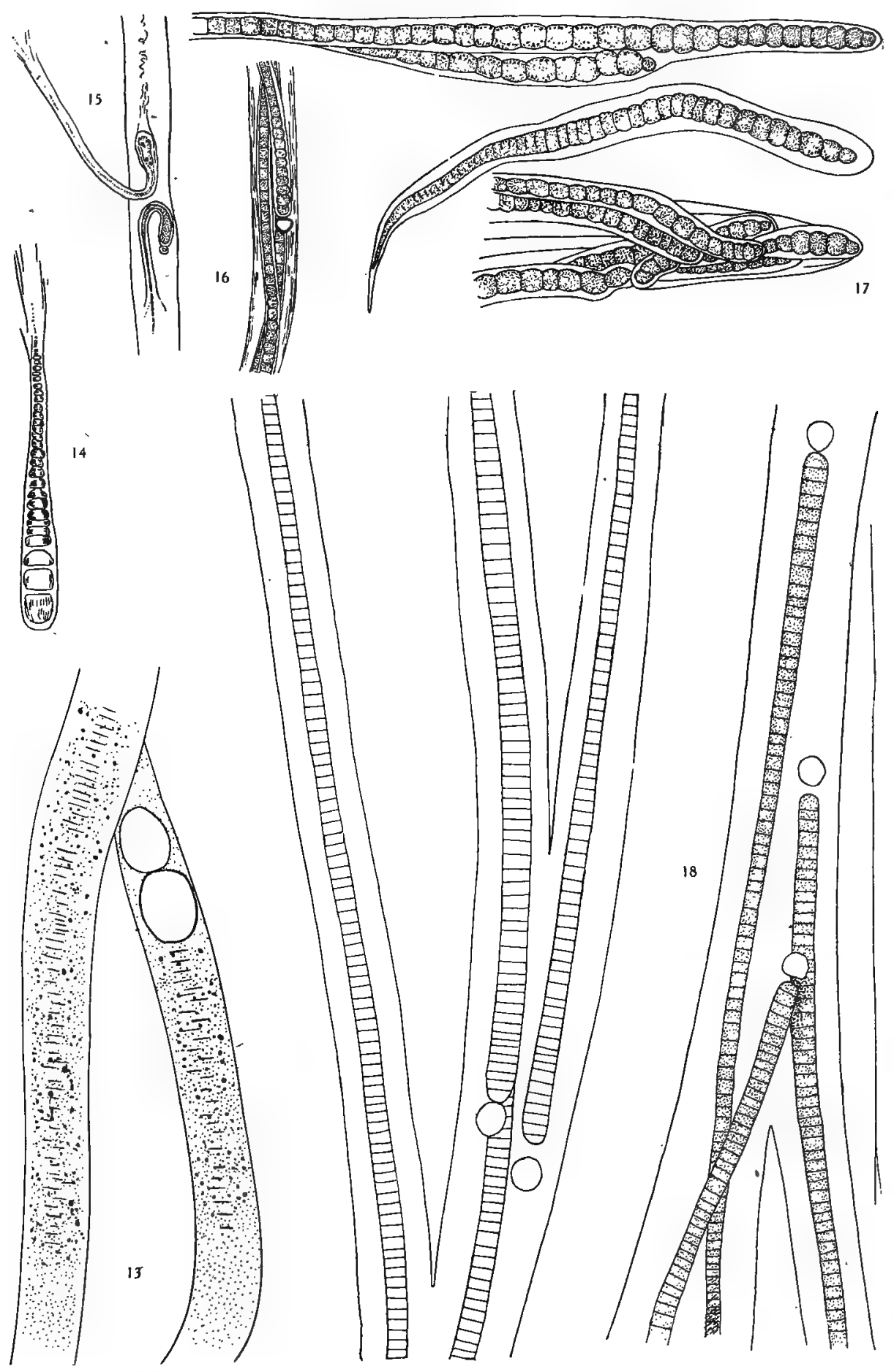




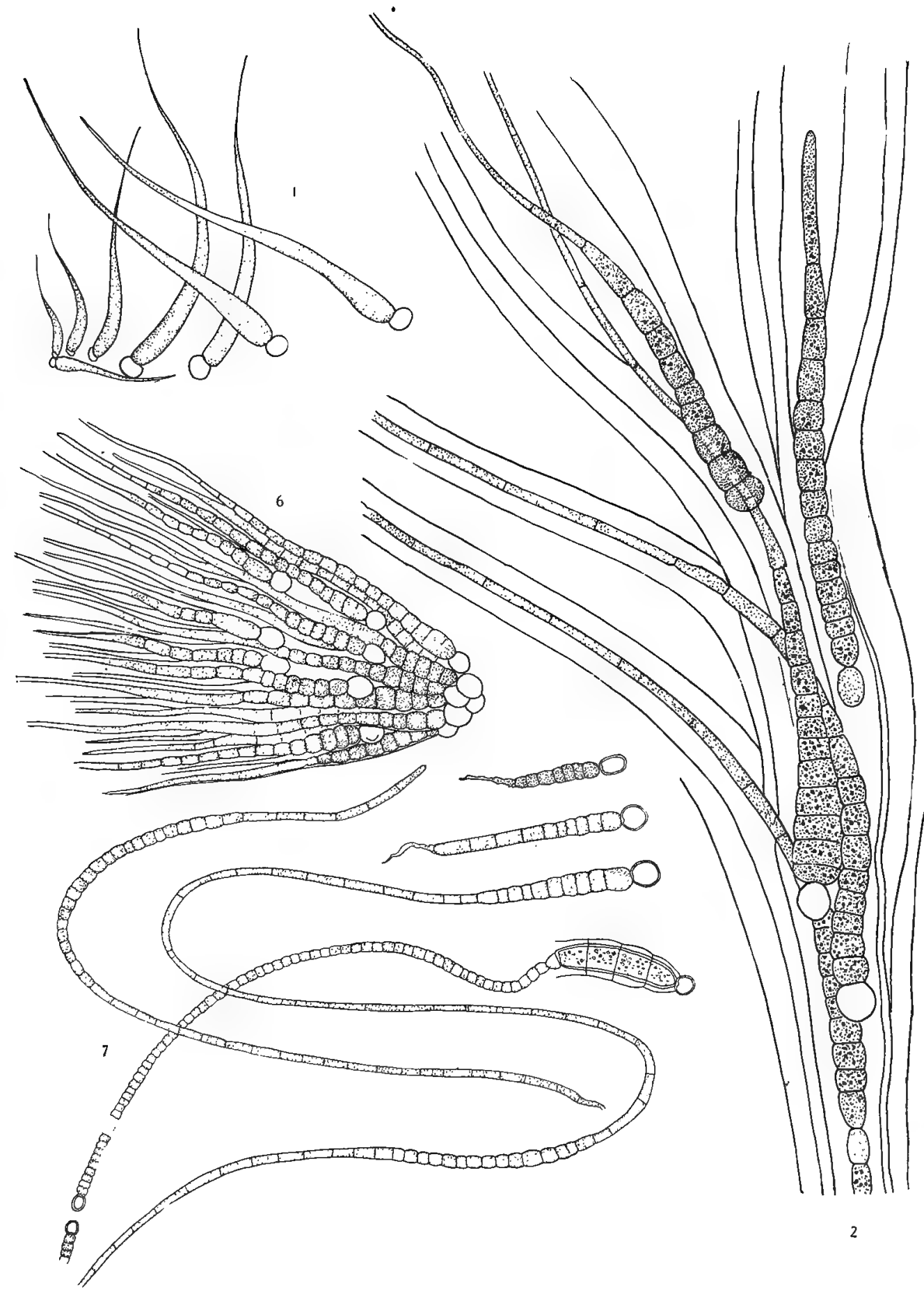



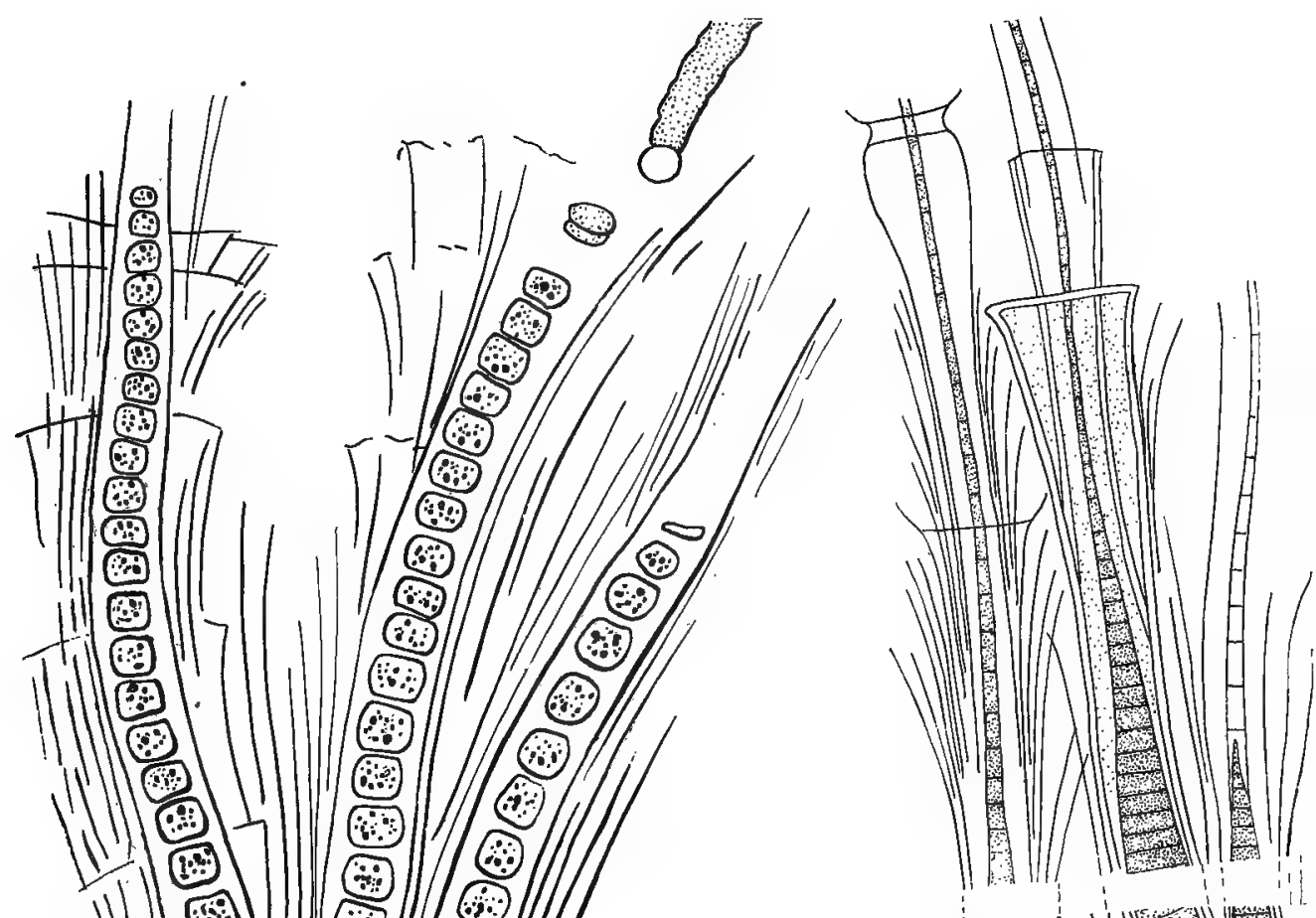

ili)

ㅂ..ㄴ..…

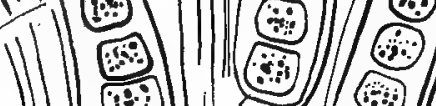
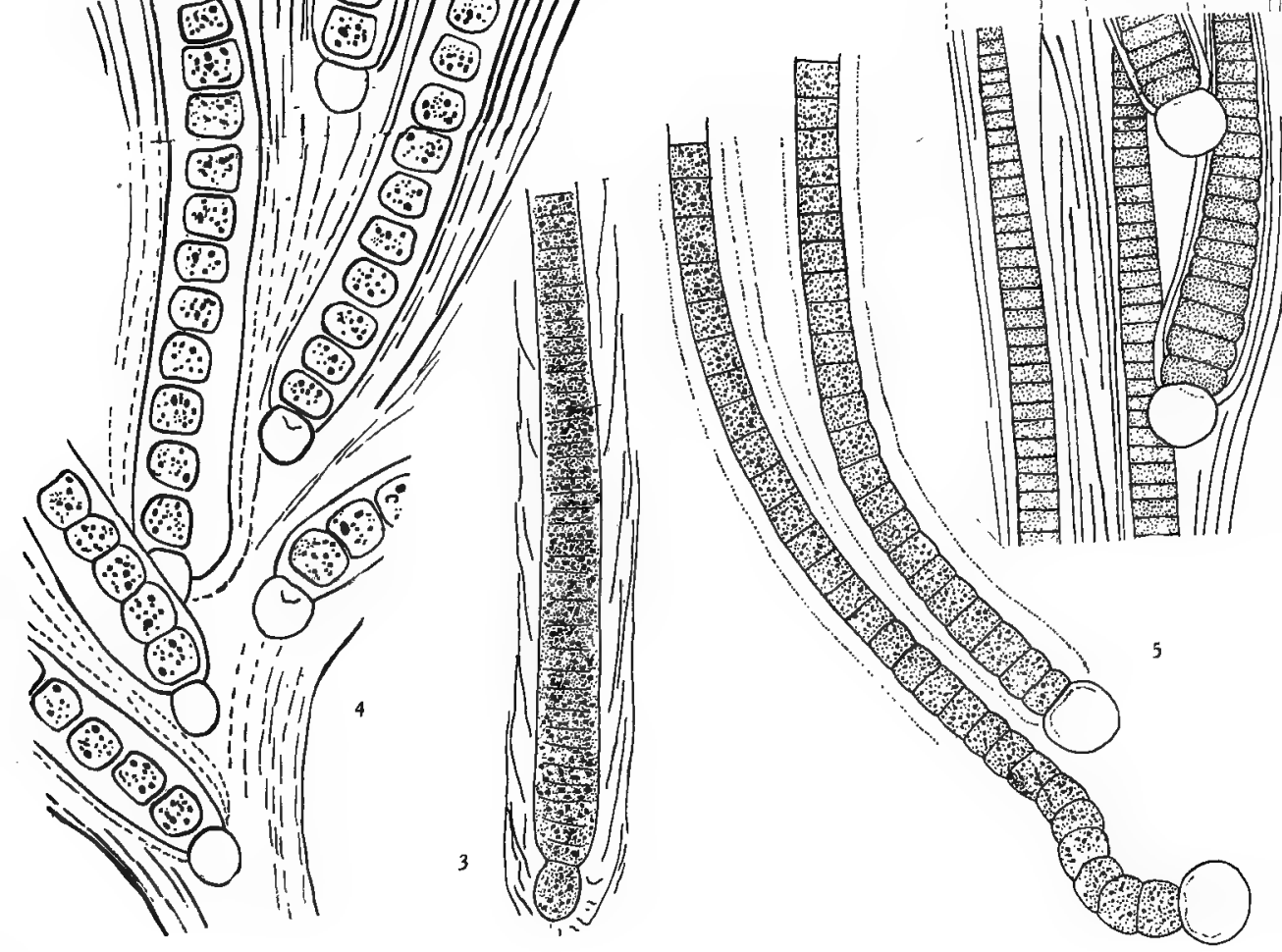



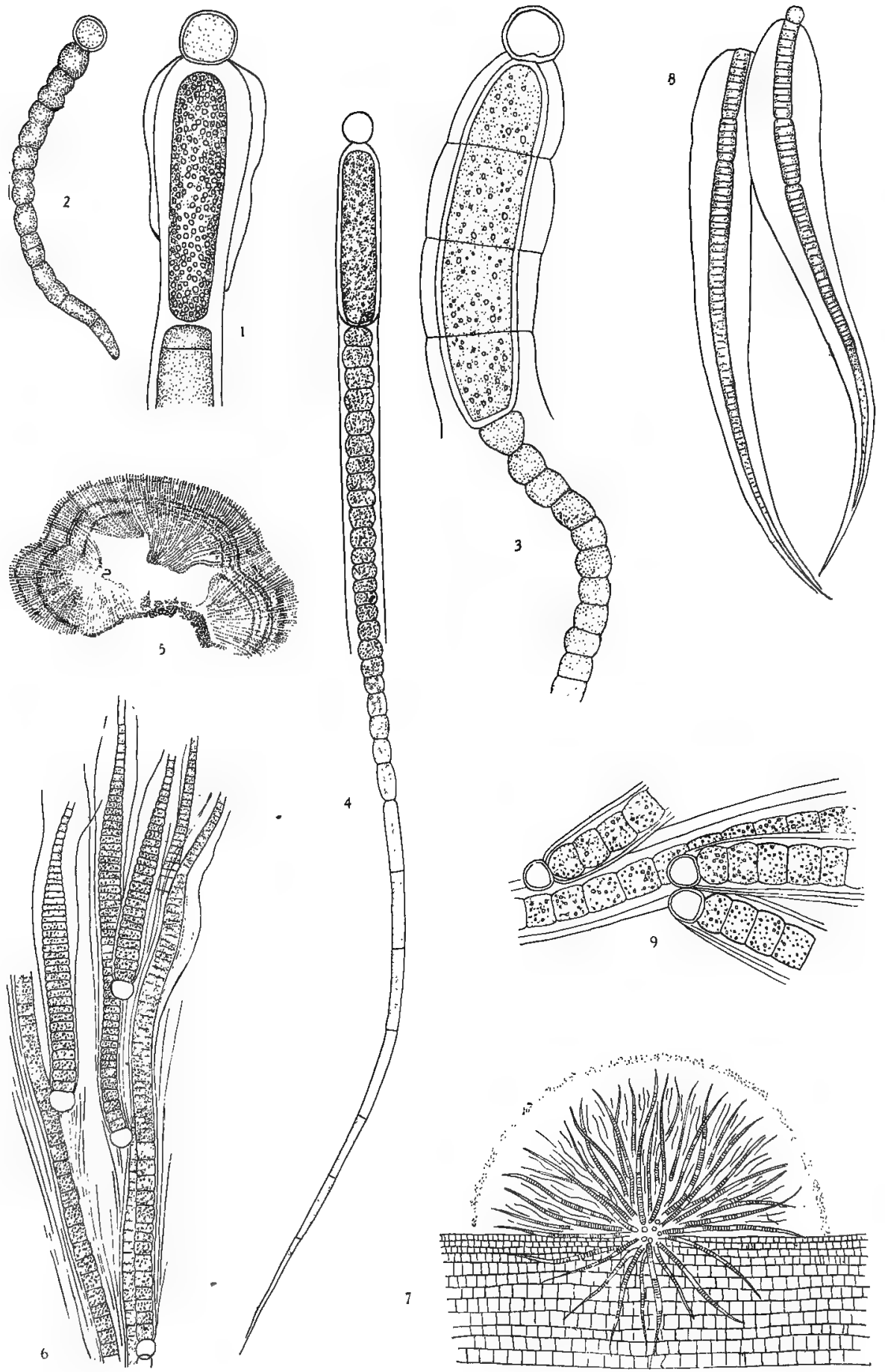

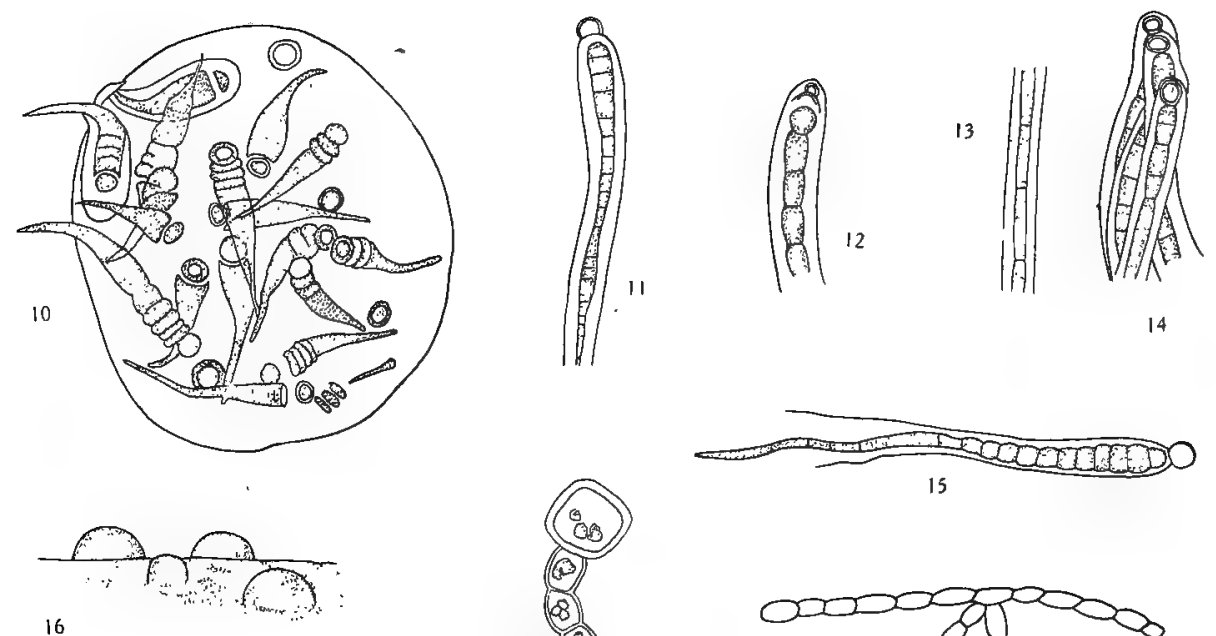

15

16

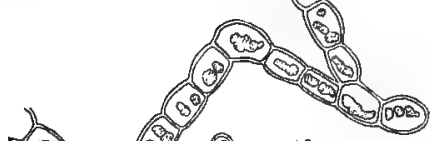

1
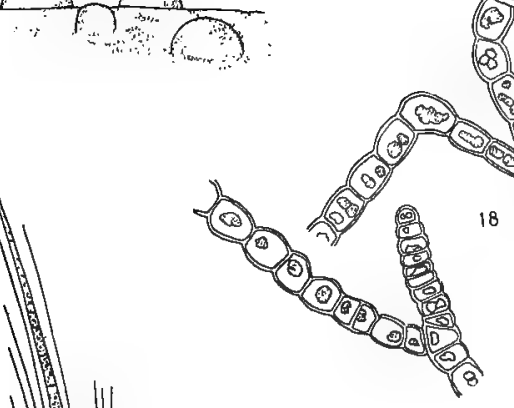

(8)
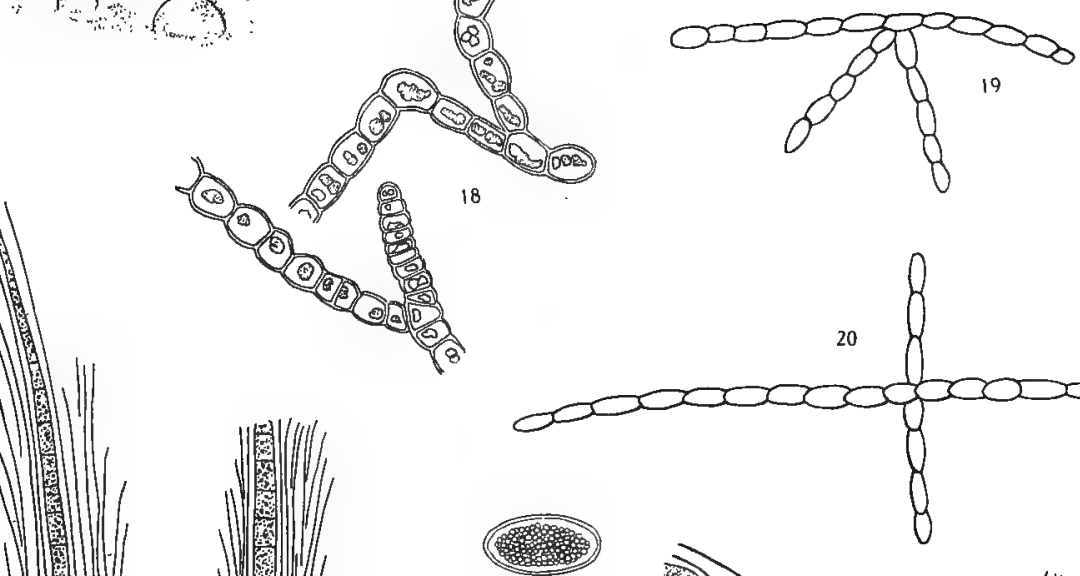

22
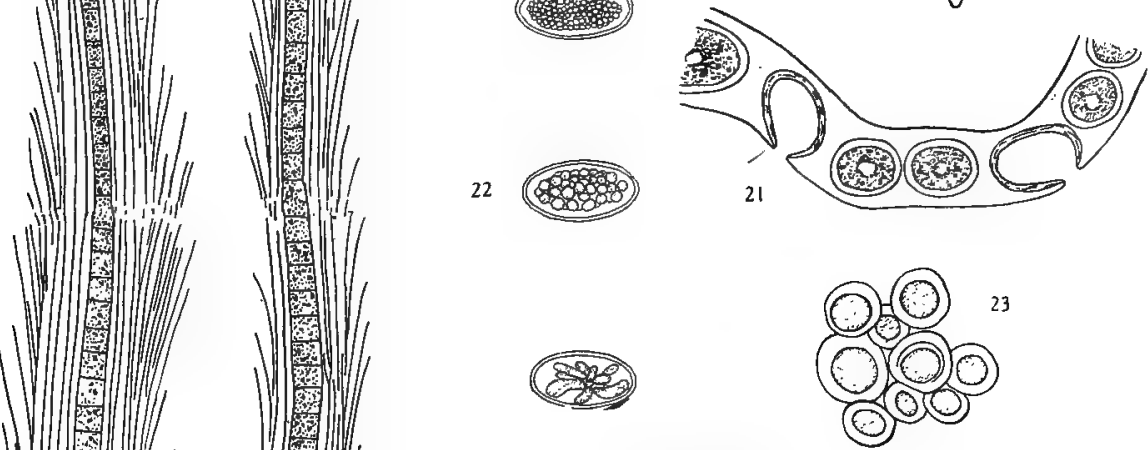

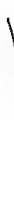
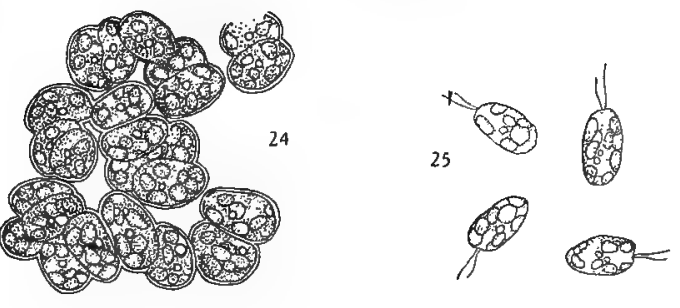




